Urban Rituals in Sacred Landscapes in Hellenistic Asia Minor 


\title{
Religions in the Graeco-Roman World
}

\author{
Series Editors \\ David Frankfurter (Boston University) \\ Johannes Hahn (Universität Münster) \\ Frits G. Naerebout (University of Leiden) \\ Miguel John Versluys (University of Leiden)
}

VOLUME 196

The titles published in this series are listed at brill.com/rgrw 


\section{Urban Rituals in Sacred Landscapes in Hellenistic Asia Minor}

By

Christina G. Williamson

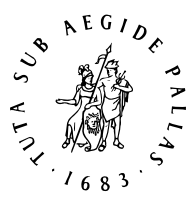

B R I L L

LEIDEN | BOSTON 
This is an open access title distributed under the terms of the CC BY-NC 4.0 license, which permits any non-commercial use, distribution, and reproduction in any medium, provided no alterations are made and the original author(s) and source are credited. Further information and the complete license text can be found at https://creativecommons.org/licenses/by-nc/4.o/

The terms of the Cc license apply only to the original material. The use of material from other sources (indicated by a reference) such as diagrams, illustrations, photos and text samples may require further permission from the respective copyright holder.

Published in Open Access with the support of Nwo, the Dutch Research Council.

Cover illustration: Mylasa seen through the windows of Andron A at Labraunda (photo author).

Library of Congress Cataloging-in-Publication Data

Names: Williamson, Christina G., author.

Title: Urban rituals in sacred landscapes in Hellenistic Asia Minor / by Christina G. Williamson.

Description: Leiden ; Boston : Brill, [2021] | Series: Religions in the Graeco-Roman world, 0927-7633; volume 196 | Includes bibliographical references and index.

Identifiers: LCCN 2021008130 (print) | LCCN 2021008131 (ebook) | ISBN 9789004461260 (hardback) | ISBN 9789004461277 (ebook)

Subjects: LCSH: Shrines-Turkey. | Temples, Greek-Turkey. | Sacred space-Turkey. | Cities and towns, Ancient—Turkey. | City and town life-Turkey. | Turkey—Religion. | Turkey—Religious life and customs.

Classification: LCC BL795.S47 W55 2021 (print) | LCC BL795.S47 (ebook) | DDC $292.3 / 809392-\mathrm{dc} 23$

LC record available at https://lccn.loc.gov/2021008130

LC ebook record available at https://lccn.loc.gov/2021008131

Typeface for the Latin, Greek, and Cyrillic scripts: "Brill". See and download: brill.com/brill-typeface.

ISSN $0927-7633$

ISBN 978-90-04-46126-0 (hardback)

ISBN 978-90-04-46127-7 (e-book)

Copyright 2021 by Christina G. Williamson. Published by Koninklijke Brill NV, Leiden, The Netherlands. Koninklijke Brill NV incorporates the imprints Brill, Brill Nijhoff, Brill Hotei, Brill Schöningh, Brill Fink, Brill mentis, Vandenhoeck \& Ruprecht, Böhlau Verlag and V\&R Unipress.

Koninklijke Brill NV reserves the right to protect this publication against unauthorized use.

This book is printed on acid-free paper and produced in a sustainable manner. 
For Wob

$\because$

Christina G. Williamson - 978-90-04-46127-7 Downloaded from Brill.com04/26/2023 03:25:54PM via free access 
Christina G. Williamson - 978-90-04-46127-7 Downloaded from Brill.com04/26/2023 03:25:54PM via free access 


\section{Contents}

Preface XIII

List of Figures and Tables XVI

Abbreviations XXIII

1 Introduction 1

1 Major Urban-Oriented Sanctuaries in the Countryside in Asia Minor 3

2 Country Sanctuaries and the 'Second Rise' of the Polis in Asia Minor 6

$3 \quad$ Creating Identity 9

4 Indicators of Urban Identity - the Framework of Analysis 12

5 Case Studies - Four Sanctuaries and Two Cities in Karia 13

6 Road Map to This Volume 14

2 Approaching Country Sanctuaries 17

$1 \quad$ Framing the Question 17

1.1 'Extra-Urban' Sanctuaries in the Greek World 18

1.1.1 The Core-Periphery Model and the Origins of the 'Extra-Urban' Sanctuary 18

1.1.2 Frontier Sanctuaries and the 'Bi-Polar' Model 25

1.1.3 Opposition: the Continuum Perspective 30

1.2 Classifying Sanctuaries in Asia Minor - Greek/Anatolian or Urban/Rural? 34

1.2.1 Categorizing Sanctuaries in Hellenistic Asia Minor 37

1.2.2 Geography, Economy, and the Question of Sacred Lands 43

1.2.3 Priesthoods and Sanctuary Administration 48

1.3 Reflection 51

2 Approaches from Outside the Box $5^{2}$

2.1 Spatial Memory and Visual Regions 53

2.2 Rational Rituals 6o

2.3 Network Models 65

2.4 Regional Identity 71

2.5 Reflection 76

3 The Framework of Analysis 77

3.1 Historical Development 80

3.2 Physical Environment 81 
3.3 Urban Integration $\quad 82$

3.3.1 Monumental and Ritual Space 82

3.3.2 Ritual Performance 83

3.3.3 Legal Administration and Organization 84

3.3.4 Urban Mediatization 85

3.4 The Case Studies 87

3 Memory and Control: Mylasa and the Sanctuary of Zeus Labraundos 93

1 Mylasa-Historical Background 96

2 The Sanctuary of Zeus at Labraunda 103

2.1 Historical Overview of Labraunda 104

2.2 Data and Sources 107

3 Environment of Labraunda 110

3.1 Physical Environment 110

3.2 Social-Geographical Location 112

3.3 Visibility 113

4 Signs of Urban Integration at Labraunda 114

4.1 Monumental and Ritual Space at Labraunda 115

4.1.1 Architecture 116

4.1.2 Public Space - Concentric and Linear 127

4.1.3 Sacred Road 130

4.2 Ritual Performance at Labraunda 134

4.2.1 Festivals 135

4.2.2 Banqueting 136

4.2.3 Games 138

4.3 Legal Administration and Organization of Labraunda 140

4.3.1 Administration and Priesthoods 140

4.3.2 Local Community and the Syngeneia of Korris 149

4.3.3 Economic Resources 152

4.4 Urban Mediatization at Labraunda 154

4.4.1 Scope and Network 155

4.4.2 Civic Decrees 157

4.4.3 Cult Iconography in Urban Contexts 164

5 Interpreting Change in the Relationship between Mylasa and Labraunda 171

4 Urban Microcosms: Syngeneiai and the Sanctuary of Sinuri 179

1 Historical Overview of the Sanctuary of Sinuri 180

1.1 Data and Sources 182 
2 Environment of the Sanctuary of Sinuri 184

2.1 Physical Environment 184

2.2 Social-Geographical Location 185

2.3 Visibility 188

3 Signs of Urban Integration at the Sanctuary of Sinuri $\quad 189$

3.1 Monumental and Ritual Space at the Sanctuary of Sinuri 189

3.1.1 Architecture 190

3.1.2 Public Space - Concentric and Linear 202

3.1.3 Sacred Road 204

3.2 Ritual Performance at the Sanctuary of Sinuri 206

3.2.1 Festivals 207

3.2.2 Banqueting 210

3.3 Legal Administration and Organization of the Sanctuary of

Sinuri 211

3.3.1 Administration and Priesthoods 212

3.3.2 Local Community - the Pelekos and Pormounos Syngeneiai 215

3.3.3 Economic Resources 221

3.4 'Urban' Mediatization at the Sanctuary of Sinuri 226

3.4.1 Scope and Network 226

3.4.2 Civic Decrees within the Syngeneia 229

3.4.3 Cult Iconography 232

4 Interpreting Change in the Relationship between Mylasa, the Sanctuary of Sinuri and the Syngeneiai 234

5 Festival Networks: Stratonikeia and the Sanctuary of Hekate at Lagina 241

1 Stratonikeia - Historical Background 243

2 The Sanctuary of Hekate at Lagina 254

2.1 Historical Overview of the Sanctuary of Hekate at Lagina 254

2.2 Data and Sources 259

3 Environment of Lagina 261

3.1 Physical Environment 261

3.2 Social-Geographical Location 263

3.3 Visibility 265

4 Signs of Urban Integration at Lagina 266

4.1 Monumental and Ritual Space at Lagina $\quad 267$

4.1.1 Architecture 268

4.1.2 Public Space - Concentric and Linear 282

4.1.3 Sacred Road 285 
4.2 Ritual Performance at Lagina 291

4.2.1 Festivals 291

4.2.2 Banqueting 297

4.2.3 Games 299

4.3 Legal Administration and Organization of Lagina 301

4.3.1 Administration and Priesthoods 302

4.3.2 Local Community - The 'Katoikountes in the Peripolion' 307

4.3.3 Economic Resources 309

4.4 Urban Mediatization at Lagina 312

4.4.1 Scope and Network 312

4.4.2 Civic Decrees 315

4.4.3 Cult Iconography in Urban Contexts 321

5 Interpreting Change in the Relationship between Stratonikeia and Lagina $\quad 325$

6 Building Urban Community on the Margins: Stratonikeia and the Sanctuary of Zeus at Panamara 331

$1 \quad$ Historical Overview of Panamara $33^{2}$

$2 \quad$ Data and Sources 338

3 Environment of Panamara 341

3.1 Physical Environment 341

3.2 Social-Geographical Location 344

$3 \cdot 3$ Visibility 346

4 Signs of Urban Integration at Panamara 348

4.1 Monumental and Ritual Space at Panamara 349

4.1.1 Architecture 350

4.1.2 Public Space - Concentric and Linear 358

4.1.3 Sacred Road 359

4.2 Ritual Performance at Panamara 365

4.2.1 Festivals 365

4.2.2 Banqueting 372

4.2.3 Games 374

4.3 Legal Administration and Organization of Panamara 376

4.3.1 Administration and Priesthoods 376

4.3.2 Local Community - The Koinon of the Panamareis 384

4.3.3 Economic Resources $\quad 387$ 
4.4 Urban Mediatization at Panamara 389

4.4.1 Scope and Network 389

4.4.2 Civic Decrees 394

4.4.3 Cult Iconography in Urban Contexts 399

5 Interpreting Change in the Relationship between Stratonikeia and Panamara 403

7 Urban Rituals in Sacred Landscapes 411

$1 \quad$ Frontier Sanctuaries? 417

2 Internal Social Cohesion - Building the Polis 419

3 External Connectivity - Festival Networks 421

$4 \quad$ Urban Identity 422

$5 \quad$ Assessing the Theoretical Approaches $\quad 425$

5.1 Visual Regionalization 426

5.2 Concentric and Linear Space $\quad 426$

$5 \cdot 3$ Rational Rituals 428

5.4 Network Model 429

5.5 Regional Identity 430

6 Assessing the Framework of Analysis $43^{1}$

$7 \quad$ Final Remarks 434

7.1 Suggestions for Further Research 435

Bibliography 439

Indices 492

$1 \quad$ Index of Ancient Sources 492

1.1 Literary Sources 492

$1.2 \quad$ Epigraphic Sources 493

1.3 Numismatic Sources 501

$2 \quad$ Index of Persons $5 \mathrm{O} 2$

$3 \quad$ Index of Deities 5 o4

$4 \quad$ Index of Places 506

$5 \quad$ General Index 508 
Christina G. Williamson - 978-90-04-46127-7 Downloaded from Brill.com04/26/2023 03:25:54PM via free access 


\section{Preface}

Towns in Oklahoma, where I grew up, are planned on a grid rather than natural topography, creating a curious tension between the concrete lines and the eroding bright red soil underneath. This urban grid is punctuated by religion, now visible in the attraction of the mega 'extra-urban' churches that create new communities across municipalities, while older traditional 'innercity' churches often belong to a greying congregation. Perhaps this is what attracted me to this topic in the ancient world where, despite the obvious differences, the power of urban religion to redefine social identities and reshape sacred landscapes was at least as dynamic and complex. This is what this book is about.

Sanctuaries in the ancient Greek world have long been examined by scholars through the urban-rural dichotomy, yet Hellenistic Asia Minor poses a separate set of questions and concerns, as older 'country' shrines were drawn into the developing urban sphere. Overarching issues of social and political cohesion appear to have been more important in this era than boundaries, as communities were reorganized along the template of the Greek city. Such concerns rise to the surface on close examination of a wide range of data, rather than the imposition of a monolithic model. This book offers a holistic approach, a framework of analysis that embraces a wide variety of sources and highlights both patterns and variations in developing relationships between sanctuaries and cities. Applied here to four such relationships as an initial probe, this framework can help identify the dynamics and agencies at work in many other cases as well. Hopefully it will be used by many and will undergo refinement in the process.

At the base of this book is my doctoral research and dissertation at the University of Groningen which could not have appeared without the help, influence and insights of many others. In the first place, I would like to thank Onno van Nijf for his unfailing support. Our collaboration has been fruitful and we are now co-directing the project Connecting the Greeks - multiscalarfestival networks in the Hellenistic world (funded by the Netherlands Organisation for Scientific Research (Nwo)), that has emerged in part from the research presented here. I would also like to thank Peter Attema and Martijn van Leusen, who both shaped my view of landscape and sparked my desire to learn to work with geographic information systems (GIS). I am indebted to Felix Pirson, who inspired my approach to the visuality of landscape, further resulting in the project Commanding Views - monumental landscapes and the territorial formation of Pergamon, 3rd to 2nd c BC (Nwo and the Joukowsky Institute 
for Archaeology and the Ancient World, Brown University). At Brown, Lynn Carlson patiently guided me through the complexities of viewsheds and visual analyses in ArcGIS; the maps and viewsheds in this volume were generated by myself using ArcGIS 10.5.1.

The photos were taken on various trips to Turkey, sponsored by the Netherlands Institute in Turkey, with thanks to the director Fokke Gerritsen, and Felix Pirson, of the German Archaeological Institute, division Istanbul, and the generosity of the Dutch Philologische Studiefonds, and the Groningen Research Institute for the Study of Culture (ICOG). Martijn van Leusen and the Groningen Institute of Archaeology generously lent support with the mobile ArcGIS environment. All of the photos from fieldtrips are published by permission of the Turkish Ministry of Culture and Tourism, and the directors of current fieldwork where applicable. In this context I am especially grateful for the hospitality and generosity of several teams. I would like to thank Olivier Henry, Lars Karlsson, and Pontus Hellström, also for the many excellent discussions of Labraunda and their provision of fieldwork reports ahead of publication. I am grateful to Ahmet Trrpan for hosting my stay in Turgut in 2009, and sharing results from Lagina, and to the current director, Bilal Sögüt, who kindly extended his permission to use these images. I have appreciated his insights and those of co-director Zeliha Gider concerning Lagina, as well as Aytekin Büyüköser, now directing fieldwork in the area around Panamara, who has also given his permission to use the imagery from the site even though it awaits excavation. I look forward to following these projects in the future, and seeing how many of the interpretations suggested here will survive new discoveries.

Much of this book matured during a post-doctoral fellowship at the Joukowsky Institute for Archaeology and the Ancient World, at Brown University. This period was made possible by a grant from Nwo, and I am grateful for their continued support in offering this volume as an open access publication. I have also immensely benefited from the discussions on religion and urbanism of the community at the Max-Weber-Kolleg, University of Erfurt, and am grateful for the generous fellowship that allowed me to finalize the manuscript. The editors and copy-editors at Brill of the Religions of the GraecoRoman World series, and the anonymous reviewers, all deserve special thanks for their careful eye and many useful suggestions, all of which have made this a much better book. Thanks are also due to Pim Schievink, who helped with the indices and copy editing of the final version. I take full responsibility for any remaining errors.

My interest in the Hellenistic world was sparked by Ko Feije, an inspiring and whimsical mentor, and a great source of encouragement. Irina Diakonoff, Jan Jaap Hekman, and Marianne Kleibrink are also responsible in part for 
my continued pursuit of archaeology, rather than studying it for only a year as a source of inspiration for artwork - plans change. Many others have also encouraged me along the way, more than can be mentioned here, but special attention goes to Elly Weistra, Yolanda Brandt and Diederik Kraaijpoel $\dagger$, as well as Mary Hollinshead, Gary Reger, Marietta Horster, and Sue Alcock. My parents both constantly offered their moral support in every way they could, and although my mother did not live to see the final publication, her deep love of the English language may surface, albeit faintly, through the words of this book. None of this, however, would have come to anything without the endless patience of my husband, who let me drag him up and down the hills of Turkey and endured my ramblings, frustrations, and sometimes long absences as this volume came to completion. I dedicate this book to him. 


\section{Figures and Tables}

\section{Figures}

1.1

2.1

3.1

3.2

Map showing cities with major country sanctuaries in Asia Minor, corresponding with Table $1.1 \quad 4$

Map of southwest Asia Minor showing the locations of the case studies $\quad 91$ Map locating Mylasa and the shrines of Zeus Labraundos and Sinuri 93 Labraunda. View of the sanctuary, with the split rock in the upper right (photo author 2019) 99 (photo author 99 Andron A (Idrieus's andron) is to the left and the split rock to the right (photo author 2010) 111

Labraunda. View to the south from the Akropolis Fortress. Four watchtowers (grey squares) share visibility, while Burgaz Kale is over the ridge beyond Tepesar Kale (photo author 2008) 112 The viewsheds of Mylasa (green) and Labraunda (fuchsia) 114 Plan of Labraunda in the Hellenistic period. Map after Henry (2017), Figs. 2, $15 \quad 116$

7 Labraunda. Monumental staircase leading to the Middle Terrace (photo author 2008) 118

8 Labraunda. View towards Mylasa and the southwest framed by the windows of Andron A; on the right, the view through the central window towards Mylasa, the Sodra Dağı, and part of the sacred road (photos author 2008) 120

9 Labraunda. View of the Temple Terrace from the Split Rock. The temple is to right (photo author 2019) 121

10 Route of the sacred road from Mylasa to the sanctuary of Zeus at Labraunda. Trajectory after Karlsson (2010), Fig. 7, and Baran (2011) 130

11 Mylasa. The labrys on the keystone of the Baltalı Kapı; note the eyes carved into the blades (see Kızl (2009)) (photo author 2019) 133

Labraunda. The South Propylon and the end of the sacred road. View towards the south and Mylasa, visible in the plain left of the mountain on the right side of the picture (photo author 2008) 133

Round altar with double-axe, from Şeftalı Irın, southwest of Mylasa (Bodrum Museum of Underwater Archaeology, photo author 2009) 166 Small altar with Zeus Labraundos, probably Roman by analogy with Akarca 1959, Pl. Xx, no. 3 (Bodrum Museum of Underwater Archaeology, photo author 2009) $\quad 166$ 
3.15a-e Hekatomnid and Mylasan coins showing Zeus Labraundos 168

4.1 Map with the environment of the sanctuary of Sinuri 179

4.2 The sanctuary of Sinuri, on the Tarla Tepe hill in the center of the picture, seen from the west (photo author 2010) 184

4.3 Sinuri. Extent of the view from the sanctuary to the west and the Bozdağ in the distance (photo author 2010) 187

4.4 Sinuri. View from the northern 'acropole' complex looking west with the sea, the Myndos peninsula and the peaks of Kalymnos visible in the far distance (photo author 2011) 187

4.5 Viewsheds of Mylasa (green), the sanctuary of Sinuri (purple) and 'acropole' (fuchsia) $\quad 188$

4.6 Plan of the sanctuary of Sinuri. After Devambez 1959, 47 and Pedersen 1991, 104 and Fig. 104; orientation assessed by author 189

4.7 Sinuri. View of the sanctuary showing the southeast flank of the temenos wall, the drafted corner is visible (photo author 2010) 190

4.8 Sinuri. South section of the Archaic terrace/temenos wall (photo author 2010) 191

4.9 Southeast corner of the sanctuary with the fourth century temenos wall, showing the ashlar construction with headers and stretchers (photo author 2008) 192

4.10 Sinuri. Archaic gateway with buttresses in the south wall (photo author 2010) 193

4.11 Sinuri. Archaic gateway with mid-fourth century blockage of the entry (photo author 2010) 193

4.12 Sinuri. Central space of the sanctuary, view to the west. The Doric stylobate is in the middle right. The upright blocks belong to the Byzantine basilica (photo author 2010) 195

4.13 Sinuri. The eastern stoa. Red marble block, $118 \times 42.5 \times 67 \mathrm{~cm}$, carrying I.Sinuri 9 , honorific decree for Leon Iasonos et al. concerning the building of a stoa; the well is in the background (photo author 2010) 195

4.14 Sinuri. The eastern stoa. Section of the stylobate, with holes for dovetail clamps (photo author 2011) 196

4.15 The 'acropole' complex, c. $45^{\circ} \mathrm{m}$ north of the sanctuary of Sinuri. Terrace structure. Southwest corner, with polygonal wall (photo author 2011) 198

4.16 The 'acropole' complex. Square chamber with threshold in the southern wall (photo author 2011) 198

4.17 The 'acropole' complex. Smaller bi-chambered structure north of the terraced structure. Facing east. In the middle is the crosswall separating the two areas (photo author 2011) 199 
4.18 The 'acropole' complex. Walls and profiled blocks (photo author 2011) 200

4.19 Ceramic concentration in terrace wall near the 'acropole' (photo author 2011) 200

4.20 Rock-cut tomb c. 25 o m north of the sanctuary of Sinuri (photo author 2011) 201

4.21 Rock-cut feature c. $110 \mathrm{~m}$ north of the sanctuary of Sinuri (photo author 2010) 201

4.22 Two images of the white marble block carrying I.Sinuri 16 . This heavily damaged block, measuring $100 \times 62.5 \times 5^{2.5} \mathrm{~cm}$, bears an honorific decree by the syngeneia of Pormounos for [Ou]liades $\operatorname{Po}[\ldots]$. The image on the left shows the text, indicating that this block was set up vertically. The last line states

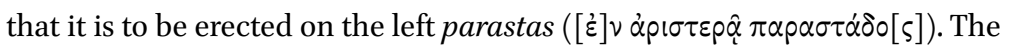
image on the right shows the smooth side; presumably this was the left door jamb (parastas) of the gateway (pylon) mentioned in the inscription (photos author 2008) 203

4.23 Sinuri. Path northeast of the sanctuary, leading onto the area north of the sanctuary; the vaulted tombs from the Roman period are just around the rocks to the right (photo author 2010) 205

4.24 White marble block with the inscription I.Sinuri 2. This block (later used as orthostat), $67 \times 130 \times 47 \mathrm{~cm}$, bears the dedication of an altar to Sinuri by the seven treasurers (tamiai) of the syngeneia of the Pormounou. Based on this inscription, Louis Robert was able to identify the site as the sanctuary of Sinuri (the block has since been damaged at the top). Its current position reflects its secondary use as an orthostat in the Byzantine basilica (photo author 2008) 208

4.25 Ashlar bearing the inscription I.Sinuri 44. This is the earliest mention of the Pormounou syngeneia (end of second and beginning of third lines), an honorific decree in which Samiades, son of Theodotou, is admitted into the syngeneia (photo author 2010) 217

5.1 Map of Stratonikeia and the environment of Lagina and Panamara 242

5.2 Koranza. Column from the area of the Apollo and Artemis temple, at the edge of the plateau looking NE, across the Hayırlıdere valley to the Gökbel mountains in the background (photo author 2009) 248

5.3 Lagina. View of the temple from the southwest stoa (photo author 2008) 257

5.4 Lagina. View from the south with the Hayırlıdere valley to the northeast, and the rising Gökbel mountains further north - the Archaic site of Hacibayramlar Höyük was located in the foothills across the valley. The sanctuary of Hekate is visible in the clearing to the left (photo author 2009) $\quad 262$ 
5.5 View from Lagina towards the east-northeast across the Hayırlıvasi area and the Marsyas valley (photo author 20o9) 263

5.6 The combined viewsheds of Stratonikeia (green), Lagina (fuchsia) and Panamara (violet); together these encompassed the known incorporated communities, except Kurbet Köy (possibly Koliorga) to the west 265

5.7 Lagina. View across the sanctuary from the northwest corner to the east with the Oyuklu mountains in the distance (photo author 2011) $\quad 267$

5.8 Plan of the sanctuary complex of Hekate at Lagina by the first century BC (plan after Z. Gider, in Gider (2012), with permission) $\quad 269$

5.9 Aerial photo of the propylon, seen from the east (photo courtesy of Prof. Ahmet Tirpan) 270

5.10 Lagina. From the northwest corner of the stoa complex. The theatron is visible in the lower right, the temple in the center (photo author 2008) 271

5.11 Lagina. Doric columns with smoothed lower surfaces; the theatron is visible in the background (photo author 2008) 271

5.12 Lagina. Altar seen from the temple, with marble paving ending in the rubble core supporting the steps (photo author 2009) 272

5.13 Lagina. Coffered ceiling fragments, with reliefs of a double-axe and a trident (photo author 2009) 274

5.14a-c Lagina. Temple of Hekate. a) Plan, showing $8 \times 13$ Corinthian columns and 2 Ionic columns in antis in the pronaos (after Tirpan and Söğüt 2007, 401 Resim 1); b) One of the Corinthian capitals from the temple (photo author 2019) c) Aerial overview from the north (photos a and c courtesy of Prof. Ahmet Tirpan; photo b author 2019) $\quad 276$

5.15 Lagina. The central part of the 'west' temple frieze, showing Hekate in the midst of a Gigantomachy (Istanbul Archaeological Museum, photo author 2009) 278

5.16 Lagina. Section of the 'north frieze', showing Amazons and Greek soldiers in amicable relations, with Hekate to the right, holding a phiale (photo courtesy of Prof. Ahmet Tirpan) 278

5.17 Lagina. The southwest krepis of the temple. Note the 'graffiti', including several outlines of feet (photo author 2011) $\quad 282$

5.18 Lagina. View of the propylon seen from the altar; the Akdağ peak is visible through the doorframe; to the right the monument base for Menekles and Epainetos (photo author 2019) 284

5.19 Lagina. Temple of Hekate looking southeast, with Aladağ peak in the distance (photo author 2009) 285

5.20 Map of the sacred road between Stratonikeia and Lagina. Trajectory after Söğüt (2012), Map $1 \quad 286$

5.21 Sacred road to Lagina, south of Yeşilbağilar (photo author 2009) 287 
5.22 Lagina. 'Sacred pool' or spring-fed reservoir near the sacred road (photo author 2009) $\quad 287$

5.23 The North Gate of Stratonikeia, seen from the northwest; the archway is from the later second century AD. Part of the sacred road is visible to the left, next to the sarcophagus (photo author 2008) 289

5.24 Section of the Hymnode inscription on the wall of the bouleuterion, I.Stratonikeia 1101. Instructions for the hymnodes during the festivals of Zeus Panamaros and Hekate, third century AD (photo author 2008) 295

5.25 The social network of Lagina. Map and table show the 57 cities listed on the temple walls of Lagina (I.Stratonikeia 508) recognizing the asylia, following the Senatus consultum de Stratonicensibus of 81 BC (I.Stratonikeia 505) and participating in the Hekatesia-Romaia festivals

5.26 Lagina. Monument for Menekles and Epainetos, I.Stratonikeia 1426-1427, seen from the propylon with the temple and altar in the background (photo author 2019) 321

5.27 Stratonikeian coins showing Hekate and Zeus 322

6.1 Panamara and environment, with an indication of the sacred road. 332

6.2 Panamara, seen from the Bencik Dağı northwest of the sanctuary, looking south. The sanctuary is near the bare spot on the hill just right of the center. Left of Panamara is the Kapız valley with the Koca Öküz hills on the opposite side; the Marsyas valley is in the far left (photo author 2011) 334

6.3 Panamara. Looking south towards the Gebeneadere valley, with several architectural fragments in the foreground; the Marçat Dağları is in the background (photo author 2010) 339

6.4 Sketch by A. Laumonier of the sanctuary at Panamara (BCH 6o (1936), Plate 41) 340

6.5 Panamara. View from the southwest; the sanctuary terraces and temple platform are visible at the top of the hill, to the right of the electricity mast (photo author 2011) 342

6.6 Panamara. Seen from the north, with the Marçat hills rising in the distance. The electricity mast just to the right of the top marks the northwest corner of the sanctuary (photo author 2011) 343

6.7 Panamara. View to the northeast, with the abandoned village of Bağyaka and the strip mines. The Madranbaba range is just visible in the distance (photo author 2011) 343

6.8 Panamara. View from the steep east side of the sanctuary. The Koca Öküz hills are in the near foreground, with the Marsyas valley and the southern perimeter of Yatağan (east of Stratonikeia) visible just beyond. In the distance are the northern slopes of the Oyuklu hills (photo author 2010) 347 
6.9 Panamara. View from the shrine towards the east-southeast. The southern extent of the Koca Öküz is visible in the foreground. The Marsyas valley is on the other side of these (not visible in the picture) with the Oyuklu hills beyond to the left in the far distance (photo author 2008) 347

6.10 Panamara. View of the top showing schist walls with mounds of marble and schist blocks. The white marble block to the left in the foreground is a remaining fragment of I.Stratonikeia $257 \mathrm{~b}$, a priestly inscription from the later second century AD (photo author 2008) 349

6.11 Panamara. Rustic orthogonal wall at the southwest corner of the temenos (photo author 2010) 353

6.12 Panamara. Exposed schist and ashlar walls with fragments of amphora and tile (photo author 2010) 353

6.13 Panamara. Rock and schist wall along the northeastern perimeter (photo author 2010) 354

6.14 Panamara, north side. Exposed section of the north temenos wall (photo author 2010) 354

6.15 Panamara. Escarpment along the steep southeast edge of the hilltop (photo author 2010) 355

6.16 Panamara. Hilltop with scattered architectural fragments, ceramics, a coffer, and roughly in the center the lower part of the inscription I.Stratonikeia 220a, now further broken (photo author 2008) 356

6.17 Panamara. Door jamb (?) fragment with two priestly inscriptions from the Imperial period, I.Stratonikeia 240 and 253, now broken at the top (photo author 2008) $\quad 356$

6.18 Panamara and the large terraced area at the northern part of the sanctuary. In the background is the Bencik Dağı (photo author 2008) 357

6.19 Panamara. Sacred road leading to the large terraced area (photo author 2008) 357

6.20 Panamara. Section of the road, partly terraced as shown here, roughly one kilometer southwest of the sanctuary (photo author 2011) 36o

6.21 Panamara. Sections of the sacred way southwest of the sanctuary cut through the rock (photo author 2011) 36o

6.22 Panamara. Sections of the sacred way, cut through the rock (photo author 2010) 361

6.23 Panamara. Sections of the sacred way west of the sanctuary (photos author 2010) 361

6.24 Panamara. Built tomb along the sacred road near the sanctuary (photo author 2010) $\quad 362$

6.25 Panamara. Four adjacent rock-cut tombs along the sacred road west of the sanctuary (photo author 2010) $\quad 362$ 
6.26 Panamara. Exposed marble doorway, with a three-faceted frame; the entry is c. $70 \mathrm{~cm}$ wide (photo author 2010) 363

6.27 Panamara. Votive coffers, probably for hair dedications. On the left a marble coffer in the northern area near the temenos wall; illustration of such a coffer from Panamara by J. Devillard (photo author 2O1O; BCH 12 (1888), 480) 369

6.28 Social network of Panamara. Map of the identifiable communities involved in the worship of Zeus at Panamara at different times, testified by inscriptions 390

6.29 Zeus on coins from Stratonikeia and Keramos 400

6.30 Stratonikeian coins showing equestrian Zeus and Hekate 401

\section{Tables}

1.1 List of cities and their major country sanctuaries, corresponding to the map in Figure 1.14

2.1 Boffo's nine categories of sanctuaries in Hellenistic Asia Minor, with examples (Boffo 1985) 39

2.2 The framework of analysis 88

3.1 List of political decrees at Labraunda from the Hellenistic period 164

3.2 List of honorific decrees at Labraunda from the Hellenistic period 165

4.1 Hellenistic inscriptions at Labraunda (37 total) and Sinuri (84 total) 231

4.2 Breakdown of the Hellenistic honorific decrees found at Mylasa according to issuing body 237

5.1 Breakdown of inscriptions at Lagina according to type and period 303

6.1 Breakdown of inscriptions at Panamara according to type and period 381 


\section{Abbreviations}

This volume adheres to the abbreviations in the Supplementum Epigraphicum Graecum (SEG).

BMC Caria

$\mathrm{FGrH}$

IAph2007

I.Iasos

I.Keramos

I.Knidos I

I.Labraunda

I.Mylasa

IMT SuedlTroas

$\operatorname{IosPE} I^{2}$
Head, B.V. (1897) Catalogue of the Greek coins of Caria, Cos, Rhodes, \&cc, A catalogue of the Greek coins in the British Museum, London: Trustees of the British Museum. Jacoby, F. (1921ff) Die Fragmente der griechischen Historiker, Berlin.

Reynolds, J., Roueché, C., and Bodard, G. (2007) Inscriptions of Aphrodisias: <http://insaph.kcl.ac.uk/iaph2007>.

Blümel, W. (1985) Die Inschriften von Iasos, Inschriften griechischer Städte aus Kleinasien, Band 28, Bonn: R. Habelt. Varinlioglu, E. (1986) Die Inschriften von Keramos, Inschriften griechischer Städte aus Kleinasien, Bd. 30, Bonn: R. Habelt. Blümel, W. (1992) Die Inschriften von Knidos, Inschriften griechischer Städte aus Kleinasien, Band 41, Bonn: R. Habelt. Crampa, J. (1969) Labraunda. Swedish excavations and researches. Vol. III. Part 1. The Greek inscriptions Part I. 1-12 (Period of Olympichus), Acta Instituti Atheniensis regni Sueciae, Series in $4^{\circ}$, V, III, 1, Lund, and (1972) Vol. III. Part 2. The Greek inscriptions Part II. 13-133, Acta Instituti Atheniensis regni Sueciae, Series in $4^{\circ}$, V, III, 2, Lund: Gleerup.

Blümel, W. (1987) Die Inschriften von Mylasa, Inschriften griechischer Städte aus Kleinasien, Band 34-35, Bonn: Rudolf Habelt.

Barth, M. and Stauber, J. (1996) Inschriften Mysia \& Troas, [Leopold Wenger Institut. Universität München. Version of 25.8.1993 (Ibycus). Packard Humanities Institute CD \#7, 1996. Troas, "Südliche Troas", nos. 401-684 (+ 685-698, unbestimmter Fundort). Includes: Reinhold Merkelbach. Die Inschriften von Assos. "Inschriften griechischer Städte aus Kleinasien”, 4. Bonn 1976]: PHI.

Latyschev, B. (1916) Inscriptiones antiquae orae septentrionalis Ponti Euxini graecae et latinae, Vol. 1, 2nd edn., Inscriptiones Tyriae, Olbiae, Chersonesi Tauricae, St. Petersburg. 
I.Rhod.Per.

Iscrizioni di Cos

I.Sinuri

I.Smyrna

I.Stratonikeia

I.Tralleis

LSAM

$L C L$

MAMA IX

Milet I,3

SNG Copenhagen

SNG Helsinki

SNG von Aulock

Staatsverträge III
Blümel, W. (1991) Die Inschriften der rhodischen Peraia, Inschriften griechischer Städte aus Kleinasien, Band 38, Bonn: R. Habelt.

Segré, M. (1993) Iscrizioni di Cos, I-II, Monografie della Scuola Archeologica di Atene VI, Rome: L'Erma di Bretschneider. Robert, L. (1945) Le sanctuaire de Sinuri près de Mylasa. Première partie. Les inscriptions grecques, Mémoires de l'Institut français d'archéologie de Stamboul, 7 , Paris: De Boccard.

Petzl, G. (1982) Die Inschriften von Smyrna, Inschriften griechischer Städte aus Kleinasien, Band 23-24, Bonn: Rudolf Habelt.

Şahin, M.Ç. (1981-2010) Die Inschriften von Stratonikeia, 3 vols., Inschriften griechischer Städte aus Kleinasien, Bd. 21-23, Bonn: Habelt.

Poljakov, F.B. (1989) Die Inschriften von Tralleis und Nysa. Teil I: Die Inschriften von Tralleis, Inschriften griechischer Städte aus Kleinasien 36,1, Bonn: Habelt.

Sokolowski, F. (1955) Lois sacrées de l'Asie Mineure, Travaux et mémoires (Ecole française d'Athènes), fasc. 9, Paris: De Boccard. Loeb Classical Library (1911-), Cambridge, MA.

Cox, C.W.M., Cullen, J., Mitchell, S., Levick, B., and Potter, J. (1988) Monumenta Asiae Minoris Antiqua (MAMA) IX: Monuments from the Aezanitis, Journal of Roman Studies Monographs 4, London: Society for the Promotion of Roman Studies.

Kawerau, G. and Rehm, A. (1914) Milet I,3. Das Delphinion in Milet, Berlin: Druck und Verlag Georg Reimer.

(1968) The Royal collection of coins and medals. Danish National Museum, Sylloge nummorum Graecorum. Deutschland. 17, Copenhagen.

Westermark, U. and Ashton, R. (1994) The Erkki Keckman

Collection in the Skopbank. Karia, Sylloge nummorum Graecorum. Finland. Part 1. Karia, Helsinki.

Robinson, E.S.G. (1967) Sammlung von Aulock. Nachträge III. Ionien, Karien, Lydien. Nr.7759-8298, Sylloge nummorum Graecorum. Vol. IV Fitzwilliam Museum. Leake and General collections. Part Vir. Lycia-Cappadocia, London.

Schmitt, H.H. (1969) Die Staatsverträge des Altertums. Band III. Die Verträge der griechisch-römischen Welt von 338 bis $200 v$. Chr., Kommission für Alte Geschichte und Epigraphik des DAI, München: Beck. 


\section{Introduction}

Located on a fertile mountainside amidst boulders, springs and pine trees, the site of the shrine of Zeus at Labraunda is now an idyllic retreat from the bustle of urban Milas and the highways that carry traffic from Bodrum to Izmir. The peaceful setting of the sanctuary, however, belies the power of the place when it was a hub in the Hekatomnids' network of territorial control in the fourth century BC, and a century later, when it became contested space between the resident priests, the civic body of Mylasa, and a local governor under the Seleukid kings. The question of who Labraunda belonged to is one that has many different answers, all of which involve its sacred landscape and the people whose lives were invested in its fortunes.

Sanctuary, landscape, and community are three intertwined strands that are central to this research, which seeks to understand their role in the processes of urbanization that were characteristic of the Hellenistic period in Asia Minor. Towns sprang up almost overnight, yet were from the start under the protection of a deity that was well established in the vicinity. As religious centers, places of cult in Asia Minor could take on many different forms, reflecting the needs and especially the composition of the societies to whom they belonged. This could vary from a local 'specialist' shrine, to a common center for a cluster of regional settlements, to a major complex at the heart of a theocratic community. Landscape was an important part of the equation as the location of shrines resonated with the desires and perceptions of the community. Whether on hilltops, in valleys, along coasts, near rivers or thoroughfares, sanctuaries were centers of their own sacred landscapes, shared by settlements, farmsteads, or cities, and connected to them by routes, pathways, and sightlines. These sanctuaries were tightly bound to their countries, in every physical, social, and political sense.

This research examines four such 'country sanctuaries' in Karia, in southwest Asia Minor, as case studies to interpret the larger transformations that took place at such local or regional shrines in the Hellenistic period, a time when many of them were turned into major civic sanctuaries. The turbulent period that Karia underwent as it passed in the fourth-century from rule of the Hekatomnids, satraps of the Persian rulers, to later rivalling Hellenistic kings may be read in the biographies of its major sanctuaries, as at Labraunda, but also at the shrine of Sinuri, both near Mylasa, and the sacred centers of Hekate at Lagina and Zeus at Panamara, both near Stratonikeia. Each of these

(C) CHRISTINA G. WILLIAMSON, 2021 | DOI:10.1163/9789004461277_002

This is an open access chapter distributed under the terms of the CChY-NC 4.olicense.iamson - 978-90-04-46127-7 
cult places are extremely well documented and the transformations that they underwent shed light on the pivotal role of sanctuaries in helping local communities come to terms with their new position in an expanding world of cities, shifting allegiances and hierarchies of power. As such, each case forms a microcosm that allows us to identify issues that were surely relevant to other areas of Asia Minor as well.

In the wake of Alexander the Great, Asia Minor underwent an unprecedented wave of urbanism as the Greek city, or polis, became the common denominator in a globalizing world. This world also found itself confronted with new and colliding superpowers; new poleis were founded to anchor their rule to their territory, while older communities wishing to keep up with the times often reinvented themselves through Hellenic institutions. ${ }^{1}$ Several of these communities were restructured along the political and spatial format of the Greek polis while others were created as military colonies or administrative centers, or even as new centers of regional power. That many of these poleis are still major cities in modern Turkey today is a testimony to the effectiveness of their transition.

In a world in which politics and religion were tightly interwoven, the incorporation of the gods already embedded in the sacred landscape of the region was surely integral to the success of these new or restyled cities. Several of these gods were adopted as protective deities that stood symbol for the rising city. In return, their sanctuaries were monumentalized and made the venues of great civic festivals - a symbiosis clearly took place between both entities as they merged into one. This makes it all the more interesting to observe that several of these sanctuaries were located well beyond the confines of the urban centers of the poleis that they came to represent (Figure 1.1 and Table 1.1, p. 4-5).

In this book I argue that these sanctuaries embodied this urban transformation. They were used to forge the identity of the developing polis, accommodating local communities while redirecting the new civic focus. Gods that were local or regional began to appear on civic coinage, received grand festivals and processions, and their once rustic shrines took on the shape of urban space. As the rising polis took its identity from these gods, so the gaze of the gods was shifted towards the new community, and their sanctuaries reorganized to meet its aspirations. But what exactly happened to these places of cult, why were they so important to the polis? How were landscape, space, and especially ritual implicated in this transformation? These are some of the larger questions addressed by this present investigation.

1 E.g. Gauthier (1984), also (1987-1989); Savalli-Lestrade (2005); van Nijf (2008); Mileta (20ogb); Cohen (1995). 
The phenomenon of urban-oriented sanctuaries located beyond the civic center was fairly common in Hellenistic Asia Minor. As the map in Figure 1.1 and corresponding table both show, at least 3 o cities are known to have had major sanctuaries that were situated beyond the limits of the town proper. Some of these sanctuaries were 'extramural', located just outside the city walls or perimeter. Others were farther away marking critical places in the countryside, such as federation sanctuaries in neutral spaces (e.g. Xanthos, Kastabos), oracular shrines at natural features (e.g. Didyma, Klaros, Patara), shrines along a vital passage of access (e.g. Labraunda, Meter Steunene at Aizanoi), or peak sanctuaries that dominate naturally commanding positions (e.g. Meter Theon near Pergamon, Men Askaenos near Pisidian Antioch, Zeus Stratios near Amaseia). This list of cities with major sanctuaries at a distance is not exhaustive yet does give an indication of their distribution. Roughly half of these cities were new ruler-driven foundations (or refoundations of older cities) in the Hellenistic period, with several appearing in the more inland regions, especially Mysia, Lydia, and Karia. ${ }^{2}$ Others were autochthonous poleis, i.e. local communities or agglomerations of communities with a long-established presence in Asia Minor that underwent a major phase of urban development or expansion in the Hellenistic period. Several were a combination of both top-down and bottom-up initiatives.

The question is how pre-existing sanctuaries, with their local or regional appeal, came to be urban-oriented, or rather, why they were so crucial to the cities that took hold of them. This book focuses on such new or developing poleis that grafted their identity onto an existing sanctuary and its god(s) in the wider region of the territory of the central settlement. Specifically it centers on Karia, a landscape that harbored many smaller hilltop communities that found themselves confronted with the reality of wave of urbanization in the period after Alexander the Great. The sanctuaries of Zeus Labraundos and Sinuri, both drawn into the orbit of the rising polis of Mylasa (no. 15 on the map), and the sanctuaries of Hekate at Lagina and Zeus at Panamara, who became the two poliad deities of the Seleukid foundation of Stratonikeia (no. 16), especially highlight important dynamics in the transformation of a sanctuary and its community. The selection of these will be discussed in more detail below.

In studies of Archaic and Classical Greece and Magna Graecia, such sanctuaries are generally qualified as 'rural' or 'extra-urban' and are often interpreted

2 Cohen (1995). 


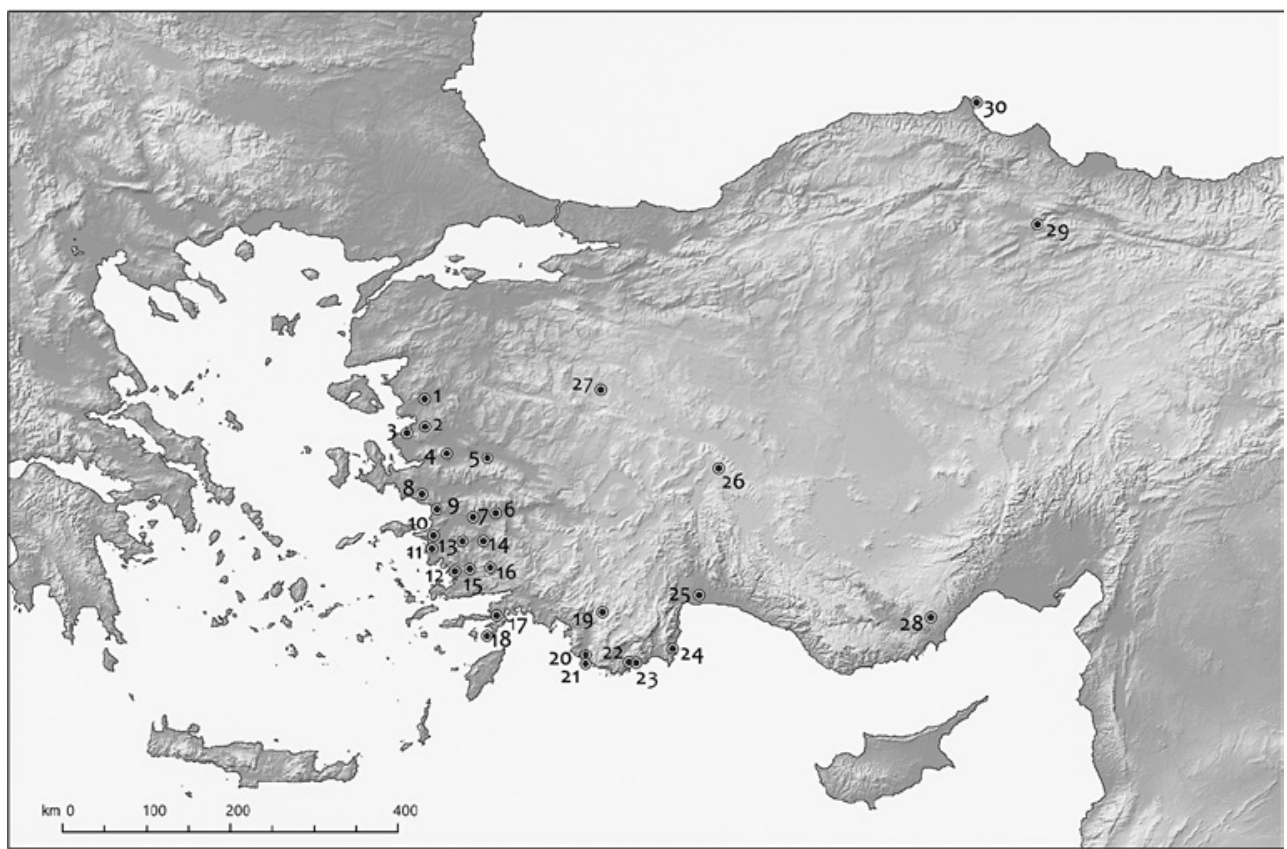

FIGURE 1.1 Map showing cities with major country sanctuaries in Asia Minor, corresponding with Table 1.1

TABLE 1.1 List of cities and their major country sanctuaries, corresponding to the map in Figure 1.1

No. Polis

Sanctuary

Distance to

urban center

\begin{tabular}{llll}
\hline & & Meter Theon (Mamurt Kale) & $>30 \mathrm{~km} \mathrm{SE}$ \\
1 & Pergamon $^{\mathrm{a}}$ & Meter (Kapıkaya) & $6.5 \mathrm{~km} \mathrm{NW}$ \\
& & Asklepios & $5 \mathrm{~km} \mathrm{SW}$ \\
& & Athena Nikephoros (extramural) & $?$ \\
2 & Aigai & Apollo Chresterios & c. $3 \mathrm{~km} \mathrm{E}$ \\
3 & Kyme & Meter & Extramural \\
4 & Magnesia under Sipylos $^{\mathrm{a}}$ & Meter Sipylene & c. $7 \mathrm{~km} \mathrm{E}$ \\
5 & Sardis $^{\mathrm{a}}$ & Artemis & $1 \mathrm{~km} \mathrm{SW}$ \\
& & Apollo Pleurenos & $?$ \\
6 & Nysa $^{\mathrm{a}}$ & Kore \& Pluton (Acharaca) & c. $6 \mathrm{~km} \mathrm{~W}$ \\
7 & Tralles $^{\mathrm{a}}$ & Zeus Larasios (Larasa) & $?$
\end{tabular}


TABLE 1.1 List of cities and their major country sanctuaries (cont.)

\begin{tabular}{|c|c|c|c|}
\hline No. & Polis & Sanctuary & $\begin{array}{l}\text { Distance to } \\
\text { urban center }\end{array}$ \\
\hline 8 & Notion/Kolophon ${ }^{\mathrm{a}}$ & Apollo Klaros & c. $13 \mathrm{~km}$ to $\mathrm{S}$ \\
\hline 9 & Ephesos ${ }^{a}$ & Artemis & c. 2.3 to $\mathrm{NE}$ \\
\hline 10 & Priene $^{\mathrm{a}}$ & Poseidon (Panionion) & $10 / 27 \mathrm{~km}$ to $\mathrm{N}$ \\
\hline 11 & Miletos & Apollo Didyma & $20 \mathrm{~km}$ to $\mathrm{S}$ \\
\hline \multirow[t]{2}{*}{12} & Iasos $^{\mathbf{a}}$ & Artemis? (Çanacık Tepe) & c. $3 \mathrm{~km} \mathrm{~N}$ \\
\hline & & NW extramural sanctuary & Extramural \\
\hline 13 & Amyzon ${ }^{\mathrm{a}}$ & Artemis & $?$ \\
\hline 14 & Alabanda $^{a}$ & Artemis & Extramural \\
\hline \multirow[t]{2}{*}{15} & Mylasa $^{a}$ & Zeus Labraundos & $13 \mathrm{~km} \mathrm{~N}$ \\
\hline & & Sinuri (Tarla Tepe) & $12 \mathrm{~km} \mathrm{SE}$ \\
\hline \multirow[t]{2}{*}{16} & Stratonikeia (Karia) ${ }^{\mathbf{a}}$ & Hekate (Lagina) & c. $13 \mathrm{~km} \mathrm{~N}$ \\
\hline & & Zeus (Panamara) & c. $12 \mathrm{~km} \mathrm{~S}$ \\
\hline \multirow[t]{2}{*}{17} & Bybassos & Hemithea (Kastabos) & c. $2 \mathrm{~km} \mathrm{E}$ \\
\hline & & Oyuklu Tepe & Extramural \\
\hline 18 & Loryma & Apollo & c. $0.5 \mathrm{~km} \mathrm{~S}$ \\
\hline 19 & Oinoanda ${ }^{b}$ & Leto & $?$ \\
\hline 20 & Xanthos & Leto & c. $3.5 \mathrm{~km} \mathrm{~W}$ \\
\hline 21 & Patara & Apollo & Extramural \\
\hline 22 & Trysa & Zeus \& Helios & Extramural \\
\hline \multirow[t]{2}{*}{23} & Myrab & Apollo (Sura) & c. $4.5 \mathrm{~km} \mathrm{~W}$ \\
\hline & & Moskar & $5 \mathrm{~km} \mathrm{~N}$ \\
\hline 24 & Olympos ${ }^{\mathrm{b}}$ & Hephaistos (Chimaera) & c. $4 \mathrm{~km} \mathrm{~N}$ \\
\hline 25 & Perge & Artemis Pergaia & $?$ \\
\hline 26 & Pisidian Antioch ${ }^{\mathrm{a}}$ & Men Askaenos & c. $3.5 \mathrm{~km} \mathrm{SE}$ \\
\hline 27 & Aizanoib & Meter Steunene & $2.3 \mathrm{~km} \mathrm{SW}$ \\
\hline \multirow[t]{3}{*}{28} & Olba Diokaisareia & Zeus Olbios (Uzuncaburç) & c. $32 \mathrm{~km}$ to $\mathrm{NW}$ \\
\hline & \& Seleukeia on the & & \\
\hline & Kalykadnos $^{\mathrm{a}}$ & & \\
\hline 29 & Amaseiab $^{b}$ & Zeus Stratios & c. $10 \mathrm{~km} \mathrm{E}$ \\
\hline 30 & Sinope & Zeus Dikaiosyne (Asar Tepe) & c. $6 \mathrm{~km} \mathrm{SW?}$ \\
\hline
\end{tabular}

a Cities listed in Cohen 1995 as Macedonian (re)foundations in the Hellenistic period.

b Autochthonous cities that were either newly founded or underwent a major developmental phase in the Hellenistic period. 
as signaling liminal locations, particularly political borders. ${ }^{3}$ In Asia Minor, however, many of these 'extra-urban' shrines were initially major centers in their own right, pre-dating the cities that later came to absorb them. ${ }^{4}$ The term country sanctuary is a much better qualifier as it is more neutral and implies a rural but not necessarily remote setting, while carrying territorial overtones. Embedded in a different kind of social and economic structure, these sanctuaries were often a common point of connection for several spatially distinct and otherwise autonomous communities. As the Greek urban system became projected onto the wider landscape of Asia Minor, however, these communities either were forcibly incorporated into new poleis or voluntarily reorganized themselves in terms that accorded with this model. This phenomenon can especially be observed in Karia where such country sanctuaries had a visibly vital role in this process. Asia Minor

A defining characteristic of the Hellenistic period is the wave of urbanism that rose in the wake of Alexander the Great. In Asia Minor alone, over a hundred new poleis were founded in this era. ${ }^{5}$ Cities were administrative centers and hence key instruments of territorial control, allowing for structured rule and transactions (especially taxation) between local populations. colonies and garrisons (e.g. salaries for military troops) and the royal seat. ${ }^{6}$ Besides providing channels of hierarchical access, urbanization also facilitated communications among peer communities. The urban network in the Hellenistic world was one of the greatest avenues for the exchange of ideas as well as trade, ensuring the rapid 'globalization' of the polis culture and the spread of common knowledge as it penetrated into regions well beyond the Mediterranean and the Hellenistic kingdoms. ${ }^{7}$

3 E.g. de Polignac (1995), the contributions in Alcock and Osborne (1994); studies regarding this issue are discussed at length below in Chapter 2.

4 Much like the regional cults 'which have a topography of their own', in Werbner (1977), ix.

5 Cohen (1995) counted 150 poleis in Asia Minor that were founded, or refounded, in the Hellenistic period (not all of these have been located); also Fraser (1996); Mileta (20o9a) and (20ogb).

6 Along with the cities is the increase in use of the monetary system, rather than exchange in goods, see Aperghis (2000) and (2005).

7 Sperber (1996); Ober (2008). For the 'globalization' of Hellenistic culture, Ma (2003); van Nijf (2012); Pitts and Versluys (2014). Further discussed in Chapter 2. 
Religion was at the heart of the ancient Greek city. ${ }^{8}$ Tightly woven into the fabric of its topography, sanctuaries embodied the pleasure of the gods and the polis at its finest, and were the channel of civic pride. State-of-the-art technology was often used in their architecture, renowned sculptors were hired, magnificent urban festivals and processions with music and performances were planned with precision - the polis put itself on display at these shrines and their festivals were clearly designed to impress. ${ }^{9}$ That these highly focused areas are often found at remote locations, far beyond the confines of the inhabited center, demands an explanation, especially to the modern academic and urban mind. This seeming paradox between prime urban space located not in the heart of the city, but in its distant countryside, is the undercurrent throughout this present research.

The phenomenon of liminal religious centers is an important theme in anthropology, with significant studies by Victor Turner who views them as a counterbalance to political centers. In his conceptualization of pilgrim shrines, the 'centers out there', they form an important pendant of 'anti-structure' to the structure of the city. ${ }^{10}$ Such sacred centers offer a degree of inclusion that transcends the exclusive divisions of the city, fostering what Turner designates as communitas - a spontaneous, intensive kind of bonding, typically revolving around a common religious focus, and that is in sharp contrast to the pragmatic organization of the city. ${ }^{11}$ Ritual practice is essential to this sense of cohesion but liminality, in fact, is key to Turner's theory, as the distance and seclusion of such outlying sacred centers emphasizes their separateness from political authority. Pilgrimages to such remote spots are a central element of initiation rites, especially rites of passage, and so according to this view it is no wonder that we find major sanctuaries at distances from urban centers. This structuralist polarity of civilization-versus-wilderness is also a common theme among scholars of ancient Greek religion, expressed via rituals and myths, e.g. the link between young men, their sojourns, even including werewolves at the mountain shrine of Zeus Lykaios in Arkadia. ${ }^{12}$ Inversion of the norm is the core business of such liminal places, where "the individual replaces the group as the

8 E.g. Sourvinou-Inwood (1990) and (1988); Kindt (2009); Strootman (2014); van Nijf and Williamson (2016).

$9 \quad$ Chaniotis (1995) and (2013); also van Nijf (2012).

10 Turner (1973) (slightly modified in Turner (1974b), under the name 'Pilgrimages as social processes', 166-230); also Werbner (1977) who adapts it somewhat.

11 Turner (1969), further developed in Turner (1974b).

12 Buxton (1992), Burkert (1997). On sanctuaries as liminal spaces, see e.g. Polinskaya (2003); McInerney (2006). Discussed at length in Chapter 2. 
crucial ethnic unit" as Turner states. ${ }^{13}$ Experiencing pilgrimage is a second key to this theory, in the presumption that sacred travel was predominately undertaken in isolation, with heightened awareness, and that rituals at the shrine created new social groups that had little to do with the pragmatic institutions of the city. ${ }^{14}$

While rituals at rural shrines surely promoted the kind of intimate bonding that Turner understands as communitas, this model cannot account for the highly organized festivals and processions that brought entire populations out to sanctuaries in the ancient world. Typically organized by the urban elite, these festivals in fact (re)produced the fundamental structure and social hierarchies that made up the very fabric of the city - they embodied the city..$^{15}$ Moreover, the model cannot account for the dramatic increase in such urban rituals at remote sanctuaries in post-classical Asia Minor, nor their role in generating collective identity and a sense of belonging.

Scholars of early Greece, on the other hand, envision this phenomenon as being intertwined with the very rise of the city itself. The separation of administrative and sacred centers and their connection through ritual and physical presence is considered by some to be essential to the definition of the polis and its territorial claims; the 'bi-polar' model developed by François de Polignac is the example cited most often. ${ }^{16}$ Major shrines in the distant chora, or countryside, serve as 'frontier sanctuaries' in this model, marking and defending the borders of the emerging Greek city-state in the face of rivalling communities during the later Geometric and Archaic periods in Greece. This theory generally presupposes the coeval emergence of cities and great 'extra-urban' sanctuaries in early Greece. ${ }^{17}$ Problematic with this view is the supposition of a blank landscape onto which political territories could readily be mapped via sanctuaries. 18

While the widespread urbanization of Hellenistic Asia Minor certainly signals a 'second rise' of the Greek city, the situation and context is very different

13 Turner (1973), 215.

14 E.g. Brown (1971). On pilgrimage in the ancient world, see esp. Elsner and Rutherford (2005); Luginbühl (2015); Kristensen and Friese (2017).

15 See among many others: Chaniotis (1995) and (2013); Chankowski (2005); Luginbühl (2015); Stavrianopoulou (2015).

16 De Polignac (1984), Le naissance de la cité grecque; later revised in the English edition, de Polignac (1995), Cults, territory, and the origins of the Greek city-state; but also Vallet (1968); Asheri (1988); Graf (1996); also several contributions in Alcock and Osborne (1994). These and other theories concerning remote, or 'extra-urban' sanctuaries, are discussed in Chapter 2.

17 See especially the discussion in Malkin (1996).

18 Polinskaya (2006); Mackil (2013a), 149. 
from Archaic Greece. New cities were planted by rulers in landscapes that were already richly articulated with religious centers and communities, often with mixed populations that had long been exposed to Greek customs, as in Karia. Some of these communities had already acquired the label of polis, perhaps for lack of better term. Others began to centralize and develop in the direction of the Greek urban model, adopting its institutions and democratic form of government. Rather than creating themselves ex nihilo, these emerging cities typically grew by absorbing older local communities through processes of synoikism (uniting several villages or towns into a larger community) or sympoliteia (joint citizenship) whether this was voluntary or enforced from above. The once autonomous communities were turned into suburbs of the new city, often as demes (districts) or phylai (tribes). ${ }^{19}$

Studies of religious institutions in Hellenistic Asia Minor have had to deal with a different model, that of a persistent Anatolian theocratic society whose currents were thought to underlie the temple economies visible in several Hellenistic cities. ${ }^{20}$ This monolithic view, proposed by W.M. Ramsay, was categorically taken apart by Pierre Debord, who carefully examined the many institutional, social, and economic roles that sanctuaries could take on in the Hellenistic era as sacred centers met the changing needs of their communities. ${ }^{21}$ His view has since been refined and even refuted by others. ${ }^{22}$ While these and other studies take urbanization into account, their main concern is economy. They do not address the role of landscape and territory in their assessment of sanctuaries, nor do they adequately address ways that sanctuaries and their rituals fostered social cohesion among the changing and heterogeneous groups that formed the population base for the new poleis.

\section{3}

\section{Creating Identity}

Starting with Émile Durkheim, scholars of religion have observed the innate capacity of religion to reflect social structures, but especially to produce them,

\footnotetext{
19 Discussed e.g. in Gauthier (1987-1989); Houby-Nielsen (2001); Eich (2004); Reger (2004); Walser (2009); Schuler (2010); Schuler and Walser (2015); LaBuff (2016).

$20 \quad$ Ramsay (1911), esp. 18.

21 Debord (1982) Aspects sociaux et économiques de la vie religieuse dans l'Anatolie grécoromaine, Leiden.

22 Boffo (1985) I re ellenistici e i centri religiosi dell'Asia minore, Pisa, dividing the roles into several categories. Dignas (2002a) Economy of the sacred in Hellenistic and Roman Asia Minor, Oxford interprets temple autonomy in ways reminiscent of Ramsay's model. These studies are discussed in Chapter 2.
} 
as Clifford Geertz stressed. ${ }^{23}$ Yet how this actually works is rarely analyzed. Emily Mackil noted the tendency to view religion as "a black box through which individuals pass and then exit as an integrated community" ${ }^{24}$ She cites Barbara Kowalzig as a trailblazer in understanding ways that religion articulated but also mediated several levels of contact in the Greek world, ${ }^{25}$ and in her own work Mackil maps in detail ways of interpreting community-forming processes at the level of federated sanctuaries.

Forging several distinct communities into a single political entity was surely a formidable task. ${ }^{26}$ The main challenge would have been one of coordination. ${ }^{27}$ A critical step in this process is creating a shared identity, i.e. a common goal that each member can relate to and embrace. Most of the new foundations or refoundations under discussion here seem to have gone peacefully, implying a large-scale willingness to take on the new identity of the polis. ${ }^{28}$ Several factors would certainly have been at work and the agents of change would have had to succeed at different scales: the interpersonal level, with individual contacts; the social level, especially with regard to status and class; the political level of urban councils, and the decisions taken in their efforts to turn a collection of people into an urban body; and finally the larger scope of peer cities at the regional level or beyond, who had to acknowledge this new identity. All of these levels could simultaneously be addressed via festivals. It is because of this multi-strand process that the term 'urban' is used, invoking a cultural concept that goes beyond the 'civic', usually more focused on institutional realities.

Creating a new social group as a polis, or redefining a group as a democratic polis, would have brought a number of challenges of its own. In the first place, the surrounding landscape in which many of its new citizens already worked and lived would have to be incorporated as territory. In the second place, there was already a pretty good idea in circulation as to how a Greek polis should behave and what it should look like, as well as a strong desire to conform to this idea so as to be recognized as such by other poleis. ${ }^{29}$ Finally and most crucially,

\footnotetext{
23 Durkheim (1912); Geertz (1980).

24 Mackil (2013a), 148.

25 Kowalzig (2007b).

26 Eich (2004); Reger (2004); Mackil (2013a).

27 The field of rational choice theory and evolutionist studies, e.g. Glaser (2010); Tomasello (2009); Chwe (2001). The arguments are laid out succinctly in Turchin (2006a).

28 But see Ager (1998), who gives an example of a less smooth synoikism between Lebedos, Teos, and Ephesos under Antigonos I, in which the Lebedians clung to their own communal identity.

29 Twentieth-century studies speak of 'civic culture' after Almond and Verba (1963) (see also the critique in Pateman (1980)). This concept may be applied to the polis, with a similar
} 
religion, particularly the local cult and especially the way in which it was practiced, would be central to this idea of polis and hence to its vitality. ${ }^{30}$

While Greek cities had a pantheon of gods, one would serve as a patron, or poliad, deity with whom they had a special and intimate bond. This god or goddess cared about the city, watched over its community and protected them from harm. This is the deity who typically came to symbolize the polis on its coinage and in its political dealings with others, and whose festivals were used as prime political events, the focus of civic pride and the avenue of contact with other poleis. It is now recognized that this phenomenon is on the increase in the later Hellenistic period. ${ }^{31}$ This coincided with the new wave of urbanization, as cities sought to anchor their identities through religious logic. Yet how these divine guardians were selected is not always clear. Pre-existing communities often already had a principal cult of their own, so as they were absorbed into larger urban entities the question arises as to whose god or goddess was chosen as poliad deity. Significant factors in this are sanctuary location and the formation of civic territory, the capacity of a local or regional cult to foster urban identity, and how the cult itself was affected by the new status. A number of theories, discussed in Chapter 2, will be used to address these issues, but especially two areas of study stand out as having a direct bearing on the overlap of urban and religious identity. The first pertains to ritual and its capacity to create a shared focus of attention that innately generates common knowledge, the preconditions for any kind of cooperation or joint action. ${ }^{32}$ The second area is the study of regional identity, within the field of social geography, which emphasizes the role of territory, boundaries, symbolism, institutions and external recognition. The model of these stages as developed by Anssi Paasi is particularly helpful in understanding the processes of urban identity in the Hellenistic world, so much so, that for the purposes of this study

awareness and 'socialization' into the political context and institutions of the city, see Herrmann (1984); Chaniotis (1997); van Nijf (2012).

30 Weingast (1995). Benedict Anderson, in his seminal Imagined communities, Anderson (1983 [2006]), 5 considers religion, and kinship, more than ideology, as one of the binding forces in the idea of nationality; see also Eric Hobsbawm's now classic The invention of tradition, Hobsbawm and Ranger (1992), 1-15, and the contributions in Religious identity and 'the Invention of Tradition', van Henten and Houtepen (2001).

31 Chaniotis (1995); Meadows (2018).

32 I conflate the conceptual approaches regarding: cognitive ritual - McCauley and Lawson (2002) and (2007); collective memory - Halbwachs (1992); Connerton (1989); and 'rational rituals' - Chwe (2001). These are all discussed separately and in more detail in Chapter 2 and assessed in the conclusion in Chapter 7 . 
I equate his model of regional identity with that of urban identity, with a few important modifications discussed at the end of this volume. ${ }^{33}$

\section{Indicators of Urban Identity - the Framework of Analysis}

Of course, not all cults in a sacred landscape were concerned with fostering urban identity. The disparity of literature and wealth of sources on sanctuaries in Hellenistic Asia Minor made it quickly clear that a systematic and comprehensive analysis was needed to avoid the pitfall of cherry-picking aspects that would support a preconceived model or interpretation. Both in identifying the urban engagement of shrines, but especially in analyzing this relationship, several factors had to be taken into account, such as history, landscape, architecture, rituals, administration, and finally material evidence of their use in mediatization strategies. Subsequently a framework of analysis was developed, if only as a check-list, in order to ensure that conclusions are not only data-driven but that these factors are taken into account as well.

This framework includes a historical overview that functions as a site biography, based to a large extent on literary or epigraphic sources. This is followed by an assessment of the wider physical environment of the sanctuary, including its vistas, and the potential of its landscape to have attracted the interest of the polis in the sanctuary. Turning into the sanctuary itself, the framework separates categories of analysis into domains of: monumental space (architecture, public space, and processional routes); ritual performance (festivals, banquets and games if applicable); legal administration (priesthoods and other offices, the local community, and economic resources); and urban mediatization (including scope or network, civic decrees, the use of iconography). These areas especially require careful attention as they all reveal different dimensions through which urban involvement can be manifested. Because of this, there will inevitably be some overlap in the presentation of the data within each case study. Nonetheless, it is the rigorous application of this framework to each case study that allows for the changes that took place at each sanctuary to surface most clearly, highlighting the specific areas of transformation, while providing a base for comparative analyses of the different case studies.

This framework of analysis serves as a lens through which each case study can be examined and evaluated. This will highlight the critical paths towards the evolving relationship between a city and a sanctuary, while revealing how unique this was and whether the beginnings of a larger pattern may be

See esp. Paasi (2009) and (2010), discussed further in Chapter 2 and assessed in Chapter 7. 
discerned. The ultimate goal is not to develop yet another monolithic model, but to provide a methodological approach which is systematic enough to shed light on the nature of the relationship between country sanctuaries and their respective cities, yet dynamic enough to accommodate the many specific circumstances and variations in this relationship.

\section{$5 \quad$ Case Studies - Four Sanctuaries and Two Cities in Karia}

This research revolves around the sanctuaries of four Karian deities - Zeus Labraundos, Sinuri, Hekate at Lagina, and Zeus Panamaros - and how they were critical in the development of two cities in Karia, Mylasa and Stratonikeia, both of which underwent a remarkable process of urbanization and were two of only three cities in Karia that Strabo found worth mentioning. ${ }^{34}$ Inland Karia is characterized in the pre-Hellenistic period by its hilltop communities that were often organized into wider federated bodies, or koina. ${ }^{35}$ Typically these koina centered on a common sanctuary; two top-level federations include the Karian League, which met at the sanctuary of Zeus Karios near Mylasa, and the Chrysaoric League, based on the sanctuary of Zeus Chrysaoreus near (later) Stratonikeia. But these are only the tip of the iceberg, and Marchese and Debord have both revealed that this pattern repeated itself at several levels down the line - native Karia was a complex system of nested communities, that were also interconnected at multiple levels. ${ }^{36}$ In this socially articulated landscape, dotted with hilltop settlements organized around sanctuaries, the impact of the Greek polis is especially visible through the wealth of evidence, much of which is epigraphic, that also illuminates several issues confronting evolving cities, and the various agencies that arose as a result. Taken together, the four case studies examined here provide a repertoire of situations and solutions that will overlap with several other areas of Asia Minor, although less well documented.

Mylasa and Stratonikeia are two neighboring poleis in west-central Karia that both exhibit the impact of the shift to the urban paradigm albeit in different ways. As home of the Hekatomnid dynasty, Mylasa had already been turned into a proper 'city' in the early fourth century вС by the satraps,

34 Strabo 14.2.22, with Alabanda as the third city of note.

35 On koina as sacred and political entities: Graninger (2011); Capdetrey (2012); Mackil (2013a); McInerney (2013); Freitag (2015); Constantakopoulou (2015).

$36 \quad$ Marchese (1989); Debord (2003); Rutherford (2006). 
probably through a kind of synoikism of the surrounding communities. ${ }^{37}$ Once it achieved independence by the Seleukid rulers in the mid-third century BC, however, it began to set its own course as an autonomous city with a democratic constitution. Roughly in the same period, the Seleukids founded a new 'city' or colony to the east, that of Stratonikeia, probably organized in part by local communities. Eventually the new polis engulfed the neighboring communities, a process that became more apparent after its own independence from Rhodes (by Rome) in the second century.

Their differing origins - Mylasa as a self-restyled polis, and Stratonikeia as a 'colony' - make these two cities good candidates for observing ways that community was integrated with landscape and sanctuary. Country sanctuaries were critical to the development and expansion of both cities. Mylasa laid claims to the high-profile sanctuary of Zeus Labraundos, some 14 kilometers to the north, and gained control over the area which included the sanctuary of the Karian god Sinuri, roughly 15 kilometers to the east. Stratonikeia absorbed the local cult of Hekate at Lagina, about 8 kilometers to the north, and eventually took complete control over the sanctuary of Zeus Karios at Panamara, about 10 kilometers to the south, turning both deities into its civic gods. Despite their differences there are important parallels. Both cities had a composite citizen base, and both may be shown to have embarked upon a policy of expansion following their autonomous status. Both cities also had important sanctuaries in the distant regions of their territories, and these sanctuaries seem to have been related to their territorial ambitions. But as it will be demonstrated in this research, this was only part of the story. Territory combined with ritual, perceptions of space and landscape, and contact with the extended inter-polis world were all parts of the primary role that each sanctuary fulfilled as it became a focal point for urban identity. The way in which this functioned is the object of the rest of this volume.

Road Map to This Volume

The approach to this topic is reflected in the structure of this volume. The first chapter frames the main question, beginning with interpretations of outlying

37 Rumscheid (2010), 97-98; Radt (1969/70), 168-169, n. 17. In the context of this research, the term 'synoikism' is used to describe the creation, or enhancement, of a polis through the centralized aggregation of the surrounding communities, without necessarily implying a simultaneous forced relocation or depopulation of the countryside; this process is especially apparent at Stratonikeia, Debord (2001a); van Bremen (2000); also Cavanagh (1991). 
sanctuaries as part of the core-periphery model of the city and its hinterland, but focusing on the Archaic Greek world, and principally the Peloponnese or Magna Graecia. Scholars of Hellenistic Asia Minor, on the other hand, have had to deal with Ramsay's long prevailing view of shrines in Asia Minor as falling into one of two classes: either as Anatolian centers of an essentially theocratic society, or as Greek polis sanctuaries. The second section of this first chapter deals with some turning-point responses, even though they primarily address economic and administrative aspects of sanctuaries as they focus on degrees of autonomy rather than their shifting roles in the human landscape. Three principal views are assessed for their strengths as well as inadequacies in addressing the present research question. The third section then turns to a number of alternative theories drawn from other disciplines in the cognitive and social sciences that help shed light on the topic. Reconsidering some fundamental concepts, such as the role of memory, ritual, space with regard to collective identity can help show how critical these sanctuaries, their topographies, and their festivals were towards state formation and the creation of a new common identity. The concept of 'rational rituals', developed by Michael Suk-Young Chwe, ${ }^{38}$ is used to explore ways that ritual generates the common knowledge necessary to foster social cohesion. Network models, currently popular as they relate to the phenomenon of social networks, are valuable in understanding how sanctuaries functioned as nodes in wider networks of communities based on ties of cult. Finally the concept of regional identity and especially the stages involved in its development, modeled by Anssi Paasi, ${ }^{39}$ will be discussed as a tool for understanding the roles of landscape, architecture, festivals, priesthoods, civic decrees and iconography in the development of urban identity. These theories can help identify important domains of focus when analyzing the case studies. The final section in Chapter 2 outlines the methodology of this research, presenting a detailed discussion of the framework of analysis. This carries the overarching domains of history, environment, and a list of indicators of urban involvement at each sanctuary as well as the types of data that can provide answers. This includes physical data such as architecture, inscriptions, sculpture, ceramics, and coins, but also spatial information such as geography, elevations, and viewsheds. Epigraphy forms a major source, as it reveals important information on civic institutions and political, social, or economic concerns; literary sources, except for Strabo, are rare but mentioned where available. One of the strengths of this framework is that it highlights the multifarious changes that took place at each sanctuary as it was

38 Chwe (2001).

39 Paasi (2009), with more of an archaeological turn in Paasi (2010). 
drawn into the urban network. As a tool this framework facilitates a comprehensive and detailed analysis of the relationship between a sanctuary and a city, going past the rubrics of 'polis religion', 'frontier shrine' or 'temple estate', and into the underlying mechanisms and occasionally even the motivations behind their tightening bond.

In the following four chapters, the framework is applied to the prominent sanctuaries of the landscapes of Mylasa and Stratonikeia. Chapters 3 and 4 discuss the relationships between Mylasa and the sanctuaries of Zeus Labraundos and Sinuri, respectively, while Chapters 5 and 6 discuss those between Stratonikeia and the sanctuaries of Hekate at Lagina and Zeus Panamaros, respectively. Each of these chapters opens with an overview of the history and data sources for each sanctuary, followed by an assessment of the environmental situation. The urban indicators are then reviewed according to the available data, divided in the domains of monumentalization, ritual performances, administration, and urban mediatization at each sanctuary that had a bearing on its role with regard to the polis. Each chapter ends with an interpretative analysis of the nature of the relationship between the sanctuary and its polis, and how this relationship came into being, as well as a discussion of the role fulfilled by the sanctuaries in the chora from the perspective of their corresponding poleis. This is a highly nested approach, thick with information; summaries are provided at the end to help the reader navigate to the most relevant parts.

The final chapter sets the individual studies in context and returns to the larger issues of this pursuit. This includes a side-by-side comparative analysis of the case studies, followed by an overall discussion of the most important factors that appear to have been at work in the relationship between city and sanctuary. An assessment of the methodology is given with an evaluation of the theories borrowed from other disciplines (discussed in Chapter 2) as to their overall usefulness and the modifications that were necessary to adapt them to these particular situations. Throughout this book it will become clear that country sanctuaries were powerful intersections of ritual, community, and landscape, as well as the many forms that this could take. It will also become clear that the sense of identity and place that they could provide is exactly what made them so vital to emerging urban centers, seeking to establish themselves in a rapidly expanding world of cities. This book will shed light on this phenomenon and will hopefully contribute towards new interpretations of such sanctuaries in future discussions. 


\section{Approaching Country Sanctuaries}

Although rising poleis in the Hellenistic period in Asia Minor frequently invested in established sanctuaries that were located far away from their urban centers, a line of inquiry to approach this phenomenon has yet to be developed. Investigations of such country sanctuaries until now have largely focused on questions of cultural identity or local autonomy in the face of shifting political landscapes. Yet the factor of human geography in this relationship is seldom problematized, even though long an object of study for the Archaic Greek world. A gap thus remains concerning country sanctuaries in Hellenistic Asia Minor and how they should be interpreted with regard to evolving urban systems. The aim of this chapter is to produce a framework of analysis that takes into account the complexities of the situation. Prior research on the phenomenon of 'extra-urban' sanctuaries in Archaic Greece and relevant studies in Asia Minor are taken as point of departure, raising significant aspects that need to be addressed. To understand the dynamics, however, theories drawn from other disciplines - spatial memory, 'rational rituals,, ${ }^{1}$ network theory, and regional identity - are introduced that will help illuminate important factors regarding matters of motivation, agency, and impact behind the tightening relations between city and sanctuary. Taken together, the previous research, theories, and alternative models, inform the main domains of investigation defined in the framework of analysis, discussed in the final section of this chapter.

Monumental shrines in rural areas are lightening rods for discussions on the conceptualization of the city and its countryside in the ancient Greek world, and of cultural identity and degrees of autonomy in Asia Minor. The first section of this chapter reviews some of the most pivotal theories and the debates they have sparked regarding the interpretations of established sanctuaries in the countryside that have led to this present research.

1 Chwe (2001).

(C) CHRISTINA G. WILLIAMSON, 2021 | DOI:10.1163/9789004461277_003

This is an open access chapter distributed under the terms of the CEhPY-NC 4.OGlicense.iamson - 978-90-04-46127-7 


\subsection{Extra-Urban' Sanctuaries in the Greek World}

The urban-rural axis has become a central component of archaeological discourse on the ancient Greek city. Drawing on the Christaller's Central Place Theory, the Greek polis is perceived to be divided into concentric zones radiating out from the town center, or asty, and its countryside, the chora. ${ }^{2}$ Rural sanctuaries that were once considered remote or isolated in the landscape are now generally seen in the context of the chora, i.e. still within the sphere of urban space, but at points near or far from the nucleus, and are classified accordingly. Coinciding with the core-periphery model is the interpretation of sanctuaries near political borders as frontier sanctuaries, a view that especially gained momentum after the appearance of François de Polignac's seminal work La naissance de la cité grecque in 1984. His 'bi-polar model', which depicts the Greek polis as typically consisting of an urban center with a major 'extra-urban' sanctuary at the border, brought attention to the role of frontier sanctuaries, so much so that 'extra-urban' and 'frontier' are often interchanged as qualifiers. ${ }^{3}$ De Polignac's work is both influential and problematic, drawing criticism for its monolithic view of the Greek city and for the underlying coreperiphery and urban-rural biases. Later alternatives for interpreting grand country sanctuaries turn instead to models of continuity and network theory; these will be explored in the last part of this section.

\section{Sanctuary}

Studies on the ancient Greek cityscape long focused on the formal classification of architectural remains and town planning, e.g. tracing Hippodamian influences, ${ }^{4}$ with shrines in rural settings being typically treated in splendid isolation. ${ }^{5}$ In the 1970 s this began to change as New Archaeology with its environmental bias and Braudel's monumental work on the role of landscape

2 Christaller (1933), schematized in Hölscher (2013), 48, Abb.1.

3 E.g. Voyatzis (1999), 151, drawing from de Polignac (1995), 33-41.

4 See overview in Osborne (1987), 13-26. An important exception is Numa Fustel de Coulanges, whose epic work addressed the city-state, rather than the town, with religion as key to its functioning, de Coulanges (1864); Finley (1977). Also, Louis Robert was keenly aware of role of landscape and climate at the sites he visited in Turkey in the 1930s, evidenced for example in his extensive notes taken en route to the sanctuary of Sinuri; Virgilio (2010). E.g. Castagnoli (1971) and Ward-Perkins (1974) on orthogonal planning.

5 On sanctuaries, Berve and Gruben (1961), and Tomlinson (1976). Scully (1962) is an important exception with its focus on landscape features; Thompson (1963) rejected his thesis due to lack of correlates in classical literature. Also Stillwell (1954) and Lehmann (1954) who took aesthetic criteria into account in temple location, and the ground-breaking Semple (1927) on templed promontories in connection with seafaring. The natural setting of sanctuaries 
in Mediterranean history made inroads on classical archaeology, especially among Anglo-Saxon scholars. ${ }^{6}$ From this time onwards, systematic investigations of the surrounding countryside, including intensive field surveys, began to be an integral part of field research. Robin Osborne was one of the earlier historians to focus on the countryside as the productive base for the classical city. ${ }^{7}$ Religious festivals coincided with agrarian calendars while sacrifices (requiring livestock) served to seal the relationship between city, countryside and the gods. Osborne's model of the classical city depicts cultivated fields worked by citizens who as hoplites also defended their borders; an image in sharp contrast with the later professional armies and increase in city walls. ${ }^{8}$ Osborne's views are rooted in Athens and Attika. Most of the population of Attika is believed to have lived in the countryside, as indicated by Thucydides (2.16.1) and confirmed thus far by survey data. The populations of other poleis in Classical Greece, however, appear to have been concentrated in towns, also indicated by field survey data. ${ }^{9}$ Susan Alcock noted the impact on Hellenistic Greece as local shrines often fell to neglect, while major country sanctuaries continued and even rose in popularity, such as those for Demeter..$^{10}$ But this does not mean that towns were made up of 'city-folk' only, nor that the

is more recently being explored from several angles, e.g. the contributions in Engels, et a. (2019), Häussler and Chiai (2019), and Scheer (2019).

6 Braudel's La Méditerranée et le monde Méditerranéen a l'époque de Philippe II, first published in 1949 with a revised English edition in 1972, revolutionized the study of history by correlating geography, socio-economics and political history. See Cherry et al. (1991) and Bintliff (1991) for the impact on archaeology. Russian archaeology took an earlier turn in this direction, e.g. Rostovtzeff's emphasis on regional economies in the Hellenistic and Roman worlds, Rostovtzeff (1941) and (1957), and Shcheglov's surveys in the northwest Crimea in the 1950s, see Shcheglov (1992) and Carter et al. (2000), 714. Also, German Landeskunde, developing in the nineteenth-century; Kirsten et al. (1956), discussed in Bintliff (2006), 23 .

7 Osborne (1987).

8 Osborne (1987), 164: "The city which in the fifth century had fought for its fields and had maintained its identity through border disputes and the military training which they involved, in the third century was reduced to having a quibble about the unproductive mountains settled by a third party in a piece of diplomatic play-acting. In a process of gradual separation warfare became divorced from the farmland and from the farmer, and the Greek city lost its essential identity."

$9 \quad$ Shipley (2002); Bintliff (2006), but see also the nuances in Lang (1999). Remote sensing and other new technologies of sub-surface surveying are changing scholars' perceptions of landscape use; e.g. for Asia Minor: Pirson (2012) on the countryside of Pergamon, or Lohmann et al. (2019) on Latmos, among numerous others.

10 Alcock (1994). Alcock attributes this to a demographic decline combined with increased competition between wealthy families and cities. Hero-cults were also used in this period to mark places of significance, Alcock (1997). 
landscape was desolate. In the John Bintliff's model, citizens were "farmers by day, urbanites at night," and would typically have owned land within an hour's walk or so. ${ }^{11}$

The difference between city and countryside in this context is more a matter of time and season than a hard division of space. There would seem to be less of a need to use sanctuaries to bind the rural periphery to the urban center if this were a regular part of peoples' lives anyway. Yet the city-countryside axis has been a steadfast criterion in distinguishing sanctuaries over the past decennia, and despite Osborne's and Bintliff's shift in focus to the countryside, the point of reference is still the built-up town center. This is part of the legacy of the Central Place Theory, developed by Walter Christaller in the 193os. ${ }^{12}$ Drawing on Von Thünen's nineteenth-century model of the 'isolated state', with various economic zones radiating from the center, ${ }^{13}$ Christaller's theory presumes a strong hierarchical categorization of space (and society) with a natural inclination towards centralization and an acute awareness of borders. ${ }^{14}$

The core-periphery model has strongly influenced the terminology used to classify ancient Greek cities and their sanctuaries. Terms such as 'extra-mural', 'sub-urban', 'extra-urban', and even the negation 'non-urban'15 all reference an urban context and imply a degree of correspondence between the sanctuary and the political center to which the wider territory belonged. Yet certain major shrines were considered to be far removed from the centers of civilization, especially among the colonies in Magna Graecia. ${ }^{16}$ Scholars in the early twentieth century were at a loss to explain these seemingly isolated cults: if they were as important as their architecture suggests, why were they founded so far away from the centers of power? ${ }^{17}$ Three explanations were developed. The first is the 'indigenous' theory, which proposes that these were native cults later appropriated by the Greeks along with the territory in which they were

11 Bintliff (2006), 30. Ruschenbusch (1985) indicates the size and catchment area of the average polis, with a radius of $5^{-6}$ kilometers and a population of $2000-4000$ persons; Athens was a 'Megalopolis' (cf. the lower figure of 150,ooo estimated by Osborne (1987), 49); Bintliff (2006), 20-23; also Bintliff (2008), and Hansen (2004).

12 Christaller (1933).

13 Von Thünen (1826).

14 Carried further in the World-Systems Analyses of Hopkins and Wallerstein (1982); see also Hall and Nick Kardulias et al. (2011).

15 De Polignac (1995), 32-88.

16 E.g. the shrine of Hera Argiva on the Sele is $8 \mathrm{~km}$ from Poseidonia, the Heraion at Lacinia, $9 \mathrm{~km}$ from Croton, Apollo Alaios on Cape Ciro, $40 \mathrm{~km}$ from Croton; also smaller sanctuaries such as San Biagio, $7 \mathrm{~km}$ from Metaponto, and Francavilla Marittima, $18 \mathrm{~km}$ from Sybaris.

Also Graf (1982), 166; re-addressed in Graf (1996). 
located. ${ }^{18}$ The 'Mycenaean' theory holds that these sanctuaries were remnants from Mycenaean cult-sites, later appropriated by the natives, then finally reappropriated by the Greeks. ${ }^{19}$ Finally, the 'pre-Colonialist' theory assumes they were part of the 'first contact' between pre-colonial Greeks and indigenous peoples, and were later appropriated by the second wave of Greeks as colonists. ${ }^{20}$ All three views have in common the assumption that these cult places pre-date the Greek cities and had further little to do with them; despite its teleological overtones, the use of blanket qualifiers such as 'extra-mural' or 'extra-urban' was actually meant to underscore this distant relationship. ${ }^{21}$

In 1967 , however, Georges Vallet showed that a number of rural sanctuaries also post-date the foundations of the cities; therefore other explanations had to be sought for their location. ${ }^{22}$ He postulated that, rather than being a cultural or historical accident, they were very much relevant to the life of the polis. He broke down the then current singular category 'extra-mural' into 'suburban' and 'extra-urban', emphasizing the relationships of sanctuaries with the cities in their proximity. In his carefully defined typology, sub-urban cults are generally close to town (within 1 kilometer), are low-key and are usually concerned with fertility or agrarian or pastoral issues. Extra-urban cults (typically 7-10 kilometers from town) are again subdivided into two types according to size: the smaller sanctuaries tend to be located on the surrounding hills overlooking the plain of the city, perhaps with small settlements of their own; ${ }^{23}$ the grand monumental sanctuaries, for the civic gods, could be located farther away but were founded with or after the cities to which they were related. As with the smaller shrines, much like the sacred villages of Asia Minor, settlements at these sanctuaries were common, although these are interpreted as

18 Oldfather (1912); Giannelli (1924); Ciaceri (1940), 2off. These theories are further discussed in Asheri (1988), 3, who believes them to be colored by Italian nationalism.

19 Pugliese Carratelli (1962).

20 Dunbabin (1948), 181ff. He takes issue with the 'indigenous' view as proposed by Ciaceri (1940) and builds his theory instead on analogies with colonialism in the British Empire, especially in Australia and New Zeeland; De Angelis (1998).

21 Pugliese Carratelli (1962); Hermann (1965).

22 Vallet (1968), except for San Biagio that antedates Metaponto. Zancani-Montuoro pointed out in her response on p. 170-178 of the same volume that Francavilla Marittima also antedates Sybaris, allowing for indigenous influence. This important observation, however, does not detract from Vallet's main point on the significance of these sanctuaries for the polis, albeit it at a later point.

23 Vallet (1968), 89-91; some sanctuaries in this type were also located along the coast. Either way, they would almost seem to have a protective position around the main settlement. The deities at these sites are unfortunately unknown. 
housing for cult personnel, or sometimes as garrisons when fortified. ${ }^{24}$ Political and historical documents found at these remote sites pertaining to events that concerned the civic body (e.g. decrees, citizen registries, priesthoods) testify to their strong bond with the polis, just as with the case studies from Asia Minor discussed in this volume. Vallet sees these sanctuaries as particularly vital to the political life of the polis, just as the land itself is vital - they anchor the polis to its territory while opening it up to the wider community, transcending its boundaries. ${ }^{25}$ This concept would later be carried much further by François de Polignac.

Since Vallet's work, the categories of 'sub-urban' and 'extra-urban' have become commonplace in studies on sanctuaries, albeit with further nuances and sub-divisions. One of the clearest examples is Ingrid Edlund-Berry's typology, with 'extra-mural', 'extra-urban', 'political', 'rural', and 'nature' as categorical settings for sanctuaries in Etruria and Magna Graecia. ${ }^{26}$ She observes that in Etruria extra-urban sanctuaries are generally an extension of the urban sphere and could be located anywhere, whereas in Magna Graecia they are principally located at territorial boundaries. Like Vallet, she believes these high-profile sanctuaries had mediatory roles: they marked the frontiers of the Greek world while providing "a neutral space as a meeting place for different groups of colonists and perhaps even non-Greeks." 27 In many ways Edlund-Berry's views are similar to Vallet's with the important exception that she attributes less significance to size and distance and more to their function in the human landscape as criteria. This is a crucial distinction, and one which is much more helpful in understanding sanctuaries as part of a sacred landscape

24 Vallet (1968), 93. The role of the military at rural cults deserves more attention in general. Vallet sees the "piccolo città santa" (p. 93, n. 6o) as being fortified during processions and festivals (on the risk of violence at processions, see Chaniotis (2006), 211-213). In his response to Vallet in the same volume, p. 216-220, Roland Martin discusses the suburban cults of Asia Minor as being involved in a peripheral defense system for the city; he further considers certain extra-urban cults to primarily have served the indigenous or mixed populations from the more remote regions, and so functioned as sacred neutral zones for religious, commercial and political interaction.

25 Vallet (1968), 94 : “... une fonction politique active et ceci dans une double perspective: comme marquée d'une empreinte matérielle et surtout morale de la polis sur son territoire et d'autre part comme le lieu géométrique de rencontres, je n'ose dire panhelléniques ou panitaliotés, mais qui, en tout cas, dépassent largement le cadre de la polis.".

26 Edlund-Berry (1988), 41-43. These categories are reflected in Pedley (2005), 39-52, as 'sanctuaries in Nature', 'interurban', 'urban', 'suburban', and 'rural'.

27 Edlund-Berry (1988), 143. She further observes that sanctuaries associated with cities, but also used by non-locals tended to have a more monumental appearance, p. 138 . 
accommodating not just the political, but also the social, economic and, of course, religious spheres.

Several other scholars have further elaborated these categories, adapting them to fit their own particular area of study. ${ }^{28}$ What they all show is how a close examination of the archaeological and historical data leads to a new revision of the theoretical categories, each tailored to the specific questions of the researcher. ${ }^{29}$ David Asheri took an extreme position in 1988 in practically calling for a moratorium on theory until each and every case throughout the Greek world has been analyzed in detail. ${ }^{30}$ Although this is unrealistic, he is correct to show how static and context-sensitive such categories are, and how they hardly accommodate evolving complexities such as synoikisms, territorial expansion, or urban relocations. In short, 'extra-urban' cults may not always have been extra-urban, and he seems to find this category of little use when it comes to interpreting these outlying sanctuaries. ${ }^{31}$ Regarding the situation in Asia Minor, I concur with his views and have therefore avoided the term as far as possible, preferring instead to call them 'country sanctuaries.' ${ }^{32}$ As a heuristic aid such classifications are valuable but can easily lead to unintended associations and retroactive projections when used indiscriminately. The adjective 'country' is less prone to these biases while still conveying the landscape setting as well as a degree of territoriality belonging to the sanctuary

28 The volume Placing the gods, Alcock and Osborne (1994) was especially influential in bringing the studies of outlying sanctuaries to the foreground, with several case studies showing how existing theories, particularly de Polignac's 'bi-polar model' (more below) could be applied, rejected or modified. Although the subtitle of the volume is broadly 'Sanctuaries and sacred space in ancient Greece', nearly all of the contributions concern political aspects of sanctuaries and their relations to borders.

29 Such as Rosina Leone, who like Vallet uses distance as a criterion, besides cult type and function, to classify sanctuaries in the chora of Magna Graecia as 'rural', 'frontier', or 'peripheral'; Leone (1998), 16-18. 'Frontier' sanctuaries in her view are political and generally later than the rest; 'peripheral' sanctuaries were mostly feminine cults and were pivotal because they concerned both the fertility of the citizens and the countryside; 'rural' sanctuaries were more masculine and chthonic, oriented to the local population, Leone (1998), 23-30, 31-35. See also Boffo (1985) for Asia Minor.

30 Asheri (1988).

31 Asheri (1988), 6, 7-10. He continues with three provocative case studies, two sanctuaries in the environs of Messina and one close to Rhegion, to argue that population movements and the creation of new ethnic suburbs within the polis were more likely drivers than external political factors. A common thread with his predecessors, however, is that these sanctuaries served as a point of cultural or ethnic identification, as well as a zone of contact with the outer world.

32 Alternatively they are could also be designated as 'outlying' sanctuaries, although this is also problematic as it implies a single perspective, outlying from where and to whom? 
itself, an aspect particularly relevant concerning the extent of sacred lands owned by the shrines, as well as the extent of their communities.

The studies discussed so far primarily deal with the meaning of the geographical distance of remote sanctuaries from towns and what their relevance was to the community. At the same time, however, a parallel line of thought was being developed on the geography of the gods as a structuring factor in the ancient Greek mind. Scholars focusing on mythology took an early interest in the urban-rural axis while establishing a canon of the Greek pantheon that classifies the realms of the individual gods according to the corresponding areas of human concern..$^{33}$ Oppositions believed by structuralist anthropologists to be universally human were matched to divine domains through sets of oppositions, e.g. male-female, outdoors-indoors, cultivated-wild, rationalirrational, and center-periphery, to interpret ways in which the Greeks conceptualized their world. ${ }^{34}$ This line of thought was subsequently extended to the polis to show how the pantheon of gods and the ideas they embody were intrinsic to the socio-political and spatial organization of the Greek community. ${ }^{35}$ Sanctuaries are at the intersection of the human and divine, and Albert Schachter observed that site location is largely determined not only by natural features in the landscape (e.g. mountains, springs, trees, or passes, roads, transitional areas), but also by their social and political connotations. ${ }^{36}$ The Olympian deities were thus anchored through their shrines to topomorphic types of places in civic territory which corresponded to the social spheres over which they presided. ${ }^{37}$ Sanctuaries to Athena, Aphrodite, Apollo (Pythios) are typically found in the urban center as these three were concerned with

33 See esp. Nilsson's monumental Die Religion der Griechen, 1927. But also Nietsche's Die Geburt der Tragödie aus dem Geiste der Musik, 1872, articulating the archetypal binary pairs of opposites between the Apollonian and Dionysian spirits (e.g. cultural-natural, rationalirrational, creative-destructive, civilized-wild). The later ideas borrowed from structuralist anthropology and applied to Greek mythology have been greatly influential, especially as developed by Jean-Pierre Vernant, Pierre Vidal-Naquet, and Marcel Detienne; Vernant (1965b); Vernant and Vidal-Naquet (1972); Detienne and Vernant (1974).

34 Vernant, for example, discussed the contrast between Hermes and Hestia as embodying the differences in ideals between masculine-outdoors-travel with the feminine-indoorshome (hearth), Vernant (1965a).

35 And how the polis determined religion, see esp. Sourvinou-Inwood (1990). See further Bruit Zaidman and Schmitt Pantel (1992), Cole (1995), and Burkert (1995). Also Morgan's work on the ethnos in a similar vein: Morgan (1990), 1-25; also Morgan (1997) and (2003), esp. 107-163 'communities of cult'.

36 Schachter (1992), 57: site location as "a balance, sometimes delicate, sometimes crude, between the needs of policy and the needs of cult." His study revolves around the sacred landscapes of seven poleis: Argos, Corinth, Eretria, Thasos, Thebes, Athens, and Sparta.

Also de Polignac (1984), see below. 
political organization and civic matters; Dionysos was most at home in the 'irrational' countryside, but so were Zeus and Demeter, who were worshiped there as agrarian deities and at corresponding sanctuaries in town; Hera and Poseidon marked the territorial borders of aggressive poleis, while Artemis sanctuaries are generally found near transitional zones or disputed borders. ${ }^{38}$

Schachter's spatial patterning of the divine, although suspiciously neat, resonates with several sites in mainland Greece. In Asia Minor, however, with its mosaic of cultural influences, many other factors were also at work, producing unexpected combinations, such as 'wild' Dionysos at the center of Teos, or Artemis on the agora at Magnesia on the Meander. ${ }^{39}$ Hekate, guardian of marginal waysides, gateways, and crossroads, became the principal goddess of Stratonikeia. Caution must be used in applying such patterns, and one must take into account the many local variations that made the divine constellation of each polis unique. ${ }^{40}$ Nonetheless, Schachter's work highlights the place of the gods in the wider political, social, and sacred landscape of the polis, and goes beyond the labels of 'urban' versus 'extra-urban' by interpreting the setting of cult through psychology and myth.

\subsubsection{Frontier Sanctuaries and the 'Bi-Polar' Model}

The scholar most often cited with regard to outlying sanctuaries is François de Polignac, who presented his 'bi-polar model' in 1984 in his seminal work $L a$ naissance de la cité grecque. ${ }^{41}$ His argument on the pivotal role of sanctuaries in the rise of the polis acknowledges the topomorphic attributes of the gods, but concentrates on the historical relevance of location. In doing so he elaborates on what he calls the 'non-urban' sanctuary, ${ }^{42}$ although his main concern

38 On Artemis he adds that "In colonies the disputed area, in the early stages of settlement, is the city itself." Schachter (1992), 36. Cole explores in more detail the location of cults for Artemis and Demeter; Demeter Thesmophoros is often a cult that links town to country, usually at the edge of town or in remote places in town, see Cole (1994); on Artemis cults being located at more dangerous border areas, see Cole (1999-2000) and (2004), chapters 6 and 7 .

39 Although highly aggrandized by Hermogenes in the third century BC, both sanctuaries at Teos and Magnesia on the Maeander date from the late Archaic period.

40 Polinskaya (2006). Sourvinou-Inwood (1990), 300-301, 318, who similarly categorizes the gods according to socio-political function, allows room for local variations according to individual polis' pantheons.

41 De Polignac (1984), revised and translated in 1995 as Cults, territory, and the origins of the Greek city-state.

42 Esp. de Polignac (1995), Ch. 2 'The nonurban sanctuary and the formation of the city'. In his discussion of Magna Graecia (p. 92) he identifies four basic categories of sanctuaries: the monumental urban sanctuary; the monumental non-urban sanctuary (his main focus); the non-monumental peri-urban (i.e. suburban) sanctuary; and the non-monumental 
lies with the grand sanctuaries typically situated at the outer perimeters of polis territory, i.e. the 'extra-urban' sanctuaries as Ingrid Edlund-Berry defines them. ${ }^{43}$ These sanctuaries, commonly dedicated to Hera, Poseidon, or Artemis, were in his view instrumental to the formation of the polis. They represent the boundaries of the civilized, agrarian world against the world of the wild and are seen as a means of bringing order to disorder; through these sanctuaries the gods provide true mediation between man and nature. Yet they are also often located at a second kind of border, that of political frontiers. ${ }^{44}$

De Polignac brings these sanctuaries to the fore as he contests the 'monocentric' model of the polis in which the principal sanctuary is located on an akropolis within the town center. While this model certainly applies to Athens and its development in the Dark Ages, it is not typical of most Greek poleis. ${ }^{45}$ The rise of the polis should be investigated not at its center but at the scene of action: the territory and the hardening of the borders that took place in the late ninth and early eighth centuries вС. The agrarian crisis of this time led to the increased cultivation of fallow land, pushing up into the wild regions where remote sanctuaries were (already) located. As Osborne had argued, these became contested areas as communities on either side began to organize themselves into hoplite forces to apply pressure on each other. Remote shrines, once marking the wilderness, were now at the heart of conflict. ${ }^{46}$ These frontier sanctuaries became territorial claims and focal points of pride for the victorious communal body. According to de Polignac this eventually sparked a form of urbanization that became what he calls the 'bi-polar city', with two foci of power: the inhabited center with a great urban sanctuary on an akropolis counter-balanced by a great extra-urban sanctuary located at the periphery of the chora. ${ }^{47}$ These two poles are physically linked through ritual: the festivals taking place at the frontier sanctuary but especially the grand processions

sanctuary in the outer territory. Stek (2009), 58-65 gives a good discussion of de Polignac's ideas in relation to Italic sanctuaries.

43 Edlund-Berry (1988), $75 \mathrm{ff}$.

44 De Polignac also referred to Vernant and Vidal-Naquet in his section on frontier sanctuaries as the prime intermediaries between man and nature or the gods, de Polignac (1995), 34-36, esp. p. 36 n. 3 .

45 De Polignac (1995) 81-88 'The bi-polar city and the Athenian exception'; also discussed above in connection with areal and population sizes of cities.

46 Osborne (1987), 164; de Polignac (1995), 6o: "Religious sites, like the land itself, were the objects of a process of appropriation crowned by the building of a sanctuary that designated the frontier the group claimed for its territory in the face of its neighbor-adversaries."

"The effect of the monumental, liturgical, mythological, and historical importance of the great extraurban sanctuaries is to give the civic and religious space two poles, and it is not the case that the urban pole is the more important," de Polignac (1995), 82. 
leading out from the town across the countryside and to the sanctuary on the border. ${ }^{48}$ Such processions were not necessarily only political but could also involve agrarian rituals or initiation rites, showing how important the cult was to the vitality and future of the community.

De Polignac's ideas are original, greatly expanding Vallet's political interpretation of frontier sanctuaries, and have been influential in raising awareness of the countryside as a vital component of the polis. Despite this, he has drawn heavy criticism for being overly focused on theory and less on solid evidence, and thus imposing the bi-polar model on situations that cannot always bear it. ${ }^{49}$ Also, his emphasis on political boundaries illumines only one aspect of these cults at the cost of several others; not every border sanctuary was political or militant. ${ }^{50}$ Furthermore, his bi-polar model isolates both urban and non-urban political sanctuaries from the abundant sacred landscape in all its diversity, of which they were also an integral part. Finally, he is accused of leaning too heavily on structuralist oppositions, such as core-periphery, citycountryside, civic-wild, all laden abstractions in themselves. ${ }^{51}$

Nonetheless, de Polignac's thesis has inspired several studies on outlying cult places which have brought important nuances to this model. ${ }^{52}$ Fritz Graf, for example, discussed the ritual of processions with regard to the momentum of direction: centripetal processions drew the demes of the chora into the center of town, e.g. the Panathenaia, or the Great Dionysia, while centrifugal processions crossed the countryside to a remote sanctuary. ${ }^{53}$ Tonio Hölscher discusses the processions to major shrines in the chora of Attika as a means of

48 De Polignac (1995), 40-41. De Polignac's archetype is Argos and the Argive Heraion, on a promontory across from Argos and overlooking the fertile Argive plain: de Polignac (1995), 41-43 and 52-53. Cf. Hall (1995), who argues for a much later date for Argos' appropriation of the Heraion. Bintliff (1977b), 98, in a discussion of ceremonial landscapes, addresses processions as power displays, drawing on Vogt (1968).

49 Esp. the Argive Heraion, Hall (1995); on the sanctuaries in the chora of Metaponto, Carter (2006), 16o and pers. comm. 11.2006; on the sanctuary at Francavilla Marittima, Kleibrink et al. (2004), 52; on the Heraion at Foce del Sele, Malkin (1996), 78.

50 De Polignac also recognizes the role of border sanctuaries as places of meeting and mediation, de Polignac (1995), 36 and de Polignac (1994). For frontier sanctuaries as sacred channels of safe passage, see Sinn (1996).

$5^{1}$ Antonaccio (1994), 81-86 and Polinskaya (2006), 65. An overall assessment is presented in McInerney (2006), 37-38 and Pedley (2005), 52-56. Against the core-periphery model in general, see Sherratt (1993), "Who are you calling peripheral?" Dependence and independence in European prehistory'.

52 Most notably the contributions in Alcock and Osborne (1994), Placing the gods. See also Susan Guettel Cole's application of de Polignac's ideas (among others) in interpreting the role of the female in ritual landscapes, Cole (2004). 
creating spatial hierarchy in the territory of the polis; similar motivations may also be found behind the New Year processions from Miletos to Didyma, as Alexander Herda has argued. ${ }^{54}$

Frontier sanctuaries could also fulfill a different political role: one of providing safe passage across territorial borders, something that was not taken for granted in an era when raids and political violence were considered normal. Ulrich Sinn considers this function for several sanctuaries in the Peloponnese located on mountain ridges that border two or three political territories; they are in rugged and inhospitable terrain, but were highly visible due to their monumental architecture and prominent locations. ${ }^{55}$ Rather than aggressive signs of territorial claims, Sinn sees these frontier shrines as thresholds, creating access and platforms of communication through the joint festivals that were held there, rather than in the towns of the mutual parties; invitations were de facto treaties of friendship between poleis. ${ }^{56}$ The rise of the recognition of asylia and the invitation to panhellenic games in the Hellenistic period is testimony to such gestures of goodwill on a 'global' scale, in which outlying political sanctuaries occupied this mediatory role; this is discussed in more detail with regard to the sanctuary of Hekate at Lagina in Chapter 5 .

There was also an economic side: poleis that could be accessed via these sacred channels were more likely to prosper as they attracted trade via wandering workshops, traveling artisans and artists. ${ }^{57}$ Country sanctuaries facilitated contact across different kinds of economies. James McInerney postulated that the risk factor implicit in the civilization-wilderness polarity is much more fundamental to the mental structuration of space than the urban-rural axis. ${ }^{58}$ Wilderness areas are typically used for grazing, and pressure on borders often

54 Hölscher (2013); Herda (2006) and (2011).

55 Sinn (1996), 70-74, e.g. the joint organization of the frontier sanctuary to Artemis Hymnia by Orchomenos and Mantineia. He develops the idea of asylum and major outlying sanctuaries put forth in Sinn (1993), 102-107; few of these shrines have been excavated, and he largely draws on Pausanias.

$5^{6}$ Sinn discusses the example of the sanctuary of Artemis Limnaia at the frontier between Messenia and Lakonia. Apparently this was contested space between the two poleis and yet they held joint festivals here, with common assemblies and sacrifices, Sinn (1996), 71, and n. 23. De Polignac also discusses the meditatory role of sanctuaries, more in the context of peer-rivalry in quasi-neutral zones, de Polignac (1994).

57 Cycladic construction techniques in Alipheira, and Corinthian tiles in Aetolia are examples of 'wandering workshops'; the Artemision of Ephesos, protected through the grant of asylum, functioned as an international bank in the Hellenistic period, Sinn (1996), 67-68. Debord (1982), 24-25, also on sanctuaries with the status of asylia as providing additional safe access and economic protection.

$5^{8}$ McInerney (2006), 38, 56. He refers to Vidal-Naquet on the use of wilderness in civilization, p. 39 n. 21. 
came from the pastoral sector, marginalized by the expanding cultivated fields. The best lands available were sometimes made sacred in order to avoid claims and disputes. Herds were generally allowed to pass through while grazing, as Sinn argued, or during festivals for the sacrifices. ${ }^{59}$ However laws ensured short stays to prevent both overgrazing and squatters' claims. ${ }^{60}$ The ongoing stabilizing effect on the community and its economy that remote sacred areas held is precisely due to their neutral position.

The location of country sanctuaries may be determined by a mix of factors. Proximity to cultivated lands, natural features, areas too wild or remote for human habitation are only some of the reasons. ${ }^{61}$ Others will have began as centers of their own local communities, only later to be absorbed and marginalized through synoikism and annexations by larger poleis, as with Magna Graecia but also some of the cases in this study. Still others may mark the direction of future territorial advancement. Irad Malkin uses de Polignac's model to explain the sudden appearance in the early Hellenistic period of sanctuaries of Zeus Ammon along the western border of the territory of Cyrene, encroaching upon rival Carthage. ${ }^{62} \mathrm{He}$ sees the real value of de Polignac's model in understanding the later Hellenistic development and expansion of poleis. ${ }^{63}$ Elif Koparal notes the richness of the ritual landscape in the frontier zone between Klazomenai and Teos, but sees the shrines as part of a larger sacred network. ${ }^{64}$ Susan Alcock interprets rural shrines as central to the construction of urban identity and internal awareness of territory, rather than as frontier markers to other communities. Major rural cults continued to play an important role as a ritual way for "urban dwellers" to "take possession" of their land, even in the Roman period, while at the same time providing an outlet for the urban elite to manifest themselves. ${ }^{65}$ This is what made them so attractive to Rome as controlling devices - they could be either amplified, e.g. through the addition of the imperial cult, or dislocated in adverse regions as frontiers were redrawn. ${ }^{66}$

\footnotetext{
$59 \operatorname{Sinn}(1996)$.

6o McInerney (2006), 53-55.

61 E.g. Nordquist (2013); Miles (2016); Koparal (2019).

62 Malkin (1996).

63 Malkin (1996), 81, using de Polignac's concepts in what he calls a "pragmatic approach" rather than the "heavy-symbolism "intentionalist" methodology.

64 Koparal (2019), also discussing the re-use of older shrines.

65 Alcock (1993), 161, on the changing sacred landscape of Greece under Roman rule further observing an overall decline of minor rural shrines.

66 Cults were thus used as a disciplinary measure; e.g. the cult image of Artemis Laphria of Kalydon in Aetolia was reassigned to Nikopolis and Patras; Tegea lost the cult statue of Athena Alea to Rome, Alcock (1993), 157-158. This is similar to Pompey's radical
} 
These studies demonstrate the very wide variety of shrines labelled by scholars as 'frontier' sanctuaries, from the archaic era through to the Roman period, underscoring how difficult it is lump them together under any one category other than their relative location. A common current, however, is the general acceptance, albeit tacit, of the core-periphery model and urban-rural bias as explanatory for their function.

\subsubsection{Opposition: the Continuum Perspective}

The polarity between town and countryside has been called into question by scholars who consider it to be a modern, post-industrial paradigm retrojected onto the Greek mind. The terminologies used to qualify sanctuaries according to location (e.g. 'sub-urban', 'extra-urban', even 'non-urban') implicates the urban bias as starting point, as mentioned above. The Greeks themselves only used descriptive terms - a sanctuary was in the chora, near local landscape features (e.g. on a mountain or hilltop, by a stream or forest, etc.) or near town pro poleos, 'before the town', indicating the outsider perspective of farmer or traveler. ${ }^{67}$ Terms were often loosely used in antiquity and the word polis could equally refer to a political community, urbanized or not, its wider territory, or just its built-up center. Yet over the years, modern scholars have subjected these terms to extensive definitions and refinements in order to produce a heuristic vocabulary. ${ }^{68}$ In this respect, asty and chora are now the primary terms used respectively for the built-up center and the surrounding territory; together they constitute the geographical polis as we know it, but we should not assume they were as strictly defined in antiquity.

Studies on the ancient polis generally distinguish between town and country with the goal of drawing the countryside into the picture as a serious object of study in itself. Until recently this distinction has seldom been questioned. In social studies, however, objections to this classification were already being raised long ago. In searching for a good description of the difference between peasants and city-dwellers in Latin America, anthropologist Robert Redfield

reorganization of the area around the powerful sanctuary of Pontic Komana, one of Mithridates's hearths during the wars, see Debord (1982), 6o-61.

67 E.g. the City Dionysia of Athens, $\Delta$ เovن́

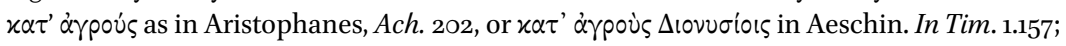
see Polinskaya (2006), 67-74, and n. 32. Demeter sanctuaries are often described as being

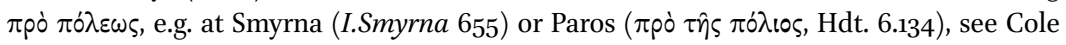
(1994), 211-212.

68 E.g. Sakellariou (1989), Hansen (1997) and (2007) and the publications of the Copenhagen Polis Centre. Hölscher (2013), 48 Abb. 1 gives a scheme showing the concentric circles from asty to eschatia (the outer ring of the chora). 
came to the conclusion in 1953 that dividing societies along a rural-urban dichotomy was too simplistic and ignored the wide spectrum of variations. ${ }^{69}$ He introduced instead the concept of a 'rural-urban continuum', a term that acknowledges the opposition while negating it at the same time. Regarding town and country in ancient Greece, Sally Humphreys decided that the terminology in question pertains to "a potential contrast which in any given society may be minimized (continuum) or emphasized (dichotomy)."70 Factors that in her view should considered include: the degree of centralization, i.e. size and densities of settlements (nucleated or dispersed); popular beliefs or attitudes about city-dwellers versus country-dwellers; hardness of boundaries, both physical (walls) and institutional (laws, policies); and the degree of traffic between the boundaries. ${ }^{71}$ Time is also an important measure. In an effort to understand the rise of federal sanctuaries, Emily Mackil argues that country shrines generally developed from the interaction between multiple local or regional communities, rather than being a sign of territorial domination by a sole polis. $^{72}$

The distinction between town and countryside is thus not always as clear cut as it might seem. Even the juxtaposition of the two entities exposes the implicit modern values ascribed to either category. Irene Polinskaya demonstrates that de Polignac's bi-polar model, while bringing attention to the countryside, in fact hardens the opposition through its either/or approach, leaving between the poles only empty 'space', space that is in reality teeming with life social, economic, political, and sacred. ${ }^{73}$ Such neat abstractions cannot do jus-

69 Redfield (1953), arguing that the farmer, the vagrant, and the suburbanite all make use of the countryside in different ways. Useful discussions of this are found in Wheatley (1972), 602-6o5, and Stoddart (1999), 910. The term 'rural-urban continuum' has also been used by the U.S. Census Board in county classification; wayback.archive-it .org/5923/20120620120804/http://www.ers.usda.gov/Briefing/Rurality/RuralUrbCon.

70 Humphreys (1978), 134 .

71 Asheri's theory on the relocation of certain ethnic groups to just outside the city walls in Messina, with extra-urban sanctuaries to 'service' these groups, shows one of the complex situations in antiquity, Asheri (1988), mentioned above. See also Bintliff's anthropologically inspired approach to Minoan and Mycenaean peak sanctuaries as ritual places which were fully integrated with the cycle of the landscape and the economic needs of the communities, Bintliff (1977b), 92-104 in his section on 'Ceremonial sites and the landscape', and especially 98-104; discussed in more detail in his dissertation Bintliff (1977a), 145-170.

72 Mackil (2013b), 149: "It now seems unlikely that poleis initially demarcated their territories by the construction or monumentalization of rural sanctuaries at the borders. Rather, it appears that religious communities existed prior to the formation of particular political communities, and the former had a deep impact on the creation of the latter."

Polinskaya (2006). 
tice to the great variety in cults and sanctuaries or the 'local religious worlds' of communities, many of which preempted the processes of urbanization. ${ }^{74}$ In her view, qualifiers such as 'extra-mural' are meaningless as city walls just followed the defensible contours around the settlement, and are a relatively late phenomenon. ${ }^{75}$ Political centers come and go, so any spatial reference to these must include the dimension of time. Finally, when it comes to cult, the categories of 'urban', 'sub-urban' and 'extra-urban' flatly ignore the uniqueness of each polis' constellation. Instead of subdivisions based on oppositions, Polinskaya argues that sacred topography of a polis should be approached as "a religious and spatial continuum. ${ }^{76}$ Like Asheri, Polinskaya calls for a detailed approach that considers each polis as a unique entity; unlike him, she expects too many differences to warrant any generalizing theories.

Studies on the extent of polis territory lean more towards a continuum view. Bintliff estimates that the most poleis would have had been small, with a territorial radius of maybe five or six kilometers and a population of 4000 to $6000 .{ }^{77}$ Citizens would have been intimately familiar with the surrounding landscape where the base of their livelihood lay. The shrines of these poleis, however distant from the town center, would normally have been much closer together, and hence more frequently accessible, than in a megalopolis such as Athens. This generally fits Horden and Purcell's view of the Mediterranean as a network of micro-regions, or 'micro-ecologies', each with its own unique topographical situation, often bordered by natural features such as mountains, rivers, or sea. ${ }^{78}$ Though less adamant than Polinskaya, they also envision ritual

74 Polinskaya (2006), 65: "The main source of religious diversity was the existence of multiple local religious worlds corresponding to the geo-political fragmentariness of the Greek world throughout antiquity."

75 Polinskaya (2006), 76-77, arguing that the Greek city had nothing like the Roman pomerium. Yet walls arguably had a representational value, e.g. the many images of Tyche crowned with city walls. Moreover the increased zoning of burial sites indicates a clear demarcation between the space of the living and that of the dead.

76 Polinskaya (2006), 8o, 85. One of her examples are the many sacred places connected by the Molpoi procession from Miletos to Didyma. This inscription, LSAM 5 , is discussed extensively in Herda (2006). Graf saw this same inscription as lending support for centrifugal procession typical of the bi-polar model, referring to the space between the two poles as 'wild'; see above and Graf (1996), 65.

77 Bintliff (2006), citing Ruschenbusch (1985). The figures are drawn from Greece proper, and do not include the colonial cities of Magna Graecia, which generally had larger territories with larger populations; see the inventory of the Copenhagen polis Centre, Hansen and Nielsen (2004) and now Hanson and Ortman (2017).

78 Horden and Purcell (2000), esp. 403-46o, "The geography of religion" in their monumental work The corrupting sea. They clearly state that their views are neither Durkheimian (i.e. religion as the reflection of social cohesion) nor Marxistic (i.e. religion as imposed by 
topography as reinforcing a continuum of city and countryside. ${ }^{79}$ They stress how tightly integrated it was with the 'productive environment', situated in the economic countryside as well as at sanctuaries, with trade opportunities through the seasonal fairs during the festivals. ${ }^{80}$ The sacred landscape also overlaps with the 'perilous environment'; places of cult could be perched at numinous but also dangerous, albeit sublime, positions in the environment. ${ }^{81}$ Such places were commended to the gods while their prominent sanctuaries acted as a signpost for mortals. ${ }^{82}$ A third role concerns their interaction with the wider environment, inducing mobility and facilitating regional alliances. As Sinn and McInerney had noted regarding frontier shrines, Horden and Purcell stress ways that sacred journeys to remote sanctuaries intentionally crossed and connected various kinds of ecological zones, involving different production types (e.g. agriculture, herding, fishing, hunting) and different types of terrain (e.g. plains, forests, mountains). ${ }^{83}$ As points of connection, sanctuaries were often located at passages where one domain crosses over into the next. Because of this they could also be buffer zones between territories; e.g. Corinth and Megara were separated by the sanctuary of Poseidon at Isthmia, and Megara and Athens were separated by the sanctuary of Demeter at Eleusis. In fact, because many of the major rural sanctuaries antedate the poleis with which they came to be associated, Horden and Purcell believe it likely that the siting of the city was predicated on the region of the sanctuary, rather than vice-versa. ${ }^{84}$

decision-takers) nor do they suggest any kind of environmental determinism, p. 406-407. There is no room here to provide an adequate assessment of their monumental work; for critical reviews see, among others, Lucia Nixon in JRS 92 (2002), 195-197; Anthony Molho in the Journal of World History 13 (2002), 486-492; James Fentress \& Elizabeth Fentress in Past \& Present 173 (2001), 203-219 ('The Hole in the Doughnut').

79 Horden and Purcell (200o), 435-436, $45^{2}$.

8 o Cf. Debord (1982), 24-25; Sinn (1996); Chandezon (2003); McInerney (2006).

81 Semple (1927); Nordquist (2013) argues that Greek sanctuaries were rarely located in numinous settings; also Williamson (2020a) on sanctuaries and the sublime.

82 Shrines could be used to mark perilous places, or for wayfinding: e.g. Semple (1927) on dangerous 'templed promontories' and Nixon (2006) on the role of roadside chapels and icon stands in medieval and modern Sphakia on Crete, which both shape the sacred landscape and are shaped in return by the roads they mark. New Roman highways had a similar impact in Etruria, e.g. Ward-Perkins (1972).

83 Sinn (1993) and (1996); McInerney (2006) discussed above.

84 "The location of cities, then, did not bring about the construction of shrines in between them. Rather, religious imperatives led to the construction of shrines in out of-the-way places: cities subsequently developed on the nodes in the routes joining these sacred places," Horden and Purcell (2000), 457. This would accord with Turner Turner (1973), briefly discussed in the introduction; also Dignas (2002a), 243. An example in Asia Minor 
Sacred landscapes can shift in composition and especially meaning. Time, again, is a crucial factor in the ways that sanctuaries were perceived and in the roles that they were given, but also in the configuration of sacred movement across the landscape. Modifications to this space are therefore highly significant as they can manipulate, change, or reengineer the common experience; this is particularly the case where sanctuaries or other landmarks, especially tombs, are concerned. Viewing sanctuaries as magnetic elements in a spatial continuum means that they must be seen against the complexities of their landscapes, and cityscapes, in a fluid way that incorporates movement and change. Phenomenological approaches to space offer some guidelines into the many alternative ways of approaching space, such as Tim Ingold's 'taskscapes', focused on functionality, or Christopher Tilley's social and existential space, among other types. ${ }^{85}$ Each kind of space, and the symbols, boundaries, and stories that it harbors, will come with its own kinds of experience and prescribed ways of moving through it, reinforced by pathways, monuments and inscriptions - experiences that were clearly entangled. ${ }^{86}$ Much more than a background, landscape is a chronotopic actor in this signifying system. The studies discussed here invite us to go beyond focusing on the civic, political, urban or rural value of individual country sanctuaries. What if we could truly consider them within the complexities of their extensive and dynamic networks - sacred, political, social, economic, and personal? This would surely lead to a much richer understanding of ways that they actually integrated landscape and community.

\subsection{Classifying Sanctuaries in Asia Minor - Greek/Anatolian or Urban/ Rural?}

The western coast of Asia Minor is dotted with Greek cities and major sanctuaries yet has largely been left out of discussions of 'extra-urban' shrines. At the same time this facet has been of little concern to scholars of Asia Minor. Studies of sanctuaries in this region have instead followed a very different path from those of the mainland or western Greece. Rather than their location vis-à-vis urban topography and civic territory, these shrines are usually

is the sanctuary of Zeus Chrysaoreis, of the Chrysaoric League, as one of the factors in the siting of the colony of Stratonikeia, discussed in Şahin (1976); see below in Chapter 5 .

85 Ingold (1993), (2000), (2011). Tilley's other spaces include somatic (unconscious) space, perceptual (ego-centric) space, architectural (inside-outside) space, and cognitive (theoretical, abstract) space; Tilley (1994), 16-17, also (2004).

86 It goes beyond the scope of this volume to discuss the impact of this in detail, but see the contributions in: Wescoat and Ousterhout (2012); Cusumano et al. (2013); Kristensen and Friese (2017); Friese et al. (2018 (forthcoming)). 
assessed according to their cultural or ethnic identity, specifically along an Anatolian-Greek axis. This is among others due to the availability of sources, which for a long time was largely restricted to epigraphy, falling principally within the domain of specialists. But it especially has to do with the longstanding authority of Sir William Mitchell Ramsay, who opened his 1890 work The historical geography of Asia Minor with a discussion of 'Hellenism and Orientalism' as a general principle. ${ }^{87}$ Ramsay traveled extensively and was drawn in particular to the large sacred complexes like Pessinus, the two Komanas (in Pontos and Kappadokia), and the sanctuary of Men Askaenos near Pisidian Antioch. Strabo, writing in the Augustan era, describes such cultrun 'poleis' as extremely wealthy with vast estates. ${ }^{88}$ Ramsay took this to be commonplace throughout Anatolia:

It is well known that in pre-Greek time a large part of Asia Minor was portioned out in theocracies, i.e., priest-kings representing the god, at great sanctuaries ruled over a considerable district whose population were servants and subjects of the central hieron. ${ }^{89}$

Lack of evidence notwithstanding, Ramsay's conceptualization became the prevailing model and was followed by such luminaries as Rostovtzeff and Tarn..$^{90}$ Moreover, these Anatolian independent theocracies were considered to be naturally antagonistic with the more 'secularized' Greek polis-model that overran most of the countryside by the later Hellenistic period. This

87 Ramsay (189o), 23 Part I. Ramsay's travels to Asia Minor were intended to highlight the historical inaccuracies of the Bible, which he was, however, unable to do: "I set out to look for truth on the borderland where Greece and Asia meet, and found it there. You may press the words of Luke in a degree beyond any other historian's and they stand the keenest scrutiny and the hardest treatment ..." Ramsay (1915), 89. Many see him as a protagonist of evangelical Christianity and the authority of the Bible, claims which he himself never made.

88 Strabo 12.5.3 on Pessinus: 'The priests were in ancient times potentates, I might call them, who reaped the fruits of a great priesthood, but at present the prerogatives of these have been much reduced, although the emporion still endures' (transl. H.L. Jones (1928) The geography of Strabo, LCL 211). On Strabo and the so-called temple states, see Isager (1990), 82, who discusses how Strabo's focus was the polis, and in the vast and sparsely urbanized areas of central Anatolia, these large 'states' were the closest thing to a polis that he knew.

89 Ramsay (1911), 37, the first lines of his 'Sketches in the religious antiquities of Asia Minor'; he continues, stating that it was "a necessary characteristic of such a theocracy that there should be only one centre, one hieron, one sanctuary."

$90 \quad$ E.g. Rostovtzeff (1923), and (1941), 505ff; Tarn (1931) (later revised with R.D. Griffith in 1931). The term 'temple state' is a modern concept imbued with vagaries, discussed in Isager (1990), 82-84; Sökmen (2009). 
polarization of Oriental versus Hellenizing influences underpinned academic studies of Asia Minor and was only challenged when scholars such as Louis Robert, Alfred Laumonier, Mario Segré, Franciszek Sokolowski, and Thomas Broughton began to study the epigraphic record and to better comprehend the diversity and complexity of society, institutions, and religious organization through the priesthood, sacred laws, and temple economies. ${ }^{91}$

The simplicity of Ramsay's model, however, also accounts for its tenacity. It took nearly a century before alternative and much more nuanced views of sanctuaries in Hellenistic Asia Minor began to develop, principally through the work of Pierre Debord, in his Aspects sociaux et économiques de la vie religieuse dans l'Anatolie gréco-romaine, published in $1982 .{ }^{92}$ Rejecting Ramsay's bias of ethnicity, Debord considers the organization and function of sanctuaries in nearly every regard - except religious - and, in keeping with his times, suggests that the urban-rural axis is a much more informative lens for viewing their spheres of operation. While Debord primarily takes a lateral look at shrines (as does this present study), Laura Boffo focuses on their hierarchical role as socio-political mediators between ruler and community in her thesis, Ire ellenistici e i centri religiosi dell'Asia minore, published in 1985 , only three years after Debord's. Based on Strabo and epigraphic data, she distinguishes types of shrines by their degree of autonomy. ${ }^{93}$ Autonomy is central to the third pillar discussed in this section, Beate Dignas's thesis, Economy of the sacred in Hellenistic and Roman Asia Minor, published in 2002, but she deals with this very differently than Boffo and Debord. ${ }^{94}$ Discarding their categories, she takes the view that shrines in Asia Minor had an innate authority and always operated as independent nodes within a triangular relationship that also involved cities and rulers.

Through the lens of these three major works, this section explores the different categories of sanctuaries in Asia Minor according to their geographic, social and political role, as well as their institutions and institutionally acknowledged statuses. Besides their location in civic topography, these are all relevant towards understanding the functioning of sacred centers in Greek cities in Hellenistic Asia Minor and are integral to the framework of analysis, applied throughout the rest of this volume.

91 This is just a selection of scholars and their works: e.g. Robert (1937), also (1935c); Laumonier (1958); Segré (1936) and (1948); Sokolowski's reference work on sacred laws, LSAM; and Broughton (1951); also of course Jones (1940). A good overview of this early development is given in Virgilio (1987), see also below.

92 Debord (1982) is the publication of his doctoral thesis from Besançon in 1976.

93 Boffo (1985).

94 Dignas (2002a). 


\subsubsection{Categorizing Sanctuaries in Hellenistic Asia Minor}

Pierre Debord is one of the first to holistically address religious centers in Hellenistic Asia Minor and to look beyond ethnic labels in his assessment of them. His aim is to situate religious institutions, in all their diversity, within a rational environment driven primarily by economy and social rank, but also as one that was subject to change. He continues the general line of inquiry of previous scholars, mentioned above, in focusing on aspects of trade, finances, and hierarchical organizations. ${ }^{95}$ But he clearly opposes Ramsay's polarized view of sanctuaries in Asia Minor as being either central to an indigenous theocracy or dominated by a Greek polis. ${ }^{96}$ While acknowledging the difference between Greek and non-Greek perspectives, he argues that their many forms of expression do not permit a binary division into neat silos, isolated from each other. The various local populations were probably long exposed to ideas imported from abroad, just as the Greeks in Asia Minor were themselves open to new influences that were continually changing their own constitution. This "compartmentalized mosaic" of cultures, as Debord calls it, ${ }^{97}$ thus renders any distinction meaningless that does not transcend the simple dichotomy between the (eastern) non-Greek 'temple state' complexes on the one hand and the (western) Greek polis sanctuaries on the other. He therefore introduces a third and middle category: the 'indigenous' shrines, typically the center of village clusters. ${ }^{98}$ These three categories also represent the main types of economies and social organizations, and are related to their geographical locations and degree of institutionalism, discussed further below.

This overlaps somewhat with the criteria that Boffo uses in interpreting the mediating roles of sanctuaries. ${ }^{99}$ Especially in examining dedicatory and honorific inscriptions, she highlights the appearance of keywords such as eunoia (goodwill), asylia (inviolability), ateleia (tax exemption), and eusebeia (piety) as the primary signifiers in transactions between ruler and community that

95 Summarized in Virgilio (1987), 345-350.

96 Debord (1982), Chapter 5, 'Théories antagonistiques et testimonia', 127-139. Ramsay's interpretations are now also generally dismissed in the new publications of his notebooks at the Pisidian Antioch, Ramsay et al. (2006).

97 Debord (1982), 291.

98 Debord (1982), 163-169, and somewhat reminiscent of Vallet's depiction of extra-urban sanctuaries in Magna Graecia discussed above, Vallet (1968), 89-93. A similar tri-partite division is used by Brandt (1992), 67-72, for Pamphylia and Pisidia, although his middle category includes the larger 'halbautonomer' sanctuaries located in the chora of a polis, but mostly economically independent, e.g. Apollo Didymeus, Artemis Pergaia, the Athena temple at Ilion, and Men Askaenos of Pisidian Antioch, much like Boffo's categories 5 and 6.

99 Boffo (1985) and (2003). 
were negotiated via the main sanctuary and its cult. For example, a royal grant of inviolability (asylia) for a sanctuary would typically be followed, or sometimes pre-empted, by the community's praise for the ruler's goodwill (eunoia) and piety (eusebeia), sealing the bond between both parties via the sanctuary and its cult. Rulers and communities typically relied on religion as a channel of diplomacy to secure what they needed from each other - for the ruler this was local support and loyalty, for the community royal support and protection, and for the sanctuary direct benefactions. This implies an intimate and fluid relationship between a sanctuary and its community, the one standing as symbol for the other.

In order to come to grips with the social and political significance of religious centers and how they mediated royal benefactions, Boffo distinguished nine categories of sanctuaries, depending on the organizational type of community, regional influence, and degree of political autonomy (see Table 2.1). Sanctuaries appearing in different categories underwent a transformation over the course of this period.

Of these, sanctuaries that involved a polis (category 6), are the most prominent and comprise the bulk of her work. ${ }^{100}$ Expressions of mutual goodwill were readily formulated between rulers and the local administrative bodies, the boule and demos (council and assembly), and created a moral if not juridical bond of co-commitment. The stakes were typically eleutheria (freedom) or autonomia (freedom to use own laws) in exchange for complete loyalty to the king. ${ }^{101}$ With their divine authority, sanctuaries were the ideal means of procuring both - a royal display of regard for a shrine would be met with the highest praise and honors from the associated polis. Seleukid support in rebuilding the temple of Apollo at Didyma became the binding political connection between the rulers and the city of Miletos. According to Boffo, the Seleukids were primarily interested in the renown sanctuary and its oracle, but the Milesians understood the language of diplomacy and knew how to turn this to their advantage. ${ }^{102}$

\footnotetext{
100 Boffo's chapter on 'sanctuaries associated with cities', $145^{-267}$, takes up a third of the book.

101 Eleutheria became a pivotal phrase especially in the later relationship between Rome and the Greek cities, e.g. the 'slogan of freedem', Dmitriev (2011).

102 Discussed in detail in Boffo (1985), 174-185, esp. 178-179.
} 
TABLE 2.1 Boffo's nine categories of sanctuaries in Hellenistic Asia Minor, with examples (Boffo 1985)

Boffo's categories of sanctuaries and communities, with examples

1 Grand ethno-tribal temple complexes, commonly called 'temple states'

2 Indigenous 'urbanized' sacred centers known as 'sacred cities'

3 Sacred villages (hierai komai) that evolved to urban status

4 Indigenous sanctuaries of local influence (katechon, hierai komai, those with theophoric names, or topographical epithets)

5 Temple complexes as centers of leagues, or with panegyrics, autonomous from a polis

6 Major Greek sanctuaries belonging to a Greek polis but with a degree of autonomy (cases of asylia or ateleia, or euergesia and eusebeia, etc.)

7 Religious centers reorganized by royal authority

8 Sacred centers that were incorporated into the territory of new Macedonian cities

9 Cult centers resulting from the official consecration of a city to a deity
Komana of Kappadokia and of Pontos (Ma); Zela (Anahita); Kabeira (Men Pharnakos); Pessinus (Meter/Attis); Olba (Zeus); Pisidian Antioch (Men)

Kastabala (Artemis Perasia/Kubaba); Mopsos; Metropolis (Meter)

Aphrodisias (main example) a $^{\mathrm{a}}$

Hierocaesarea; 'Attouda'; 'Apollonoshieron', 'Dioshieron'; 'Aizanoi' (Zeus); 'Astyra' (Astyrene); Larisa (Apollo

Larisenos)

Athena Ilion; Panionion; Karian leagues at Lagina (Hekate), ${ }^{\mathrm{b}}$ Panamara (koinon of the Panamareis); Hyllarima; Alabanda ('Antiocheia of the Chrysaoreis'); Labraunda; Mylasa; Lykian League at Patara (Apollo Patroos oracle); Perge (Artemis - panegyria) Sardis (Artemis); Ephesos (Artemis, Demeter Karpophoros); New Kolophon (Apollo Klaros); Priene (Athena Polias); Miletos (Apollo Didymeus); Teos (Dionysian Technitai); Magnesia on the Maeander (Artemis Leukophryene); Smyrna (Aphrodite-Stratonike; Meter Sipilene); Pergamon (Asklepios); Aigai (Apollo Chresterios); Amyzon (Artemis); Mylasa (Labraunda); Mylasa (Sinuri); Kastabos (Hemithea) Hierapolis in Phrygia (main example)

Antigonia/Alexandria Troad (Apollo Smintheus at Chrysa); Pisidian Antioch (Men); Nysa (Pluto \& Kore); Stratonikeia (Lagina-Hekate; Panamara-Zeus); Apollonia Salbake; Alabanda/Antiocheia of the Chrysaoreis (Zeus Chrysaoreus/Apollo Isotimos); Tralles (Zeus Larasios); Laodikea (Zeus 'Diospolis')

Xanthos (main example)

a The sanctuary of Athena at Ilion, in category 5, might also be included here - Debord surmises its phases, from sacred territory to sacred village, to town, and eventually to city, as typical for Asia Minor, Debord (1982), 177 .

b A better example would have been Hiera Kome near Stratonikeia, with the sanctuary of Zeus Chrysaoreus: one honorific decree by the Karian-wide Chrysaoric League was found at Lagina (I.Stratonikeia 1418), but it was not their center. 
Debord goes even further in arguing that sanctuaries were central to the process of urbanization that was brought on by rulers as they sought to create a denser structure of administrative centers in the landscape. ${ }^{103}$ This is why he maintains that the greatest bias for distinguishing sanctuaries is 'urban' versus 'rural', since sanctuaries in or near towns were most affected by 'global' ideals while those in rural areas were, in his view, generally bypassed from this evolution. ${ }^{104}$ This was not just a top-down process; at the local level it seems to have led to an internal response from communities eager to obtain royal support and regional status, as the example of Didyma shows. Reciprocity was important in the relations between the central ruler and the local community: sanctuaries were a key factor, not only as public advertising, but also for their integral value to the community. A number of stakeholders may be identified in this process. For rulers, shrines were linchpins in their "politics of fidelity"105 with the goal of establishing order and stability. ${ }^{106}$ Royal protection and economic sanctions that would be widely recognized were exchanged for the loyalty of the community, particularly in providing access to strategic places for the military but also to the sanctuary's resources (e.g. treasury) in times of need. At the other end, a community could take the initiative in securing their position with royal authorities by pro-actively issuing decrees of praise and gratitude, inducing

103 Debord (1982), 177. The polis was clearly instrumental to the success of Alexander's conquests, e.g. Fraser (1996), van Nijf (2008). See also Aperghis (2005), linking the development of Seleukid urbanization in Mesopotamia with intensified agricultural exploitation and the need for administrative centers that could handle royal monetary exchange.

104 Debord (1982), 99-100, especially in the Roman period, but also reflected in his views of Hellenistic Karia in Debord (2003) and (2005); see also Ricl on Roman Lydia and Phrygia, Ricl (2003), 79: “... a distinction should be drawn between remote rural sanctuaries frequented by villagers and functioning with the help of a modest temple personnel, and the more important and better organized sanctuaries located in close proximity to urban centres." Mastrocinque, however, interprets this on a much more general level, with the 'centripetal and centrifugal forces' of the Greek polis system which drew the significant sanctuaries into the orbit of the city, while others spun off into obscurity, Mastrocinque (1979), 216-218 (referring to Graf (1996)). Rutherford (2006) follows a similar line as he suggests that cities like Mylasa worshiped a Greek-styled Zeus while smaller villages would have continued to worship the Anatolian Tarhuntas.

105 Boffo (1985), 302, referring to Rome's recognition of the sanctuary at Panamara as $\alpha \sigma^{\circ} \lambda \alpha$

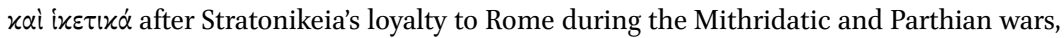
in the hymnode inscription I.Stratonikeia 1101, line 3, see Figure 5.24 and Chapter 5 , under Ritual performance at Lagina.

106 Boffo (1985), 331, citing Bickerman 1938, 133. 
concessions. This may also explain in part the progressive swing of indigenous sanctuaries and settlements towards Hellenistic forms that the rulers would be more familiar with. ${ }^{107}$ Finally, it will also have been highly important to the sanctuaries who was doing the talking for them and the degree to which their priests and personnel were involved in the negotiation processes, as they represented the direct interests of the shrine.

Beate Dignas, however, challenges assumptions of the dependency of sanctuaries in Asia Minor on civic institutions in the Hellenistic and Roman periods. In stark contrast with both Debord and Boffo, she argues instead that sanctuaries always had a strong authority of their own, even throughout these later periods. Rather than a bartering chip at the mercy of others, they formed a node of equal weight in a triangular relationship between ruler, city, and sanctuary. Her chief evidence for this is the independent, or sacred, economy of sanctuaries, which their administrators maintained by appealing directly to rulers, or to the local city as necessary. Rather than differentiating between types of shrines, Dignas stresses what they had in common. In this she leans toward the opposite end of the spectrum, treating the sanctuaries of Asia Minor across the board essentially as species of the same genus. Like Ramsay, she considers temple state sanctuaries as the extreme yet representative example of the kind of sovereignty that all sanctuaries originally possessed, independent of a separate political community or administrative center. Unlike Ramsay, however, she includes the 'Greek' sanctuaries in this monotype. ${ }^{108}$ In this she is critical of Debord's distinction and his view of 'urban' cults as completely immersed in civic life through its institutions, directed by the aristocracy (at least by the imperial period). ${ }^{109}$ On the contrary, Dignas argues that cities and cults had always operated in separate spheres, even suggesting a

107 This may also explain the early labelling as 'polis' of communities that otherwise bore none of the typical characteristics (governmental form, urban center, etc., see Mileta $(2009 \mathrm{~b})$ and $\mathrm{Ma}(2003), 38)$. Koranza is a good example, known as a polis prior to its incorporation as a deme into Stratonikeia in Karia - see Chapter 5 on the sanctuary of Hekate at Lagina (which was itself a deme of Koranza). Another is Kastabala, which outwardly took the name of Hierapolis, minted on coins of the second and first centuries BC with the title hiera kai asylos ('sacred and inviolate'), while inwardly maintaining its indigenous character; Boffo (1985), 54-6o.

108 Dignas (2002a), 224: "As far as the political and economic role of the cults is concerned, this study challenges the sharp distinction between the civic sanctuaries and the religious centres commonly labelled as indigenous, rural, or non-Hellenized." In her fourth chapter she further discusses how the different 'types' of sanctuaries fit in with her basic model.

109 Or as he calls it, "l'osmose totale entre la cité et la vie religieuse," Debord (1982), 293. 
fundamental "lack of identity" between them. ${ }^{110}$ Although she does not deny the civic dimension of sanctuaries, her own guiding bias is still 'city' versus 'cult'. Terms such as 'polis religion' or 'state cult' are problematic - the fact that the polis may have regulated one aspect of a cult does not mean they controlled all aspects, in her view, and this observation is surely correct. ${ }^{111}$ She continues to argue that shrines are natively autonomous; while in some cases they were overtaken by emerging poleis, in others they included the polis in their own expanding scope. This is what she states, for example, regarding Panamara and Stratonikeia - the evidence, however, now leans in the opposite direction. ${ }^{112}$

Dignas' study vividly highlights the generally strong economies of sanctuaries. Yet Boffo makes it clear that considering sanctuaries in Asia Minor through a single lens grossly overlooks nuances in their networks of power, administration, and community. In this she steers us far away from Ramsay's monolithic view of the 'temple state' version as the base Anatolian model. She also goes much farther than Debord in discerning the various relationships that could develop among 'indigenous' sanctuaries and their communities. This idea can, however, be taken even further: the adoption of a 'universal' language, the terminology, style and general behavior, also meant participating in a wider 'global' network of peers. ${ }^{113}$ While this is not Boffo's central research question, this is surely also what communities were after - besides good relations with rulers, they were also visibly eager to create stong ties with their peers and the wider community, facilitated by the recognition, support and concessions of the ruling forces. Having their sanctuaries declared inviolable (asylos) as 'neutral zones', sometimes even tax-exempt (through the grant of ateleia), and extending such grants to include the entire community as far as possible, opened new avenues of trade and economic advantages. At the same time, it provided the opportunity for them to host major inter-urban festivals, drawing on the wider Greek community, and thereby putting their city on the map. ${ }^{114}$

110 Instead her own study "suggests that the complete osmosis between city and religious life did not exist at any time and it emphasizes patterns of behavior illustrating a lack of identity between cities and cults," Dignas (2002a), 8 .

111 Dignas (2002a), 9-10.

112 Dignas (2002a), 243, referring to a pre-published version of van Bremen (2004b). In this article, however, van Bremen shows a strategic interest by the polis in the sanctuary, discussed at length in Chapter 6.

113 Ma (2003), 29-30; discussed in more detail below. On the homogenization of 'political culture', see van Nijf and Alston (2011).

114 The growth in panhellenic and other 'überregionaler' festivals is characteristic of the Hellenistic period, Chaniotis (1995); Parker (2004), who qualifies the term; Wiemer (2009), 117; van Nijf and Williamson (2015). 
In short, Boffo's nine categories are a prime asset in revealing the colorful diversity in the religious, social and political organization of these communities in Hellenistic Asia Minor and their relationships with their gods and their rulers. But the mechanisms of change, the shifts between categories, how local or regional 'indigenous' religious centers were turned into major civic sanctuaries, and the factor of landscape, have yet to be understood.

\subsubsection{Geography, Economy, and the Question of Sacred Lands}

Geography is a factor which Debord in particular recognizes as central to the type of sanctuary as well as its economy. He observes, as did Ramsay, that several great sanctuaries of Central and Eastern Anatolia in the Hellenistic period were located along major east-west thoroughfares and would have functioned as way-stations, or even emporia, attracting trade. ${ }^{115}$ Several were also located at political frontiers, such as Hattuša, Gordion and Sardis, connecting different regions but also attracting royal interest. The temple of Zeus at Aizanoi in Phrygia received at one time gifts (tracts of land) from both kings of neighboring Pergamon and Bithynia. ${ }^{116}$ Aizanoi itself is in a kind of frontier zone between these rivalling kingdoms and it was in their interests to win the favor of the community by investing in their sanctuary. In the west, the oracular sanctuaries of Didyma and Klaros, located along the coast, served as points of mediation for a wide range of clients. ${ }^{117}$ As with healing cults, these were specialist sanctuaries meeting universal needs and were therefore likely to be inter-urban in character and location. Indigenous federation sanctuaries also

115 Debord (1982), 10 (map), 11-18; he discusses the possible roles of merchant and artisan associations at the sanctuaries, representing commercial interests while creating a social profile at the same time.

116 MAMA IX 8, a bilingual inscription on the walls of the temple of Zeus that depicts how Hadrian restored lands once given to Zeus at Aizanoi by Attalos and Prusias, presumably Attalos I and Prusias I, Habicht (1956), 93; Laffi (1971); also Boffo (1985), 109-110 and Debord (1982), 145-146 (discussed above) who both see this as a political rivalry being played out at a sanctuary in the buffer zone of both kingdoms. Aizanoi later absorbed by Pergamon under Eumenes II and became "ein kleines Abbild Pergamons," Atik and Rheidt (2004).

117 Debord (1982), 18-22, with maps on p. 19 and 21 of the origins of clients of the oracular sanctuaries at Didyma and Klaros, respectively. Didyma, which peaked in the third to first centuries BC, generally served the Ionian coastal area, neighboring Karia, and the Milesian colonies in the Pontic and pro-Pontic regions. Klaros gained popularity in the later imperial period among the newer Roman colonies and the Hellenized cities of the interior, e.g. Phrygia, Lykaonia and Pisidia, Northern Anatolia, inner Karia, but also Thrace and Western Pontos; few coastal cities consulted the oracle. 
tended to be in 'neutral zones', usually situated in areas beyond the range of any one particular village or settlement. ${ }^{118}$

Location and accessibility of sanctuaries was clearly important in connection with festivals, particularly those with organized processions and the sacred roads that carried them. Festivals were prime outlets for commerce, especially when they were conveniently located, and under immunity. In the Hellenistic period, cities and sanctuaries went to great lengths to procure the privileges of asylia (inviolability) or ateleia (tax exemption), and to declare this publicly. This protective status surely enhanced their civic standing and expanded their wider economic impact. ${ }^{119}$ Some sanctuaries had permanent market facilities (e.g. Lagina) and acted as a sort of agora or at least a seasonal fair, occasionally with hotel facilities as well (e.g. Panamara). ${ }^{120}$ As such they were points of exchange between local and regional communities and were embedded in the economic life of the community in a symbiotic relationship.

Another economic aspect pertaining to the geography of sanctuaries is the question of sacred land, or hiera chora. A large portion of studies on sanctuaries in Asia Minor have been concerned with this aspect, and it forms a central element of Debord's thesis. ${ }^{121}$ This is also where he takes his most critical stance against Ramsay. ${ }^{122}$ As mentioned above, Ramsay believed that most of Asia Minor had once belonged to sanctuaries, each with a population that largely consisted of sacred slaves, or hierodouloi, organized in villages under the authority of priests and prophets; the Macedonian conquests brought an abrupt end to this when Hellenistic rulers brutally confiscated lands to establish new colonies. ${ }^{123}$ Jones was the first to directly oppose this view, ${ }^{124}$ observing

118 On federation sanctuaries: Debord (2003); Graninger (2011); Mackil (2013a).

119 Debord (1982), 24-25 and Boffo (1985), discussed above. Also Gluskina (1977), Rigsby (1996). This applies especially to the sanctuary of Hekate at Lagina, see below Chapter 5 .

120 On fairs and festivals, see e.g. de Ligt (1993); Chandezon (2000); Iannaconne et al. (2011); Papazardakas (2011); Frejman (2020); also for Republican Italy, García Morcillo (2013). The 'live market', or biotike agora, at Lagina is attested in the later imperial period, see Chapter 5 . Panamara was known to have lodgings for pilgrims to spend the night, see Chapter 6.

121 Debord (1982), 127-162. Sacred lands and land leasing has been the object of several studies over the last few decennia. See also: Horster (2010); Isager (1992); Chandezon (1998); Osborne (1988); van der Spek (1986); Martin (1973); and Finley (1951).

122 Ramsay (189o), generally followed by Rostovtzeff (1941) and Bickerman (1938).

123 Ramsay (189o); according to Rostovtzeff (1923), rulers saw themselves as eminent owners of all the land, sacred or otherwise.

124 Jones (1940), 309. Jones found support among Broughton ('Roman Asia Minor' in Frank et al. (1933-1940)) and Broughton (1951), Zawadzki (1952-1953), and Magie (1950). Bickerman (1938) had previously expressed his views that Seleukid rulers hardly impacted 
that rulers actually donated lands to sanctuaries on occasion, ${ }^{125}$ and that there is simply no solid evidence for large holdings of even major shrines in preMacedonian times, let alone the suggestion that this would have been commonplace for sanctuaries throughout Anatolia. Also, most of the sacred lands known to have existed appear to consist of individual, piecemeal plots rather than vast estates; they were not necessarily contiguous nor anywhere close to the sanctuary that possessed them. ${ }^{126}$ Rather than spanning across Eastern Anatolia with its 'temple states', Debord observes that most of the shrines that had sacred lands in the Hellenistic Asia Minor were actually in Karia. ${ }^{127}$ While this may result from the chance survival of documents, it may also reflect the type of holding, since the larger sanctuaries in the east presumably possessed fewer, yet more extensive, tracts of land.

The term hiera chora is usually used to refer to property belonging to a sanctuary that was commercially exploited, rather than an area that possessed some numinous quality. Besides cultivated fields it could refer to pasture, forests, even salt flats, ponds or sand pits, or areas with restricted access, sometimes allowed only for the herds of animals belonging to the sanctuary. ${ }^{128}$ Debord's three categories of sanctuaries also have correspondingly different uses of sacred lands. ${ }^{129}$ The great eastern 'temple states' were presumably worked by thousands of hierodoulo $i{ }^{130}$ whereas the smaller 'indigenous'

the existing feudal structure. Robert and Robert (1954), 231-232 took a slightly more nuanced position based on Apollonia Salbake, believing that the Seleukids did control the revenues of sacred villages which in turn resisted them; see below.

125 As at Aizanoi, MAMA IX 8. The governor Olympichos dedicated some of his personal holdings, which had been royal gifts, to the sanctuary of Zeus Osogollis at Mylasa, discussed in Chapter 3 .

126 Occasionally temple funds were used by a city or association to purchase tribal lands, Debord (1982), 130, discussing Jones (1940), 309. This certainly coincides with the picture from the documents at Labraunda and Mylasa, listing and describing the individual tracts of property that were sold or donated to sanctuaries, and the lands adjacent to them, see Chapter 3 .

127 Debord (1982), 137-139; Pernin (2014). See also below.

128 Debord (1982), 170, e.g. most sanctuaries had a sacred wood, or hieron alsos, p. 170 n. 59. On restricted access around the marginal areas around sanctuaries, see McInerney (2006). See also Cazanove and Scheid (1993); Ampolo (1993); Jacob (1993); Bonnechere (2007).

129 Debord (1982), 163-169, following Robert and Robert (1954), 295 and recognizes with them the wide range of variations among sanctuaries, according to region and situation.

130 E.g. the hiera chora of Pontic Komana was known for its vineyards, Strabo 12.3.36. An exception is Pessinus, the only temple state with no clear indication of sacred lands. 
sanctuaries, associated with villages or federations (koina), probably held sacred lands as common property, e.g. the Pormounos kinship group (syngeneia) that administered the sanctuary of Sinuri. ${ }^{131}$ Finally, sacred lands belonging to the more Hellenistic civic-oriented sanctuaries were generally administered by the polis rather than the clergy directly; Debord believes this to be the base of the conflict between Mylasa and the priest Korris at Labraunda, discussed in Chapter $3 \cdot{ }^{132}$

Sacred land leases are particularly well documented in the second century вС in the area around Mylasa in Karia, and Dignas uses the conflict between Labraunda and Mylasa to substantiate her main argument on the general autonomy of sanctuaries. ${ }^{133}$ The area of Mylasa exercised a unique construction of hereditary leasing where the seller and his heirs transferred their property to the god, but immediately rented it back and exploited the land under a very low rate of rent. While not uncommon in the Greek world, especially Delos, the land-lease documents from Karia and specially the area of Mylasa represent the largest corpus of transactions of sacred property. ${ }^{134}$ Besides Mylasa, they stem from the nearby communities of Olymos, Hydai, and the sanctuaries of Sinuri and Zeus Labraundos, all of which had been absorbed by Mylasa by the end of the third century вс. ${ }^{135}$ The transactions consist of the proposal by the owner, the purchase by the shrine, and the leasing of the land back to the original owners and his heirs. ${ }^{136}$ Why this practice suddenly surged in the second century BC is debated. Dignas argues that this was an act of piety, to ensure an income for the gods that could only be secured through sacred lands, while providing ready cash against low rent for the lessee. ${ }^{137}$ In

131 Debord uses Lydian Katekaukemene as an example, showing how the land was owned by the community, with the god as patron, Debord (1982), 174-175. At the sanctuary of Sinuri, the land is seen to belong to both the god and the syngeneia of Pormounos, see below Chapter 4.

132 See Debord (1982), 169 and (2011), and below in Chapter 3 .

133 Dignas (2002a), 95-106; also Carless Unwin and Henry (2016), van Bremen (2016). These are discussed in more detail in connection with Labraunda, Chapter 3 , and the sanctuary of Sinuri, Chapter 4.

134 See Isabelle Pernin's corpus, Pernin (2014); Dignas (2002a), 96; Debord (1982), 154 and 158, further discusses tenant farming on sacred lands around Ephesos, Halikarnassos, and Aphrodisias.

135 Gary Reger suggested a higher date, relating it to coinage that was compatible with Rhodian standards, in Ashton and Reger (2006), 125-132.

136 Described in detail in Debord (1982), 169; Dignas (2000) and (2002a), 92; Chandezon (2003), 240-241; and now Pernin (2014), 401-455, esp. 422-427.

137 Dignas (2002a), 104. On p. 24 she demonstrates the sellers' obvious personal gain, but later states that this was only a by-product; the true motivation was "a combination of piety and atavism." Also Dignas (200o) and (2002a), 99-102. 
her view, the gods were the primary beneficiaries of this practice that guaranteed a steady budget for festivals and regular sacred activities. Debord sees parallels in the medieval period, when land was placed in divine hands for protection especially in times of risk, justifying the low rate. ${ }^{138}$ Raymond Descat and Isabelle Pernin suggest a direct link between the release from the control of Antiochos III, enforced by Rome, and new economic opportunities. ${ }^{139}$ Sacred lands could enjoy a special, protected status that private properties did not have, as the example of the lands at Sinuri will show. ${ }^{140}$ In any event, the hereditary construction of the leases will also have played a large factor in their emergence in the first place.

In contrast with Western Greece and the mainland, the geography of sanctuaries in Asia Minor has largely been analyzed from an economic perspective, taking the role of sacred lands as point of departure. Much work remains to be done in placing the sanctuary within its social and political geography. Boffo's categories can be useful in this regard, e.g. the connection between local settlement, federated cities, or urban center. For example, the term katoikoi, used in various contexts for those dwelling in or near the sanctuary, relates to the social geography of shrines. This term could indicate rural communities that settled in sacred villages, or hiera komai, as in Boffo's categories 3 and especially 4, also attested at the sanctuary of Sinuri. ${ }^{141}$ Katoikoi can also designate communities in close contact with developing cities but not yet absorbed by them, as with the sacred villages that came into conflict with Apollonia Salbake (Boffo's category 8). ${ }^{142}$ Finally, katoikoi may also imply full-fledged citizens who live

\footnotetext{
138 Debord (1982), 169 and later Descat and Pernin (2008) and Virgilio (2010).

139 Descat and Pernin (2008).

140 See the discussion in Chapter 4 of the land-lease construction of Sinuri after the violation of lands by the troops of Antiochos III. This shows the vulnerability of such lands in troubled times.

141 See Debord (1982), 90-92; Boffo (1985), discussed above. Hiera Kome is also the name of the community (turned deme) at the site of Stratonikeia, probably for the sanctuary of Zeus Chrysaoreus, see Chapter 5 below.

142 Two sacred villages of the Saleioi (one in the mountains, the other in the plains) revolted against the new polis of Apollonia Salbake; the nature of the conflict is unclear, but it escalated enough to require royal intervention, as at Labraunda: discussed in Debord (1982), 147-148, who also refers to the sensitive analysis of Apollonia Salbake Robert and Robert (1954), 231-312, relating its foundation to the geography of the area. Boffo includes Lagina in this category, yet the katoikoi do not appear until the imperial period; they issued certain honorific decrees together with the demos and boule, and so might appear to have been a parallel organization, but the same may be said of the gerousia at Stratonikeia, see below in Chapter 5 .
} 
elsewhere, as at Labraunda where the local residents of the sanctuary were considered citizens of Mylasa. ${ }^{143}$

The economic role that these sanctuaries had was clearly important, but not their only drawing card. Their symbolic role within the landscape was surely just as important in their new political role as anchors in civic territory. Debord's urban-rural dichotomy, while indeed taking us beyond non-informative questions of ethnicity, meanwhile imposes a new modern polarity on the social landscape, the problems of which are discussed above. It furthermore introduces the problem of how to assess the many sanctuaries located at points far beyond the urban centers, sometimes in very rural areas, that were nonetheless critical to the process of urbanization. ${ }^{144}$ Focusing instead on the nature of the relationship with the polis, as Attilio Mastrocinque has done, could be more productive. ${ }^{145}$ In many cases older 'rural' sanctuaries were highly instrumental in alleviating tensions that might otherwise have arisen in the composite community of a new polis; such cults offered a central focus and common identity, while simultaneously imbuing a sense of shared territory. These issues are addressed in this present research, which also considers aspects such as ritual performance and visual associations that Debord intentionally excluded from his already broad focus, yet which are vital towards understanding the success of this relationship.

\subsubsection{Priesthoods and Sanctuary Administration}

A final concern that studies of sanctuaries in Asia Minor often address is the way in which they were administered and their degree institutionalism, revolving on the role of the priest. ${ }^{146}$ As Debord argues, this position was the hinge between the sanctuary, society and the authorities. He distinguishes priesthoods through two "diametrically opposed poles": the 'Greek' magistrate acting on behalf of the city in an elected position, versus the 'indigenous' priest,

\footnotetext{
143 Discussed below in Chapter 3.

144 See the map in Figure 1.1, in the Introduction, and the list of cities in Table 1.1.

145 In a discussion on the centripetal/centrifugal forces of the polis in Hellenistic Karia and Ionia, Mastrocinque observes that the more successful sanctuaries were those that were drawn into the orbit of the city, while the more recalcitrant were flung aside (e.g. the sacred villages of the Saleioi at Apollonia Salbake), Mastrocinque (1979), 216-218.

146 E.g. the contributions in Horster and Klöckner (2011) and Horster and Klöckner (2013).
} 
who is absolute master of the domain and occupies the function for life. ${ }^{147}$ The line between these two poles, however, was anything but clear and there were many variations between. ${ }^{148}$ Nonetheless, Debord focuses on the distinction between the two types, arguing that since the 'indigenous' priests would have had greater autonomy, and more privileges, they also would have offered the most resistance to the processes of Hellenism. In his view, the position of the 'indigenous' semi-autonomous clergy began to crumble after the Macedonian conquests, along with the political system, eventually making way for the institutionally based installment of the office of priesthood via the polis. ${ }^{149}$ This contrast informs Debord's discussion of the controversial priesthood at Labraunda, which went from a hereditary office (i.e. 'indigenous' in Debord's scheme) to one that was elective and annual (i.e. 'Greek'), at least by the first century вС if not before. In his 1982 volume he saw this conflict, a dispute between the priest and the polis over control of the sacred lands of the shrine, in the same light as the revolt of the sacred villages against Apollonia Salbake - both extreme examples of the path taken at several 'indigenous' sanctuaries as they were absorbed into the system of the 'Greek' polis. ${ }^{150}$ In a later publication, Debord considers Labraunda to be more of an isolated and complex case. ${ }^{151}$

The office of priesthood is the second prong of Dignas' argument for the autonomy of sanctuaries, with the same Labraunda conflict as her archetypal example. Dignas takes the direct access which the priests at Labraunda had to the kings in their appeal as evidence for their sovereignty. ${ }^{152}$ She also views it as proof of the inherent tensions between an autonomous community focused on a sacred center governed by priests, and the system of distributed power

147 Debord (1982), 52 .

148 Debord (1982), 51-75 discusses the priesthood. He observes that you could not draw a line between a Greek coastal fringe and an indigenous interior; the adoption of Greek names by indigenous priests is an example, Debord (1982), 51. The list of priests at Sinuri illustrates this shift later in the second century вС, see Chapter 4. However, the use of Greek names in local populations was a widespread phenomenon, e.g. Piras (2010); Aubriet (2013).

149 Debord (1982), 54 and 263-293 for a sketch of the attitudes of temporal powers towards local sanctuaries.

150 Debord (1982), 51-53.

151 Debord (2011), further discussed in Chapter 3 below.

152 Dignas 2002, 59-66: "kings as mediators," and 95-96. In the first conflict, the priest Korris appeals directly to Seleukos II, I.Labraunda 1 and 3 . 
modeled on the Greek polis, where the principal authority is the boule and demos. For Dignas, it is no wonder that conflicts arose in areas where cities exercised increasing power over local sanctuaries, as at Mylasa and Apollonia Salbake; given the widely differing systems, this would have been the norm..$^{153}$ Yet if this were the case, such conflicts should have been more common. As it stands, these are the only two examples currently known from all of Hellenistic Asia Minor. ${ }^{154}$ The lack of evidence may well be due to the need by the polis to present a harmonious picture, as Dignas argues, ${ }^{155}$ but presuming an underlying current in the exact opposite direction when there is no corroborating evidence is very tenuous.

The studies by Debord and Dignas have elucidated several important aspects about priesthoods in Hellenistic Asia Minor regarding the authority of the office. Ongoing work, however, has shown that these offices, like the cults which they serve, are too varied to be divided along axes of 'indigenous' versus 'Greek', or 'urban' versus 'rural' in any satisfying way. ${ }^{156}$ More interesting is the common language that was being developed across the board as a wide variety of sanctuaries were being harnassed to civic identities. The nature of priesthood is a touchstone for the degree to which a shrine is integrated with civic institutions, but it should also be considered within the overall context of its cult, along with its shrine, its festivals and rituals, and especially the social fabric that supported it.

153 Discussed in Debord (1982), 147-148, Robert and Robert (1954), 231-312. Dignas uses both cases to support her argument of the general independence and authority of sanctuaries and their priests, Dignas (2002a), 67-69, discussed below; these both seem to be highly exceptional cases, however, and it is difficult to see how representative they might have been of a wider undercurrent.

154 Debord also notes the potential for clashes with the Greek system of administration, but views these cases as exceptions to the rule of harmonious transitions rather than indicative of a wider trend, Debord (2011), 144-145.

155 Dignas 2002, 69; see also Alcock (2002), 23: "Such texts [literary and epigraphic evidence CGW] best illustrate dominant commemorative narratives, and it is rare for them to offer alternative versions or a glimpse into the potential range of counter-memories."

156 See especially the contributions in Horster and Klöckner (2011) and (2013); Dignas and Trampedach (2008). Also Meier (2012) in connection with construction activities. 


\subsection{Reflection}

Studies of shrines in Hellenistic Asia Minor have long been dominated by the ethnic bias, yet these more recent approaches show that the impact of urbanization and the model of the polis had far-reaching consequences. Debord uses the urban-rural bias to explain the growing political significance of polisoriented sanctuaries while Boffo sees this as only one of many types of cult organization in Asia Minor, albeit one which obviously gained traction; Dignas focuses on the tension between city and sanctuary. As comprehensive as they are, none of these studies investigates the role of civic landscape or ritual space. Debord's axis actually stresses a divide between the urban and the rural, even though models developed for Archaic and Classical Greece show that both areas were vital to the polis. At the same time, however, even these models reinforce the distinction by simply classifying sanctuaries according to their distance from the urban core, e.g. 'extra-mural' and 'extra-urban'. Such categories can reveal spatial patterns, yet obscure the implication of other factors, as with community type in Boffo's classification. Also, mapping these spatial categories onto psychological traits affiliated with the Greek pantheon presumes a degree of coherence that was simply not the case in Hellenistic Asia Minor, where the polis model was usually imposed upon a mosaic of pre-organized communities. The core-periphery model that underlies the urban-rural bias is good for studying the impact of new centers in existing landscapes, but is poorly equipped for understanding how they brought communities together or what their position was in the urbanizing world.

Nonetheless, these approaches taken together show a number of issues to watch for when studying the phenomenon of the absorption of country sanctuaries by rising poleis. Besides the spatial location with regard to the town center, we need to take into account their 'urban rituals', e.g. festivals and processions, the scope of their festivals, their economies, their administration and nature of priesthoods, degrees of autonomy, and their symbolic power. These also need to be understood within their spatial and social environments, not only with respect to the urban center and the border, but also with local settlements, other shrines, tombs, or fortifications. In this study the modern line between urban and non-urban, or extra-urban is intentionally blurred. Moreover, these 'urban rituals' should be assessed from the perspective of movement through their landscapes/civic territory - what local features, communities, or economic zones were connected through sacred routes, and how was this experienced, by whom? All of these are potential indicators of their incorporation in the institutional framework of the polis.

Rather than impose yet another blanket model on country sanctuaries, it is important to examine the data from a closer point of view. Political status, 
territorial integrity, and economic gain were just as critical to developing poleis in Hellenistic Asia Minor as they were in Archaic and Classical Greece, but the context was different. Cities were shaped out of composite communities, and internal social cohesion and urban integration were as much at stake as external political boundaries. In order to understand these processes, one must also understand how space affects the social and political condition, not only by drawing centers and borders, but by understanding how these sanctuaries and their landscapes could invoke a 'sense of place' and belonging on the inside, while offering a perspective on the outer world. Such a comprehensive view calls for an approach that transcends the disciplinary boundaries applied until now, and applying theories that can accommodate the fuller contexts of these special places.

\section{Approaches from Outside the Box}

The gap concerning studies of the urbanizing role of country sanctuaries is due in part to the nature of the data and the specialisms required in their analyses. The 'extra-urban' sanctuaries of Archaic and Classical Greece, evidenced by their material culture, are largely discussed by archaeologists, whereas the religious centers of Asia Minor, with their epigraphic records, have long been the domain of ancient historians. As we have seen, however, both approaches leave several important questions unanswered. It remains to be understood what the role of sanctuaries was in turning sacred landscape into political territory, beyond (possibly) defining its borders. How was the environment perceived at a sacred level, and how might sanctuaries have helped realign local memories to the new situation? Enough studies deal with ritual as a producer of hierarchy, but was the distance between the political and sacred centers also effective in forging a sense of community? What impact did these country sanctuaries have on the new social structure? Regarding the new political world, what mediatory role was fulfilled by these sanctuaries, and what kinds of wider networks did they address? In what ways did they serve to create a central identity and channel of community pride for their cities? Besides synthesizing current approaches, this research also turns to alternative avenues in addressing these questions. This section discusses processes of spatial memory and 'mental mapping', the general role of ritual in the development of social cohesion, the importance of local and 'global' networks, and the establishment of regional identity as promising directions, drawn from the social and spatial sciences, that can shed bring new perspectives on interpreting the many 
layers that together shaped the bond between a developing city and a distant sanctuary.

\subsection{Spatial Memory and Visual Regions}

Before we can interpret changes in the configuration of political territories, and the gravitational pull of rising urban centers on established sacred and economic landscapes, it is necessary to understand how the human mind conceptualizes space as it is processed through memory. How landscape is experienced and especially recalled, and how these memories may be guided by significance of place is one of the objects of study in the spatial sciences. The term 'mental map' is often used to refer to an individual's perception of the world. ${ }^{157}$ In psychology, this idea, more commonly known as 'cognitive map', 158 extends to include the construction of spatial memories in the human brain. Barbara Tversky observed that a much better metaphor is 'cognitive collage' as it does justice to "the complexity and richness of environmental knowledge," whereas the word 'map' implies a false degree of metrical accuracy. ${ }^{159}$ Instead of distances, the human brain remembers space through 'mental snapshots' of single views, making new snapshots as the perspective shifts, but also combining this with other 'memory snippets' of spatial information. ${ }^{160}$ This makes for a haphazard collection of mental material that people use to recall places or give directions. While this applies to the modern era, it seems especially appropriate in a world that was navigated largely without the aid of cartography. ${ }^{161}$

157 There is no room here to go into the plethora of usages of the terms 'mental maps' or 'cognitive maps'. A good overview, however, may be found in Langenohl (2005) and especially Portugali (1996). See also the 'Common Sense Geography' construction of historical spatial memory through ancient texts, Geus and Thiering (2014).

$15^{8}$ First introduced by Tolman (1948) in his article 'Cognitive maps in rats and men'.

159 Tversky (1993), 21. Tversky's work focuses on the linguistic representations of space. On the different approaches between 'image' and 'map', see also Hirsch (1995), 16-21. Here I discuss the subconscious perception of space, rather than formal representations, which for navigation in antiquity often took the form of lists or itineraries, see e.g. Salway (2001); Talbert and Brodersen (2004); Warburton (2017 (2018)).

16o Tversky (1993), 15 and 21. 'Memory snippets' can be real or imagined, e.g. known travel times, second-hand directions, historical events known to have taken place, local legends, etc.

161 See also Fehr (1970), 54: "Der antike Mensch fasste seine Umwelt nicht als ein unbegrenztes Raumkontinuum auf, sondern orientierte sich im Sinne einer 'körperräumlichen' Vorstellung an den Einzelgegenständen und Geländeflächen seiner Umgebung." 
All of the senses are engaged in navigating one's way through the world, yet vision occupies a special place in acquiring knowledge over great distances. ${ }^{162}$ As Tversky observed, the brain organizes its environment through visual memories, mental snapshots. Colin Ellard calls this visual 'regionalization', or more simply, 'chunking space.'163 Because features that occur within a single view are remembered together, they are mentally grouped together and so 'feel' nearer than features that are not in view. This perceived closeness makes the environment much more comprehensible, although it has very little to do with actual metrical distance. ${ }^{164}$ In a sense, space is collapsed between features that are 'chunked together' in this way. Tversky furthermore observed that "people judge the distance from an ordinary building to a landmark to be smaller than from a landmark to an ordinary building." 165 Hirsch refers to ways that such familiar or renown places, especially of intensive regular activity but also stories, are 'foregrounded' against a 'background' of possibilities. ${ }^{166}$ These metaphors emphasize the kind of foreshortening that takes place in the mind's eye as such localities of significance are brought into higher resolution. Places of meaning are foregrounded and therefore serve to structure mental maps.

Sanctuaries obviously fulfilled this position, especially when they could be seen from a distance, as with Labraunda that commands the plain of Mylasa. But connecting routes are also important as they would produce a series of mental snapshots, one taken at every turn, that are later sequentially stitched together by the brain. The result would be an expanded 'visual region', with one snapshot flowing over into the next as the route is recalled. In this respect, processions played an equally important role in not just connecting city and sanctuary, but in collapsing the space in between. This closeness would have been intensified with every stop along the way - at shrines, altars, tombs, but also springs, trees and other resting points - and every repetition of the

162 Llobera (2007) and Wheatley (2014) address the dismissal of the 'primacy of vision' in contexts advocating a more holistic sensorial approach. Some studies on the referential role of the senses in general: Butler and Purves (2013); Hamilakis (2014); Toner (2016); Betts (2017).

163 Ellard (2009), 126-128.

164 Ellard (2009), 126-128; Tversky (1993), 15-16.

165 Tversky (1993), 18, drawing from Sadalla et al. (1980) on reference points and perceived relationships between them.

166 Hirsch (1995), esp. 4-6, 22-23; similar to Lynch's distinction between nodes and landmarks, Lynch (1960), 47-48. The concept is further developed by Stewart et al. (2004), 184 and 206, who consider caribou crossings as 'foregrounded' places in the Inuit perception of landscape. Price (2012), on myth as a way of foregrounding places. Williamson (2016b) on foregrounding places in the landscape of Pergamon. See also the role of skill and 'taskcapes' in Ingold (1993) and (2000). 
ceremony ensured that the space between was mentally 'chunked', merging the vistas along the twists and turns into one comprehensive unit of space. Understanding these stops as familiar anchors of reference adds a new dimension to their importance.

These anchors are crucial to the composition of a visual region, and hence to the formation of a sense of territory. Technically a visual region is similar to what is known in archaeology and geography studies as a 'viewshed', a map of the extent of visibility from one or more vantage points. A viewshed is also known as an 'isovist', or 'isovist field', although these terms are more often used in urban or architectural design to refer to the shape or volume of the viewshed. ${ }^{167}$ Isovists provide units of spatial analysis used in modeling human circulation; it has been shown, for example, that popular isovists are not necessarily those which provide the largest viewshed, but those that connect two or more viewsheds. ${ }^{168}$ This helps explain why so many decrees were set up in or near gateways, e.g. at Labraunda, the sanctuary of Sinuri, and at Lagina. Transitional zones offer the greatest potential for action and this is where people tend to linger. Besides landmarks, such spatial 'hinges' also served as visual anchors that linked mental snapshots together and directed human movement.

Spatial syntax deals with types of space and their sequences. Kevin Lynch's definition of paths, edges, districts, nodes, and landmarks as the basic elements of the city is still a reference point for studies on urban space. ${ }^{169}$ Of these, especially paths and nodes describe different kinds of human movement. Paths are linear routes representing movement, ${ }^{170}$ and ways to get to nodes, places of activity or "where things happen."171 Although developed for the urban environment, this movement-stasis paradigm can be applied to any context of travel and destination, such as the contrast in sacred space between processional routes as paths of movement, and sanctuaries as nodes of activity.

I use the term concentric space to signify nodes as delimited ritual space with a static focus and an inward-facing character, directed towards a central ritual action or performance such as a sacrifice, contests or banqueting. As enclosed

167 Benedikt (1979): "An isovist is the set of all points visible from a given vantage point in space and with respect to an environment."

168 Readinger (2002). Isovist analyses were applied to the Tate Gallery in London to analyze the circulation and predict bottlenecks, many of which were at entryways, see Batty (2001).

169 Lynch (1960), 46-83; discussed in Ellard (2009), 196 as elements that also help us remember space.

170 Lynch (1960), 47: "people observe the city while moving through it."

171 Ellard (2009), 196, on nodes. 
yet spacious areas, capable of accommodating a large gathering, their isovists typically have a relatively even open shape. Such concentric spaces correspond with the idea of social space, "the nucleus for the establishment of an endless number of culturally specific orders and relations,"172 i.e. a place where people go to spend time together. This kind of concentric space, full of intensive activity, emotions, memories, and traditions, is surely 'foregrounded' in the mental organization of geography. ${ }^{173}$

Furthermore, I use the term linear space to represent 'paths' with a moving focus that successively connect places, functioning as the spatial 'hinges' discussed above. This can be either kinetic, such as sacred roads as the vehicle of processions, or visual, through sightlines, in which only the eye progresses from one point to the next, creating an immediate association among the features within its scope. ${ }^{174}$ Just as physical paths provide real access to distant targets, these visual paths work to compress the perception of space, bringing the objects within view into a close and comprehensive visual region, as discussed above. Examples may be found at Labraunda, where the sacred road serves as kinetic linear space, bringing processions from the city, while visual linear space is represented by sightlines towards Mylasa and across southern Karia, framed in the windows of the andrones at the sanctuary. ${ }^{175}$ Either way, linear space has much more to do what Tim Ingold describes as wayfaring, and the "intimate bond that, in wayfaring, couples locomotion and perception."176 Rather than just moving from A to B, travelers by eye or by foot are closely observing the environment and looking for signs of places to rest, to worship, and to remember.

Fehr describes visual linear space with regard to ancient 'platforms', or terrace architecture, and the deliberate exploitation of views. Such vistas over majestic landscapes gave rulers a sense of total control. ${ }^{177}$ Certain parts of the landscape, however, could also visually be isolated by 'framing' them, for

172 Summers (2003), 117, on enclosed architectural space as social space.

173 For a modern parallel, see Setha Low's vibrant observations of plazas in Latin America, Low (2000).

174 See also Summers (2003), 157-159 on paths as connectors. The importance of embodied ritual movement is especially stressed in Connerton (1989), h. 3, and Connelly (2011).

175 Discussed in more detail in Chapter 3; also Williamson (2014c).

176 Ingold (2016 [2007]), 81 .

177 Fehr (1970), 49: "Das Machtgefühl des Großkonigs angesichts des sich zu seinen Füßen ausbreitenden Geländes läßt sich vor dem Hintergrund jenes Herrschaftsanspruches über die Natur selbst ohne weiteres begreifen," in discussing Darius's battle against the Skythians in Pontos. Tuan (1977), 38-40, discusses the need to command visual space as connected with power: "Modern nations like to think that a high peak, if not the world's highest, lies within their border," p. 4o. Further discussed in Williamson (in press-a). 
example through stoa architecture but also through the use of windows and doors that direct an axis between the viewer and the target of vision. Fehr interprets such visual axes as being closer to the Roman perception of space, ${ }^{178}$ but the connection with temple orientation, commonly towards the sunrise or some other astronomical phenomenon was also intrinsic to Greek architectural principles. ${ }^{179}$ The intentional framing of a view across the landscape takes shape in the Hellenistic period, and Fehr traces this back from Pergamon to Late Classical Labraunda. ${ }^{180}$ The southeast axis of the temple and altar of Meter Theon at Mamurt Kale was observed by its excavators to be perfectly aligned with the temple of Athena on the akropolis of Pergamon thirty kilometers away, and beyond that another six kilometers to the sanctuary of Meter at Kapıkaya; some believe that the gaps between temple and stoa on either side frame this view. ${ }^{181}$ Kinetic and visual linear space could both be used to foreground remote places of significance, and thus collapse the distance in between.

${ }_{17}$ He bases this largely on the linguistic difference between the Greek and Latin words $\delta \dot{\alpha}$ $\varphi \alpha \sigma \iota \varsigma$ and prospectus; $\delta \dot{\alpha}^{\prime} \varphi \alpha \sigma \iota \varsigma$, from $\delta \iota \alpha \alpha i v \omega$, to appear or shine through, emphasizes the target of vision as subject, impressing itself upon the passive viewer, whereas the word prospectus, from prospicio, to look outward, implies the viewer as subject, actively creating the visual axis (Blickachse), since he or she is the one doing the looking out from the architecture, Fehr (1970), $5^{6-58}$, and 61, with an extensive discussion on $\delta$ í่ $\varphi \alpha \sigma \iota \varsigma$ on p. $5^{8} \mathrm{n}$. 139. See also a building inscription from Iasos, I.Iasos 22, lines 9-11: $\tau \dot{\alpha} \varsigma \delta 1 \alpha-\mid \varphi \dot{\alpha} \sigma \varepsilon 1 \varsigma$ $\tau \hat{\omega} \nu \sigma \tau \nu \lambda \circ \pi \alpha \rho \alpha \sigma-\mid \tau \dot{\alpha} \delta \omega \nu$ (date unknown).

179 Dinsmoor (1939); now Boutsikas (2009) and (2015); Boutsikas and Ruggles (2011).

180 Fehr (1970), 'Plattform und Blickbasis', Pergamon and Labraunda are discussed in p. ${ }^{2-39}$. Fehr draws on Martin (1951), 147 and (1974), who ascribes this to Persian influence transferred to Karia through the Hekatomnid satraps; Pedersen (2004), 429. Another example is the platform of the Hellenistic temple of Athena in Ilion that included a peristyle courtyard left open on the north side, presumably to view the plain of Troy, Rose (2012). An earlier example, however, may be found in the fifth century propylaia on the akropolis in Athens, interpreted in Martin-McAuliffe and Papadopoulos (2012) as framing the view to Salamis. For the Roman period, see also the concept of 'urban armature' as developed by MacDonald (1986), using similar principles to describe the axial directionality of colonnaded streets.

181 Conze and Schazmann (1911); Nohlen and Radt (1978), 71. Further addressed by Schalles (1985), 27, in discussing the expansion of the sanctuary by Philetairos: "Diese Sichtverbindung [between sanctuary and Pergamon - CGW] wurde durch die Neubebauung nicht nur nicht eingeschränkt, sondern für den Besucher des Tempelvorplatzes durch flankierende Hallenbauten eher hervorgehoben. Zwischen diesen und dem Tempel verblieben einige wenige Meter Zwischenraum, dem Schutz vor der oftmals rauhen Witterung gewiss nicht dienlich, aber ein wirkungsvoller architektonischer Rahmen für den Blick des Pilgers auf den Burgberg." For the implications of this axis, see Wulf (1999), 41, also Williamson (2014a). 
The importance of the spatial dimension is especially clear when we consider that the human mind thinks, and particularly remembers, in terms of space. Robert McCauley and Thomas Lawson call this 'situated cognizing', meaning that our physical environment triggers our thoughts and produces memories and associations through spatial orientation. ${ }^{182}$ Memory resides in places but it is its tangibility that causes it to surface. This partly explains why not only monuments, but also landscapes and the places they connect are so powerful to group identity. Maurice Halbwachs stated as much in his seminal work On collective memory: "If a truth is to be settled in the memory of a group it needs to be presented in the concrete form of an event, of a personality, or of a locality."183 Monuments and rituals create 'collective memories' by intention. They are among the many varieties of the 'lieux de mémoire' that anchor social memory to key locations, particularly in times of rupture as Nora argues. ${ }^{184}$ The effect is accelerated when such places are infused with ritual performance, inherent mnemonic instruments of repetition and spectacle. The question, of course, is whose memories are being promoted to the collective consciousness and whose are being brushed aside with the creation of these monuments and ceremonies. ${ }^{185}$

Ritual space reinforces memory. Performing rituals in concentric or linear space creates a stack of memories that tie these events and all the corresponding associations to the specific places in which they occur. The processional routes that were ritually traversed year after year served to embed the landscape into the spatial 'cognitive collages' of the community as did the memorable features along the way, e.g. the altars, villages, tombs, trees, and springs. The personal stories that would have accumulated during these processions and festivals helped turn the environment between the city and the sanctuary into a 'memorial landscape' for everyone who was involved. ${ }^{186}$ Echoes of

182 McCauley and Lawson 2007, 213-214. They note for example that dementia is greatly accelerated or even induced when elderly people are moved from a familiar environment into a foreign one.

183 Halbwachs (1992), 200, in discussing the sacred topography of Jerusalem; cited in Alcock (2002), 25, who views Halbwachs as an early "mnemoarchaeologist." Architectural space was a powerful mnemonic aid for rhetorical speeches, as described by Simonides, discussed in wonderful detail in Yates (1966).

184 Pierre Nora's concept of 'lieux de memoire' was developed with regard to the role of landscape and 'place' in the history of France and the paradoxical need for tangible memories in an amnemonic society, Nora (1984-1992).

185 Sue Alcock addresses this in her discussion of the archaeology of memory, Alcock (2002), 15-23; also the introduction of Van Dyke and Alcock (2003), 1-13, esp. 3-6.

186 Dwyer and Alderman (2008), 173-174: "It is not just that these performances happen in or at places of memory. Rather, the memorial landscape is constituted, shaped, and made 
violence underlie this concept, ${ }^{187}$ yet while this was certainly a factor, it was much as anything the way that personal experience was interwoven with collective ritual action that gradually etched the habitual memory of the city into the landscape, making the sacred route a 'lieu de memoire' in the broadest sense. ${ }^{188}$

The same dynamics may be applied to the space at the sanctuary, although here the enclosed concentric spaces made excellent arenas for the top-down engineering of collective memories. Besides the sacrifices and feasting, this is often where individuals were honored, and where the important political or communal events were commemorated in stone, or with statues. In this sense, these concentric spaces served as 'memory theaters', preserving and perpetuating a particular view of the community through these monuments. 189 These were the mnemonic devices that are part of the mechanisms of urban identity and were therefore typically set up in the 'most conspicuous place' in the sanctuary; ${ }^{190}$ their carefully chosen locations reveal the critical spots in ritual space.

Country sanctuaries, with their often spectacular views, were undergoing significant changes. Their natural visual regions now encompassed and helped compress political territory. Their sacred spaces could be exploited to emphasize this facet, whether linear, through processions or visual connectivity, or concentric, through new rituals that focused on the polis. A grand investment in place-making on a large scale was in progress that turned local or regional shrines into warehouses of urban memory, transformed by ritual and its residue.

important through the bodily performance and display of collective memories." Price (2012) on myth, memory, and place.

187 Alcock (2002), 19-21 on 'disturbing memories'. Lagina, Panamara, Labraunda and the sanctuary of Sinuri were all involved to some degree in the turmoils of the third to first centuries BC, discussed in the case studies below.

188 Connelly (2011); Chaniotis (1995) and (2013). Also Chaniotis (2006) on the emotional dimension of rituals.

189 Such monuments are the 'durable, inscribed' type, discussed in Alcock (2002), 28; see also Dwyer and Alderman (2008). Pontus Hellström considers Labraunda in the Hellenistic period as a 'Memory Theater', referring to an intentional preservation of the dramatic Hekatomnid state of the sanctuary, Hellström (2009), 278-279, discussed further below in Chapter 3. See also Samuel (1994) on the importance of place as a mnemonic device. Marietta Horster discusses the Eleusinian as a place of 'corporate memory' through inscribed monuments, Horster (2013).

190 The epiphanestatos topos, or the most conspicuous place, is a clause commonly found in honorific inscriptions designating where the inscription is to be displayed (and leaving it open for interpretation). 


\subsection{Rational Rituals ${ }^{191}$}

Memory is thus rooted in both place and ritual. Ritual is a conduit for the cognitive need to comprehend the world through structure and order; it reinforces pathways in the brain and patterns in the mind. ${ }^{192}$ According to McCauley and Lawson, ritual is full of structure and repetition that both strengthen memory and enhance the desire or even compulsion to do things in 'the right way'. ${ }^{193}$ Collective ritual is especially concerned with the accurate transfer of knowledge, more so than about religious content. Performance is critical and so ritual is full of mnemonic devices that provide the framework an accurate rendition of ritual; these memory aides are necessary not just because of the frailty of human memory, but also because it is creative and playful, prone to variations. ${ }^{194}$ The ultimate goal of these mnemonic effects, however, is not so much to produce the perfect ritual as it is to create a continuity of community through a shared focus. ${ }^{195}$ Frequent, habitual repetition is one means to this end, but another is through the power of spectacle, the creation of vivid 'flashbulb memories' that particularly heighten the senses, triggering acute recall. ${ }^{196}$ Memories evoked by this type of ritual are more readily passed down through generations by verbal transmissions, re-enactments, or written accounts in literate societies. Successful public rituals are thus those that make a lasting impression. Form and frequency are both important albeit separate dimensions in the memorability of ritual, but especially the factors of sensory pageantry and emotional arousal are strong triggers for the creation of 'flashbulb

191 Chwe (2001), Rational ritual. Culture, coordination, and common knowledge. I am indebted to Josh Ober, who introduced me to Chwe's concepts and the problem of common knowledge and coordination.

192 McCauley and Lawson (2002), 23-24 and (2007), 222, emphasize the capacity for ritual as already present in pre-school children; cf. Tomasello's findings on the early reception of normative actions and ability of cooperation, Tomasello (2009), 45-46. See Ritual Form theory, developed by McCauley and Lawson (2002) and (2007). Also Tomasello (2009); Hervieu-Léger (2000), esp. 124-127. For an overview of ritual theory, see Bell (1992), but also Connerton (1989), 44-53 on psychoanalytic, sociological and historical perspectives to ritual; also Smith (1987) and Grimes (1999) with regard to ritual theory and place.

193 McCauley and Lawson (2007), 211.

194 McCauley and Lawson (2007), 214. Ritual mnemonics are compared to 'prosthetic devices' that help one access knowledge that one already possesses, much in the way that a pencil can help one work through a math equation that is too complicated to do by memory alone. See also Connerton (1989), 57-58 on ritual language as a mnemonic device.

195 McCauley and Lawson (2007), 219-220: "to increase the probability of a communal sense of continuity in the transmission of cultural materials and to decrease the probability of introducing socially divisive variations"; McCauley and Lawson (2002), 83; also Tambiah (1985).

196 McCauley and Lawson (2002), 56-64; Czachesz (2010) on the accuracy long-term effects. 
memories.'197 The miracle of Zeus at Panamara, while not a ritual in itself, would have created such a 'flashbulb memory' that was relived by later generations through the processions of the god coming down to Stratonikeia, but also through reading the story written on the walls of the temple. ${ }^{198}$ The priests of Hekate at Lagina also hosted spectacles, especially music and games, that kept escalating in scale in the imperial period, no doubt in order to retain their spectacle impact. ${ }^{199}$ These imperial eccentricities are part of a trend towards spectacle that is characteristic of the Hellenistic period, as Angelos Chaniotis has made clear. ${ }^{200}$

The cognitive approach to ritual focuses on form rather than content or symbolism. ${ }^{201}$ For Paul Connerton and especially Michael Suk-Young Chwe, form is content. The ultimate goal of ritual is social cohesion, channeled by the collective memories that ritual creates, as Connerton stresses, or by common knowledge, as Chwe puts forth. ${ }^{202}$ This approach to ritual is a significant departure from the standard set by Emile Durkheim, in which ritual corresponds with underlying social realities, rather than actually producing them. ${ }^{203}$ Focusing on form alone exposes the communicative mechanisms of ritual and illumines its capacity to create joint attention by generating common knowledge - the prerequisite to the sense of 'we'-ness that lies at the base of a cooperative community. ${ }^{204}$

Public ceremony, then, is all about capturing the attention of the participants, to spark a shared experience by creating a common focus, whatever this focus may actually have been. 'Rational rituals', as the game theorist Michael Suk-Young Chwe calls them, thus generate common knowledge, the root of collective identity. ${ }^{205}$ Common knowledge is any knowledge that is not only mutually shared, but that is especially known to be mutually shared; this

197 McCauley and Lawson (2002), 89-178 and more concisely in McCauley and Lawson (2007), 236-246.

198 The event is related in I.Stratonikeia 10; see below, Chapter 6.

199 Peer rivalry would have been a factor, see Chapter 5 .

200 Chaniotis (1997), (2010), and (2013).

201 Summarized in Connerton (1989), 44-53.

202 Connerton (1989), 47-71; Chwe (2001), discussed below.

203 Durkheim (1912); also Rappoport (1979), on ritual as reproducing social classes. It goes beyond the scope of this work to discuss what many other have done so succinctly, esp. Bell (1992), 171-223.

204 Tomasello (2009), 69-77; also Collins (2004), discussed further in Williamson (in press-b).

205 Chwe (2001), 6: "To understand public rituals, one should understand how they generate the common knowledge that the logic of rationality requires. To understand how rational individuals solve coordination problems, one should understand public rituals." On group identity, Chwe (2001), 91-94. 
forms the basis for any kind of joint action or collaborative effort. ${ }^{206}$ Shared experiences and opinions enable a group to define itself, but how is cohesiveness created in the first place, and how can everyone's participation in joint action be guaranteed? This is the classic problem of coordination in rational choice theory, and Chwe believes that public rituals are the key: by capturing everyone's attention simultaneously, a shared experience is immediately created - everyone knows that what they experience is common to all. ${ }^{207}$ The significance of public rituals then lies not so much in their meaning, verbal content, cosmological symbolism, or even historical context, ${ }^{208}$ even though these may emphatically declare shared belief and intention. The significance rather lies in the way in which they are delivered. ${ }^{209}$ Public rituals are media; like advertising campaigns, they make sure that everyone is not only aware of the product, but is also talking about it with each other. ${ }^{210}$

Visuality is therefore crucial. In order to maximize their coverage, stationary public rituals are therefore best performed in 'inward-facing circles' where everyone can not only observe the main event, but can also observe each other's reactions. King Arthur's Round Table, pueblo kivas, modern parliamentary chambers and town halls are all built on this concept, called 'the magic circle' by medievalist Johan Huizinga - worlds in themselves where different rules apply. ${ }^{211}$ The bouleuterion (council house), the stadion, and especially the theater and odeion (recital hall) are excellent examples of performative spaces in the round in the ancient Greek world, set apart in urban topography. ${ }^{212}$ These ritual spaces are shaped by embodied ritual action, since this is always 'forsome-goal' or 'for-someone' and therefore demands an audience, as David

206 The mutual experience of "I know that you know that I know that you know, etc." is gained primarily through eye-contact, also known as 'recursive mind-reading': Tomasello (2009), 72 : “... recursive mind reading ... is the cognitive underpinning of all forms of common conceptual ground."

207 Chwe (2001), 11-13, 74-94; the problem of coordination is further described in Chwe (200o). Turchin gives a comprehensive overview of this aspect with regard to rational choice theory and theories on cooperation, in Turchin (2006b), 107-137. Ober addresses this problem with regard to the rising democracy in Athens in Ober (2008), 168-210.

208 Chwe (2001), 19 cites Lynn Hunt on the French Revolution: "... political symbols and rituals were not metaphors of power; they were the means and ends of power itself," Hunt (1984), 5 .

209 In this regard Chwe differs from Weingast (1995), 450-455, who considers a shared belief system as the solution to the problem of coordination.

210 Chwe (2001), 21, 37-49.

211 Huizinga (1949), discussed further in Guano (2013). See also Williamson (in press-c).

212 Chwe (2001), 25-33. Greek theaters were used for several other civic events besides theaters, Chaniotis (2007) and van der Vliet (2011). 
Parkin argues. ${ }^{213}$ Joannis Mylonopoulos further discusses ways that spectatorship is built into sacred space, to allow the audience to observe ritual mimetic actions such as sacrifices or mystery rites, since viewing itself is part of the ritual. ${ }^{214}$ Sanctuaries were designed to accommodate these 'ritual mimetic actions' and should be studied from the angle of the observer. Some had theaters of their own, but more often they were equipped with stairways, tiers or steps that served as a tribune, or theatron, as with the sanctuary of Hekate at Lagina. ${ }^{215}$ Chwe goes one step further, however, in emphasizing that the participants should not only be able to see the ritual, but also to make eye-contact with each other. It is with these factors in mind that I designate the nodes (in Lynch's spatial syntax) of ritual activity at sanctuaries as concentric spaces, emphasizing the centripetal focus, the potential for mass spectatorship, and the capacity for the mutual gaze. Architectural defined spaces with a clear central focus serve this function, whether they are actually round or not.

Besides rituals in a centripetal space, processions provide another excellent avenue of common knowledge as the focus of the spectacle is moved around to reach the widest possible audience. ${ }^{216}$ Whereas Clifford Geertz, like de Polignac discussed above, had argued that processions are primarily about territorial domination, ${ }^{217}$ Chwe contends instead that their ultimate goal is publicity, ensuring maximum coverage as an extension of the ritual dispersion

213 Parkin (1992), 17; in his view of ritual as "formulaic spatiality" he argues that ritual revolves around physical performative actions, rather than words spoken (or sung?); also Tambiah (1985); Bell (1992), and later Hull (2014) on the social value of rituals in "persistent places" in small-scale societies.

214 Mylonopoulos (2006). On p. 92 n. 95 he quotes Durand (1989), 119: "To celebrate a rite is to do something ... the spatial distribution of actors and actions, the layout of the space itself, the unfolding and organization of the series of movements, the atmosphere and geography of the rite - all are critical." Mylonopoulos' main examples include the Amphiaraion of Oropos, the Kabeirion on Samothrake, the Demeter sanctuaries at Corinth and Pergamon, and Brauron. On the phenomena of cultic theater, Nielsen (2002), 138, and 266, ranking Lagina among the Anatolian sanctuaries of goddesses affiliated Kybele, possessing a theatron.

215 See also Hollinshead (2015) on monumental staircases; on ritual drama, Nielsen (2002).

216 Chwe (2001), 20-22.

217 Geertz (1983), 132: "Royal progresses ... locate the society's center and affirm its connection with transcendent things by stamping a territory with ritual signs of dominance ... When kings journey around the countryside ... they mark it, like some wolf or tiger spreading his scent through the territory, as almost physically part of them," cited in Chwe (2001), $20-21$. Chwe argues that this lone wolf analogy ignores the point of publicity and attention. Processions as power displays were discussed above in connection with 'extra-urban' sanctuaries, de Polignac (1995) etc.; see also Seed (1995) on processions of domination by Europeans in the New World. 
of common knowledge. ${ }^{218}$ For remote sanctuaries in antiquity, however, various factors may have been at work simultaneously. The processions known from Lagina and Panamara drew the entire diverse and socially stratified community across the landscape, creating a sense of community while connecting areas of significance as they progressed outwards towards the sanctuary and then back towards town. Chaniotis in particular has shown how such processions, apart from their element of spectacle, embodied the ideal civic and social order, with everyone taking their place. ${ }^{219}$ This is an important departure from Turner, who endorses the element of communal bonding during non-urban processions and festivals, yet stresses their primary aim of creating an alternative 'anti-structure' community, distinct from the social order of the urban center. ${ }^{220}$ Turner is, however, right to highlight the agency of geography. Processions were excellent community builders with their vehicles of common knowledge, as Chwe argues, but landscape itself would also have been integral to the experience, a common focus in its own right as it literally passed before the eyes, ears, noses, hands, and feet of the community. This is why I designate sacred roads as kinetic linear space, incorporating movement and direction, as discussed above. Woven into the topography, sacred roads were also part of social and urban space: processions turned travelers into performers of landscape. ${ }^{221}$ Processions to country sanctuaries were not only essential to producing a sense of community, but also a sense of common territory.

Processional routes and inward-facing circles are highly charged spaces. Activating them through rituals can have powerful consequences. Arenas and stadia are notorious scenes of riots, e.g. Pompeii in AD 59, or the Nika revolt, while Chaniotis has also argued that the emotional force unleashed by festivals did not always have the intended effect. ${ }^{222}$ Rituals are excellent coordinating mechanisms, but also highly volatile if not carefully controlled. Thinking of

218 Chwe (2001), 20-21: "Progresses are mainly a technical means of increasing the total audience, because only so many people can stand in one place; common knowledge is extended because each onlooker knows that others in the path of the progress have seen or will see the same thing. That the monarch moves is hence not crucial; mass pilgrimages or receiving lines, in which the audience moves instead, form common knowledge also."

219 Chaniotis (1995), 158-16o; Chaniotis (2006) and (2013). See also Graf (1996); Chankowski (2005); Mylonopoulos (2006), 104-107; Viviers (2010); Connelly (2011); Stavrianopoulou (2015), also Huet (2015), although focused on the Roman world.

220 Turner (1973) and (1974a), discussed above in the introduction.

221 On landscape as performance: Dwyer and Alderman (2008); Pearson (2015); also Donaldson (2006) on 'performing the region', discussed below.

222 Chaniotis (2006), on how they were not always as beautiful as intended, with the range of emotions at these intensive events, and the need for rules and mob control. 
urban festivals at country sanctuaries in this way allows us to interpret their role in creating social cohesion, like any other sanctuary. Unlike other urban festivals, however, it also highlights the function of the procession and hence landscape and its role in defining territory and a communal sense of belonging. Viewing these phenomena through the lens of 'rational rituals', rather than simply territorial domination or social hierarchies, makes us look for the object of common focus, whatever this may have been - landscape, object, ritual. Furthermore, it compels us to understand them in their social and spatial contexts, linear or concentric, as part of a performance that generated common knowledge, and thus a sense of unity that would have been so vital to rising poleis.

\subsection{Network Models}

Besides highlighting their capacity to foster internal social cohesion, the lens of 'rational rituals' also allows us to consider the potential of country sanctuaries as nodes in wider networks. This can follow two theoretical directions, both drawn from the sociological sciences. The first is to return to the aspect of memory with a focus on the assemblage of material culture at sanctuaries and its value in creating a coherency of associative relationships for the community involved at the sanctuary - this is aligned with Actor-Network Theory. A second direction is to follow a more general application of network theory to understand the function of the sanctuary itself as a central node in a web of cult relationships, and how this may have been exploited by the polis to establish its own position in the region.

Actor-Network Theory (ANT) was developed by Bruno Latour as a reaction against the rigid ontological hierarchy that underlies traditional theoretical frameworks within classical sociology. ${ }^{223}$ With ANT, he proposes instead a very flat model of objects without distinction, so that humans and objects possess equal potential to bring about change, whether they are 'macro actors', such as institutions, or 'micro actors', such as individuals or things. ${ }^{224}$ Essential to this is the connectedness of things to the past and their ability to trigger memories, all of this occurring within a highly diffuse and constantly changing assemblage of associations, as in a network. ${ }^{225}$ Latour is against setting

223 Discussed in Latour (2005), 13-15. Latour's groundwork is set out in Latour (1987), Science in action. How to follow scientists and engineers through society.

224 An actor is, simply put, anything that causes change. "... if an actor makes no difference, it's not an actor," Latour (2005), 130. See also Alcock (2002), 28-30; Rowlands (1993), 44 stresses the role of objects as mediators of past and present.

225 "Network is a concept, not a thing out there. It is a tool to help describe something, not what is being described," Latour (2005), 131. 
out a theoretical framework in advance, as I am now doing, but argues instead that one should 'follow the actors themselves', tracing lines of associations to see where they lead. ${ }^{226}$ The principal merit of ANT for this present research is its presumption that things, such as landscape, architecture, or imagery, influence human behavior and create a web of connections as they do so. ${ }^{227}$ This may be applied, for example, to the ritual spaces that I discuss further in this research that were engineered by humans, yet in turn served to influence the way humans perceive themselves and each other, determining even the nature of the ritual performances that took place there. The spatial settings were often defined by architecture, and the style chosen would have brought with it associations that informed the observer about the type of space that he or she was in, e.g. the half-smooth stoa columns at Lagina were very agorareminiscent, signaling urban space. This person may in turn have left graffiti on the architecture, as they did on the steps of Hekate's temple at Lagina and in the propylon, that again modified the general associations emanating from these structures, and influenced subsequent visitors, and so forth. ${ }^{228}$ This short sketch is but one example. Of the case studies addressed in this current study, ANT has proven most fruitful with regard to Labraunda, especially following Guggenheim's adaptation of ANT for architecture and memory. ${ }^{229}$ Whereas Latour focuses on the mutability of things through their mobility, Guggenheim instead focuses on the mobility of humans around and through immobile but nonetheless mutable architecture. Moreover, architecture can possess a longer time-span that reinforces its ability to invoke memories of the distant past. This has helped discern the web of associations at the fourth century complex at Labraunda, invoking its Hekatomnid past, that was employed by Hellenistic Mylasa to legitimate its position in the region in the third century вс. ${ }^{230}$ The initial results of this analysis using ANT show how the evocative power of objects could also be employed to create or induce a focused ritual experience. In the context of this research ANT especially helps understand how certain artifacts were given a role in creating a mindset that made the bond between a sanctuary and the nearby polis seem logical and natural. Actor-Network Theory has valuable potential as a tool for elucidating such webs of associations and

\footnotetext{
226 Latour (2005), 12.

227 Guggenheim (2009), 41.

228 The sanctuary of Hekate at Lagina is discussed in Chapter 5 .

229 Guggenheim (2009); see also Alcock (2002), 28-32, on the role of monuments and memory.

230 Discussed at the end of Chapter 3.
} 
it would be worthwhile to further explore its potential in combination with studies of landscape or spatial memory. ${ }^{231}$

Rather than the plethora of associations that ANT addresses, most applications of network theory tend to focus on relationships between things in kind. As discussed above, Horden and Purcell presented a sweeping view of the Mediterranean as a complex network of micro-regions, tightly linked through the 'productive environment' and the 'cult network'.232 For the Greek world, the model of peer polity interaction developed by Colin Renfrew and John Cherry to interpret the developments of the Early Bronze and Iron Ages marks a step in this direction. ${ }^{233}$ Debord had already suggested that religious festivals were hubs in trade networks in Asia Minor. ${ }^{234}$ In fact, his work spans two distinctive paradigms: his focus on the urban-rural axis is rooted in the underlying core-periphery model, whereas his attention to geography, roads, and these trade networks also gives weight to connectivity and interaction between communities and states.

Core-periphery and network models represent two different ways of looking at such distant urban sanctuaries - either as beacons of the polis, marking its frontiers, or as hubs of interaction in a wider network of cult. ${ }^{235}$ Network models, however, tend to be applied as counterpoint to the strong hierarchy of space and society inherent to Central Place Theory and implied in the coreperiphery model. ${ }^{236}$ Rather than a series of uni-directional relationships, networks present a much more dynamic and dispersed image, both socially and geographically - one that relies on multiple interconnections to function..$^{237}$ Network theory has earned its place as a paradigm in studying the ancient world, due in part to Horden and Purcell's monumental study, but also to early pioneers such as John Bintliff, who in 1977 used networks to explain the rise of Mycenae as regional super-center, and Madeleine Jost, who in 1994 discussed the network of sanctuaries across rural Arkadia. ${ }^{238}$ More recently, Irad Malkin explored network approaches as an alternative lens for interpreting Greek

231 Spatial uses of ANT: Madden (2010); Allen (2011); also van Oyen (2016).

232 Horden and Purcell (2000), 403-46o.

233 Renfrew and Cherry (1986).

234 Debord (1982), 24-25, discussed above.

235 As mentioned above, de Polignac also examines the mediatory role of such sanctuaries in de Polignac (1994). Also, not every sanctuary in every border area should be interpreted as having had the same function.

236 Christaller (1933); Hopkins and Wallerstein (1982), discussed above in Chapter 2.

237 See Meijers (2007), for an excellent analogy regarding hospital catchment areas, assessing the paradigm shift from a centristic towards distributed approach in the Netherlands.

238 Bintliff (1977b), 88-92; Jost (1994). 
colonization. ${ }^{239}$ Christy Constantakopoulou has effectively applied network theory in her analysis of Delos and the Cyclades, ${ }^{240}$ while Tom Brughmans, Anna Collar, and Fiona Coward have made major methodological advances in applying this in archaeological and historical contexts. ${ }^{241}$ The most popular form of network analysis is Social Network Analysis (SNA), which addresses the flow of information through individual contacts, focusing on people as nodes and their relations as ties (or edges). ${ }^{242}$ Not every dataset can support the full range of such intensive quantitative analyses, yet when shifting the focus to the dynamics of relationships and connections, this approach can generate new lines of inquiry. ${ }^{243}$ Network analysis could address, for example, whether sanctuaries functioned as specialist nodes in a wider cult network (e.g. oracles, healing cults, sanctuaries belonging to associations and federations), or how their festivals were levied by poleis to engage with their peers and other powers. ${ }^{244}$ Many avenues of research are opening up, but for the present purposes the theory will be used to investigate the role of sanctuaries as mediators in inter-urban networks based on ties of cult.

The vitality of a cult network might on the one hand lend support to the idea of a continuation of the (semi-)autonomy of sanctuaries. On the other hand, close scrutiny is called for regarding the agents of network. John Ma views this against the wider background of interacting poleis, which he describes in terms of peer polity interaction. ${ }^{245}$ Borrowing the term from Renfrew and Cherry, who used it to explain change in Bronze Age Greece, Ma inverts the model to explain stability and continuity in the otherwise highly turbulent Hellenistic

239 Malkin (2005) and (2011). See Malkin et al. (2007) and the contributions in Mediterranean Historical Review 22.

240 Constantakopoulou (2007) and (2017).

241 Brughmans (2013); Collar (2013); Brughmans et al. (2015); Brughmans et al. (2016) and the Connected Past consortium, connectedpast.net.

242 A good explanation of SNA is found in Collar (2007); Brughmans (2010). The importance of random or 'weak' ties versus intensive or 'strong ties' in creating a 'small world' is addressed in the seminal article by Granovetter (1973) and (1983). The 'Small World' model, based on the widespread phenomenon of mutual acquaintances, was further developed by Watts and Strogatz (1998). See also Gould (1993); Wasserman and Faust (1994); Chwe (2000); Scott and Carrington (2011).

243 The possibilities and limitations for the archaeological application of SNA are discussed among others in Brughmans (2010) and (2012).

244 Van Nijf and Williamson (2016) and the website connectedcontests.org and the research project Connecting the Greeks. Multi-scalar festival networks in the Hellenistic world, at the University of Groningen (2019-2023), sponsored by the Netherlands Organisation for Scientific Research (NWO) and conducted at the University of Groningen, see connectingthegreeks.com.

$245 \mathrm{Ma}$ (2003); Renfrew and Cherry (1986). 
period. In a lucid exposé, he discusses the central importance of connectivity and mutual recognition as a joint venture between poleis that created strong horizontal bonds counterbalancing those between rulers and cities. ${ }^{246} \mathrm{Ma}$ identifies four prime mediators in these inter-polis relationships:247 1) syngeneia, or kinship, used to establish a link with other poleis based on some ancient or mythical shared ancestry, often involving moral obligations; ${ }^{248}$ 2) asylia, a declared inviolability of a sanctuary that required recognition from the wider Greek world; ${ }^{249}$ 3) theoroi, embassies from poleis who traveled to different sacred festivals, often announcing festivals in their own cities; ${ }^{250}$ and 4) arbitrators, or foreign (neutral) judges called upon to settle disputes between poleis. ${ }^{251}$ Ma shows how these four vehicles of connectivity with the wider world not only reflect the mental maps of the various poleis, but actually served to create them. ${ }^{252}$ This study will examine all but the last of these criteria. Asylia is particularly interesting as a term of brokerage between cities, since the concept is commonly understood by scholars as an expression

$246 \mathrm{Ma} \mathrm{(2003),30:} \mathrm{"Peer} \mathrm{polity} \mathrm{interaction} \mathrm{was} \mathrm{a} \mathrm{collective} \mathrm{work} \mathrm{...} \mathrm{A} \mathrm{mesh} \mathrm{of} \mathrm{strong} \mathrm{horizon-}$ tal connections of collaboration, assertion and recognition was an eminently desirable thing in a world of powerful vertical pressures tending towards integration and subordination. The existence of a network of dialogue between cities meant that the relation between any local community and a ruler was never exclusive, because the local community also participated in a world of polis relations ... To a considerable extent, the protocols of peer polity interaction shaped the parameters of superpower behavior."

247 Listed in Ma (2003), 14 and discussed throughout the article. His focus on broad network contacts is probably why he does not mention sympoliteia, or civic mergers, although these typically resulted in the 'twin stelai' phenomenon - different cities which share the same decrees in their public (usually sacred) spaces. This phenomenon is addressed in the doctoral research projects of Sjoukje Kamphorst at the University of Groningen and Marie Drauschke at the University of Münster.

248 On syngeneia in general: Noack (1951); Bresson and Debord (1985); Curty (1995); Will (1995); Jones (1999); Lücke (2000); and Erskine (2003). The letters written by the priest of Panamara in I.Stratonikeia 22-39a are examples of this kind of syngeneia, discussed in Chapter 6; the syngeneiai at the sanctuary of Sinuri were more internalized, see Chapter 4.

249 On asylia: Gluskina (1977); Mastrocinque (1984); Belloni (1984a); and especially Rigsby (1996); on territorial asylia, now Knäpper (2018).

250 On the role of theoroi, and their hosts, the theorodokoi, as linchpins in inter-poleis networks: Perlman (2000); Kowalzig (2007a); Rutherford (2007), addressing theoric networks; Rutherford (2013).

251 Kantor (2016) addresses this at Mylasa in the imperial period. Examples in the Hellenistic period include Iasos, Blümel (2007), 42-46 (translated in Blümel et al. (2014) no. 50), with judges from Knidos, and Iasos, with judges from Priene, Crowther (1995) and Crowther (1993). This is further addressed in the doctoral research of Sjoukje Kamphorst at the University of Groningen.

252 Ma (2003), 19-22. 
of the hierarchical bond between ruler and city. ${ }^{253}$ Ma acknowledges that his interpretation intentionally bypasses this vertical dimension in focusing on the horizontal operations of the inter-polis network. ${ }^{254}$ Yet this raises two problems: one is that several new cities were in fact founded by rulers (hence Debord's bias towards urbanism), ${ }^{255}$ and the other is the critical role of the new 'local panhellenic' festivals as major generators of urban interaction, which Ma acknowledges but omits from his analysis as he attributes their origin to rulers. ${ }^{256}$ Rulers may well have stimulated these festivals in part, but it was clearly taken over by cities making it even more worthwhile to investigate their role in the dynamics of peer-to-peer urban networks.

Even more important in understanding how urban networks worked is the role of sanctuaries as hubs as principal channels of communication between communities. ${ }^{257}$ In fact, Ma ends his article with allusions to the annual rituals that were part of the network-forming processes, the words spoken, the joint sacrifices, the tokens exchanged. ${ }^{258}$ Vehicles of common knowledge, these may certainly be interpreted as rational rituals, even lieux de mémoire. This once again demonstrates the role of ritual in creating community, but also helps explain the rise in inter-urban 'panhellenic' festivals in the Hellenistic period. ${ }^{259}$ Cities generally presented themselves to each other through their gods and so it makes sense that the sanctuary that helped pull communities inwards to become a polis would be the same shrine that that polis would

253 E.g. Boffo (1985), discussed above in Chapter 2. Ma (1999), 157 briefly discusses administrative aspects of asylia under Antiochos III in the context of internal status and external diplomacy, also p. 172-173 and his discussion of the Teian decrees of asylia, p. 16o-165.

254 Ma (2003), 27: “... the picture I have given for peer polity interaction in the Hellenistic world has deliberately omitted the supra-polis powers, Hellenistic kings and regional leagues, and finally the intervention of Rome. These powers impinge only weakly in the account of institutions and symbolic discourse; yet their preponderance was obvious."

255 See Cohen (1995) and Mileta (2009b) on royal foundations of cities; Ma (2003), 38.

$256 \mathrm{Ma}(2003), 27$, discussing the Ptolemaia in Alexandria, founded by Ptolemy II, as "the first for which the Greek communities were formally requested to grant acceptance as 'panHellenic'..." Here he follows Robert (1984), 35-45; ruler involvement is further discussed by Cohen (1995); Aperghis (2005); Mileta (2009b), 82-87, and now Strootman (2014). But see Parker (2004) who underscores the growth in 'panhellenic' festivals as a civic initiative; also Chaniotis (1995) and Wiemer (2009), 117. On the civic dimensions of athletic contests: van Nijf (1999) and (2012); also van Nijf and Williamson (2015) and van Nijf and Williamson (2016) on festival networks.

257 Several instances of connection in Ma (2003) concern sanctuaries: e.g. three of his four basic terms almost always refer to sanctuaries (p. 14); the "traveling decrees" were typically set up in sanctuaries (p. 19-22); individuals were often honored by foreign cities in the sanctuaries of their own towns (p. 17-18).

258 Ma (2003), 39.

259 Parker (2004). 
use to interact with the outer world of cities - as is the case with Lagina and Stratonikeia, where many layers of intra- and inter-urban identity melded at the shrine - this is further discussed in Chapter 5 .

The level of data collection required for sophisticated network analysis exceeds the scope of this current investigation, yet even a metaphorical application of network theory will demonstrate that sanctuaries such as Labraunda and Panamara were also active hubs in a wider web of contacts that extended beyond the territory of their respective city. At the same time, it will show how the shadows of city and sanctuary began to emerge and fuse together. The mediatory formulas of syngeneia and asylia are, among others, good barometers for gauging the exploitation of a sanctuary by a polis as it defined its place in the regional political landscape.

\section{$2.4 \quad$ Regional Identity}

With their emphasis on a centralizing government and its institutions, young or expanding poleis will have had many of the same needs as any developing state: the need to create a common and shared identity, the need for a joint goal, and hence joint attention, but also the need to be recognized externally. These factors were discussed above in connection with rational rituals and network dynamics. Yet particularly the geographical distance between the urban centers and the sanctuaries in which they invested their identity, combined with the territorial concerns that many poleis had, make it worthwhile to consider these factors through the lens of regional identity building. 'Region' is an ambivalent term and can mean many things in many contexts and scales. In antiquity, it is used to designate larger areas encompassing multiple poleis with a common cultural heritage. Karia, for example, has been examined from this perspective by Gary Reger. ${ }^{260}$ In this study, however, I use the concept as an analogy to understand key processes in the development of a polis, how it establishes its administrative center and consolidates its greater territory, including the sanctuaries and dispersed communities.

Drawn from the social sciences, modern studies on regional identity usually focus on agency in creating a central identity, but with the advantage of being able to conduct interviews with the actors. Rooted in data and grounded theory, this approach dismisses any larger theoretical framework, like ANT or SNA. ${ }^{261}$ Archaeological and historical data, however, rarely allow for this level

26o Reger (2007), (2011), and (2013). Federations and leagues also give ancient perspectives on region.

261 'All is data' is one of the basic tenets of grounded theory, developed by Glaser and Strauss (1967). In this approach, the field notes taken from interviews are turned into 'open code', 
of granularity, but they can show the effects of decisions taken by individuals, even if we do not know who they were. The data from the case studies allow for the discernment of larger patterns and in fact show striking parallels with the stages of development in constructing a modern regional identity as identified by Anssi Paasi, whose work I draw on in this section. ${ }^{262}$ His studies incorporate the roles of boundaries, symbols, and identity into a framework of region that revolves around the process of institutionalization, resonating with Ma's focus on institutions as the common ground of urban interaction. Paasi identifies four critical stages in the process of building a region: territorial shaping; symbolic shaping; institutionalism; and the establishment of the region through external recognition. ${ }^{263}$ Each stage has a bearing on the present research.

The very base of a region, in Paasi's view, is territorial shaping. ${ }^{264}$ According to him, attachment to territory relies on "four experiential dimensions." These include: the social, with those who inhabit it; the political, concerning expansion; the cultural, with collective memories; and the emotional, which amplifies identity. ${ }^{265}$ Boundaries are instruments of territorial identity not just as border, but because they give territory a cartographical shape that can acquire an iconic function, as it comes to symbolize the space occupied by a region. A caveat with ancient poleis is that we are seldom able to identify their boundaries, although it is probably safe to assume that most of the citizens would have had at least some idea of where they were or were not. ${ }^{266}$ A separate issue is that in antiquity people's 'mental maps' were not informed by the bird's eye view, and so we should instead think of their idea of territory in terms of the 'cognitive collages' of hodological perspectives, or 'street-view' of the landscape. This is the point where visual regionalization can overlap with the spatial definition of urban territory, which in antiquity extends beyond the walled spaces. Natural features such as mountains, rivers, trees, and of course sanctuaries would have been landmarks that helped give this territory a shape in the minds of the community. Linear rituals, such as processions that by repetition created an intimate familiarity with the landscape, were equally critical

in which everything is presumed to have meaning - these are then cross-referenced, i.e. turned into 'axial codes' and eventually from this the 'theoretical code' is ultimately distilled; see also Corbin and Strauss (2008).

262 Paasi (2009).

263 Paasi (2009), 133-137, on the development in the nineteenth and twentieth centuries of the concept and its later resurgence.

264 Paasi (2009), 123-124, argues that, despite internet and globalization, "... the contemporary world is still a complex constellation of more or less bounded spaces that exist at various spatial scales. These spaces are 'regions' or 'territories'."

265 Paasi (2009), 124.

266 E.g. testified by boundary disputes, Ager (1996). 
as they marked the natural landmarks but also the villages, tombs, and shrines en route that foregrounded these key places. These rituals all enabled the community to 'perform the region', as they tied territory and community together by collectively crossing the countryside now designated as belonging to them as a city. ${ }^{267}$ This is a very different approach to territory from that discussed at the beginning of this chapter, in which frontier sanctuaries and ritual processions primarily symbolize territorial domination. Much more in line with this approach is the concept of social spatialization, developed by Rob Shields, through which the territory of a region is built into the collective imagination of the community as well as in its institutions. ${ }^{268}$ This is especially clear in the case studies of this present research as well as their festivals, which played a central role in the symbolic shaping of the region of the polis.

Symbolic shaping is the second stage in the formation of regional identity and can take many forms besides the shape of the territory on the map. One is the landscape itself, parts of which can be stereotyped and idealized as inherently characteristic of the region, such as a mountain, forests, or a panoramic view. ${ }^{269}$ Modern media helps generate imagery of the landscape but in antiquity local mythologies and legends should also be considered in this light. An example is the frieze with personifications of local landscape features on Hekate's temple at Lagina, or the expansive view of the Mylasan plain and southwest Karia, 'framed' through the architecture at Labraunda. ${ }^{270}$ Names are also critical, not just the persistent use of a regional name, but also re-naming places, or in this case renaming deities. ${ }^{271}$ Paasi further mentions the power

267 Donaldson (2006), also 'performing the landscape', Dwyer and Alderman (2008); Pearson (2015). This of course involved a high degree of ritual dynamics, studied in detail for festivals and processions especially by Angelos Chaniotis, e.g. Chaniotis (2013), discussed above. This is very different from the kind of 'regional cult' discussed in Werbner (1977) where, following Turner, sacred and political topographies are separate entities.

268 Shields (1991), 31: he uses the term to encompass the physical interventions in the landscape, such as the built environment, within the social imaginary.

269 Meinig (1979), 164: "Every mature nation has its symbolic landscapes. They are part of the iconography of nationhood, part of the shared set of ideas and memories and feelings which bind a people together." Meinig further discusses here landscape as embodying American ideals and values, and how the media serves to propagate this image. Of course, stereotyping a landscape in this fashion already implies a super-regional consciousness, by promoting what is 'typical' for the region in question, and therefore 'atypical' of the others.

270 Labraunda is discussed below in Chapter 3; on the 'south' frieze of the temple at Lagina, see Chapter 5 .

271 Stratonikeia changed the epithet of Zeus Karios to Zeus Panamaros, and gave Hekate at Lagina a new epithet, of Soteira. At the same time, Stratonikeians increasingly included the demotic in their personal names, reflecting the older villages which had 
of allegory, or legends, as a symbolic depiction of a region, usually in a struggle over territorial space; this perfectly fits the Stratonikeian accounts of the epiphanies of Hekate and particularly Zeus in historical crises as saving their city, operating as a charter myth. ${ }^{272}$ Regions also promote themselves through their icons, such as flags, emblems, or a coat of arms; principal deities and their attributes, such as the double-axe of Zeus Labraundos, serve this same function, showing how their images were used to symbolize the polis especially on its coinage. ${ }^{273}$ Finally, festivals celebrating the region play a strong role in creating its symbolic identity; such public ceremonies work as rational rituals, combining community, territory, and institutions in grand spectacles that fix the public focus on the region and its composition, engraining this into the collective memory. ${ }^{274}$ The symbolic shaping of civic territory in the case studies presented here will be found to take place principally through its cults and sanctuaries. The same can be said of most cities in the ancient world, yet it is particularly noteworthy how rising cities turned to cults that were already 'popular' in the area. The social capital, in Bourdieu's terms, of the ancient gods with their local communities was diverted towards the developing poleis. ${ }^{275}$ Deities such as Zeus Labraundos or Zeus at Panamara, with widely acknowledged cults, were transformed into the principal gods of the poleis in whose territory they now found themselves. Festivals were reorganized and their shrines became new urban spaces, drawing the entire community out to the far corners of civic territory. Their images were fixed on civic coinage, daily reminders of the bond between city and sanctuary. Symbolic shaping is the area which especially shows how critical these older resident gods were to the new or expanding poleis, which took their identity from them but also redefined it in the process, so that the two entities, deity and polis, would mesh and become inseparable.

The third stage in building regional identity is institutionalism. This stage represents the development of both formal and informal institutions and overlaps with the first two stages since it is necessary to produce and maintain the territorial and symbolic shape of a region. Regions are social constructs

been absorbed into the polis; see below Chapters 5 and 6. Finally, personal Karian names appear to have been used in Hellenistic Mylasa to recall the Hekatomnid dynasty that had once ruled from there, see Piras (2010), 226-229 and Aubriet (2013), discussed further below in Chapter 2 .

272 These episodes from the turbulent first century BC are discussed in detail below in Chapter 5 .

273 Meadows (2018) on the increasing bond between cities and a main, protective deity.

274 See Connerton (1989), 41-71; Chwe (2001), discussed above.

275 Bourdieu (1986). 
that Paasi argues to be "complicated constellations of agency, social relations and power" in constant flux, with crucial institutions presiding over culture, media, and administration as they are responsible for the "structures of expectation" that are used to build identity narratives and mobilize collective memory: critical agents are especially the cultural/media elite who are best capable of producing the narratives necessary for regional identity. ${ }^{276}$ For the polis in antiquity this means that a major role in defining regional identity would have been ascribed to the priesthood of the deity who stood symbol for the city. Such priesthoods were generally occupied by the urban elite, as will be discussed in the case studies. Paasi's concept of regional identity allows us to examine priests as the media elite, using their cultural capital (again in Bourdieu's terms), to smoothly re-engineer the festivals of these local sanctuaries to meet the needs of the city. 277 Political contact with the wider world almost always transpired through the main urban cults, and priests helped extend the network of cult through grants of asylia and ties of syngeneia, thus embodying the role of statesmen and public relations officials. But besides these official institutions, unofficial practices such as habits and common ways of doing things are also institutions of region. At Panamara we see, for example, how new ritual practices were eventually inscribed in communal memory, such as the unusual but popular dedication of hair in the imperial period. Priests probably had an active role in the design of many of these rituals and were surely central figures in the 'spatial socialization' of the community, helping imprint the territory onto the collective imagination of the community through ritual. ${ }^{278}$ The absorption of these rituals by the community made them key participants in building the spatial framework of regional identity.

A region, or territorial entity, implies some level of political autonomy. For this to be effective, however, it must also be accepted in the social consciousness of the larger network of regions. ${ }^{279}$ The establishment of the region through external recognition is therefore the final stage in the construction of its identity and relies on the successful integration of the previous three stages of territorial definition, symbolic shaping, and institutionalism. Paasi further observes that the institutionalism of a region usually occurs at the expense of other regional units as they are de-institutionalized, either through integration or dispersion. This is exactly what happened at both Mylasa and Stratonikeia,

276 Paasi (2009), 133 .

277 Bourdieu (1986). This is surely one of the main reasons behind the conflict between the priests of Labraunda, who were operating as independent agents, rather than on behalf of the polis, see Chapter 3 .

278 Shields (1991), 31, mentioned above.

279 Paasi (2009), 136. 
visible in the synoikism that lay at the base of the construction of these poleis, as they absorbed the communities around them into their urban body. ${ }^{280}$ The degree of external acceptance is especially demonstrated when other poleis address the newer overarching polis as peer, rather than the older communities directly, even though some of these had once been poleis in their own right. This is, again, where the role of festivals comes in - the diplomatic missions requesting broad acknowledgment of asylia for their sanctuaries and the declaration of inter-urban bonds of syngeneia (kinship) based on cult, and the theoric missions that were launched, all to establish the position of the rising city in the wider network of cities. These networks, as seen above, were based on the homogeneity of institutional contacts, facilitating communication in terms and in the language that was globally understood.

Discussions on the construction of regional identity tend to revolve around the role of the actors, and in the case studies below we can identify rulers as initiators, since they were typically the ones who triggered the synoikisms as at Mylasa or who established colonies as at Stratonikeia. But as such cities gained autonomy and were free to pursue their own course of action; it would have been the governmental bodies and magistrates, made up of urban elite, who initiated territorial and symbolic shaping, who, along with the people, were the ones 'performing the region'. But this is of course a modern perspective. In antiquity, the ones that mattered most in public opinion were the gods themselves - this is why the perception had to be maintained that the bond between the new urban center and the sanctuaries in the ancient sacred landscapes, now political territory, was the initiative and pleasure of the gods. Divine protection over the rising polis and its territory was one of the most critical factors of success in establishing the 'regional identity' of the ancient city, and incorporating these sanctuaries, and their communities, into civic territory was one of the best ways that this could be accomplished.

\section{$2.5 \quad$ Reflection}

Besides the urban-rural, city-countryside, or core-periphery paradigms, there are a number of alternative avenues of investigating the role of country sanctuaries. The paths investigated in this section principally serve to illumine their capacity to integrate landscape and community, while creating a sense of social cohesion and territory unity, aspects that an expanding polis would need to consolidate its new citizen base and present a unified face to the outer world.

280 See the historical development of these poleis, discussed in first sections of Chapters 3 and 5 , respectively. 
This section has examined how familiar landmarks such as sanctuaries can serve to optically compress distance by being 'foregrounded', making them seem closer than they actually are. This is due in part to the way spatial memory works, more as cognitive 'collages' of views and memories, rather than a 'mental map'. The series of views and experiences gained by ritually traversing sacred space would meld into a larger comprehension of place, and cognitive collages could become visual regions. This internalization of space is crucial towards establishing a sense of territory, even more so than delineating boundaries. Space has a social dimension, and concepts borrowed from spatial syntax help distinguish its impact on the ritual experience: 'concentric space' refers to enclosed nodes, with static yet intensive activity, while 'linear space', refers to paths of movement, e.g. processional routes or sightlines that connect places in the mind's eye. Ritual and space are powerful mnemonic devices: combining them in public contexts, especially through spectacles, can create intense experiences and indelible memories. The effect of public 'rational rituals' as mass media in creating joint attention is amplified by space, whether concentric space, with sacrifices or contests, or in linear space, through processions and shared experiences. The common knowledge produced through such rituals is essential to the symbolic shaping of territorial identity, in Paasi's terms. Sanctuaries were also time travelers, accruing webs of associations built on layers of human memory. Network theory helps unravel these connections while focusing on the ties of cult that connected diverse communities, across both space and time. This capacity, besides location, seems to have been a reason that rising cities turned to older established cults as they forged a new sense of community. At the same time, the cult and its festivals formed an authoritative point of contact between the city and the greater world.

The concept of regional identity pulls several of these aspects together in a system that allows us to examine more closely ways that sanctuaries were conductors of identity for rising cities, both from an internal and external perspective. Critical factors of territorial and symbolic shaping, institutionalism and external recognition may be identified in our cases as cities profiled themselves through cult, and are hence incorporated in the analytical approach.

Against this background of methodological concerns and ways of tackling them, we can now turn our focus to the main question - the matter of interpreting the transformation of country sanctuaries in Hellenistic Asia Minor. This study aims in the first place to unravel the logic behind the increasing 
entanglement between rising poleis and autochthonous sacred centers as they were incorporated as mainstream urban sanctuaries, with their local or regional gods being turned into civic patrons. In the second place, the study aims to provide a viable approach of analyzing the changes at these sanctuaries in all their complexity. The typologies, models, and theories discussed in the previous sections provide a number of barometers that can help measure the dynamics in the city-sanctuary relationship, and a brief review will help outline the prime domains of analysis.

The occurrence of sanctuaries on the periphery of a polis is considered a regular phenomenon in the development of the polis landscape of Greece and Magna Graecia in the Archaic and Classical era. Based primarily on archaeological data, studies in this area have demonstrated the importance of cult location in the political landscape, but tend to dwell on categories defined by the urban center and its territorial borders - hence the labels 'extra-mural', 'extra-urban', or 'frontier'. While useful as heuristic devices, these categories can also easily mask the wonderfully complex and messy human situations that sanctuaries respond to. Studies using these categories in fact often isolate cult places in order to magnify their political relevance, particularly in the case of 'frontier sanctuaries'. The core-periphery paradigm that usually underlies this approach generally neglects the fundamental fluidity of sacred landscapes, with connectivities that shift and often transcend political borders. Sanctuaries and their rituals were located in multiple overlapping networks of action and meaning and should be examined in this light as well as their position within political territory and potential as guardians or gateways of frontiers. Meanwhile, scholars of sanctuaries in Asia Minor in the Hellenistic period have taken a very different approach, one that considers sanctuaries in their wider social and economic as well as political contexts. Their studies produce several key indicators that, when explored in depth, can more precisely inform us as to the roles that sanctuaries fulfilled, either in relation to their local communities or to their poleis. Specifically these indicators include: the location of the shrine with regard to roads, economic zones, and surrounding settlements; the presence of local or sacred villages that may have formed the base of its community and administration; the economic resources of the sanctuary and how they were controlled; the nature of the priesthood and how this was office was fulfilled; the degree of ruler involvement. Based largely on epigraphic data. these studies are primarily concerned with historical developments, social geography, legal administration and economy, and the urban mediatization of sanctuaries an sich. They do not, however, address the larger geography of sanctuaries or their role as transformers of the surrounding 
landscape into civic territory, despite the frequency in Asia Minor of civic sanctuaries located in the countryside (see Introduction, Figure 1.1).

Although these approaches show the various roles that a sanctuary may have had, none of them sufficiently addresses the profound dynamics of change: what happens to a sanctuary as it is absorbed by an expanding polis and targeted as the principal locus of urban cult? Many of the major 'extraurban' sanctuaries in Asia Minor began as pre-urban sanctuaries in a landscape that was already socially articulated; often they were already centers of networks of local or more regional communities - sometimes these were known as syngeneia (kinship groups) or koina (federations). How these older social and religious networks were affected by the rise of a nearby polis still has to be assessed. At the sanctuary itself, the change was usually visual through prominent architecture, put up by the city. The way in which this altered ritual space, both inside the sanctuary but also in the wider landscape, is widely acknowledged but seldom examined, even though this played a major part in realigning the perceptions of cult.

Many of these issues are addressed by theories drawn from other disciplines, as discussed in the previous section. In some cases this involves certain fundamental concepts, such as the cognitive perception of space as Tversky has shown, or spatial syntax and how certain public spaces shape behavioral patterns of movement, particularly through nodes and paths as concentric and linear spaces. In this way landscape, architectural space, and ritual action together triangulate the experience of collective identities. Memory is inextricably linked to this combination, and the cognitive theory of ritual proposed by McCauley and Lawson highlights how highly effective sanctuaries and their festivals were in structuring a collective focus for the communities of the shrine. Chwe's concept of 'rational rituals' further informs ways that festivals and processions generated joint attention and thus common knowledge, providing the basis for social cohesion and cooperation. Network theory helps position sanctuaries both internally (locally) and externally, highlighting them as hubs in a larger interurban network based on cult, through which cities promoted themselves and measured their position against their peers, while forging bonds of friendship and alliances communicated through the use of common conventions and institutions. Institutions are finally the focus of studies in building regional identity, which although taken from modern political-geographical studies, strikingly resonate with processes in antiquity that will appear in the case studies mentioned below.

These theoretical approaches are tools to be used where appropriate for interpreting ways that the rising polis grappled with its internal social cohesion 
and territorial integrity, as well as its external position among its peers. The question is whether a pattern can nonetheless be discerned that might help explain why it was as common in Hellenistic Asia Minor as it was in Archaic Greece for a developing city to have a companion sanctuary in the more distant reaches of its territory, but that this came about through very different historical paths. The multifarious mosaic of cultures and settlement types in Hellenistic Asia Minor already shows that models borrowed from other periods can at best address only part of this situation. The danger lies in a seeming fit when viewing the phenomenon in isolation; for example, all of the case studies in this volume may be argued to be located near the limits of civic territory, but to then proceed to interpret them as 'frontier' sanctuaries will take us in the wrong direction. Rather than force a model on several different case studies, it is more useful to take only a few case studies and examine them from a wide variety of angles in order to come to terms with the relationship between city and sanctuary in all its complexity, and as it developed over time.

In light of the above, three central questions rise to the fore. First, how did the relationship between the sanctuary and the polis develop historically? Second, how relevant is the physical environment to this development? And finally, what changes can be identified as a sanctuary was drawn into the orbit of the polis, and how do these indicate urban involvement? These are the main lines of inquiry that in the past have been addressed separately, but need to be integrated in order to acquire a comprehensive understanding of the role of these sanctuaries. They are further developed below.

\subsection{Historical Development}

With regard to the overall impact at the sanctuary of its incorporation into the polis, it is important to gain an understanding of the antiquity of the cult and its degree of 'autonomy' prior to the involvement of the city, as well as the identity of the communities to which it belonged. The studies by Boffo and Dignas especially underscore the significance of any kind of contact with the ruling forces, independent of the polis to which it later belonged. But it is equally important to understand the development of the polis in light of the actors responsible for change as well as the turning points in history that helped determine the course of evolution in this relationship between city and sanctuary over time.

Questions regarding the historical development will include:

- What was the overall impact of the polis on the sanctuary and its community, i.e. what kinds of vertical relationships were there with rulers before or after, and what kinds of horizontal relationships were there with other communities, i.e. how autonomous was the sanctuary prior to the 
advent of the polis, and how was this affected by its incorporation into the urban realm?

- What were the defining moments in the life of the sanctuary that impacted the polis? How smooth was the transition towards urban cult? Can any key actors be identified in the relationship between sanctuary and city?

- How long did this relationship last, did it undergo any noticeable change over time, and what brought it to an end?

\subsection{Physical Environment}

The second factor pertains to the physical environment and the social landscape. Understanding the physical situation of the sanctuary is crucial to interpreting site choice and possibly the connection with that particular deity, but will also shed insight into the significance of both cult and site to the expanding polis. Natural features, the general landscape, e.g. rocky, fertile, forested, but also altitude and climate are all important aspects that could be peculiar to the deity and relevant to human economic, commercial, or strategic concerns. The social and political geography of the sanctuary is equally important. Proximity to territorial borders with neighboring poleis and (sacred) roads might point to a function as frontier sanctuary, while locations near difficult passages could also point to a mediatory function. The overlap of sacred and urban landscapes should also be considered through the continuum lens, connected by places of meaning such as tombs, shrines, settlements, water, economic zones, etc.. Visibility is another concern: the view of the sanctuary and the view from the sanctuary across the landscape, as well as those in between, together comprise the 'visual region' that was appropriated by the polis along with the cult place itself. The visual prominence of the sanctuary was another way of foregrounding it, making distant places seem much closer and thus compacting the perception of civic territory as a comprehensible and natural entity.

Questions pertaining to the social and physical environment will include:

- How did the physical location of the cult place contribute to the identity and development of the sanctuary? What relevance did this have to the city, e.g. strategically or economically?

- Could the social location of the sanctuary have served to integrate community, cult and territory? Is there evidence for a 'continuum' of activity between city and sanctuary? Was it close to roads, settlements, tombs, economic zones, other cults? Was it close to any borders or other communities that might indicate a role of frontier sanctuary?

- Was there a visual connection between sanctuary and city? Did the sanctuary visually dominate the wider area as a landmark? Did the sanctuary connect any viewsheds of importance to the polis? Can the sanctuary be seen 
to be part of the 'territorial' or 'symbolic' shaping of the polis through its location?

\subsection{Urban Integration}

The third category is the most complex as it comprises the many indicators of urban integration that can inform our view of the tightening relationship between the rising polis and the older sanctuary. The central concern is the detection of transition at a sanctuary as it was incorporated into a nearby polis. The transformation of the shrine could be subtle or overt, but in most cases it would have been multifarious. In order to accommodate these complexities, the many avenues of change will be clustered in four larger domains: monumental and ritual space; ritual performance; legal administration and organization; and urban mediatization.

\subsubsection{Monumental and Ritual Space}

Monumental and ritual space is one of the areas with the most potential to show how the physical relationship between the sanctuary, the landscape, and the community was shaped and spatially integrated into a composite whole. In light of the theoretical avenues discussed above, one may ask how the architecture of the sanctuary worked to 'foreground' the sanctuary, as a landmark, with its surroundings in the mind's eye of the community. Space within the sanctuary was also important to the perception or sense of community, particularly enclosed or 'concentric space', as Chwe's inward-facing circles which facilitate rational rituals. Space then not only reflected ritual performance, it also would have shaped it by giving it direction and focus, whether concentric or linear. Visual linear space may have been used in ritual contexts to direct the view and foreground certain areas in the mental maps, i.e. 'cognitive collages', of the community. Doors, windows, and gateways, but also terraces and the use of stoas, can highlight sightlines, indicating an alignment of ritual space towards natural or social features in the wider landscape. Kinetic linear space took the form of roads which physically and ritually connected places of significance, e.g. settlements, shrines, tombs, and the different economic zones. Processions along sacred roads thus ritually connected such places, creating a 'spatial continuum', in Polinskaya's view. At the same time this contributed to the 'territorial shaping' of the regional identity of the polis, in Paasi's terminology. In both respects, the changing visual perspective en route was critical, with the sanctuary situated in either in a continuing 'visual region' from the polis or in a separate one of its own, e.g. blocked by mountains, but connected by a sacred road. 
Questions that should be asked of the architecture and monumental space will include:

- How, by whom, and for whom was monumental architecture employed at the sanctuary? What kind of impression did it make? Did the polis add or change anything to the architectural composition? Was the sanctuary used by the polis as a landmark?

- How did architecture shape ritual space? Can any large public enclosed areas with a focus, i.e. concentric spaces, be discerned in the architectural layout? Were any sightlines emphasized, i.e. visual linear spaces? How were paths used at the sanctuary, i.e. kinetic linear space?

- Were sacred roads connecting the sanctuary to the polis marked in any special way? What kinds of landscapes or monuments did they pass, and how would this have affected the political community? What kinds of 'visual regions' did they connect, and how were these relevant to the polis, e.g. strategically, or through 'territorial shaping'?

\subsubsection{Ritual Performance}

The second area of urban integration concerns ways that ritual performance was impacted by the transition to state cult. Ritual most expresses the intimate and symbolic bond between the sanctuary and whatever community worshiped there, and as such is a good mirror for understanding this relationship, as far as the data permits. Besides monumental architecture, festivals played a major role in foregrounding the sanctuary and its landscape in the mental maps of the citizens of the polis. Frequency and 'sensory value', or the degree of spectacle as McCauley and Lawson observed, are direct ways of both imprinting collective memories and accessing them individually. The ritual actions of the festivals should then be analyzed where possible for their social value, in order to better understand the ways in which joint attention was created through a shared focus. As such they may be gauged as 'rational rituals', in Chwe's terminology. While public rituals can enhance or even produce a sense of community, it is also important to understand how these rituals, or festivals, were redefined by the polis and which communities they were intended to address (and impress). Besides the climactic sacrifices, the processions, banquets, and contests would also have led to a heightened sense of community. All of this would have strongly contributed to the 'symbolic shaping' of the polis as a region, in Paasi's terms.

Regarding ritual performance, the following questions need to be addressed where possible: 
- How did ritual performance contribute to the bond between city and sanctuary? Were festivals reorganized or were any new festivals added to the ritual calendar, especially panhellenic festivals? How often did they take place and were other venues in urban space besides the sanctuary involved? Can urbanizing rituals be identified, and interpreted as 'institutions', i.e. urban habits that were integral to the identity of the polis?

- Can these ritual performances be understood as 'rational rituals'? Which ritual events were used to create joint attention, a communal focus? Were there spectacles, or 'flashbulb memories'? Can rituals be shown to engage or even manipulate social memory?

- For whom were the communal ritual activities intended? Were they geared towards internal social cohesion or a wider interaction beyond the borders of civic territory? Can the festivals be seen to contribute to the 'symbolic shaping' of the polis?

\subsubsection{Legal Administration and Organization}

The third area of urban integration concerns the degree of legal administration and organization of the sanctuary, focusing on the priesthood and cult personnel, but also the local community at the sanctuary and its economic resources. A significant factor concerning the priesthood is whether the polis introduced a new line as civic magistrates or if an earlier organization was still in effect. Debord and Dignas in particular have proven the importance of understanding how priesthoods were fulfilled, whether they were hereditary, annual or for life, and if they were appointed by the polis. The degree of autonomy and authority priests could have is also critical in understanding their urban connection, and whether this derived from the antiquity of the cult or the regime of the polis. Priesthoods were one of the most visible institutions of the polis, and they could fulfill the role of cultural or media elite in Paasi's model of the construction of regional identity. In this function they may have been critical actors in forging the link between the polis and the distant sanctuary. With sanctuaries that were more involved in the wider region, e.g. through panhellenic festivals, priests may even have served as statesmen or public relations officials. Sanctuaries also typically had a local community, as Debord pointed out; the way in which this community was impacted by the incorporation into the polis also reflects the nature of the relationship between city and sanctuary. It is important to know not only where this community lived, e.g. near the shrine, in town, or elsewhere, but also whether its identity changed under the polis, and whether they were included in the citizen body or seen as a separate entity. A third element of sanctuary administration pertains to the economic resources - especially the sacred lands as is so prevalent 
in the area around Mylasa. Such lands would certainly tie the sanctuary to the chora of the polis, shaping civic territory while filling in parts of Polinskaya's 'spatial continuum' with fields and farms, possessed by the divine and worked by citizens (or sacred slaves as the case may be). Yet other sources of income for the sanctuary, such as markets, or even an emporion function, will have figured in the sacred economy as well.

Questions relating to the legal administration and organization of the sanctuary will include:

- Did the sanctuary have a local community and was this noticeably affected by the polis? Where did they live and what was their status, e.g. were they autonomous or were they considered as citizens? What was their role with regard to the cult?

- What was the economic base of the sanctuary, and how and by whom was this controlled? Were there sacred lands that were linked the cult or shrine to the territory of the city, and who administered these?

- What kind of 'autonomy' did the sanctuary still have under the polis? Who controlled the sanctuary, and how was it administered? What was the nature of the priesthood, e.g. conditions of appointment and frequency? Can the priests be identified as major actors in producing (or resisting) urban identity at the sanctuary? How did they contribute to the urban institutionalism of the shrine?

\subsubsection{Urban Mediatization}

Finally, the ways in which the polis used the cult and sanctuary as a platform for its social and political affairs through mediatization forms the fourth area of urban integration. Mediatization concerns the production of realities through their communication, describing here a crucial path of integrating the deity within the urban realm. ${ }^{281}$ The first factor concerns the audience. Besides the local community, it is important to understand the pre-existing scope or network value of the sanctuary in the wider region and how this was impacted by the advent of the polis. If the sanctuary was a hub in a cultic network, the polis may have capitalized on this in some fashion, or it may have even used it as a fulcrum to extend its own network via the 'institutions' of asylia and syngeneia, as demonstrated by Ma, or by the panhellenic festivals to draw in a wider circle of participants. The polis could exploit such a cult network, using it to establish its own identity through external recognition, the fourth stage in Paasi's model of regional-identity building. The sanctuary would moreover have fostered joint attention; besides the shape of ritual space and the rational

281 Hepp et al. (2015); on religious mediatization, Hjarvard 2008. 
rituals of the festivals, this was achieved through the media, the monuments and decrees set up there that reflected urban institutions and created an urban ritual focus through the cult. The nature of the decrees shows the targeted audience of this urban focus and whether it was aimed internally or externally, i.e. towards the polis itself, through honorific decrees or commemorations of events, or outwards, e.g. through interurban contracts or correspondences, or decrees of proxeny. Either way, these media shaped urban memory and set the sanctuary as one of the prime urban spaces in the chora of the polis. But the cult also extended beyond the confines of the sanctuary and into urban iconography. Paasi describes the importance of emblems in the symbolic shaping of regional identity, and the images of the deities of these distant sanctuaries on coinage created an immediate and mobile association between deity, sanctuary and polis.

Aspects of urban mediatization may be discovered through the following questions:

- What was the scope of the sanctuary and how was this impacted by the polis? Was the sanctuary a hub in a network of communities, did other communities join in the festivals there? Was asylia or syngeneia used to compel other poleis to recognize the sanctuary, its festivals, and indirectly the polis? Who initiated these external ties? Do they reflect the establishment of an urban identity?

- How was urban identity mediatized at the sanctuary? What kinds of decrees were set up, what did they concern and for whom were they intended? What kinds of events were commemorated through monuments and how did this impact social memory? Do they reflect an inward focus (social cohesion) or a more outward perspective (political identity)?

- What kind of symbolic capital did the deity possess beyond the sanctuary? Was his/her image or attributes used as an emblem, e.g. on coinage? How did this develop over time and did it contribute to the 'symbolic shaping' of the polis?

These general areas - historical development, environmental factors, and the many changes in form, ritual, administration, media and representation as a shrine is integrated into the urban sphere - all need to be taken into account in order to understand the processes at work in transforming a country shrine into an urban religious center. Table 2.2 (pp. 88-89) gives an overview of these domains, the questions, and the kinds of data that are assessed in the analyses in the rest of this volume. 
Rather than yet another monolithic model, the point is to develop a methodological approach that integrates the various facets involved in the relationship between a sanctuary and a neighboring polis as it begins to expand, working towards an interpretation of the changes that took place in the process. While theory is used to develop a line of inquiry, the investigation begins with a close reading of the data that subsequently is interpreted via the best match in theory. The framework presented here lists the main indicators of urban integration at country sanctuaries and serves as a basic template in assessing sanctuaries, with those in the rest of this volume as prime case studies. Since the relationship between a city and a sanctuary could take a variety of forms, any of these criteria may indicate a bond; they do not all have to be met for a sanctuary to be considered linked to urban identity. Also, data that might address some of these factors may in some cases simply no longer be available. Nonetheless, this framework is a systematic yet flexible tool for comparative analyses that allows us to move beyond categorical explanations to examine the motivations and mechanisms of change. An evaluation for a wider application of the framework as tool is presented at the end of the volume, following the results of the analyses. In the following chapters, the issues listed here will be addressed in each of the case studies, and the answers will vary. Even these few examples, in very comparable situations, will demonstrate that the relationship between city and sanctuary is highly complex and seldom straightforward.

\subsection{The Case Studies}

Over thirty cities in Asia Minor relied on major country sanctuaries, as shown in the introduction (Table 1.1). Many of these were either new or underwent a strong developmental phase in the Hellenistic period, whether at the external initiative of a ruler, as with colonies or synoikisms, such as Pisidian Antioch, or from an internal movement, as with many of the poleis in Lykia, or a combination of both. Ideally all of these connections should be investigated, but as this study also aims to test the framework it will rigorously applied to only a few case studies. The sanctuaries in question should be relatively close to a border, in order to test their potential conformity to the 'frontier sanctuary' model or whether they were even involved with the borders of the expanding polis. Furthermore, there should be enough evidence to address all or at least most of the indicators shown in the table. The main criteria are the availability and quality of data, as well as type (Table 2.2, right column). The overwhelming availability of inscriptions has been noted above, while the archaeology in many cases is still in progress or has yet to be initiated. Monumental architecture has been recorded for the larger part (with some notable exceptions), 
TABLE 2.2 The framework of analysis

$\begin{array}{lll}\text { Indicator } & \text { Looking for ... } & \text { Data type }\end{array}$

\section{Historical}

Historical relationship overview of area prior to polis involvement, literary sources, rise of the polis, development of relationship inscriptions, numismatics with the sanctuary, critical events (turning moments), individual actors

\section{Environment}

Physical

natural phenomenon, natural geographical borders, landscape type, availability of water

Social-geographical location proximity to polis, and political boundaries, also to roads, other shrines and villages, tombs, economic resources

Visibility viewshed of the sanctuary

(panoramas?), viewshed of polis, visual dominance over the environment/ city territory, role as visual hinge connecting views geographical data, cartography, satellite images historical topography geographical data, cartography, satellite images, literary sources geographical data, cartography, satellite images architecture

\section{Urban integration Looking for ... Data type}

\section{Monumental and ritual space}

\begin{tabular}{|c|c|c|}
\hline Monumentality & $\begin{array}{l}\text { visual prominence and representational } \\
\text { status, stylistic associations }\end{array}$ & $\begin{array}{l}\text { architecture, monumental } \\
\text { art inscriptions, spatial } \\
\text { design }\end{array}$ \\
\hline Public space & $\begin{array}{l}\text { concentric space: open spaces in/near } \\
\text { the sanctuary for gatherings (festivals, } \\
\text { banqueting) and monuments, visual and } \\
\text { kinetic linear space: paths, gateways, doors, } \\
\text { sightlines, framed views }\end{array}$ & $\begin{array}{l}\text { architecture, inscriptions, } \\
\text { ceramics (all kinds) }\end{array}$ \\
\hline $\begin{array}{l}\text { Processional } \\
\text { routes }\end{array}$ & $\begin{array}{l}\text { kinetic linear space: connectivity (paved?) } \\
\text { between polis and } \\
\text { sanctuary, topographical features } \\
\text { showing a spatial 'continuum', i.e. } \\
\text { monuments, shrines, settlements, } \\
\text { tombs, but also farms and fields, } \\
\text { landscape types }\end{array}$ & $\begin{array}{l}\text { historical topography, } \\
\text { geographical data, } \\
\text { ancient roads }\end{array}$ \\
\hline
\end{tabular}


TABLE 2.2 The framework of analysis (cont.)

Urban Integration $\quad$ Looking for ... Data type

Ritual performance

Festival rituals

bond with polis, ritual focus and joint

architecture, inscriptions, attention, degree of 'spectacle', frequency,

literary sources, ceramics involvement of the wider community (votives)

Banqueting participants, ritual actions, formal and architecture, inscriptions informal banqueting facilities (stoas), water ceramics (tableware) supply, tableware

Games events, location, facilities, participants, architecture, inscriptions, (panhellenic?) competitions \& involveliterary sources ment of the wider community

Legal administration and organization

Administration degrees of local autonomy and civic instiand priesthoods

Local community

Economic resources

Civic decrees

Cult iconography in urban contexts tutionalism, controlling parties over the sanctuary and its resources

local settlement at/near the sanctuary, evidence for community-based administration, status as separate community or citizens of the polis

financial base for sanctuary, festival, and priests, integration in landscape via sacred lands, or emporion-function (trade network?)

Urban mediatization Scope and network

multiple communities at sanctuary, relationships of syngeneia (kinship), recognitions of asylia (inviolability), presence of theoroi (delegations), athletic participation, coinage distribution public documents, dedications, decrees, grants of asylia, commemoration of specific events

deity as emblem of state, evidence of worship of deity in urban center, beyond the sanctuary inscriptions, literary

sources, numismatics

domestic architecture/ tombs ceramics, inscriptions, literary sources

Inscriptions, literary sources

inscriptions, numismatics

inscriptions, monumental art

numismatics, inscriptions monumental art 
yet pottery by comparison is grossly underrepresented in most publications. Recent advances made in the studies of Hellenistic pottery warrant a thorough (re)examination of the pottery at all of the sites mentioned here. ${ }^{282}$

Despite these lacunas, a number of sanctuaries nonetheless possess enough evidence to substantiate interpretations of their developing relationships with an expanding polis. The resulting image will hopefully be greatly nuanced or revised by future studies and especially future progress in archaeological research.

The case studies for this research were selected for their ability to meet the criteria mentioned above, but also for their suitability for a comparative analysis. This will make patterns more evident and reduce the attribution of differences and similarities to local custom. Therefore, rather than drawing a sample across Asia Minor, this study focuses on the exceptionally well documented sanctuaries belonging to two cities in Karia, Mylasa and Stratonikeia (Figure 2.1). Each of these cities has not one but two major sanctuaries in its hinterland that underwent a large-scale transformation in the Hellenistic era. This provides a unique opportunity to examine the different dynamics in each relationship as they pertained to urban identity and its ideals.

For Mylasa, these are the sanctuaries of Zeus Labraundos, located roughly 14 kilometers to the north, and the Karian god Sinuri, some 15 kilometers to the east. Labraunda had been promoted as the central Karian cult by the Hekatomnids, satraps of the Achaemenid empire in the mid-fourth century, who simultaneously turned it into a regional shrine and dynastic sacred center. In the later third century, the shrine and estates were controlled by Mylasa and Zeus Labraundos had become one of its main state cults. The sanctuary of Sinuri had also received patronage from the Hekatomnids. It appears to have been independent until sometime in the third century, when it noticeably fell within the jurisdiction of Mylasa. Administered by a sub-community of the polis, its decrees nonetheless reveal the impact of the polis at this sanctuary, near the border with Stratonikeia, in the overall integration of civic territory.

Stratonikeia was founded at a site roughly in between its two main sanctuaries: the shrine of Hekate at Lagina was some 8 kilometers to the north (via the ancient route between the mountains), while that of Zeus at Panamara was some 10 kilometers to the south. The sanctuary of Hekate at Lagina initially belonged to nearby Koranza, a polis in its own right. In the early second

282 Bilde and Lawall (2014). I am indebted to Pia Bilde† for her hospitality in allowing me to attend the workshop. 


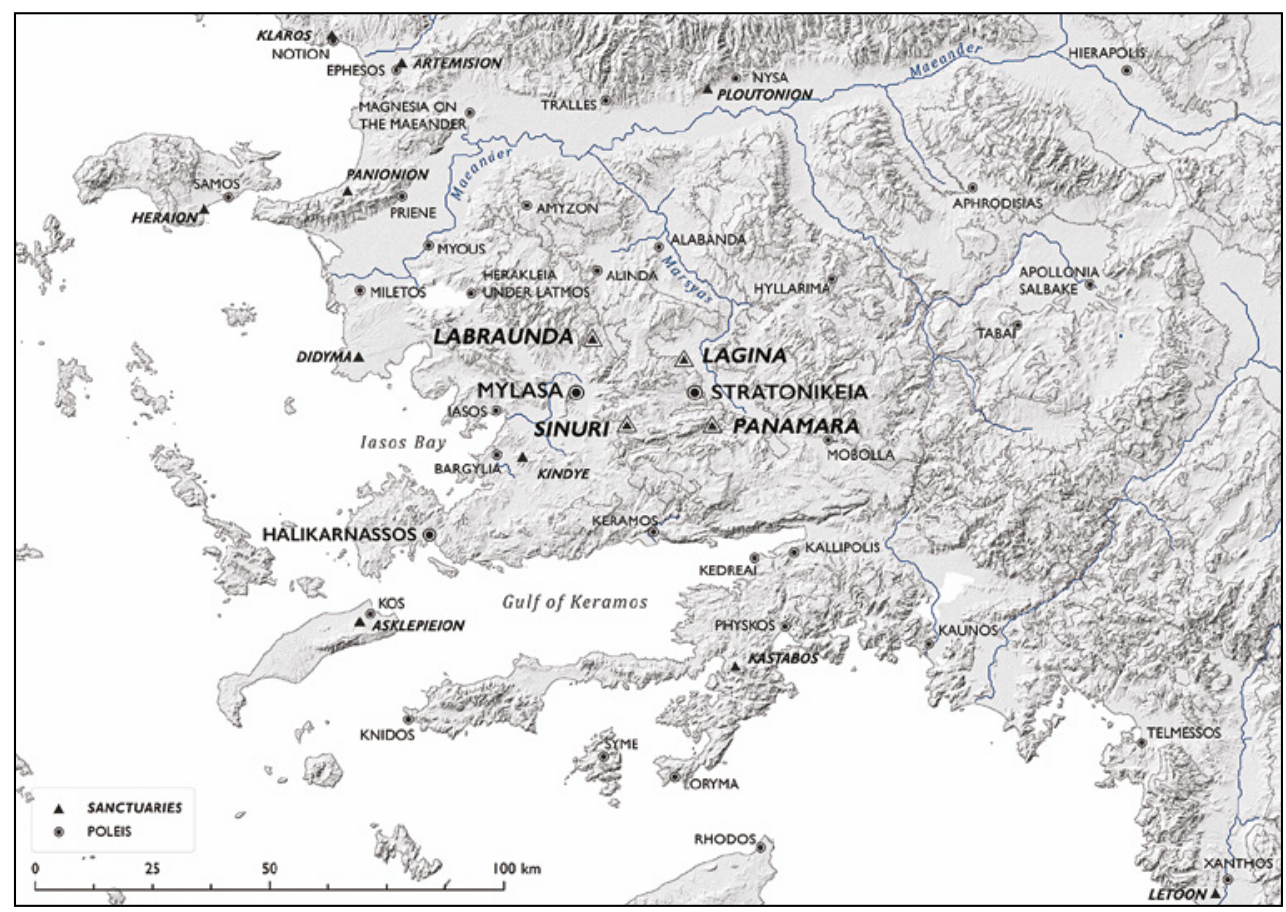

FIGURE 2.1 Map of southwest Asia Minor showing the locations of the case studies

century, if not before, Koranza became a deme of Stratonikeia while Hekate was promoted to patron goddess of the new city. The sanctuary of Zeus Karios at Panamara was initially a regional hilltop shrine administered by a distinct community; in the course of the second century it was entirely taken over by Stratonikeia; the polis now had both Zeus and Hekate as its patron gods.

These sanctuaries were also located in geographical locations that may well represent the physical boundaries of the civic territory, thus providing potential insights for a 'frontier' role, and whether the shrines fulfilled this function. Both cities, however, were also clearly composite entities, being socially and physically built up through processes akin to synoikism, where local communities were merged or even relocated to enhance the citizen population. Mylasa's early history is shadowy, but it appears to have been an agglomeration of the surrounding communities clustered together as a polis under the Hekatomnid satraps in the fourth century вс. ${ }^{283}$ Stratonikeia, on the other hand, was

283 Strabo 14.2.23 speaks of Mylasa as 'a mere village in ancient times'; on the presumed synoikism, see Rumscheid (2010), 97-98, and below in Chapter 3. 
clearly a Macedonian foundation, founded by the Seleukids probably as an outpost in Ptolemaic-oriented southern Karia. Local communities were, however, involved as at some point the surrounding villages had been absorbed as demes, although it is unclear exactly when this process took place or at whose behest. $^{284}$ Both cities demonstrate territorial ambitions and an aggressive expansionist policy. The fact that they were neighbors and for a time perhaps even rivals invites close scrutiny of their mutual borders as pressure zones with great potential for border conflict. ${ }^{285}$ Finally, three of the four sanctuaries have been excavated and published, albeit in varying degrees of completion. ${ }^{286}$ The fourth sanctuary, that of Zeus at Panamara, has yielded an epigraphic record that exceeds by far all of the others, even though the site awaits systematic excavation. It should be noted that as Stratonikeia developed in the Roman period, the epigraphic record at both sanctuaries grew immensely; several inscriptions from this period will be included in this present study as they articulate developments that initiated in the Hellenistic period.

284 Strabo 14.2.25 mentions Stratonikeia as 'a settlement of Macedonians'. On the villagedemes, see Şahin (1976), Debord (2001a), and van Bremen (2000), discussed below in Chapter 5 .

285 At least one border conflict is known between the two poleis, in I.Mylasa 134, discussed in Ager (1996), 101; see also Reger (2010).

286 Labraunda was excavated by the Swedish starting in 1948 and later under the direction of Pontus Hellström and Lars Karlson; currently under Olivier Henry and the Institute français d'études anatoliennes (IFEA). Labraunda has been extensively published, see labraunda.org. Lagina is one of the oldest Turkish excavations, and was until recently directed by Prof. dr. Ahmet Tirpan, now by Prof. dr. Bilal Söğüt, who also directs the excavations of Stratonikeia. Reports appear regularly in the Kazı Sonucları Toplantası. Sinuri was excavated by the French in the 193os, Devambez (1959). Louis Robert published the inscriptions, I.Sinuri. Panamara remains to be excavated although the inscriptions were published by Mehmet Çetin Şahin in the first volume of I.Stratonikeia. 


\section{Memory and Control: Mylasa and the Sanctuary of Zeus Labraundos}

Mylasa is situated in inland Karia (Figure 3.1), a mountainous region known primarily for its hilltop settlements and sanctuaries until it underwent a wave of urbanization in the fourth century BC. The Hekatomnids, the local dynasty chosen to rule Karia as satraps under the Achaemenid empire, conducted an intensive reorganization of the region that included the foundation of cities and the monumentalization of key sanctuaries. Mylasa was home to the Hekatomnids and hence one of the first to benefit from their legacy. The polis remained a major center in the region for generations to come.

With its rich sacred landscape, Mylasa provides an excellent starting point for this study. By the first century BC, Strabo writes of Mylasa and its sanctuaries:

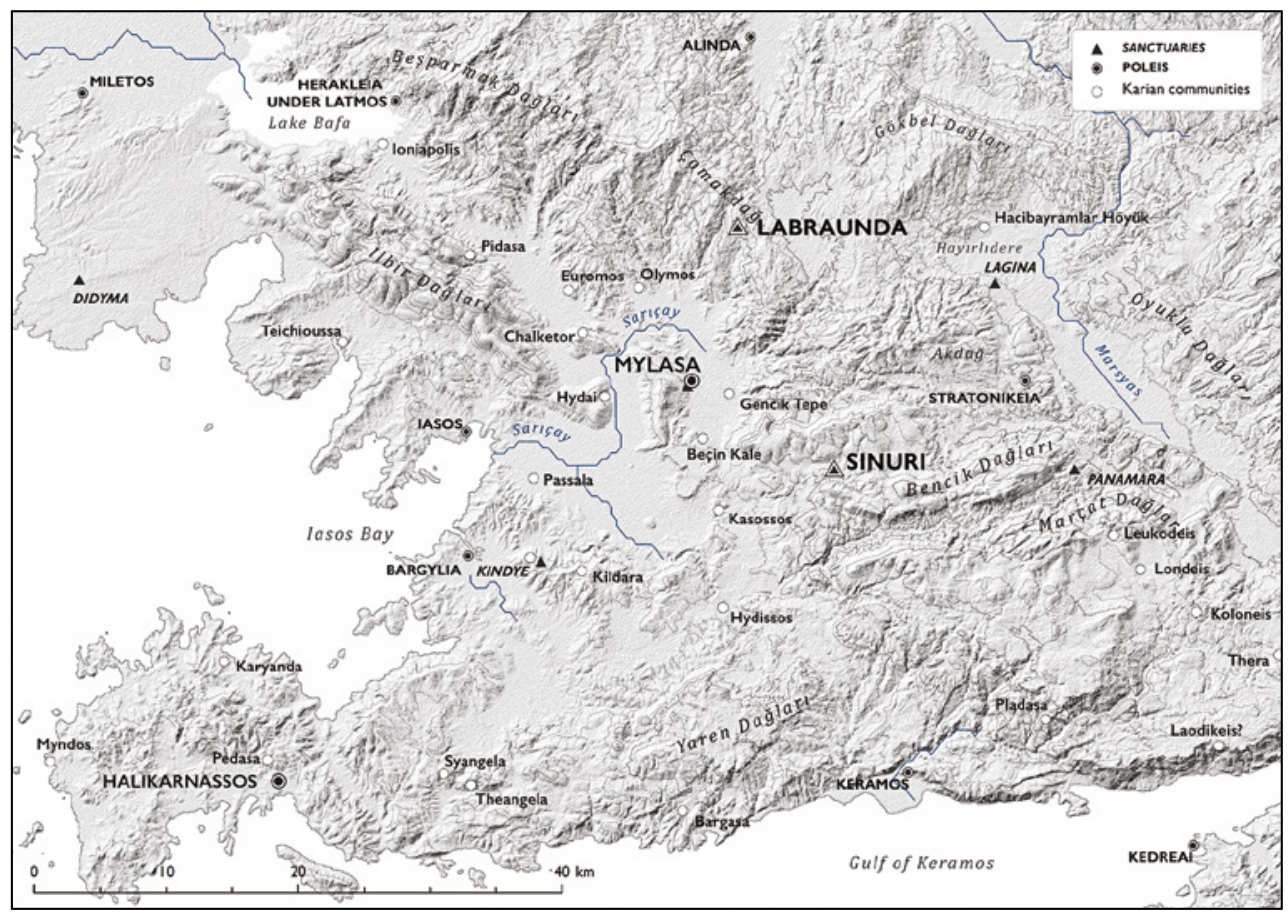

FIGURE 3.1 Map locating Mylasa and the shrines of Zeus Labraundos and Sinuri

(C) CHRISTINA G. WILLIAMSON, 2021 | DOI:10.1163/9789004461277_004

This is an open access chapter distributed under the terms of the CChPS-NC 4.OGlicense.iamson - 978-90-04-46127-7 
... the Mylasians have two temples of Zeus, Zeus Osogo, as he is called, and Zeus Labrandenus. The former is in the city, whereas Labranda is a village far from the city, being situated on the mountain near the pass that leads over from Alabanda to Mylasa. At Labranda there is an ancient shrine and statue of Zeus Stratios. It is honored by the people all about and by the Mylasians; and there is a paved road of almost sixty stadia from the shrine to Mylasa, called the Sacred Way, on which their sacred processions are conducted. The priestly offices are held by the most distinguished of the citizens, always for life. Now these temples belong peculiarly to the city; but there is a third temple, that of the Karian Zeus, which is a common possession of all Karians, and in which, as brothers, both Lydians and Mysians have a share. It is related that Mylasa was a mere village in ancient times, but that it was the native land and royal residence of the Karians of the house of Hekatomnos. ${ }^{1}$

Strabo communicated to his readers the principal sanctuaries associated with Mylasa of his day. The sanctuary of Zeus Osogollis, ${ }^{2}$ mentioned first, was probably the chief sanctuary of Mylasa by the late first century вс. Located 'in the city', as Strabo emphasizes, it had a strong role in the rural economy of the polis, as several inscriptions testify. ${ }^{3}$ The sanctuary of Zeus at Labraunda, 'far from the city', is located in the hills some 14 kilometers to the north, and was one of the most significant construction projects of the Hekatomnids in the mid-fourth century BC. Strabo remarks that both sanctuaries 'belong peculiarly to the city', juxtaposing them with a third sanctuary, that of Karian Zeus, which was the regional center of the Karian federation; its whereabouts, however, have yet to be identified. ${ }^{4}$

1 Strabo 14.2.23 (transl. H.L. Jones (1929) The geography of Strabo, LCL 223).

2 On the name of Osogollis, rather than Osogo or Osogoa, see Blümel (1990). This unusual maritime Zeus, or Zenoposeidon, is discussed in Parker (2017), 94-95.

3 See below on the land-lease contracts of the sanctuary of Zeus Osogollis. The sanctuary has been identified in the modern town of Milas by the stretch of polygonal wall that may have defined part of its terrace, Laumonier (1958), 105, and Hauvette-Besnault and Dubois (1881), 98. Based on Machon's description of the sanctuary of Zeus Osogollis (here called Zenoposeidon) as before the gates ( $\pi$ ò $\tau \hat{\omega} \nu \pi v \lambda \hat{\omega} \nu)$, (Gow Machon Fr.8 (=Ath.viII.337c), lines 55-56), Laumonier locates it outside but near the walls, Laumonier (1958), 105. Mylasa, however, had no walls (Rumscheid (1999b)) and given its proximity to the town center as well as Strabo's description, the sanctuary of Zeus Osogollis is here considered an 'urban' sanctuary, although it may well have been at the edge of town, connecting it with the plain to the south and towards Beçin Kale.

4 This was once considered to be at Uzunyuva, the large platform with the single column on the Hisarbaşı hill in Milas, e.g. Laumonier (1958), 43; Bean (1971 [1989]), 22; Voigtländer (1991). 
Archaeological investigations have revealed at least three more sanctuaries in the territory of Mylasa that Strabo does not mention: a sanctuary for a goddess at Kale Mevkii, between Mylasa and Labraunda; ${ }^{5}$ a more monumental sanctuary to an unknown deity at Gencik Tepe, roughly three kilometers east of town (Figure 3.10); ${ }^{6}$ and the sanctuary of the Karian god Sinuri, some 15 kilometers southeast of the urban center (Figure 3.1). Like Labraunda, this last shrine was also extensively remodeled and terraced by the Hekatomnids. The sanctuary at Gencik Tepe seems to have undergone a renewal in the late third or early second centuries BC, but despite its monumentality, not enough is known about its cult, organization or community to include it in this study; the same is true of the cult place at Kale Mevkii. The sanctuary of Sinuri, however, has been extensively documented and shows close ties to Mylasa that will further be addressed in the Chapter 4.

The sanctuaries of Zeus Labraundos and Sinuri were both targeted for benefactions by the Hekatomnids, yet a very different relationship with Hellenistic Mylasa developed with each shrine. Labraunda, which still stood symbol for Karia, was important for the political and regional identity of the Mylasans, but it became contested space. The sanctuary of Sinuri, on the other hand, was fixed on a subdivision of the citizen population, yet one that changed identity and was subsumed by the polis in the Hellenistic period. This chapter opens with a general historical overview of Mylasa, that also forms the backdrop to Chapter 4, then proceeds to Labraunda as the first case study to be assessed using the framework of analysis set out in Chapter 2. The framework will allow us to systematically examine the many complex changes that took place to each cult in the transfer of power from the Hekatomnid satraps to the democratic polis. After these detailed analyses, the relationship between city and sanctuary is discussed in each case, focusing on the significance of these shrines to Mylasan community.

Illegal excavations have since shown it to be an unfinished 'proto-Maussolleion', Rumscheid (2010), suggested to have later functioned as the 'sacred agora' in Mylasa, Marek and Zingg (2018), 125-126. Alternative suggestions for the shrine of Zeus Karios include: the unidentified monumental sanctuary at Gencik Tepe, Säve-Söderbergh and Hellström (1997); the stairway and podium inside the castle at Beçin Kale, Baran (2009), 306-311; or even the sanctuary of Zeus Karios at Panamara, Debord (2001b), 31-34, as potential home of the Karian League. The suggestion of Beçin Kale in Cook (1961) is unlikely, and is also suggested to have been a precursor to the Maussolleion, Henry (2013).

5 Rumscheid (2005) mentions marble fragments from the fourth century BC and a relief of a goddess with worshipers, found near the remains of a church.

6 Säve-Söderbergh and Hellström (1997); Radt (1969/70), 170. 
Settled from at least the Late Geometric period, Mylasa was in antiquity considered an ancient Karian center. ${ }^{8}$ As Strabo mentioned, it was the home of Karian Zeus and the hub of the Karian League. Herodotos had already described the sanctuary as common only to the Karians and their kin:

[the Karians] hold that they are the aboriginal dwellers on the mainland and ever bore the name which they bear now; and they point to an ancient shrine of Karian Zeus at Mylasa, whereto Mysians and Lydians, as brethren of the Karians (for Lydus and Mysus, they say, were brothers of Kar) are admitted, but none of any other nation, though they learned to speak the same language as the Karians. ${ }^{9}$

Cult was a vehicle for kinship communities, and an even stronger marker of identity than language. This passage shows how places of cult could create openings across political borders on the one hand, but on the other how they could also be highly exclusive, setting up alternative criteria that elevated the worshiping group, galvanizing them in this case through the authority of the past.

Although Mylasa was an ancient regional center, it only took shape as an urban center under the Hekatomnids in the fourth century. Mylasa was the hometown of Hekatomnos, who was appointed satrap during the reign of Artaxerxes II (404-358 BC) and was surely already a prominent figure among the Karian elite. ${ }^{10}$ Karia underwent a major transformation at the hands of the Hekatomnid dynasty, particularly Maussollos (c. 377/6-353/2 BC), successor

See also Williamson (2013e). I am grateful to Frank Rumscheid, who commented on an earlier draft and corrected several of my interpretations on the urban area of Mylasa, particularly with regard to the sanctuary of Zeus Osogollis. Any remaining errors here are entirely my own.

8 Some finds from the Mycenaean period were found in the area, but most begin in the eighth to seventh century вC, Rumscheid (1999b); 206, also (1999a), 171-176 on Late Geometric pottery found in the fill of a Roman peristyle building in Milas. Rumscheid (1999b), 206-207 further argues against the Mylasa originally being located on the fortified hilltop at Beçin Kale, five kilometers to the south (e.g. Cook 1961), as unsubstantiated. Hdt. 1.171.23-30 (transl. A.D. Godley (1922) The Persian wars, LCL 119). The Karian League was especially active in the fifth and fourth centuries during the Ionian revolt, Hdt. 5.37.1-3, 5.119.7-10, and 5.121.2-8. Their role seems to have subsided somewhat with the rise in the third century of the Chrysaoric League (see below on Labraunda).

10 On the Hekatomnids in general: Hornblower (1982); Ruzicka (1992); Pedersen (20012002); Carstens (2009). 
to Hekatomnos, who embarked upon a building program across the region that resulted in several defense systems, monumental sanctuaries, the consolidation of cities (synoikisms), and the rise of Halikarnassos as cosmopolitan center. The Hekatomnids gave Karia, traditionally made up of clusters of hilltop communities, a sense of unity and consolidation that it had not known before nor would again.

Mylasa and its landscape were also central to their program. When Maussollos came to power he transferred the royal seat from Mylasa to Halikarnassos. Located on the Myndos peninsula, this was closer to the powerful international centers that he was interested in, such as Kos, Knidos, and Rhodes. ${ }^{11}$ Nonetheless, Mylasa remained a major polis in the Karian interior, where Maussollos's brother Idrieus remained as governor, until Maussollos's death in 353/2 BC, when he then assumed the role of satrap until his own death in 344/3 BC. ${ }^{12}$ Like Halikarnassos, the population of Mylasa was probably inflated through a synoikism of the existing settlement with some of the surrounding hilltop communities, e.g. at Beçin Kale and Gençik Tepe. ${ }^{13}$ Mylasa's divisions of phylai and syngeneiai (kinship groups) appear to incorporate the living memory of many of these local communities.

Mylasa lies in a fertile plain and its exposed position, rather than on a defensible hilltop, was noted by Strabo as unusual for such a prominent city. ${ }^{14}$ Maussollos is reported to have taxed the citizens for a circuit wall, although there is no evidence that this was actually built. ${ }^{15}$ Frank Rumscheid, however, observed that a considerable system of fortifications dating from the Hekatomnid period may be located on the hills around the city, while Reger and Descat have shown that the main routes of access to the plain were highly

11 Poul Pedersen (2013) gives an enlightened discussion of the 'Ionian renaissance' as an indication of the 'Hellenization' of Karia in opposition to Hornblower's view of the 'Karianization' of Karia, Hornblower (1982).

12 In the early Hellenistic period, the Macedonian satrap Asandros may even have moved the residency back from Halikarnassos to Mylasa where he received ambassadors, see Hornblower (1982), 103 and n. 192. Strootman and Williamson (2020) on the juxtaposition of monumental building in Halikarnassos and Mylasa, especially Labraunda.

13 Rumscheid (2010), 96-99. This corresponds with the description in Strabo 12.2.23 of Mylasa as a village $(\kappa \omega \dot{\omega} \mu)$ in ancient times. The name 'Mylasa' is plural, perhaps reflecting a collective of communities (my thanks to Pontus Hellström, who pointed this out to me).

14 Strabo 14.2.23, 'But one may well be amazed at those who so absurdly founded the city at the foot of a steep and commanding crag. Accordingly, one of the commanders, amazed at the fact, is said to have said, "If the man who founded this city, was not afraid, was he not even ashamed?"' (transl. H.L. Jones (1929) The geography of Strabo, LCL 223).

Ps.-Arist. Oikon. 2.2.13 (1348a, 12ff); Hornblower (1982), 7 o n. 126; Rumscheid (2010), 96-97. 
secured for Mylasa. ${ }^{16}$ The extent of construction activity in the town itself from this early period is largely obscured by the modern infrastructure. A glimpse came to light, however, in 2010: the monumental platform on Hisarbaşı hill, long considered the stylobate of the temple of Zeus Karios, was postulated by Frank Rumscheid as a proto-Maussolleion, based on similarity of architectural details with the Maussolleion in Halikarnassos. ${ }^{17}$ Clandestine excavations confirmed this, revealing spectacular subterranean chambers with some of the earliest vault architecture, painted walls, and a sculpted sarcophagus from the fourth century that surely belonged to one of the rulers. ${ }^{18}$ Like the Maussolleion in Halikarnassos, this major funerary monument was located at the heart of the new urban center.

As counterpoint, the shrine of Zeus Labraundos, up in the mountains north of Mylasa, was promoted by the satraps as the sacred focus of Karia, and especially of their dynasty (Figure 3.2). In the hills overlooking the plain of Mylasa they established a complex rivaled in magnificence only by Halikarnassos. Poul Pedersen draws a compelling comparison between Labraunda and the palace-temple complex on the Zephyrion peninsula in Halikarnassos. ${ }^{19}$ In both cases divine authority is combined with political power in a striking, highly prominent location. Labraunda was the most splendid sanctuary of the Hekatomnids, but not the only one to enjoy their patronage. The sanctuary of Sinuri also benefitted from their building program, proving its relevance at this time. While the inscriptions at Labraunda are in Greek, communicating to a cosmopolitan audience, the bilingual inscriptions at the shrine of Sinuri

16 Rumscheid (1999b); Reger (2010) on the question of the 'Little Sea' towards Iasos, and Descat (2013) on the route from the south near Hydissos and Sekköy/Talagreia.

17 Rumscheid (2010). This structure on Hisarbaşı hill, locally known as Uzunyuva, consists of a large platform with a single Corinthian column (with a stork's nest, hence the name Uzunyuva, 'tall nest'). This was long held to be the temple of Zeus Karios based on Herodotos's description of this shrine as being in Mylasa: also Hdt. 5.119.2, e.g. Laumonier (1958), 43; Bean (1971 [1989]), 22. Further researched by Voigtländer (1991). The single Corinthian column is an honorific monument from the mid-first century вС for the orator Euthydemos, Rumscheid (2010).

18 In the fall of 2010, illegal excavations exposed the burial at a depth of $12 \mathrm{~m}$ below the platform (see e.g. dailysabah.com/travel/2018/o8/o1/monumental-tomb-in-turkey-opensnew-horizons-in-history-of-archaeology). At a conference in Münster in 2013, Abuzer Kızıl described the architecture, while Fahri Işik proposed that the intended occupant was Hekatomnos: Kızll (2013); Işsk (2013). Rumscheid's analysis suggests a later date, more consistent with Idrieus. On Hekatomnid tombs, see also Henry (2010) and (2014), and Pedersen (2017).

19 Pedersen (2013), 41, also (2009), 334-337. Apollo was the principal deity in Halikarnassos and Pedersen includes the Hekatomnid coinage showing a Hellenic Apollo on the obverse and Karian Zeus Labraundos on the reverse; see also Konuk (2013). 


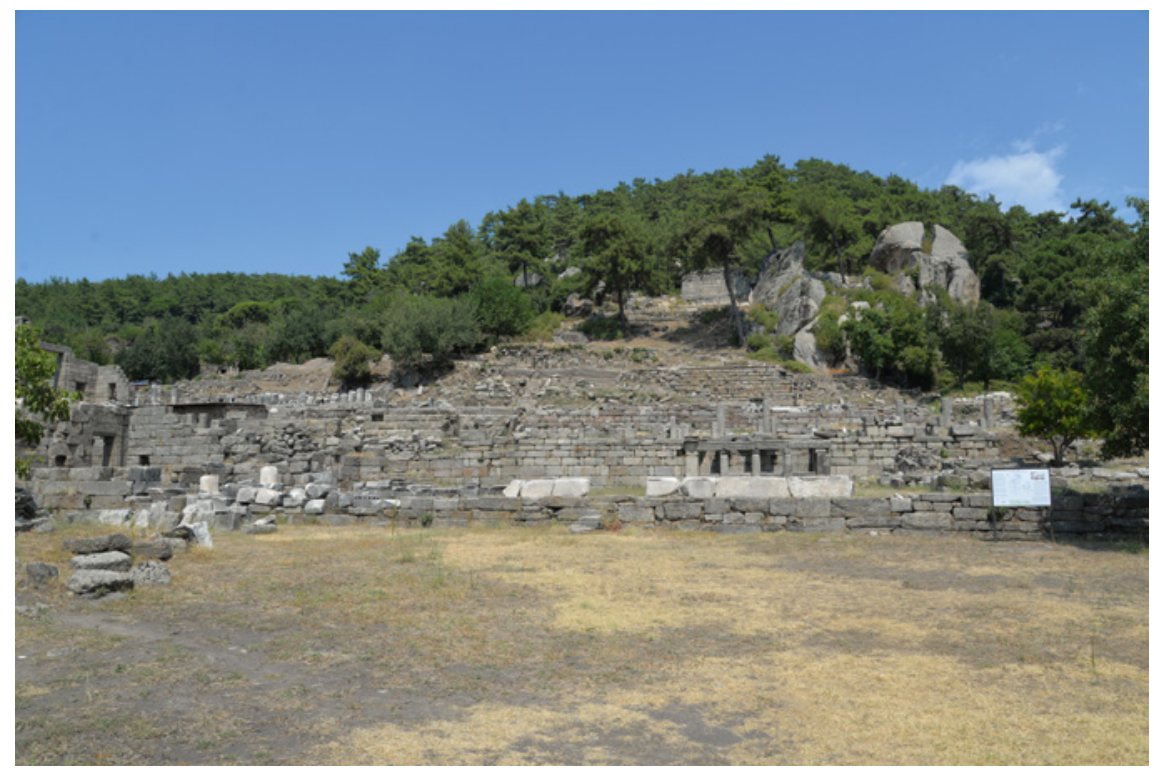

FIGURE 3.2 Labraunda. View of the sanctuary, with the split rock in the upper right PHOTO AUTHOR 2019

underscore the deeply Karian nature of the god and his community, a syngeneia, a kind of kinship collective. This syngeneia appears to have been independent until the Hellenistic period, when control over the shrine shifted to a syngeneia under a different name that clearly belonged to Mylasa. ${ }^{20}$ Sinuri was not an urban deity, yet the incorporation of his shrine into the area annexed by Mylasa demonstrates the territorial extent of the polis by this time. More importantly, the way it was administered illustrates how sub-communities could use sanctuaries just as poleis did to navigate their own geographies of identity, further discussed in Chapter 4.

As mentioned above, the sanctuaries of Zeus Labraundos and Sinuri were not the only sacred sites in the landscape of Mylasa, yet they were both clearly vital to the interests and aspirations of the polis, each in a unique way. Both sanctuaries had already been targeted by the Hekatomnids in the fourth century, and both were subsequently caught up in the political, social, and territorial composition of the democratic polis after the passing of the Hekatomnids. Hellenistic Karia underwent a turbulent period as power changed hands several times between the Macedonians, Ptolemies, Seleukids, even Rhodes,

20 The bilingual inscriptions are I.Sinuri $73^{-75}$, see Adiego (2000). The sanctuary at Sinuri was specific first to the Pelekos syngeneia and later that of Pormounos; see below. 
and finally Rome. ${ }^{21}$ An early indication of the effect this had in the area is the stronghold at Kuyruklu Kalesi. ${ }^{22}$ The fortified plateau may have served as a place of refuge for the Mylasans, whose vulnerable polis was in the valley and still unprotected by walls. In the early third century BC, the Ptolemies were active in this area along with the Chrysaoric League, a Karian federation that was sympathetic towards the Ptolemies and later settled near Stratonikeia. ${ }^{23}$ Antiochos II reacted and seized Mylasa from Ptolemaic influence, and in the 24OS BC his successor Seleukos II 'liberated' the polis through his strategos (general) Olympichos, who then took up residence in the area as governor. ${ }^{24}$ During his regency, controversies arose between the priests of Labraunda and Mylasa, and although they escalated to the king, Olympichos played a key role in settling them in favor of the polis. Some twenty years later, however, he was directed to evacuate the region under the rule of the Macedonian Philip v, who firmly declared that Labraunda belonged to Mylasa. ${ }^{25}$

Towards the end of the third century, Mylasa entered into a peaceful agreement of civic equality (isopoliteia) with Miletos, inscribed at the sanctuaries of Zeus Labraundos, Zeus Osogollis (in Mylasa), and Apollo Didymeus near Miletos. ${ }^{26}$ The third century, however, ended in geopolitical turmoil when Antiochos III, and especially his general Zeuxis, swept through the area of Mylasa in their campaign to restore the old extent Seleukid kingdom. The upheaval has been interpreted by some to be at the root of the many petitions

21 Ada, sister and wife of Idrieus, was allied with Alexander the Great against her brother Pixodaros and left Karia to Alexander when she died. The following period is complex and only the key events are mentioned here; see also Billows (1995), 90-107; Aubriet (2009) and (2013).

Wolfgang Radt believes the fortifications date from the early Hellenistic period, although the site shows a settlement phase from the Archaic or Classical period, Radt (1969/70), 169-170; Rumscheid (1999b), 216-217, dates the walls to the second half of the fourth century BC by analogy with Latmos.

23 The Chrysaoric League and their Ptolemaic affiliations are evident in I.Labraunda 43-44, dated to 267 вC; see Mastrocinque (1979), 66-70 and 220-226; Gabrielsen (2000), 156-161, also (2011); van Bremen (2017). Later attempts by this league to take control of the sanctuary with Labraunda's priest are discussed below, under Legal Administration.

24 On Ptolemaic and Seleukid influence in Karia and Mylasa and the Second Syrian War, see Ma (1999), 41-42. Seleukos II's liberation of Mylasa is primarily testified in I.Labraunda 3, discussed in more detail below. Also Crampa's comments in I.Labraunda, p. 82-85; Bencivenni (2003), 247-298, esp. 265ff., and Aubriet (2012). A brief discussion of the date is given in Carless Unwin and Henry (2016), 31, n. 15. Olympichos's position in the area is discussed further below, but see also: Debord (1969); Isager and Karlsson (2008); Debord (2011); Isager (2011); Aubriet (2012); Henry and Aubriet (2015); van Bremen (2016); Carless Unwin and Henry (2016); Marek and Zingg (2018), 120-126.

25 As is evident from I.Labraunda 5 , discussed below.

26 Milet I,3 146; Staatsverträge III 273-276, no. 539. 
for asylia by towns for their sanctuaries and territories in this era. ${ }^{27}$ Their troops took the town and apparently pillaged the countryside, including some of the lands belonging to Sinuri. These were later restored through Antiochos's intervention, who took further measures to ensure that the shrine of Zeus Labraundos would be left in peace. ${ }^{28}$ This was a defining moment for the Hellenistic polis, which leveraged the great sanctuary at Labraunda to negotiate its position with the ruling powers. ${ }^{29}$

The second century began more peacefully. Mylasa was one of the cities declared independent after the Treaty of Apamea in 188 BC, but was nonetheless attacked by Rhodes after the island power was bereft from its peraia on the mainland in Karia by Rome in $167 / 6$ BC. The attack was, however, prompted by Mylasa's occupation of neighboring Euromos in the wake of the power vacuum left by Rhodes. ${ }^{30}$ This only slowed Mylasa's expansion. Eventually it engaged in sympoliteia with Olymos and Euromos and absorbed the surrounding communities of Labraunda, Chalketor, and Hydai. ${ }^{31}$ At some point it established a harbor facility at Passala. ${ }^{32}$

The Mithridatic Wars in the 8os of the first century had little impact on Mylasa. The city's eastern neighbor, Stratonikeia, would come out of this event with solid ties to Rome that significantly propelled it forward. By the middle of the century, Mylasa had become one of the provincial courts of Asia Minor (conventus Asiae). Yet in the $4 \mathrm{OS}$ BC, Mylasa suffered heavily from the attacks

27 Mastrocinque (1984); Flashar (1999); Knäpper (2018). On this period in the history of Mylasa, see esp. Ma (1999), 67-70; also W. Ruge in $R E$, s.v. 'Mylasa', esp. 1050-1052.

28 On the occupation of lands belonging to Sinuri, Virgilio (2010), and below. Antiochos III's letter promising to respect Labraunda is I.Labraunda 46 . The turbulence created by the campaigns and conquests of Antiochos III is sometimes seen as a motive for the surge of asylia inscriptions at sanctuaries, discussed in Roels (2018a), esp. 234-238, with references.

29 E.g. Debord (2011), Reger (2010); further discussed below.

$30 \quad$ Polyb. 21.46.4 and Livy 38.39.8 on Mylasa and Rhodes after the Treaty of Apamea in 188 BC. On the political situation between Rhodes, Mylasa, and Euromos after 167 BC, Polyb. 30.5.11-15; Livy 45.25.11-13; see also Rigsby (1996), 407-415, nos. 187-209.

31 On Mylasa's expansionist policy, see Reger (2004), 164-168 and Reger (2010), identifying two pulses in Mylasan expansion: a mid-fourth century, under Maussollos, and one that the polis initiated in the mid-third century via sympoliteia of neighboring poleis. I.Labraunda 137 offers further evidence of a sympoliteia with neighboring Olymos at this time, Henry and Aubriet (2015), 699; this inscription designates the area between Mylasa, Olymos, and Labraunda under the topnym Larysynia, Carless Unwin and Henry (2016). Epigraphic evidence for property holdings in this area is examined in van Bremen (2016), $11-16$.

32 The importance to landlocked Mylasa of Passala and 'the little sea' are discussed in Reger (2010), and now Aubriet (2017). The acquisition of coastal property by Mylasa from Kindye is discussed in detail in Descat (2013), van Bremen (2013), and again Descat (2014). 
by Labienus and his Parthian troops. Strabo blames this in part on the taunting of the orator Hybreas, who, however, also helped restore the city afterwards. ${ }^{33}$

Political bodies known from inscriptions reflect the transition to the Hellenistic era in Mylasa. Under the Hekatomnids, decisions at Mylasa were made in the kyria ekklesia, the regular assembly meeting as prescribed by law, and were ratified by 'the three tribes.' ${ }^{34}$ These tribes may well have been remnants from the Hekatomind synoikism of the surrounding communities. The tribes are thought to continue in the Hellenistic period, when the population of the city was reorganized into three main phylai: the Otorkondeis, the Konodorkondeis, and the Hyarbesytai, with the Otorkondeis making the most frequent appearance in the inscriptions. ${ }^{35}$ Another level of sub-community was the syngeneia, or 'kinship' group, as mentioned above in connection with the sanctuary of Sinuri. Some of these were subsidiary to a phyle; e.g. the Tarkondareus syngeneia and that of the Maunnites both belonged to the Otorkondeis phyle, while the Aganiteis syngeneia belonged to the phyle of the Hyarbesytai. ${ }^{36}$ Other syngeneiai certainly operated within the sphere of the polis, such as the syngeneia of Korris at Labraunda, and of Pormounos at the sanctuary of Sinuri. It would seem that participation within syngeneiai was not mutually exclusive. Members of the Tarkondareus syngeneia were also active within the Pormounos syngeneia; one of the later priests at Labraunda belonged to the Maunnites syngeneia but would also have been involved with

33 Quintus Labienus was a commander under Brutus who had just mustered Parthian support when he learned of Brutus' downfall; instead of bringing them to Rome as planned, he began a rampage through Asia Minor, hoping to take the province by force. This episode is discussed in more detail below, in relation to Stratonikeia, as it had more impact on the sanctuaries of Hekate at Lagina and Zeus at Panamara. Strabo 14.2.24 tells of the role of Hybreas in the devastation of Mylasa by provoking Labienus, but also in its restoration.

34 E.g. I.Mylasa 1, 2 are decrees in the mid-fourth century using the clause: हैंठ

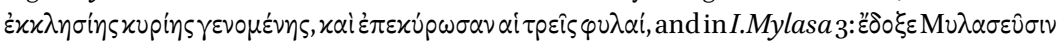

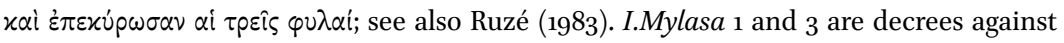
persons who plotted against Maussollos in $367 / 6$ and $355 / 4$ (an assassination attempt during the festivals at Labraunda); I.Mylasa 2 is a decree against the sons of Peldemos for damaging a statue of Hekatomnos in 36o/1; see Caldesi Valeri (1998); Hornblower (1982), 68-70.

35 See also Rhodes and Lewis (1997), 341-347 on the development of the Mylasan political system; they also observe how the phylai also passed honorific decrees for those who performed positive actions towards the polis, p. 344-346 n. 2 referring to Jones (1987), 328-332.

36 On the Tarkondareus and Maunnites, W. Ruge in $R E$, s.v. 'Mylasa', 1055-1056; on the Aganiteis, I.Mylasa 121-122; see also below in the discussions of the sanctuary of Sinuri (Chapter 4). 
the Korris syngeneia at Labraunda, presuming that this was still active in the late second century вс. ${ }^{37}$ Most of these sub-communities had their own cults to Zeus. ${ }^{38}$ This plethora of groupings, and each with its religious center of gravity, explains in part the rich sacred landscape of Mylasa and Laumonier's observation on the disproportionate number of cults for the population. ${ }^{39}$

In this sense, it is important to realize that different sanctuaries served different and overlapping layers of Mylasan identities, whether syngeneia, phyle, or the civic body as a whole. The Otorkondeis, for example, held in common the sanctuary of Zeus Otorkondeon, but they also played a prominent role in the administration of the sanctuary of Zeus Osogollis, which became one of the primary urban sanctuaries of Mylasa. Labraunda, on the other hand, was much more of a regional sanctuary, interwoven with Karian (and Hekatomnid) identity, but now also carried the political identity of the city in its slipstream. At the same time it was the platform for the local syngeneia of Korris. The sanctuary of Sinuri was the focal point for the identity of the Pormounos syngeneia. Mylasan society was thus highly nested, with the many overlapping segments having a religious center through which they could celebrate themselves and negotiate their layered identities.

Examining the sanctuaries in the more remote regions of the chora of Mylasa as urban spaces will enable a better understanding not only of how they functioned, but also of the different ways in which they were significant to the polis, what kind of urban identity was expressed through them, and the role that their location in the landscape may have had in determining their significance.

The case study of Labraunda demonstrates several dynamics that could be involved as a polis acquired control over a major sanctuary of regional

37 E.g. Pammenes, son of Hermogenos, of the Tarkondareus was one of the ktematonai, or sacred land managers, for the Pormounos syngeneia, I.Sinuri 47a and 50. Hekatomnos, son of Ouliades, and priest of Labraunda in the late second century BC was also active in the Maunnites syngeneia, e.g. I.Mylasa 501; see below on the Korris syngeneia.

$38 \quad$ E.g. the phylai of the Otorkondeis and Zeus Otorkondeon and the Hyarbesytai with Zeus Hyarbesyton; the syngeneiai of the Aganiteis at their sanctuary of Zeus Aganiteon and of the Maunniteis with Zeus Maunniton; discussed further towards the end of this chapter. Laumonier (1958), 39. The sanctuaries of the phylai and syngeneiai are discussed in more detail at the end of Chapter 4 , as it is relevant to the community at the sanctuary of Sinuri.

40 This section draws from Williamson (2013d), (2013e), (2014a), and (2014c). I am particularly indebted to Pontus Hellström, Lars Karlsson, Olivier Henry, Axel Frejman, Jesper 
significance. This case study explores the impact of the legacy of the Hekatomnids at Labraunda and the bearing that this continued to have on the relationship between the sanctuary and Hellenistic Mylasa.

As the Hekatomnids moved their satrapal seat to the coast at Halikarnassos, they simultaneously designated the mountain shrine of Zeus Labraundos, near their hometown of Mylasa, as their primary sacred center (Figure 3.2). The splendor of the complex resonates with royalty, as does the monumental approach via the paved road that connected the shrine with Mylasa and reinforced it as the primary point of contact for this central Karian cult. The selection of the sanctuary of Zeus Labraundos, rather than the renowned Zeus Karios, is significant and underscores a conscious decision to tie this sanctuary in particular to the Hekatomnid dynasty. Part of this is surely connected with the landscape and position of the shrine on a mountainside overlooking the plain of Mylasa and beyond to much of their territory. The monumentality given to Labraunda by the Hekatomnids is discussed in detail in this section, in particular as it relates to the landscape. It is this combination that lent the shrine a power of place that explains a great deal of why Hellenistic Mylasa also selected this sanctuary, out of all those in its territory, to represent itself in the turbulent years that followed the passing of the Hekatomnids. This is when the polis struggled to redefine its political position amidst changing kingdoms and maintain its grip on the mountain shrine. Labraunda itself became contested space and the changes that took place in the Hellenistic period were primarily about control, rather than adding to the complex or its rituals in any major way. In fact, the noticeable lack of change at the site has been interpreted by the excavator Pontus Hellström as a deliberate attempt at retaining the Hekatomnid legacy, and turning this powerful sanctuary into a 'memory theater.41

\subsection{Historical Overview of Labraunda}

Finds at the site go back to the seventh century BC, although the earliest literary reference to Labraunda is in Herodotos, in connection with the Ionian revolt in 497 BC, when the Persians defeated the Milesians and their Karian allies in a battle near the Marsyas (Çine) river:

Presently, when the Persians had come and had crossed the Maeander, they and the Karians joined battle by the river Marsyas. The Karians

Blid, and Felipe Rojas for many discussions of the excavations, and for sharing their thoughts on the biography and nature of Labraunda. 
fought obstinately and for a long time, but at the last they were overcome by the odds. Of the Persians, as many as two thousand men fell, and of the Karians ten thousand.

Those of them who escaped were driven into the precinct of Zeus of Armies [Zeus Stratios] at Labraunda, a large and a holy grove of planetrees. (The Karians are the only people whom we know who offer sacrifices to Zeus by this name.) When they had been driven there, they deliberated how best to save themselves, whether it would be better for them to surrender to the Persians or to depart from Asia. ${ }^{42}$

Herodotos thus describes the sanctuary of Zeus at Labraunda in the Archaic period as a modest shrine with a sacred grove of plane trees, indicating an open-air shrine. Archaeological evidence, however, indicates that there was a temple and a mud-brick altar, discussed below. Herodotos's depiction of the Karians discussing their odds at the sanctuary is sometimes taken as proof that the sanctuary was the meeting place of the Karian League, ${ }^{43}$ although the text only states that they were driven ( $\kappa \alpha \tau \varepsilon 1 \lambda \dot{\eta} \theta \eta \sigma \alpha \nu)$ there by the Persians, probably in pursuit from Alabanda in the north.

The history of the site changed when Hekatomnos targeted Labraunda as the sacred center of Karia, radically reshaping the hillside into a cascade of terraces that supported an innovative monumental complex, connected to Mylasa by a paved road. The bulk of building activity is now believed to have taken place between 377/6 and 351/о вС, i.e. while Maussollos was still satrap and Idrieus was governor of Mylasa. ${ }^{44}$ The initiative of the Hekatomnids will have served to create a triangular relationship between the rulers, the sanctuary (and its priests), and the communities in and around Mylasa, which despite the Karian scope probably made up the largest group of worshipers at the shrine. With its sumptuous architecture and majestic setting, Labraunda may well have functioned as an 'extended palace' for the Hekatomnids where they

42 Hdt. 5.119.1-2 (transl. A.D. Godley (1922) The Persian wars, LCL 119). This passage relates to the sanctuary as a place of refuge for the Karians during the Ionian revolt, where the Karians met to discuss further plans. The epithet for Stratios, 'war-like', is also used by Strabo (14.2.23), and also applies to Zeus at Amaseia (App. Mith. 66, 70), but otherwise rarely appears at either Mylasa or Labraunda and will not be further discussed in this context.

43 E.g. Kaletsch in Brill's New Pauly (2006) s.v. 'Labraunda': "The shrine was the central meeting place of the old Karian league (Hdt. 5.119.2) with its annual panēgyrís."

44 E.g. Hellström (2011a), 355. "I suggest that both andrones were erected during the lifetime of Maussollos, that Andron B was built in the 370 s and that Andron A was dedicated not later than 351/o, before Artemisia died and Idrieus became satrap." 
received their audiences in a staged setting, as Anne Marie Carstens argues. ${ }^{45}$ This viewpoint is gaining ground. Olivier Henry, the current excavator, interprets much of the complex as palatial while the sacred precinct was restricted to the temple terrace. ${ }^{46}$ The palace-temple combination would in this case mirror the situation on the Zephyrion peninsula in Halikarnassos, where the royal palace was constructed in close range to the temple of Apollo. After his move to Halikarnassos, Maussollos in fact began to issue coinage with Apollo on the obverse and Zeus Labraundos on the reverse. This not only linked the cosmopolitan deity with mountainous Karian god, but by association established a connection between the coastal residence and the sacred center deep in the heart of Karia, as Koray Konuk and Poul Pedersen have noted. ${ }^{47}$ Labraunda appears to have been intended as a counterpart to Halikarnassos in several respects, including a dynastic burial, if the Built Tomb above the temenos indeed contained the remains of early family members, as has been suggested. ${ }^{48}$

After the passing of the Hekatomnids, the shrine underwent little change. Two monumental fountains appear to have been added, but otherwise the complex remained largely as designed by the Hekatomnids. During the third century, around 240 BC, the sanctuary and its property came to be contested space as the priest of Labraunda made a direct appeal to Seleukos II against Mylasa's financial involvement. Seleukos ordered the affair to be investigated by Olympichos, his governor in the area, who decided in favor of Mylasa. Some twenty years later, a second and more serious attempt to take control of the sanctuary was made by the priest at that time, together with the Chrysaoric League, which may have convened at the sanctuary. ${ }^{49}$ Philip v, who was then ruler, declared in the end that Labraunda belonged to Mylasa, and the matter

45 "I believe that Labraunda was the key sanctuary for the Hekatomnids, where they staged and used the rural site as an extended palace, suited for processions, audiences, banquets in a magnificent setting ... under the protection of an ancient deity," Carstens (2009), 100; also Karlsson (2015a) on Labraunda as a Persian paradeisos.

46 Henry (2017).

47 Konuk (2013), 107-108; Pedersen (2013).

48 Henry (2017), 566-568. The suggested combination of palatial residence, religious center, and royal burial in an extra-urban setting is reminiscent of El Escorial near Madrid, that was at once monastery, royal burial place for Charles V, and palace for Philip II, a combination discussed further in Strootman and Williamson (2020).

49 On the Chrysaoric League, see now Gabrielsen (2011). The League was already involved with Labraunda in the early third century, I.Labraunda 43 and 44 ; their attempt with the priest to take control of Labraunda towards the end of this century is recorded in I.Labraunda 5 . 
was apparently settled. ${ }^{50}$ Towards the end of the third century, the sanctuary was protected from attack by Seleukid troops thanks to a letter posted at the entrance from Antiochos III, ordering his commander Zeuxis to ensure that the sanctuary was protected. ${ }^{51}$ Labraunda was thus more fortunate than the shrine Artemis at Amyzon, and of Sinuri.

Despite the decrease in building activity in the Hellenistic period, finds and inscriptions show that Labraunda continued to function as a major sanctuary, albeit for Mylasa, reinforcing the picture given to us by Strabo. The ongoing popularity of Labraunda in later times is indicated by a second phase of building activity in the imperial period. Several inscriptions concerning dedications and regulations date indicate the popularity of the shrine in the first and second centuries AD; in this period Labraunda became famous for its pool of oracle fish with golden earrings. ${ }^{52}$ In the fourth century the sanctuary was changed once more into a large Christian complex, with at least two churches and a tetraconch bath. ${ }^{53}$

In short, we can distinguish five general phases in the life of the sanctuary at Labraunda, beginning with: 1) the Archaic period, when the cult place of Zeus Labraundos was a modest shrine; then 2) the Late Classical period, when it was radically transformed into a monumental and palatial complex by the Hekatomnids; 3) the Hellenistic period when the polis of Mylasa rose to the foreground; 4) the imperial period, when the festivals were re-organized by the polis and additional buildings were added; and finally 5) Late Antiquity, when the sanctuary was turned into a major Christian center. This study focuses on the transformation of Labraunda in the Late Classical and Hellenistic periods.

\subsection{Data and Sources}

Until its discovery in the nineteenth century, Labraunda was only known through the references in Herodotos (5.119) and Strabo (14.2.23) mentioned above. After some expeditions in the mountains north of Mylasa, it was identified in 1827 by Anton Prokesch von Osten, and confirmed in 1838 by Count

$5^{\circ}$ I.Labraunda 5 , discussed in detail below in the section on the Legal Administration of Labraunda.

$5^{1} \quad$ I.Labraunda 46.

$5^{2} \quad$ Plin. $H N$ 32.16; Ael. $N A$ 12.3o.

53 On the structures from Late Antiquity, see Jesper Blid in Karlsson (2010), 80-9o, and Blid (2011). The construction of a monastery in the area of Herakleia under Latmos, as well as the basilica built at the sanctuary of Sinuri speaks of a highly active Christian community in the hills around Mylasa in this later period. 
Hermann Pückler-Muskau. ${ }^{54}$ Nearly a century later the first systematic investigations of the site were undertaken by Alfred Laumonier, in anticipation of future excavations that were unfortunately impeded by the second World War. ${ }^{55}$

Excavations were eventually undertaken by the Swedish in 1948, under the direction of Axel Persson from Uppsala University, continuing until 1953, with one extra campaign in 1960 directed by Alfred Westholm of the Gothenburg Art Museum. The pottery was studied by Pontus Hellström in 1965, whose focus was primarily on the pieces that could be identified at the time, the imported ware. ${ }^{56}$ This is one of the earliest detailed publications of pottery and lamps in southwest Asia Minor, following that of Priene in $1904 .{ }^{57}$ Hellström's main objective was to present a typology for the pottery at Labraunda that could serve as comparative material for other fieldwork in the region, as at Iasos and Aphrodisias. At the time he observed a decline in the quality of the ceramics in the Hellenistic period. ${ }^{58}$ Hellenistic pottery, however, is a growing field, and Hellström expressed the hope that future studies from other contemporary sites would lead to a better understanding of ceramics in Karia, perhaps even changing the results from Labraunda. ${ }^{59}$

After the initial excavations, continuing studies of the architecture of Labraunda mandated further investigations. This took place under the auspices of the Swedish Institute in Istanbul and under the direction of Pontus Hellström in seven campaigns from 1988 to 2003. From 2004 until 2012 the fieldwork was directed by Lars Karlsson of Uppsala University. In 2012 the excavations at Labraunda became an international project and is currently under the direction of Olivier Henry, of the University Lumière Lyon, and the Institut

54 Anton Prokesch von Osten published his discovery in Denkwürdigkeiten und Erinnerungen aus der Orient 1.III, 449-450. The German count Hermann Pückler-Muskau followed the suggestions of W.M. Leake in 180o. Richard Chandler thought he had re-discovered Labraunda in the expedition of the London Society of Dilettanti in 1764-1766, but in fact he found nearby Euromos; see Hellström (2011b), which is the source of information for the rest of this paragraph. I am very grateful to Pontus Hellström for his generosity in sharing this article and his article on the andrones in advance of the publication of Labraunda and Karia.

55 Laumonier (1936), 303-318.

56 Hellström (1965). The stratigraphy of the site was widely disturbed due to postdepositional processes, and so the chronology had to be reconstructed through parallels, Hellström (1965), 1-2.

57 Wiegand (1904).

58 Hellström (1965), 13.

59 Hellström (1965), 2-3. 
Français d'Études Anatoliennes (IFEA) in Istanbul and Ömür Çakilometersaklı of Karabuk University in Ankara. ${ }^{60}$

A separate but important source of data is the coinage pertaining to Zeus Labraundos. At Labraunda itself, 418 coins were recovered during the excavations - these could potentially provide information on the wider network of the sanctuary, yet the origins of only a fraction of these have been identified so far. ${ }^{61}$ However, many specimens depicting the god, found elsewhere, have fortunately been published. The earliest appear with the Hekatomnids, whose coinage has been the subject of a number of fruitful studies leading to new interpretations of their dynastic strategies. ${ }^{62}$

The inscriptions of Labraunda have provided a wealth of data concerning the sanctuary and its relations with Mylasa, and have moreover yielded vital insights into the economy of shrines, the priesthoods and cult personnel, and royal administrative issues in this era in general. In particular, the 'Olympichos dossier' (I.Labraunda 1-12) was separately assessed by Jonas Crampa, and has proven a bountiful mine for discussions on the triangular relationship between city, sanctuary, and kingdom in the Hellenistic world. ${ }^{63}$

Labraunda is the most extensively documented out of all four sanctuaries addressed in this research. Published data sources thus include the interim excavation reports and the final volumes in the series Labraunda. Swedish Excavations and Researches, covering the architecture, inscriptions, sculpture, and pottery, as well as the preliminary reports published through the Kazı Sonuçları Toplantısı (KST) ${ }^{64}$ The 6oth anniversary of the excavations at Labraunda were celebrated in Stockholm in November 2008 and the

6o See labraunda.org/Labraunda.org/Team_eng.html for a list of team members and participating institutions.

61 Discussed in Nilsson (2011), 253.

62 E.g. Konuk (1994) and (2013); Ashton et al. (2002a); Ashton et al. (2002b). Akarca (1959) includes a thorough analysis of Zeus Labraundos and his iconography in her study of Mylasan coinage, while Delrieux (1999) examines Mylasan coin issues with both Zeus Labraundos and Zeus Osogollis, the other principal deity of Mylasa.

63 I.Labraunda Vol. III. Parts 1 and 2 (1969/1972). His translations and interpretations were critically assessed by Habicht (1972) with alternative readings suggested by Piejko (199o) and van Bremen (2017). The Olympichos dossier, discussed further below, has since been expanded with I.Labraunda 134; Isager and Karlsson (2008); Isager (2011), and I.Labraunda 137, Carless Unwin and Henry (2016) and van Bremen (2016). Several interpretations on the autonomy of sanctuaries discussed in Chapter 2 are based in part on this dossier, Debord (1982), Dignas (2002a), Boffo (1985).

64 The Kazı Sonuçları Toplantısı is the annual presentation of archaeological fieldwork in Turkey. See the Labraunda website, labraunda.org/Labraunda.org/Annual_reports_eng .html. 
proceedings provide an important supplement to the earlier publications. ${ }^{65}$ As of 2012, fieldwork reports appear in Anatolia Antiqua, journal of the IFEA. Recent fieldwork and the many exciting discoveries continuously lead to changing interpretations of the site, its function, and its history, making it quite a task to keep up with the times. The views presented here reflect the state of affairs at the time of writing, but this could easily change depending on what next year's fieldwork may bring.

\section{$3 \quad$ Environment of Labraunda}

\subsection{Physical Environment}

Located some five kilometers north of the modern village of Kargicak, Labraunda is situated at the eastern end of the Beşparmak Dağları (Figure 3.1). Both village and sanctuary are located along a ridge of the Çomakdağ that gently slopes down to the south-southwest and the plain of the Sarıçay river, just north of modern Milas. At roughly $685 \mathrm{~m}$ ASL, Labraunda is perched on the southern side of the steep hill along a passage through the mountains to the north. The shrine overlooks the point where the ridge divides in two, providing an excellent view to the plain of Mylasa as discussed below. The general area is abundant in water, some 42 springs have been documented near the sanctuary, and provides the main supply for Milas. ${ }^{66}$ Pine trees cover the area now, although the occasional plane tree is reminiscent of the sacred grove mentioned by Herodotos. ${ }^{67}$

The Beşparmak Dağları is an ancient and heavily eroded range, known for its several worn and weirdly shaped boulders, especially farther to the west by Mount Latmos and the Bafa lake area. At Labraunda, a large egg-like boulder dominates the cult place; split from top to bottom, a niche was carved into its side (Figure 3.3) and beddings for ashlars show that a square tower was built on top, possibly as part of the temenos wall system of the fourth century or later. ${ }^{68}$ This prominent and unusual natural feature appears to have been the original locus of cult. Recent excavations revealed material dating from the late Neolithic and early Bronze Age, with a peak in the Archaic period, and

\footnotetext{
65 Karlsson and Carlsson (2011).

66 Karlsson et al. (2008), 129; Baran (2011), 52, 90-94.

67 Hdt. 5.119. The sanctuary of Sinuri was also known to have had a sacred grove, as did the sanctuary of Hekate at Lagina, Chapter 5. On sacred woods, see Cazanove and Scheid (1993), and Bonnechere (2007).

Hellström and Karlsson (2004), 76 .
} 


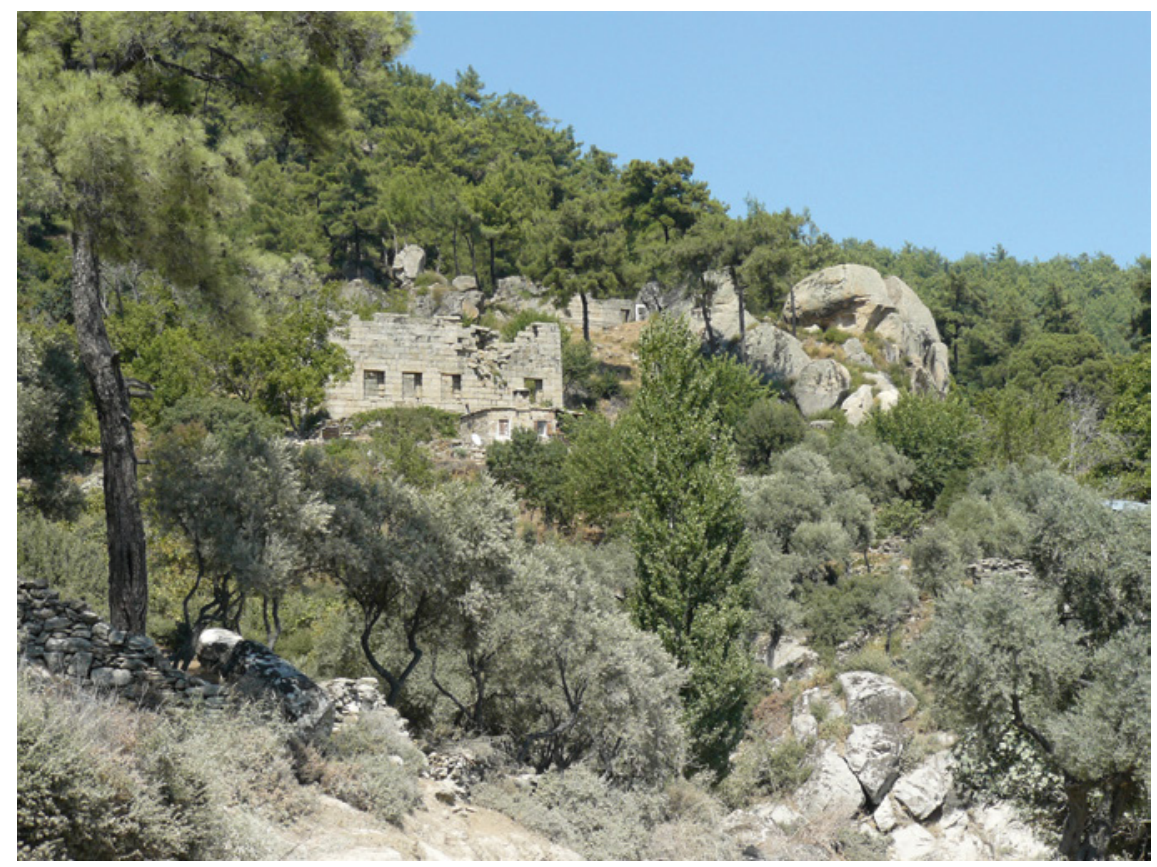

FIGURE 3.3 Labraunda. View of the sanctuary from the southwest and the sacred road. Andron A (Idrieus's andron) is to the left and the split rock to the right PHOTO AUTHOR 2010

receding in the Hellenistic era. Finds indicate that the deity worshiped here may initially have been Kybele or Meter; Lars Karlsson compellingly argues that the split boulder may represent the union of the mountain goddess with the Hittite weather god Tarhuntas, resulting in flow of springs that feed the plain below. ${ }^{69}$ Karlsson further argues that Tarhuntas, who characteristically bore a double-axe, was later identified with Zeus Labraundos, whose cult began to take precedence at the site in the Late Classical period.

69 Karlsson (2013c); Karlsson in Henry et al. (2013), 298-30o, on the excavations at the split rock in 2012. Also Karlsson (2019) and I am indebted to Lars Karlsson for sharing this paper with me, as well as his paper on the terracottas at Labraunda, including a Kybele figurine, at the conference 'Figurines de terre cuite en Méditerranée orientale grecque et romaine' in Izmir in June 2007. In this context it is interesting to note that a sanctuary for an enthroned goddess, perhaps Demeter, may have been located at Kale Mevkii, roughly 8.5 kilometers south of Labraunda along the same ridge, Rumscheid (2005). 


\section{2}

Social-Geographical Location

As mentioned above, the sanctuary of Zeus Labraundos lies along an important mountain pass to the north. ${ }^{70}$ As such it connects the green valley of the Sarıçay valley around ancient Mylasa with the fertile areas to the north near the ancient cities of Alinda and Alabanda, and the Marsyas valley, a tributary of the Maeander river. Labraunda is roughly equidistant from Alinda, 17 kilometers to the north, and Mylasa, 14 kilometers to the south, but also from the ancient towns of Euromos and Chalketor to the southwest, skirting the southern flank of the Beşparmak Dağları (Figure 3.1). The polis of Olymos was even closer to Labraunda, at roughly ten kilometers away; it is however located at the opposite end of a valley and was visually cut off from the sanctuary by the ridge running north-south. Beyond the mountains to the east lies the valley that connects with the area of Koranza and the sanctuary of Hekate at Lagina, absorbed by Stratonikeia in the second century BC, as discussed in Chapter 5 .

This ridge of the Çomakdağ carries the main road to Labraunda from the south (Figures 3.4, 3.10). Just before it approaches the sanctuary, the road, paved with smooth stone by the Hekatomnids, makes a sharp turn to the east where it continues beyond the sanctuary, then switches back to the north towards Alinda and Alabanda. Labraunda's strategic location may well have marked a vital border of Mylasa's territory to the north and in any case would have controlled the sacred road, the main passage in either direction.

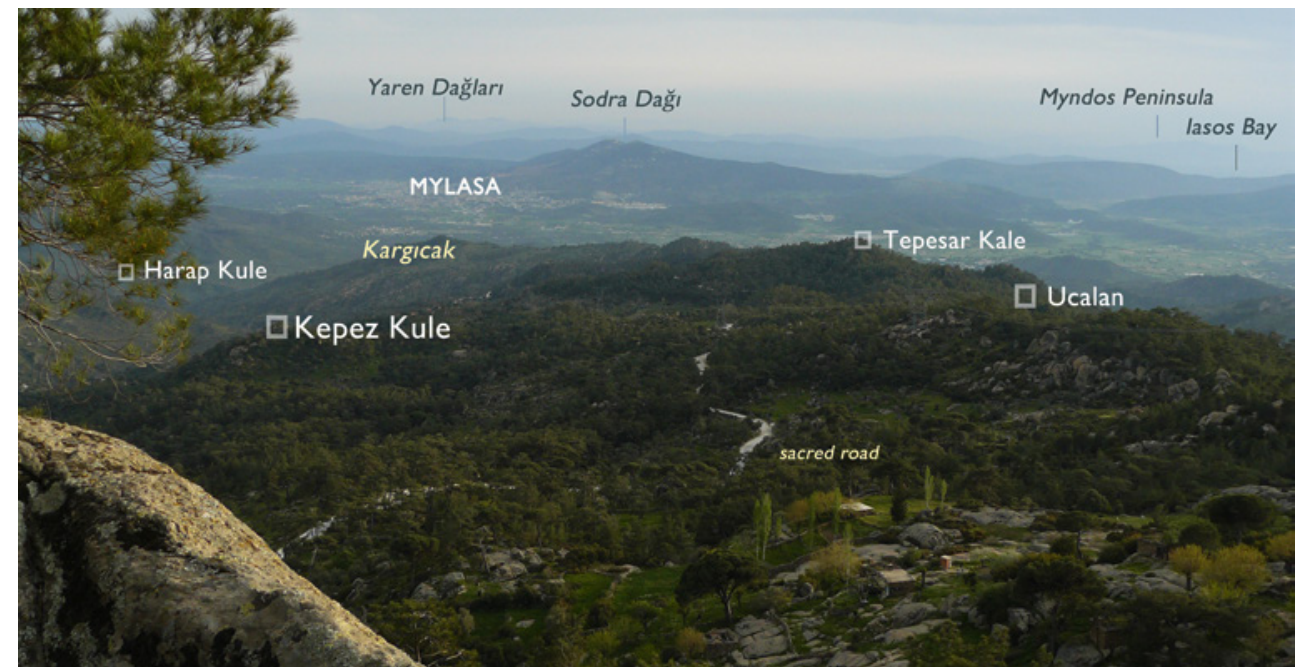

FIGURE 3.4 Labraunda. View to the south from the Akropolis Fortress. Four watchtowers (grey squares) share visibility, while Burgaz Kale is over the ridge beyond Tepesar Kale РнОтО AUTHOR 2008 
The sanctuary of Zeus Labraundos must have acted as a connecting station along this critical route that provided access to several communities in this part of Karia. ${ }^{71}$ This may explain the large number of fortifications near the sanctuary, dating from the fourth century BC. No less than five watchtowers were built at different points overlooking the route, with a modest stronghold higher up the hill, above the sanctuary (Figures 3.4, 3.5). $\cdot{ }^{72}$ Most of these shared sightlines with each other and with the Akropolis Fortress at Labraunda.

\subsection{Visibility}

Labraunda overlooks the valley just east of the Çomakdağ ridge that carries the road from the south. Perched above, the sanctuary and fortress higher up afford a breathtaking panorama across much of southwest Karia that was not lost on Lieutenant R.M. Smith, who recorded the site and its views on behalf of the British Museum in $1857 \cdot{ }^{73}$ As seen in Figure 3.5, to the west are the hills beyond Euromos and Chalketor, the sea and Iasos Bay, near ancient Iasos and Bargylia. Crowning the horizon to the southwest are the hills of the Myndos peninsula, near Halikarnassos (modern Bodrum). More to the south is the valley of the Sarcçay (the Kenios in antiquity), with modern Milas and Sodra Dağ that towers above it, the green plain to the east and south of town, including the area around Gencik Tepe and the fortified settlement of Kuyruklu Kalesi, ${ }^{74}$ the ancient plateau of Beçin Kale south of the polis, and beyond to the Yaren range separating the plain of Hydissos from the Gulf of Keramos. The southeast is dominated by the mountains of the Akdağ, east of which lie Lagina and Stratonikeia. The sanctuary of Sinuri cannot be seen from Labraunda, although the range just north of it is in full view.

This sweeping panorama must have been a determining factor by the Hekatomnids in their selection of Labraunda as primary sacred center for Karia. Encompassing much of southern Karia with Mylasa roughly at the center of this visual region (Figure 3.5), it will be argued further below that the view was equally critical to the independent Hellenistic polis as it capitalized

71 Hild (2014), 39-40. On sanctuaries as connecting stations, see Sinn (1996); Debord (1982), Ch. 1.

72 The fortifications of the Akropolis Fortress and the five watchtowers Burgaz Kale, Ucalan, Kepez, Tepesar, and Harap, discussed further below under Sacred Road.

73 Lt. Smith's report is included in Newton and Pullan (1862), 614, where after examining the windows in Andron A, he observes: "The view from them [the windows - CGW] is most striking, embracing the plain of Mylasa, Paitschin, Leros, Calymnos, Cos, Budrum, and the mountains all round." Further discussed in Laumonier (1958), 48 and Hellström (2011b).

74 On Gencik Tepe, see Säve-Söderbergh and Hellström (1997); on Kuyruklu Kalesi as a late fourth century fortification, see Radt (1969/70). 


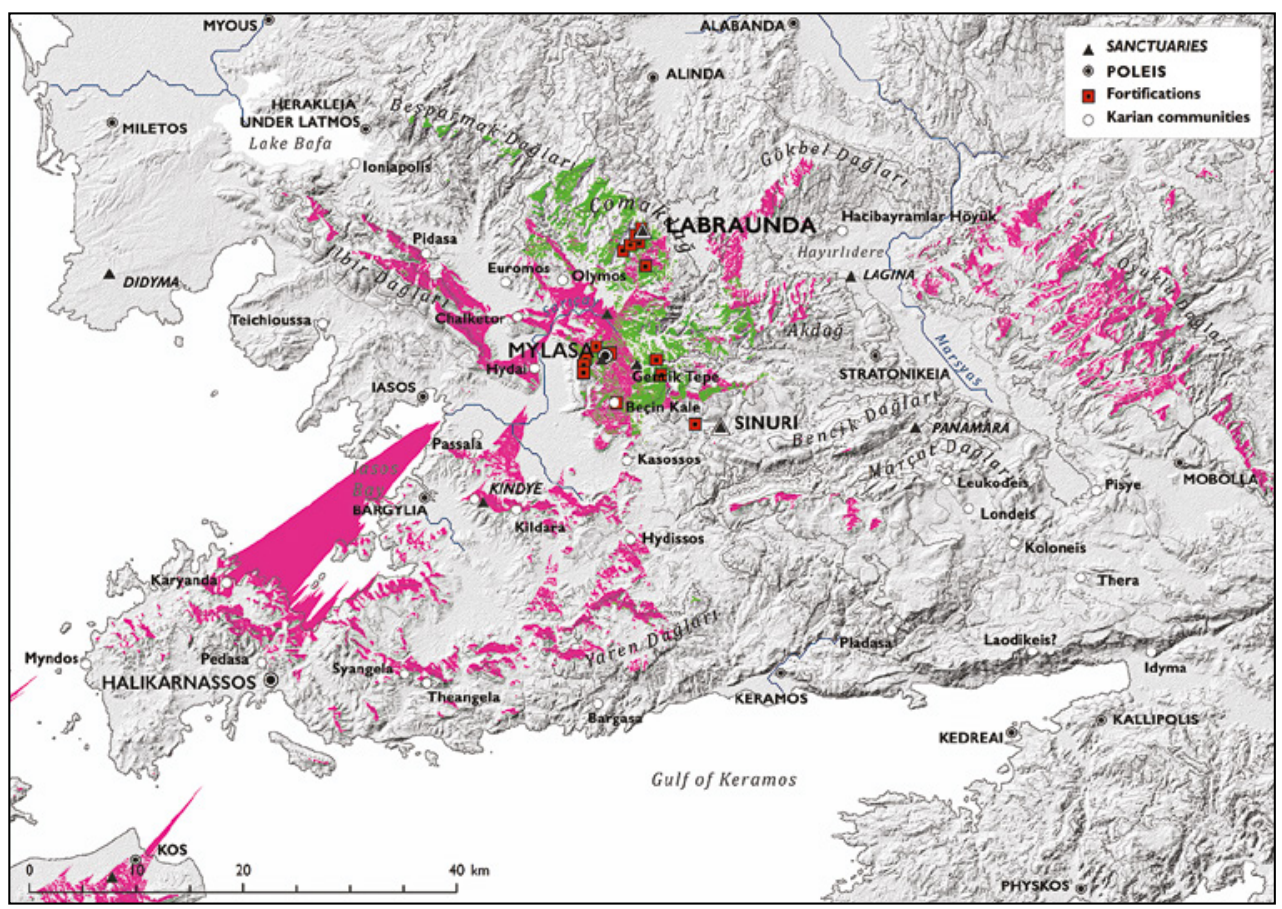

FIGURE 3.5 The viewsheds of Mylasa (green) and Labraunda (fuchsia)

on the tight integration of the sanctuary with the landscape and visual environment that the Hekatomnids had created. The landmark function of Labraunda would have been greatly enhanced by monumental architecture, making it easier to spot on the pine-clad hillside. Even today, the sanctuary may be seen from Milas as well as Beçin Kale on a clear day, if one knows where to look.

Major changes took place at the sanctuary of Zeus Labraundos under the Hekatomnids in the Late Classical period. These are closely examined here with a focus on how this impacted ritual and ritual space, but also how the later claims to the sanctuary made in the Hellenistic period. It will become apparent that, despite the annual festivals, the bond between Labraunda and Mylasa was not categorically self-evident - the polis had to go to great lengths to assert its control over the sanctuary. As contested space, Labraunda is a prime case study to observe developments in relations between city and shrine, with vested interests on the part of the polis, on the one hand, and the local priests, on the other. 


\subsection{Monumental and Ritual Space at Labraunda}

The majority of the architectural transformations at Labraunda took place in the mid-fourth century $\mathrm{BC}$, under the rule of Maussollos and his brother Idrieus. ${ }^{75}$ Prior to this, Labraunda consisted of a 'sacred grove of plane trees', mentioned by Herodotos (5.119), and a small Ionic temple in antis at the western end of a terrace, from the late sixth century вс. ${ }^{76}$ The oldest Archaic structure at the shrine, the Mudbrick Building, ${ }^{77}$ had apparently been levelled to create the terrace, which was bound to the south by a retaining wall and presumably accessed from the east via a gateway, Propylon Y. Originally constructed in the fifth century, this gateway appears to have undergone repairs in the third century $\mathrm{BC}$ and again in the second century $\mathrm{AD}$, showing its continued use. ${ }^{78}$

The Hekatomnid metamorphosis of this relatively modest shrine to Zeus into a grand ceremonial complex marks a turning point in the history of the ritual landscape of Mylasa. The dynastic aggrandizement of the sanctuary appears to have been informed as much by the Achaemenid legacy of monumental self-representation as it did with philhellenic tendencies. Labraunda was clearly a projection of ruler identity and ideology. ${ }^{79}$ Nonetheless, their use of architecture and terraces to create ensembles of coherent space that engage the wider environment was proto-typical for the Hellenistic period. Hekatomnid Labraunda clearly integrates two kinds of approaches to space: 'concentric space', i.e. space which is directed towards an internal focus, and 'linear space', i.e. space which is visually extended towards an external focus, either through a specific sightline such as a framed view, or through a physically connecting road. ${ }^{80}$ At Labraunda, both kinds create a dialogue with the landscape, while reinforcing the natural dominant position of the shrine in the region.

75 But see also Hellström (2011a), who suggests that Maussollos and Idrieus may in fact have been carrying out Hekatomnos's designs for the sanctuary, pushing the origin of these transformations further back to his reign in the first part of the fourth century вС.

76 Thieme (1993) and Hellström (2007), 40 and 111; Baran (2006) and (2009), 301-304.

77 The mudbrick structure was excavated in 1953 at the eastern end and was initially interpreted as an altar, Säflund (1956), but is now considered as possibly an early base for the cult image of Zeus, Hellström (2019). The stone foundation of the mudbrick structure is shown in Hellström and Thieme (1982), Pl.27 and as Wall 5 in Westholm (1963), 26, Fig. 15 (though somewhat normalized to the cardinal points in its orientation).

78 Westholm (1963), 106, more recently investigated in J. Blid and R. Hedlund in Henry et al. (2015), 294-304, who discuss the Roman reconfiguration of the originally Doric façade in the Corinthian order. See also Hedlund (2014).

79 See Carstens (2009), 80-100, and (2011) for Achaemenid influences at Labraunda.

80 The concepts are described at length above in Chapter 2 under Concentric and linear space. 


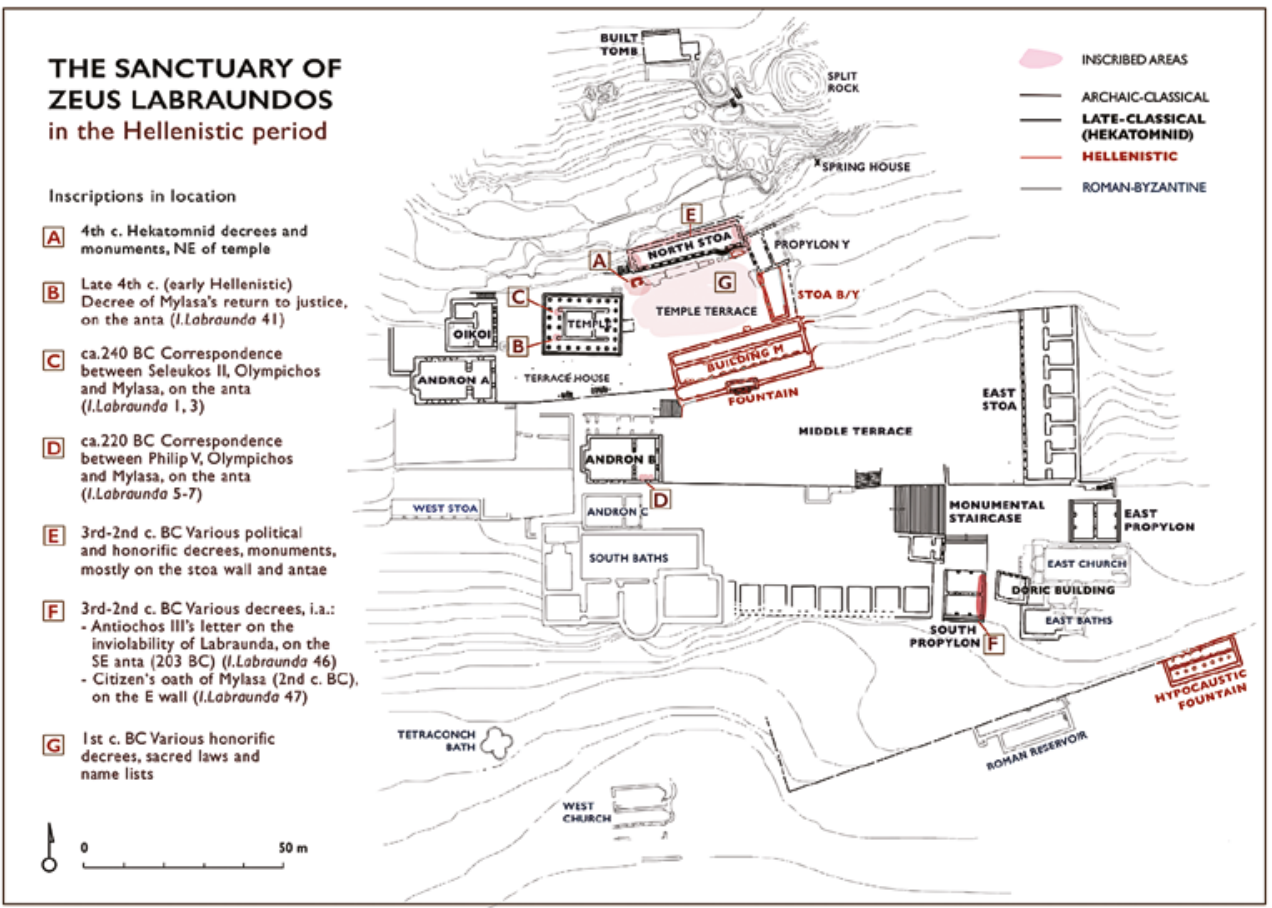

FIGURE 3.6 Plan of Labraunda in the Hellenistic period. Map after Henry (2017), Figs. 2, 15

\subsubsection{Architecture}

Several radical construction activities took place at the sanctuary in the fourth century, perhaps the most impressive of which was the massive earth excavations and retaining walls to support and display the new complex. The sanctuary, which was initially contained on the narrow temple terrace, was now extended to cover four more terraces below; the entire surface area of ritual space at Labraunda thus came to encompass $7200 \mathrm{~m}^{2} .^{81}$ Furthermore, the general orientation of the sanctuary was aligned to follow the cardinal directions rather than the natural shape of the hillside (Figure 3.6). ${ }^{82}$ The spectacle nature of the complex is underscored with the inclusion of a stadion, a rare feature for this period, and discussed below in the context of games.

81 Pedersen (1991), 99, Figure 2.99, shows the Hekatomnid expansion as $4200 \mathrm{~m}^{2}$ in addition to the $3000 \mathrm{~m}^{2}$ of the original upper terrace; Pontus Hellström however points out that the original terrace was much more modest, closer to $1000 \mathrm{~m}^{2}$ making the Hekatomnid addition closer to $6000 \mathrm{~m}^{2}$ (pers. comm. 15.04.2011).

82 Pedersen (1991), 101-102. The earlier terrace appears to have followed the natural contours of the hill, although the archaic temple is oriented towards the east. 
The complex was clearly built to impress, and terracing allowed for filtered access: the visitor was gradually guided via staircases along several stately buildings before they were allowed or invited to ascend to the main ritual space before the temple. ${ }^{83}$ This zig-zag approach may have been an intentional complication of the access to Maussollos' hall and the temple, to increase awareness of the solemn occasion and heighten the impact of the monuments. ${ }^{84}$ The sacred way led onto the first terrace, supported by an imposing retaining wall, which leveled the ground near the formal propylaia, or gateways, for those coming either from Mylasa through the South Propylon or from Alinda and Alabanda through the East Propylon. The fact that both gateways were constructed so close to each other may well be a further indication that Maussollos intended Labraunda to be a Karian-wide sanctuary, not just for Mylasa.$^{85}$ Beyond this, one traveled up the grand staircase onto the next terrace to the west (Figure 3.7), and then immediately through a smaller staircase to the north; this bottleneck must have created some congestion, heightening the anticipation of reaching the next level. Mary Hollinshead has taken on the topic of ceremonial staircases and their ritual and somatic effect, demonstrating how they create both direction and focus for the pompe. In the case of Labraunda, she argues that they were used to enhance the overall sense of spectacle, leading to the ceremonial andrones on the middle terrace. ${ }^{86}$ Pontus Hellström further argues for the use of the monumental staircase as a theatron,

83 Pedersen (1991), 114-115 on Hekatomnid terraces and the anticipation created by gradual access.

84 Hellström (1991a), 304-308 points out the trace of the route in various periods, observing similarities with Delphi; Carstens sees closer parallels with Near Eastern models of intentionally complex routes, such as at Persepolis, where "the way never directly leads towards the audience hall. There is a series of obstacles or stations on the way [...] all these hindrances serve to sacralise or solemnize the event," Carstens (2009), 86-87. With large groups of people of different ages, sexes, and mental states brought together in close quarters, processions would also have induced more mundane states of heightened awareness, and aroused emotions; also Chaniotis (2006) and (2013).

85 Hellström (2009), 270. The gateways are not strictly co-eval: the South Propylon adheres to the same schematic design as the temple of Zeus (and the temple of Athena Polias in Priene), whereas the East Propylon, which has no preserved dedicatory inscription, is less regular but more practical (lower steps, wider central doorway), and uses a different base foot-unit, Jeppesen (1955), 43-5o. Westholm believes the East Propylon was earlier, but that both were part of the same overall design, Westholm (1963), 109. Rumscheid, however, argues for later date in the third quarter of the fourth century for the East Propylon on stylistic grounds, Rumscheid (1994), 79-82 in vol. 1 and no. 119 in vol. 2. Becker believes the East Propylon was begun by Maussollos but finished at a later date, Becker (2003), 24.

86 Hollinshead (2012), 33-35 on Labraunda, and Hollinshead (2015), 11-15, also more in general. 


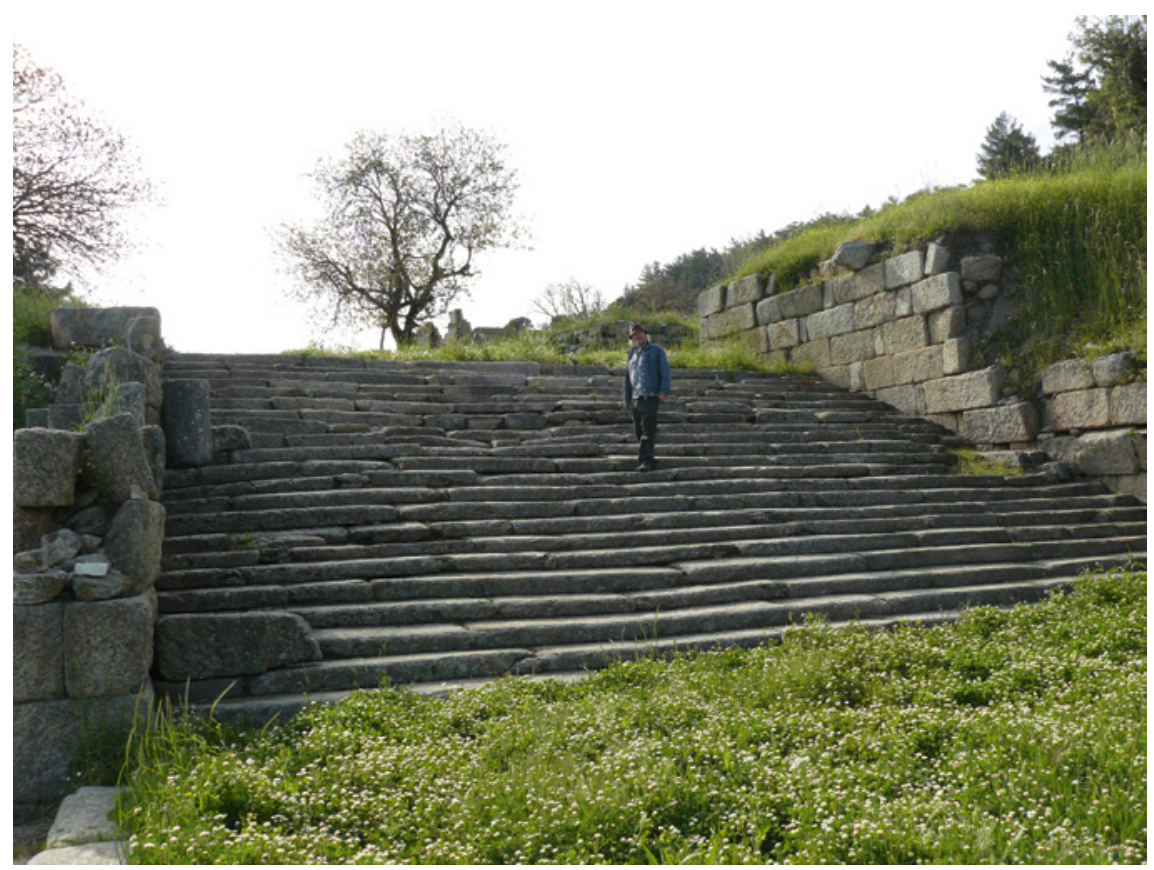

FIGURE 3.7 Labraunda. Monumental staircase leading to the Middle Terrace PHOTO AUTHOR 2008

for some kind of ritual performance with perhaps the East Propylon functioning as backdrop. ${ }^{87}$

Characterized by dining facilities, the middle terrace is closed off to the east by a portico, the East Stoa (Figure 3.6), with six banqueting rooms at the back; each room could accommodate eleven couches for diners in symposium. ${ }^{88}$ Along the northwest end was a retaining wall with a large fountain, and at the opposite, western end of this terrace was the first of two andrones, as labeled by their architraves. These were sumptuous banqueting chambers, with plastered walls, mosaic floors and niches to hold sculpture, and have been suggested to have functioned as royal reception halls. ${ }^{89}$ Maussollos's andron

87 Hellström (2015), inspired by Nielsen (2002).

88 Hellström (1989b); the sixth room was postulated in Hellström (1991b), in which the structure in 'Area W' was confirmed as a stoa with banqueting rooms (rather than part of a palace as was previously suggested). He considers that since each couch could have held two people, then 132 people could dine simultaneously in the East Stoa, Hellström (2011a), 153-154.

89 Carstens (2009), 85-89, 94-10o draws an analogy between Labraunda and Near Eastern palaces, noting the importance of royal receptions combined with banqueting, which she aptly calls "dining in paradise" (p. 88; also Karlsson (2015a)); she considers their use as 
(Andron B) would have been one of the first visible structures from the sacred way. A second andron (Andron A) built by Idrieus was positioned higher up on the terrace behind the temple; it is still visible today and was initially taken by the early explorers to be the main temple (Figure 3.2). ${ }^{90}$ Practically overshadowing the temple itself, these grand structures were both built in a mixture of orders, with Ionic columns standing in antis below a Doric entablature. ${ }^{91} \mathrm{~A}$ sculpted male bearded sphinx was found near Andron B, probably one of a pair that was set as corner akroteria on the roof, clearly displaying Achaemenid influences. ${ }^{92}$

Each andron was spacious inside, with large airy windows. Those of Andron A measure c. $1.85 \times 1.05^{-1.10} \mathrm{~m}$ (Figure 3.8); the only fully preserved window of Andron $B$ is in the crosswall, measuring $1.62 \times 1.05^{-1.07} \mathrm{~m}$, the windows in the south wall were probably similar in size. ${ }^{93}$ There was room for about 20 dining couches along the sides and the rear, where a large niche, two meters above the floor, is presumed to have held statues of Zeus and members of the dynasty. ${ }^{94}$

meeting place for Karian federations, Carstens (2009), 75-100; also Hellström (1989a). The royal setting is more extensively discussed in Henry (2017), who sees the complex as part shrine, part palace. Isager and Pedersen (2014) discuss the andrones in Labraunda in connection with a Hekatomnid andron of Zeus Akraios in Halikarnassos, known only from a dedicatory inscription. For the sumptuous materials, Henry et al. (2018), 288 and 293.

9o Idrieus's andron is the target of the 'Conservation Project of the Andron A in Labraunda', a project by the Institute Français d'ëtudes Anatoliennes (IFEA) and the Middle East Technical University in Ankara (METU); see Henry et al. (2013), 310-322 and Henry et al. (2014), 256-262.

91 Hellström (1996a), 136, describing Maussollos's andron, notes how the temple-like character emphasized its function for "super-prestigious, ritual banqueting." Also Karlsson (2013a).

92 Gunter (1989), 92-94 with images; Carstens (2010) and (2011), 126-129; Held (2011). The combination of Ionic and Doric orders with Achaemenid-like sculpture in any event reflects cross-cultural influences and may well indicate the international ambitions of the Hekatomnids, Hellström (1996b), 136; Held (2011); Karlsson (2013a).

93 The extant dimensions of the windows of Andron A are c. $1.7 \times 2.1 \mathrm{~m}$, Hellström (2007), 131-132. The sizes given here reflect the viewable area, reduced by the window sill, frame and revetment. My thanks to Pontus Hellström for this information (pers. comm. o6.07.2011).

94 On the andrones in general, see Hellström (2007), 90, 131-132. Idrieus's andron was similar to that of his brother Maussollos; both were larger than the temple of Zeus, with raised floors around the edges (1 m in width), see Hellström (1989a), 101-104. Hellström (1996a) argues that the andrones represent a new "élite, non-egalitarian way of banqueting" as intended by the satraps, see also Hellström (2009), 271 and (2011a). Whether the (presumed) dynastic sculpture in the niches represents ruler worship may be debated, yet we know of an altar to Maussollos at Labraunda from I.Labraunda 49 and 134, Isager and Karlsson (2008); Idrieus also received cult honors at Iasos as Zeus Idrieus, Fabiani (2015) and Carbon (2016). Also Maddoli (2010) on the Maussolleion at Iasos. 

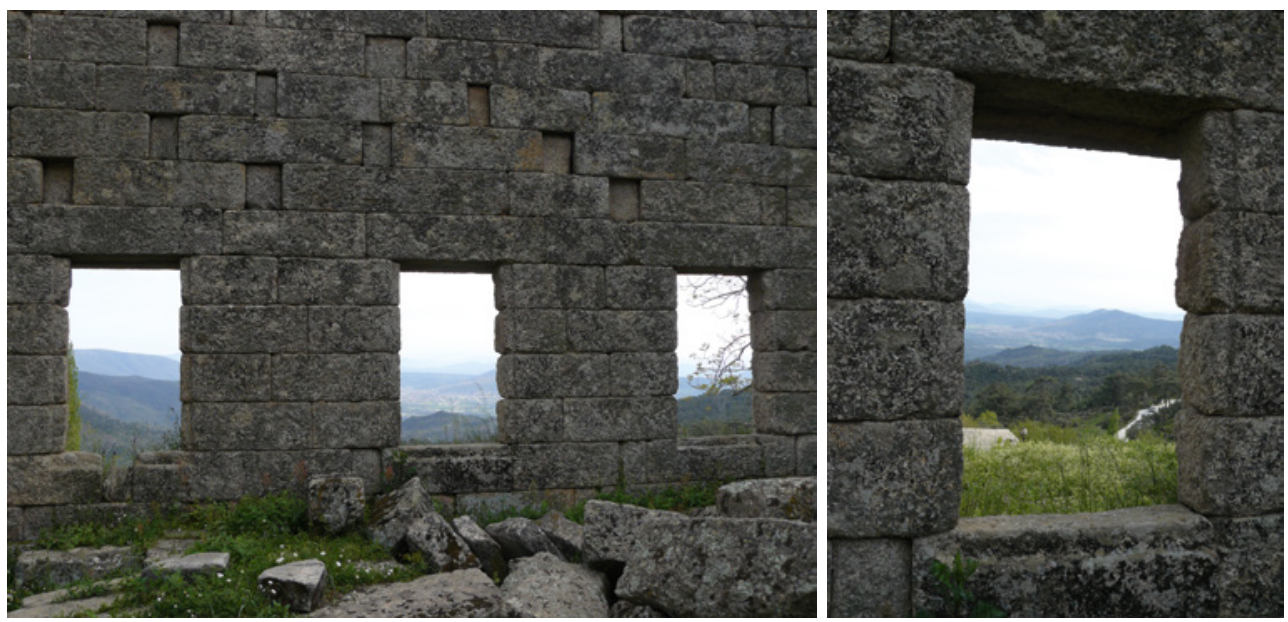

FIGURE 3.8

Labraunda. View towards Mylasa and the southwest framed by the windows of

Andron A; on the right, the view through the central window towards Mylasa, the Sodra Dağı, and part of the sacred road

PHOTOS AUTHOR 2008

While the middle terrace was designed for formal ritual dining, the upper terrace immediately east of the temple remained the core ritual space at Labraunda (Figure 3.9). One might envision the ensemble below as a grand prelude towards this climax, a concept that would become more widely applied in the Hellenistic period. ${ }^{95}$ The terrace was likely approached through a path requiring a couple of switchbacks before one made the final approach from the east and enjoyed a full view of the temple with Idrieus's andron in the background. The north side of the terrace was articulated by the Stoa of Maussollos, entirely rebuilt in the imperial period as the Stoa of Poleites (North Stoa, Figure 3.6). ${ }^{96}$

95 Such as the Asklepieion on Kos, Pedersen (1991), 114-115.

96 The North Stoa was dedicated by the priest Poleites (I.Labraunda 23), but re-uses stones bearing Maussollos's dedication of a stoa (I.Labraunda 13). This led Westholm to interpret this as a Roman reconstruction of Maussollos's stoa (Westholm (1963), 106); this view is followed by Crampa in his discussion of I.Labraunda 13. Hellström, however, considered the possibility of two different structures in Hellström (1991a), 299-300, 304 n. 40, since the Roman inscription mentions the dedication of the stylobate, columns, and entablature; F. Tobin observed that the stylobate of the North Stoa is Roman, Henry et al. (2014), 269. Liljenstolpe and von Schmalensee (1996), 146, however, argued in favor of Westholm's postulation Poleites's reconstruction of the Stoa of Maussollos and that is now the accepted view, e.g. Hedlund (2014), 62, Henry (2017), 555 . 


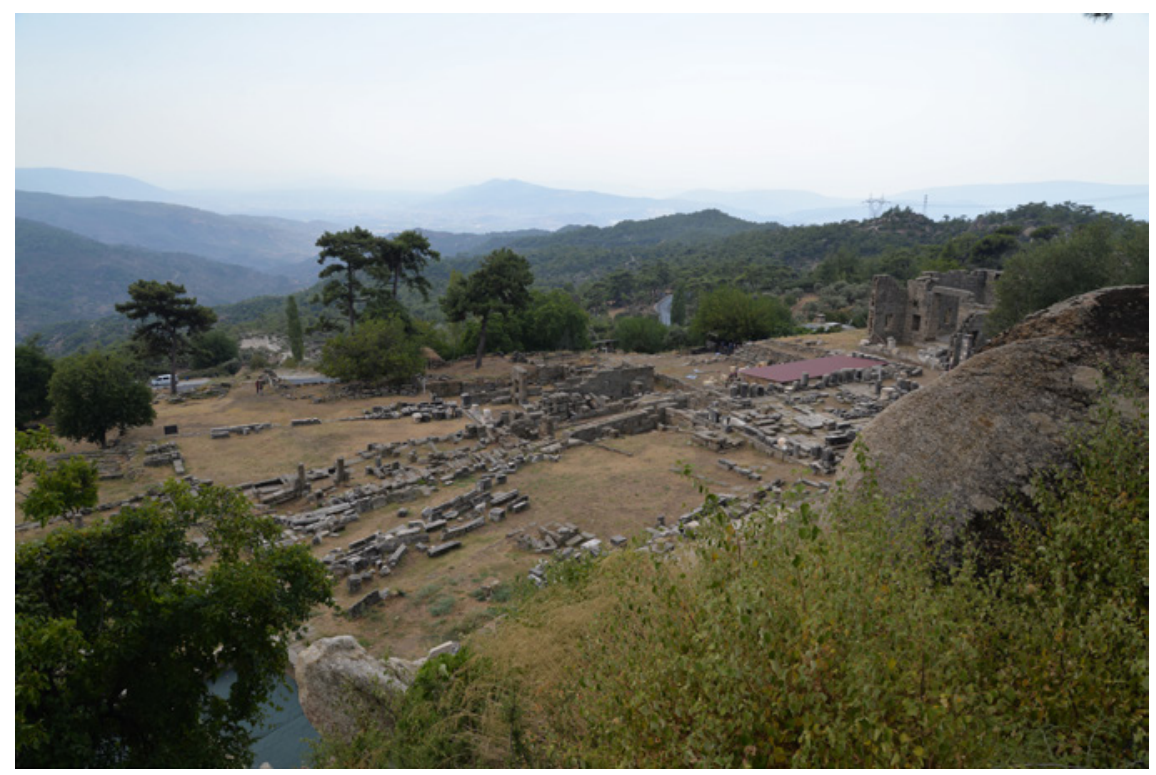

FIGURE 3.9 Labraunda. View of the Temple Terrace from the Split Rock. The temple is to right Рното AUTHOR 2019

Idrieus had the temple rebuilt. ${ }^{97}$ Constructed on the foundations of its Archaic predecessor, the squat cella was now extended with a (very shallow) opisthodomos, and fitted with a $6 \times 8$ column peristyle in the Ionic order on a threestep krepis. ${ }^{98}$ The stylobate made the footprint of the temple larger than that of the andrones, but the cella, roughly of the same dimensions as its Archaic

97 I.Labraunda 16 is a dedicatory inscription from the architrave of the temple.

98 Hellström and Thieme (1982), on the temple in general. The dimensions of the peristyle are presumed to have been restricted by the altar before the entrance, Hellström (2007), 111 and Henry (2017), 554-555. This would be an early example of an Ionic temple with an opisthodomos, borrowed from the Doric order. This combination is more well-known from the Athena temple in Priene (350-33о вС), of which Gruben states "Demgemaß erhält nun auch der Naos nach dorischem Muster symmetrische Fronten mit zwei Säulen zwischen den Anten. Damit begegnet zum ersten Male nachweislich der Opisthodom auf ostionischem Boden," Gruben and Hirmer (1966 [1986]). Yet the temple of Zeus Labraundos, dedicated by Idrieus, is either co-eval with the Athena temple, or earlier. This combination is attributed to Pytheos, who also co-designed the Maussolleion in Halikarnassos; as architect for the Hekatomnids, it is likely that he or his team designed the temple at Labraunda as well, Hellström (2007), 117. For possible connections between Pytheos and Hekatomnos at Mylasa, via the poem by Hyssaldomos, discovered in the Uzunyuva excavations, see the intriguing discussions in Marek and Zingg (2018). 
predecessor, is much smaller. Had it not been for the peristyle, the temple would have been entirely overshadowed by the rest of the monumental architecture at the complex. ${ }^{99}$ This is especially true when viewing the sanctuary upon approach from the road (Figure 3.3); the temple occupies a much more central place, however, when seen from the temple terrace and the split rock above (Figure 3.9).

Behind the temple was the building complex designated as 'Oikoi', perhaps an administrative structure or treasury, apparently reserved for the priests. ${ }^{100}$ Immediately in front of the temple is a small squarish foundation, a little over $3 \times 3 \mathrm{~m}$, from the Archaic period that is interpreted as an altar. This function has not been confirmed by finds, and the proximity to the temple seems like a fire hazard. ${ }^{101}$ Nonetheless, a parallel may be found in the altar and temple of Zeus Lepsynos at nearby Euromos. ${ }^{102}$ As observed above, this area certainly does seem to be the architectural, and ritual, focus of this terrace and one might expect a more prominent altar at the center of such a grand complex, although monumental altars were more common in the Hellenistic era. ${ }^{103}$ Labraunda

99 Pontus Hellström once suggested that Idrieus intentionally added the peristyle in order to shift the architectural balance at the sanctuary back towards Zeus, Hellström (1996b), 137-138. The design of the sanctuary indicates a unified plan, with Idrieus's dedications being carried out while governor of Mylasa and after Maussollos's move to Halikarnassos, Hellström (2011a), esp. 154-155. The original height of the temple is estimated to be two meters lower than Andron A, see Henry (2017), 556-557.

100 The identification of this structure is based on the architrave dedicatory inscription by Idrieus, I.Labraunda 17, discussed below; see also Hellström (2007), 119-125: "The function of the Oikoi Building is not evident. It has been supposed that it served as a building for the priests of the sanctuary and as an archive, maybe a prytaneion (council house). It may also have served for ritual meals, in the same way as the two andrones and the East Stoa. A main purpose for the Oikoi Building may, however, have been as a treasury for the safe-keeping of valuable gifts to the god."

101 Excavations revealed no artifacts, pottery, votives, ash or bones, yet the Archaic mudbrick altar was clearly no longer functional (as it was partly built over by the North Stoa). Hellström and Thieme (1982), 24-25 suggested this may have been a thesaurus or a bothros, although the lack of finds remains similarly problematic. Current opinion supports a view of the small structure before the temple as the altar: Hellström (2007), 111; Henry (2017), 554-555. The location and ongoing use of this structure may well have determined the extent of the peristyle, as suggested in Hellström (2007), 111 and Henry (2017), 554-555.

102 D. Laroche in Kizll et al. (2018), 182-184, who proposes a construction date of $330-300$ BC for the altar, predating the temple. This would be similar to Labraunda, where the square structure was farther from the Archaic temple, Thieme (1993), 55, Fig. 8, and may well have determined the extent of the peristyle as suggested in Hellström (2007), 111, and Henry (2017), 554-555.

103 Balthis (2006); Linfert (1995). Kuhn (1985), 258, believes a (larger) altar would have been on this terrace due to the prominence of the temple terrace behind. 
held at least one other altar that was still known and presumably in use in the Hellenistic period: that for Maussollos, as inscriptions testify. ${ }^{104}$

Nearly all of the new or renovated structures were marked with dedicatory inscriptions by either Maussollos or Idrieus on their architraves above the entrances where everyone could see them. In and of itself, this phenomenon of ostensible dedication, with the name of the ruler directly connected to the god, set a precedent that would be followed in the Hellenistic era. ${ }^{105}$ Idrieus inscribed his dedications on his andron (A), as well as the Temple, the 'Oikoi', the South Propylon, and probably the 'Doric Building', likely a fountain house. ${ }^{106}$ Unlike Maussollos, Idrieus seems to have deliberately included the

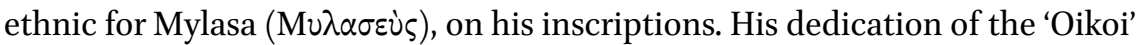
best illustrates this: Idrieus, son of Hekatomnos, Mylasan, dedicated the oikoi to Zeus Labraundos. ${ }^{107}$ This added emphasis on Mylasa has been interpreted as reflecting his role as hyparch of Mylasa during Maussollos's reign as satrap. ${ }^{108}$

The royal andrones have with reason attracted quite a bit of scholarly attention. ${ }^{109}$ Of particular interest is Maussollos's dedication of his andron (B): Maussollos son of Hekatomnos dedicated the andron and what is inside to

104 Isager and Karlsson (2008); Ameling (2013).

105 E.g. Alexander the Great's dedicatory inscription on the temple of Athena in Priene (Roels (2018a), 242-246) or the architraval dedication of Philetairos on the temple of Meter Theon at Mamurt Kale (Williamson (2014a)). The influence of the Hekatomnids on dedictatory inscriptions is further discussed in: Hornblower (1982), 274-293; Umholtz (2002); Isager (2011); Roels (2018a), 291; Mylonopoulos (2019).

106 Idrieus's dedications: I.Labraunda 15 (Andron A); I.Labraunda 16 (Temple); I.Labraunda 17 ('Oikoi'); I.Labraunda 18 (South Propylon); I.Labraunda 19 ('Doric Building'). Idrieus's andron was a room with a view, like that of his predecessor, but had windows along both flanks of the structure; Williamson (2014c).

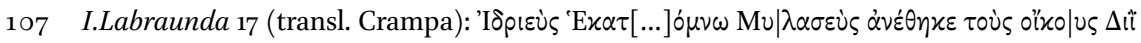
$\Lambda \alpha \mu \beta p \alpha u ́ v \delta \omega[\ldots]$.. See also Debord (1999), 404.

108 Pedersen (2009), 334-337 and Hellström (2011a), 155. Hellström observes that if this is correct, then the chronology of the architecture should be moved up somewhat since Idrieus probably finished Labraunda after Maussollos's move to Halikarnassos, rather than after his death $353 / 2$ BC, as is traditionally held. Earlier interpretations of Idrieus's inclusion of the Mylasan ethnic include Hellström (1996b), in which it is seen as being indicative of a more inward turn in policy, focusing on Karia, rather than the wider international political circle, as Maussollos had done. This concords with Crampa's view, I.Labraunda (vol. 2) p. 6.

109 Pontus Hellström has published extensively on these extraordinary structures: Hellström (2011a), (2009), (1996a) and Hellström and Blid (2019). They are further incorporated in studies, including among many others: Henry (2017); Hedlund (2014); Carstens (2011); Pedersen (2009). The dining function is further discussed below. 
Zeus Labraundos. ${ }^{110}$ Like Andron A, Maussollos's andron was certainly a 'room with a view' as it was atypically fitted with large windows. ${ }^{111}$ Yet Maussollos's banqueting hall, built first, has windows on the south side alone, framing the breathtaking panorama across Mylasa and a large part of Hekatomnid territory beyond that - surely this view was one of the most valuable things inside the andron (Figure 3.5 and frontispiece). ${ }^{112}$ The same panorama could be enjoyed from most of the sanctuary, but it is significant that it was occasionally set within in a cadre, as was literally the case through the andron's windows. The linear space of this view, visually connecting the sanctuary with the city and the surrounding landscape, was thus put to use in a ritual context - in this case, the act of dining by the elite who probably controlled much of Mylasa. In a broader sense, the view was also framed by the terrace architecture in general, a concept more common in later complexes of the Hellenistic period. ${ }^{113}$ At Labraunda, one would regularly find oneself surrounded by walls except for the open south side towards Mylasa. Visually stressing the view in these contexts is an example of how ritual space could be used in a directive, linear way. It not only creates an intimate bond between the worshiper and the wider and distant region, it also steers the gaze of the viewer, in this case towards Mylasa.

The sanctuary at Labraunda thus underwent a radical metamorphosis in the fourth century BC at the hands of the Hekatomnids. Architecturally speaking, this transformation from a relatively modest cult place that focused on

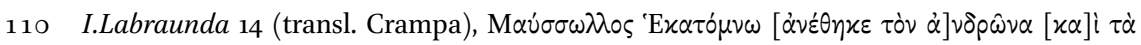

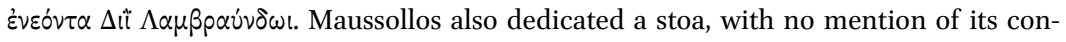

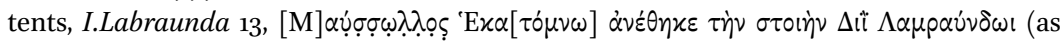
inscribed on one of the antae). Idreius's dedication of his andron (A) also makes no

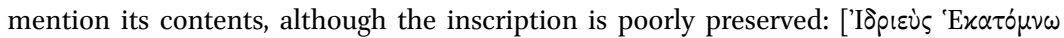

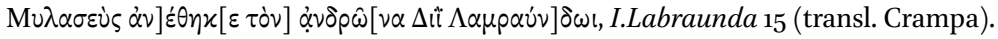

111 Laumonier relates the windows of the andrones to Zeus's role as a sky-god, Laumonier (1958), 99; on Zeus Labraundos as a weather god, see also Karlsson (2013c).

112 I develop this argument more fully in Williamson (2014c).

113 Fehr (1970), 38-39: "In Labraunda begegnet uns ausserdem eine Vorstufe zu den pergamenischen Terrassenhallen ... die pergamenischen Terrassenhallen übernahmen offenbar den karischen Baugedanken des auf einer Mauer ruhenden Stylobats und kombinierten ihn mit der den Griechen seit langem vertraueten Stoa am Rande eines Platzes," referring to Martin (1951), 147f. Also Pedersen (2004), 409: "It is suggested that some technical details of the Philetairian fortifications were probably invented in Karia at the time of Maussollos and that perhaps even the great terrace architecture of Pergamon may owe something to the 4th cent. Karia as suggested by R. Martin in 1974," see Martin (1974); see Williamson (2014a) on Mamurt Kale. Pedersen had previously observed that Hekatomnid terrace architecture, which created a setting becoming to gods and rulers, may well have been a conceptual prototype for Hellenistic architectural design, such as the terraced Asklepieion on Kos and the layout of Pergamon itself; Pedersen (1991), 114-115. See also Lehmann 1954, on temples being embedded within a larger 'baroque' complex. 
natural features into a monumental complex of successive enclosed spaces, foreshadowing architectural concepts that would become much more common in the Hellenistic period, was the most significant turning point in the history of the sanctuary.

Although Hekatomnid architecture remained intact and in use throughout the Hellenistic period, scholars long held that the only addition was the fountain house on the middle terrace. ${ }^{114}$ In light of the conflicts between the priests and the polis as recorded in the inscriptions at the site, Labraunda was considered to have undergone a period of stagnation after the passing of the Hekatomnids until the Roman era when architectural activity resumed. ${ }^{115}$ Recent excavations, however, tell a different story. The sanctuary appears instead to have been in continuous and intensive use throughout the Hellenistic period, an image testified by the ceramics, but now also corroborated by the architectural record. ${ }^{116}$ One of the largest buildings at the site is a Doric two-aisled stoa in the middle of the temenos and tentatively dated to the third to second century BC (although it was rebuilt in the second century AD). ${ }^{117}$ Building $\mathrm{M}$, as it is called, is situated along a narrow terrace above and behind the earlier Hellenistic fountain house and below the temple terrace. Although its function and relation with these structures is not yet entirely clear, it was the most conspicuous structure of Hellenistic Labraunda and is surely key to understanding the sanctuary in this era. With its location on a 'ledge' between the temple terrace and the area before Maussollos's andron, it would have provided a sheltered position from which one could enjoy the shrine and its scenery. Perhaps this was an act of the democratic polis, in affording an articulated view across the landscape below to the public at large, not just for those that were invited

114 Westholm interpreted the fountain as being Roman, Westholm (1963), 94, but Hellström sees more Hellenistic parallels and also the orientation of the fountain which suggests that it predates the wall, Hellström (1991a), 304.

115 Westholm (1963), 112 on Period v, the Hellenistic period: "Although various conditions in Labraunda are mentioned in a number of inscriptions from the Hellenistic time, there is no one of the excavated structures which was built in that period. The activity of the Hekatomnides was apparently sufficient for a long period ahead." Hellström (1965), 1-3 and Hornblower (1982), 311-312 see this as a period of decline. Hellström's hypothesis on Labraunda as 'memory theater', Hellström (2009), is based on the presumed lack of building activity, which he considers intentional rather than consequential. Since then some Hellenistic construction been identified, yet this perspective is still crucial for understanding Hellenistic Labraunda, see also Williamson (2013d). The imperial period saw several additions to the shrine, including Andron $\mathrm{C}$ and the baths.

116 See the preliminary reports in Anatolia Antiqua, especially from 2013 and on.

117 Blid and Hedlund in Henry et al. (2013), 327-336 and in Henry et al. (2014), 294-304. Perhaps future investigations will reveal whether any inscriptions were placed in this stoa; it would have been an ideal location. 
to dine in the elite andrones. In any event, this structure was enlarged in the imperial era and given a second storey, similar to Poleites's stoa. ${ }^{118}$

Another monumental feature is the structure in the area southeast of the temenos known as the Hypostyle Building. Once thought to be Roman, this is now identified as a fountain house from the Hellenistic period, rebuilt in Roman times. ${ }^{119}$ Stoa B/Y, immediately south of Propylon $\mathrm{Y}$ and east of Building M, similarly knew an initial construction phase in the Hellenistic period with a renovation phase in Roman times. ${ }^{120}$ The Roman phases of these buildings shows poor construction that led to several repairs in later periods. ${ }^{121}$ This lower quality may be indicative of the resources available to the polis, but the very presence of such public facilities is nonetheless unequivocal testimony to the ongoing popularity of the shrine. The noteworthy desire for abundantly available fresh water is indicated by the construction of the hypostyle fountain house and the smaller fountain house on the middle terrace. A third monumental fountain house, similar to the one on the middle terrace, was discovered roughly $110 \mathrm{~m}$ northwest of the temenos and was partially excavated in $2013 .{ }^{122}$

Another spatial indicator of the continued popularity of the shrine is the erection of honorific monuments. Although the Hellenistic inscriptions at Labraunda are discussed in more detail below, the largest free-standing honorific monument at the sanctuary is the marble exedra at the east end of the temple terrace, possibly from the third century BC. The location next to Propylon Y makes this a choice spot, one of the first features of the sanctuary that would have been seen by visitors passing through this portal. Unfortunately we know very little about the exedra or whom it honored. Holes in the top indicate that nine bronze statues once crowned the structure. The inscriptions, however, bear only the name of an individual, Demetrios, son of Python, otherwise unknown. ${ }^{123}$ Although the provenance of the marble is unknown as of yet, it

118 Blid and Hedlund in Henry et al. (2014), 303-304.

119 F. Rojas et al. in Henry et al. (2016), 304-316.

120 Blid and Hedlund in Henry et al. (2014), 295; Hedlund's analysis showed anta blocks belonging to this structure bearing the inscriptions I.Labraunda 45 and 71 , providing a terminus ante quem in the Hellenistic period, Hedlund (2014).

121 Building M was "constructed in a haphazard way, which ultimately led to the collapse of the building," Blid and Hedlund in Henry et al. (2013), 327-336 and in Henry et al. (2016), 304. The Hypostyle Building was constructed on foundations that were "roughly cut, poorly joined and not clamped," Rojas et al. in Henry et al. (2016), 315.

122 O. Henry in Henry et al. (2016), 269-272.

123 I.Labraunda 29a-c; Crampa dates these to the third century вс based on the lettering. The exedra was excavated in the 1940 os but was cleaned in 2013 and published by F. Tobin in Henry et al. (2014), 269, Fig. 28. See also below, under Civic Decrees. 
is tempting to connect the construction of this feature with some of the finer architecture that Mylasa was known for. ${ }^{124}$ There is an abundance of marble in the area, including the Sodra Dağı which towers above the city and was quarried in antiquity for its white marble. By the first century BC, Strabo wrote that because of the quarry, Mylasa, 'as much as any other [city], is in every way beautifully adorned with porticoes and temples'. ${ }^{125}$ It would have made sense to extend the same kind of garniture to the sanctuary, if it was an important public space for the polis. From the preliminary results it would seem that in the Hellenistic period there was a mixture of functional public buildings hastily constructed in local gneiss, such as the Hypostyle Building, and elegant privately funded features built in fine marble, like the exedra - hopefully future investigations at the shrine and in the environment of Mylasa will shed more light on this construction hybridity in the Hellenistic period.

Besides these additions, however, the Hekatomnid design was left intact and the buildings were maintained and used. In this way the legacy of the Hekatomnids lived on, along with their power which the architecture continued to emit through its resonance with the landscape. The excellent facilities would thus have been a perfect match for the needs of the Hellenistic polis, which now used the sanctuary to follow its own agenda in propagating Mylasan identity.

\subsubsection{Public Space - Concentric and Linear}

One of the main goals of the Hekatomnid renovations at Labraunda was obviously to create a place that could host considerably large audiences; as mentioned above, the leveled surface area was considerably expanded to $7200 \mathrm{~m}^{2}{ }^{126}$ The terraces allowed not only for good access, directing the flow of traffic via a gentle serpentine route up the hill and along the various facilities (e.g. banqueting areas, fountains), but also for segregate gatherings, both inside and outside of the sanctuary. The clearest example of concentric space is found in the stadion, constructed west of the shrine for the games (discussed further below).

The retaining wall south of the propylaia must have acted as a kind of 'vestibule' while the festival crowds were channeled through the gateways to the sanctuary. The wide terrace between the East Stoa and Andron B was then a second reception area, after the monumental staircase, and before

\footnotetext{
124 The marbles of Labraunda are being examined by A. Freccero, Henry et al. (2014), 276-277.

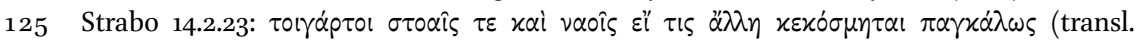
H.L. Jones (1929) The geography of Strabo, LCL 223).

126 Pedersen (1991), 99, Fig. 99.
} 
approaching the temple area - both of these areas allowed for a large part of the festival crowd to congregate during their stay at the sanctuary. The quantities of tableware and lamps indicate that Labraunda was in fact regularly and intensively occupied. ${ }^{127}$ With its ample facilities, water supply, and wide and varied spaces, a large gathering could easily have camped out at the sanctuary for the greater part of a week. ${ }^{128}$

On the next terrace, the area in front of Maussollos's andron may also be identified as concentric space. Building $\mathrm{M}$, a stoa elevated on a higher plane that looks out across the shrine, also faces this space. Although not round, the clear focus of these areas with ample room for spectators corresponds with Chwe's idea of an 'inward-facing circle', allowing for all the participants to not only view the central ritual, but also to observe each other viewing the event. ${ }^{129}$ As he states, this is one of the prime ways to generate common knowledge, which is the basis for group cohesion and the goal of most public (i.e. 'rational') rituals.

The temple terrace, with its surface area of roughly $1000 \mathrm{~m}^{2}$, had an internal visual focal point in the central area, framed by the temple and Propylon $\mathrm{Y}$ (and later the North Stoa) and should be considered as concentric ritual space. ${ }^{130}$ Monuments moreover identify critical spots, and these were initially concentrated on or around the temple. The space contained within the temple terrace held a statue dedicated by Hekatomnos, founder of the dynasty, and another of Ariarames, the son of (a) Maussollos. ${ }^{131}$ Two other inscriptions from the fourth century were also found on the temple terrace; these include fragments of a stele bearing a list of names, perhaps envoys, and a plaque that may have been a decree by a certain Hekatomnos. ${ }^{132}$ With its focus on ritual, but also on dynastic members, this terrace was certainly the primary ritual and public space of this sanctuary. ${ }^{133}$ The locations of inscriptions and the exedra monument show that the temple and the temple terrace continued to be used as

127 Hellström (1965), although in this publication he argues for a decline in the Hellenistic period, p. 13; this is discussed below under Festivals.

128 The festivals of Zeus Labraundos lasted for perhaps up to five days, see below.

129 Chwe (2001), 30-33, discussed in Chapter 2.

130 Discussed in more detail in Williamson (2014a).

131 I.Labraunda 27 and 28, respectively. On the identity of Ariarames, see Crampa's discussion on p. 28-29; he tentatively dates the inscription on this statue base (I.Labraunda 28) to the end of the fourth century вс.

132 I.Labraunda 67 and 83, respectively. A third decree, I.Labraunda 40, was found reused in a later floor behind Andron B; this was a proxeny decree issued by Maussollos and Artemisia for the people of Knossos; unfortunately its original setting is unknown.

133 See also Williamson (2013e) on Labraunda as public space. 
important public spaces in the Hellenistic period (Figure 3.6, Areas A-C, E and $G)$.

Two more critical spots in the sanctuary may be identified through inscriptions in this period. One was the South Propylon, particularly in the third and second centuries BC, when it was marked by a number of documents, including the citizen's oath of Mylasa (Figure 3.6, Area F). ${ }^{134}$ This was of course the end of the processional route from Mylasa, and thus the hinge connecting the world of the polis to the realm of Zeus Labraundos. A second critical spot was the anta of Maussollos's andron (Figure 3.6, Area D), which bore the decree by Philip v stating that Labraunda belonged once and for all to Mylasa. ${ }^{135}$ This andron, like that of Idrieus, was one of the most representative interior spaces at the sanctuary, with monumental windows that 'framed' Mylasa. Inscribing this final decision here added emphasis to the visual link with the polis that had already been laid.

The hillside of Labraunda afforded a panoramic view across the landscape to Mylasa and beyond. The architectural construction on the terraces shaped this view and connected it to ritual space at the sanctuary; the windows in the andrones narrowed the focus even more, by literally clustering parts of the landscape together with Mylasa at the center. Using ritual architecture in this way to define the view moreover instructs the eye as to what it is seeing within a ritual context. ${ }^{136}$ Emphasizing such sightlines brings faraway places 'within reach' since two (or more) visual points are comprehensively connected, crossing space and time with a single movement of the eye. It further helps create a mental spatial hierarchy in the landscape by defining this particular view as a 'region', from which the relationships in the rest of the landscape can or should be understood. ${ }^{137}$

A more kinetic use of linear space in a ritual context is of course the processional route, which connects two (or more) places by physically crossing space and time in a ritualized way. This route is certainly one of the most tangible ways of connecting the sanctuary to the city.

134 Other than Idrieus's architrave inscription for the South Propylon, I.Labraunda 18, all of the inscriptions posted here date from the third (I.Labraunda 46, Antiochos III letter of protection from $203 \mathrm{BC}$ ) or second centuries BC: I.Labraunda 68 (a list of names from c. 200 BC), I.Labraunda 47 (the Mylasan civic oath), I.Labraunda 9 and 134 (honorific decrees for Olympichos, re-cut in the second century вС).

135 These inscriptions are further discussed below.

${ }_{13} 6$ Fehr (1970) explores the development of emphasized sightlines prior to the Roman period; see also Williamson (2014a).

137 Discussed in the section Spatial memory and visual regions, in Chapter 2 under Approaches from outside the box. 
4.1.3 Sacred Road

One of the first construction works by Maussollos would actually have been the sacred way linking this sanctuary to Mylasa. The road runs more or less directly north from Mylasa, crossing the fertile plain of the Sarıçay en route to the Çomakdağ ridge and continuing on into the mountains and wilderness areas, where it is punctuated by springs and tombs, but also by the fortifications discussed above. ${ }^{138}$ Some 14 kilometers long, this processional road is $7-8$ $m$ wide and was paved, presumably for much of its course (Figure 3.10). Several stretches are still intact and it is partly followed by the modern road, especially in the mountainous areas from the modern village of Kargicak up to the sanctuary. A tremendous effort went into the construction of this road: a number of terraces and structural supports were built to make it as straight as possible, and its surface was made firm and smooth with large flat slabs. This would

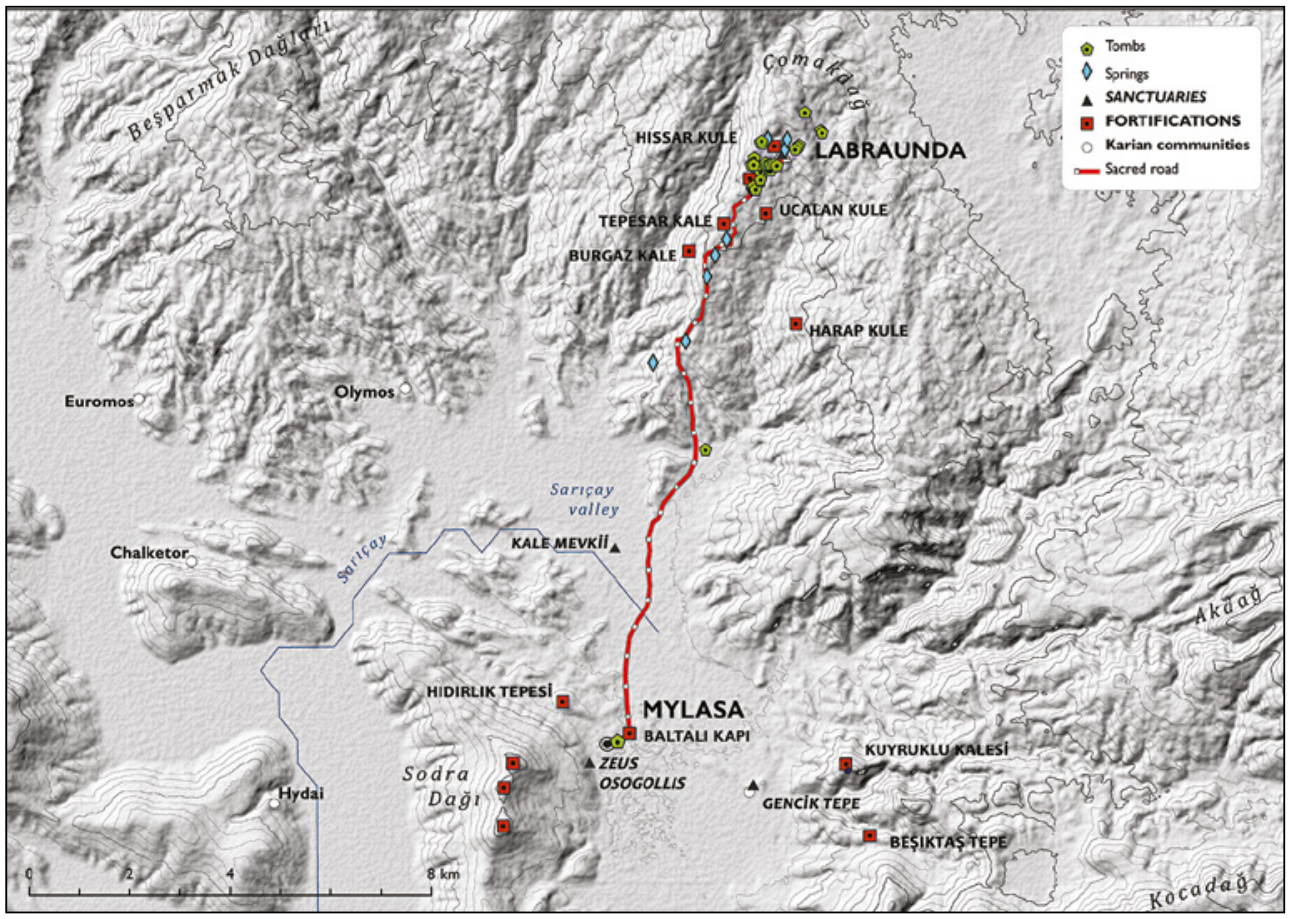

FIGURE 3.10 Route of the sacred road from Mylasa to the sanctuary of Zeus at Labraunda. Trajectory after Karlsson (2010), Fig. 7, and Baran (2011)

138 Baran (2011), 52-66 discusses the sacred way in detail; the 61 tombs discovered so far, ranging from Classical to Late Roman are studied by O. Henry in Karlsson et al. (2008), 116-121; Durusoy (2014). 
have facilitated the transport of the construction material to the site, and is held by some to be the main purpose for the pavement. ${ }^{139}$ Nonetheless, this road may well have been the most attractive and monumental route of its day, and with springs at regular intervals it made for a fairly comfortable journey. ${ }^{140}$

The relatively high concentration of watchtowers, in visual range with each other and the Akropolis Fortress in a 'watch-and-warn system', must also have ensured safe passage along this road, both during the festivals as well as for regular traffic (Figure 3.4). ${ }^{141}$ Most of these towers have now been excavated, and their finds and construction technique indicate an origin in the Hekatomnid period for the Akropolis Fortress, Tepesar Kale, and Burgaz Kale, which was the most southern fortress in this system. In the third century the chain seems to be expanded with the watchtowers of Ucalan Kule, Kepez Kule, and farther to the south Harap Kule, as well as expansions to the Hekatomnid fortifications. ${ }^{142}$ Labraunda is situated on the main pass to the north that also leads to the plain to the east, the Hayrrlidere valley, and the area of Lagina, discussed in Chapter 5. The fortifications served to protect the sanctuary as well as this road itself, which not only carried pilgrims towards the sanctuary of Zeus but also gave critical access to north and central Karia. ${ }^{143}$ Recent excavations show their ongoing use in the Hellenistic period, especially at the Akropolis Fortress, which may well have been the fortification known as 'Petra' and used by Olympichos. ${ }^{144}$

139 On the road see Westholm (1963), 9-10 and Baran (2011), $5^{2}$ “... it might be suggested that the Hekatomnids built a substantial road which had stone paving, small bridges for gully drainage, and strong retaining walls in order to ease transportation of marble to the site during the building activity and the increase the accessibility for the pilgrims and visitors of the sanctuary." See now E. Durusoy and A. Güliz Bilgin Altınoz in Henry et al. (2013), 342-350, with a map of the features in Fig. 87; also Durusoy (2014), Fig. 12.

140 Karlsson et al. (2008), 129, and Baran (2011), 52, 90-94 who lists 42 ancient fountain houses near the sacred road, the construction of which generally points to the Hekatomnids.

141 Karlsson et al. (2008), 111-116; Karlsson (2011), 217, 233. Also on the Akropolis Fortress, Baptiste Vergnaud in: Henry et al. (2013), 285-298; Henry et al. (2014), 280-292; Henry et al. (2015), 317-330; Henry et al. (2016), 397-412; Henry et al. (2017), 215-221.

142 The fortifications of Burgaz Kale, Tepesar Kale, and Ucalan Kule, all on the east side of the sacred road, as well as the Akropolis Fortress, were excavated between 2007-2010. Burgaz Kale has been suggested as being near the frontier with Olymos, Pimouguet-Pédarros (2000), 314. Kepez Kule has not yet been excavated; for Harap Kule, Karlsson (2011), 217, 228. The Akropolis Fortress was also intensively used in the Hellenistic period, B. Vergnaud in Henry et al. (2015), 280-292), and in the Byzantine period, see Lars Karlsson's historical overview of the strategic location of Labraunda, Karlsson (2011), 247-25o.

143 The Hekatomnid fortifications near Labraunda are considered part of the wider network of a Karian defense system, Karlsson (2011), 248-249 and Pimouguet-Pédarros (2000).

144 I.Labraunda 4 and 6, discussed in more detail below. The excavations of the Akropolis Fortress show an intensive use in the Hellenistic period (mentioned above) although 
The processions from Mylasa were an integral part of the annual festival at the sanctuary. Little is actually known however about the composition of the processions, although with this being one of the major urban festivals of Labraunda it should be assumed that the entire citizen population took part in the event (at least those capable of making the journey). We should thus envision an annual trek of the population from Mylasa towards Labraunda, where they would camp out for the greater part of a week. ${ }^{145}$ Specific rituals involving the procession itself, such as the kleidos agoge at Lagina, ${ }^{146}$ are however unknown for the festival of Zeus Labraundos, yet the watchtowers, tombs, and monumental gateways at both ends indicate that this was a formal and solemn event. This continued well into the imperial period, as evidenced by the arched gate that marks the entry into the city, known as Baltalı Kapı after the doubleaxe carved into the keystone (Figure 3.11). This labrys, the identifying mark of Zeus, was noted by Abuzer Kızl to have eyes carved in relief in each blade the gaze of Zeus towards Labraunda, as he argues. ${ }^{147}$

The passage towards Labraunda gave pilgrims a clear view towards the sanctuary and the mountains to the north, but also guided them across diverse ecological and economic regions of the polis, from farmland and pastureland through the more remote mountainous regions, escorted all the while by a defense chain of command posts. Besides these spatial zones, the many tombs lining the road towards the sanctuary could remind pilgrims of the factor of time, as they passed by those who had gone before. Once at the sanctuary, they could look behind them to see Mylasa at the middle of a sweeping panorama that included much of this part of Karia (Figure 3.12). ${ }^{148}$ In this way, this monumental road transported Mylasans across the critical areas of their territory and provided them with a wide perspective of their own place in the world and in Karia, giving them a strong sense of community and identity. ${ }^{149}$

numerous sites in this rocky region were also called 'Petra'; I.Labraunda 137, line 9 speaks of a fortified 'Petra' in the territory of Olymos, discussed further in Henry and Aubriet (2015) and Carless Unwin and Henry (2016).

145 See below on the festivals.

146 The procession of the key from Hekate's sanctuary in Lagina to Stratonikeia, discussed in Chapter 5 .

147 Kizll (2009), with images.

148 But also note the approach to Labraunda from Alinda and Alabanda, via the eastern propylaea, via a road that was also at least partly paved; Westholm 1963, 110-112, and Hellström (2009), 270.

149 Chaniotis (1995), 160, “... unter den einzelnen Elementen des Festes die Prozession dasjenige ist, das die polis in ihrer Gesamtheit erfasst, repräsentiert und zu einer gemeinsamen Handlung bewegt; die Prozession ist das Spiegelbild der polis. In ihr findet sich die 


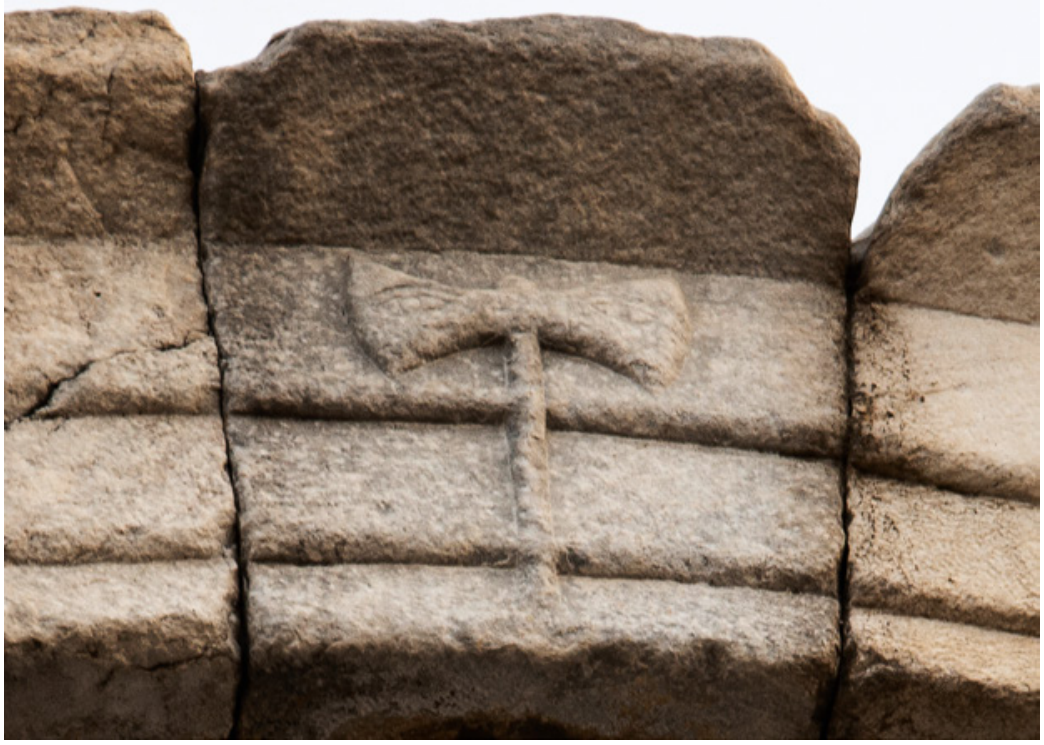

FIGURE 3.11 Mylasa. The labrys on the keystone of the Baltalı Kapı; note the eyes carved into the blades (see Kizll (2009))

PHOTO AUTHOR 2019

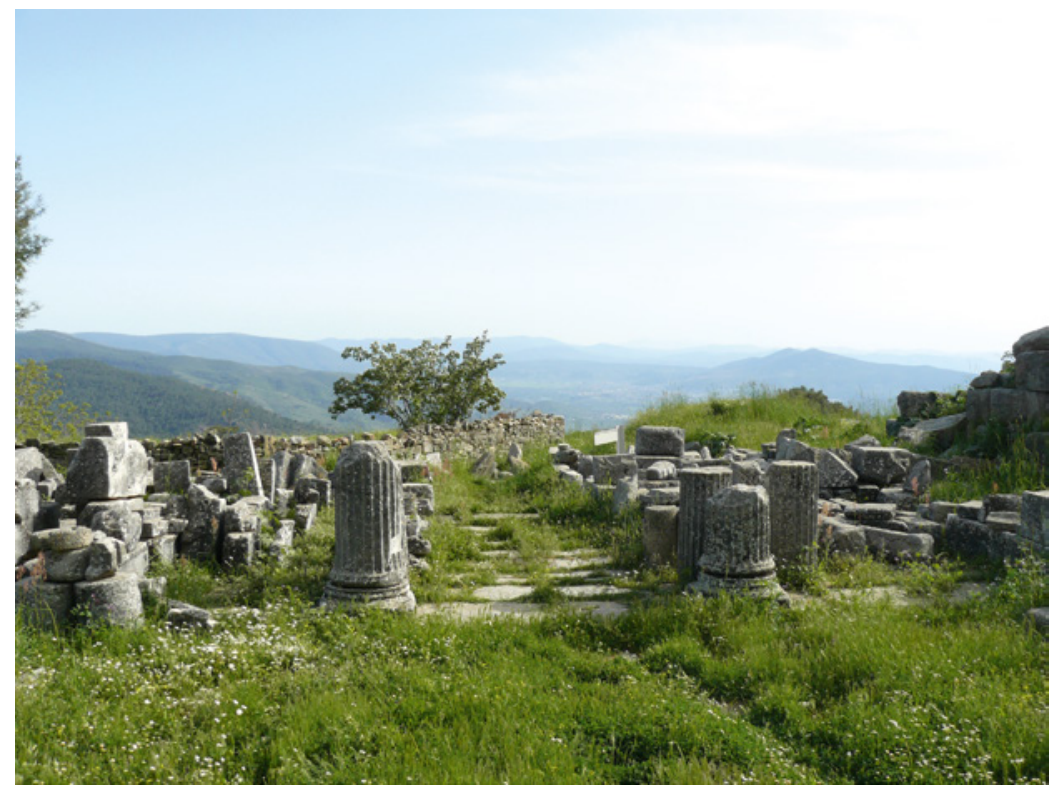

FIGURE 3.12 Labraunda. The South Propylon and the end of the sacred road. View towards the south and Mylasa, visible in the plain left of the mountain on the right side of the picture

PHOTO AUTHOR 2008 
To summarize, the natural prominence of Labraunda was exploited by the Hekatomnids in the Late Classical period when they radically transformed the shrine into a major political and sacred center that corresponded with their royal residencies at Mylasa and Halikarnassos. Greek, Achaemenid and Karian influences were intertwined on the cascading terraces, climaxing at the temple. The open area was spacious enough to accommodate a large crowd that could observe the main ritual as well as each other, and the splendid panorama, framed by architecture, across the Karian landscape, visually connecting the shrine with communities beyond, and Mylasa in particular. Monumental architecture served to foreground the shrine, thereby collapsing the distance between. Linear ritual space served this purpose as well via the processions that kinetically joined the polis to the sanctuary across different types of landscapes, economic zones, and along the many springs and tombs. In the Hellenistic period, the shrine was left intact and surely retained a sense of the power of the legendary rulers that had unified Karia. Pontus Hellström is right to depict Labraunda as a 'memory theater'. ${ }^{150}$ Inscriptions mark public and political flashpoints at the Hellenistic shrine. Zeus Labraundos had become an emblem for Karia, and it accorded well with Mylasa to imprint its urban identity upon this internationally recognized cult.

\subsection{Ritual Performance at Labraunda}

The radical reorganization of ritual space at Labraunda by the Hekatomnids must have coincided with a similar impact on the cult practices. ${ }^{151}$ The split rock clearly appears to have been the initial locus of cult with the dedications of votives. Especially interesting among these are the terracottas found in the early excavations depicting Kybele/Meter, dating from the Late Archaic and (Early) Classical periods, while the several girls carrying hydria (hydrophoroi koroi), and female protomes, dating from later periods as well, remind us of the female presence at the shrine. ${ }^{152}$ Several arrowheads from this era were also found on the temple terrace, mostly near the temple but also in the Mudbrick

gesamte Gemeinde zusammen, und zwar in einer Art, die jedem ihrer Mitglieder eine Rolle, eine Aufgabe, eine hierarchische Stellung zuweist."

150 Hellström (2009), 278. For a comparison, Horster (2013) on inscribed 'corporate' memories at the Eleusinion.

$15^{1}$ On the impact of ritual space on ritual practice: Parkin (1992), Tambiah (1985); also Williamson (2014a).

152 Karlsson (2013c); Karlsson in Henry et al. (2013), 298-300 and the conference paper Karlsson (2013b). Most of the 80 terracottas found at Labraunda were of the Hellenistic 'Tanagra' and similar types, see Karlsson (2015b). 
Building near Propylon Y - these may well have been connected to the militant character of Zeus Stratios. ${ }^{153}$

Although we know little about Archaic Labraunda, it seems apparent that the ritual changes initiated by the Hekatomnids were focused on the annual festival for Zeus Labraundos. Besides the processions, discussed above, there is evidence of extensive banqueting at the sanctuary which probably took place primarily during the festivals, as well as of athletic contests and games. These would have set the tone for the general nature of the rituals at Labraunda for the Hellenistic period.

\subsubsection{Festivals}

The annual festival, or panegyris, for Zeus Labraundos, was expanded from one to probably five days, and was open to all Karians. ${ }^{154}$ A good deal of the Hekatomnid festivals must have been focused on the rulers and their dynasty. Besides the presumed erection of their statues in the banqueting halls, this is also where they made a public appearance, as we know from an assassination attempt on Maussollos that took place during the annual festival in 355/4 BC..$^{155}$

The ceramics at Labraunda consist largely of tableware and lamps and give an indication of the way in which the sanctuary was used. ${ }^{156}$ The Late Classical period saw a few pieces of Attic red-figured ware, but much more common were the black-glazed plates and bowls, often with impressed palmettes, and mostly Attic in origin. ${ }^{157}$ Attic black-glazed ware drops off in the

153 Hellström (2019). He draws the arrowheads and spearheads in connection with the militant character of Zeus Stratios (Hdt. 5.119.1-2 and Strabo 14.2.23), and the structure called 'Terrace House I' where several of arrowheads were found. I have omitted this Archaic structure from discussion until it is further investigated and published. Säflund believed that the mudbrick structure was an altar, Säflund (1956), 3, although Hellström (2019) argues that it was more likely the base for a statue of Zeus.

154 The festival is called the panegyris in I.Mylasa 3 , line 5; see Hellström (2011a), 149-150. The festival is further mentioned in I.Labraunda 54 with a list of what the events day by day unfortunately this is too fragmented to be of any use here, although Crampa understands it to include five days altogether (p. 85). The incomplete lists of names in I.Labraunda 53-54 and 67 are interpreted as envoys to the festival. I.Labraunda $53-54$ are furthermore imperial copies of a festival decree from the fourth century BC, inviting all Karians to participate in the festival, although the lists of names at the sanctuary imply that most derived from Mylasa - see below on the scope of the sanctuary.

155 I.Mylasa 3 . This attempt on Maussollos's life was the third assault on the satraps: I.Mylasa 1 mentions a plot against Maussollos that had been found out (367/6 BC), and I.Mylasa 2 a statue of Hekatomnos had been vandalized ( $361 / 0$ BC).

156 Hellström (1965).

157 Hellström (1965), 11-15 presents the Attic red-figured and black-glazed pottery; the Panathenaic amphora, on p. 7-11, is discussed below under Games. The objective of the 
Hellenistic period, apparently replaced with local products, especially the fish plates, "poor products with a thin, mat glaze."158 Fine pottery and lamps in the Hellenistic period is rare and this was initially interpreted as a sign of reduced interest. Yet the many mould-made bowls and lamps show that activity at the sanctuary certainly continued, perhaps on a different scale or with a different ritual use. ${ }^{159}$ Unguentaria, small oblong flasks or bottles probably intended to carry precious fluid, were common at Labraunda in the Hellenistic period, and may indicate a specific votive ritual. ${ }^{160}$

The apex of cult ritual is typically the sacrifice, and this surely took place on the temple terrace. Assuming the square structure before the temple is in fact the altar, then this would have served a number of purposes. In the first place, it would have provided the cult image of Zeus with an interrupted view of the sacrifices performed. In the second place, it would have allowed ample space for quite a gathering on the temple terrace, space that would become more and more consumed with honorific monuments, particularly along the northern side. Finally, it would have been directly visible to those entering from Propylon Y, and at the same time its proximity to the edge of the temple terrace would have made the fire and smoke columns visible to those on lower terraces, at least until the construction of Building M in the Hellenistic period.

\subsubsection{Banqueting}

As discussed above, banqueting facilities were the central component of the new architectural complex at Labraunda, ensuring that some 150 or more people could dine in symposium simultaneously; many more (e.g. women and children?) were probably served outdoors in the open or under temporary shelters. ${ }^{161}$ Although we do not know where the food was prepared, the quanti-

volume, as stated in the introduction on p. 2, was to present a general typology of the material from the sanctuary; it was not meant to be a comprehensive catalog, and quantitative analyses were not performed, precluding further interpretations regarding frequency of types.

158 Hellström (1965), 13, drawing a parallel to the lack of building activity in the Hellenistic period; see now Hellström (2009), in which he sees Hellenistic Labraunda as a 'memory theater', discussed below.

159 Hellström (1965), 19-23 for the so-called 'Megarian' bowls, and 49-54 for the lamps. A variety of reasons may account for the change in pottery type, e.g. the shift in focus to Mylasa, a change in the length of festival days, or a wider change in Mylasan economic and trade patterns.

16o Hellström (1965), 23-27. Unguentaria were also found at Lagina, see Chapter 5. On the common appearance of unguentaria in tombs, Anderson-Stojanović (1987).

161 Hellström (2011a), 153-154. The two andrones had floor space for 19 or 20 klinai each, and the six rooms of the East Stoa could each hold 11 klinai, see Hellström 2007, 97-99, 
ties of tableware - both local fabrics and fine Attic black-glazed - unearthed during the excavations certainly testify to widespread formal dining. ${ }^{162}$

Although feasting and sacrificial consumption had no doubt already been a part of the cult at Labraunda, under the Hekatomnids this took on an entirely new dimension. Ritual dining was now directly an extension of ruler representation, combined with divine presence. Anne Marie Carstens and others have suggested that the andrones were used as royal reception halls where political meetings were held, and that with the royal andrones the complex at Labraunda took on the role of an Achaemenid-style garden palace, where they could dine 'in paradise.' ${ }^{163}$ An andron building was dedicated in Halikarnassos to Zeus Akraios, known only from an inscription, and is suggested to have belonged to the Zephyrion palace-temple complex. ${ }^{164}$ Banqueting clearly made up an important part of Hekatomnid ideology, as the dynastic symposiast on the relief of the sarcophagus in the tomb at Uzunyuva shows. ${ }^{165}$ Besides demonstrating the importance of the Totenmahl motif among the Hekatomnids, as Pedersen argues, the Uzunyuva relief also presents us with an impression of their intended reception at real dining functions, as in Halikarnassos and Labraunda, where they surely occupied the central position in the staged arrangement.

The inclusion of formal dining facilities was certainly pivotal to the new Hekatomnid design of Labraunda, and Pontus Hellström observed that "the different levels of dining facilities ... made hierarchical separation of different status groups possible."166 Especially in the andrones, he sees a directional pattern in the arrangement of the klinai, or couches, in the axial space of the royal

Hellström 1989 and Hellström 1996a; Hellström 2007, 23-25 further calculates that each kline could hold 2 diners. The area before the East Stoa was excavated in 1988-1991 and a ceramic study, in 2006, shows that the pottery is mostly tableware, reinforcing the interpretation of dining rooms. Facilities for food preparation have not yet been identified; see Karlsson et al. (2008).

162 Hellström (1971); also indicated in the area near the East Stoa, studied by Lovisa Strand, Karlsson (2008), 109 n. 1, and under excavation at the time of this writing (reports appear in Anatolia Antiqua).

163 Carstens (2009), 88 on "dining in paradise", 86-91; also Karlsson (2015a). Hellström (1989a) suggested that andrones were constructed for meetings of the Karian and Chrysaoric federations and argues for their royal use in Hellström (1996a). Their use for the Karian League finds further support in Carstens (2009), 100 and (2011), 124-130.

164 Isager and Pedersen (2014). The significance of banqueting in civic and royal contexts is further addressed in Strootman (2018).

165 The banqueting scene on the sarcophagus at Uzunyuva is briefly discussed in Konuk (2013), 111 and more at length in Pedersen (2017), 241 and 242, Fig. 22.4, in the context of the Totenmahl and its implications for the Maussolleion in Halikarnassos.

166 Hellström (2011a), 153. 
andrones that would follow the rank of the individual diners. Dining in the andron was already quite prestigious in itself, with plastered walls and mosaic floors. ${ }^{167}$ A different, yet also formal mode of dining was provided in the East Stoa, which was non-axial, and thus more egalitarian and Greek. ${ }^{168}$ In this way, ritual dining combined with these different kinds of formal spaces could easily be used to distinguish visitors at the sanctuary. This could have been critical if the Achaemenid appointment of Hekatomnos, a member of the local elite, to rule as satrap over his peers was indeed perceived as "a shock to the Karian elite," as Hellström postulates. ${ }^{169}$ Including them in the splendor at the sanctuary would have been one of the surest ways of gaining their support - this is another argument to see Hekatomnos as the mastermind behind the transformation of Labraunda, later carried to fruition by his sons Maussollos and Idrieus. ${ }^{170}$

This arena of power negotiation through ritual dining was a legacy the Hekatomnids left to Labraunda and may well have been one of the strongest selling points of the cult place. It is highly conceivable that administrators of Hellenistic Mylasa used this sanctuary to bestow privileges on the local elite or distinguished guests; such public activities certainly continued on a large scale as indicated by the addition of the fountain houses and perhaps Building M. The windows of the 'royal' andrones still framed Mylasa, as mentioned above, and this may have been why the final ruling by Philip v, declaring the sanctuary of Zeus Labraundos as ultimately belonging to Mylasa, was inscribed in the anta of Maussollos's andron, close to the view towards Mylasa and the people that enforced the bond between the polis and the sanctuary.

\subsubsection{Games}

Some 200 meters southwest of the sanctuary was a stadion, one of only two in Hellenistic Asia Minor known to be linked to a sanctuary. ${ }^{171}$ The construction of the stadion is consistent with a date in the fourth century, and it is generally taken to be part of the overall Hekatomnid building program at Labraunda;

167 Henry et al. (2018), 288 on the mosaics, vegetal and Hekatomnid in date, of Andron A (A.-M. Guimier-Sorbets) and 293 on the plaster and wall decoration of the same structure (A. Freccero).

168 Hellström (2011a); also in Hellström (1996a), 168.

169 Hellström (2011a), 152. Hornblower considers the possibility of the choice of Hekatomnos as satrap as connected with his religious office of 'King of Karian League', Hornblower (1982), 55-56, 59 .

170 Hellström (2011a), 152-155.

171 Roos (2011), 257; the other stadion is at Didyma, in the precinct of the Apollo sanctuary. 
adding athletic contests to the cult rituals would fit in well with the expansion of the festivals from one to four or five days. ${ }^{172}$

The stadion measures $34 \times 189 \mathrm{~m}$, with space for 12 to 14 runners and a length of $172 \mathrm{~m} .{ }^{173}$ The lack of natural level space near the sanctuary probably led to its curious construction. Built across a hillside, it resembles an elongated raised platform, with a 'tunnel' for drainage a little to the west. Roos had to exercise his imagination to postulate where exactly the spectators may have taken up their positions, since the area immediately around the stadion is more or less level with it. ${ }^{174}$

Unfortunately there are almost no references to the games and events that took place here, but that they continued into the Hellenistic period is clearly indicated by the inscription honoring an individual and admitting him into the clan or syngeneia of Korris, the priest at Labraunda in the second half of the third century вс. ${ }^{175}$ Two privileges bestowed on this individual include a golden crown which he would receive during the games for his virtue and benevolence as well as front-row seats. ${ }^{176}$ As with so many urban theaters and stadia, this shows that this 'arena' of physical excellence at Labraunda was also a place where community virtues were publicly rewarded. ${ }^{177}$ As an inwardfacing circle, the stadion was an excellent coordinating device for engaging the crowd, facilitating mutual eye-contact and fostering a sense of unity and identity, an aspect that surely added to the power of place at Labraunda. ${ }^{178}$

In summary, transforming ritual space impacts the rituals themselves, whether it reflects ritual change or precipitates it. ${ }^{179}$ The spatial climax of the Hekatomnid monumental complex on the temple terrace sharpened the focus on the rituals that took place before the temple, such as the sacrificial ritual. The facilities and abundance of fresh water at Labraunda allowed for a large group to 'camp out' at the sanctuary for a longer period of time as the main festival, the

172 Roos (2011), 265; Hellström (2007), 142-143. Also a fourth-century Panathenaic amphora indicates the importance of the idea of competition in the newly redesigned sanctuary, Hellström (1965), 7-8, discussed below.

173 Roos (2011), 258-263. But this is the platform, the race course would have been smaller as he observes.

174 Roos (2011), 264-265; he discovered a few step-like features cut from the rock on the slope a little to the north that may have been a quarry, but may also have served as stands.

175 I.Labraunda 11 , third quarter of the third century BC. This inscription is discussed in more detail below.

176 I.Labraunda 11 , lines $7-8,10$.

177 For this phenomenon in the Roman period, see van Nijf (2010).

178 Chwe (2001), 30-33.

179 E.g. Parkin (1992), 18: "Ritual is formulaic spatiality," on the bodily performative aspects of ritual. 
panegyris, was expanded to four or five days. Massive feasting was another structuring ritual performance. The population would have been divided into those who dined in the Achaemenid-like royal banqueting halls, those in the more 'egalitarian' Greek andrones in the East Stoa, and those who took their meals al fresco, or in temporary shelters in the common areas. This would have continued in the Hellenistic era, as well as the competitive games, which served to (re)produce shared values and local identities. ${ }^{180}$ The sanctuary clearly continued in use at this time, testified by the addition of a central stoa and monumental fountains for additional public water. Ritual seems to have continued as well, with the main change being the shift in context from the Hekatomnids to the polis of Mylasa, but also to the community around the priests, who made their own claims to the sanctuary.

\subsection{Legal Administration and Organization of Labraunda}

The administration of a sanctuary and its local organization is a mirror of its relationship with the city to which it belongs. The priesthoods and the status of the community living at the sanctuary or involved in the cult can thus reflect the level of urban, or local, involvement. ${ }^{181}$ Equally important is the control of the economic resources, as the cash flow going in and out of the sanctuary will reflect the degree of autonomy or dependency of the sanctuary on the polis. These aspects - the priesthoods, the organization of the local community, and the financial administration of the sanctuary and its holdings - are clearly illumined as Labraunda became contested space in the third century вс.

\subsubsection{Administration and Priesthoods}

Nearly all of our knowledge of the priesthoods at Labraunda, and what this function entailed in the Hellenistic period, is derived from a special set of documents at Labraunda. Their content shows that the relationship between the priests of Labraunda and the boule and demos of Mylasa was certainly a barometer for the relationship between the polis and the sanctuary, and how complex this was. These documents, inscribed on the walls of the temple and the andrones, were copies of royal correspondence that concerned two separate episodes in the second half of the third century $\mathrm{BC}$, in which the priests of Labraunda were at odds with the Mylasans. ${ }^{182}$ These letters have been the

180 For games and community in Roman Asia Minor, see esp. van Nijf (2010); also van Nijf (2001) and (2002).

181 For a parallel with Klaros in Roman Asia Minor, see Busine (2013).

182 I.Labraunda $1-3$, and 137 , are in content dated to c. 240 BC and contain the correspondence between Seleukos II and his strategos Olympichos, governor at Mylasa, over the first dispute between Korris, priest at Labraunda, and Mylasa (I.Labraunda 2 and $3 \mathrm{~b}$ are 
subject of a great deal of discussion. ${ }^{183}$ For the context of this study, I will summarize the main points of their contents and then focus on what they reveal about the degree of dependency of the sanctuary on Mylasa in the Hellenistic period.

In the first argument, dated to roughly $240 \mathrm{BC}$, Korris, then priest of Labraunda, filed a complaint directly with Seleukos II against Mylasa, saying that the polis had 1) appropriated sacred lands that were under his management by virtue of his ancestral privileges, 2) kept the profit from these lands, and 3) withheld the sacrificial dues which they owed to the priest. ${ }^{184}$ Seleukos took Korris's claims seriously and ordered his resident strategos Olympichos (whom the priest had circumvented in his complaint) to investigate the matter and take appropriate action, instructing him not to allow Mylasa in the meantime to encroach upon anything belonging to the sanctuary and the priest. ${ }^{185}$ Olympichos interviewed both the priest and the officials of the city. ${ }^{186}$ In the presence of the priest, who had claimed that his ancestral privileges had been violated, Mylasa declared that Labraunda was theirs, and that they had

later copies). The second dispute, I.Labraunda $4^{-7}$ is dated to c. 220 BC and involves Antigonos Doson, Philip v, Hekatomnos (then priest at Labraunda), the Chrysaoric League, Mylasa, and Olympichos. The dossier on Olympichos sheds a great deal of insight into the stakeholders at Labraunda with respect to Mylasa, aided by the discoveries of I.Labraunda 134 (Isager and Karlsson (2008); Isager (2011)) and I.Labraunda 137 (Henry and Aubriet (2015); Carless Unwin and Henry (2016)) and Milas Museum Inv.no. 2012/31a (van Bremen (2016)). For more discussions (among many others): Debord (1969) and (2011); Reger (2010); Aubriet (2012).

183 Disputes between priests and cities, as at Labraunda, have been used to argue for the original autonomy of sanctuaries in general in Asia Minor: see especially Dignas (2002a), 68-69, Virgilio (2001), Debord (1969) and Debord (1982), 51-53. Mastrocinque, following Debord, also sees it as symptomatic of the inherent tensions between the Greek polisoriented system and the indigenous hierarchy, centered on sanctuaries and priestly authority; Mastrocinque (1979), 216-218, citing two other disputes between priests and poleis, at Apollonia Salbake and Myndian Telmessos versus Halikarnassos. Debord (2011) brings several nuances to this position, in light of later discoveries, which are discussed below. Isager (1990) sees it more as a clash of political systems, theocratic versus democratic. Reger considers the Labraunda conflict within the wider context of Mylasan expansion, Reger (2010), 51-53; also Reger (2013) who includes the windows of the andrones and the possible effect of the visual relationship with Mylasa on the priests; my thanks to Gary Reger for giving me access to this article.

184 I.Labraunda 1 is a letter from Seleukos to Olympichos, reviewing the complaint and giving him instructions.

185 I.Labraunda 1 . Lines 7-9 contain the restriction on Mylasa, followed by the clause in lines 9-11: 'For we decree that the concessions made [to Korris by virtue of ancestral privileges]

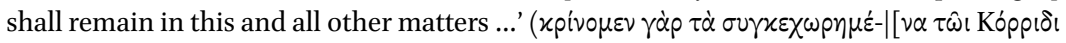

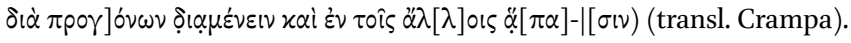

186 I.Labraunda 3. 
been falsely accused by Korris, since they in fact allowed him to administer the sacred lands according to his ancestral rights, and since they had paid him the sacrificial dues as well. Olympichos, who had taken an oath to serve and protect the interests of Mylasa, ${ }^{187}$ ruled in favor of the polis; his decision was apparently endorsed by Seleukos II since his letter to the Mylasans was inscribed on the northwest anta of the temple (Figure 3.6) and no more was heard of the matter. ${ }^{188}$

Some twenty years later, however, a second dispute arose when Hekatomnos, priest of Labraunda at that time, made an appeal to Philip v of Macedon, who succeeded Antigonos Doson and occupied the area around 220 BC. ${ }^{189}$ Philip responded by addressing the people of Mylasa, ${ }^{190}$ informing them that Hekatomnos had presented him with a letter written by Philip's father, i.e. Antigonos Doson, to the Chrysaoric League ${ }^{191}$ in which Antigonos Doson had agreed that the priesthood and the sacred lands would belong to Hekatomnos,

187 I.Labraunda 3 and 137. Olympichos referred to the oath that he copied for the people of Mylasa, in which he had vowed to 'assist the Mylasans, at they requested, in preserving what belonged to them in the country, both the [sacred things] in the shrine of Zeus Labraundos and all the other things, and also the land in the neighborhood of Labraunda and the other land which was [theirs] and all the other items which had been granted to

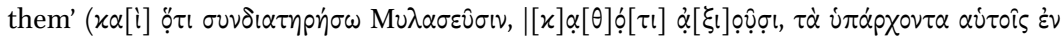

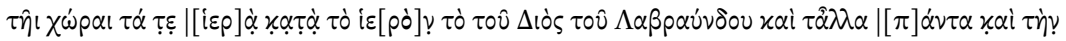

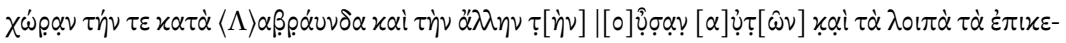
$\chi \omega \rho \eta \mu \varepsilon \dot{\varepsilon} \alpha \pi \dot{\alpha} v \tau \alpha$ ), in I.Labraunda 3 , lines 10-14 (transl. Crampa). Later, he declares that he would adhere to his oath and continue to 'try to assist you [i.e. the Mylasans] in preserv-

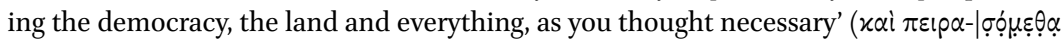

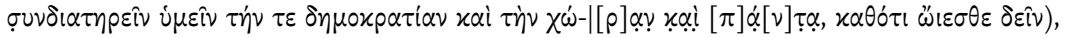
lines 29-31 (transl. Crampa). The oath and its implications are discussed in Henry and Aubriet (2015) and Carless Unwin and Henry (2016) in connection with I.Labraunda 137.

188 Since it had already been decided that Labraunda would belong to Mylasa at Seleukos's liberation of Mylasa, Crampa believes that "... the king and Olympichus seem to have rather lazily settled the case, whatever its details, in the city's favor," in I.Labraunda p. 85. Yet it is clear that Seleukos gave weight to the priest's complaints. Virgilio considers the reliance of kings on cities, and observes that in cases of resistance to civic authority, they tend to favor the cities as a rule, Virgilio (2001). Pontus Hellström observed that if the date of 240 BC is correct, then Seleukos II was in Syria while Hierax was gaining ground, making it extra vital to ensure the support of local cities (pers. comm. 27.03.2011).

189 This dispute is contained in I.Labraunda 4 and $5^{-7}$, dated to the period when Philip v was in Mylasa, c. 220 BC.

190 I.Labraunda 5.

191 The Chrysaoric League, a Karian-wide federation that was strong in the third and second centuries and had connections with the Ptolemies. Although they later settled near Stratonikeia, the first reference to the League is at Labraunda, I.Labraunda 43, dated to 10 June, 267 BC, in which a Ptolemaic official, Apollonios, son of Diodotos, is honored at Labraunda by the League for being an incorruptible and blameless judge and passing fair 
according to his ancestral rights, and that he, Philip, did not believe a word of it. This argument recalls the previous dispute over the administration of the sacred lands belonging to Zeus Labraundos, except that by this time it is clear that all of the revenues from the land, whether through the priest or through those who leased it, were collected by the city who then reinvested it, presumably channeled through a sacred funds, back into the festivals and sacrifices at Labraunda. The Mylasans further emphasize that everyone residing in the sanctuary is in fact a citizen of Mylasa. Finally, they reminded Philip that Seleukos II, when he granted Mylasa its freedom, also granted them Labraunda since they 'possessed it from the beginning.' ${ }^{192}$ Their need to stress this point implies on the one hand the opposite case, that they did not really control the shrine; despite the many interfaces between Labraunda and Mylasa there is little proof prior to the mid-third century вС that would substantiate their claims. ${ }^{193}$ On the other hand, the Hekatomnid promotion of the sanctuary should also be seen in context with their wider investment in the security of the regions surrounding the plain of Mylasa, as Descat and Reger have argued for the access routes from the south and west, respectively. ${ }^{194}$ Surely the chain of fortifications lining the sacred road to Labraunda reiterate this wider concern. In this vein, Mylasa would have naturally considered Labraunda as vital to the polis and therefore belonging to it.

Whereas Korris's dispute with Mylasa primarily concerned his own position, the ancestral claims of the later priest Hekatomnos were obviously interpreted as a much more serious threat to Mylasan control over the sanctuary. Philip v clearly felt that Hekatomnos and the Chrysaoric League were trying to manipulate him into delivering Labraunda to them. Wary of Olympichos as well, he personally investigated the matter (probably under the guidance of Mylasan envoys) and evidently saw and read the documents inscribed at the sanctuary from the ruling of twenty years before. Basing his decision on that, he

sentences. This inscription shows that the Chrysaoreis met at Labraunda in the early third century and clearly used it as their own public platform.

192 I.Labraunda 5 , lines 22-36; the rest of this inscription concerns Seleukos's strategos Olympichos.

193 See, for example, the inscription $S E G 591503$ (Gauthier (1999)), an honorific decree for judges from Kolophon for restoring the 'ancestral laws' of Mylasa, which states in line 24

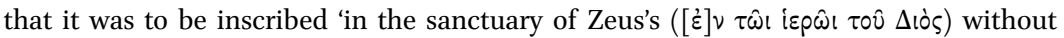
designating which Zeus. The editor takes this lack of epithet as an indication that Mylasa did not yet possess Labraunda, since it otherwise always distinguished between Zeus Labraundos or Zeus Osogollis; the inscription is then presumed to belong to the early third century, when the area was under Ptolemaic control (as shown in I.Labraunda 43).

194 Descat (2013) on the acquisition of the strategic access route near Sekköy which he identifies as Talagreia; Reger (2010) on the 'Little Sea' near Iasos. 
judged in favor of Mylasa. Philip's review of prior disputes between Mylasa and Labraunda neatly shows how inscriptions could affect a later generation. ${ }^{195}$ They also show how the Macedonian commander upheld a decision made by his Seleukid predecessor, perhaps to curry favor with Mylasa and ensure continuity and stability in the area. The general content of this dossier and the fact that it was all recorded at the sanctuary made it clear to everyone that Labraunda, still an impressive place worth fighting for more than a century after the Hekatomnids, ultimately belonged to Mylasa.

Hekatomnos's actions thus evoked the opposite response of what he had intended, since Philip v determined 'that the shrine belonged neither to the Chrysaoreis nor to the other Karians but was yours [i.e. the Mylasans], and also voted to [exclude] the Chrysaoreis [from the shrine] as they desired to appropriate it for themselves.' ${ }^{196}$ He further evicted the Chrysaoric League, renounced the priest for telling lies, and ordered Olympichos to evacuate the stronghold 'Petra', probably the Akropolis Fortress above the sanctuary. ${ }^{197}$ Olympichos appears to have had his own agenda with Labraunda, perhaps supported by Mylasa. The other letters pertaining to this episode, I.Labraunda 6 and 7, as well as I.Labraunda 4, concern Olympichos's evacuation of the area and final transfer of control over Labraunda to Mylasa. ${ }^{198}$

In this last dispute, therefore, the controversial matter of control over the sanctuary was apparently settled once and for all. Inscribing these rulings at the sanctuary itself was obviously the best way of ultimately establishing Mylasa's possession of Labraunda and broadcasting this for all to see - for the surrounding communities who visited the sanctuary, the Mylasans themselves who worshiped there, but also for the priests who lived there. One cannot help

195 Idrieus's use of the ethnic Mylaseus in his architrave inscriptions (on Andron A, I.Labraunda 15; the Temple, I.Labraunda 16; the 'Oikoi', I.Labraunda 17; the South Propylon, I.Labraunda 18; and perhaps the 'Doric Building', I.Labraunda 19, though this may be later, see below) surely galvanized the link between the polis and Labraunda for the following generations.

196 I.Labraunda 5 , lines 14-18, transl. Crampa.

197 On 'Petra', Henry and Aubriet (2015), 686-691.

198 These letters are published by Crampa in the order in which they appeared on the south anta of Maussollos andron (Andron B), from top to bottom; I.Labraunda 4 was inscribed on the north anta of Idrieus's andron (Andron A), see Figure 3.6 and Crampa in I.Labraunda in vol. 1 p. 22, 27-28 and vol. 2 p. 221. I.Labraunda 7 is the letter from Philip to Olympichos, ordering him to transfer the shrine, the land and everything else back to Mylasa, while I.Labraunda 4 and 6 are letters from Olympichos to Mylasa, stating his intention to restore everything back to the Mylasans while defending his actions as having been at their request and on their behalf. Also Hedlund (2014), van Bremen (2016). On Olympichos, see e.g. Savalli-Lestrade (2001), 281-283; Virgilio (2003), 170-184; Aubriet (2012) and Henry and Aubriet (2015). 
but wonder if it was an exercise in humility for them to observe how the correspondence in which they were made out as liars was carved first into the sides of the temple walls, just across from the 'Oikoi', their administrative structures, and then later in Maussollos's andron, still one of the most prestigious structures on the premises (Areas C and D on Figure 3.6).

This brings us, finally, to the question of the nature of the priesthood at Labraunda. These letters certainly display a considerable degree of at least perceived autonomy on the part of both Korris and Hekatomnos, who if they really were under the jurisdiction of the polis, would have been circumventing both the legal structure of Mylasa as well as the position of Olympichos in directly addressing the ruler. ${ }^{199}$ An inscription discovered in Iasos that mentions the benefactions of Hekatomnos, son of Korris, and priest of Zeus Labraundos, introduces a new perspective on the subject. ${ }^{200}$ This is an honorific inscription for Hekatomnos, in which he is given a golden crown of maximum weight for his virtue and benevolence towards the city (of Iasos) and with respect to his ancestors ( $\pi$ pórovol). Gianfranco Maddoli, who published the inscription, establishes the hereditary priesthood at Labraunda in the Hellenistic period, and thus the lineage of the priests themselves, drawing a connection back to the dynasty of the Hekatomnids, although the direct link is unknown. ${ }^{201}$ That the Hekatomnids were personally involved in the cult is beyond doubt (e.g. the ample appearance of the god on their coinage), but this could also shed new light on evidence such as the Tegean relief which shows Idrieus and Ada worshiping Zeus Labraundos. ${ }^{202}$ In the opposite chronological direction, however, Maddoli is able to map the lineage of the priests of Zeus Labraundos, starting with Korris in the mid-third century, through Hekatomnos and on down to the beginning of the first century вс. ${ }^{203}$

Maddoli's hypothesis provides a new angle for interpreting Hellenistic Labraunda and the position of its priests, giving Pierre Debord cause to reexamine the situation. ${ }^{204} \mathrm{He}$ underscores the intimate relationship between

199 Although the point of Dignas (2002a) is that kings were regularly mediators between cities and sanctuaries; her position however has been criticized by Corsten and Debord: Corsten (2006); Debord (2011), 135 .

200 Maddoli (2007), 306-316 no. 2oB.

201 Maddoli (2007) and (2010), 128-129. Debord also presumed some kind of link, Debord (1982), 33 ० n. 5 .

202 Now in the British Museum, see below.

203 Maddoli (2007), 316, with references. This complements Crampa's previous attempts in I.Labraunda, p. 200.

204 Debord (2011), analyzing the situation from the point of the different actors involved in the conflict: the priests, the city, the king, the Chrysaoric League, and Olympichos. He also views the Iasian honorific decree of the Labraundan priest in the context of a dispute 
the Hekatomnids, who resided in Mylasa, and Labraunda, evidenced by the iconography of the god on their coinage, and of course their heavy monumentalization of the sanctuary. Their strong personal ties with Labraunda would especially make sense if the priesthood were directly linked to the dynasty, for example through a side branch of the family. ${ }^{205}$ Following this, it would only be logical if an offshoot of the dynasty would continue to promote their status, even after the passing of the Hekatomnids. Debord explains this in part by emphasizing the polis as the new organizing element in the political grid in the Hellenistic world:

Elle est toute la partie occidentale de l'Anatolie le relais naturel du pouvoir royal, qu'il s'agisse d'une cité grecque ou de modèle grec comme Mylasa. Cette dernière entend bien recuperer au moins dans son propre environnement tout l'heritage hecatomnide et presente a cet effet de solides arguments concrets. Par conséquent tout finit par rentrer dans l'ordre, c'est-à-dire que le sanctuaire est absorbé définitivement par Mylasa. ${ }^{206}$

In this context, the underlying fabric of the dispute between the priests and the polis could be interpreted as a question of who the legitimate heirs were of the Hekatomnid legacy - of course the priests tried to capitalize on their own heritage and 'ancestral privileges', but it was not an even game since the city ultimately had the power and especially a legal and institutional system that was universally recognized.

It seems then that we are dealing with a critical difference of perception as to what exactly was negotiated between the city and the priests in the terms of the 'freedom' supplied to Mylasa by Seleukos II and enforced by Olympichos, in which the administration of Labraunda was transferred to the polis. The Mylasans obviously understood that they would ultimately be responsible for the administration of the sanctuary and its holdings; as Debord argues, they were probably primarily interested in streamlining the administration of

which Iasos had with Mylasa who encroached upon their area, and that the Iasians were probably eager to support anything that might potentially weaken the Mylasans, Debord (2011), 137-138. The dispute of 'The Little Sea' is discussed in more detail in Reger (2010), 44-49.

205 Debord (2011), 143. Hellström (2011a), 152 observes that the Persian appointment of the Hekatomnids as satraps "not only against normal Persian practice. It was probably also a shock to the Karian elite." Their close relationship, possibly as priests, with Karian-centered Labraunda may have been one of the reasons for their appointment.

206 Debord (2011), 144. 
Labraunda to follow that of their other polis sanctuaries. ${ }^{207}$ At the same time, however, they also wished to respect the position of the residing priests and so Mylasa agreed that the priests would retain certain tasks, yet be accountable to the polis. The priests on the other hand apparently interpreted this more as a construction of final - and separate - responsibilities, especially pertaining to the sacred lands and their proceeds. ${ }^{208}$ Although they themselves were apparently considered as citizens of Mylasa, it must have been difficult for Korris and his son Hekatomnos to make the transition from dynastic priesthood to civic magistrate (perhaps particularly with regard to the sanctuary's treasury), which was the normal role (and elective office) for the priests of most urban cults in the Greek polis. ${ }^{209}$ The compromises which were obviously made, such as respecting their 'ancestral privileges', must have left enough room for vagaries that eventually led to conflicting views, which escalated to the level of the ruler. Although many of the details in the matter will remain speculative, Debord is right to argue that against the backdrop of the Hekatomnids, the case of Labraunda versus Mylasa is unique and therefore cannot be lumped together with other examples of clashes between 'indigenous' priests and Greek cities as a general sign of inherent tensions between native authority and the Greek model of polis administration. ${ }^{210}$

Nonetheless, as Debord points out, the priesthood at Labraunda hardly suffered from this event. ${ }^{211}$ The clan, or syngeneia, of Korris was already strong enough to model itself on the polis, extending decrees of proxeny to new members, granting them citizenship, giving them tracts of land, honoring them with a golden crown, or a front seat at the games, allowing them to participate in whatever belonged to Korris and his kin, and inscribing this decision in the sanctuary. ${ }^{212}$ By the second and early first century BC, a number of the family members are seen in leading positions among the Mylasan elite, taking their

207 Debord (2011), 138-139.

208 Debord in fact sees Korris as wanting to be the master of his own domain, using religious authority to achieve secular ambitions, Debord (2011), 137.

209 E.g. Bruit Zaidman and Schmitt Pantel (1992), 49-5o, noting however some prominent exceptions such as the priesthoods of Athena Polias and Poseidon Erechtheus in Athens which were for life and restricted to a particular family.

210 Two other known examples include that of the Apollonia Salbake, established as a garrison and eventually taking control of the neighboring sacred villages, much to the dismay of the local priests (Robert and Robert (1954), 285, no. 166), and Myndian Telmessos against Halikarnassos (Debord (1982), 51-53; Mastrocinque (1979), 216).

211 Debord (2011).

212 I.Labraunda 11-12; Labraunda thus also served as a public podium for this priestly syngeneia, through the blurring of personal and urban space. See also the next chapter for parallels. 
place in the boule, acting as urban benefactors, and even being involved in land management. ${ }^{213}$

How long was the priesthood at Labraunda occupied by Korris's family? Maddoli was able to trace the lineage down to a third Korris in the early first century BC. ${ }^{214}$ In the later first century BC, Strabo remarks how at Labraunda 'the priestly offices are held by the most distinguished of the citizens, always for life', rather than being an annually held office. ${ }^{215}$ Yet we have no indications that the priests at this time were related to each other. Also, in the later first century $\mathrm{BC}$ or early first century $\mathrm{AD}$, we know of a certain Mylasan named Pollis who was listed as successively being the annual civic magistrate (stephanephoros), priest of Zeus Osogollis (in town) and priest of Zeus Labraundos, as well as market official (agoranomos) ${ }^{216}$ Laumonier therefore believes that Strabo is recalling the older situation, whereas under the pax romana the polis and religious organization of the sanctuaries underwent an extensive reorganization. ${ }^{217}$ By this time priesthoods were annually elected, and were in any event not based on family ties. ${ }^{218}$

Another religious administrative office exercised in the Hellenistic period was that of neokoros. This position appears in the later third century $\mathrm{BC}$, in a letter in which the priest and the neokoros refuse to repay a loan, probably to the Chrysaoric League. ${ }^{219}$ Dignas emphasizes how the neokoros took a stand, together with the priest, showing the authority of this position in the financial

213 Debord (2011), 144 mentions: Ouliades, son of Hekatomnos, son of Korris, grants a large tract of land, worth 7000 drx to the sanctuary of Apollo and Artemis at Olymos at the turn of the second to first centuries BC (I.Mylasa 864); Hekatomnos, son of Ouliades, who was apparently foremost in a list of contributors to a stoa, with a very high sum of $200 \mathrm{drx}$. (I.Mylasa 5o1, line 3 (Blümel et al. (2014) no. 21)) is also involved as priest of Labraundos in the land leases of Olymos (e.g. I.Mylasa 814 (Blümel et al. (2014) no. 43), 816B-D, 848); in the first century вС, a Hekatomnos, priest of Zeus Labraundos, dedicates a statue of the priest of Zeus Osogollis to Zeus (I.Mylasa 406); also Korris, son of Hekatomnos, priest of Zeus Labraundos, was secretary in the boule (I.Mylasa 102, lines 2-3).

214 Maddoli (2007), 316.

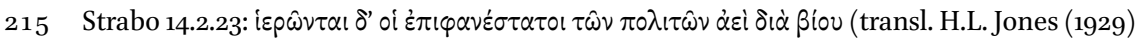
The geography of Strabo, LCL 223).

216 I.Mylasa 326 is an honorific decree for Pollis for dedicating eight columns to the sanctuary of Zeus Osogollis; see also Laumonier (1958), 58.

217 Laumonier (1958), 111.

218 I.Labraunda 59 and 6o indicated annually elected priesthoods at Labraunda in the second century AD, discussed also on p. 201.

219 I.Labraunda 45, line 6 mentions the priest and the neokoros together. The letter misses the first and last lines, but Crampa infers the Chrysaoric League as addressee due to the reference to the 'common expenses' ( $\tau \dot{\alpha} \alpha$ xovv $\dot{\alpha} \alpha \pi \alpha \dot{\alpha} \nu \alpha)$ in line 3, and interprets this as a dissension between the League and the priest at Labraunda (probably for membership in the League), who this time was supported by Mylasa as the polis now controlled the sacred 
administration of the sanctuary. ${ }^{220}$ Rostovtzeff had already observed how the role of the neokoros carried considerable weight regarding the financial affairs at sanctuaries, even gaining in importance by the imperial period. ${ }^{221}$ This seems to be the case at Labraunda, where two imperial decrees emphasize the final responsibility of the neokoros for the proper administration and management of the sanctuary, showing this to be both an appointed office and a highly distinguished title which one carried even when no longer in office. ${ }^{222}$ Labraunda had by this time thus become fully institutionalized according to the current urban model of sanctuary administration.

\subsubsection{Community and the Syngeneia of Korris}

In their plea to Philip $v$, the Mylasans stressed that everyone residing in the

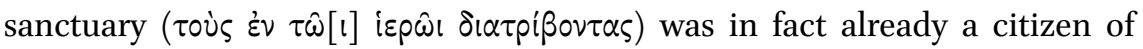
Mylasa and was divided among their tribes and subject to the same laws. ${ }^{23}$ We know that there was a community called the syngeneia of Korris, ${ }^{224}$ and that it was large enough to be subdivided into tribes, since the honorand in I.Labraunda 11 is assigned to the tribe of Ibanollis. ${ }^{225}$ Olympichos, after the second dispute, refers to Korris's kinship-based group as a patra rather than

funds; the letter was probably written by Olympichos, see I.Labraunda vol. 2 p. $5^{8-59}$; also van Bremen (2017).

220 Dignas (2002a), 209.

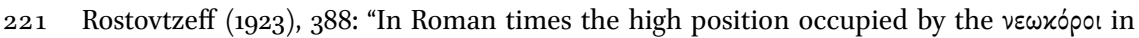
Asia Minor, e.g. in Smyrna and in Aezani, may have been an heritage from the Hellenistic period. I cannot help thinking that the Hellenistic vewxópor gradually replaced the native high priests, especially in the management of the temple finances and the temple estates," cited in Crampa, I.Labraunda vol. 2 p. 121, in connection with no. 6 o.

222 Neokoroi are attested in I.Labraunda 59 and 6o. I.Labraunda 6o restricts the access of those allowed to speak to the priest to '[those who have already been priests] of Zeus Labraundos, their servants, the one who has been elected or has undertaken to be the priest of this god in the following year, his neocoroi, both the appointed ones and those who have already held the office, or the god's public servants, when they do not serve the doorkeeper' (transl. Crampa, vol. 2 p. 120), followed by penalties for violating this. See also Dignas (2002a), 209-210.

223 I.Labraunda 5 , lines 31-33.

224 I.Labraunda 11-12. Syngeneiai, or 'kinship groups', were common in Karia and used to denote any kind of community based on a real, perceived or desired familial relationship, e.g. Korris admitted outside (non-relative) members to his syngeneia, as discussed above. On this syngeneia, see especially Bresson and Debord (1985), 205-206. The position of syngeneiai between cities and communities is discussed in more detail below, particularly in the case studies of Sinuri and Panamara.

225 I.Labraunda 11, line 11. On the significance of the name Ibanollis, see Debord (2011), 137. 
a syngeneia. ${ }^{226}$ Bresson and Debord take this as a sign that Labraunda had already been absorbed by Mylasa by the time of Olympichos's letter, and that the syngeneia had become a "simple patra" of Mylasa. ${ }^{227}$ Yet since these terms do not always appear to be strictly defined, ${ }^{228}$ it seems hazardous to date the absorption of Labraunda by Mylasa using only this single reference.

At Labraunda, some remains of settlement activity have been found west of the temenos and north of the stadion, in the area of the excavation house. Several tombs have been discovered near Labraunda. The most prominent is certainly the Built Tomb that crowns the site, just north of the temenos and near the split rock. An altar was discovered in the open area before the tomb and the ensemble now seems to date from the early Hekatomnid era; it may well belong to members of the dynastic family. ${ }^{229}$ If this is the case, then it would lend additional support for the interpretation of Labraunda as a royal center, with the monumental burial of the dynasts served to mark their presence for all time. Most of the tombs in the area, however, are much more modest, consisting primarily of rectangular trenches cut from the bedrock and covered with a stone gabled lid; whether these were the tombs of pilgrims or the residents of the settlement near the sanctuary is unknown. Over 120 of such tombs, ranging from Late Classical to Late Roman, were discovered along the sacred road within two kilometers of Labraunda. ${ }^{230}$ Tombs near sanctuaries may be more common than once thought - see the other case studies in this volume - yet this number speaks for a large community of either local residents or devoted pilgrims. North and east of the stadion rock-cut foundations were found for two houses, "presumably contemporaneous with the shrine,"

226 I.Labraunda 4, line 6. The term patra is largely restored by Crampa by analogy with the sympoliteia between Olymos and Labraunda, and in Mylasan decrees, e.g. I.Mylasa 863, which shows the division of Olymos and Labraunda into demes, syngeneia and patrai; see Crampa's commentary on line 6 in I.Labraunda, p. 25. In his discussion of the sympoliteia between Olymos and Mylasa, Reger (2004), 164-168, observes that the phyle of Olymos is referred to as syngeneia after the treaty; grants of citizenship, however, continue.

227 Bresson and Debord (1985), 206.

228 See also Jones (1987), 320, on the simultaneous usage of syngeneia and patra in late third century Mylasa.

229 Henry (2014), Henry et al. (2016), 41-416, and Henry (2017), 566-568, pushing this date earlier than suggested in Hellström (2007), 135-137, who considered the priest Korres as a potential occupant. Olivier Henry is more cautious in identifying the occupants of the tomb, but does not exclude early members of the Hekatomnid dynasty. The earlier date is equally interesting in connection with the development of the barrel vault, traditionally considered a Macedonian invention, Boyd (1978). The Built Tomb at Labraunda received a number of reburials in the Hellenistic period, O. Henry in Henry et al. (2013), 301-310 and in Henry et al. (2014), 292-294.

230 Henry (2017), 565; also O. Henry in Karlsson et al. (2008), 116-121. 
as well as a press for wine or oil.231 The area around the sanctuary has been subjected to systematic surveys by Axel Frejman, who has found evidence for a more extensive settlement, including a farmstead below Labraunda, within a larger road network that clearly situates the site within the wider social and economic landscape. ${ }^{232}$

While it may be assumed that Korris's syngeneia occupied the settlement near Labraunda, but in urban contexts syngeneia were not always bound to a specific locality. The Pormounos that centered on Sinuri seems to have been a dispersed collective. At Mylasa, the three main tribes of old, the Otorkondeis, the Hyarbesytai, and the Konodorkondeis, were further subdivided into syngeneiai. Hekatomnos, son of Ouliades, was a member of the Maunnites syngeneia, which had become a subdivision of the Otorkondeis phyle. ${ }^{233}$ Yet he was also priest of Labraunda, and as such would no doubt have been a member of the syngeneia, or patra, of Korris, assuming that it was still functional at that time. Whether he actually lived at the settlement in Labraunda, commuted from Mylasa, or both, is unknown.

Many questions remain regarding both the settlement and the syngeneia or patra remain to be answered. For example, although Labraunda already belonged to Mylasa and its residents were full citizens of the polis by the time of I.Labraunda 5 in the later third century, nonetheless a re-division of both Olymos and Labraunda took place at some point after the sympoliteia with Olymos. ${ }^{234}$ Both communities are enrolled into the phylai, syngeneia, and patrai of Mylasa; for Olymos this could be a logical consequence of the sympoliteia, but if the 'citizens' living at Labraunda were already Mylasans then it is unclear why they would need to be enrolled again in these municipal divisions; Labraunda was probably not yet fully incorporated into Mylasa at this point.

231 Hellström (1990), 248-249. I am indebted to Pontus Hellström, who graciously sent offprints of these early KST reports when I could not access them otherwise.

232 Frejman (2020), 23-127 on Labraunda; see A. Frejman in: Henry et al. (2015), 310-314; Henry et al. (2016), 357-364; Henry et al. (2017), 201-204; Henry et al. (2018), 262-267. Also Frejman (in preparation).

233 This could be one explanation of his generous contribution towards building a stoa that no doubt belonged to the Otorkondeis, I.Mylasa $5 \mathrm{Ol}$ (second or first century BC) since all of the contributors were from either the Maunnites or Tarkondareus syngeneiai. On the Maunnites and Tarkondoreus as subdivisions of the Otorkondeis, see Laumonier (1958), 58, and Bresson and Debord (1985), 208-209.

234 I.Mylasa 861, 863. Laumonier (1958), $40 \mathrm{n}$. 5 sees the residents at Labraunda as an independent community on equal footing with Olymos, i.e. as syngeneia, after its absorption which was once thought to be in the mid-first century вс, but see Reger (2004), 164-168 on the sympoliteia. Laumonier (1958), 40 n. 9 refers to the ethnics 'Labrandenus' and 'Labrandios' in the same inscription. 


\subsubsection{Economic Resources}

Labraunda's sacred lands were a viable source of income and were at the center of the initial conflict between the priests and the polis in the third century BC, discussed above. Olympichos seems to have initiated a construction of land-lease in the area around Mylasa when he donated property that he had purchased from Queen Laodike to Mylasa via the sanctuary of Zeus Osogollis. ${ }^{235}$ The inscription calls for a hereditary lease at an annual rent of five percent, with the proceeds going towards the festivals of Zeus, presumably Zeus Osogollis. The inscription was to be displayed at that sanctuary, but also in the sanctuary of Zeus Labraundos, 'in the most conspicuous place'. ${ }^{236}$ The list ends with a description of the properties, including lands sacred to 'Zeus Osogoa Allolios' and 'Ys Sinuri', although apparently none belonging to Zeus Labraundos. ${ }^{237}$ Labraunda had clearly acquired the role of urban podium by that time.

Lands belonging to Labraunda are mentioned in some of the decrees from Olymos, just west of Labraunda (Figure 3.1). Olymos initiated a land-lease construction in the later second and first centuries BC for the sanctuary of Apollo and Artemis, and several tracts are described as being adjacent to lands belonging to Zeus Labraundos. ${ }^{238}$ Three more inscriptions at Labraunda pertain to dealings with land. Two are heavily fragmented and are dated to the late second century вс. One concerns the renewal of a land-lease, probably by Mylasa, and presumably concerns lands belonging to Zeus Labraundos although this is not clear. ${ }^{239}$ The other is even more fragmented and just mentions a donation involving trees and probably land. ${ }^{240}$ These are discussed further below in the context of urban mediatization at the sanctuary. Finally, an inscription cut into the face of a rock was discovered near the monumental fountain northwest of the shrine and is suggested as belonging to an estate in the late Hellenistic

235 I.Labraunda 8. The context of such land donations by rulers is interpreted both within the Achaemenid and Macedonian traditions: Briant (2006); Thonemann (2009); Descat (2013); also van Bremen (2016), 16-17, 20-21, on the connection with Queen Laodike.

236 I.Labraunda 8B, lines 24-26, also discussed below under Civic Decrees.

237 I.Labraunda 8C, line 31.

238 E.g. I.Mylasa 8o5, 8o6, 817, 831. See also above for the role of especially Hekatomnos, son of Ouliades and priest of Labraunda, in several land-lease transactions of Olymos. The Mylasan land-lease construction, in which especially the sanctuaries of Zeus Osogollis and Sinuri were also heavily engaged is discussed in more detail in the next chapter.

239 I.Labraunda 5 o.

240 I.Labraunda 90. 
period. ${ }^{241}$ Nearer to Labraunda, the surveys conducted by Axel Frejman, mentioned above, aim to better understand the integration of the sanctuary with its own hinterland in the fertile and well-watered Beşparmak Dağları. Frejman argues for a market function at Labraunda, where local meat and produce could be traded at this central place along the mountain road. ${ }^{242}$

Attempts have been made towards identifying and locating some of the domains listed in the Olympichos dossier as the inscriptions tend to be specific regarding natural features and the owners of bordering property as identifying markers. ${ }^{243}$ Altogether they present an image of a patchwork countryside with a mixture of private and individual sacred plots that could belong to different deities. Exactly how extensive the estates of Zeus Labraundos were, however, is impossible to tell, but it was obviously the primary source of income for the sanctuary, and thus enough to be a bone of contention between the priests and the polis. Controlling the resources of the sanctuary obviously meant controlling the economic vitality of the sanctuary itself. With their long-term history of involvement at the sanctuary, it is only logical to envision Korris and his successors assuming a personal responsibility in the financial affairs of the sanctuary and the management of the sacred lands. This would explain their surprise, and dismay, in realizing that they could now be circumvented by revenues passing directly from the lessees to the polis, even though Mylasa states that the proceeds were reinvested in the sanctuary. ${ }^{244}$ That the priests were included at all in the chain of responsibilities was clearly only by the grace of the polis - in reality they were relieved of their ultimate control of the administration of Labraunda.

In sum, most of the information on the organization of Labraunda dates from the Hellenistic period, thanks to the increase in the 'epigraphic habit' but especially to the lengthy conflict between the polis and the priests as to who controlled the shrine. The dispute appears to hinge on differing interpretations

241 Henry et al. (2014), 272 and Fig. 31. The upper part of the inscription is eroded, but the name AN $\triangle \mathrm{PONIK}$ is preserved, in large letters, $\mathrm{c.} 17-20 \mathrm{~cm}$, and inscribed at a height of $2.15 \mathrm{~m}$ above ground, clearly meant to be seen from afar.

242 The surveys are reported by Frejman in: Henry et al. (2015), 310-314; Henry et al. (2016), 357-364; Henry et al. (2017), 201-204; Henry et al. (2018), 262-267. On location and market function: Frejman (2018); Frejman (2020), 23-127; Frejman (in preparation). Reports on fauna remains from the early imperial period show an emphasis on sheep and goat, I. Stojanovitch in Henry et al. (2018), 282-285.

243 Carless Unwin and Henry (2016), who discuss among others the territory mentioned as Larysynia in I.Labraunda 137. Also Pernin (2014), and the discussions around the property transaction between Mylasa and Kindye, witnessed by delegates from Karian cities in I.Mylasa 11, see Descat (2013); van Bremen (2013); Descat (2014).

244 I.Labraunda $5,23-27$. 
of the stakeholders. As Debord pointed out, the priestly family were connected with the ruling dynasty, probably through a blood tie, and were still running the sanctuary in the early Hellenistic period. ${ }^{245}$ The liberation of Mylasa by Seleukos II in 246 BC, however, included Labraunda and of course its sacred lands, which were considerable and now under Mylasan control. The residing priest would surely have felt this as an infringement of his hereditary rights. A generation later another priest even conspired with the Chrysaoric League to take control of Labraunda. These conflicts and the way in which they were handled clearly show a shrine in transition. The priests obviously had wide latitude, writing to the kings directly and even running their own local community (syngeneia). At the other end, the polis of Mylasa, a mosaic of local entities yet always represented in these texts by the singular demos, ${ }^{246}$ was insistent that Labraunda had always belonged to it, and that the community at the sanctuary was in fact made up of Mylasan citizens. On the surface these conflicts could be interpreted as a cultural miscommunication between the 'indigenous' priests and the institutionalized (i.e. 'Hellenized') polis, or between local versus centralized administration. Yet the Hekatomnid legacy at Labraunda and the underlying question of its legitimate heirs may well have been the heart of the problem. Whoever administered the powerful sanctuary had ultimate control over its ancient and monumental space, its rituals, its vast resources, and its wider appeal. The priests had a vested interest in maintaining control over the sanctuary, and were well-disposed towards the Karian-centered Chrysaoric League in reestablishing the regional impact of the shrine. Mylasa, however, clearly had other plans for Labraunda, where its own population took pride of place. In the end, the polis triumphed, the sanctuary became an urban podium, and a shift took place in the priesthood, which, by the later Hellenistic period, had become an elective and annual office, one of the regular institutions of the polis.

\subsection{Urban Mediatization at Labraunda}

Until now we have examined the spatial, religious, and administrative transformations at Labraunda under the increasing involvement of Mylasa. This section investigates the various ways in which the cult place and its deity came to transmit urban ideology, e.g. through decrees or symbolism. First, it

\footnotetext{
245 Debord (2011), discussed above.

246 Mylasa was a composite body, made up of phylai, syngeneiai and patrai that appear to be more preoccupied with their own community than with that of the polis, this is discussed further in the next chapter. Yet in political situations, such as this at Labraunda, it is the demos of Mylasa who speaks and is addressed as an entity, e.g. I.Labraunda 3 , line 29 and I.Labraunda 5 , lines 1-2, 24.
} 
is important to ascertain the scope of Labraunda's sacred network, i.e. who worshiped Zeus Labraundos, who was the audience at this sanctuary, who was it meant to impress? Following this, the kinds of communications, decrees and documents that represent the city of Mylasa at Labraunda will then be discussed. The last part of this section deals with the opposite process of how the god of Labraunda was represented within the urban sphere, e.g. through his imagery on coinage, or the iconic use of his attributes, especially the double-axe. All of this will be viewed in light of change or consistency with the Hekatomnid period in order to discern the extent to which the polis was retaining the mechanisms of the dynasty while using the sanctuary for their own purposes.

\subsubsection{Scope and Network}

In the first literary mention of Labraunda by Herodotos, quoted at the beginning of this case study, Karians are seen fleeing as a group to the sanctuary of Zeus, pursued by the Persian army. ${ }^{247}$ Although perhaps not the center of the Karian League, Labraunda was nonetheless well-known in Karia by the advent of the Hekatomnids, whose transformations seem to be driven by the idea of promoting the sanctuary as the primary religious center in Karia. Their newly reorganized festival - in which they had a starring role - were explicitly aimed at all Karians. ${ }^{248}$ Delegates from various places were apparently invited to join in the panegyrics. ${ }^{249}$ Also, stamping the image of Zeus Labraundos on their coinage, used throughout the region, should be seen as a kind of mass-advertising in the technology of the day. The lack of Karian script, however, may raise questions as to how central this shrine actually was to Karian ideology. ${ }^{250}$ A fourth century вс plaque from Tegea, depicting the cult image of Zeus Labraundos with Idrieus and Ada worshiping it from aside, demonstrates the awareness on mainland Greece of the tight link between the god

247 Hdt. 5.119, quoted above.

248 I.Labraunda 53 , lines $1-3$. This is an imperial copy of a fourth century вС decree on the festivals at Labraunda, see also Piejko 1990, 147 no. 53.

249 I.Labraunda 67 (corresponding with I.Mylasa 8) is a heavily fragmented list of names, thought to be envoys to the festival, from the fourth century вС, inscribed on a stele found in front of the northeast anta of the temple. Unfortunately the origins of these people are unknown. I.Labraunda 72 is an imperial copy of a Hellenistic list of names, also thought to be envoys.

250 Karlsson and Henry (2009) discusses a Karian graffito, on a fourth century BC Attic gloss ring foot found at the fortification of Burgaz Kale, that shows similarities in Karian script from Sinuri-Kildara, Euromos, Stratonikeia, but not Mylasa. although a fourth century graffito, perhaps indicating that soldiers from across Karia helped guard the mountain shrine and passage. 
and the ruling dynasty. ${ }^{251}$ Yet the conscious epigraphic choice for Greek does not make Labraunda less Karian; instead it underscores the cosmopolitan aspirations of the Hekatomnids, even if there is much more evidence for regional involvement at the shrine. A fourth-century Panathenaic amphora, for example, was dedicated in the sanctuary with an inscription by a certain [Hyps] ikles from Herakleia, probably nearby Herakleia under Latmos. ${ }^{252}$ The East Propylon should also be seen in this Karian-wide context too, since it allowed formal entry to the sanctuary for pilgrims coming from the north, while the South Propylon served those arriving from Mylasa. ${ }^{253}$

Jonas Crampa is somewhat skeptical of the success of the promotion of Zeus Labraundos by the Hekatomnids, as the names appearing on inscriptions at Labraunda generally lack any ethnic designation and are hence probably Mylasan. ${ }^{254}$ One may, however, also argue that most of the prosopography at the sight dates to later periods and it does seem to be the case that as the bond between the sanctuary and Mylasa grew tighter and tighter, the scope of the sanctuary narrowed to Mylasa. However, it is also true that Zeus Labraundos's signature double-axe came to symbolize Karia, and that his cult was installed at other places in the region, ${ }^{255}$ but also abroad as a Karian-centered venue for 'expatriates', with examples in Piraeus, Athens, Cyprus and Egypt. ${ }^{256}$ We may lack solid evidence of an intensive involvement from wider regions in the festivals of Zeus Labraundos in the Hellenistic period, yet his cult was nevertheless broadly recognized as a Karian, not just Mylasan, affair, even though the epigraphic record at the sanctuary in this period is focused on the polis.

251 Now in the British Museum (Inv.no.1914,0714.1); Laumonier (1958), 24 n. 2.

252 Hellström (1965), 7-8, who argues his restoration of the name 'Hypsikles'. He considers that this was likely erected in a prominent place, e.g. as a votive offering in the newly built temple of Zeus (pers. comm. 23.03.2011).

253 Hellström (2009), 270.

254 Crampa, I.Labraunda p. 197 believes that except under the Hekatomnids, the cult of Zeus Labraundos was mostly local, noting the exceptions of someone from Alabanda who made a dedication, in I.Labraunda 37; also the name lists with perhaps envoys from Arlisses (I.Labraunda 67), Karyanda (I.Labraunda 72) and Bargylia (I.Labraunda 110).

255 Besides in Mylasa, Hornblower lists: Miletos, Herakleia under Latmos, Halikarnassos, Aphrodisias, see Hornblower (1982), 344. Laumonier includes Stratonikeia, Laumonier (1958), 6o-61. Several double-axes appear in the ceiling coffers at the sanctuary of Hekate in Lagina, and a small altar with a double-axe was found there as well (personal observation, 2009).

256 A third century stele for Zeus Labraundos in Piraeus, Laumonier (1958), 24 n. 2; the cult of Zeus Labraundos further spread of the cult to Kos, Cyprus (Zeus Labranios), and Limyra in Lykia, Athens (IG II ${ }^{2}$ 1271), Egypt; also Hornblower (1982), 345 n. 118 and 357 and Laumonier (1958), 6o-61. Iasos had a cult for Zeus Idrieus, I.Iasos $5^{2}$. 


\subsubsection{Civic Decrees}

Other than the architraval dedications, Mylasa figures little in the epigraphic record at Labraunda in the late Classical era. Two proxeny decrees from the fourth century granted foreigners free entry to Karia and the right to hold property, to import or export, to register in the phyle of their choice, and to

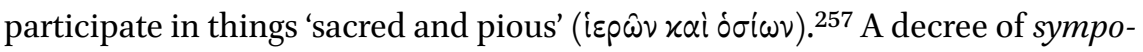
liteia between Pedasa and Latmos under the last satrap, Asandros, stipulated that it was to be inscribed at Labraunda. ${ }^{258}$ The fact that these decrees concerning the constitution of the Karian community were made public here at this remote mountain sanctuary demonstrates the regional political role that Labraunda occupied under the satraps. ${ }^{259}$

As stated above, however, this clearly changes in the Hellenistic era, when most of the inscriptions concern Mylasa. Center spot is of course the dossier of royal correspondence discussed previously concerning the conflicts between the priests and the polis, and ultimately confirming Mylasa's control over the sanctuary of Zeus Labraundos. ${ }^{260}$ A compelling tail to this dossier is an honorific decree for the strategos Olympichos, who was commemorated for his benefactions to the city. ${ }^{261}$ The inscription, found at Labraunda, calls for a statue of him being crowned by the Demos, to be erected in the agora, with an altar before it 'similar to the one of Maussollos in the sanctuary of Zeus Labraundos'.262 This decree directly frames Olympichos as a kind of neoMaussollos, yet clearly operating in the interests of Mylasa. The cultic honors given to the strategos are indicative of the complex process of democracy in the Hellenistic polis. Olympichos is honored with a procession, a sacrifice of two bulls, and a feast including the priests, the athletic victors of crowned games,

257 I.Labraunda 40, line 12, under Maussollos, granting immunity and import/export rights, and I.Labraunda 42, a decree made by the Macedonian Eupolemos, strategos in Mylasa towards the end of the fourth century, although the inscription itself is dated by Crampa to the second quarter of the third century, based on letter-forms.

$25^{8}$ Reger (2004), 151, with references. This inscription stipulates that it was to be placed in the sanctuary.

259 It is possible that corresponding decrees were also published in Mylasa, Halikarnassos, or another Karian port-of-entry, although none have been found thus far.

26 I.Labraunda $1-7$, discussed above.

261 I.Labraunda 49 and the new fragment I.Labraunda 134, discovered at the sanctuary in 2002 by Lars Karlsson and published in Isager and Karlsson (2008) and Isager (2011).

262 I.Labraunda 134 (Isager and Karlsson (2008)), lines 9-11 (translations by Isager and

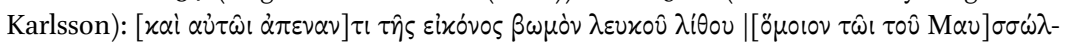

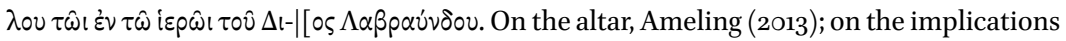
of cultic honors for Olympichos (and his wife Nikaea and their children), see Henry and Aubriet (2015), esp. p. 70o, also Aubriet (2012). 
and the magistrates. ${ }^{263}$ This is significantly to take place on 'the day on which the people regained its freedom and democracy,',264 highlighting the precarious balance between the dependency on the goodwill of local rulers such as Olympichos and the ability of the city to govern itself. ${ }^{265}$ Olympichos was to actually be crowned by the people of Mylasa as their benefactor, and this was moreover to be proclaimed during the gymnic games for Zeus Osogollis. Such public events functioned as mass advertising, generating common knowledge, and the inscription itself was clearly meant to serve as another coordinating mechanism, evident from the final clause: 'To ensure that it will be apparent to all how the people of Mylasa honors its benefactors, and in order to commemorate him [Olympichos] this decree shall be inscribed on stelai of stone and one of them placed in the sanctuary of Zeus Labraundos'.266 All of this indicates the space of negotiation between polis and strategos but especially demonstrates the new role of Labraunda as public podium for Mylasa, and how it became tightly integrated with its urban space, even though it was miles away from the center of town where the main events were staged.

Certain decrees on relations between Mylasa and other poleis also specifically stipulate that they be published in the sanctuary of Zeus at Labraunda. Decrees of isopoliteia with Miletos, and perhaps with neighboring Euromos, were also erected at Labraunda, ${ }^{267}$ as were honorific decrees by Mylasans for non-Mylasans (e.g. Romans) or vice-versa. ${ }^{268}$ An interesting but elusive

263 I.Labraunda 134, lines 14-17.

264 I.Labraunda 134, lines 12-14, listing the date as the 14th of the month Apellaios. A threeday truce follows next, during which the 'citizens and others' meet together wearing crowns. Events further included the singing of a hymn for Olympichos during the quadrennial Taureia, 'in the same way as for the city founders', lines $23-24$.

265 Two other inscriptions concerning Olympichos note the importance of democracy I.Labraunda 3 , line 30, and I.Labraunda 8B, lines 13-15.

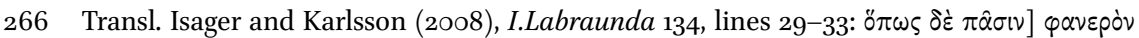

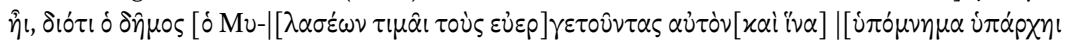

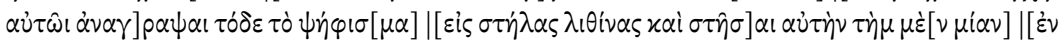

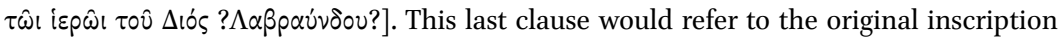
at the sanctuary; I.Labraunda 49 and 134 are copies from the second century вС, found in the area of the Roman baths. The site for the second inscription is unknown, presumably in the agora of Mylasa, or in the sanctuary of Zeus Osogollis, as with I.Labraunda 8, see also van Bremen (2016). On 'double inscriptions' and their placement, see also new research by Kamphorst (forthcoming), Drauschke (forthcoming).

267 I.Mylasa $\mathrm{T}_{51}$ for the isopoliteia with Miletos, this was to be erected in the sanctuaries of Zeus Osogollis and Zeus Labraundos. Isopoliteia with Euromos may have been intended in a fragment mentioning the neighboring polis, I.Labraunda 84; both inscriptions are dated to the late third century.

268 I.Labraunda 48 (second century BC); I.Labraunda 62 (c. 129 BC); and I.Labraunda 63 (early first century BC, based on lettering). 
example of an honorific monument concerns the exedra on the temple terrace, discussed above. Located at the eastern end of the temple terrace, this podium is estimated to have held nine statues. The inscriptions bear only the name of an individual, Demetrios, son of Python; Crampa dated them to the third century, based on the lettering. ${ }^{269}$ Other documents focused directly on internal Mylasan politics: two powerful examples include a fragment from the early Hellenistic period, inscribed directly on the southwest anta of the temple (Figure 3.6, Area B), referring to the restoration of justice and democracy at Mylasa after the downfall of tyranny, ${ }^{270}$ and a later second century inscription that bears the citizen's oath of Mylasa, inscribed in the east wall of the South Propylon (Figure 3.6, Area F). ${ }^{271}$ This oath, to safeguard the democracy of the polis at personal risk, was engraved at a place where everyone entering the sanctuary from Mylasa could see it and presumably internalize it with each visit. ${ }^{272}$ Although we do not know whether this oath was also posted in town, the very fact that it was inscribed here at Labraunda is perhaps more than anything else indicative of the very tight relationship between the sanctuary and the polis, and the highly urban function of this sanctuary. 273

Another example of the personal nature of these public documents is a decree related to property financing. Olympichos, while still in charge, initiated a mechanism of donating or selling private lands to a sanctuary and then leasing them back to the original owner with interest. ${ }^{274} \mathrm{He}$ dedicated some of

269 I.Labraunda $29 \mathrm{a}-\mathrm{c}$. The exedra was excavated in the 1940 s but is now published in Henry et al. (2014), 269, Fig. 28.

270 I.Labraunda 41, though fragmentary, shows the new political shift through references to the old tyranny and regulations allowing restoration to anti-Persian exiles. A certain Arlissis is mentioned - a Mylasan by the same name had been involved in a conspiracy against Maussollos and was sentenced by the Persian court to death, I.Mylasa 1; his family may have been seeking restoration of his name or some kind of compensation. Crampa dates it to the period shortly after Alexander's conquest.

271 I.Labraunda 47 (also Piejko 1990, 146-147) is the oath of the citizens of Mylasa, in which the reader promises to not to plot against democracy nor to allow anyone else to do so, and to be hostile to any unjust citizen or stranger; the reader invokes blessings to himself and his family through profit from his resources, land and its produce, cattle, children and houses, if he keeps his oath, and the opposite if he does not, This is similar in formula to the citizen's oath of Tauric Chersonesos but much compacter, IosPE $\mathrm{I}^{2} 401$; on both of these oaths in their spatial contexts, see Williamson (2013a).

272 The pivotal role of the South Propylon is discussed above and in Williamson (2013a) in connection with this inscription; also Isager (2011), 209.

273 E.g. Isager (2011), 209, who also supposes that another copy would have been inscribed in town or in the sanctuary of Zeus Osogollis.

274 I.Labraunda 8 and now Milas Museum Inv.no.2012/31a, discussed in van Bremen (2016). Olympichos dedicates all the lands that he purchased from Queen Laodike. Several later inscriptions from the sanctuary of Zeus Osogollis exhibit the various stages of this 
his lands to the sanctuary of Zeus Osogollis at Mylasa; the revenue was to be spent on the monthly festival. Olympichos hoped that his dedication would live in our memory and be kept'.275 Intending to set an example for others to follow, he further stipulated that this was to be inscribed in the sanctuaries of both Zeus Osogollis and Zeus Labraundos 'in the most conspicuous place.'276 Unfortunately we do not know exactly where this was perceived to be at Labraunda, since the stele was found in pieces in a later rubble pit; but part of a possibly joining fragment was discovered near the South Propylon, which was certainly a conspicuous place for those coming from Mylasa. ${ }^{277}$ A later addition to this inscription lists several subsequent land-lease transactions, with the lands described in meticulous detail. ${ }^{278}$ Although these transactions were all conducted through the cult of Zeus Osogollis in town, the fact that they were inscribed here underscores the urban role of Labraunda, and it also ties both of these sanctuaries together as central to Mylasa. ${ }^{279}$

unusual land-lease construction (misthosis) practiced in Mylasa, but also in Olymos; see Laumonier 1940; on Mylasa, see I.Mylasa 204, 207, 211, 212, 213, 214, 215, 216, 230, and 762, and Vol. 1, p. 74-76. I.Mylasa 212 gives insight into the financial construction (translation available in Blümel et al. (2014), no. 10. For an overview of the phases involved in this type of hereditary land-lease arrangement see further Chandezon (2003), 240-241; Dignas (2002a), 92; Descat and Pernin (2008), and now Pernin (2014), 401-445, esp. 422-427.

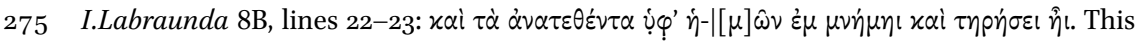
inscription was re-cut in the second century вС, when the land-lease construction at the sanctuary of Zeus Osogollis became quite popular, Dignas (2000), 123-124 and Virgilio (2001), 441; see also above.

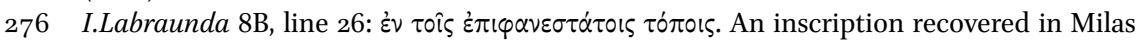
in 2011 (Milas Museum Inv.no.2012/31a) is a candidate for the version at the sanctuary of Zeus Osogollis, see van Bremen (2016). The sanctuary of Zeus Osogollis is located in modern Milas and was probably located within the urbanized area of ancient Mylasa, at least by Strabo's time (Strabo 14.2.23, see below); Rumscheid (1999c), 35 n. 6 o.

277 It should be noted that both inscriptions were second century вс copies of third century decrees - the location of the originals is thus completely unknown. Crampa furthermore considers the possibility that I.Labraunda 9, a fragment mentioning the priest of Zeus Osogollis as thanking Olympichos for a benefaction, may once have been part of I.Labraunda 8. See further below on the gateway as a 'conspicuous place' for dedications. Hellström also discusses the location of inscriptions and copies from later periods, Hellström (2009), 278-279.

278 See Horster (2010) on long lists of sacred lands as creating a 'virtual religious landscape' in the mind of the one viewing the inscription, further discussed in Chapter 4 on the sanctuary of Sinuri.

279 Reger alternatively suggested that in light of the recent events Olympichos personally "showed his colors with a major favor to the Mylasans' tutelary deity, and he rubbed Zeus Labraundos's nose in it by his order to advertise his generosity to a rival in a 'most prominent place' in that god's sanctuary," Reger (2010), 53. This is certainly an attractive idea, but I view this inscription more as an act of inclusion, enforcing Labraunda's active 
Sanctuaries certainly had an archival function, but the locations of inscriptions in ritual space were also often carefully selected for their visibility (Figure 3.6). ${ }^{280}$ The recurring designation 'in the most conspicuous place' implies not only that they were meant to be read, or at least seen, but also that there was a hierarchy of space. ${ }^{281}$ Certain places were perceived as more 'conspicuous' than others, no doubt depending on the use and flow of traffic at the sanctuary. The locations of a number of inscriptions and monuments are known, giving an idea of where some of these public spaces were in the sanctuary. If we sort them chronologically, we can observe a shift in focus, starting with the temple itself; 282 a statue for Hekatomnos was erected just northeast of the temple, perhaps even before the sanctuary's renovations under Maussollos, and nearby was another (later) statue for Ariarames, son of Maussollos (Area A on Figure 3.6). ${ }^{283}$ In this area a stele was erected in the mid-fourth century listing several names, probably of envoys, to the festivals. ${ }^{284}$ In the Hellenistic period the temple was still initially the medium for inscriptions. The earliest dates from the end of the fourth century and significantly celebrates the new post-Hekatomnid democracy of Mylasa and its return to justice; it was recorded on the southwest anta of the temple (Figure 3.6, Area B). Just below this was Olympichos's oath while the opposite northwest anta bore the Seleukid correspondence concerning the polis' control of the sanctuary (Figure 3.6, Area C). ${ }^{285}$ The elevation of the inscriptions in the reconstructions,

participation in the Mylasan sacred landscape, rather than one of exclusion. Also, I consider the promotion of the cult of Zeus Osogollis as more of a positive act in the general development of Mylasa after its freedom, rather than a negative one aimed at Labraunda.

28 o See also the discussions above on I.Labraunda 1-7, the royal correspondence concerning the rights to the sanctuary. For temple inscriptions in general, von Hesberg (2009) and Roels (2017).

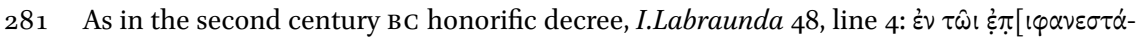
$\tau \omega \iota \tau$ $\delta$ $\pi \omega$ l. This phenomenon is briefly discussed, among others, in Mylonopoulos (2013), 136-137.

282 Signe Isager also discussed the significance of the locations of the inscriptions at Labraunda, Isager (2011), 204-214.

283 I.Labraunda 27 and 28 respectively; see Crampa p. 28-29 on Ariarames, also mentioned above.

284 I.Labraunda 67.

285 On the southwest anta: I.Labraunda 41 is the late fourth century вС inscription on the restoration of justice (see above), I.Labraunda 137 is the oath of Olympichos; see Henry and Aubriet (2015) and Carless Unwin and Henry (2016). On the northwest anta: I.Labraunda 1 and 3 give the correspondence between Seleukos, Olympichos and Mylasa on control over the sanctuary. The inscriptions on the antae of the temple are further elaborated on in Hedlund (2014) with a detailed reconstruction of the western elevation in Henry and Aubriet (2015), Fig. 4 and Carless Unwin and Henry (2016), Fig. 5 . 
at nearly five meters above the stylobate, might have precluded a casual reading, but would have ensured a good visibility of these documents that were so important for Mylasa.

The ensuing series of letters, between Olympichos and Philip v, were inscribed farther downhill, on the southern anta of Maussollos's andron (Figure 3.6, Area D). Though clearly official in function, this andron seems less obvious a candidate for the publication of such crucial documents, since most decrees were located higher up on the temple terrace. Labraunda's prime public space for democratic Mylasa seems to be the temple terrace, ${ }^{286}$ where several decrees, political and honorific, as well as monuments were set up, lining the area of the terrace which clearly functioned as public space (Figure 3.6, Areas E and G). ${ }^{287}$ This was not the only critical spot, however; the Mylasan citizen's oath was inscribed on an ashlar in the east wall of the South Propylon in the second century вС (Figure 3.6, Area F). ${ }^{288}$ This monumental entrance to the sanctuary was also the logical place for Antiochos III to post his letter to his troops, instructing them not to violate the sanctuary during their campaigns in the area. ${ }^{289}$ It may have been where Olympichos's exemplary dedication of lands was engraved, and where he was honored by Mylasa. ${ }^{290}$

286 On the date of the temple terrace and the North Stoa, see note 96 above.

287 A description of all of these is beyond the scope of this paper; monuments include the third century вс exedra at the east end of the temple terrace, facing south, I.Labraunda 29 (discussed above); a statue for Gnaius Domitius, son of Gnaius, at the northeast corner of the temple, I.Labraunda 62 (Carlsen (2011)); several honorific decrees inscribed on the walls of the stoa: I.Labraunda 11-12, 43-45 (concerning the Chrysaoric League); political or economic decrees: I.Labraunda 42 (by Eupolemos), 51 (on an economic-juridical matter), and 90 (donation of lands). Several honorific decrees, sacred laws or lists of names from the first century $\mathrm{BC}$ were found in the general area of the temple terrace: I.Labraunda $63,70-71,86,89,93$, establishing a trend in for this terrace that would continue until at least the second century AD (see Figure 3.6, Area G).

288 I.Labraunda 47, see above; on this inscription and its location see also Williamson (2013a).

289 I.Labraunda 46, from 203 BC; see above. Some name-lists were also inscribed here, as well as a decree involving Euromos, I.Labraunda nos. 68-69, 84 respectively. In the third century AD, a Roman officer inscribed at this gateway a promise of peace to the dwellers of the sacred lands, I.Labraunda 61 , proving its continued communicative function. Interestingly, no inscriptions have been recorded at the East Propylon. Westholm believes it to be contemporary with the South Propylon, Westholm (1963), 110-112, while Rumscheid dates it to the third quarter of the fourth century BC, Rumscheid (1994) ${ }^{1}$, 79-82.

290 I.Labraunda 8 (see above) and 9 respectively. I.Labraunda 49 is now also known to be an honorific decree, commemorating Olympichos for his benefactions to Mylasa, since a large corresponding fragment was found, Isager and Karlsson (2008) (I.Labraunda 134) this inscription was re-cut in the second century вС, and although neither fragment was found in situ, it is tempting to believe that they were located in the area of the South 
The inscription at the beginning of this discussion, concerning the honors awarded to Olympichos, was actually a copy made in the second century вС, a time when several of the inscriptions at the sanctuary were re-cut. ${ }^{291}$ Signe Isager and Lars Karlsson consider this phenomenon in light of the changing political climate following the Aristonikos wars when Karia, which had supported Rome, was joined to the new province of Asia. ${ }^{292}$ Isager and Karlsson note the installment of the honorific statue for the Roman benefactor Gnaius Domitius, son of Gnaius, at a key spot in the sanctuary (next to the temple and near area A on Figure 3.6), probably due to his role in "consolidating the status of Mylasa." ${ }^{293}$ Providing fresh and legible inscriptions at Labraunda of some of the most defining moments in the history of the polis was obviously the best means for Mylasa, in the shadow of Rome, to bolster "its political position to the outer world as well as the collective memory of its own inhabitants."294

This choice in fact underscores the kinds of decrees that Mylasa had inscribed at Labraunda. While other urban sanctuaries were often used as podia for public awards, Labraunda was more of a political space. The list in Table 3.1 shows the Hellenistic political decrees at Labraunda, five of which were issued by Mylasa and concern either the constitution, legal or economic matters, or external relations. ${ }^{295}$

Propylon, where I.Labraunda 9 was found (I.Labraunda 8 and 49 were found in a hole south of Andron C).

291 I.Labraunda 134 (=Isager and Karlsson (2008)), mentioned above. Inscriptions that were recut in later periods include: I.Labraunda 3(B) and 8, Olympichos's two letters of support for Mylasa, are both second-century вС copies of third-century originals, as was I.Labraunda 9 and 49/134, the honorific statue and decree for Olympichos by Mylasa; Boffo (1985), 244 believes that I.Labraunda 8 was copied in the context of the surge of land-leases for Zeus Osogollis. Other third-century inscriptions were re-inscribed in the imperial period, including I.Labraunda 1(B), the letter by Seleukos II, and I.Labraunda 10, the letter by the Chrysaoric League to Mylasa, and probably 88, a letter by an unidentified Hellenistic ruler to his governor. Virgilio sees this as evidence for Mylasa's continued need to justify their claims to Labraunda for various reasons, Virgilio (2001), 441.

292 Isager and Karlsson (2008), 49-50; Marek (1988), 302-303, believes Karia became part of the province of Asia only after the Mithridatic wars in the first century вс.

293 Isager and Karlsson (2008), 49-5o, discussing I.Labraunda 62, mentioned above. See also Carlsen (2011).

294 Isager and Karlsson (2008), 50. They observe that the inscriptions chosen for re-cutting primarily centered on Mylasa gaining its freedom, and its democracy.

295 Tables 3.1 and 3.2 are based on the dates and information given by Crampa in I.Labraunda. Given the fragmentary nature of many of the inscriptions found at the sanctuary, these lists can only suggest a general trend in the nature of the documents; see also Table 4.2 in Chapter 4 on the sanctuary of Sinuri. 
TABLE 3.1 List of political decrees at Labraunda from the Hellenistic period

\begin{tabular}{|c|c|c|c|}
\hline Inscription no. & Period & Issuing body & Concern \\
\hline I.Labraunda 41 & Late 4 th с вс & Mylasa & Democratic constitution \\
\hline I.Labraunda 42 & Early 3rd с вс & $\begin{array}{l}\text { Eupolemos } \\
\text { (Macedonian } \\
\text { ruler) }\end{array}$ & $\begin{array}{l}\text { Grant of ateleia (tax exemp- } \\
\text { tion) for a Koan and proxeny } \\
\text { by Plataseis }\end{array}$ \\
\hline I.Labraunda 44 & Early 3rd с вс & $\begin{array}{l}\text { Chrysaoric } \\
\text { League }\end{array}$ & $\begin{array}{l}\text { Immunity through } \\
\text { Ptolemy II }\end{array}$ \\
\hline I.Labraunda 84 & Early 2 nd c вC & Mylasa & Concerns polis of Euromos \\
\hline I.Labraunda 47 & 2nd c BC & Mylasa & Citizen's oath \\
\hline I.Labraunda $5^{1}$ & $\begin{array}{l}\text { Early 3rd с вс } \\
\text { or } 2 \text { nd-1st с в } \text { с }^{\text {a }}\end{array}$ & Mylasa & Economic/legal matter \\
\hline I.Labraunda 89 & 1st с вС & Mylasa & $\begin{array}{l}\text { Decree on conditions in the } \\
\text { shrine? }\end{array}$ \\
\hline
\end{tabular}

a Date disputed: before 267 BC, van Bremen (2017), or "Republican period," Crampa in I.Labraunda II, pp. 75-77.

The honorific decrees set up here, listed in Table 3.2, were primarily for those who played an important part in the political situation of the polis. Here only half of the decrees were awarded by Mylasa, two for Olympichos, and two for Roman officials. The honors received by a Mylasan from a foreign polis (I.Labraunda 48) underscore the role that Labraunda had as political podium, with an emphasis on external relations, for the polis of Mylasa (see also Table 4.1 in the next chapter for a breakdown of the types of inscriptions from Labraunda in comparison with those from the sanctuary of Sinuri).

\subsubsection{Cult Iconography in Urban Contexts}

Mylasa clearly exerted itself at Labraunda, not only through the decrees discussed above, but through the occupation of the sanctuary by a large share of the urban body during the festivals. But there was another side to this relationship, the inclusion of Zeus Labraundos within the urban realm at the polis.

One important sign of the presence of Zeus Labraundos in the daily lives of the citizens are the dedications to Zeus Labraundos, often as altars, found in Mylasa and its environs. Some of these were actually inscribed to the god, 
TABLE 3.2 List of honorific decrees at Labraunda from the Hellenistic period

\begin{tabular}{|c|c|c|c|}
\hline Inscription no. & Period & Issuing body & Honorand \\
\hline I.Labraunda 43 & 267 вС & Chrysaoric League & $\begin{array}{l}\text { Ptolemaic } \\
\text { official - Apollonios }\end{array}$ \\
\hline I.Labraunda $29 \mathrm{a}-\mathrm{c}$ & $3 \mathrm{rd} \mathrm{c} \mathrm{вс}$ & $?$ & $\begin{array}{l}\text { Demetrios, son of } \\
\text { Python? }\end{array}$ \\
\hline I.Labraunda 11 & $25^{\circ}-23$ о вС & Syngeneia of Korris & Unknown \\
\hline I.Labraunda 12 & $25^{\circ}-230$ ВС & Syngeneia of Korris & Unknown \\
\hline I.Labraunda 9 & Later 2nd с вс & Mylasa & Olympichos \\
\hline I.Labraunda 49/134 & Later 2 nd с вс & Mylasa & Olympichos \\
\hline I.Labraunda 48 & 2nd c BC & Foreign polis & $\begin{array}{l}\text { Mylasan - Dionysios, son } \\
\text { of Timonax }\end{array}$ \\
\hline I.Labraunda 62 & c. $129 \mathrm{BC}$ & Mylasa & $\begin{array}{l}\text { Roman - Gnaius } \\
\text { Domitius }\end{array}$ \\
\hline I.Labraunda 63 & Early 1st с вС & Mylasa & $\begin{array}{l}\text { Roman - proconsul } \\
\text { Cornelius Lentulus }\end{array}$ \\
\hline I.Labraunda 93 & Early 1st c BC & (fragmented) & (fragmented) \\
\hline
\end{tabular}

while others carried a relief of the god, probably his cult image, or simply bore his characteristic double-axe (Figures 3.13-14). ${ }^{296}$

Coins were a very direct and ubiquitous way of broadcasting a bond between a deity and a city. The imagery, figure or face, sculpted on them is immediately associated with the party issuing the coin, whether polis or ruler, and on a relatively mobile object, circulating from hand to hand for a number of generations. Zeus Labraundos's close relationship with the Late Classical satraps is demonstrated by his appearance on issues of Hekatomnid coinage, beginning

296 I.Mylasa 314 is a marble altar, from the second century вс, with a relief of a double axe and the dedicatory inscription ' $\Delta$ iò $\Lambda \alpha-\mid \beta p \varepsilon ́ v \delta 0 v$ '. Two more dedications to Zeus Labraundos, now in the Milas Museum, were discovered in the Uzunyuva excavations and published in Marek and Zingg (2018), 185, no. 27 by Demetrios, son of Thraseas, from the second century BC, and no. 28 by Demetrios, son of Poution, with the worn letters allowing only a rough dating to the Hellenistic period. Akarca also shows four more altars with reliefs of double-axes, later worked into walls in Milas, Akarca (1959), 40 n. 1 and Pl. XIX, nos. 1, 3, 4, 5. No. 3 on this plate, resembling a fountain head, may be the same object now located in the Bodrum Museum. Other dedications in Mylasa to Zeus Labraundos, but undated, are I.Mylasa 311 (votive altar), 312, 313. I.Mylasa 533 is a dedication from the Roman period. 


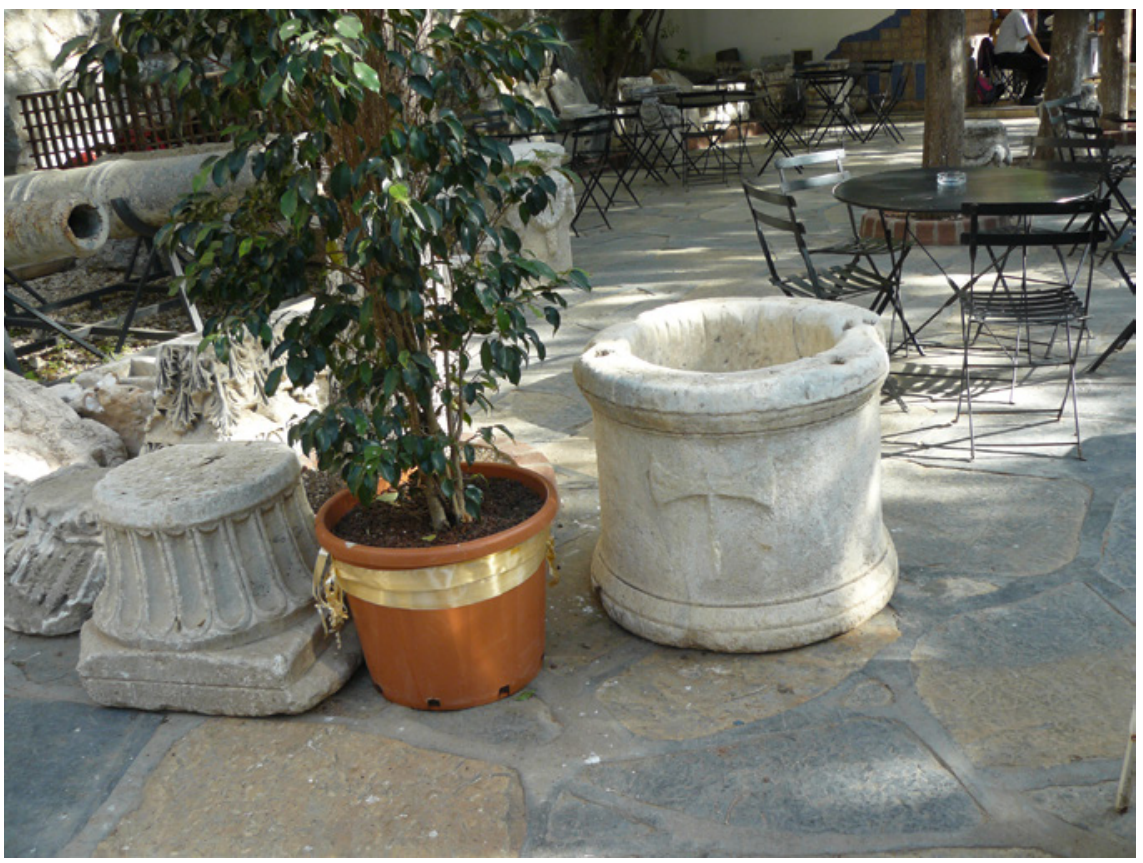

FIGURE 3.13 Round altar with double-axe, from Şeftalı Irın, southwest of Mylasa BODRUM MUSEUM OF UNDERWATER ARCHAEOLOGY, PHOTO AUTHOR 2009

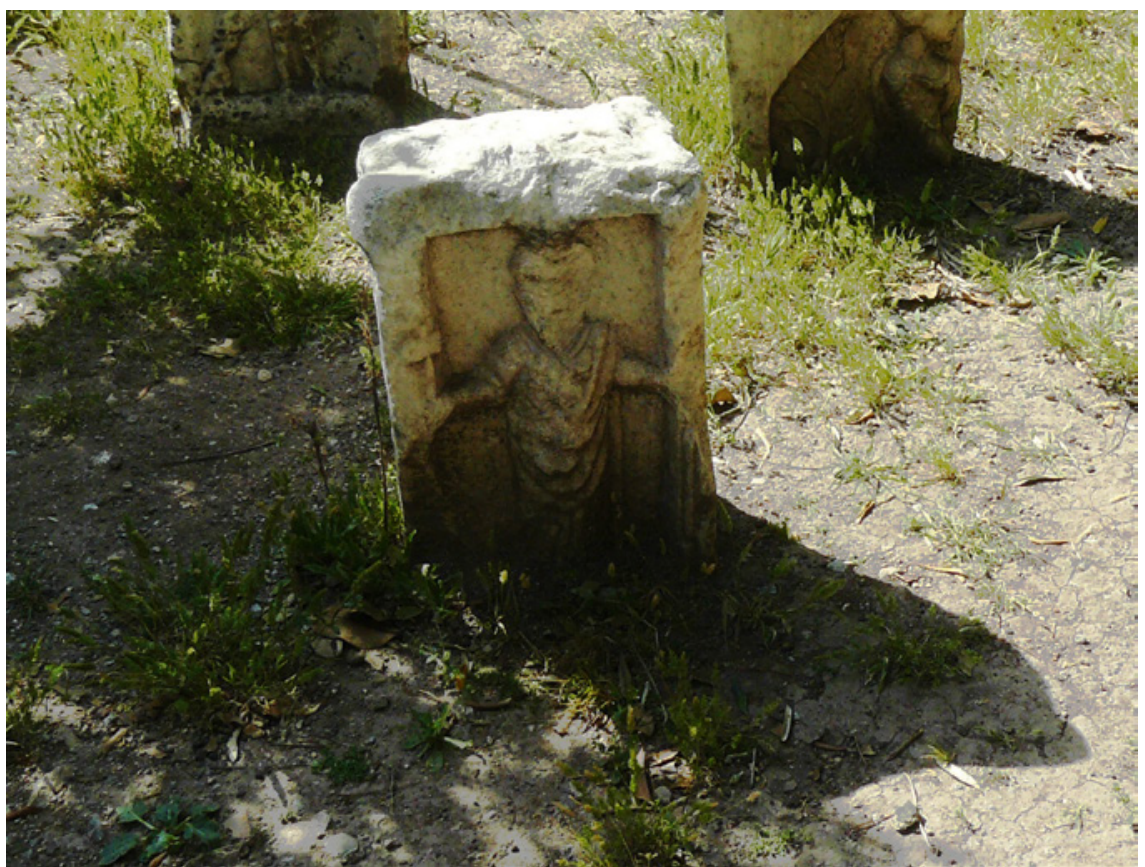

FIGURE 3.14 Small altar with Zeus Labraundos, probably Roman by analogy with Akarca 1959, Pl. Xx, no. 3 
with Hekatomnos (Figure 3.15a).297 Zeus is shown on this silver tetradrachm striding to the right carrying his double-axe in his right hand over his shoulder, and his lance or scepter upright in his left; he wears a chiton covered with a himation which is drawn across his body and carried over the right arm. This was a specific portrayal of the god in action, rather than his static cult image which would have been the more usual portrayal of devotion to the god, as shown in the relief from Tegea, in which Idrieus and Ada are depicted worshiping at the side of Zeus. ${ }^{298}$ This relief shows Zeus with the double-axe over his right shoulder with the himation over his left arm, and the scepter in his left hand, as on the coinage; yet here the god is standing still and facing the viewer, with six large globular pendants across his chest, reminiscent of Ephesian Artemis. ${ }^{299}$ Perhaps depicting his cult image in the temple, this is more typical for the iconography of Zeus Labraundos on coinage from later imperial Mylasa, and altars like the one in the Bodrum museum (Figure 3.14b). ${ }^{300}$

Hekatomnos thus chose instead for an active representation of Zeus Labraundos on his coinage, and placed the strident god on the obverse, with a roaring lion on the reverse. Maussollos retained the image, yet placed Zeus Labraundos on the reverse of his coins. On the obverse, several bear the image of Apollo, poliad deity of Halikarnassos (Figure 3.15b), underscoring the tight connection between the cosmopolitan, coastal city and the inland, Karian sanctuary. ${ }^{301}$ Yet an interesting Mylasan issue carries instead Zeus Osogollis, with trident and eagle, on the obverse (Figure 3.15c). ${ }^{302}$ Zeus Labraundos clearly had connections with all of Karia, as did the Hekatomnids, whereas Zeus Osogollis was the primary deity of Mylasa. Placing these two emanations of Zeus on either side of his Mylasan coinage created a triangular relationship

297 On this coin type see Ashton et al. (2002b), 125-128.

298 Fourth century relief from Tegea, now in the British Museum (Inv.no.1914.7-14.1); see e.g. Gunter (1989), 96, with a good photo in Fig. 6; Carstens (2009), 93-94; Hellström and Thieme (1982), 32-33; Akarca (1959), 41-42, with a list of references in p. 41 n. 5; Laumonier (1958), 24 n. 2 and 64-66.

299 Laumonier discusses these at length in Laumonier (1958), 70-80, in connection with his discussion of the 'primitive' types of images of Zeus Labraundos.

300 Laumonier (1958), 70-83 discusses in detail a number of these images, which he believes are archaizing representations from imperial times; Zeus appears stiff and swaddled, protruding pendants on his breasts, and outstretched arms, holding the double-axe and lance, e.g. Akarca (1959), types 16.2 and 16.3, from the Hadrianic period. Euromos, however, also portrayed Zeus in this fashion on its coins from the second or first century BC, e.g. SNG Copenhagen 333 .

301 Pedersen (2009), 334-337; Konuk (2013).

302 This coin was part of the Pixodaros hoard, published by Hurter (1998) as Type B, and discussed further in Delrieux (1999), 36, and Ashton et al. (2002a), now Konuk (2013). 

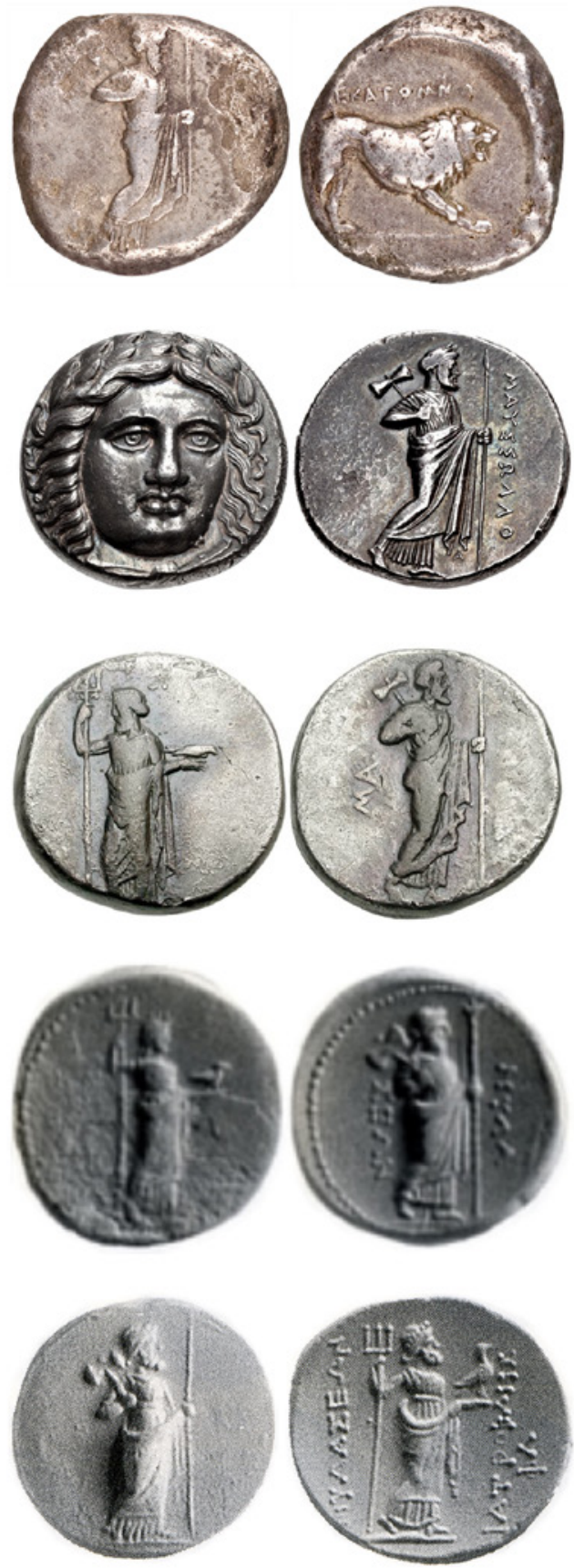

a. Hekatomnos. Silver Tetradrachm, c.380 BC BC

Obverse: Zeus Labraundos striding right, holding double-axe and scepter

Reverse: roaring crouching lion with EKATOMNOY, inside circular incuse.

Ashton et al. (2002), 125-128; Konuk (2013), 15

Type discussed in Delrieux (1999), 36, Plate 10, Fig. 2. Classical Numismatic Group,

e-auction 452, Lot 353: 18.09.2019

\section{b. Maussollos. Silver Tetradrachm, 370-360 BC}

Obverse: Apollo, laureate and facing $3 / 4$ right Reverse: Zeus Labraundos striding right, holding double-axe and scepter, small $A$ under his drapery, MAY $\Sigma \Sigma \Omega \wedge M O$ to right.

SNG von Aulock 2358 (this coin type). Type discussed in Delrieux (1999), 36, Plate 10, Fig. I.

Clossical Numismatic Group.

Auction Ex TritonX, lot 307: 10.01.2017.

c. Maussollos. Silver Tetradrachm, 377/6-353/2 BC

Obverse: Zeus Osogollis standing $3 / 4$ left, holding eagle and trident

Reverse: Zeus Labraundos striding right, holding double-axe and scepter, with MA.

Hurter 1998, Type B (this type). Type discussed in Delrieux (1999), 36, Plate 10 A-B.

Classical Numismatic Group.

Auction Triton XIII, lot 1320:05.01.2010

\section{d. Mylasa. Silver Tetradrachm, 3rd century BC}

Obverse: Zeus Osogollis standing right, holding eagle and trident

Reverse: Zeus Labraundos striding right, holding double-axe and scepter, with MYAA- $E E \Omega N$ on either side; within a circle of beads

Delrieux (1999), Group A no. IA, Plate 9 IA.

\section{e. Mylasa. Silver Tetradrachm, 3rd century BC}

Obverse: Zeus Labraundos standing right holding double axe (labrys) and scepter

Reverse: Zeus Osogollis standing right holding trident

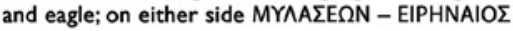
(magistrate).

Delrieux (1999), Group B no.4 (this type).

Classical Numismatic Group.

Auction Triton VII, lot 265: 01.2004

FIGURE 3.15A-E Hekatomnid and Mylasan coins showing Zeus Labraundos 
between himself and both deities, while forging a tight bond between his hometown Mylasa and the shrine at Labraunda.

Aşkıdil Akarca published two specimens of coins from Hellenistic Mylasa, with Zeus Labraundos and Zeus Osogollis on either side. ${ }^{303}$ She observed how faithful the Hellenistic issues of Mylasa were to this Hekatomnid type of Zeus Labraundos (Figure 3.15d). ${ }^{304}$ What she could not have known at that time was that even the combination with Zeus Osogollis was derived from the coins of Maussollos; the Pixodaros hoard, found in the 1970s in Bodrum (ancient Halikarnassos) and dating from the $340 \mathrm{OSC}$, contained two coins of this type. ${ }^{305}$ The primary difference, as Delrieux observes, is that Zeus Osogollis is turned around and facing right, much like Zeus Labraundos. ${ }^{306}$ This emphasizes the similarities between the two gods even more. Whereas Akarca had at her disposal only two specimens from the Hellenistic period depicting Zeus Labraundos, Delrieux was able to study another 11 tetradrachms and two additional didrachms, most of which were from a more recently discovered hoard (the 'Rhodian-Mylasian hoard'). ${ }^{307}$ Through close comparison with other coinage from this hoard, Delrieux believes all of the issues with Zeus Osogollis and Labraunda to have been dated from the second part of the third century вС; he relates the issues to the liberation of Mylasa by Seleukos II in c. 246 вс. ${ }^{308}$ Those with Zeus Osogollis on the obverse, like Maussollos coin, were likely the early issues in this group, but the others, with Zeus Labraundos on the obverse, were not far behind.

If Delrieux's dates are correct, then the issues may have been an attempt to consciously recall the coinage of Maussollos, in which both gods were combined. The early issues in fact show Zeus Labraundos on the reverse, embraced

303 Akarca (1959), 33 and nos. 9-10. No. 9 shows Zeus Osogollis on the obverse with Zeus Labraundos on the reverse (Delrieux (1999) Group A, specimen $1 \mathrm{~b}$ ), while no. 10 is the opposite (Delrieux (1999) Group B, specimen 6).

304 Akarca (1959), 33: "Leur source d'inspiration ce sont les monnaies des satrapes de Carie du IV ${ }^{\mathrm{e}}$ siècle, à tel point que la représentation de Zeus Labraundos est empruntée directement à ces monnaies. Dans le premier émission, Zeus Labraundos est une copie fidèle des monnaies comme sur celles-ci."

305 Hurter (1998), Type B (Pixodaros succeeded Idrieus as satrap in Karia, his coins are very similar to those of Idrieus, showing Zeus Labraundos on the reverse, with Apollo, the chief god of Halikarnassos on the obverse). The coin shown in Figure 3.15b represents a third specimen of Type B.

306 Delrieux (1999). Group A.

307 Delrieux (1999), 33-36.

308 Delrieux (1999), 42-45; these coins would then coincide with the Rhodian standard for tetradrachms. 


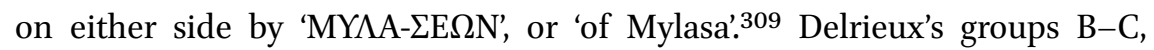
with Zeus Labraundos on the obverse and Zeus Osogollis on the reverse (e.g. Figure 3.15e) may then date from the success of Mylasa's claims to Labraunda; from this time it would not have been as necessary to 'label' the god as Mylasan, since that was now self-evident. Yet the overt associations with Zeus Osogollis remained; Zeus Osogollis was at this time being promoted as an important poliad god of Mylasa - associating the names of the magistrates with the more urban sanctuary probably made more sense. ${ }^{310}$ The perception of the gods as pairs is evident in a number of inscriptions, at times joined by Zeus Eleutherios. ${ }^{311}$

This association between Zeus Labraundos and Zeus Osogollis was also expressed in the bronze coins, in which the symbols of both gods were combined: the trident on one side, and the double-axe on the other. ${ }^{312}$ Reducing the presence of the deities to these symbols implied that everyone understood the references to the deities; for Zeus Labraundos this underscores the appearance of the double-axe as his 'logo', even though such hatchets were commonly associated with sacrifice. ${ }^{313}$ The double-axe is in any event found throughout Mylasa, as on the altar shown in Figure 3.14a-b, but also carved into walls in various places, such as the north gate of Mylasa, Baltalı Kapı (Figure 3.11). ${ }^{314}$ In fact, the double-axe became a highly successful emblem and is further found throughout Karia, appearing among others in a relief found at the sanctuary of Sinuri, in the ornamentation at the sanctuary of Hekate in Lagina, and in later representations of Zeus Panamaros, implying a direct association between these deities and Zeus Labraundos. ${ }^{315}$

309 Delrieux (1999), Group A, Pl. 9, specimen nos. 1A, 1B and 2.

310 The general Olympichos had dedicated some of his lands to Zeus Osogollis, with the proceeds explicitly designated to help pay for the festivals, I.Labraunda 8, see above.

311 E.g. I.Labraunda 6, lines 8-9 refer to Zeus Ososogollis, Zeus Labraundos and Zeus Eleutherios; Henry and Aubriet (2015), 695, also Debord (2001b). The priest of Zeus Labraundos, Hekatomnos, son of Ouliades, was often attested with the priest of Zeus Eleutherios, Euthydemos, son of Theoxenos, in land transactions in the later second century, e.g. in Olymos, I.Mylasa 801, 803, 814, 816B, and at Thraseas, I.Mylasa 207 and $207 \mathrm{~B}$.

312 Akarca (1959), nos. 22-26. Delrieux suggests that these were issued slightly later, at the end of the third and beginning of the second century, Delrieux (1999), 45.

313 See Laumonier (1958), 85-95 on the double-axe and its connotations as a general sacrificial instrument, not just in Karia but also on Krete.

314 Akarca (1959), Pl. XIX, figs. 1-5 include the altar in Fig. 13, and four more examples of the hatchet carved into walls. On Baltalı Kapı, Kızıl (2009), with images.

315 On the relief at Sinuri, see in I.Sinuri p. 14 and Pl. vil and below, Chapter 4; the appearance of the double-axe at Lagina is discussed further in Chapter 5 , and at Panamara in Chapter 6. 
In short, the monumentality of Labraunda and the expansion of its festivals went hand in hand with the shift at this mountain cult place towards a larger regional scope under the satraps, who explicitly opened the shrine to all Karians, inviting them to participate in the cult of Zeus Labraundos while acknowledging their power. After the Hekatomnids had passed, however, the focus at the sanctuary began to shift again as the polis gained ultimate control via Olympichos by the end of the third century Bс. Labraunda underwent a new phase as urban podium for Mylasa, just as Mylasa embarked on a new phase as an autonomous polis. The documents posted at the shrine, although fewer in number than at other Mylasan sanctuaries (e.g. the sanctuary of Sinuri, discussed in the next chapter), are highly political and typically concern the entire polis, such as the citizen's oath, and its external relationships with other political entities. Even the honorific decrees are for individuals who were somehow critical to the integrity of the political body, such as Olympichos, or Dionysios, honored here as a Mylasan by a foreign city. The polis left its stamp on the shrine by inscribing documents in places most obviously connected with Mylasa, e.g. at the south gateway or on structures with a view towards the town. The Hekatomnid design of the sanctuary appears to have been respected, even enhanced by the Doric stoa (Building $\mathrm{M}$ ) and the additional fountains. This may well have been part of a deliberate effort to recall the monumental power of the dynasty, as a 'memory theater' in Hellström's words. The polis also capitalized on Hekatomnid memory by recycling their imagery of Zeus Labraundos in its coinage, and if Delrieux's chronology is correct then this occurred around the time that Labraunda was contested space between the polis and the priests. Mylasa thus appropriated Labraunda as a public platform for its own goals, but in doing so appears to have made conscious use of the legacy of the Hekatomnids and mass media to propagate their claim to the sanctuary.

Interpreting Change in the Relationship between Mylasa and Labraunda

Out of all the sanctuaries in its chora, that of Zeus Labraundos was of particular importance to the Hellenistic Mylasa, given the considerable lengths to which the polis went in order to retain control. While this was clearly connected to the monumental heritage of the Hekatomnids, the changes at the sanctuary, reviewed above, as well as its geography allow for a deeper analysis of why this mountain sanctuary was so critical to the polis over a century after the passing of the dynasty. 
In order to do so it is helpful to take a step back and consider the situation in light of some of the more well-known models of relationships between poleis and remote major sanctuaries discussed in the first chapter. These models tend to focus on the distinction between town and countryside, with an emphasis on territorial borders. ${ }^{316}$ Shrines far from the urban center and near the border with the next community are typically designated as 'frontier sanctuaries'. As they rose to prominence, such sanctuaries are seen as marking critical spots in the political landscape that identify contested areas between neighboring communities. Following de Polignac, this reflects the need for a polis to establish territorial dominance in the face of a peer, neighbor, or rival community. ${ }^{317}$ Considering the physical and geographical data alone, it is tempting to interpret Labraunda as such a frontier shrine. Highly monumentalized and on a critical mountain pass at the northern edge of Mylasan territory, Labraunda was probably close to the natural borders of the poleis of Alinda to the north, and near the territory of Olymos to the west. Territory was surely a major concern to Mylasa, as witnessed by its aggressive and expansionist policies. However, besides the location itself, nothing at the shrine itself indicates that any of these borders were particularly worrisome for Mylasa. If anything, the inscriptions listing sacred lands belonging to Zeus Labraundos as being adjacent to those of Apollo and Artemis of Olymos speak for a patchwork landscape with fuzzy borders between the two poleis; in fact the landscape is depicted as belonging more to the gods than the political entities. Olymos was eventually absorbed by Mylasa, extending its territory even farther to the west. This probably happened in the third century already, meaning little need for Mylasa to use Labraunda to mark the western frontier at this point in time. ${ }^{318}$ Alinda, on the northern side of the mountain pass, seems to have figured little, if at all, on the political agenda of Mylasa.

Labraunda and its estates probably pre-date the formal organization of these poleis and their territories. The sanctuary would, however, have already occupied a central place among the local communities that were later incorporated into the poleis. This is a fundamental difference with the landscape of Archaic Greece addressed by the 'frontier' models. In Hellenistic Asia Minor,

316 E.g. Guzzo (1987); de Polignac (1995); Malkin (1996); discussed in Chapter 2.

317 De Polignac (1994) and (1995).

318 On the absorption of Olymos, Euromos, and Labraunda into Mylasa, see Cousin and Diehl (1898), 433-435, who place this in the mid-first century BC, as does Crampa in I.Labraunda, p. 25. Reger (2004), 164-168, however, dates the sympoliteia with Olymos in the third century BC; this view is finding more support, see LaBuff (2016), 109; van Bremen (2016); with the most compelling evidence in I.Labraunda 137, line 9, the 'Olymid Petra' discussed in Carless Unwin and Henry (2016). 
communities that evolved in alignment with the polis formula did so in a landscape that was already highly articulated and socially stratified. Mylasa is generally seen as the composite result of a synoikism of such local communities, and so when it later absorbed Olymos and Euromos, it was in a sense just taking this policy to the next step. ${ }^{319}$ Other than promoting and safeguarding the new treaties in stone, sanctuaries in these areas hardly seem to have been concerned with border issues. This is not to say that Labraunda did not figure in the territorial ambitions of Mylasa; it certainly did, but for other reasons than its proximity to a boundary with a neighboring polis.

Labraunda was itself contested space for a time between the priests and the polis, but it did not fall into limbo in the Hellenistic period as was once thought. ${ }^{320}$ Inscriptions and the ceramic record testify to a continued and intensive use that is now also reflected in the architectural developments. For all intents and purposes the monumental design of the Hekatomnids was left intact, but there were some significant modifications, including the three monumental fountains and the Doric stoa stretching across the Middle Terrace. ${ }^{321}$ These structures clearly served the public at large, providing them with extra water sources, additional shelter, and a protected view across the shrine and the Karian landscape below. One might interpret this as an 'opening up' of the facilities to a wider audience, letting a larger share of the population enjoy the amenities of the complex built by the legendary rulers, particularly if a large section was originally built as a royal palace. Pontus Hellström observed the general respect for the Hekatomnid shrine in later periods, evidenced by the care taken to preserve their dedicatory inscriptions; he even suggests that one of the architrave inscriptions may have been faked in the Hellenistic or Roman period to make it appear Hekatomnid. ${ }^{322}$ Working from the extant view of a complete standstill in building activity in the Hellenistic period, he asked whether this might have been “due to a decision to preserve Labraunda's

319 Local communities such as Beçin Kale, Gencik Tepe; Rumscheid (2010), 96-99, suggests the fourth century for the synoikism; Hornblower (1982), 69 n. 119 based on Radt (1969/70), 168-169 supposes the fifth century. On the development of Mylasa, see above at the beginning of this chapter.

320 Discussed above, also n. 115 .

321 Also the reuse of the Akropolis fortress and the multiple burials in the area testify to the intensive use of the site in the Hellenistic period, see Henry et al. (2014), 280-304; Henry et al. (2017), 15-221, 229-246; Henry (2017).

322 Referring to the less elegant nature of the architrave inscription on the 'Doric Building', Hellström (2009), 278-279. Also when the North Stoa was (re)built in the imperial period by the priest Poleites (I.Labraunda 23), he either reused or left intact Maussollos's dedicatory inscription (I.Labraunda 13). 
Hekatomnid memory theater?"323 Although it is now clear that some building activity did take place in the Hellenistic period, this question still merits consideration. The prime sanctuary of the legendary Karian rulers with its imposing architecture would certainly have evoked the ancient power of its builders, lending authority to those now in control. ${ }^{324}$

With its corporeal presence and ontological imminence, architecture has a special capacity to trigger the imagination of the past while retaining a functional use in the present. Michael Guggenheim examined architecture and memory through the lens of Actor-Network Theory, developed by Bruno Latour. ${ }^{325}$ In this theory, objects are inherently connected to time, and thus function as actors in a complex network of associations, most of which are built of memories. ${ }^{326}$ Objects have a way of 'conflating' time, by bringing the past immediately into the present, thereby imposing memories and connections onto human sensory perception. This is why they are sometimes intentionally isolated, e.g. in museums or laboratories, in order to 'stabilize' these networks, and more typically to isolate a particular network of associations from contamination by others. ${ }^{327}$ Buildings, however, are much more complex since they contain multiple associative networks that cannot be 'stabilized' they are continuously in use and inherently possess multiple temporalities all at the same time. ${ }^{328}$

323 Hellström (2009), 278; I explore this further in Williamson (2013d). The term 'memory theater' is used here as a place where memories of the past are combined with performances of the present, rather than as a strict mnemonic device as Giulio Camillo's 'Memory Theater', discussed in Yates (1966), 129-172.

324 The only negative tone at the sanctuary regarding the satraps is the very early Hellenistic inscription celebrating Mylasa's 'return to justice' after the downfall of the 'tyrants', I.Labraunda 41, dated to the late fourth century вС.

325 See Chapter 2 on the Actor-Network Theory, Latour (1987) and (2005); and Middleton and Brown (2005).

326 Guggenheim (2009), 41-43, this also may be the exception that proves the rule.

327 Guggenheim (2009), 41: "The stabilization of a network by enrolment is called blackboxing, a process whereby actants are stabilized in their use and meaning. At the same time, enrolment and black-boxing change the actants that are enrolled. What is called truth in science for ANT is nothing other than the stabilization of networks."

328 A good example is given in Guggenheim (2009), 46-47: "To use a building always means to use it partially, to use it in the presence of others and to interact with others in, through and with the building. The multiplication of uses creates networks that are outside of anyone's control, and specifically outside the control of any functional system. For example, while a tourist might stand in front of the Villa Savoye and look at it as an artwork, the inhabitant may be inside just preparing breakfast, while the plumber fixes the heating system and a restorer analyses the composition of the walls. All these uses may exist alongside each other, but they may even interact in all kinds of unexpected ways." 
What this theory allows us to do at Labraunda is to view the buildings as 'actors', creating and recalling all kinds of memories and associations at the same time. Using the sanctuary as a 'memory theater' does not mean that it was turned into a 'museum'. The architecture at Labraunda may have been preserved, but its associative networks were not stabilized in any way, nor could they have been if we believe Guggenheim - the sanctuary continued to be the center for festivals and ritual performances from generation to generation. The inscriptions from the third and second centuries, virtually the only additions to the sanctuary besides the fountain house, reiterate its ongoing use. They demarcated the ritual 'concentric' spaces at the sanctuary, showing that it was used in much the same way as the Hekatomnids had designed, while accentuating the areas that were particularly important to Mylasa, i.e. the nodes in the 'linear' space that joined the sanctuary with the polis: the 'framed' view of the polis from the andrones, and the South Propylon, the hinge at the end of the sacred road from Mylasa. The Hellenistic polis thus left its stamp on the Hekatomnid design of the sanctuary. Rather than being a question of passive finances or political inertia, architectural restraint was instead a way of actively tapping the ancient Hekatomnid associations to underscore the intrinsic authority of the sanctuary, and especially to highlight the polis as legitimate heirs of this landscape of power. ${ }^{329}$

The coinage from Hellenistic Mylasa reinforces this interpretation. The Hekatomnid image of Zeus, striding forward with his double-axe over the shoulder (Figure 3.15), was visually 'cited' in the imagery on the coins from the latter part of the third century (following Delrieux's chronology). Labraunda was contested space in this period, and reproducing this image of the god that had become familiar throughout Karia would have been another way for the polis to stress continuity with the Hekatomnid period. Copying Maussollos's coinage, with Zeus Osogollis on one side and Zeus Labraundos on the other, would furthermore have engaged the associative 'network' of the satraps' coins, creating an immediacy of the ancient rulers in the present day. It also would have established a link between the satrap who built much of the sanctuary and the polis that was now administering it. Finally, using the coinage with both figures of Zeus would have recalled the ancient connection between the two deities themselves, Zeus Osogollis in the city and Zeus Labraundos in the countryside, both symbolizing Mylasa.

Yet it is significant that the polis did not make exact replicas of the Hekatomnid coins; they made Zeus Osogollis look more like Zeus Labraundos, reversing his direction (but not changing which hands held what); some issues

329 See Williamson (2013d). 
were 'crowned' with a circle of beads, but most important, the name of the Hekatomnid ruler was replaced by that of the polis. Much like the sanctuary architecture, the coinage is about preserving the Hekatomnid past, but it is even more about using it to legitimate the present authority of Mylasa. Different from architecture, however, is the ubiquity and mobility of coins. Their mass-production qualifies them in the jargon of the Actor-Network Theory as 'immutable mobiles', objects that travel from one 'functional system', to the next, accumulating webs of associations along the way. ${ }^{330}$ With their capacity for mass-advertising, these coins are part of the 'rational ritual' process, ${ }^{331}$ mediatizing the message along one of the most efficient networks imaginable, that of trade, hand-to-hand. But the message encoded in the coins relied on the background knowledge of the recipient, and Mylasa was no doubt counting on the effectiveness of the networks of associations already created by the Hekatomnids for their success with these coins. They were the ones who made the image of Zeus Labraundos commonplace throughout Karia. That the double-axe practically became a logo for Karia for centuries to come is thanks to their initiative of drawing the focus of the community to the cult at Labraunda.

Preserving Hekatomnid architecture and re-using their iconography are two indirect ways that Mylasa tapped the power of the ancient rulers that had unified Karia. The effectiveness of this may be seen in the onomastics of Hellenistic Mylasa. In her study on the frequency and type of Karian personal names in the Hellenistic period, Daniela Piras found that the otherwise wholesale shift towards Greek names was mitigated primarily in Mylasa, where there was a sudden circulation of Karian names that were almost exclusively Hekatomnid. ${ }^{332}$ Although this may simply be homage to a shared ancestry, it seems more likely that it reflects a renewed interest in the powerful rulers of the previous era, particularly when taken together with the traditional iconography in the coinage and the architectural 'preservation' at Labraunda. If so, this trend would be a remarkable contrast with the anti-tyrant sentiments that surface through an inscription at Labraunda, dated to late fourth century, i.e.

330 Latour (1987), 226-227. Guggenheim applies an inversion of Latour's term, "mutable immobiles," to architecture, to underscore its singularity and yet changeability of meanings, Guggenheim (2009), 45-48.

331 Chwe (2001), esp. 21-22, on ritual as "saturation advertising," in effectively creating common knowledge.

332 Piras (2010), 226-229, discusses the surge of Karian names such as Hekatomnos, Pixodaros, or Artemisia, given to children whose fathers often had Greek names. Aubriet (2013) discusses onomastics as an expression of a 're-Karianization' of Mylasa. 
the period just after the Hekatomnids had passed; this fragmentary inscription mentions a return to justice following the 'tyranny' of the dynasty. ${ }^{333}$

What Mylasa was doing at the sanctuary and with the image of Zeus on its coins perfectly coincides with its stance in the conflict with the priests over Labraunda. The Hekatomnids were the ones who 'created' both Mylasa and Labraunda by radical redesign - the one as a new urban center and the other as the religious center of Karia. It is logical that the Mylasans would see themselves as the rightful heirs of this particular Hekatomnid legacy, and therefore guardians of the sanctuary, just as the priests did by ancestral rights. The main difference was that Mylasa had the institutions of the polis - the legal system, the festivals, and the advertising capacity of coinage - at its command to enforce its role and leverage the symbolic capital of the deity. ${ }^{334}$ The irony, however, is that the newly independent polis that once referred to the Hekatomnids as 'tyrants', nonetheless relied on their fame and ongoing popularity to legitimate its own authority, both at home and in the region, while at the same time participating in the wider Greek world as an autonomous and democratic polis.

The central role of Labraunda in Hekatomnid ideology thus explains in part why the sanctuary was so important to Mylasa more than a century later - the cult was necessary to the symbolic shaping of the newly independent polis. But another reason for the Mylasans to be so interested in this sanctuary and its design may well coincide with the same reason that the Hekatomnids chose this sanctuary in the first place - the power of the place. Location is vital to Labraunda. Besides being along a main mountain pass, at a critical spot that intersected the spheres of different communities, it is also on a commanding height with a view towards most of southwest Karia. The Hekatomnids surely appreciated the superb panoramic view, as well as the tactical advantage of the location. As mentioned above, sightlines emphasized by architecture tend to collapse space between objects, making them feel closer than they actually are because they have mentally become more comprehensible. ${ }^{335}$ The antiquity of a site, combined with oral and inscribed traditions, serve to further heighten

333 I.Labraunda 41, probably from the southwest anta of the temple. Crampa interprets the inscription as a decision of democratic Mylasa "to alter regulations or conditions from the earlier 'tyranny' by juridical mode of action," see his commentary in Volume II, p. 41. See further Williamson (2013d).

334 Bourdieu (1986).

335 Ellard (2009), 264 "If the parts of our brain that deal with space have strong preferences for enclosed views, and if we patch together a mental collage of space by combining these views, then any time a builder erects a wall, he is influencing our conception of the spaces in which we live." 
its awareness and seeming proximity, thus foregrounding the place. ${ }^{336}$ Metrical distance aside, Labraunda felt very near to Mylasa. The windows in the andrones further emphasized the connection as they literally 'framed' the view; the central object within the frame is of course Mylasa and its landscape. This was surely not lost on the Hellenistic polis.

This mountain sanctuary of Zeus, the supreme deity, had little to do with territorial boundaries, but quite a bit with territorial domination, given the visual supremacy of the location. The sanctuary not only afforded a sweeping view of the entire region, its monumentality acted as a landmark, or a beacon of Hekatomnid, and later Mylasan, presence. Labraunda, designed in the Late Classical period by and for the satraps, worked equally well for the Hellenistic polis. The sanctuary became urban space, in which the identity of the polis in the region was central. Labraunda played a critical role in both the territorial and symbolic shaping of the polis, two critical stages in the construction of 'regional' identity as modeled by Paasi. ${ }^{337} \mathrm{~A}$ third stage is that of institutionalism, and this is one of the reasons that it was so important to the polis to make the priesthood conform to its perception of the institution of that office, since this was a critical post in ensuring that the needs of the polis were streamlined with the resources of the sanctuary, especially its symbolic capital. This symbolic capital, through the Hekatomnid heritage at the sanctuary and the power of its location in the landscape, was apparently for Mylasa the key to its establishment in the region, the fourth stage in the process of forming identity. This stage is typically associated with external recognition, yet this is an aspect which the sanctuary already possessed - by overlaying the identity of the god with that of the city, Mylasa was able to ride in the slipstream of this recognition.

The festival of Zeus Labraundos, in the heights of Karia, had thus become a central focus for the cohesion and common identity of the Mylasans, who originated from different subdivisions through which they celebrated their more local and popular identities, as the next case study will show.

336 Kantner (2008), 58-59, discusses the role of cultural memory in defining identities in landscape archaeology, using as an example the work done by Stewart and Keith on Inuit oral histories and archaeological places in northern Canada, showing how "places imagined as 'traditional' are 'foregrounded' in the landscape," based on the work of Stewart et al. (2004); see Chapter 2.

337 Paasi (2009), 134-136, discussed above in Chapter 2. 


\section{Urban Microcosms: Syngeneiai and the Sanctuary of Sinuri}

Whereas Labraunda was gradually, and not without resistance, transformed from a dynastic and regional religious center into a polis sanctuary for Hellenistic Mylasa, the shrine of the Karian god Sinuri underwent a similar transition, but at a smaller scale. ${ }^{1}$ Sinuri was a local deity about whom we know very little, other than that his sanctuary was also embellished by the Hekatomnids and was the focus of a highly vocal syngeneia, or kinship group. Very different from the commanding heights of Labraunda, the sanctuary of Sinuri is located in a narrow valley surrounded by mountains, some 15 kilometers southeast of Mylasa (Figures 4.1-4.4). Despite the modest setting, this

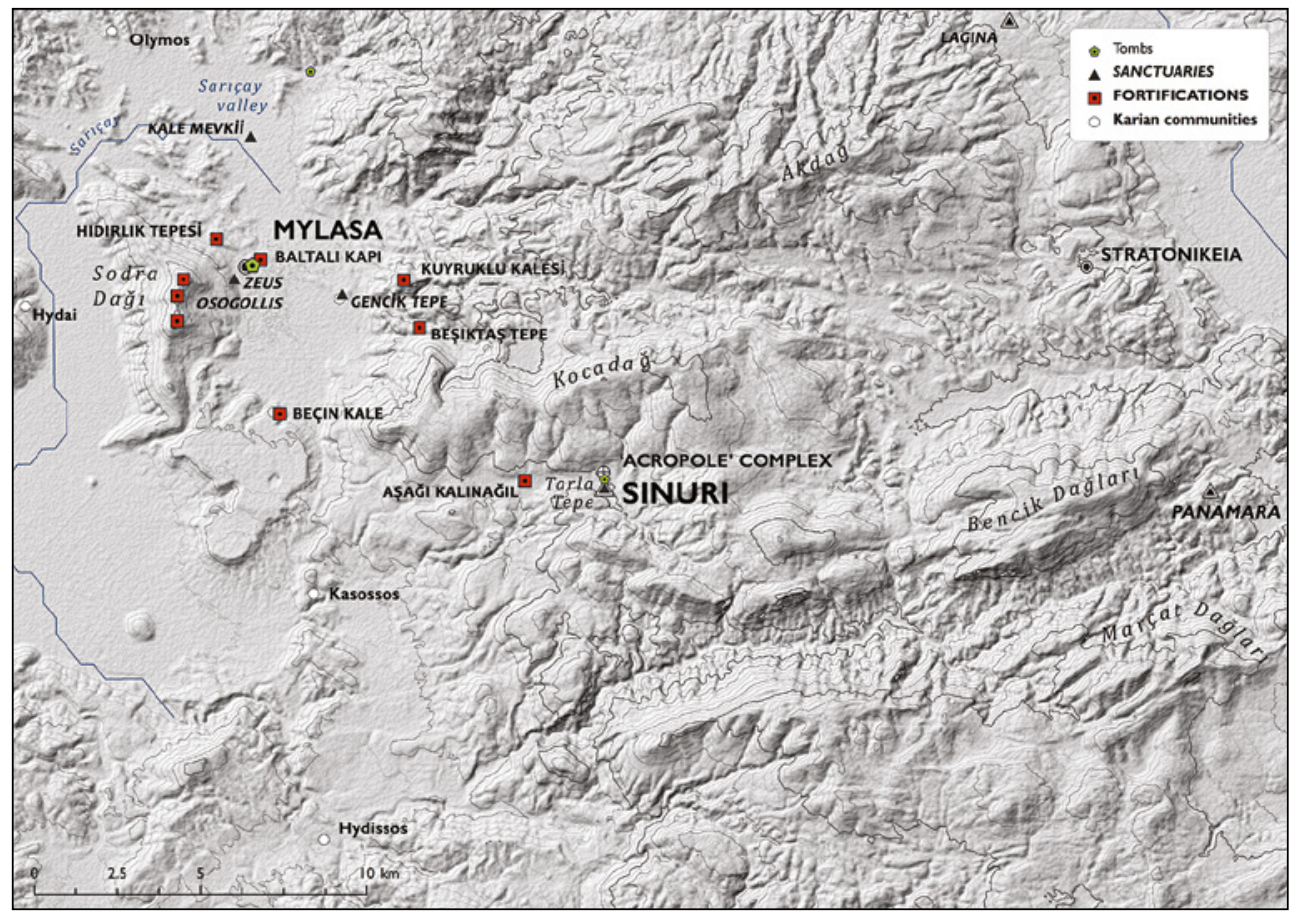

FIGURE 4.1 Map with the environment of the sanctuary of Sinuri

1 This section draws in part on Williamson (2016a).

(C) CHRISTINA G. WILliAMSON, 2021 | DOI:10.1163/9789004461277_005

This is an open access chapter distributed under the terms of the CEhPY-NC 4.OGlicense.iamson - 978-90-04-46127-7 
shrine was a monumental religious center in the chora that came to mirror the function of urban sanctuaries with regard to its administration, economic position and defining impact upon its community.

The shrine of Sinuri had apparently always been oriented towards a syngeneia rather than the Mylasa as a whole. Syngeneiai were a base unit of Karian society and they typically revolved around a sanctuary, as was especially common in the area of Mylasa. The Pormounos syngeneia, which administered the sanctuary of Sinuri in the Hellenistic period, certainly defined itself according to the institutional model of polis and used the sanctuary as a public platform to regulate their economic affairs and honor individual members of their society. Although this was not strictly speaking an urban sanctuary, it was treated as one by this sub-community of the polis, for whom it played a crucial role in solidifying their identity.

Historical Overview of the Sanctuary of Sinuri

The first clear signs of religious activity at the site of the sanctuary date from the seventh century $\mathrm{BC}$, when it may even have acted as a place of refuge; the robust temenos wall from this period would have aided this function. ${ }^{2}$ Fragments of pottery in the Fikellura or Wild Goat style indicate some degree of regional connectivity in the sixth century вс. ${ }^{3}$

The fourth century ВС was a major period in the regional recognition of the sanctuary. This is when it was patronized by the Hekatomnids, putting it on a par with the two other Karian sanctuaries to receive the attention of the satraps - that of Zeus Labraundos and Artemis at Amyzon. ${ }^{4}$ Hekatomnos

2 Older finds at the site include two stone-axes from the Neolithic period and some Geometric pottery fragments, Devambez (1959), 9 and 24 for the remains from the Geometric and Archaic periods (also Taf. 22-26). Observing signs of intensive albeit sporadic occupation, Devambez suggests a refuge function in this early period.

3 Devambez (1959), 24 and Taf. 23; Cook (1992), 26o n. 36.

4 For Labraunda, see Chapter 3 above. At Amyzon, Idrieus dedicated a structure at the sanctuary of Artemis with an architrave inscription similar to those as at Labraunda, Robert and Robert (1983), no. 1; they believed this to belong to the propylon, but see now Hellström (2009), 276 and 288 who shows it to belong to the (Ionic) temple. Regarding Sinuri, Hornblower states that "the great period of the sanctuary is the fourth century; but the evidence for this is epigraphic not archaeological: the building remains from fourth-century Sinuri are disappointing compared with the effort and money spent at Labraunda ... Labraunda and Halikarnassos, the religious center and the secular capital, were to be the showpieces, and the dedications elsewhere are on a smaller scale altogether," (Hornblower (1982), 277-278). Devambez, however, dates the second phase of the temenos walls to the first part of the fourth century, 
personally dedicated an altar table and possibly a doorway, ${ }^{5}$ while the construction technique of the later temenos walls, and the characteristic use of platforms and terraces indicate his hand in the overall reconfiguration of the sanctuary. The shrine of Sinuri is situated near the edge of the plain south of Mylasa, not far from Kasossos and Hydissos (Figure 4.1), and its renewal by the Hekatomnids may well have been part of their overall consolidation of Karia, and perhaps the creation of a buffer zone around Mylasa, as Descat suggests. ${ }^{6}$ Ada and Idrieus, successors to Maussollos in the second part of the fourth century BC, were also involved with both the sanctuary and the syngeneia of Pelekos who administered it at that time, as they instructed them to admit a certain individual into their community, extending to him, and perhaps the syngeneia, the privilege of ateleia (tax exemption). ${ }^{7}$ The inscriptions at the sanctuary by the rulers were bilingual, in both Karian and Greek, indicating a strong indigenous element, more so than at Labraunda, where the Karian script is all but absent. ${ }^{8}$

Karian inscriptions, however, disappear by the early third century вС, when the sanctuary had apparently changed hands from the Pelekos syngeneia, who are no longer heard from, to the Pormounos syngeneia. Whereas the Pelekos syngeneia seems to have been largely autonomous, with direct connections to the rulers, it is apparent that in the course of the third century the syngeneia of Pormounos were under the auspices of the polis of Mylasa, as they used its calendar and magistrates to date their decrees. In this period they begin to acquire property for the sanctuary, joining in the hereditary lease practices that were typical for the area of Mylasa, particularly in the later Hellenistic period..$^{9}$ By the end of the third century, their holdings must have already been very significant, as they appear to have been pillaged by the troops of Antiochos III when they passed through the area. ${ }^{10}$ This act of violence also put the sanctuary on

Devambez (1959), 27-30, and the Hekatomnid signature is verified by Pedersen (1991), 103, who on further discusses the Hekatomnid expansion of the sanctuary of Artemis at Amyzon (p. 100-101).

$5 \quad$ I.Sinuri 76, discussed below. See also Debord (1999), 386, 403-404.

6 Descat (2013).

$7 \quad$ I.Sinuri 73 concerning Nesaios, discussed in more detail below. I.Sinuri 75 is heavily fragmented but also contains the word ateleia.

8 E.g. I.Sinuri 74 and 75, both now interpreted as part of the same inscription, based on the Karian text, see Adiego (200o). On the use of Greek and lack of Karian script at Labraunda, see Karlsson and Henry (2009), and the discussion on the scope of Labraunda in Chapter 3.

$9 \quad$ E.g. Chandezon (1998); Dignas (200o); discussed in more detail below.

10 Based on a fragment discussed by Robert in I.Sinuri p. 12, and reconstructed by Virgilio (2010), discussed in greater detail below. 
equal footing with the Artemis sanctuary in Amyzon, which underwent a similar fate, and that of Zeus Labraundos, which was spared by a protective letter from Antiochos III. ${ }^{11}$

Most of the inscriptions from the sanctuary of Sinuri date from the next two centuries, point to a second blossoming in the Hellenistic period as the syngeneia of Pormounos begin to profile itself as a highly efficient community, accumulating more and more domains for the god and administering the sanctuary in proper fashion. In this period the sanctuary and the festivals of Sinuri are clearly at the core of the identity of this thriving community, as their awards and decrees show.

By the later part of the first century the priesthood seems to have opened up to Mylasans in general - this may also signal the demise of the syngeneia since from this time there is little evidence of activity at any level, save for two remarkable monumental Roman tombs. The significance of the place, however, must have remained apparent as it was turned into a Christian center in the Byzantine era.

\subsection{Data and Sources}

Louis Robert visited the site on 29 October, 1934 and was able to identify it as the sanctuary of Sinuri based on an inscription which he saw there (I.Sinuri 2, Figure 4.16); his invaluable diary on the discovery, with a description of the journey and the landscape, has been published by Biagio Virgilio. ${ }^{12}$ After Robert returned to Istanbul, he proposed the excavation of the site to Albert Gabriel, founding director of the Institut Français d'Archéologique de Stamboul. ${ }^{13}$ The project was assigned to Pierre Devambez, later chief curator of Greek and Roman antiquities at the Louvre. Excavations took place the following year, from 24 August to 22 October, $1935 .{ }^{14}$ The ceramics were subsequently studied in 1937 by Emilie Haspels, of the University of Amsterdam. Publication plans were interrupted by the onset of war, yet in 1945 Louis Robert was able to publish the over 8o Greek inscriptions, which Devambez had assembled

11 Robert and Robert (1983), no. 18; I.Labraunda 46. The turmoil of this era is seen by some to correspond with the increase in asylia inscriptions at sanctuaries, discussed in Roels (2018a), 234-238 and esp. Mastrocinque (1984), Flashar (1999), and Knäpper (2018).

12 Robert (1935a), 335, also (1935b), 161-162 and I.Sinuri, p. 1. This was during his second trip to Karia in the fall of 1934 - his diary records his discovery of the inscription which convinced him of the identity of the site, later published as I.Sinuri 2, the dedication of an altar to the god by the tamiai and egdikoi. Biagio Virgilio studied Robert's notes which are now in the Fonds Louis Robert della Académie des Inscriptions et Belles-Lettres in Paris see Virgilio (2010), 59-64, republished in Virgilio (2011).

13 Now the Institut Français d'Études Anatoliennes (IFEA).

14 I.Sinuri, p. 1-4. 
and squeezed, in the volume Le Sanctuaire de Sinuri près de Mylasa. Première partie. Les inscriptions grecques. ${ }^{15}$ Fragmentary though they are, these documents make up the base for most of the insights into the changes that took place at this sanctuary and how it functioned; with some significant exceptions, the inscriptions primarily date from the second bloom of the sanctuary in the second and first centuries BC. ${ }^{16}$ The fourth century Karian inscriptions were published much later. ${ }^{17}$ Devambez and Haspels published the architecture and ceramics in 1959, in the second volume of Le Sanctuaire de Sinuri près de Mylasa. ${ }^{18}$ The meager amount of Hellenistic pottery appearing in the publications is in marked contrast with the number of inscriptions from the same period that laced the walls of the sanctuary. ${ }^{19}$ Yet the study of Hellenistic pottery is a growing field: with the knowledge now available, a new examination of the pottery from the sanctuary of Sinuri would no doubt revise several of the ideas presented here.

The quantity but also quality of sources at the sanctuary of Sinuri is much more limited than at Labraunda: the ceramics record is thus far below par, and the architecture inside the sanctuary was largely demolished in the Byzantine period, when many of the building elements were rearranged into a basilica, which, as Robert phrases it, "s'est implantée sur le sanctuaire et l'a digére."20 Nevertheless, a rough plan was discerned which forms the base for Figure 4.8, and for the chronological distinction of building phases. ${ }^{21}$

15 The I.Sinuri volume. The Karian inscriptions were originally planned to be published by E. Benveniste, but see now Ray (1990); Faucounau (1994); and Adiego (2000).

16 The honorific decrees, I.Sinuri 16-43, by the Pormounos syngeneia generally date from the second to first centuries BC; while some of the inscriptions documenting the land-lease transactions may date from the third century, I.Sinuri 11-15, most appear to date from the second century вС, I.Sinuri $45^{-72}$. Four inscriptions, I.Sinuri $73^{-76}$, date from the fourth century вC, while I.Sinuri $77-8$ o are from the Byzantine period. I.Sinuri 81 is a musical fragment that is only generally dated to antiquity. None of the inscriptions at the sanctuary date from the Roman imperial period.

17 Ray (1990); Blümel (1995); Adiego (200o).

18 Devambez (1959).

19 Devambez (1959), 31: "Nous voyons donc que sur la période qui s'étend du IV e siècle jusqu'aux temps romains inclusivement notre documentation est d'une extreme indigence. Ce sont les textees épigraphiques, et eux seuls, qui nous apportent des documents sur la vie du sanctuaire."

$20 \quad$ I.Sinuri p. 103.

21 Based on the map in Devambez (1959), 47 and clarified as to building phases in Pedersen (1991), 104, Fig. 104. Neither map shows the orientation of the complex; I was, however, able to approximate this using a compass and GPS coordinates taken in 2010 (see Figure 4.8). 


\section{Environment of the Sanctuary of Sinuri}

\subsection{Physical Environment}

The sanctuary of Sinuri is situated some 15 kilometers east-southeast of Mylasa, on a hilltop called Tarla Tepe near the modern village of Çamlıbelen (Yukarı Kalınağll) (Figures 4.1 and 4.2). The sanctuary is located on a gently sloping hillside, about $540 \mathrm{~m}$ ASL, in a valley between the Bozdağ near Beçin Kale to the west, and the Bencik Dağı to the east (the sanctuary of Zeus at Panamara is at the other end of this range). The sanctuary is on the lower southern foothills of the Kocadağ mountain, which at $1022 \mathrm{~m}$ separates the valley from the Mylasa-Stratonikeia valley to the north. The mountains surrounding the sanctuary to the north, east, and south continue to rise, defining the perimeters of the valley (Figure 4.1). While these mountains and hills are more densely forested with pine trees, the area around the sanctuary and to the west of it is terraced and several modest houses and farmsteads dot the hillsides, including one just below the sanctuary, whose inhabitant in 2011 could still recall the French expeditions.

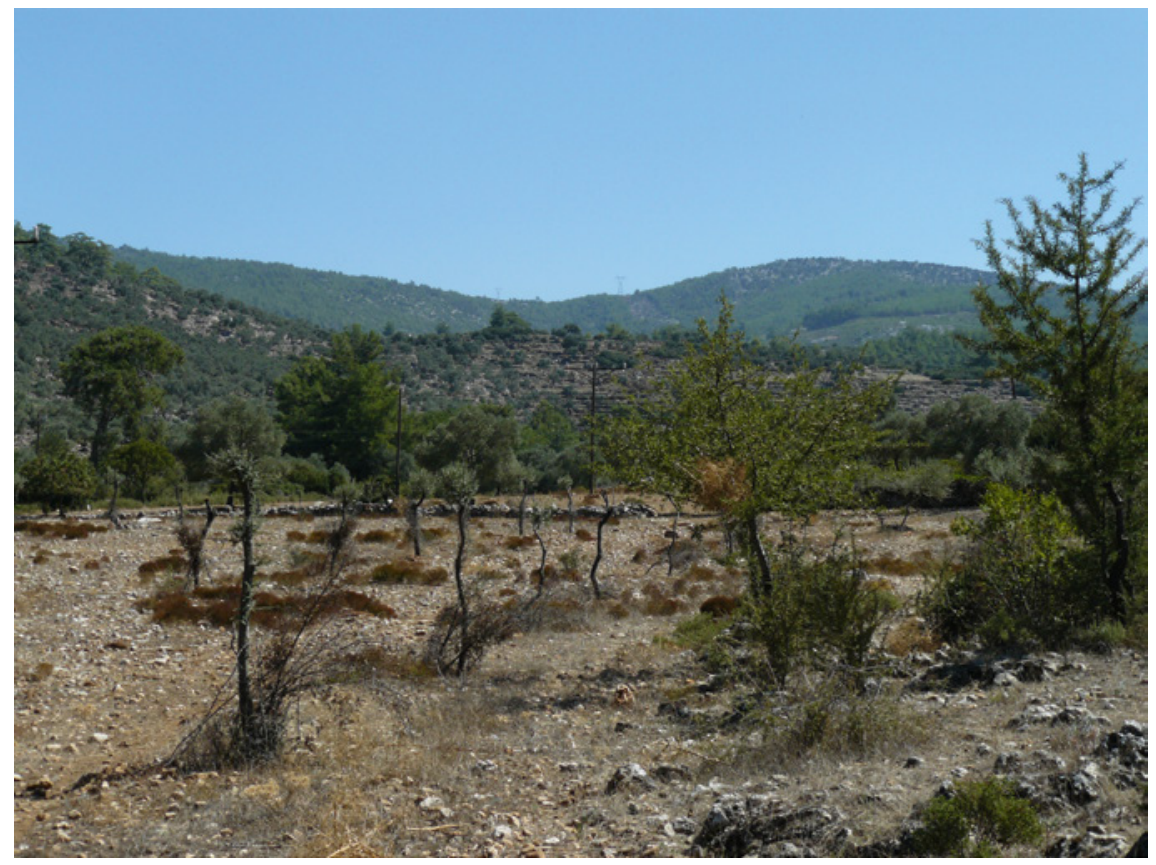

FIGURE 4.2 The sanctuary of Sinuri, on the Tarla Tepe hill in the center of the picture, seen from the west PHOTO AUTHOR 2010 
The dark red marble with white veins native to this area was used at the sanctuary, perhaps in the stoa (Figure 4.13), and is still being exploited today. Although the soil is stony, the valley is fertile and verdant in the springtime; terraces for crops and olive groves are predominant. Robert noted in 1934 that wood and charcoal were the mainstays for the villagers of Yukanı Kalınağıl (Çamlıbelen). ${ }^{22} \mathrm{He}$ also pointed out the strong contrast between the climates of the area of Mylasa and these hills which, with their higher altitude, receive more snow. ${ }^{23}$

Devambez, who excavated the sanctuary, saw no particular natural feature that might explain the choice of site. ${ }^{24}$ The fertility of the valley may also have been related to nature of the cult and the needs of the community that worshiped there, as many of the documents pertaining to land-lease contracts indicate. ${ }^{25}$ In fact, one of the inscriptions speaks of a sacred grove connected to the sanctuary. ${ }^{26}$ The sanctuary is at the threshold where the cultivated area meets the forested hills; perhaps this was the case in antiquity as well (Figure 4.2).

\subsection{Social-Geographical Location}

As Robert observed, the sanctuary of Sinuri is close to Kasossos (modern Ulaş), and nearly equidistant from the towns of Hydissos, Stratonikeia, and Mylasa, yet it was Mylasa that dominated this area throughout the Hellenistic period. Topography would have been a factor as the valley is best accessed from the west, i.e. the general direction of Mylasa. Also, Mylasa would have been concerned with its eastern territories and their integrity as the evolving boundary issues with neighboring Stratonikeia would imply. ${ }^{27}$

The sanctuary of Sinuri was always the center of a syngeneia, a community typically based on kinship ties. In the fourth century вс this was the Pelekos syngeneia, but by the Hellenistic period mention is made only of the Pormounos

22 According to his notes, published in Virgilio (2010), 61.

23 I.Sinuri p. 8-9, contrasting the general altitude of $400 \mathrm{~m}$ ASL of the valley with that of Mylasa, at c. 50 m ASL; it also snowed on the day of his visit on 29 October, 1934, Virgilio (2010), 61 .

24 Devambez (1959), 5: "Du sanctuaire au contraire, null échappé pour l'oeil, et comme il n'y a là ni source, ni grotte ni quelqu'un de ces accidents naturels autour desquels se cristallise souvent la piété des primitifs, nous ne pouvons deviner pour quelle raison ici s'est installé un culte assez important pour attirer vers ce cul-de-sac, des siècles durant, un foule de fidèles."

25 See below.

26 I.Sinuri 2.

27 I.Sinuri p. 29-31. Boundary disputes between Mylasa and Stratonikeia in the mid-second century вС are the concern of I.Mylasa 134, discussed in Ager (1996), no. 101. 
syngeneia, a community which clearly belonged to Mylasa. Whether this community lived near the sanctuary, in another location, or was more dispersed among the general population of Mylasa, however, is unknown. Roughly 500 $m$ north of the sanctuary and higher up on the hill is a second monumental but unexcavated complex with two large structures; Devambez designated this area as the 'acropole'. ${ }^{28}$ The structures here may have belonged to a settlement or an annex of the shrine; a path leading from the sanctuary below seems to run in this general direction, connecting the two monumentalized places, discussed below.

Although clear indications of an ancient road to the west have yet to be discovered, it likely will have followed the valley floor, like the modern asphalt road. Departing from Mylasa, this road first runs south, passing Beçin Kale (and the route to Halikarnassos) and bending east after western tip of the Bozdağ (Figure 4.1). This route appears to be confirmed by the presence of a tower (watchtower or fortified farm?) on a low hill a few hundred meters south of modern Aşağ Kalınağıl, and roughly 3 kilometers west of the shrine of Sinuri; the tower underscores the strategic or economic importance of this valley at least in the Late Classical or Hellenistic period. ${ }^{29}$ This structure would have been related to a road and probably to some economic or defense network in the valley. ${ }^{30}$ Robert found an area covered with ceramics near the village, and two marble fragments with traces of inscriptions. ${ }^{31}$ Beyond Çamlıbelen the valley grows steeper to the north or east and it seems unlikely, though not impossible, that there was any major thoroughfare in antiquity going in these directions. ${ }^{32}$

28 Devambez (1959), 33-34, the inscriptions are I.Sinuri 6 and $8 \mathrm{a}-\mathrm{b}$. This complex is discussed in more detail below, under Architecture.

29 Robert in I.Sinuri p. 7-8 describes a Hellenistic tower of red porphyry, $9 \times 11 \mathrm{~m}$ with walls 1 $\mathrm{m}$ thick; Akarca and Akarca (1954), 122; measured and drawn in 1997, Rumscheid (1999a)a, 175. Pimouguet-Pédarros (2000), 309-310 notes that the construction of this tower, 'Kassil Alik', is similar to that of the temenos of Sinuri; she interprets it as a watchtower and part of the Hekatomnid rural fortification system (ibid. 118-122, 124, and 317 n. 1312). Lohmann, however, believes it to be part of a farmstead because of its fertile setting and because he sees no reason to place a military watchtower at this location, Lohmann (2005), 43.

30 Pimouguet-Pédarros (2000), 124: “... la tour de Kassil Alik commandait la route de Mylasa à Sinuri." On the road network around Sinuri, Hild (2014), 44.

31 Robert in I.Sinuri, p. 7-8, I.Sinuri 1.

32 Hild (2014), 44 indicates that Sinuri was also accessible from Stratonikeia, but the terrain is prohibitive and there are few indications of contact that would suggest any major route of access from the east. 


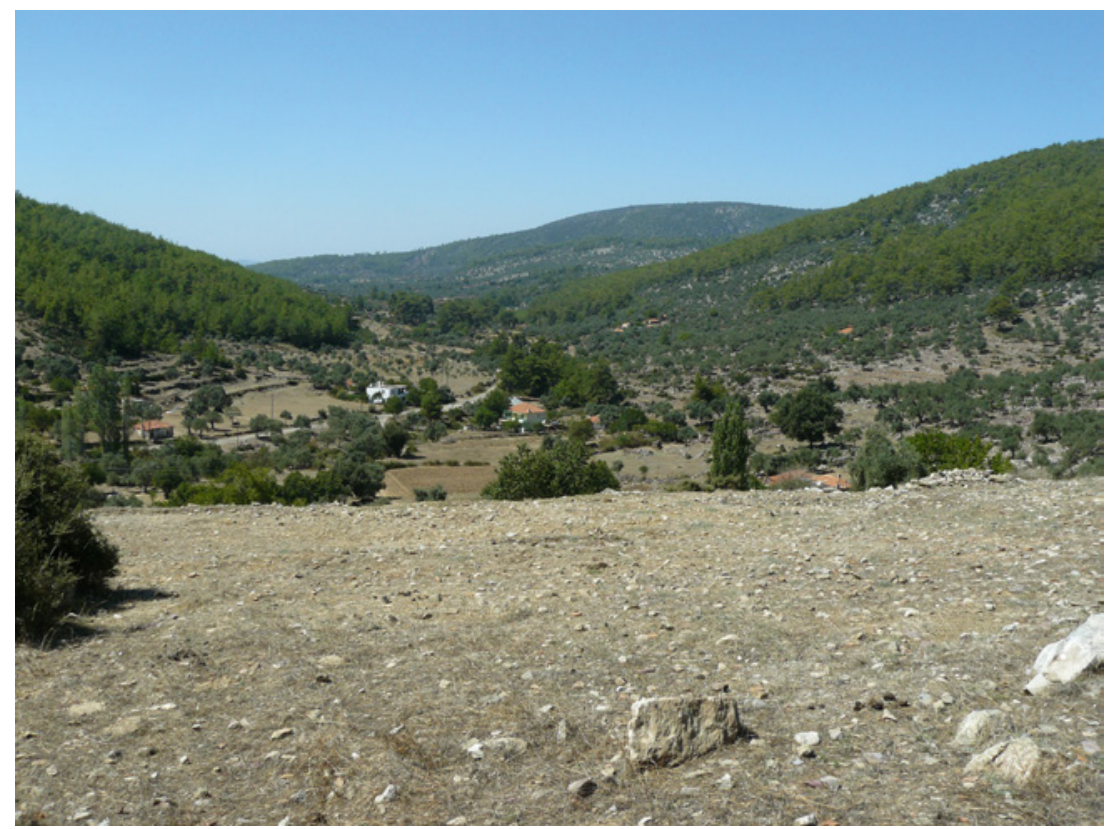

FIGURE 4.3 Sinuri. Extent of the view from the sanctuary to the west and the Bozdağ in the distance

PHOTO AUTHOR 2010

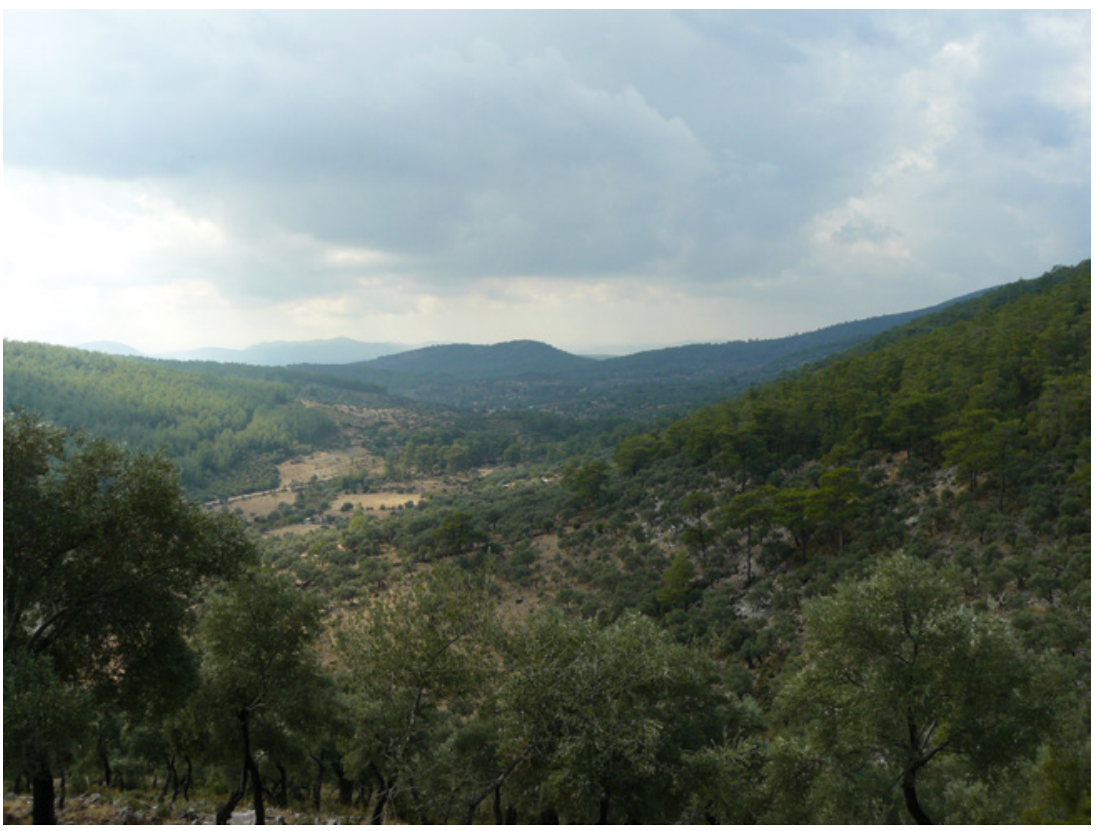

FIGURE 4.4 Sinuri. View from the northern 'acropole' complex looking west with the sea, the Myndos peninsula and the peaks of Kalymnos visible in the far distance PHOTO AUTHOR 2011 


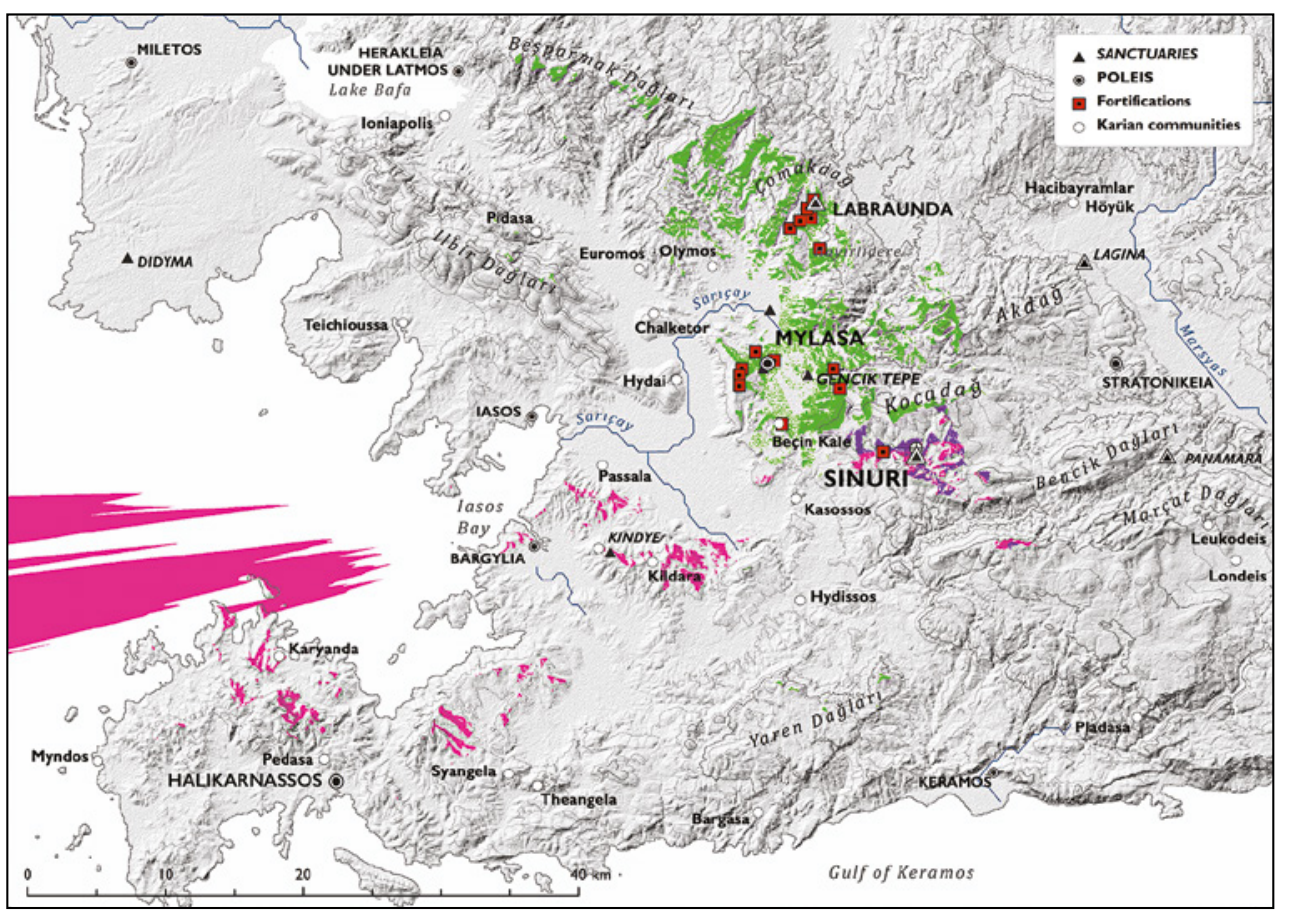

FIGURE 4.5 Viewsheds of Mylasa (green), the sanctuary of Sinuri (purple) and 'acropole' (fuchsia)

\subsection{Visibility}

The sanctuary is positioned towards the eastern and upper end of the valley, with a fair view down the valley to the west and the Bozdağ mountains southeast of Mylasa (Figure 4.3). The surrounding mountains to the north, east and south, however, obscure any view beyond and Devambez aptly describes the sanctuary as being in a 'cul de sac'. ${ }^{33}$ The structures higher up on the 'acropole' would have been visible, at least in part, although they are now entirely occluded by a forest. This area, roughly $15^{-20}$ minutes by foot to the north, offers a much better view to the west and the mountains of the Myndos peninsula near Halikarnassos, even the peaks of Kalymnos might visible on a clear day (Figure 4.4). ${ }^{34}$ The lower situation of the shrine, then, may well indicate a tight connection of the cult place with the valley. In any case, the view is entirely isolated from that of Mylasa (Figure 4.5).

33 Devambez (1959), 5, cited above.

34 Devambez (1959), 5-7. 


\section{Signs of Urban Integration at the Sanctuary of Sinuri}

The ways in which the relationship between the deity Sinuri and its community were expressed through the sanctuary in this narrow valley southeast of Mylasa are closely examined in this section, with an eye to the changes that took place in the Hellenistic period. Although the community involved was effectively a subdivision, rather than the entire polis, this is a prime example of how popular urban identity could be expressed through local shrines, and how these were conceptually modelled on the larger polis sanctuaries.

\subsection{Monumental and Ritual Space at the Sanctuary of Sinuri}

The sanctuary of Sinuri is quite a bit smaller than Labraunda and situated in a much more secluded area; nonetheless it was monumental and clearly built to impress, as the imposing robust walls make clear. The design, though partly obliterated by the construction activities of the Byzantine period, was still clear enough for Devambez to make a general plan of the layout in the different periods (Figure 4.6), showing a number of remarkable transformations which will be discussed in this part.

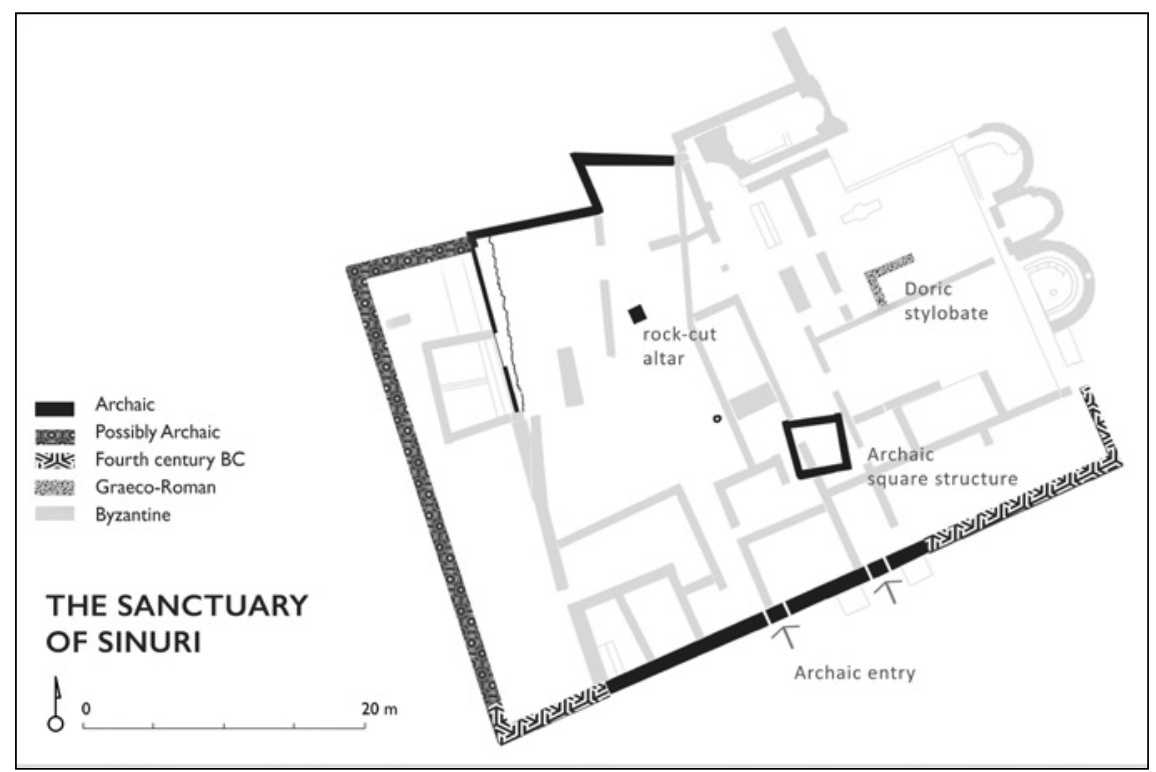

FIgURE 4.6 Plan of the sanctuary of Sinuri. After Devambez 1959, 47 and Pedersen 1991, 104 and Fig. 104; orientation assessed by author 


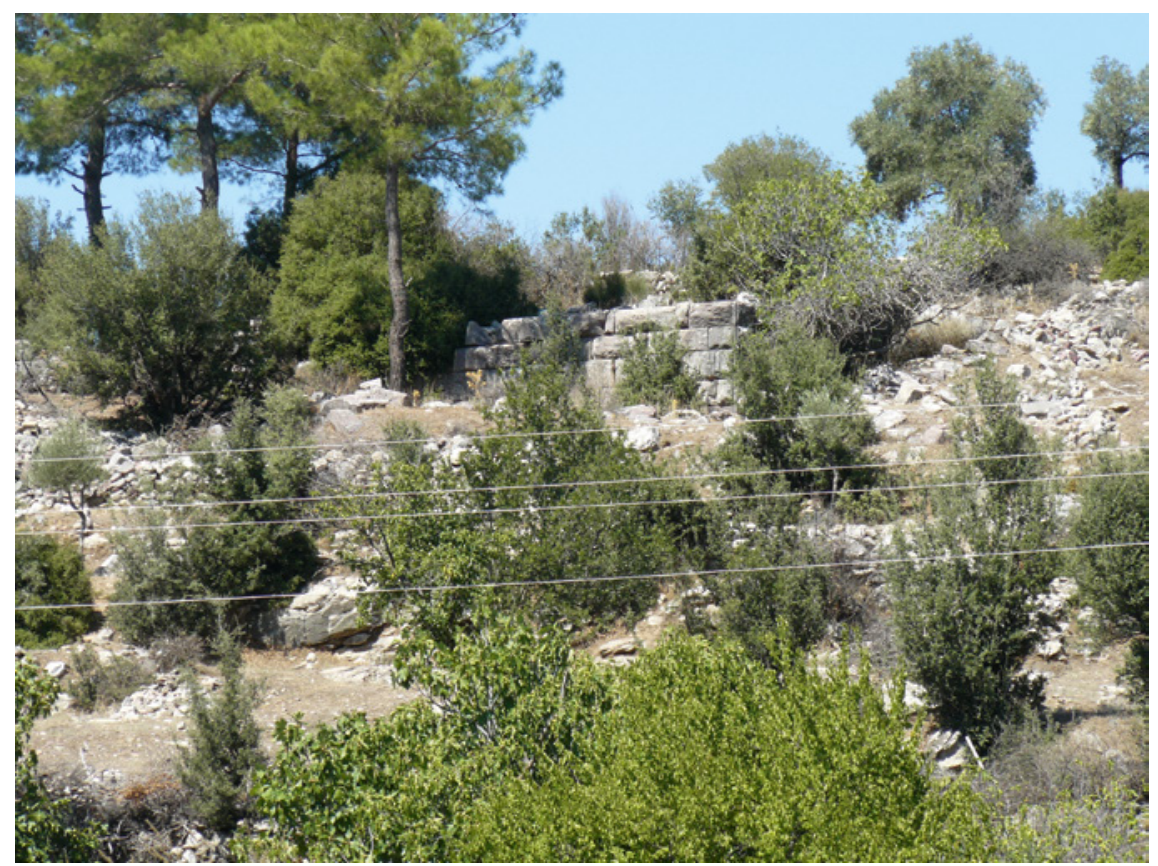

FIGURE 4.7 Sinuri. View of the sanctuary showing the southeast flank of the temenos wall, the drafted corner is visible PHOTO AUTHOR 2010

\subsubsection{Architecture}

The most prominent features are the temenos walls (Figures 4.7-9). Stretches of these are built of piled stone and date back to the Archaic period, when the first visible signs of a sacred place appear on this hilltop. ${ }^{35}$ Even in this period, the south(east) wall was the grandest, partly because it was on the lower side of the hill facing the valley, but also because of the robust construction technique (Figure 4.8). The entrance to the sanctuary in the Archaic period was located in this southern wall; Devambez considers this to be due in part to its relationship with the road from Mylasa, and the pilgrims arriving from there. ${ }^{36}$ Other structures interpreted as belonging to the Archaic period include the large rock-cut altar, a small square structure of unknown purposes, and a

35 Devambez (1959), 10-13 on the Archaic walls, $13^{-15}$ for the structures, and $23^{-25}$ for an overview of the Archaic period at the sanctuary.

36 Devambez (1959), 10 "Nous ne nous étonnerons pas que l'entrée du lieu saint ait été place ainsi vers le sud, c'est-à-dire du côte le plus proche du fond du ravin par où, sans doute, les fidèles venus de Mylasa se rendaient en pèlerinage." 


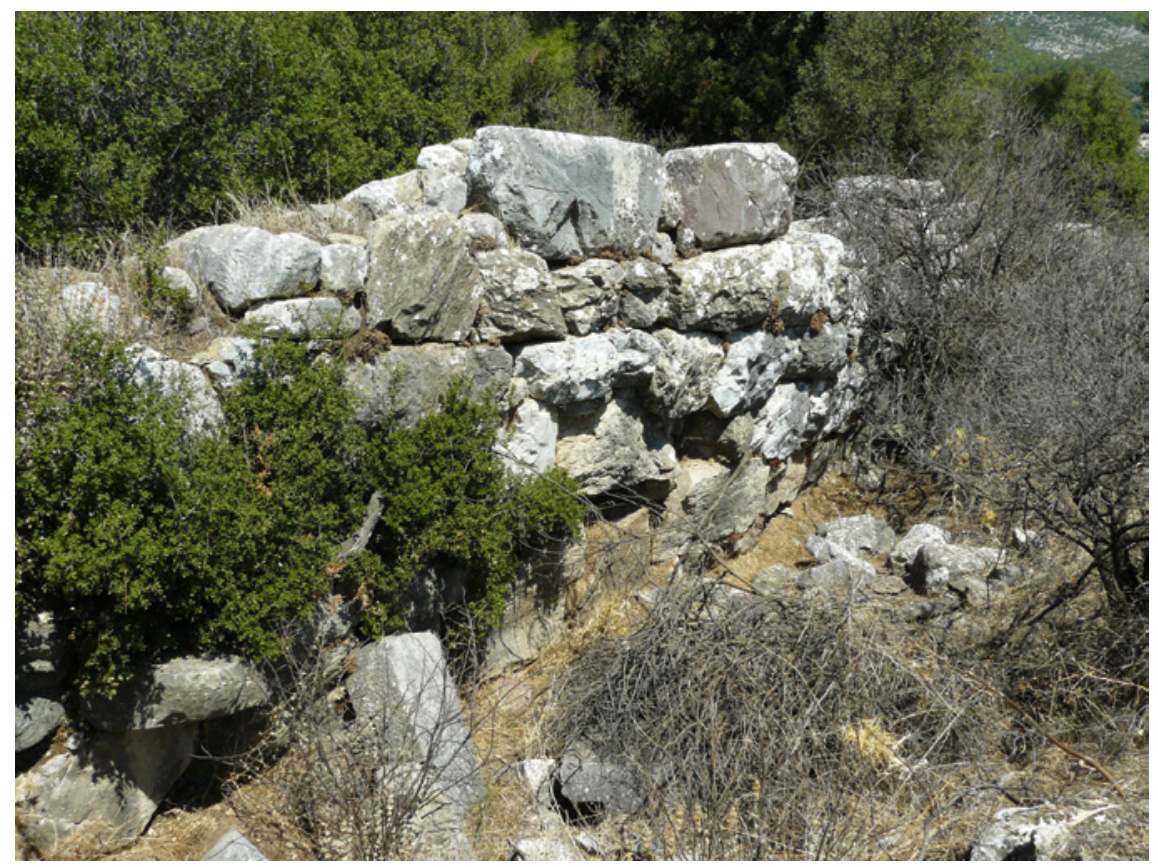

FIGURE 4.8 Sinuri. South section of the Archaic terrace/temenos wall PHOTO AUTHOR 2010

fossa, or dug-out storage area, where four large storage jars (pithoi) were found in situ. ${ }^{37}$

Like Labraunda and the sanctuary for Artemis at Amyzon, the sanctuary of Sinuri profited from royal Hekatomnid patronage in the first part of the fourth century. ${ }^{38}$ One inscription records their dedication of an altar table (trapeza) and probably a doorway (thyromata). ${ }^{39}$ The fine ashlar walls, still standing (Figure 4.9), date from this time as well, given the header and stretcher

37 Ceramics were found from the Late Geometric period on, with a peak in the late Archaic period, and a sharp decline after 5 оо вС, Devambez (1959), 9-25, 27. On the early period of the sanctuary, see Devambez (1959), 13-15; the pithoi are shown on Pl. IV, fig. 4 and Pl. XIV, figs. $2-3$.

38 Robert discusses Hekatomnid dedications at sanctuaries in general in I.Sinuri p. 102; see also Hornblower (1982), 274-293; Pedersen (1991), 100-107.

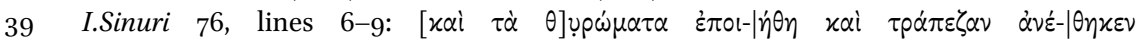

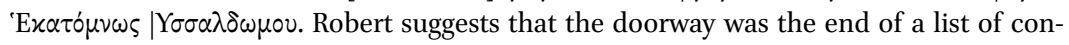
structions at the sanctuary by the syngeneia, while the altar table was specifically dedicated by Hekatomnos, hence the distinction in verbs, Robert in I.Sinuri, p. 99 . 


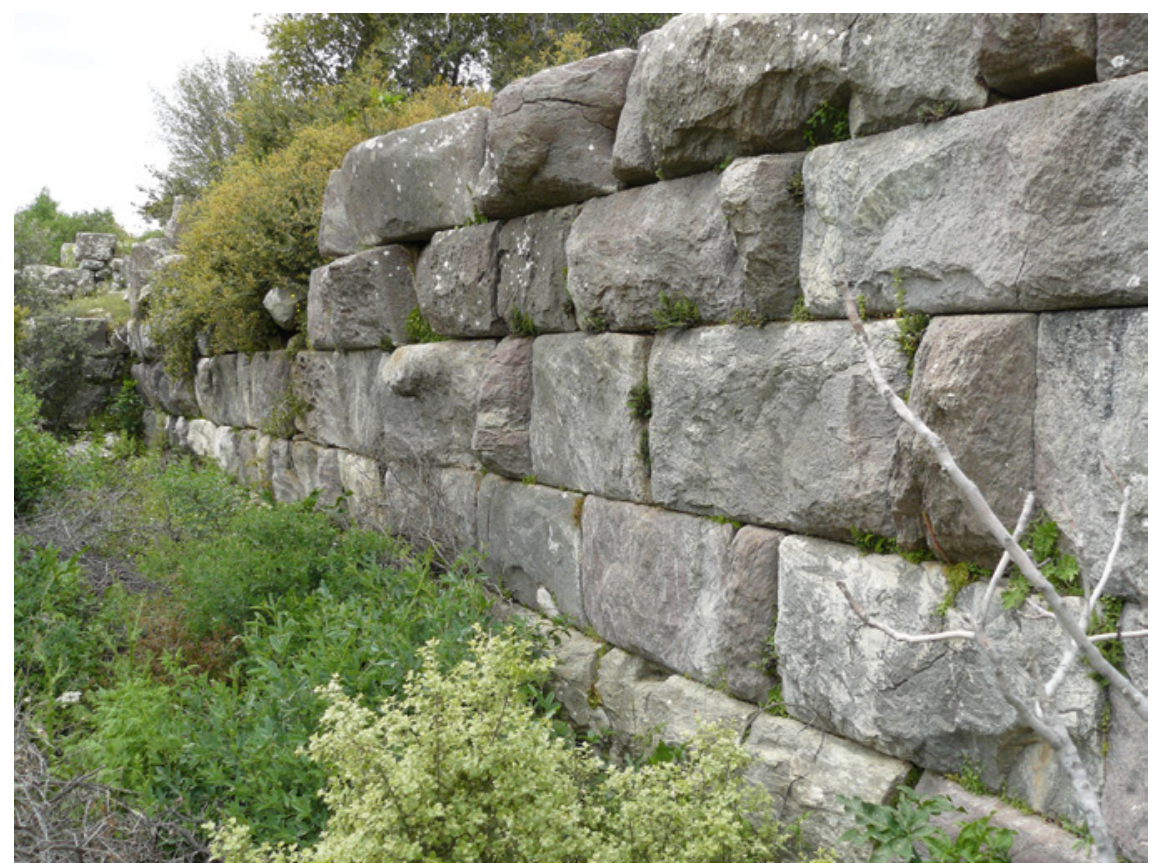

FIGURE 4.9 Southeast corner of the sanctuary with the fourth century temenos wall, showing the ashlar construction with headers and stretchers

PHOTO AUTHOR 2008

technique typical of Hekatomnid construction projects in the fourth century. ${ }^{40}$ The sanctuary was not only significantly expanded in this period to the east, but the southern temenos wall was also turned into a terrace wall: while the outer face consisted of regular ashlars, the inner face of this wall was made up of roughly piled stone, not meant to be seen; also, the Archaic southern entrance was blocked (Figures 4.10-4.11). Finally, the entire area was filled with earth. ${ }^{41}$

These modifications, together with the southwest corner of the temenos wall that underwent repairs in the same period, have been interpreted by Poul Pedersen as characteristic of the Hekatomnid 'modernization' of an old sanctuary, as at Labraunda, albeit on a much smaller scale. ${ }^{42}$ In his view, the trans-

40 Devambez dates the fine ashlar wall (Figure 4.10a-b) to the first part of the fourth century, Devambez (1959), 28-29. On Hekatomnid construction technique - here and at Labraunda, Halikarnassos, and Alinda, among many other places - see Pedersen (1991), 103-104.

41 Devambez (1959), 28-29.

42 Pedersen (1991), 103. 


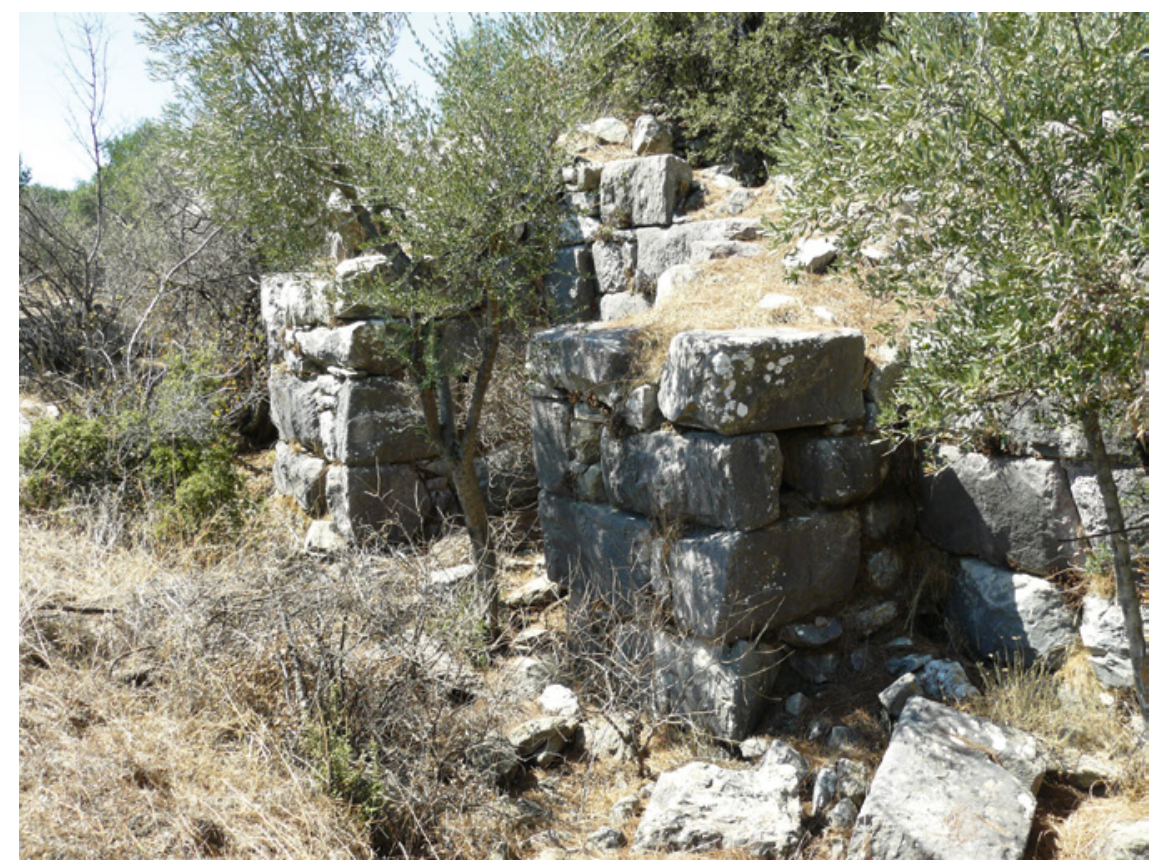

FIGURE 4.10 Sinuri. Archaic gateway with buttresses in the south wall PHOTO AUTHOR 2010

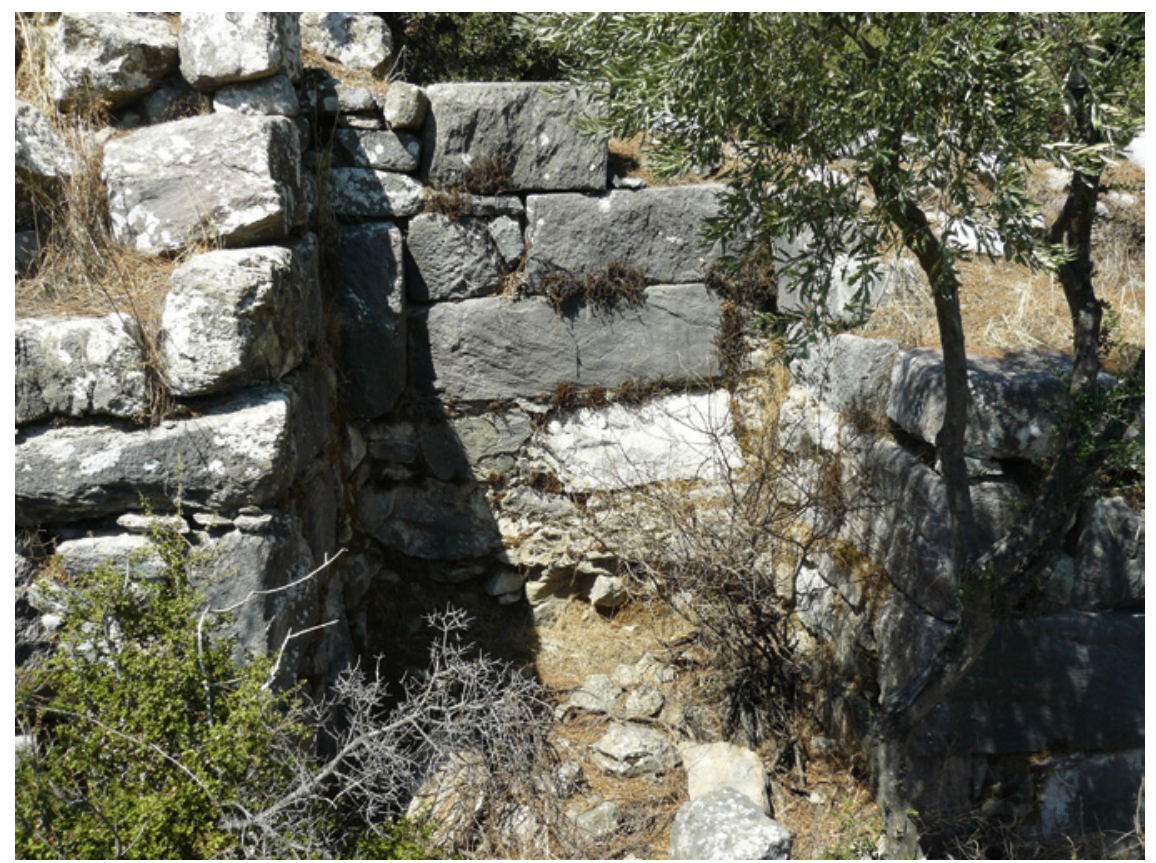

FIGURE 4.11 Sinuri. Archaic gateway with mid-fourth century blockage of the entry Pното AUTHOR 2010 
formation of the old Archaic sanctuary into a monumental platform perfectly coincides with the Hekatomnid approach, as the terraces not only expand the area for structures, but actually set them off. Like the lower retaining wall of Labraunda, the "long stretches of walling, often with rusticated, bossed ashlar work" shown in Figure 4.9 would have impressed and humbled the viewer upon approach. Moreover, the filtered access of staircases and staggered entries "were properties fitting to the buildings of gods and rulers, and in this sense the Karian terrace architecture could constitute the conceptual prototype for much Hellenistic architecture, not least the Pergamene."43

The Archaic structure was covered by the fourth century terrace, yet no evidence for a temple was found during the excavations. While this could support Carstens' suggestion that Sinuri had an open-air sanctuary, ${ }^{44}$ the fact that most of the eighty-plus inscriptions were cut into the surfaces of fine marble ashlars (rectangular architectural blocks), several of which were reused in the Byzantine structures along with other architectural pieces from the ancient sanctuary (Figure 4.12), points to some kind of monumental architecture. At least one of the inscriptions was cut in the local dark red marble (Figure 4.12-13), but many were in white marble, with a few in bluish-grey or black-and-white; these are not local and would have had to have been transported to the valley, perhaps from the quarries near Mylasa. In any event, they give us an idea of the bright and colorful contrasts in the use of building material, even though we do not know the exact location or function.

A good deal of the ashlars must have come from a stoa known to have been added to the sanctuary in the Hellenistic period. ${ }^{45}$ Figure 4.13 shows the striking block from the local red marble carrying the decision by the Pormounous syngeneia to construct a stoa, I.Sinuri 9. The direction of the text, across the narrow side of the block (shown here upside down), and the dowel hole in the short side indicate that this may have been part of a door jamb, perhaps from the stoa itself.

The Doric stylobate, discovered in the mid-eastern section of the sanctuary may have belonged to this stoa, although Pedersen considers a Hekatomnid

\footnotetext{
43 Pedersen (1991), 114-115.

44 Carstens (2009), 108-109.

45 I.Sinuri 9 (Figure 4.13b) and 1o both pertain to a decision by the Pormounos syngeneia to construct a stoa; Robert (I.Sinuri p. 28-29) relates this with I.Mylasa 502 , where a syngeneia appoints certain members to maintain the cult statue, part of the pronaos, and the altar of their sanctuary. On the stylobate, which once supported Doric columns, see Devambez (1959), 29-30.
} 


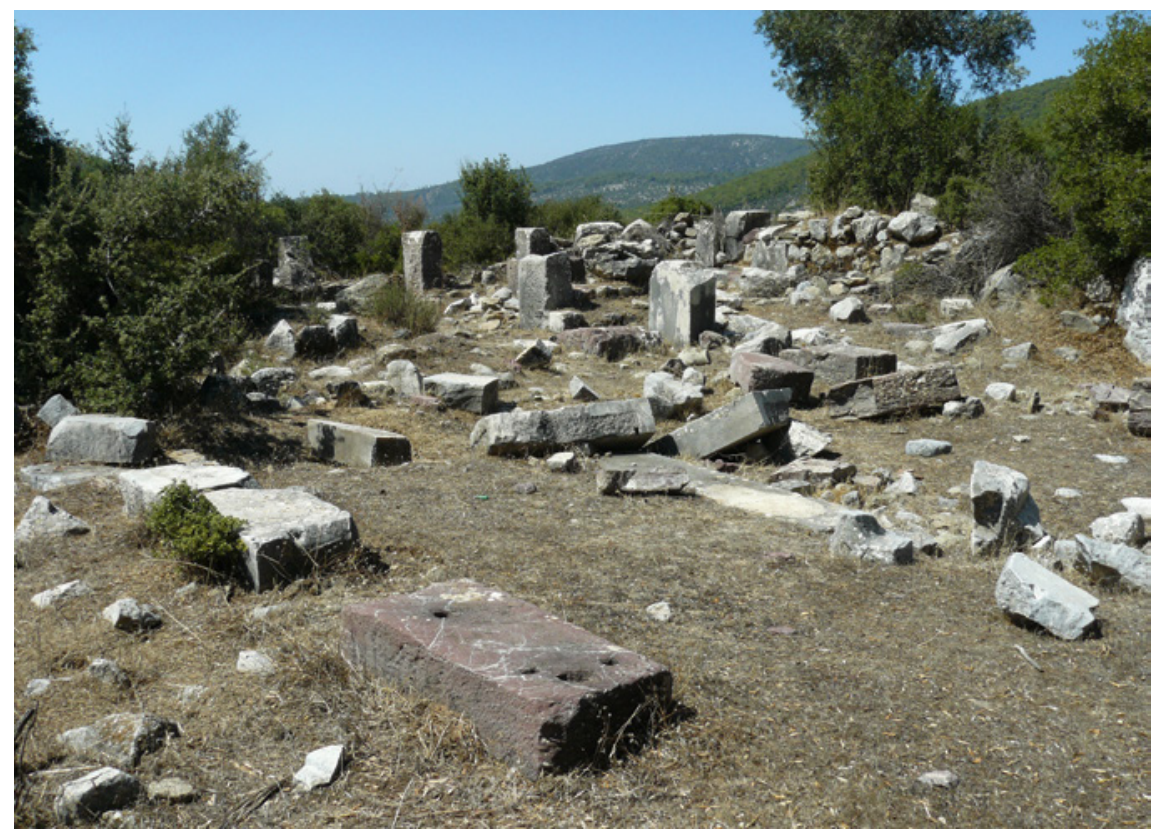

FIGURE 4.12 Sinuri. Central space of the sanctuary, view to the west. The Doric stylobate is in the middle right. The upright blocks belong to the Byzantine basilica PHOTO AUTHOR 2010

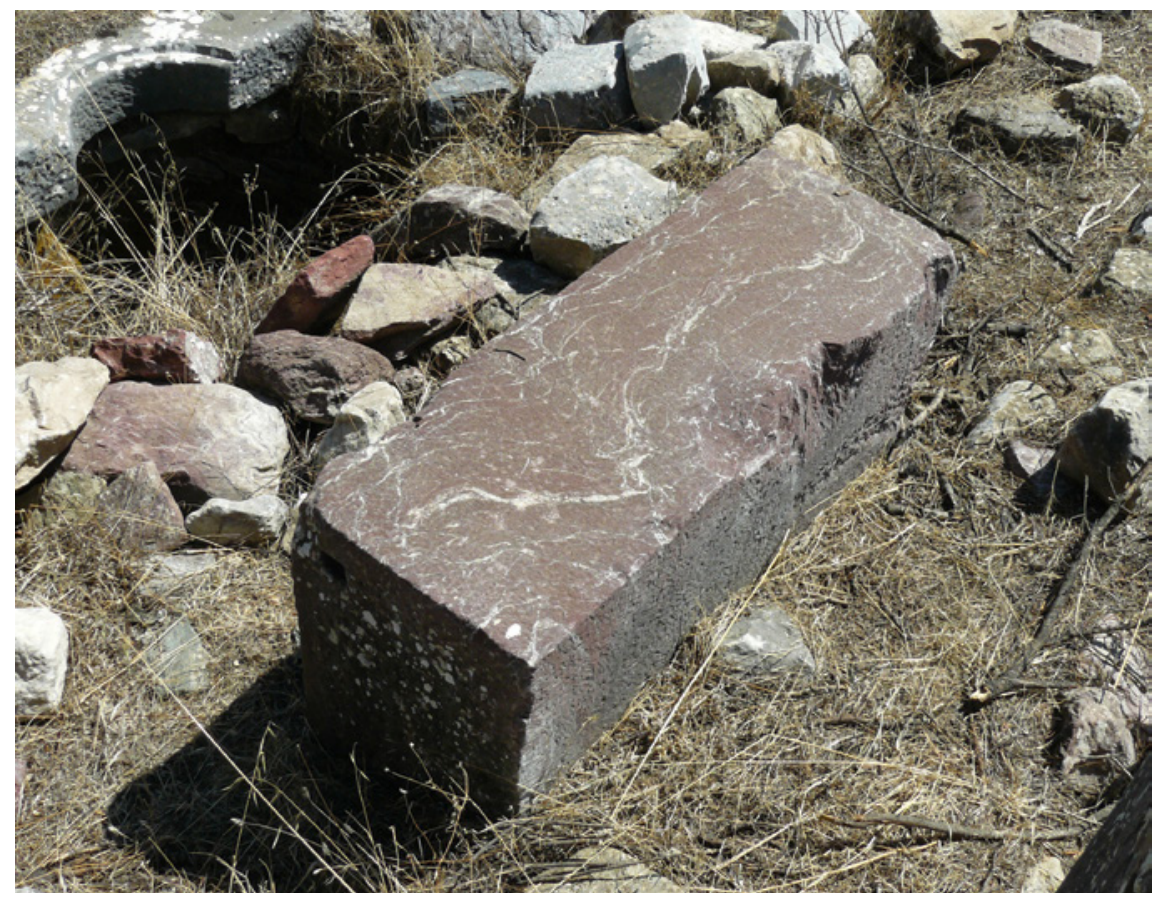

FIGURE 4.13 Sinuri. The eastern stoa. Red marble block, $118 \times 42.5 \times 67 \mathrm{~cm}$, carrying I.Sinuri 9 , honorific decree for Leon Iasonos et al. concerning the building of a stoa; the well is in the background 


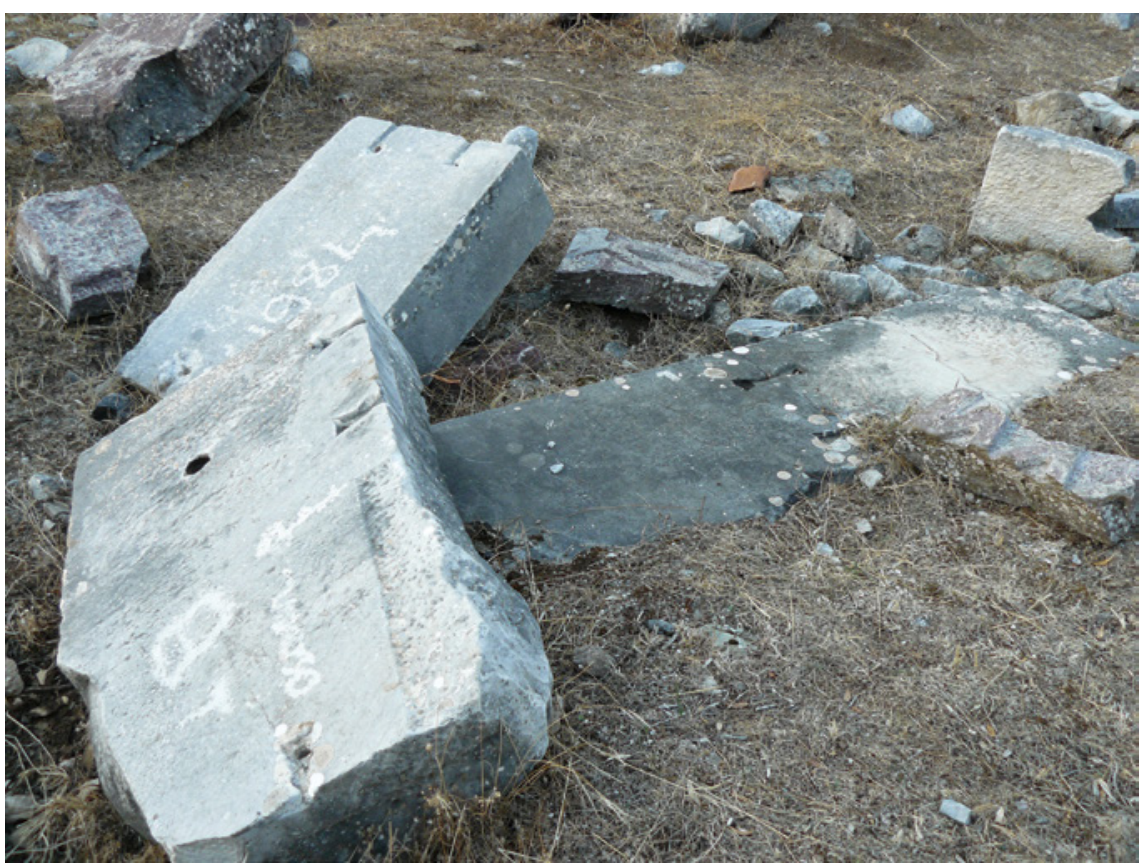

FIGURE 4.14 Sinuri. The eastern stoa. Section of the stylobate, with holes for dovetail clamps

PHOTO AUTHOR 2011

date based on the dovetail clamps (Figure 4.14). ${ }^{46}$ The trace of a column was found in the western corner indicates the southwest orientation of the structure, i.e. towards the interior of the sanctuary. Only the northwest corner of the stylobate was found, already indicating that it follows the same orientation as the south and east walls of the sanctuary (see plan, Figure 4.6). Given the narrow space between the stylobate and the eastern edge of the temenos, a stoa seems the most plausible interpretation for this structure.

One last feature that reflects the public nature of the temenos area is the bema, or step-like podium, on which some of the honorific decrees or

46 Devambez (1959), 29; Pedersen (1991), 103. If Pedersen is correct then the inscriptions would refer to a second stoa at the sanctuary, which would have been destroyed by the later construction activities. However I.Sinuri 10, discussed below, mentions the construction of a stoa in the east and that would seem to refer to this stylobate; I lean towards the interpretation of this stoa as the one referred to in the inscriptions, but making use of known techniques. 
monuments were to be erected. ${ }^{47}$ We cannot be certain as to where this was, although given the directional specifications for the location, 'on the left-hand as one enters ..., Robert suggests the gateway (pylon) in his restoration of the text. ${ }^{48}$

Roughly half a kilometer to the north of the sanctuary and fifty meters up the hill is a second monumental complex. Devambez designated this area as the 'acropole', where he discovered an embankment with retaining walls. ${ }^{49}$ He measured this terrace at some $5^{\circ} \mathrm{m}$ across, i.e. roughly as large as the surface area of the Archaic the sanctuary of Sinuri. Access was provided from the south by a ramp of c. $11.30 \times 3.60 \mathrm{~m}$. Devambez reported several marble blocks and two Doric capitals that he believed originated from this upper area. ${ }^{50} \mathrm{He}$ reported two structures on the terrace: an elongated building of $21 \times 6.50 \mathrm{~m}$, east-west, and opening to the south; and a second structure with two chambers some $20 \mathrm{~m}$ to the northwest, with an overall dimension of c. $12.75 \times 3.20 \mathrm{~m}$ and a similar alignment. Observing both the rough construction but also care given to certain details, e.g. the Doric capitals and moldings on certain pieces, Devambez remained in doubt as to the purpose of this complex, whether it had a 'rôle religieux' or were 'bâtiments civils'.51

Now heavily overgrown, these structures were 'rediscovered' by the author in 2011 (Figures 4.15-4.19). The embankments are constructed with large polygonal blocks with smoothed faces (Figure 4.15).

The southern tri-partite structure was constructed with rough ashlars on a foundation of irregular blocks, not unlike the shrine lower down. The chambers could each be entered through a central threshold, roughly two meters in width (Figure 4.16). The smaller building was found some forty meters to the northwest but was in much poorer condition, with walls of irregular doublefaced blocks. A crosswall could be distinguished (Figure 4.17), perhaps indicating two separate chambers or a chamber and a 'porch' area, not inconsistent with a small temple. ${ }^{52}$

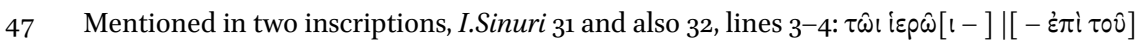
B.ं $\mu \alpha \tau[\circ \varsigma$.

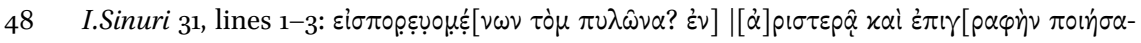

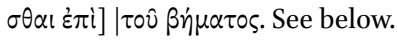

49 Devambez (1959), 33-34. Rediscovered by the author in October 2011; the heavy undergrowth and density of pine trees prevented accurate GPS recordings or verification of Devambez' measurements.

5 O Devambez (1959), 34 .

51 Devambez (1959), 34 .

$5^{2}$ Robert had suggested the possible presence of a temple on this hill, I.Sinuri, p. 20-22; see also Akarca and Akarca (1954), 122-123. 


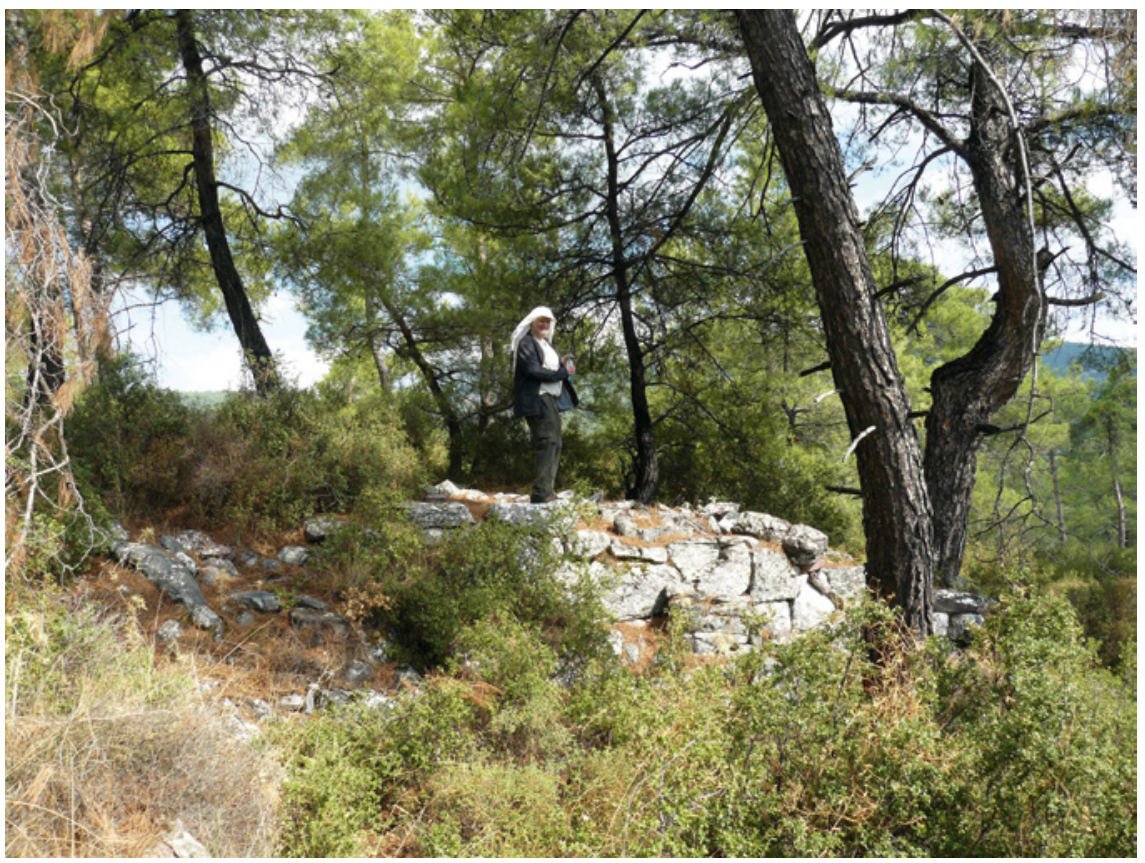

FIGURE 4.15 The 'acropole' complex, c. 450 m north of the sanctuary of Sinuri. Terrace structure. Southwest corner, with polygonal wall PHOTO AUTHOR 2011

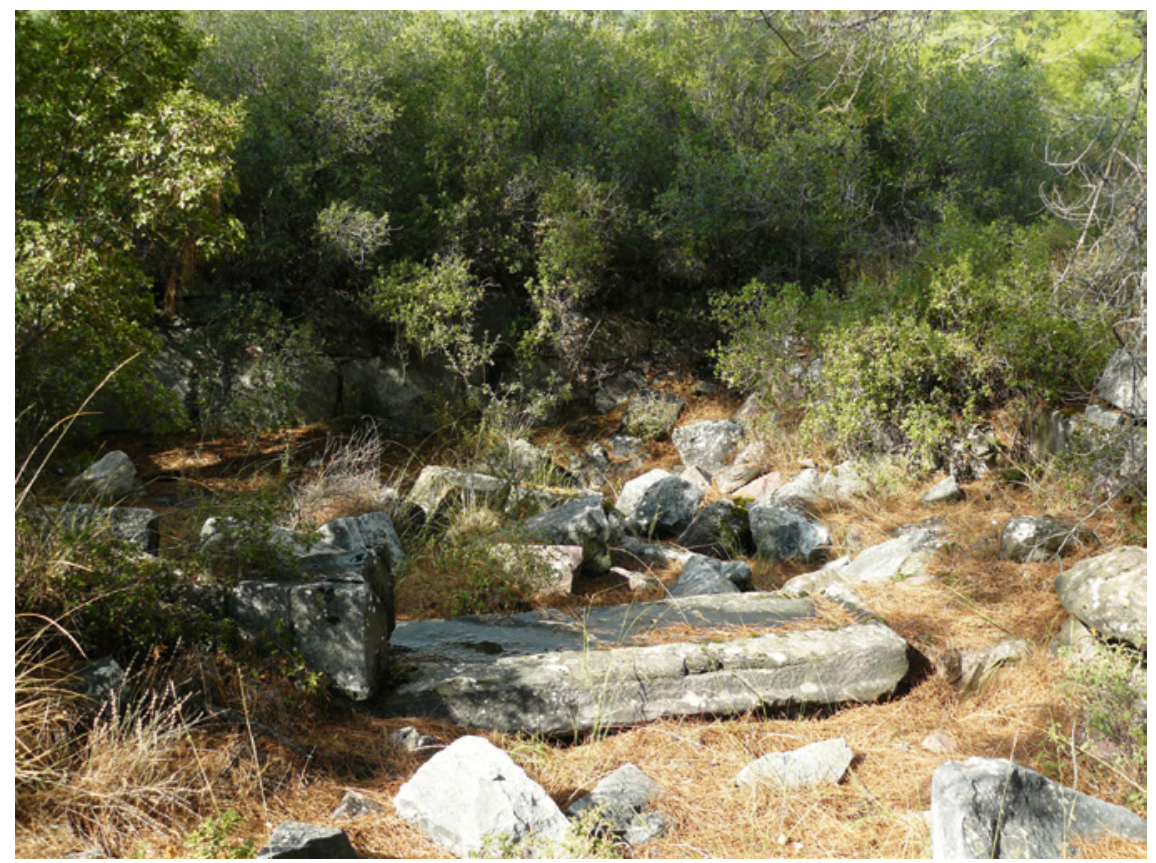

FIGURE 4.16 The 'acropole' complex. Square chamber with threshold in the southern wall рното AUTHOR 2011 


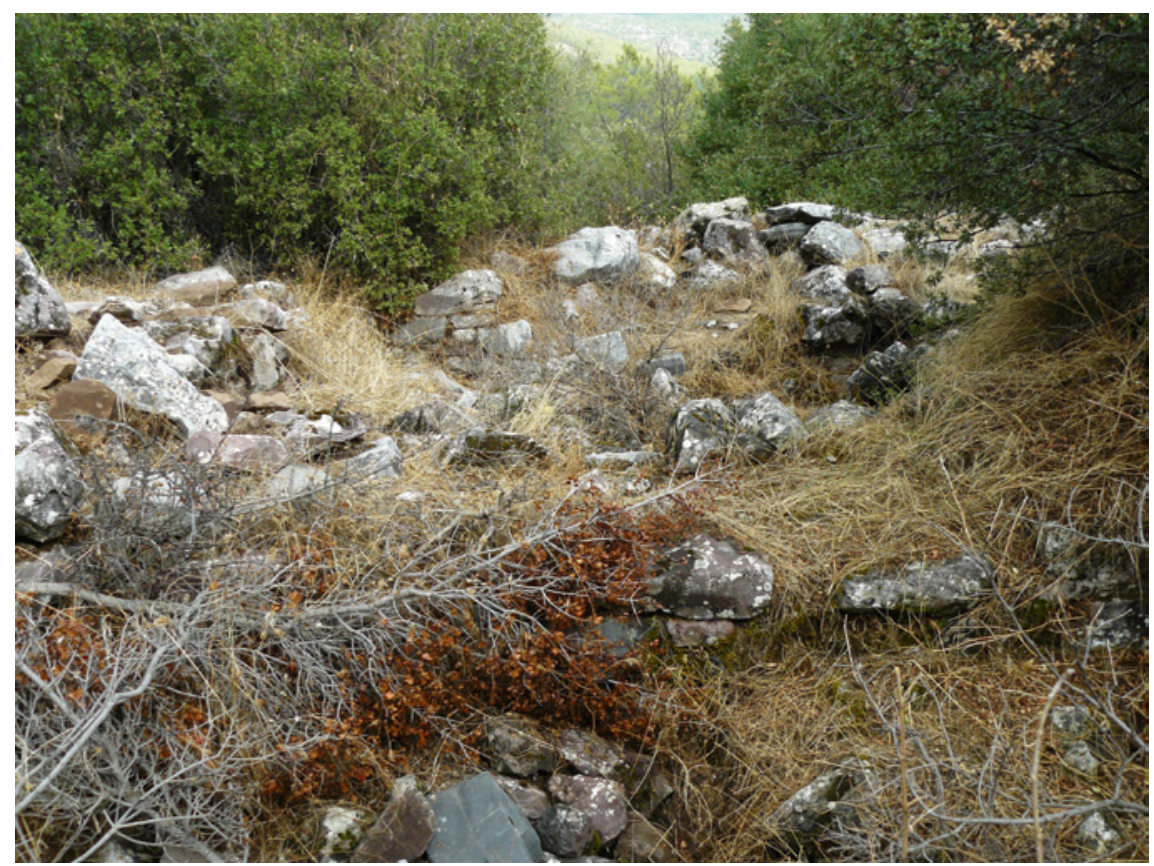

FIGURE 4.17 The 'acropole' complex. Smaller bi-chambered structure north of the terraced structure. Facing east. In the middle is the crosswall separating the two areas PHOTO AUTHOR 2011

More walls, loose ashlars, and cisterns may be found immediately to the south (Figure 4.18). Devambez did not discuss this area in any detail, yet the structures must have been coeval with the sanctuary and the two priestly dedicatory inscriptions found here clearly indicate a cultic connection. ${ }^{53}$ The stoa-like appearance of the multi-chambered structures suggests an auxiliary function, perhaps used during festivals, or as residence of the priests, or possibly connected to some settlement activity, although high concentrations of ceramics (especially storage vessels and rooftiles) seen along the terraces to the south indicate intensive use (Figures 4.19). The rock-cut tomb found roughly midway between the sanctuary and this complex could correspond with this, as well as the rock-cut feature closer to the shrine (Figures 4.20 and 4.21).

The 'acropole' complex occupies a prominent place on the hilltop overlooking the sanctuary and enjoyed a much more extensive view of the valley and the mountains beyond towards the west (Figure 4.4). Whether we should

53 Devambez (1959), 33-34. The inscriptions are I.Sinuri 6 and $8 \mathrm{a}-\mathrm{b}$, dedications by Hiereus and by his grandson Menippos, both listed as priests of Sinuri on I.Sinuri 5 . 


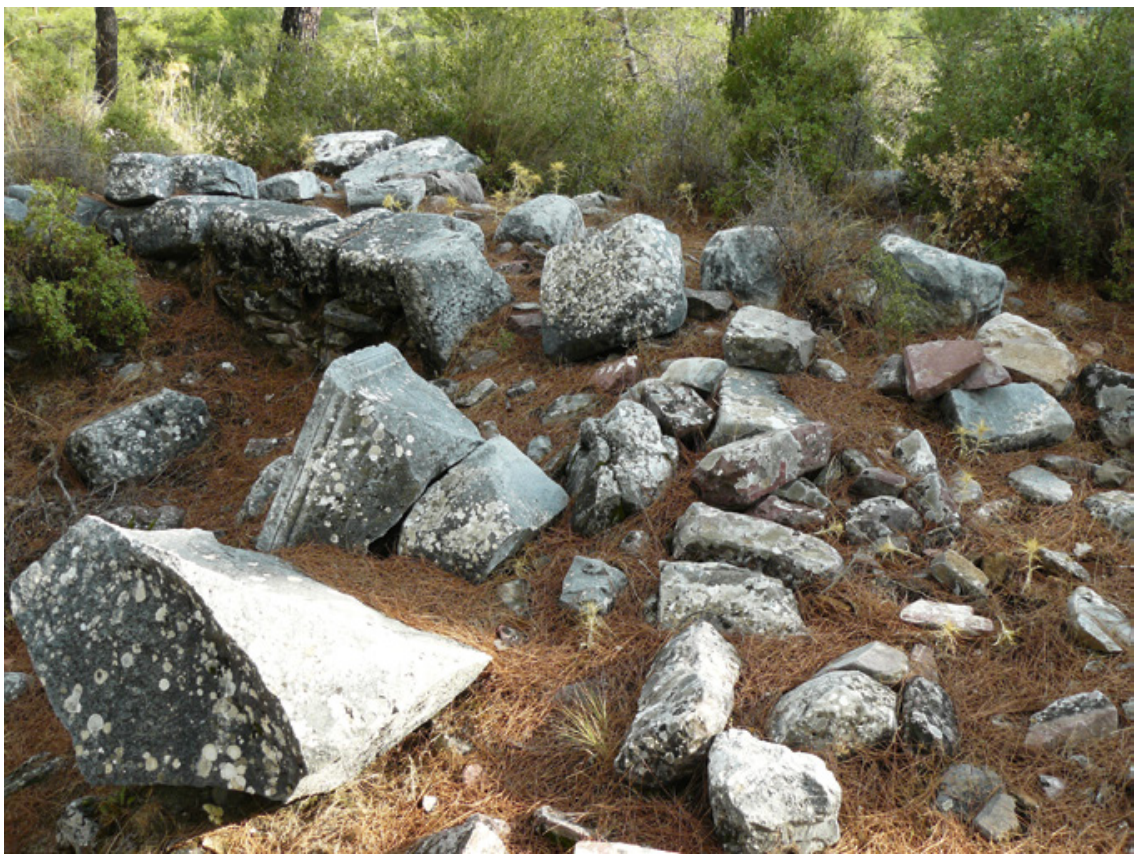

FIGURE 4.18 The 'acropole' complex. Walls and profiled blocks PHOTO AUTHOR 2011

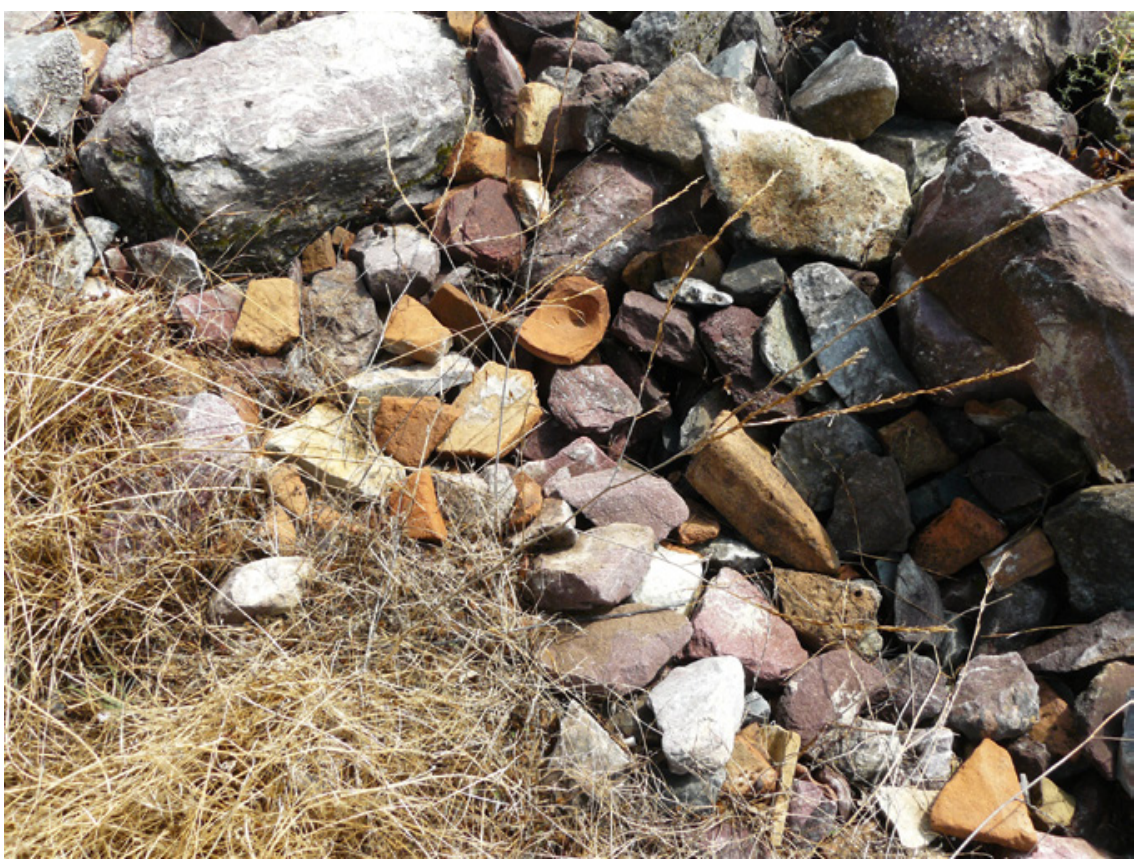

FIGURE 4.19 Ceramic concentration in terrace wall near the 'acropole'

PHOTO AUTHOR 2011 


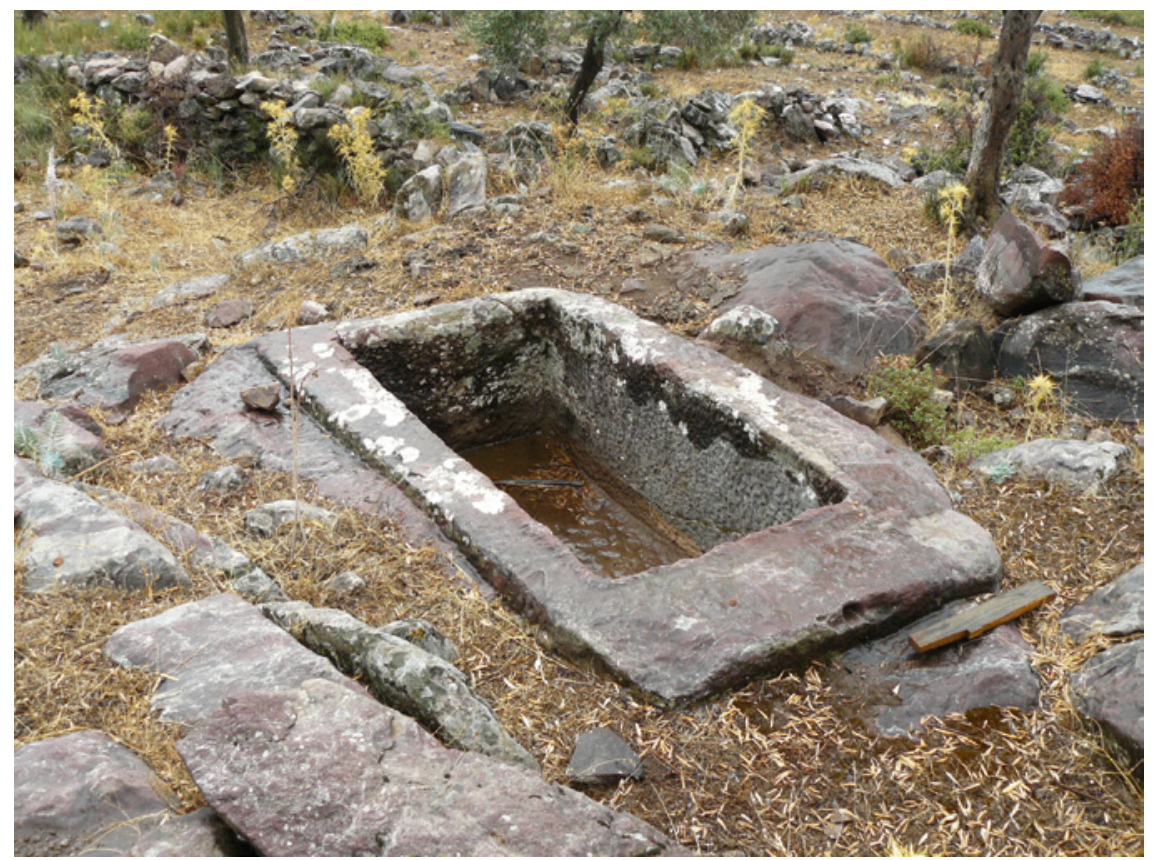

FIGURE 4.20 Rock-cut tomb c. 250 m north of the sanctuary of Sinuri PHOTO AUTHOR 2011

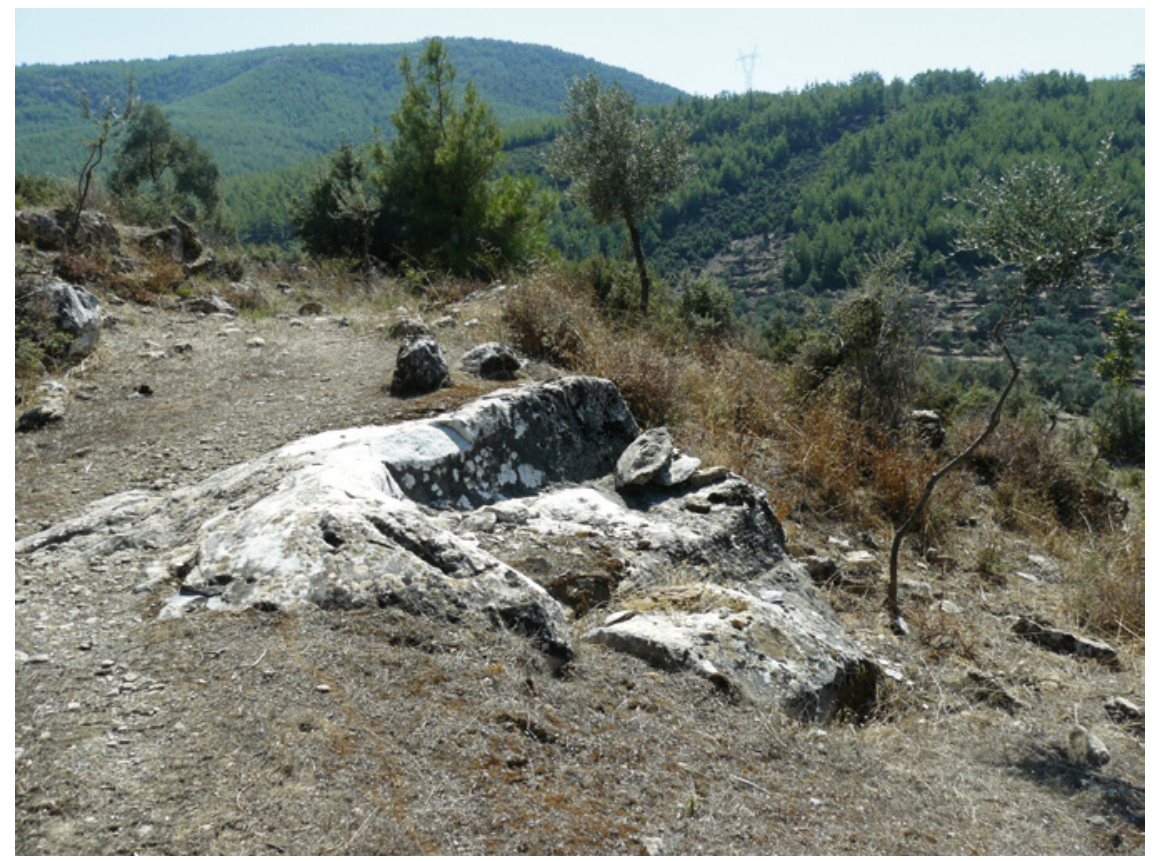

FIGURE 4.21 Rock-cut feature c. $110 \mathrm{~m}$ north of the sanctuary of Sinuri PHOTO AUTHOR 2010 
interpret this as some kind of permanent settlement, perhaps the political base for the syngeneiai, or whether it was mostly connected with the sanctuary during the festival must await further investigation, but the remains point towards a vibrant community at the sanctuary that took great pride in itself, with activities that extended well beyond the temenos of the shrine.

\subsubsection{Public Space - Concentric and Linear}

At about $30 \times 60 \mathrm{~m}$, the enclosed space of the sanctuary proper in the Late Classical and Hellenistic periods, though modest in comparison with Labraunda, was nonetheless impressive for such a seemingly remote site. ${ }^{54}$ The Doric 'stoa', or other structure that belonged to the stylobate, would have enclosed the temenos on its eastern side, drawing emphasis to the opposite area south of the altar as a space where a sizeable crowd could gather. Although less articulated than at Labraunda, this focused area would also have functioned as 'concentric space' for ritual activities to be performed and observed. ${ }^{55}$

Linear space is more difficult to discern at the sanctuary of Sinuri, with so little architectural or even landscape features to go by. Still it seems clear that the 'stoa', besides providing a backdrop, would also have created a kind of northeast-southwest axis across the sanctuary. This would have directed the view towards the west and southwest, the area south of the altar, and perhaps even towards the western access road from Mylasa. The excavator had observed that the Archaic building and the altar were both oriented towards the west (i.e. west-southwest). ${ }^{56}$ In fact, this coincides with the only 'panorama' that the valley has; the hills surrounding the sanctuary on the north, east, and south sides provide a natural telescopic view to the west, with the gentle crest of the Bozdağ at the far end (Figures 4.3-4.5).

Despite the sparsity of secure architecture at this sanctuary, several inscriptions actually tell us where the critical spots in the sanctuary were, even though they were not found in situ. Many of the honorific inscriptions explicitly state where they were supposed to be set up: next to the entrance. ${ }^{57}$ The entrance will likely have been part of the same complex with the doors (thyromata) dedicated in I.Sinuri 76, discussed above. In any event, the gateway (pylon)

54 The total area of the temenos of Sinuri is calculated at roughly $1500 \mathrm{~m}^{2}$, whereas that of Labraunda was at least $7200 \mathrm{~m}^{2}$; Pedersen (1991), Fig. 99.

55 On the terminology, see Chapter 2.

56 Devambez (1959), 30: “... l'orientation à l'ouest pourrait être rituelle dans le culte de Sinuri: c'est à l'ouest que s'ouvre le petit édifice mentionné plus haut [Archaic small square structure - CGW], vers l'ouest aussi qu'est tourné l'autel rupestre."

57 I.Sinuri 31 was to be inscribed left of the gateway, and nos. 11, 16 (Figure 4.15a-b), 28, and 33 were further to be inscribed on the left doorpost (parastas). 

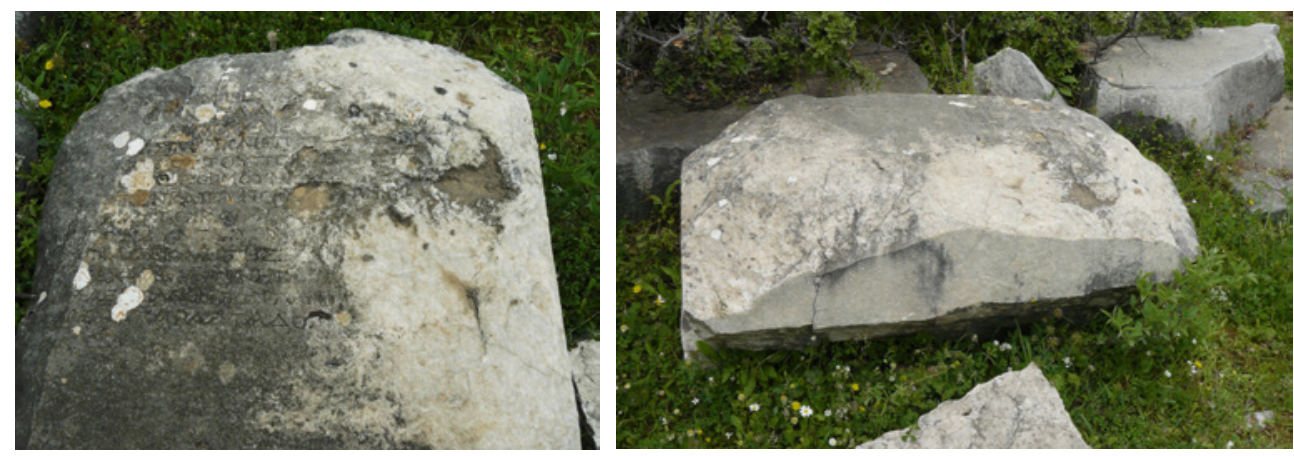

FIGURE 4.22 Two images of the white marble block carrying I.Sinuri 16 . This heavily damaged block, measuring $100 \times 62.5 \times 52.5 \mathrm{~cm}$, bears an honorific decree by the syngeneia of Pormounos for $[\mathrm{Ou}]$ liades $\mathrm{Po}[\ldots]$. The image on the left shows the text, indicating that this block was set up vertically. The last line states that it is to be erected on the left parastas ([ $[\dot{\varepsilon}] \nu$ $\dot{\alpha} \rho \sigma \tau \varepsilon p \hat{\alpha} \pi \alpha \rho \alpha \sigma \tau \dot{\alpha} \delta 0[\varsigma])$. The image on the right shows the smooth side; presumably this was the left door jamb (parastas) of the gateway (pylon) mentioned in the inscription PHOTOS AUTHOR 2008

was clearly an attractive place for the honorific decrees by the syngeneia of Pormounos in the second and first centuries BC. These inscriptions even specify whether they were to be set up on the left or right side, and if this was as one entered or exited the complex. Some designate a location on the same lateral side of the entrance, i.e. on the left as one enters or on the right as one exits, indicating a favored spot. ${ }^{58}$

Figure 4.22 shows the fragmented inscription of I.Sinuri 16, an honorific decree for a certain Ouliades, that was to be set up on the left door jamb (parastas); the right face of this block is smooth (Figure 4.22), indicating that this was in fact the left door jamb. The entrance to the sanctuary was obviously a place where everyone had to file through, and setting up monuments and inscribing honorific decrees and contracts on the walls and even the doorpost itself heavily emphasized this place, thereby heightening its already public function. ${ }^{59}$ People entering or leaving the sanctuary were thus exposed to a

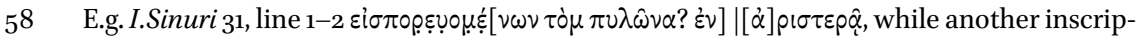
tion, concerning a land-lease contract, states that it is to be inscribed on the 'right' side

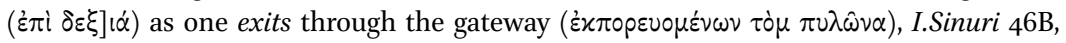
lines 15-16. See further Robert's discussion in I.Sinuri, p. 54 .

59 See the discussion above, on the findspots of I.Labraunda 9 next to the South Propylon at Labraunda; a possibly adjoining inscription is to be set up 'in the most conspicuous

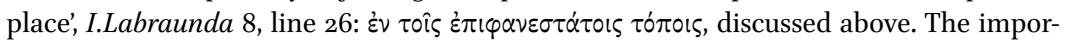
tance of such location clauses is further addressed in Roels (2018a). Sokolicek (2009), on the Magnesian Gate in Ephesos, provides a good discussion (with references) on how 
kind of 'saturation advertising' ${ }^{60}$ By micro-managing the locations of these inscriptions, the syngeneis were clearly emphasizing this spot as a critical node in their kinetic linear space, much like the South Propylon at Labraunda, or the propylon of the sanctuary of Hekate at Lagina. ${ }^{61}$ Spatial studies have shown that gateways are key public places not only because of their transitional role, but especially for their popular isovist shapes that connected spaces, allowing for a sheltered but strategic overview before one actually enters either area. ${ }^{62}$ The propylaia of Labraunda and Lagina certainly appear to have had this function, and, although we know nothing about the layout of the monumental gateway of the sanctuary of Sinuri, it is likely that it was designed in a similar fashion, perhaps with a view across the valley.

\subsubsection{Sacred Road}

As stated above, the number of inscriptions specifying their placement at the entrance of the sanctuary shows that this was a highly public spot; this is no doubt connected to its formal role as gateway during the festivals and probably implies some kind of procession and ritual entry. ${ }^{63}$ The exact location of this entrance is unfortunately unknown, although the excavator believes to have found some traces of an opening in the western wall that was also blocked at a later stage (like the entry in the Archaic wall). ${ }^{64}$ This could correspond with the large level area just west of the sanctuary, also covered with tile and pottery fragments.

Another possibility could be in the northeastern area, which was heavily disturbed by the Byzantine constructions (see plan, Figure 4.6). Directly north of the temenos there is a path, roughly $2-3 \mathrm{~m}$ wide and partly cut from

gateways in general could mark the connection between a community, the gods, and the surrounding region.

6o Chwe (2001), 20-21, compares for example processions to 'saturation advertising' by bringing the message past all the members of a community; such gateways have the same effect, although an opposite mechanism, by having all the members of the community pass by these static 'messages'.

61 For Labraunda see Chapter 3 , and Chapter 5 on the sanctuary of Hekate at Lagina.

62 See Benedikt (1979) and Batty (2001) on isovist fields, discussed in Chapter 2. The importance of such spatial hinges is further discussed in connection with the public function of the pronaos, Roels (2018b), also (2018a); on the attraction of temple doorways, Williamson (2018).

63 Similar e.g. to the South Propylon of Labraunda, discussed above; the sanctuary of Meter at Mamurt Kale, near Pergamon, by contrast, does not have a formal gateway, or propylon; it is unknown whether worshipers went there collectively or more as pilgrims, see Williamson (2014a).

64 Devambez (1959), 30: "J'ai cru cependant reconnoitre dans le mur oust de tracé d'une porte qui, par la suite, aurait été bouchée." 


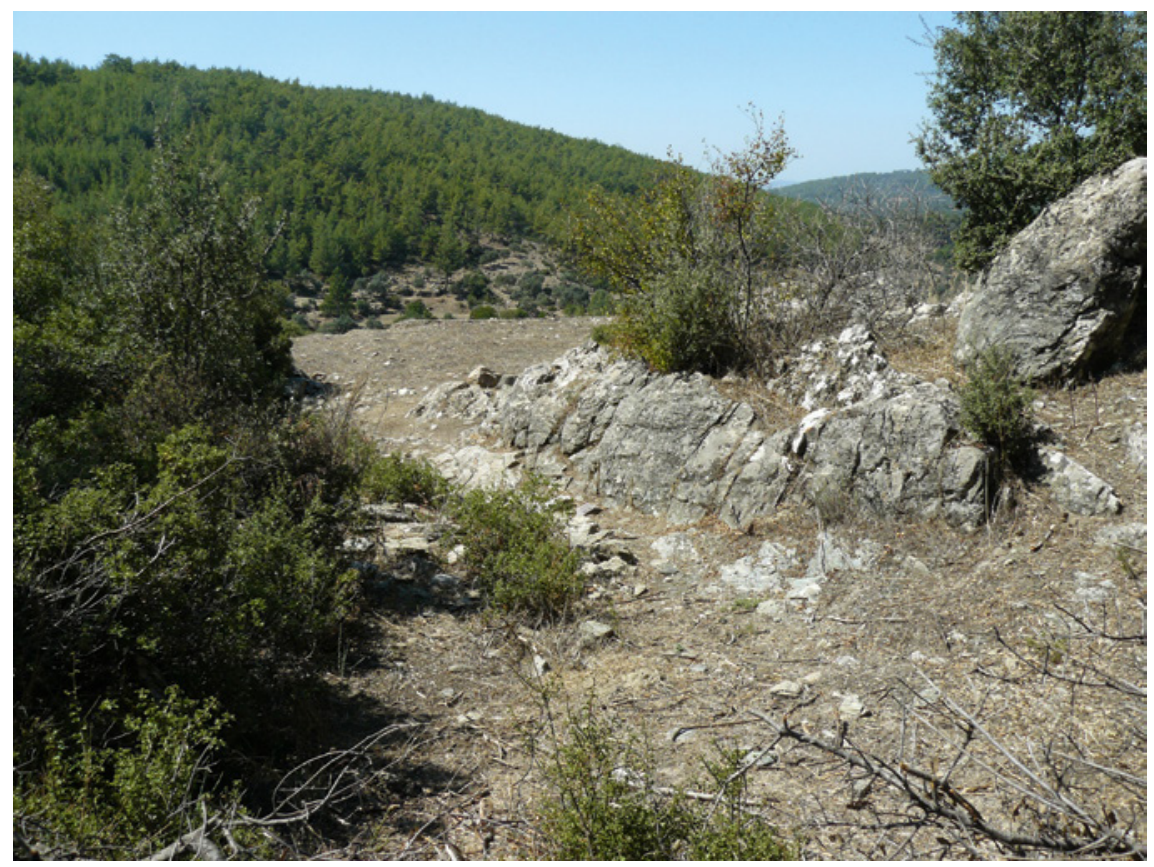

FIGURE 4.23 Sinuri. Path northeast of the sanctuary, leading onto the area north of the sanctuary; the vaulted tombs from the Roman period are just around the rocks to the right PHOTO AUTHOR 2010

the rock, leading further to the northeast and eventually to the 'acropole' (Figure 4.23). There is a high concentration of sherds in this area, but a surer sign of its antiquity are the two tombs from the Roman period, immediately north of this path. ${ }^{65}$

The course of the path beyond the sanctuary remains unknown, since the recent or sub-recent terracing of the hillside will have destroyed much of the original surface. However, scatters of ancient pottery and roof-tile are found all across this hilltop, with high concentrations immediately north of the sanctuary, as well as beyond, in a large halo around the 'acropole' as discussed above (also Figure 4.19). ${ }^{66}$ The rock-cut 'steps' and rectangular rock-cut tomb testify to further activity in this area, as previously mentioned. ${ }^{67}$ Only a systematic survey, however, will reveal the extent and nature of activity in this area.

65 The tombs were also excavated but empty Devambez (1959), 31-32.

66 Personal observation, 14 September 2010.

67 Shown by a resident of Aşağı Kalınağıl who guided us through the site on 18 April, 2008. 
From the west and Mylasa, the most logical route to the sanctuary would have been through the valley, as described above. From here it is likely that worshipers or travelers would not have crossed up the steep western face, but would have circled the hill along its more gradual ascent via the southern side, where they could also admire the imposing southeast retaining wall where the Archaic entry was located, then continuing along the eastern flank until they reached the new entry in either the northern side, or circling further beyond this to the western side.

To summarize, despite the paucity of data, the construction activities on this hilltop lead to a number of insights regarding ritual space. While the shrine of Sinuri did not occupy a commanding position in the region as did Labraunda, its location on the low hill just above the valley floor would have made it a local landmark. The snapshot-like view of this valley with the road towards Mylasa created a single coherent 'visual region', with this sanctuary at its head. ${ }^{68}$ By increasing the overall prominence of the shrine through the extensive remodeling, the Hekatomnids put the shrine of Sinuri on a par with two other major Karian sanctuaries - that of Zeus Labraundos, and Artemis at Amyzon. As with other Hekatomnid projects, this entailed elevating the shrine via a monumental platform. This also greatly expanded the useable area of public space for a sizeable crowd. As the old entrance in the southern wall was blocked, the new entrance will have given the temenos a new spatial syntax and a different appreciation of both external space, through the views linking it to the surroundings, and internal space within the complex. The addition by the Pormounos syngeneia of a stoa on the eastern edge further defined the area south of the altar as an 'inward-facing' space, heightening collective focus on the ritual events while facilitating mutual observation. ${ }^{69}$ This concentric articulation of space increased the effectivity of ritual while promoting cooperation within the community.

\subsection{Ritual Performance at the Sanctuary of Sinuri}

As discussed above, the rituals for the god Sinuri may well have been related to the general western orientation of the sanctuary. ${ }^{70}$ Little is actually known of the rituals themselves, however. The ceramics have not been studied in enough detail to reveal changes in ritual, although give a broad indication of the

68 The concept of visual regions is discussed in Chapter 2 and above with respect to Labraunda; also Williamson (2016b).

69 Chwe (2001), 30-33. This concept is explained in more detail in Chapter 2.

70 Suggested in Devambez (1959), 30. The westward facing features include the rock-cut altar, the small square Archaic structure, and the Doric stoa. 
activities at the sanctuary. Inscriptions remain our foremost source of information as to ritual use of the shrine.

\subsubsection{Festivals}

What little is known of the festivals at the sanctuary of Sinuri under the Pelekos syngeneia derives primarily from a fragmented inscription dated to the fourth century BC and concerning a certain Nesaios, who was granted admission into the Pelekos syngeneia during a festival. ${ }^{11} \mathrm{~A}$ second inscription from this period mentions a festival that Robert restores as the Syennia. ${ }^{72}$ Together these give a glimpse into the fourth century shrine as a place where constitutional matters that concerned the Pelekos syngeneia were determined and announced through festivals.

By the Hellenistic period, the festivals appear to have been reorganized by the Pormounos syngeneia during their administration of the sanctuary. Their main festival, or "la réunion annuelle," according to Robert, was apparently called the Kotamia, an indigenous designation; it is, however, more often referred to simply as the bouthysia, or 'oxen sacrifice. ${ }^{73}$ This syngeneia used the same Macedonian calendar as Mylasa and their festival took place in the month of Loos, in the summer. ${ }^{74}$ Music would have been part of the festivities, as witnessed by a single tantalizing fragment with musical notations that was discovered at the sanctuary, although its date has not been determined. ${ }^{75}$

The climactic ritual at the sanctuary was the sacrifice, and excavations revealed a rock-cut altar (shown on Figure 4.6). Hekatomnos personally dedicated an altar table (trapeza), according to I.Sinuri 76 and he may well have been responsible for the expansion of the precinct area, which greatly increased the space around the altar. Another altar was dedicated in the second or first century вС by the treasurers (tamiai) and the legal representatives (egdikesantes) of the Pormounos syngeneia, as testified in I.Sinuri $2 .{ }^{76}$ Figure 4.24 shows the

$71 \quad$ I.Sinuri 73 . The constitutional administration of the syngeneia via the shrine is discussed further below.

72 I.Sinuri 74 , line 6.

73 Robert reconstructs the name of the festival from two fragments: I.Sinuri 17a, line 5, and

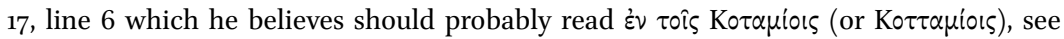
I.Sinuri p. 45. Wilhelm's suggestion that the kappa should in fact have been a beta, for a more faunal Botapiors (Wilhelm (1947), 8-11) is dismissed in Robert (1949), 6o-63. The bouthysia is mentioned in I.Sinuri 11,24 and 25 .

74 The month of Loos (roughly July) is mentioned in I.Sinuri 9, 11, and 25. On the calendar at Sinuri, Robert, I.Sinuri p. 31.

75 I.Sinuri 81 and p. 104-106. Pöhlmann and West (2001), 86.

76 This was also the inscription which aided Louis Robert to identify the site in 1934, I.Sinuri p. 16. The dedication of this altar to Sinuri had to do with the affair concerning the sacred 


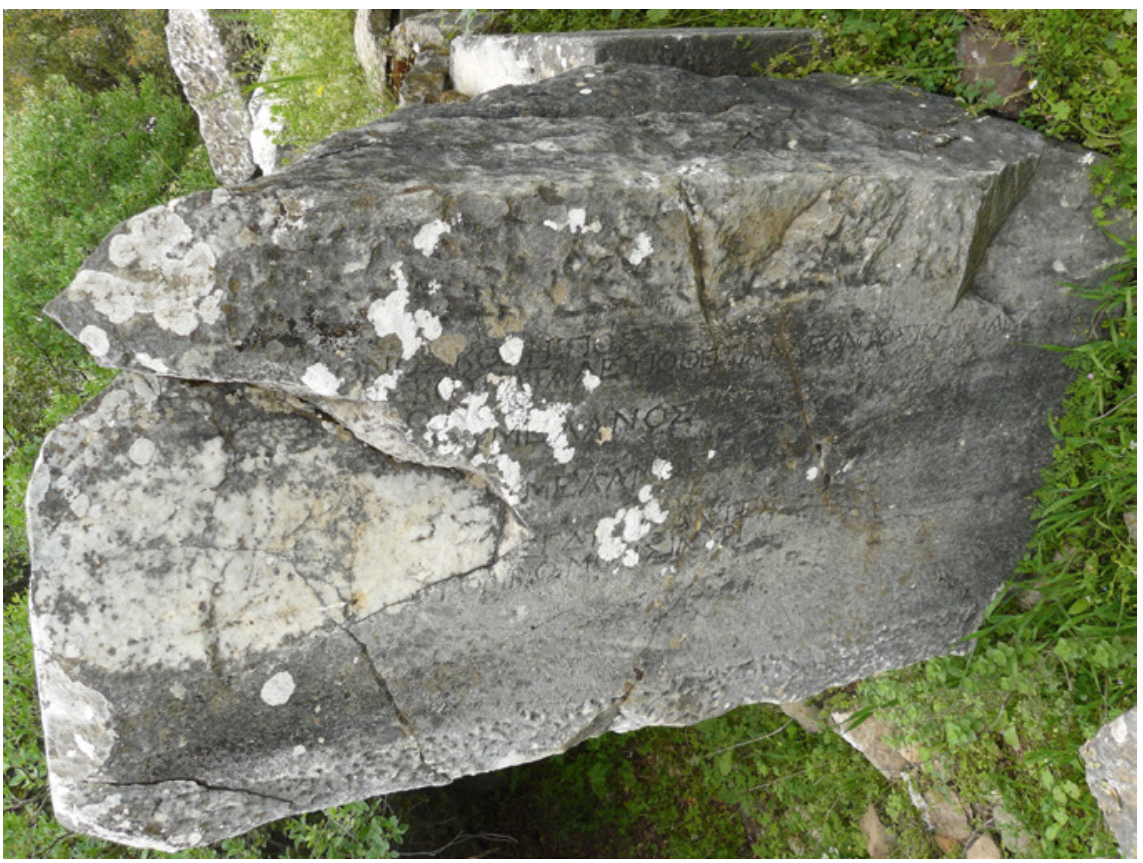

FIGURE 4.24 White marble block with the inscription I.Sinuri 2 . This block (shown sideways), $67 \times 130 \times 47 \mathrm{~cm}$, bears the dedication of an altar to Sinuri by the seven treasurers (tamiai) of the syngeneia of the Pormounou. Based on this inscription, Louis Robert was able to identify the site as the sanctuary of Sinuri (the block has since been damaged at the top). Its current position reflects its secondary use as an orthostat in the Byzantine basilica PHOTO AUTHOR 2008

large block bearing the inscription. The workmanship on the edges is different than the architectural blocks, possibly an indication of the incorporation of the block in the altar that was dedicated, but the markings could also be due to the later Byzantine use of the stone.

The oxen sacrifice, the bouthysia, would have been the main annual event for the syngeneia, whether this was during the Syennia (for the Pelekos syngeneia in the fourth century) or the Kotamia (for the syngeneia of Pormounos in the Hellenistic period). One inscription mentions the sacrifice 'to the ancestral gods, ${ }^{\prime 7}$ perhaps the Pormounos syngeneia combined in this way their own

wood, mentioned in this inscription in line 9, and more in I.Sinuri 11-14, discussed below.

77 I.Sinuri 10, lines 4-6 concern the progonikoi theoi; see also Robert p. 21-22, and Laumonier (1958), 178-179, who takes these 'ancestral gods' together with the 'savior gods' (i.e. Samothracian gods) from a dedication by the priest Menippos, son of Hieronymos 
ancestral heritage with the god Sinuri? Besides the festivities, it was also the time when the syngeneia held council, making decisions that concerned the community or the sanctuary, as some of the preambles of decrees show. ${ }^{78}$ This is when new members were admitted as citizens into the community and contracts concerning land-leases were sealed - these will be discussed below. But this is also when individuals were honored, such as Dionysios, son of Leon of Kosetios in I.Sinuri 11. The decree on the construction of a stoa is also dated to the month of the Loos, the same month in which the festival took place, and which honors those who made the stoa possible. ${ }^{79}$ In all likelihood the decisions by the syngeneia to honor members of their community were both taken and performed during these festivals. The awards were often a golden crown or statue, ${ }^{80}$ but significantly 'also a portion [of meat] from all the sacrifices performed by the syngeneia.81 This emphasis on the syngeneia and the recurrence of the honors in the phrasing of this award shows that meat was more than just a gift: the honorand was clearly given a privileged part of that which was shared by the entire syngeneia - and not just once, but each time. This practice was common to Mylasa, where it was not the polis but the phyle and syngeneia that typically honored outstanding members of the community with a golden crown (and sometimes a statue) and a reserved portion of meat from every communal sacrifice. ${ }^{82}$ Sacrifices were more than a religious performance or collective experience, they were also used to reinforce good behavior

(I.Sinuri 8) as a sign that Sinuri was gradually changing from a god centered on the kinship ties (i.e. the syngeneia) to one more open to outside influences.

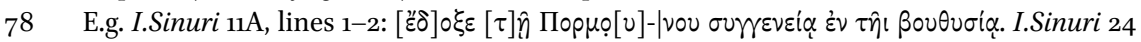
and 25 also refer to decisions made by the Pormounos syngeneia during the bouthysia.

79 I.Sinuri 9 , lines $2-3$.

8o I.Sinuri $11 \mathrm{~B}$, line 7 , and I.Sinuri 16, 18, 20-22, 37 mention golden crowns; I.Sinuri 16, lines $3^{-5}$, includes a bronze statue to be erected in the sanctuary.

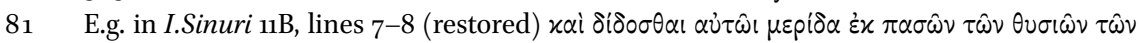

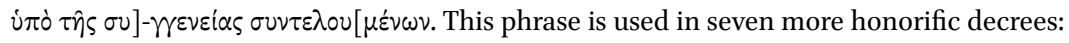
I.Sinuri 16, 18-22, 32; see also Robert's discussion on p. 54.

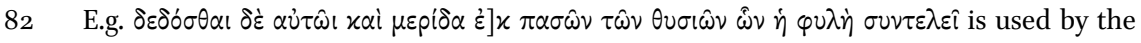
phyle of the Otorkondeis in I.Mylasa 113, line 9, with a similar phrasing in I.Mylasa 117, lines 3-5; another Mylasan phyle, the Konodorkondeis, uses similar phrasing, only they substitute 'from every sacrifice' with 'lifelong from the sacrifice' ( $\tilde{c}^{\omega} \omega \zeta \zeta[\omega \hat{\eta} \varsigma \dot{\varepsilon} \chi] \mid[\tau \hat{\omega} \nu \theta \nu \sigma l]$ Wv), I.Mylasa 119, lines 11-12 and 17-19; also by an unidentified phyle in I.Mylasa 136, line 11, and 140, line 11; and by the Mylasan syngeneia of the Aganiteis in I.Mylasa 121, line 4-5, who celebrate their sacrifices in the (as of yet unidentified) sanctuary of Zeus Aganiteon.

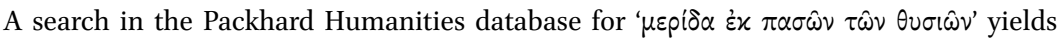
results only from Mylasa and the sanctuary of Sinuri, which may imply the peculiarity of this phrasing to Mylasa in the Hellenistic period. 
by perpetuating the memory of the social pillars of the community, thereby maintaining group identity. ${ }^{83}$

\subsubsection{Banqueting}

Sacrifices usually end in a festive banquet. Water would have been a requisite in any event for a large gathering, perhaps also for rituals. There is a well at the site although the date of this is unclear. ${ }^{84}$ Other water facilities must have been available but are unknown. The four large storage jars (pithoi) were presumably for some kind of food preparation, although these apparently date from the earlier Archaic period. ${ }^{85}$ Most of the pottery described in Devambez' report refers to tableware, with the largest quantities also deriving from the Archaic period; several fragments show Orientalizing, Black-Figured and Red-Figured ornamentation. ${ }^{86}$ The following periods are poorly represented, although two mould-made bowls were discovered from the second century вс. ${ }^{87}$ Nonetheless, in the fourth century and later, banqueting would still have been part of the rituals, and a new examination of the ceramics would surely reveal more material from these periods that may be linked to this activity. Also, the stoa (or stoas) would have provided banqueting facilities, at least as shelter, even if there were no andrones for banqueting in symposium. ${ }^{88}$ An inscription from the second century mentions the construction of a stoa at the eastern part and honors the syngeneia's financial treasurer who provided funding for it along with a banquet for the entire syngeneia. ${ }^{89}$

In sum, the ritual activities that may be discerned at the sanctuary of Sinuri reinforce the image created by architectural developments in the Late Classical and Hellenistic period. While the new design of the sanctuary created a concentric space for a large gathering, the festivals created the collective experience, as the decrees discussed further below will reveal in sharper detail. The focus on the syngeneia runs parallel to urban festivals that centered on the polis. Unsurprisingly, the main sacrifice played an especially strong role in

83 On the political role of sacrifice, see e.g. Bruit Zaidman and Schmitt Pantel (1992), 34-36; on the communal role, Schmitt Pantel (1990), and (1985), on banqueting in general.

84 The central large dot in Figure 4.8.

85 Devambez (1959), 14-15, Pl. IV, Fig. 4 and Pl. XIV, Figs. 2-3.

86 Devambez (1959), 15-23, Pl. XXII-XXVII.

87 Devambez (1959), 30-31, Pl. xxviII. The terracottas include a head of Aphrodite, a relief of Eros (perhaps from a vase); part of a terracotta lion's head was also found, probably Roman.

88 Stoa architecture is typically associated with banqueting, Börker (1983) and Kuhn (1985).

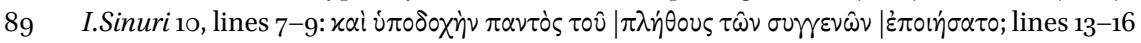

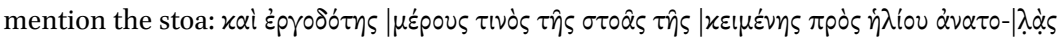

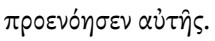


structuring community. The deliberate repetition of honors via reserved gifts of meat during the climactic ritual, year after year, created and reinforced shared memories, thus perpetuating the identity and values of the syngeneia. The divine authority invoked via the sacrifice was both focus and channel. While this deviates from the standard view of Greek polis sacrifice with distributions of equal portions of meat as way of propagating equality, or isonomia, ${ }^{90}$ the ultimate goal of this syngeneia was similar - namely their collective identity. Individuals who did what they could to protect this identity, through benefactions, good deeds, or accomplished services, were worthy of being singled out to be honored and remembered. The sacrifice was obviously the central event of the festival that focused everyone's attention. The ritual would have been simple, following a pattern known to everyone. ${ }^{91}$ Linking honors to individuals with the communal sacrifice was a natural way of building collective memory, thereby perpetuating group identity. ${ }^{92}$ Performing this together in the concentric space before the altar may certainly be understood as a 'rational ritual. ${ }^{93}$ Though at a different scale, the rituals of Sinuri reinforced the syngeneia in much the same way as urban rituals: members were honored, common events were commemorated, and financial needs were secure, all according to institution and protocol.

\subsection{Legal Administration and Organization of the Sanctuary of Sinuri}

The identity of the syngeneia administering the shrine changed from the Pelekos in the fourth century to the Pormounos in the third century. This section examines differences in how these syngeneiai organized the shrine, the role of its priests, the composition of the community, and their financial administration. Through this it will become apparent not only how tight the bond was between the sanctuary and this community, but also how embedded this was in the landscape around Mylasa. It will furthermore give insight into

9o On the isonomic intentions behind sacrifices in the Classical democratic city, see Bruit Zaidman and Schmitt Pantel (1992), 34-36; also Bremmer (2007), who considers the weighing of meat at the sacrifices of Sinuri as an indication of equal distribution. Roman sacrifices could have the opposite effect, by publicly reinforcing hierarchical distinctions, Scheid (1985). Paul (2018) places sacrificial division within the fluid boundaries of participation along with processions.

91 The importance of ritual performance as creating cognitive pattern recognition is discussed further in Chapter 2; see Chwe (2001), 27-30, esp. 28 with his discussion of Tambiah (1985) on ritual and pattern recognition.

92 Connerton (1989), 44-61; McCauley and Lawson (2007) for the mnemonic effects of ritual; discussed in further detail in Chapter 2 and below.

93 Chwe (2001). 
the transformation of such syngeneiai from independent political entities to subsidiaries of the polis in the Hellenistic era.

\subsubsection{Administration and Priesthoods}

An inscription found at the sanctuary gives a list of priests containing 16 names in three columns. ${ }^{94}$ These represent consecutive priesthoods beginning in the fourth century вс. The first priest is Pellekos, and may well have been the eponymous founder of the Pelekos syngeneia, also known from I.Sinuri 73, discussed below. Robert observes that the first five names in the list are Karian, while the next ten are Greek. ${ }^{95}$ The Greek names Menippos, Iatrokles, Aristeas, and Dionysos were common in Mylasa, as Robert points out, as was the Karian name of Thyssos. ${ }^{96}$

Another name that stands out is that of Hiereus. Robert notes the singularity of naming an infant Hiereus ('Priest') but associates it with the lifelong and hereditary position at this stage, assuming that the next in line was thus designated at birth. ${ }^{97}$ This priest, Hiereus, made a dedication to Sinuri, found at the 'acropole' to the north, and perhaps another one, for his wife, at the sanctuary. ${ }^{98}$ His grandson, Menippos, son of Hieronymos, and thirteenth in the list, dedicated his priesthood (in the service of Sinuri) to the 'savior gods' after he was rescued from 'great and incredible dangers'. ${ }^{99}$ Robert interprets these 'savior gods' as the Dioskouroi or Kabeiroi, or the Samothracian Gods, whose cult was known in Mylasa. ${ }^{100}$ At the sanctuary a sculpted stone was found in the

94 I.Sinuri 5 . The inscription begins with the header 'Priests of Sinuri'; the sixth name is illegible.

95 I.Sinuri 5, p. 19: The first five names are Pellekos, Thyssos, Yssollos, Arteimes, and again Pellekos; the sixth name is illegible. The next ten names are: Menippos, Iatrokles, Hiereus, Iatrokles, Menippos, Hieronymos, Menippos, Aristeas, Demetrios, and Menippos. On the name Pellekos, see Laumonier (1958), 182-183, and below.

96 See Robert in I.Sinuri 5, p. 19: e.g. a certain Thyssos Sysko was accused of being involved in the complot against Maussollos, and his property taken away, I.Mylasa 3. A Thyssos Imbrassidos and a Thyssos Sambaktuo were witnesses of sales of land during the reign of Maussollos, I.Mylasa 11 and 12 resp., from the fourth century. In the third century a certain Thyssos son of Apollonios was treasurer of the Otorkondeis phyle at Mylasa, I.Mylasa 201.

97 Robert in I.Sinuri 5, p. 20.

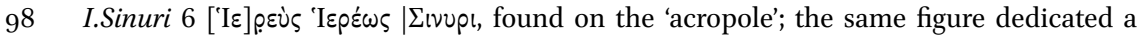
statue of his wife at the sanctuary of Sinuri, I.Sinuri 7. Also I.Sinuri 45 mentions a priest named Hiereus, of the Tarkondareus syngeneia, discussed below.

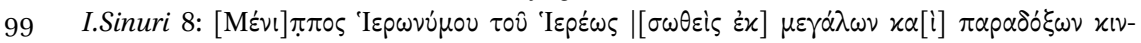

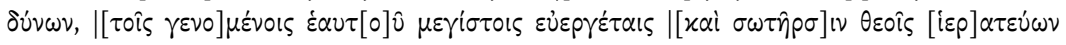

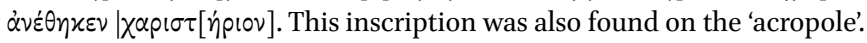

100 I.Mylasa $801,803,804,814$ and 816a, c, and e, 820, 821, and 822 mention a priest (Diodotos Melanos, son of Politos) of the Dioskourides at Olymos in connection with land 
shape of a cap with star, characteristic of the Dioskouroi; perhaps it was may be connected with this inscription. ${ }^{101}$

Based on the shape and style of the letters, Robert dates the inscription bearing the list of priests to the same general period when most of the inscriptions were produced at the sanctuary of Sinuri, i.e. between the second and first centuries BC, even though the list goes back to the fourth century. The length of time and the number of priests indicate that the priesthood of Sinuri was a lifelong position, rather than annual, and the various dedications point moreover to a hereditary post, though not necessarily generational since it seems to have gone from brother to brother on occasion rather than father to son. Robert was thus able to chart a tentative genealogy of the 'Greek' priests, starting with Menippos, even though he was unable to provide specific dates for each of the priests. ${ }^{102}$ Now, however, it appears that the same Hiereus mentioned above, who was the ninth priest, held office in the second part of the third century вс, as he is also mentioned in Olympichos's dedications of lands to Zeus Osogollis. ${ }^{103}$ Hypothetically, then, Hiereus's grandson Menippos, son of Hieronymos, could have been priest during the presumed raids of Antiochos III's troops on the domains of Sinuri - he may even have been one of those taken hostage. ${ }^{104}$ This would be one explanation for the 'great and incredible dangers' that he survived and hence his gratitude and dedication to the 'saving gods'. ${ }^{105}$

This list is thus interesting for different reasons. Besides showing the hereditary nature of the priesthood, it also exemplifies the increasing 'Hellenization'

descriptions; I.Sinuri 47a and 49 are dated to the year when the priest of the Samothracian Gods was the stephanephoros of Mylasa.

101 Robert in I.Sinuri, p. 22. The cap-shaped stone is shown on Pl. viII.

102 I.Sinuri, p. 22, for the genealogy, with a discussion on p. 24-25. Robert surmised that the first six or seven priests would have been enough to carry the priesthood down from the fourth to the second century $\mathrm{BC}$, presuming a more rapid succession after this period. However, the office of the ninth priest is now dated to shortly after the mid-third century BC, see discussion.

103 I.Labraunda 8C, line 30, as restored by Piejko (1990), 137 no. 8, following Debord

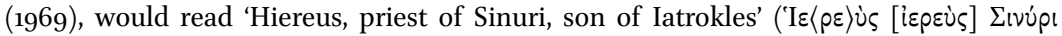

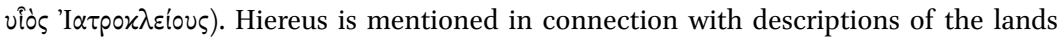
adjacent to those that Olympichos dedicates to Zeus Osogollis. The inscription is from Labraunda and is dated to c. 240 BC but was recut in the second century BC; see Chapter 3 , Labraunda, and below.

104 This event took place in 203-201 BC, when Mylasa sided with Rome against Antiochos III; the capture of sacred personnel and their property is based on Virgilio's analyses of fragments of royal correspondence between Antiochos III and the sanctuary, Virgilio (2010), discussed below.

105 I.Sinuri 8, discussed above. 
of the population, as Robert suggests. Also, somewhere in this list the administration of the sanctuary changed hands from the Pelekos syngeneia, who ran it in the fourth century, to the syngeneia of Pormounos, from especially the third century on. ${ }^{106}$ It is tempting to correlate this with the shift from Karian to Greek names, yet there is no sound base for this: Greek and Karian names occur in Mylasa throughout both periods. ${ }^{107}$ In fact, this list seamlessly and without interruption continues through the different administrations. Perhaps it was copied from earlier archives no longer extant, or may even have been memorized by each successive priest. In any event, the list implies a smooth transition between the two syngeneia, rather than a hiatus or disruptive break.

From the inscriptions in Mylasa we know of at least two more priests of Sinuri: Hybreas, son of Krateros, ${ }^{108}$ and Thargylios, son of Aristomenos, who was honored with a statue. ${ }^{109}$ Neither of these names appears in the list of priests in I.Sinuri 5 , and so Robert postulates that they were likely to have been later, after the priestly line died out and the priesthood was no longer a hereditary position. ${ }^{110}$ They are discussed in more detail below with regard to their urban contexts.

106 On the transition from the Pelekos to Pormounos syngeneia, see below.

107 Debord (1982), 51 on the common use of Greek names. Piras (2010), 225-229 on the resurgence of Karian names at Mylasa in the third century, also discussed above in connection with Labraunda. Also Aubriet (2013), 196-197 who discusses the list of priests in the context of a resurgence of Karian identity, particularly noticeable at the two extra-urban sanctuaries of Mylasa.

108 I.Mylasa 103, lines 1-2 mention Hybreas, son of Polykritos, who was the stephanephoros of Mylasa and the adopted son of Hybreas, son of Krateros, priest of Sinuri and secretary of the council; Hybreas, son of Krateros, is mentioned again as priest of Sinuri in a land-lease document in I.Mylasa 217, lines 6-7 (Blümel et al. (2014) nos. 2 and 3). Robert (I.Sinuri p. 25) believed the Pixodaros mentioned in this inscription was also a priest, but

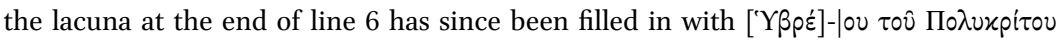
(Blümel (1992), 16), referring to the same individual in I.Mylasa 103 (Blümel et al. (2014) no. 17).

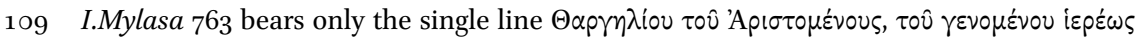
$\Sigma(v 0 \rho 1$, but it would have been an honorific award from the demos or maybe one of the phylai.

110 I.Sinuri, p. 25; Robert on the later period of the priesthood: "Je suis amené à former l'hypothèse suivante: à un moment (peut-être dans la seconde moitié du II ${ }^{\mathrm{e}}$ siècle) la famille où se recrutaient les prêtres de Sinuri, celle de Pellekôs, s'est éteinte; on a alors

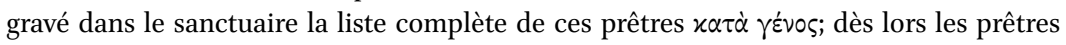
ont été choisis par la ville ou plutôt par la syngeneia, sans conditions de famille; étant donné la coutume à Mylasa à cette époque, on peut supposer que le sacerdoce a été mis en vente." A parallel for this would be the syngeneia of the Maunnites, who issued a decree posting their priesthood for sale, I.Mylasa 3 о2, dated to the first century вс. 
The priesthood may have been hereditary, but other cult officials were elected, more in symmetry with polis cults. These include the treasurers (tamiai), the commissioners in charge of maintenance of the sanctuary (ergodotai), the legal representatives (egdikoi), and those responsible for the management of the sacred lands (ktematonai). These offices were directly connected to both the community and the economy of the shrine and are further discussed below.

\subsubsection{Local Community - the Pelekos and Pormounos Syngeneiai}

Prior to the surge of synoikism in the Late Classical and Hellenistic periods, syngeneiai were the base political unit of Karian society. As such they were generally independent communities, often with a sanctuary at their center which they held in common. As their name implies, syngeneiai were typically rooted in kinship ties, often based on a mythical or legendary ancestor; sometimes such ties were invoked for political or economic favors. ${ }^{111}$ In the Hellenistic period, however, these once autonomous entities were typically subsumed by an expanding polis, in which they became a sub-division, under the phyle or demes. ${ }^{112}$ As mentioned above, in the fourth century вс Mylasa knew three tribes, or phylai: the Otorkondeis, the Konodorkondeis, and the Hyarbesytai. ${ }^{113}$ By the Hellenistic period, a number of syngeneiai were added to these, e.g. the Tarkondareus and the Maunnites were part of the Otorkondeis, while the Aganiteis belonged to the phyle of the Hyarbesytai. ${ }^{114}$

One of the earlier inscriptions found at this sanctuary is I.Sinuri 73 , a fourth century decree by the Pelekos syngeneia. ${ }^{115}$ Robert believes that this syngeneia was named after the priest, analogous to the syngeneia of Korris at

111 See below in Chapter 6, in connection with the sanctuary of Panamara, when various syngeneiai across Karia were called upon to engage in the cult.

112 E.g. the syngeneia of Korris at Labraunda was made up of citizens from Mylasa, see above. When Olymos was absorbed by Mylasa, the city's phylai, e.g. the Mosseis, were 'downgraded' into syngeneiai so they could then be incorporated into the phylai of Mylasa, e.g. I.Mylasa 863 on the division of Olymos and Labraunda into phylai, syngeneiai and patra; Cousin and Diehl (1898), 434-439 (e.g. the deme of the Maunnites in Olymos became a syngeneia of the Mylasan phyle of the Otorkondeis); Robert, I.Sinuri p. 26-27; Crampa in I.Labraunda, p. 25; Reger (2004), 164-168.

113 Presumed to be the same three phylai that ratified the decisions of the ekklesia kyria in I.Mylasa 1, 2, and 3, also mentioned above.

114 On the Tarkondareus and Maunnites, see e.g. W. Ruge in $R E$, s.v. 'Mylasa', 1055-1056; the Maunnites began as a deme of Olymos, see Cousin and Diehl (1898), 435-436 and above. On the Aganiteis, I.Mylasa 121-122.

115 I.Sinuri 73, revised in Robert (1949), 63-67. 
Labraunda. ${ }^{116}$ This inscription, from $35^{\circ}-344 \mathrm{BC}$, bears the only reference to the Pelekos syngeneia, and records their joint decision to admit a certain Nesaios into their community, by mandate of Idrieus and Ada. Nesaios is welcomed as a 'brother', demonstrating the 'fraternity-like' nature of the organization, as Robert points out. ${ }^{117}$ The involvement by Idrieus and Ada in the constitution of the syngeneia further underscores the personal Hekatomnid relations with the sanctuary, not only with the structure of the sanctuary but also with the community that administered it. The directness of this relationship and the lack of any signs of affiliation with Mylasa indicate the relative autonomy of the Pelekos syngeneia - they do not seem to have answered to any intervening level of authority.

No other indications of the Pelekos are known and within a couple of generations a different syngeneia is connected with Sinuri, that of Pormounos. ${ }^{118}$ The earliest unequivocal testimony of their presence is I.Sinuri 44 (Figure 4.25), another decree admitting an individual to the syngeneia and dating from the rule of Pleistarchos at the end of the fourth or early third century вс. ${ }^{119}$ The way in which the decision is formulated, as determined by the entire koinon of Pormounos, is very reminiscent of I.Sinuri 73, where the Pelekos syngeneis all came together to make this decision. ${ }^{120}$

In the second and first centuries BC the syngeneia of Pormounos will show close connections with Mylasa, among others through the formulation of their decrees, supporting Robert's general observation that the position of the syngeneia changes from one of autonomy to one of dependency on the polis

116 Robert in I.Sinuri, p. 95. 'Pelekos' or 'Pellekos' are the names of the first and fifth priests as listed in I.Sinuri 5 . On 'Pelekos' as a possible derivative of 'pelekus', or double-axe, see below.

117 I.Sinuri 73, line 7: $\alpha \delta \varepsilon \lambda \varphi \rho^{\circ} v \dot{\varepsilon} \alpha \nu \tau \hat{\omega} v$, discussed in Robert's commentary on p. 96. This inscription is discussed in more detail below, in connection with Civic expression.

118 The syngeneia of Pormounos is always inscribed in the genitive, as the Pormounou, Robert I.Sinuri p. 29.

119 Pleistarchos was the Macedonian ruler of Karia at the end of the fourth century and early third century, cf. Mastrocinque (1979-1980); Billows (1989), 188-193; Gregory (1995). I.Sinuri 44 shows the admission of Samiades, son of Theodotou, to the syngeneia, discussed further below.

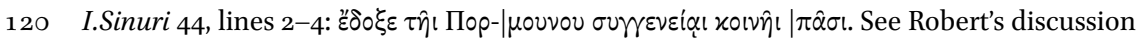
on I.Sinuri, p. 55-56, and 95, showing the similarity between this and the opening lines of

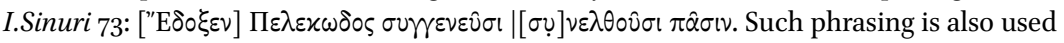
by the Panamareis to honor a Rhodian with citizenship into the koinon, see I.Stratonikeia 6, discussed in Chapter 6. Later decrees by the Pormounos syngeneia use the simpler for-

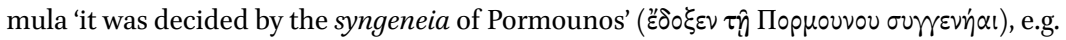
I.Sinuri $9,11,24,25$. 


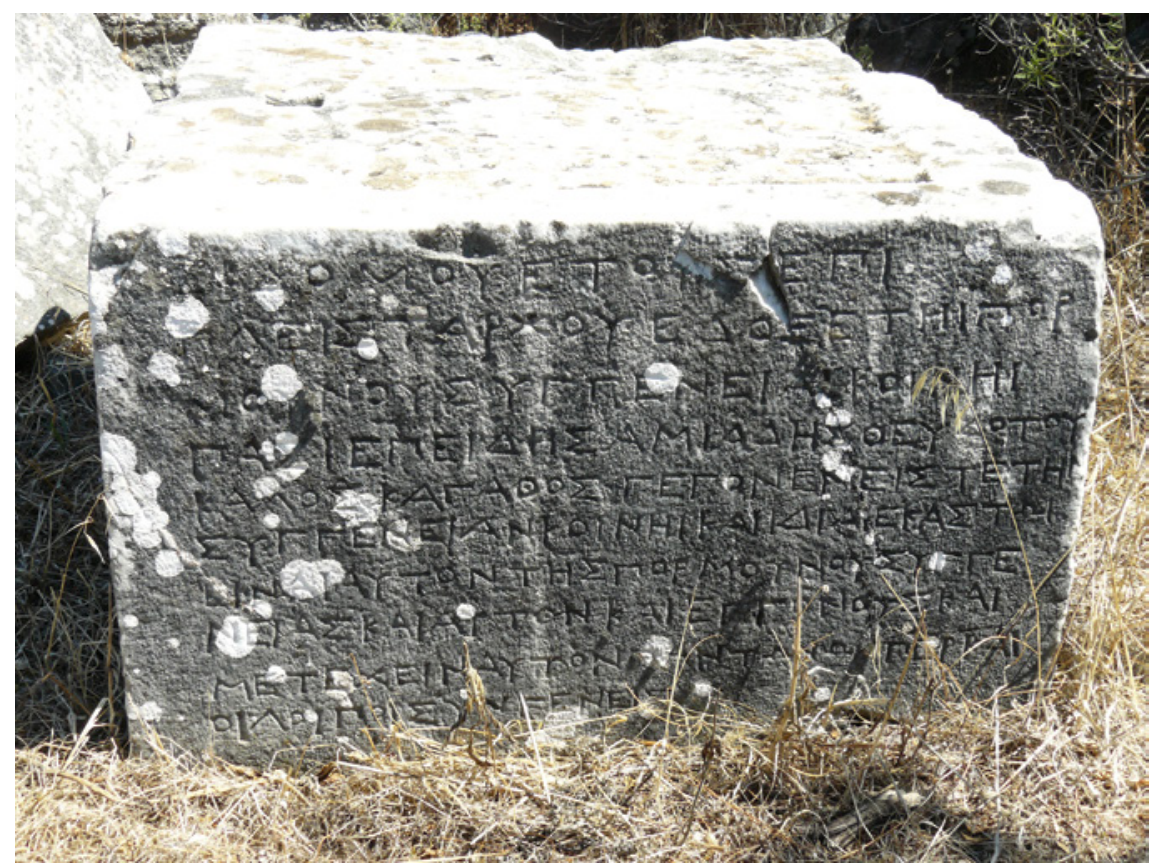

FIGURE 4.25 Ashlar bearing the inscription I.Sinuri 44. This is the earliest mention of the Pormounou syngeneia (end of second and beginning of third lines), an honorific decree in which Samiades, son of Theodotou, is admitted into the syngeneia

PHOTO AUTHOR 2010

in the Hellenistic period. ${ }^{121}$ Yet, as he observes, the sanctuary's takeover by the syngeneia of Pormounos precedes the affiliation of this body with Mylasa - the incorporation of the Pormounos syngeneia into the polis apparently did not happen straightaway, nor can the shift in syngeneia at the shrine be interpreted as a political move on the part of the polis, as tempting as this interpretation might be. ${ }^{122}$ In fact, regarding the transition from the Pelekos to the Pormounos syngeneia, Robert observed how the lettering in the fourth century inscription of I.Sinuri 75, another fragmented decree concerning the Hekatomnids

121 The stephanephoroi of Mylasa date the decrees of the syngeneia on I.Sinuri 9, 11.24-28, 45-47, and 49; Robert in I.Sinuri p. 30-31, 95. There is, however, no evidence that the Pormounos syngeneia was allotted to one of the three phylai of Mylasa. The relationship with Mylasa is discussed more in depth in the next section.

122 "De la fin du $\mathrm{IV}^{\mathrm{e}}$ siècle ou $\mathrm{III}^{\mathrm{e}}$ doit dater le bref décret de la syngeneia pour Samiades (no. 44). Remarquons que le sanctuaire n'est peut-être pas alors encore rattaché à la ville de Mylasa et que nous ne savons à quelle époque se place l'établissement d'un lien entre la ville et le sanctuaire," Robert, I.Sinuri p. 93. 
Ada and Idrieus, allows for reading ПONMOONNOY, which he believes may refer to the Pormounos. ${ }^{123}$ This position has found support in Ignacio-Javier Adiego's study of the Karian texts in these bi-lingual inscriptions. ${ }^{124}$ What the role of the syngeneia of Pormounos at this early time may have been is unclear, but as with the list of priests this interpretation speaks for a gradual transition, rather than an abrupt change. ${ }^{125}$

The second period of bloom at the sanctuary took place in the later second and first centuries. This is when the bulk of the inscriptions appear, and when a stoa was added to the complex, either the Doric stoa (Figure 4.13) or a second stoa. ${ }^{126}$ This is also when the syngeneia is more highly organized, modeling itself on the institutions of the polis. Apparently several treasurers (tamiai) were needed - a group of no less than seven tamiai dedicated together an altar for Sinuri in I.Sinuri 2 (Figure 4.24). ${ }^{127}$ The function of treasurer is further mentioned or implied in several other inscriptions. ${ }^{128}$ Another office is that of the commissioners in charge of managing the sanctuary and its contents (ergodotai), including the building activity. Four such commissioners were charged with overseeing the construction of the stoa in I.Sinuri 9 (Figure 4.14). ${ }^{129}$ The egdikos was the one responsible for giving legal representation of the syngeneia in courts of Mylasa; a cohort of these were appointed when the sacred lands were infringed upon, which will further be discussed

123 I.Sinuri 75, line 3; the Pelekos syngeneia is not attested in this inscription, but appears in I.Sinuri 73. Wilhelm suggested that the syngeneia of Pormounos may be inserted in a

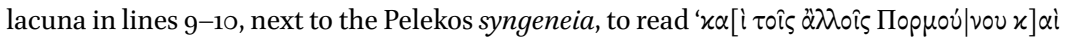

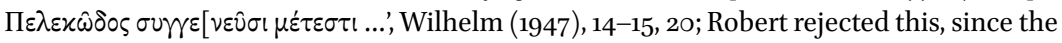
preamble refers to a dedication by the Pelekos syngeneia, in the singular, Robert (1949), 63-67; he does, however, welcome Wilhelm's restoration of $\pi \lambda \dot{\eta} \nu \dot{\alpha} \pi \circ \mu\left[0 i p \alpha \varsigma^{\cdot}\right]$ in line 12, discussed above.

124 Adiego (2000), 133-139; he further determined that I.Sinuri 74 is actually a continuation of I.Sinuri 75 , since both part of the same bilingual inscription.

125 This coincides with the list of priests, I.Sinuri 5 , which spans the periods of both syngeneiai. Whoever the 'Ponmoonnou' were, they must have been important since they are listed near the top, in line 3, just after the header which begins with Ada, daughter of Hekatomnos.

126 I.Sinuri 9 and 10 document the construction of the stoa; Pedersen (1991), 103 indicates that the stylobate of the Doric stoa was Hekatomnid; see also the discussion above under Architecture.

127 I.Sinuri 2 , line 8 . This follows an incident regarding the infringement of the sacred wood, see below. On the office of tamiai at the sanctuary in general, see Robert, I.Sinuri p. 34, 44, and 54 .

128 I.Sinuri $11 \mathrm{~B}$, line 8, and I.Sinuri 17, 17a, 46a-c, 46e; also further implied in I.Sinuri 10, 14, and 25 .

129 On the ergodotai, see Robert I.Sinuri p. 29, and p. 33 where he discusses how he believes they 'accepted' this charge in lines 27-28. See also I.Sinuri 9 and 10. 
below. ${ }^{130}$ Finally, a number of ktematonai were appointed to oversee the administration and lease of sacred lands, discussed in the next section. ${ }^{131}$

A final matter related to the syngeneia is the Hiera Kome, or Sacred Village, which appears in some inscriptions. ${ }^{132}$ These all concern land-lease documents (discussed below), and mention Hiera Kome as it relates to the descriptions of the locations of the lands in question. I.Sinuri 47a refers to a plot as being near or just across the road that leads to Hiera Kome, a small but intriguing clue for the otherwise elusive processional route, as well as the location of the sacred village. This same inscription further mentions the property, with vineyards and trees, as being in a place called 'Hysarbida', which is across the road to Hiera Kome, as well as across 'the river', presumably referring to the stream south of Aşağı Kalınağll. ${ }^{133}$ Robert states that the syngeneia was based at Kalınağıll, ${ }^{134}$ although he does not distinguish between Lower (Aşağı) or Upper (Yukarı) Kalınağıl. He suggests that the Hiera Kome could be at the 'acropole' which Devambez discovered on the steep hill immediately north of the sanctuary. ${ }^{135}$ Devambez, however, found no signs of a settlement here, although his justification of this conclusion is meager given the abundant surface record. ${ }^{136}$ Starting about halfway up the hill from the sanctuary towards

130 Egdikoi are mentioned in I.Sinuri 2, 11, 12, 13, and 14.

131 I.Sinuri 15, 47a, 50a. The office of ktematonia is also known in Mylasa, from the phyle of the Otorkondeis, e.g. I.Mylasa 203, 205, 206, 207, 207b, 211, 212, 215, and the syngeneia of the Aganiteis, in I.Mylasa 222; in Olymos the office was appointed by the polis, in connection with the sanctuary for Artemis and Apollo, I.Mylasa 801, 806, 811, and 816a; also at Hydai, where a ktematones was appointed by the koinon to administer the sacred lands of Apollo and Artemis, I.Mylasa 903, and probably 906.

132 I.Sinuri 47a, line 10; I.Sinuri 47b, lines 4-5, 12; I.Sinuri 56, line 3; I.Sinuri 58, line 1, and restored in I.Sinuri 53 , line 7 . Sacred villages, hiera komai, are also known from Labraunda (see above Chapter 3 ) and especially Lagina, where Hiera Kome became one of the demes of Stratonikeia (see Chapter 5). See also Frejman (2020), 131-154.

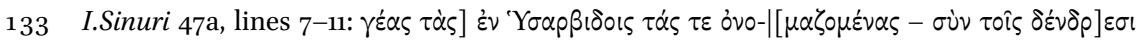

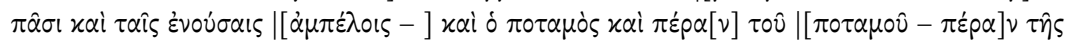

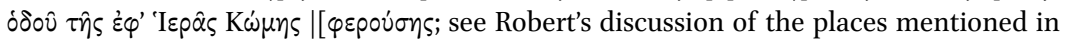
this text in I.Sinuri, p. $77^{-78 .}$

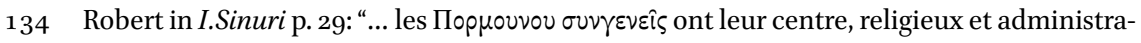
tif, et leurs domains à Kalın Ağıl." Presumably he is referring to the immediate area of the sanctuary here, which would be Yukarı Kalınağıl; the domains, however, were much more dispersed, discussed below.

135 Robert, I.Sinuri p. 78: "Je suppose que ce nom [Hiera Kome] désigne le bourg même voisin du sanctuaire de Sinuri et que c'est le nom antique de Kalın Ağıl, peut-être s'applique-t-il exactement au site habité fouillé par P. Devambez, la petitite acropole à vingt minutes au Nord du sanctuaire."

${ }_{13} 6$ This 'acropole' is where Devambez found the two monumental structures discussed above, Devambez (1959), 5 and 33: "nulle trace d'une agglomeration urbaine n'a été 
the 'acropole' there is a noticeable presence of ceramics along the terraces, including tile indicating buildings, that may well point to some kind of settlement or agricultural activity (Figure 4.19); ${ }^{137}$ the rock-cut tomb shown in Figure 4.20 is just west of this area. A much more likely candidate, however, is Robert's discovery of "un site peu significatif ... le sol est couvert de céramique," which he found on the undulating terrain in the fertile valley close to Aşağ 1 Kalınağll, about 2.5 kilometers west of the sanctuary. ${ }^{138}$ This would of course nicely fit in with the general 'westward' orientation of the temenos of Sinuri, and would even more nicely coincide with the hypothetical processional route from Mylasa, further to the west. It is of course equally possible that settlement in the area followed a much more dispersed pattern, one that might be recognized through intensive survey. This will remain a matter of speculation until the area is more thoroughly investigated.

Wherever the exact location of Hiera Kome was, the question of who lived there remains to be answered. The syngeneia is the most obvious choice place to start. No doubt the village would have housed at least the priest and the sanctuary personnel, as at Labraunda and Lagina. ${ }^{139}$ Yet whether it was home for the entire syngeneia seems improbable. The Pormounos community was obviously thriving in the second and first centuries $\mathrm{BC}$, given the number of officers, their duties, and the economic transactions, discussed below. As stated above, syngeneiai, though based on real or fabricated kinship, were often virtual or even 'imagined' communities ${ }^{140}$ - a syngeneia was thus not necessarily physically bound to a particular village or settlement. ${ }^{141}$ The sanctuary of

retrouvée dans les parages immédiats du sanctuaire, mais un petit établissement, qui n'etait pas un habitat, était installé à 20 minutes à peu près au nord des terrasses que nous avonds étudiées, sensiblement plus haut." Roughly 250-300 m north of the sanctuary, however, I did notice in September 2010 a widespread concentration of ceramics indicative of settlement or agrarian activity.

137 Personal observation, September 2010 and October 2011.

${ }_{13} 8$ Robert, I.Sinuri p. 7; this is where he found the Byzantine fragment I.Sinuri 1, probably related to the Byzantine basilica on the sanctuary of Sinuri; see also Akarca and Akarca (1954), 122.

139 See above, Chapter 3 , for Labraunda, and below, Chapter 5 for the sanctuary of Hekate at Lagina.

140 Anderson uses the term 'imagined communities' to explain nationalism, but realizing how ideologically laden this concept is, he states "it would, I think, make things easier if one treated it [nationalism - CGW] as if it belonged with 'kinship' and 'religion', rather than with 'liberalism' or 'fascism'" in Anderson (1983 [2006]), 5 .

141 It should, however, be noted that in the prosopography of the syngeneia, at least eight

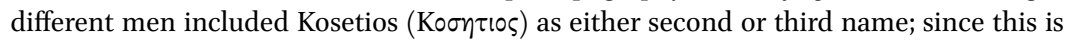
usually in the nominative, Robert suggests that this may have been a place name; see his discussion in Robert, I.Sinuri p. 16-17. 
Sinuri was certainly the religious and administrative center of the Pormounos community, yet they also had strong ties with Mylasa and it is conceivable and even likely that some of its members lived in the urban center. At least some of its sacred lands even bordered on the very edge of the city, in an area called Myrsela. ${ }^{142}$ Also, some of the sanctuary personnel who worked the dispersed sacred lands also appear to have lived on them, as indicated in a fragmentary letter by Antiochos III or his staff instructing his officer Zeuxis to return those who had been kidnapped by his soldiers to the sacred lands and to restore their property. 143

\subsubsection{Economic Resources}

Over a third of the inscriptions concern the lands belonging to the god Sinuri, and most of these involve land-lease contracts. ${ }^{144}$ As briefly discussed above, the area around Mylasa, including Olymos, knew a peculiar hereditary lease construction (misthosis) in the late Hellenistic period, in which land was sold to a sanctuary, then leased back to the original owner and his descendents. ${ }^{145}$ The sanctuary of Zeus Osogollis, combined with the Otorkondeis phyle, has the most extensive set of lease documents that show the various steps involved for each transaction, from intent to purchase, sale, possession, and then hereditary lease, each separately recorded. ${ }^{146}$ The property for lease and all its contents were described in detail, in each documented step, together with the geographical features and the surrounding lands, as shown above. These were

142 I.Sinuri $11 \mathrm{~A}$, line 11 , discussed below.

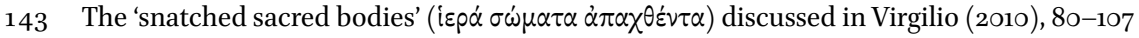
(re-published in Virgilio (2011)). Virgilio deciphered and interpreted the letter mentioned by Robert in I.Sinuri p. 12, with an alternative reading from Piejko (1990), 153-154, no. 2. The reconstruction of Antiochos III as author of the letter was questioned by Errington in $B M C R$ 31.10.2012, who proposes a subordinate instead.

144 No mention is made here of the specific area of the sacred lands, but besides the verdant valley west of the sanctuary, I consider the fertile plain directly east of Mylasa as a likely candidate. One honorific inscription mentions the recovery of sacred lands close to Mylasa, in an area called 'Myrseloi', adjacent to the town, I.Sinuri 11, see below; others were closer to Sinuri; I.Sinuri 47 a, a lease inscription, mentions the land in question being in the area of the 'Hysarbida', across the road leading to the sacred village, see above.

145 I.Mylasa vol. I, p. 74-76, nos. 201-232 (lease contracts), 251-26o (property boundaries) and the lease inscriptions published in connection with the Uzunyuva discoveries, Marek and Zingg (2018), 157-175, nos. 13-19. On Olymos, I.Mylasa 801-854, see Laumonier (1940) and now van Bremen (2016), 14. Gary Reger and Richard Ashton have suggested that the pseudo-Rhodian drachm was especially issued in connection with this land-lease construction, to help the sanctuaries of the polis finance their newly acquired lands, Ashton and Reger (2006), esp. 125-126.

146 E.g. described in Dignas (2002a), 92; Chandezon (2003), 240-241. 
legal contracts, and it was vital that tract of land in question could be properly identified by all parties concerned.

This construction was also applied at the shrine of Sinuri, and the syngeneia of Pormounos handled these transactions much in the same way as did the phyle of the Otorkondeis that administered the sanctuary of Zeus Osogollis at Mylasa. Debord discussed the process in great detail. ${ }^{147}$ At that sanctuary the contracts were also inscribed on the temenos walls, showing their use as a sacred but also public archive. These leases are an indication not only of the management of sacred revenue, but most likely concern the economy of the entire community, whether this is the polis, as at the sanctuary of Zeus Osogollis, or the syngeneia, as at the sanctuary of Sinuri. They will have provided ready cash for those selling their land and a guaranteed long-term income for the sanctuaries at the same time. Yet why there was such a rapid surge of these transactions in the second and first centuries $\mathrm{BC}$, particularly in the region of Mylasa, is a matter of some discussion. ${ }^{148}$ Part of this may be understood in light of the correspondence between Antiochos III, his officer, probably the priest of Sinuri, and perhaps the Pormounos syngeneia or the polis itself. ${ }^{149}$ Most of this correspondence is lost or heavily damaged and Robert excluded it from inscriptions of the sanctuary of Sinuri. ${ }^{150}$ Virgilio's new reading of the text, however, places the sanctuary of Sinuri side by side with Labraunda and especially Amyzon, which, with their wealth and relative remoteness, were

147 Debord (1982), 169: at Sinuri a higher rent was applied for the first ten years, after that it dropped to a symbolic amount, underscoring this as a loan construction. The land was never intended to pass to the god directly - if the rent could not be paid, then the land would be leased out to a new tenant. Debord sees parallels for this in the medieval period, when land is often placed in the hands of God in times of insecurity, for protection, justifying the low rate. Dignas also sees this construction as a way of providing "cheap longterm loans to those who could provide real-estate as security," Dignas 2002, 24. Yet besides the loan, the stress of continued exploitation of the land within the same family is also significant.

148 Laumonier believes this to be a 'curious return' to temple economy, Laumonier (1958), 109, as does Dignas, who attributes it to piety, Dignas (2002a), 95-102, also (2000). But this does not address the sudden increase in these transactions in a time when all other signs point to a major Hellenization of sanctuaries. Debord considers it as a divine security of investment, perhaps in turbulent times, parallel to lease contracts to churches in the medieval period, Debord (1982), 169. Descat and Pernin (2008) relate it to Mylasa returning to an ancient royal practice after its liberation by Rome in the second century BC; the case of Sinuri, however, is at a much smaller scale, having little to do with the polis although mirroring its practices.

149 Virgilio (2010), 91 and 93, on the recipients of the letter.

15 Although he hoped to publish it at a later date, I.Sinuri, p. 12; later included in Piejko (1990), 153-154, no. 2. 
high-risk targets for pillaging during the campaigns of Antiochos III, particularly in the years 203-201 BC. ${ }^{151}$ During this period, Labraunda received a letter of protection, in which Antiochos III instructs his troops to respect and thus avoid the sanctuary. ${ }^{152}$ He wrote a similar letter to the sanctuary of Artemis at Amyzon, but only after his troops had already plundered the sacred lands and taken hostages. ${ }^{153}$ Antiochos thus ordered his commander, Zeuxis, to command the troops to return the kidnapped personnel, or 'snatched sacred bodies', to the sanctuary, safe and sound, and to restore their property; he then did his best to prevent future incursions by declaring the sanctuary and its lands and possessions inviolate (asylia). ${ }^{154}$ By analogy with this situation, Virgilio was able to restore much of the lost text of a similar correspondence between the Seleukid king and the sanctuary of Sinuri.

Virgilio's reading of this text highlights in particular three aspects that are especially relevant to this present study: 1 ) the sanctuary of Sinuri was clearly a lucrative target, like Labraunda and Amyzon, so it must have already had some extensive holdings by the end of the third century $\mathrm{BC} ; 2$ ) these rural holdings were populated, presumably by the people who worked them; and 3) the sanctuary of Sinuri, its people and its property, must have received the privilege of inviolability (asylia). This last aspect, that of protection, may have been an extra incentive for otherwise 'private' persons to sell their property to the god and then lease it back again. The modest rent indicates that this construction was probably as much for the benefit of the lessee as it was for the sanctuary. Besides providing the sanctuary with a steady income from the revenues, and the lessees with an ample amount of ready cash on hand, the property would also have fallen under the security of a divine and especially royal grant of protection from physical violence and financial harm - at least in theory. ${ }^{155}$

That this grant of inviolability was not always foolproof is evident in the degree of legal representation, the egdikos, which the syngeneia needed to defend the sanctuary's rights to its sacred lands in court against the wrongful takeover of these holdings by others. As mentioned above, I.Sinuri 2 shows

151 Virgilio deciphered the letter based on the Louis Robert's documents and squeezes, now available via the Fonds Louis Robert; see Virgilio (2010). On Antiochos III's campaigns in Karia, with his general Zeuxis, as part of his attempt to recover the extent of the Seleukid kingdom, see especially Ma (1999), 66- 71 and $85^{-86}$.

$15^{2}$ I.Labraunda 46, inscribed on the walls of the South Propylon, a logical place for such an announcement.

153 Robert and Robert (1983), no. 18.

154 Virgilio (2010), 80-107, see below.

155 E.g. I.Sinuri $46 \mathrm{a}-\mathrm{c}$ describes how a certain Demetrios sells his land to the sanctuary and agrees to lease it back for a period of ten years at the rate of 200 drachms and some oil; after this period the fee drops to a symbolic 1 drachm; discussed in Debord (1982), 169. 
seven of these attorney-officials (who also acted as tamiai) dedicating an altar to Sinuri, following some kind of incursion of the sacred woods belonging to the sanctuary. ${ }^{156}$ A second inscription, I.Sinuri 11, praises Dionysios, son of Leon, of Kosetios, for his leading role as egdikos in a trial in the courthouse at Mylasa 'against those who attempted to appropriate the sacred lands of Sinuri,'157 which he did, with the help of council or other egdikoi, by presenting evidence of the rights of the god and the syngeneia over these holdings. ${ }^{158}$ One of the main charges against the occupants was that they had harmed the syngeneia by withholding the revenue (phoros), from the produce of these lands which the sanctuary needed to pay for the sacrifices.

An interesting detail of this inscription is that it mentions some of the land in question: in a place called Myrsela, located in, or bordering on, the town of Mylasa. ${ }^{159}$ This demonstrates that not all of the lands belonging to the sanctuary were adjacent or close to each other, nor were they necessarily close to the sanctuary of Sinuri; in fact their position on the edge of the urban center indicates that sacred lands used in this way, i.e. as economic resources rather than for some numinous quality, could hypothetically have been located in any economic zone within the territory of the city. ${ }^{160}$ Another inscription, from Labraunda, mentions the priest Hiereus of Sinuri, probably as the owner of some lands adjacent to those being donated to Zeus Osogollis. ${ }^{161}$ Other places mentioned include Hysarbida, Mosouna, and Xerassos - perhaps villages. ${ }^{162}$ Although we do not know where the syngeneia lived, these inscriptions underscore both the dispersed nature of the lands belonging to Sinuri, as well as

${ }_{15} 6$ I.Sinuri 2, lines 8-9, following the list of the seven names: $[\gamma] \varepsilon v o ́ \mu \varepsilon v o l ~ \tau \alpha \mu i \alpha l \quad x \alpha[i]$

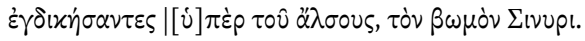

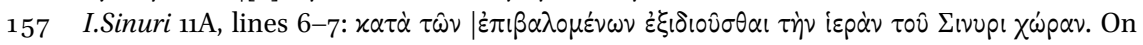
this inscription, see also Dignas (2002a), 100-101, who observes that the low rent rate may have been an incentive for people to rent lands from the gods.

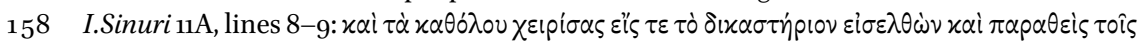

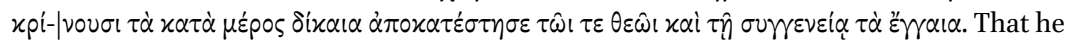
acted with council, or together with other colleague egdikoi, is implied by the use of $\pi \alpha \rho \alpha-$ $\chi \lambda \eta \theta \varepsilon i \varsigma$ in I.Sinuri p. 37 line 13. Robert believes three more inscriptions were dedications to other egdikoi, probably assigned to this same case: I.Sinuri 12, 13, and 14, p. 40-41.

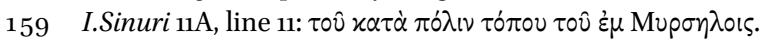

160 On the difference between kinds of sacred landscapes, see Horster (2010).

161 I.Labraunda 8C, line 30, as restored by Piejko (1990), 137 no. 8, following Debord (1969). The lands described were being donated by Olympichos in c. $240 \mathrm{BC}$, and are further

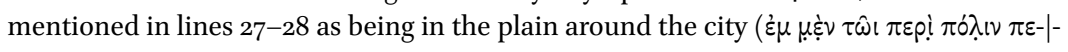
$\delta(\omega)$. Further discussed above, in Chapter 3 on Labraunda, and below.

162 Hysarbida is mentioned in: I.Sinuri $47 \mathrm{a}$, line 7 ; I.Sinuri $48 \mathrm{~b}$, line 5 ; and is restored in I.Sinuri 61, line 2. I.Sinuri $47 \mathrm{~b}$ mentions Mosouna in line 1, and Xerassos in line 9 (as well as a number of references to Hiera Kome). 
their physically close relationship with the polis. The fact that the quantity of contracts in the Hellenistic period rivals that of the Otorkondeis, the largest phyle in Mylasa, indicates a highly prominent position of Sinuri and the Pormounos syngeneia in the rural landscape of Mylasa. ${ }^{163}$

In short, the symbiosis between the cult of Sinuri and its community permeates the epigraphic record at the shrine. A major event in the biography of the sanctuary was surely when the identity of its community shifted from the Pelekos to the Pormounos syngeneia. While the former community enjoyed the favor of the Hekatomnids in the fourth century, the latter, appearing in the third century, was evidently integrated with Mylasa, at least by the second and first centuries BC if not before. The list of priests of Sinuri indicates a fluid transition. The priesthood was for life and probably hereditary, rather than being an elected position. That should hardly surprise, since this was not an urban cult. ${ }^{164}$ Yet by the second and first centuries BC, other religious offices in the cult were elected, the treasurers, the legal representation, those charged with the maintenance of the shrine, and those responsible for managing the sacred lands of Sinuri. In this regard the syngeneia, by now a sub-community of Mylasa, began to mirror itself on the institutions of the polis, even to the extent of using the same calendar and official (and typically Mylasan) jargon in their decrees. Where the syngeneia actually lived is unknown. The Pelekos community may have been more local, but the Pormounos syngeneia appears to have sacred lands scattered across the Mylasan countryside, with at least one tract adjacent to the urban center. This may reflect a dispersed community that met at the festivals of Sinuri. Wherever they may actually have resided, the cult of Sinuri played a central role in physically embedding the community within the landscape of the polis. The syngeneia of Pormounos was heavily engaged

163 This can only be a rough comparison, since all of the Hellenistic decrees found at the sanctuary of Sinuri also derive from there, and probably from the Pormounos syngeneia, while at Mylasa it is much more difficult to identify the origin of the inscriptions when the text is not specific in itself; also the record is much less complete. Nevertheless: 34 inscriptions recording land-lease contracts were found at the sanctuary of Sinuri, I.Sinuri $45^{-72}$ (some of these are sub-divided), only a few pertain to the same property; by contrast, 32 land-lease documents were found altogether at Mylasa, I.Mylasa 201-232. Fifteen of these are identified as belonging to the phyle of the Otorkondeis, most of which concern steps taken in the procurement of three different tracts: that of Iatrokles (I.Mylasa 202-204); Diodotos (I.Mylasa 205-206); and Thraseas (I.Mylasa 207-214); that Zeus Osogollis was also a large landowner is however testified by the inscriptions at Labraunda, I.Labraunda 8 and 69 .

164 Elected priests were the rule for state cults as they were generally less prone to power accrual, e.g. Debord (1982), 62-63 for Asia Minor; for Classical Athens, e.g. Garland (1984) and (1990) and Cole (2008). 
in the land-lease constructions that became so common in the Mylasan area, perhaps due to the volatility of the times and the need for additional, divine security. The meticulous descriptions of the lands inscribed on the walls of the shrine were surely as much a display of pride as an archive of transactions, creating a mental map for the visitor of the world belonging to the Karian god and his community. 165

\section{4 'Urban' Mediatization at the Sanctuary of Sinuri}

The sanctuaries discussed in the other case studies, especially Labraunda, Lagina, and Panamara, became 'urban' sanctuaries in the strict sense of the word - the deities of these sanctuaries came to symbolize the polis and a tight symbiosis developed between city and sanctuary. The sanctuary of Sinuri is different in this regard, since it addresses only a part of the polis, the syngeneia, rather than the entire citizen body. Yet as the previous section has already shown, the Hellenistic syngeneia modeled itself on the polis, adopting some of its institutions and formalities; many of the same processes are thus at work, making this sanctuary a kind of small-scale version of an urban sanctuary. This section explores ways that the sanctuary of Sinuri was used by the syngeneia to engage with the outside world while promoting its own members through the media of honorific decrees and monuments; finally, it briefly discusses the elusive iconography of Sinuri.

\subsubsection{Scope and Network}

Discussions above have already amply emphasized the shift in community at the sanctuary from the Pelekos syngeneia in the fourth century BC to the syngeneia of Pormounos, who appear at least by the third century вС. The Pelekos syngeneia is in fact represented by a single inscription, albeit a critical one, in which they are shown to give heed to a direct command from Idrieus and Ada. ${ }^{166}$ This close relationship between the rulers and the syngeneia reveals a larger role for Sinuri in the conceptual sacred landscape of Karia than implied by the low-profile nature of the shrine's location. Exactly why the Hekatomnids took such an interest in the cult of this Karian god or his syngeneia is not clear. No other cult place has been verified for Sinuri, nor was he syncretized with a Greek counterpart. ${ }^{167}$ There is, however, an inscription from Hyllarima, roughly

165 Horster (2010), 454 on the inscriptions of sacred land documents creating a "virtual and mental religious landscape" in the viewer's mind, discussed further below.

166 I.Sinuri 73, in which Nesaios is admitted into the syngeneia, discussed further below.

167 The relief of the double-axe may indicate some correspondence with Zeus Labraundos, see below. While there is insufficient evidence for the exact nature of the deity Sinuri, various hypotheses as to his origin are addressed in Robert, I.Sinuri p. 12-13 and Laumonier 
$5^{\circ}$ kilometers to the northwest, that describes the location of property being leased as 'in Sinuri, and being of Sinuri'.168 Because of the distance and the fact that the other lands mentioned in the text are much closer to Hyllarima and Stratonikeia, Robert suggests that there was either a place in this area named after Sinuri, or possibly a second sanctuary. ${ }^{169}$ While plausible, the valley southeast of Mylasa appears to have been the locus of his cult, controlled by the syngeneia.

As mentioned above, the transition to the Pormounos syngeneia by the late fourth century seems to have gone smoothly. ${ }^{170}$ At some point in the Hellenistic period, this syngeneia, and thus the sanctuary of Sinuri, was clearly part of the territory of Mylasa. ${ }^{171}$ The question is how intricate the relation between Mylasa and the sanctuary actually was. The words 'polis' and 'Sinuri' are the only legible parts of a heavily fragmented dedication at the sanctuary of Sinuri. This surely implicates the polis of Mylasa as no other polis is known to have been involved with this sanctuary. ${ }^{172}$ Other than this, Mylasa as a polis is not particularly concerned with Sinuri, although another Mylasan syngeneia, the Tarkondareus, appears in a number of inscriptions. ${ }^{173}$ In fact, a member of this syngeneia, Pammenes, son of Hermogeneos, of the Tarkondareus, was even appointed by the Pormounos syngeneia as one of the ktematones to administer the sacred lands. ${ }^{174}$ Syngeneiai were not exclusive and one could belong to different ones at the same time, as discussed above. Possibly this had to do with intermarriage and extended kinship ties. A decree of the Otorkondeis phyle at Mylasa shows the multiple interests of Aristeas Melanos, son of Apollonios: he was one of the ergodotai appointed by the Pormounos syngeneia to manage the sanctuary of Sinuri, but he was also priest of Zeus Hypsistos and Agatha Tyche

(1958), 180-183, who discusses possible Assyrian origins, as well as the names of the syngeneiai.

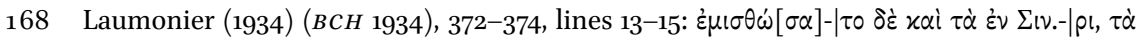

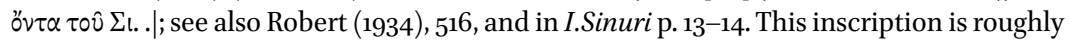
dated to the third century вс.

169 Robert, I.Sinuri p. 13-14; Laumonier (1958), 180-183.

170 The list of priests in I.Sinuri 5 appears to overlaps both syngeneiai, as discussed above.

171 Indicated among others by the dates of inscriptions to the magistrate (stephanephoros) of Mylasa, and the use of its legal infrastructure, discussed further below.

172 As Robert states, "sans doute" regarding I.Sinuri 4, and p. 18-19; dated to the third century вС.

173 E.g. I.Sinuri 14 , lines $3-4$, in an honorific inscription; I.Sinuri 45 is a testament, involving one of the Tarkondareus also named Hiereus ('Priest'), see Robert, I.Sinuri p. 64. The Tarkondareus syngeneia was a subdivision of the Otorkondeis phyle of Mylasa, discussed in Chapter 3.

174 I.Sinuri 47a, lines 2 and 5; a Pammenes, son of Hermogenos is also mentioned in I.Sinuri 50, a similar but less extensive list of ktematonai. 
in Mylasa, and was furthermore civic magistrate (stephanephoros). ${ }^{175}$ There was thus at least some degree of interaction between other citizens of Mylasa and the syngeneia of Pormounos. Vice-versa, a priest of Sinuri in the later second century, Hybreas of Krateros, is listed as the adoptive father of Hybreas of Polykritos, who was stephanephoros and involved in a Mylasan land-lease transaction. ${ }^{176}$ Finally a statue base in Mylasa is dedicated to Thargylios, son of Aristomenos, 'who became priest of Sinuri', proving that honors could be bestowed within the urban context of Mylasa on someone in this office. ${ }^{177}$

As Robert pointed out, these two priests probably held office after the list of priesthoods had already been inscribed. ${ }^{178}$ Both were in any event part of the urban fabric of Mylasa, more so than we know for the previous hereditary priests. At this point it is unclear exactly how they came by their priesthood, what their affiliation with the Pormounos syngeneia was, or whether the syngeneia was still active by the first century or whenever the statue for Thargylios was erected. ${ }^{179}$ In any event, by the end of the first century вс little more is heard from the syngeneia of Pormounos, their sanctuary, or of Sinuri. The only evidence we have of further activity are the two tombs from the Roman period, just north of the temenos, as well as a few bronze coins from Stratonikeia from the Severan period, but these were common in the area, given the regional dominance of the polis to the east in this period. ${ }^{180}$ Yet a continued awareness of the shrine may be seen in the Byzantine period with the erection of a basilica on top of the ancient place of cult.

In summary, the scope of the sanctuary of Sinuri was restricted to the level of syngeneia, although the affiliations of this body changed. In the Late Classical period the Pelekos syngeneia was apparently significant enough to draw the attention of the Hekatomnid rulers to this remote sanctuary, yet remained autonomous. After their passing, the shrine fell to the Pormounos syngeneia who, although a sub-community of Mylasa, administered the shrine via an

175 Aristeas, son of Melas, son of Apollonios appears in I.Sinuri 9, lines 24-26 as one of the ergodotai of the Pormounos sygneneia, and is stephanephoros of the polis in I.Mylasa 212, line 2, where he is still listed as priest of Zeus Hypsistos and Agatha Tyche; see Robert, I.Sinuri p. 30-31, here he further identifies two of the stephanephoroi mentioned in the Sinuri inscriptions as being active in Mylasa: Leon, son of Theomnestos, in I.Sinuri 9, and Hermios, son of Polites, in I.Sinuri 46.

176 Blümel (1989), 12-13, no. 103, line 2; I.Mylasa 217, lines 6-7 (Blümel et al. (2014) no. 2\&3).

177 I.Mylasa 763 dated to the mid-first century вс.

178 Robert, I.Sinuri p. 25.

179 See above; Robert postulates that the priesthood may have been elected by the Mylasans, rather than the syngeneia, or it may have been put up for sale as with others, see above and Robert I.Sinuri 25.

180 Robert, I.Sinuri p. 29. 
institutional model inspired by the polis. The sanctuary of Sinuri was an urban microcosm, reflecting the organizational format of the polis in a scaled down version of a regular urban sanctuary, expressing and reinforcing the essential identity of the community involved with it; this will become more apparent in the next section.

\subsubsection{Civic Decrees within the Syngeneia}

The sanctuary of Sinuri was a podium for the syngeneiai who were involved with it. As with polis sanctuaries, decrees here were also issued that concerned the constitution of the community, and by this mechanism new members were admitted while others were honored for their positive contribution to the community and the sanctuary.

In fact, the only inscription securely connected to the Pelekos syngeneia, I.Sinuri 73 , shows them honoring an individual named Nesaios, among others, by admitting him into the syngeneia as their 'brother' and granting him personal exemption (ateleia) from public dues, except for the divine, or royal, revenues, followed by a curse on anyone who violates this decree. ${ }^{181}$ Nesaios also appears in the heavily fragmented inscription I.Sinuri 74, in combination with the festival of the Syennia - possibly the festival in which he was admitted to the syngeneia. ${ }^{182}$ The privilege and the praise bestowed upon Nesaios reveals his special status; as discussed above, he evidently brought with him a personal mandate from Idrieus and Ada, the Hekatomnid rulers of Karia after Maussollos's death. 183

The Pormounos syngeneia used the sanctuary in a very similar, communal way. One of the earliest attestations of their presence is I.Sinuri 44 (Figure 4.25),

181 I.Sinuri 73, line 7: $\dot{\alpha} \delta \varepsilon \lambda \varphi \dot{\partial} v \dot{\varepsilon} \alpha \nu \tau \hat{\omega} v$, Robert sees this as an indication of the fraternitylike character of the syngeneia, see p. 96, also discussed above. Lines 11-12 are revised in Robert (1949), based on Wilhelm (1947), 16-20 - this section now reads $\varphi[$ [ó $\rho \omega[$ [v?] $\mid[\pi \dot{\alpha} \nu] \tau \omega \nu \dot{\alpha} \tau \dot{\varepsilon} \lambda \varepsilon\left\llcorner\alpha \nu \pi \lambda \dot{\eta} \nu \dot{\alpha} \pi \circ \mu\left[0\right.\right.$ ipa $\left.\varsigma^{\circ}\right]$. Hornblower discusses the early appearance of apomoira as an Achaemenid tax form, later adopted by the Ptolemies, Hornblower (1982), 72 and 162. A close parallel with I.Sinuri 73 may be seen at Labraunda in the third century, when the Korris syngeneia is shown honoring two individuals in I.Labraunda 11 and 12, see above.

182 I.Sinuri 74, line 4: . IINH $\Sigma$ AIOY, and line 6: . $\sum \Sigma$ YENNIOI $\Sigma$. Adiego has shown that this inscription is the latter section of I.Sinuri 75, both of which are bilingual; Adiego (2000), 133-139. The dedication fragment I.Sinuri 3 , from the fourth century BC probably refers

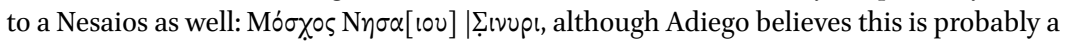
different person, Adiego (2000), 136.

183 Hornblower discusses the possibility of Nesaios as a satrapal agent of the Hekatomnids, who may have ordered the Pelekos to admit him into the syngeneia, Hornblower 1982, $72-73$. 
an inscription from the late fourth or early third century which admits a certain Samiades, son of Theodotos, into the syngeneia, allowing him and his descendants the right to share in everything belonging to the syngeneia. ${ }^{184}$ Obviously the constitution of the syngeneia was a critical matter and the sanctuary was the most appropriate place to record such significant changes; being accepted as a member was a religious act that allowed access to the resources of this community, to all things sacred and common, including participation in the festivals at the sanctuary. Inscribing this decision at the sanctuary ensured the recognition of this basic right within the community for generations to come.

The later decrees of the Pormounos syngeneia reveal a strong similarity with the political language of the polis, showing in particular how they modeled themselves on this major institution. Legality was especially a major concern. As with any legal document in the urban sphere, they began with an annual date in a widely recognizable format, i.e. based on the stephanephoros of Mylasa that year, and the month (and sometimes days) in which the decree was issued. ${ }^{185}$ The honorific decree for Dionysios, son of Leon of Kosetios, discussed above, gives a good example of this. ${ }^{186}$ After the date is established, the inscription continues with the subject of the decree, and then in line 2 the decision itself is prefaced with, it was determined by the Pormounos syngeneia .....187 The decision-taking body, i.e. the syngeneia, is now depicted as a homogenous entity, much like the boule and demos of the civic decrees. As discussed above, this is in contrast with the older formula, like that in I.Sinuri 44 just discussed, in which the decisions were taken by the entire koinon of Pormounos syngeneia, or by the Pelekos syngeneia who all assembled together. ${ }^{188}$ The next phrase is typical of the Hellenistic decrees of the Pormounos syngeneia, stating that so-and-so 'introduced and declared the motion'. This particular formula, gnomen apophenamenou, is peculiar to the Mylasa area, and is used almost exclusively by the Otorkondeis phyle, but also by the demos of Olymos, which was absorbed by Mylasa. ${ }^{189}$ The fact that

184 I.Sinuri 44, p. 56-62 on the date of this inscription and the possible identities of the eponymous Pleistarchos.

185 As stated above, the Hellenistic decrees at the sanctuary of Sinuri followed the same calendar as Mylasa, see Robert, I.Sinuri p. 30-31.

186 I.Sinuri 11.

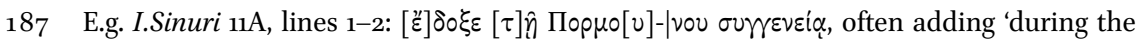

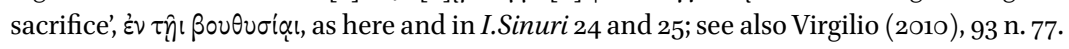

188 See Robert, I.Sinuri p. 55 and 95, discussed above.

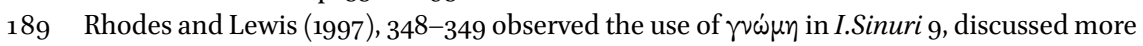

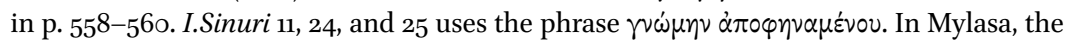
same phrase in singular or plural appears in the decrees of the phyle of the Otorkondeis: I.Mylasa 109, 110, 111, 114, 157, 203, 207, and 231; and of the phyle of the Hyarbesytai: I.Mylasa 
TABLE 4.1 Hellenistic inscriptions at Labraunda (37 total) and Sinuri (84 total)

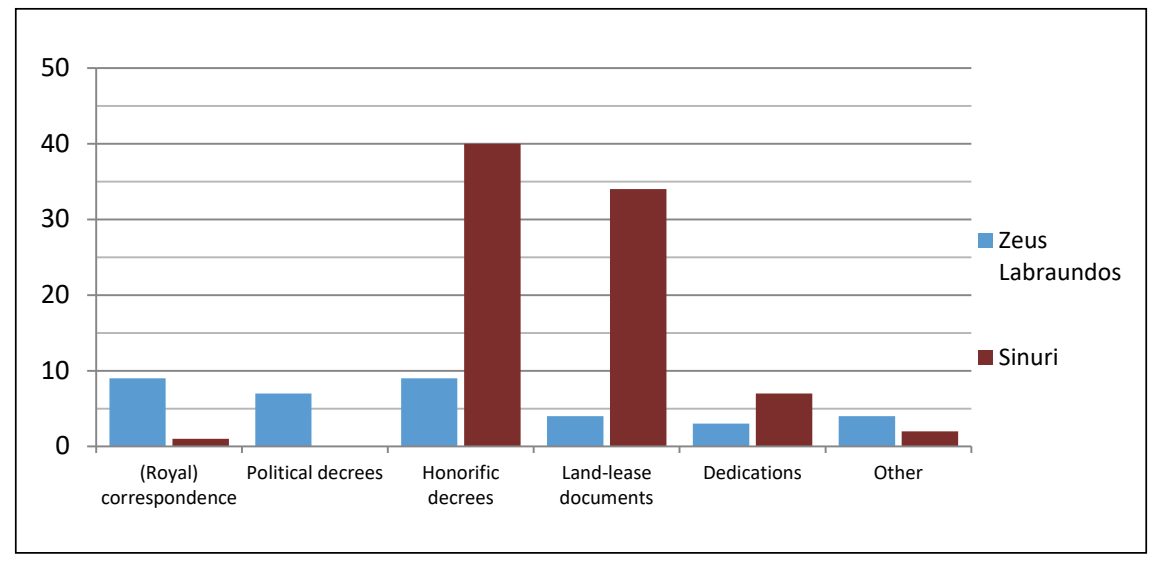

Breakdown according to type: royal, political, honorific, land-lease, dedications, other

the Pormounos syngeneia use this same formula in their own meetings demonstrates the extent of their integration in the political culture of the polis, and proves that they were not an isolated community who simply co-existed alongside the greater city. In fact, their institutionalism and way of operations indicates that they consciously adopted the organizational style of the polis. 190

Honorific decrees further make up over half of the inscriptions from the Hellenistic period found at the sanctuary of Sinuri - four times as many of this type were discovered here as at Labraunda (Table 4.1). Even allowing for the many fragments and the probability that not all of the inscriptions have yet been recovered at either sanctuary, these proportions are nonetheless highly significant, especially when taking into consideration the fact that the sanctuary of Sinuri represented only a part of the population of Mylasa, whereas the entire polis participated in the festivals at Labraunda.

The high number of honorific decrees indicates that this sanctuary was perhaps even more of an 'urban platform' than Labraunda, at least for honoring people for the ways in which they benefitted the community. In this sense it surely was the nexus of the popular identity of the Pormounos syngeneia, a

301. It also appears by the demos of Hydai, I.Mylasa 902.1, and of Olymos: I.Mylasa 8o1, $802,819,829,861$, and $E A 13,1989,7-8$, no. 895. The formula seems to be unique to the

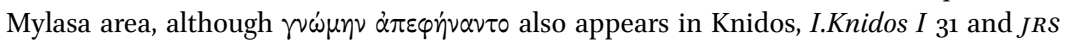
$64,1974,195^{-220}$.

190 For an in-depth discussion of 'political culture' and its permeation throughout the Hellenistic world, see van Nijf and Alston (2011). 
trend that was more widely apparent throughout the various Mylasan communities, as discussed in the concluding section of this chapter.

Taken together then, these inscriptions show an important shift in the image of the Karian syngeneia. In the Late Classical period they were largely autonomous political units, as Robert observed. ${ }^{191}$ The relationship between the Pelekos syngeneia and the Hekatomnids exemplifies how sanctuaries could be used by such independent local communities to negotiate their position with the wider ruling powers. By the Hellenistic period, however, syngeneiai had generally become nested within the structure of the nearest, or most dominant, polis. The inscriptions of the Pormounos syngeneia indicate that at least some syngeneiai were able to maintain a balance between their identity as a group and their role as a subsidiary of the polis, by using the sanctuary as their own platform.

\subsubsection{Cult Iconography}

About the god Sinuri himself, we know very little other than that he retained his indigenous name rather than being assimilated with a Greek god (for example Zeus), and that he had no female counterpart. ${ }^{192}$ Two terracottas found at the sanctuary, however, may indicate some connection with Aphrodite, ${ }^{193}$ while the sculpted Dioskouroi cap establishes a connection with the worship of the twin gods, as discussed above. ${ }^{194}$

Perhaps the most interesting find however is the double-axe sculpted in relief on a block of red marble. ${ }^{195}$ This is interpreted by Robert as an attribute of Sinuri, yet given the appearance of the double-axe elsewhere, for example at the sanctuary of Hekate at Lagina where it was certainly not an attribute of the

191 Robert, I.Sinuri p. 93: "La syngeneia, avant d'être dans les cites hellénisées une subdivision de la tribu, a dû être une cellule indépendente de la vie politique dans les campagnes de la Carie."

192 In contrast with Zeus Panamaros, who is generally believed to have been a local Karian god that was later assimilated, e.g. Laumonier (1958), 339-340; Hanslik-Andrée in $R E$ s.v. 'Panamaros': "eines dem Zeus angeglichenen altkarischen, spatter graezisierten Himmelsgottes." Hera was added to the cult once the sanctuary was locked into the orbit of Stratonikeia, see below in Chapter 6 .

193 Devambez (1959), 30-31, Pl. XXVIII. The terracottas include a head of Aphrodite, a relief of Eros (perhaps from a vase); part of a terracotta lion's head was also found, probably Roman.

194 Discussed above in connection with I.Sinuri 8, the dedication by the priest Menippos to the savior gods; see also Robert I.Sinuri, p. 22. The cap-shaped stone is shown on Pl. vilI.

195 Robert in I.Sinuri p. 14 and Pl. viII; the relief is not dated. 
goddess, ${ }^{196}$ it may well have simply been deployed as a wider Karian symbol, or as a direct allusion to Zeus Labraundos. In this case, using this emblem would have been a way of establishing a link between the powerful god of Karia and this local deity, while reinforcing the more regional identity of the syngeneia. Whether the relief was created under the administration of the Pelekos or the Pormounos syngeneia is unknown, but it is tempting to connect it with the name Pelekos, if this was in fact a derivative of the word $\pi \dot{\varepsilon} \lambda \varepsilon x \cup \varsigma$, or (double) axe. ${ }^{197}$ Both the relief and the name of the syngeneia (and priest) probably took their inspiration from the same primal Karian source.

To summarize, the sanctuary of Sinuri was thus always focused on the syngeneia, but the structure of this body underwent an important transition. In the Late Classical period, the Pelekos syngeneia appears to have largely been an autonomous political entity, answering directly to the ruling dynasty. In the Hellenistic period, however, the new syngeneia of Pormounos clearly operated under the umbrella of the polis and had some degree of interaction with it. ${ }^{198}$ Both syngeneiai held the sanctuary of Sinuri as their central place. This was where they met to discuss matters of importance, issue decrees, admit members, and ultimately to define and celebrate themselves through their festivals for Sinuri. This local level of governance seems to have remained the norm throughout the life of the sanctuary. Most of the honorific decrees found there were issued by phylai or syngeneiai, rather than by the institutions of the polis. The vociferous syngeneia of Pormounos further maintained its multifarious identity through the rituals of Sinuri. In the first place, it profiled itself as a local festive but also administrative body, focused on maintaining the cult of Sinuri. In the second place, it was clearly affiliated with Mylasa and adhered to its institutions, as demonstrated above. Finally, the double-axe relief, at least as emblem, indicates the syngeneia's regional awareness of its Karian identity. Although it concerned only a part of the urban population, this community used the sanctuary in much the same way that urban sanctuaries were used by a polis: as a public space for the community; as a place for ritual performance that strengthened social cohesion; as a source of divine but also economic

\footnotetext{
196 At Lagina two small stones or altars bearing a double-axe were found, and the double-axe appears in a number of the coffers from the ceiling of the temple, constructed in the later second century BC; see below in Chapter 5 .

197 Laumonier discusses the name and spelling of the priest Pellekos and the syngeneia Pelekos, in Laumonier (1958), 182-183; he further suggests that Pelekos could have been the original name of the god with the hatchet. The more common word is $\lambda \dot{\alpha} \beta \rho \cup \varsigma$, a possible source for the name Labraunda.

198 Robert, I.Sinuri p. 93, quoted above in note 122.
} 
security through the sacred domains; and finally, as mediator of identities individual, communal (or tribal), urban (or political), and regional.

\section{Interpreting Change in the Relationship between Mylasa, the Sanctuary of Sinuri and the Syngeneiai}

The preceding section has made it clear that the availability of sources, besides their content, will already partly determine the ways in which we can interpret the connection between the sanctuary of Sinuri and its community. Without knowing where the syngeneia of Pormounos lived, or whether processions were even part of their rituals, we can but speculate as to how the sanctuary was spatially integrated with the community. Also the upheaval of the monumental structures by the Byzantine reconstruction of the ancient sanctuary has heavily clouded our understanding of the exact layout of ritual space in earlier times.

Despite these impediments, we have nonetheless been able to ascertain several important aspects that may be used as a base for modeling the relationship between this remote cult place and the wider community of the polis. The monumentality of the temenos walls, as part of the Hekatomnid program, already points to this sanctuary in the isolated valley as an important place in the sacred landscape of Karia. Functions that particularly stand out here, more so than at any of the other sanctuaries discussed in this volume, are the strong emphasis on the sacrificial ritual itself, the finely tuned management of the sanctuary and its holdings as well as the high number of honorific decrees, and the relatively large number of land-lease documents.

The sacrificial ritual is of course the main event of ancient Greek festivals, but in the festivals of Sinuri this was stressed even more than usual - inscriptions show that the entire festival is typically designated as 'the oxen-sacrifice' (bouthysia) and the ritual itself was the defining event for the community. The architecture underscores this as well. While the area was enlarged by the Hekatomnids, the way that it was further articulated by the Pormounos syngeneia, enclosed on the eastern side by a stoa, created a kind of concentric space in front of the altar, thus spatially highlighting the sacrifice as the climactic ritual event for the community. Although the exact shape of this concentric space may not be clear, its place before the altar nonetheless shows that it would have functioned like an 'inward-facing circle', allowing for the ideal transfer of community knowledge. ${ }^{199}$ Inscriptions show that the sacrifice

199 Chwe (2001), 30-33. 
to Sinuri was in fact the moment in which the syngeneia took decisions that affected the community and honored its members for their affirmative actions, year after year. Embedding these decrees and commemorations within the sacrificial performance not only created a religious (and permanent) context for them, but proved public ritual to be the ideal medium for transmitting such knowledge and creating collective memories. ${ }^{200}$ The repetitive nature of the ritual works as a mnemonic device, much like a commercial jingle; communicating decisions and honoring members during this ceremony simply inserted this knowledge into the flow of ritual performance, thus ensuring its place within the collective memory. ${ }^{201}$ The nature of the sacrifice and the space in which it was performed both underscore the importance of social cohesion to this community, and show how the festivals for Sinuri functioned as rational rituals, at least in the Hellenistic period.

The Pormounos syngeneia clearly operated under the aegis of Mylasa, although we cannot state with any certainty whether they lived in town, on the fields, or near the sanctuary. Yet their 'home' was clearly the sanctuary of Sinuri - this was their administrative center, this was the place they held in common and which brought them together every year; this was the center of their identity. Their intricate management of the sanctuary and its lands, but especially their honorific decrees, together demonstrate how they maintained their own communal identity while adopting the practices and institutions of the polis.

On the one hand, the sanctuary of Sinuri presents a picture of an older indigenous cult place that continued to operate in much the same fashion as it always had, prior to the advent of the polis model. Such sanctuaries were the religious, social, economic and administrative centers of a local community, and were typified by a hereditary priesthood, and a degree of economic selfsufficiency, usually based on their sacred domains. ${ }^{202}$ Yet on the other, rather

200 Chwe (2001), 11-16, 25-30 on public ritual as a means of common knowledge. On ritual and the cognitive apparatus in general, see McCauley and Lawson (2002), discussed above in Chapter 2.

201 Ritual is an excellent mnemonic device, and a way of consolidating collective memories, e.g. McCauley and Lawson (2007); Connerton (1989), 49-61. This is discussed in more detail above in Chapter 2.

202 Most of Boffo's categories concerning indigenous sanctuaries in Asia Minor view them as the hearts of communities, Boffo (1985), discussed above in Chapter 2; see also Marchese (1989). This structure is similar to federation or koinon sanctuaries (e.g. Panamara discussed below in Chapter 6), or also the ethnoi in Archaic Greece, e.g. Morgan (2003), 107163. On the sacred lands, e.g. Dignas (2000), but also Horster (2004), 143-191, who studying Archaic and Classical Greece, states that most of the leased lands from these sanctuaries would not have paid for much more than the sacrifices. 
than being an anachronism, the sanctuary of Sinuri was in all likelihood representative of the way in which most Mylasans continued to express their popular identity while formally being part of the larger organization of the polis. The municipal subdivisions, the phyle and the syngeneia, that appear to have been the main channels for the social identity of the people, is demonstrated particularly through the number of honorific decrees issued by these bodies at their own local sanctuaries. ${ }^{203}$ Nearly half of the 57 honorific decrees discovered in the urban area of Mylasa were dedications made by the phylai and syngeneia, twice as many as the boule and demos issued (Table 4.2). Adding the 40 honorific decrees by the Pormounos syngeneia alone significantly increases this proportion, and, while these figures cannot immediately be taken at face value (since the sanctuary of Sinuri has been excavated whereas ancient Mylasa is still largely covered by modern Milas), they are nonetheless indicative of the wider trend of honoring individuals within more familiar and intimate circles, rather than at the civic level. ${ }^{204}$ The operations of the Pormounos syngeneia were surely similar to that of their predecessors, the Pelekos syngeneia. The main difference would be that the members of the Pormounos syngeneia were not only incorporated within the sphere of the polis, they also knew their way around its infrastructure and made rational use of its institutions to their own advantage.

This is not the place to go into the Mylasan decrees in any great detail, but the boule and demos were principally concerned with the political and external identity of the polis, and this is what was expressed in the decrees at Labraunda (e.g. Table 4.1, but also at the urban sanctuary of Zeus Osogollis, the other main deity of Mylasa). The popular identity of the Mylasans themselves, however, was still rooted in the 'local' level - perhaps reflective of the ongoing

203 E.g. the phylai of the Otorkondeis at Zeus Otorkondeon, (I.Mylasa 106, 113, 115, 156, 157, 204, 207b, 208, 209, 211, 214, and 216) or Zeus Osogollis (I.Mylasa 110, 112), and the Hyarbesytai with Zeus Hyarbesyton (I.Mylasa 301); the syngeneiai of the Aganiteis at their sanctuary of Zeus Aganiteon (I.Mylasa 121) and of the Maunnites with Zeus Maunniton (I.Mylasa 154).

204 This table is based on the honorific decrees listed in I.Mylasa, nos. 101-157; any conclusions are preliminary of course, given the size of the category 'unknown', and the fact that Mylasa has not been systematically excavated. Another example, however, is the number of cases in which individuals were crowned. The demos of Mylasa crowns individuals 6 times, in: I.Mylasa 101, 128, 148, 632, 634, and at Labraunda in I.Labraunda 48; the Korrides syngeneia also issued a crown at Labraunda, I.Labraunda 11. Individuals in Mylasa were twice as likely to receive a crown from one of the phyle, e.g. the Otorkondeis in I.Mylasa $105,106,108,110,112,113,114$, and 157; or the Konodorkondeis in I.Mylasa 119, 120; or an unknown phyle in I.Mylasa 136 and 140. The Pormounos syngeneia gave out 7 golden crowns in I.Sinuri 11, 16, 18, 20-22, and 37, discussed above. 
TABLE 4.2 Breakdown of the Hellenistic honorific decrees found at Mylasa according to issuing body

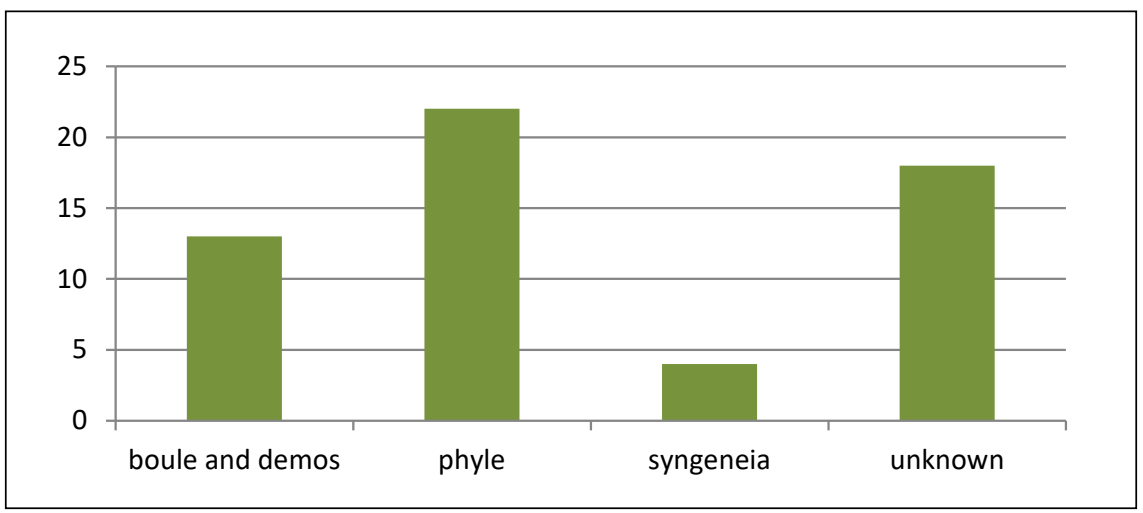

Total of 57 inscriptions, of which 39 were identifiable. Of the phylai: 15 were issued by the Otorkondeis, 2 by the Konodorkondeis, and 5 were unidentified. Of the syngeneiai: 2 were issued by the Aganiteis, and 2 by the Ogondeis

life of the communities that made up the town through the synoikism of the fourth century вС. ${ }^{205}$

Regarding the urban identity of Mylasa, in this context, one then needs to take into account the persisting diverse origins of its social composition. Through this scope it is immediately clear why the polis had such an animated sacred landscape: in the Hellenistic period Mylasa comes across as a multifarious institution, institutionally based on the Greek model of the polis yet still rooted in the local Karian communities that had been drawn together to make up the actual town. In this sense, the religions of the polis work in exactly the opposite direction of what Sourvinou-Inwood observed for the Classical period at Athens. ${ }^{206}$ It is the local communities who structure their own world and identity, the polis of Mylasa seems to have been an abstract collection of these; witness for example the many different cults for Zeus just in Mylasa alone. They were not all celebrating a central polis cult within the context of their local festivals, but their own identity instead. ${ }^{207}$

205 For the synoikism of Mylasa, see Radt (1969/7o), 168-169 n. 17; Rumscheid (2010), 97-98.

206 Sourvinou-Inwood (1990), 302: "The polis was the institutional authority that structured the universe and the divine world in a religious system, articulated a pantheon with certain particular configurations of divine personalities, and established a system of cults, particular rituals and sanctuaries, and a sacred calendar."

207 Hence the opposite of what Sourvinou-Inwood observes for Classical Athens, Sourvinou-Inwood (199o), 312-313; also Roussel (1976), 207 n. 38, 216. 
While the honorific inscriptions show the Pormounos syngeneia to be a microcosm of the structure of Mylasan society, their many land-lease inscriptions testify to the physical integration of the sanctuary and the syngeneia in the wider territory of Mylasa. By the late third century вс these lands had already become lucrative holdings, demonstrated by their attraction to Antiochos III's troops. Assuming that Virgilio's restoration is correct, the letter posted by Antiochos III furthermore shows that persons belonging to the sanctuary were actually living on these lands in and around Mylasa, since they had been taken hostage during the pillaging. ${ }^{208}$ Several of the land-lease transaction documents date from after this violent period; their detailed descriptions paint a picture of the lands belonging to Sinuri as being scattered throughout the countryside, from Hiera Kome near the sanctuary up to the edges of the town center. Based on the relatively large quantity of these transactions, a good portion of the landscape surrounding Mylasa seems to have been transferred to Sinuri under the administration of the Pormounos syngeneia. Inscriptions testify to the great concern of the Pormounos syngeneia with the proper administration of these holdings, even going to court in Mylasa when they were misused. These lands formed of course the economic backbone of the sanctuary of Sinuri and of its festivals, ${ }^{209}$ but probably also a major part of the resources of the Pormounos syngeneia itself. Although we are ignorant of a sacred way that could link the various economic zones together en route towards the sanctuary, the knowledge of the extensive holdings of the god provides nonetheless a different kind of indication of how the landscape around Mylasa was physically bound to the sanctuary of Sinuri. Besides economic, this connection was also legal, and the transactions were inscribed as juridical documents; no doubt some of these were actually copied and used as evidence in the Mylasan court during the legal defense by the syngeneia against the illicit appropriation of some of the domains. ${ }^{210}$

The inscriptions however go one step further. Besides their function as legal documents, their public locations and fact that they could be read by future generations projected a mental image of the vast estates of the god upon the visitor, just as it does with us. Marietta Horster pointed out that the often overwhelmingly long lists inscribed on the walls of sanctuaries with sacred lands could work to create a kind of "virtual and mental religious landscape" in the

208 Virgilio (2010), 8o-88 on the 'snatched sacred bodies' discussed above.

209 On the economics of sacred lands, Debord (1982), 127-180, Part 3 'Les dieux et la terre', esp. 168-169; Bringmann and Noeske (2000), 97-107; Dignas (2000); Chandezon (1998) and (2003) esp. 240-248; this is also discussed above.

210 I.Sinuri 11, discussed below. 
mind's eye. ${ }^{211}$ Even if the documents were inscribed in different places in the sanctuary, they would have created an overall impression of the great wealth of the god all around the countryside of Mylasa. This, together with the publicity from the trial, the pillaging by Antiochos III's troops, and probably the memory of the patronage by the Hekatomnids would have all worked together to make sure that the sanctuary of Sinuri was a bright dot on the mental maps of the Mylasans, whether or not it was actually part of the routine their daily lives.

Just looking at the map, one might interpret the second bloom of the sanctuary, and its investment in property, in light of border disputes between Mylasa and Stratonikeia, the rising city farther east which, like Mylasa, also began to expand especially in the second half of the second century вс. ${ }^{212}$ The sanctuary of Sinuri is located roughly midway to Stratonikeia, near what must have been the eastern perimeter of the territory of Mylasa. Yet if it were a 'true' frontier sanctuary, then one would expect it to have had a much more prominent place in the physical and mental topography of the Mylasans. Instead it appears to be almost hidden in a largely isolated valley, of primary interest only to the Pormounos syngeneia, rather than the population as a whole. The picture that emerges is a curious contrast with Labraunda. Although the sanctuary of Sinuri belonged to the sacred landscape of Mylasa, the polis did not seem to be particularly involved in the cult, e.g. through processional routes which implicitly or explicitly claim the surrounding countryside, or overt displays of urban pride or polis rivalry. ${ }^{213}$ The sanctuary of Sinuri was neither a frontier sanctuary, nor does it seem to have played any kind of pivotal role in the political power of landscape, as did the sanctuary of Zeus Labraundos. ${ }^{214}$ The shrine at the far end of this secondary valley was instead relegated to a subdivision, the syngeneia, who used it as podium for their own performances of 'urban rituals'.

The sanctuary of Sinuri is one of the best examples of the way in which ritual gave focus to a community. At the same time, it shows how the institutions and administrative practices of the polis were adopted and applied at a

211 Horster (2010), 454: "Thus, in the reader's, or viewer's mind - if he was not able to read the long texts with tiny letters - the documentation of the leases of sacred land might have generated a virtual and mental religious landscape including the vision of large estates of landed property of the respective deity."

212 E.g. I.Mylasa 134 concerns a boundary dispute between Stratonikeia and apparently one of the phylai of Mylasa; see also Ager (1996), no. 101. Stratonikeia and its sanctuaries are discussed in detail in Chapters 5 and 6.

213 E.g. de Polignac (1995); Graf (1996); Chaniotis (1995); discussed above in Chapter 2.

214 Or Meter Theon at Mamurt Kale, the highest peak in the vicinity of Pergamon, Williamson (2014a). 
smaller scale. The festivals of Sinuri gave the syngeneis a vehicle for balancing the overlapping layers of their nested identities: individual (through tasks, offices, and public honors); collective (as syngeneia); urban (through adhering to the legal and institutional forms of Mylasa, but also as landowners of a good deal of property in the territory); and even regional (the Karian double-axe, the legacy of the Hekatomnids). In this sense, it acted as an urban sanctuary, albeit one that was targeted to a subsection of the population. 


\section{Festival Networks: Stratonikeia and the Sanctuary of Hekate at Lagina}

In the two previous chapters, we saw how monumental sanctuaries in the civic territory of Mylasa could exhibit very different kinds of relationships with the polis: Labraunda was politically critical for both its strategic location and the symbolic capital of Zeus Labraundos among the wider population. By stark contrast, the sanctuary of the Karian god Sinuri played a central role in the social cohesion of its local community, giving us a microcosmic view of the aggregate polis. This chapter and the next will explore the urban dynamics of two other major sanctuaries in Karia, both of which found themselves within the territory of Mylasa's rising neighbor, the polis of Stratonikeia, roughly 3 o kilometers to the east.

Stratonikeia, a Hellenistic foundation, came to absorb the older sanctuaries of Hekate at Lagina, some eight kilometers north-northwest of the city's center, and Zeus at Panamara, roughly ten kilometers to the southeast (Figure 5.1). A closer examination of this development at each sanctuary will reveal more of the dynamics in the relationship between a country sanctuary and a composite polis. In this case, both sanctuaries ultimately served to foster internal social cohesion but also to establish a wider regional identity. Different from Mylasa, Stratonikeia was a new arrival in the Hellenistic era and both shrines appear to have been pivotal in consolidating the incorporated communities but also in the positioning of the polis on the regional and global map.

Nonetheless, there are two important points of comparison between the younger polis and Mylasa, besides their mutual border and the possession of two major sanctuaries in their respective territories: both poleis were made up of a number of ancient communities, and both were located near the home sanctuary of a Karian federation - for Stratonikeia this was the sanctuary of Zeus Chrysaoreus. Strabo in fact describes the city primarily through the lens of this sanctuary, which has not yet been identified, and that of Hekate at Lagina as follows:

Stratonikeia is a settlement of Macedonians. And this too was adorned with costly improvements by the kings. There are two temples in the country of the Stratonikeians, of which the most famous, that of Hekate, is at Lagina; and it draws great festal assemblies every year. And near the 


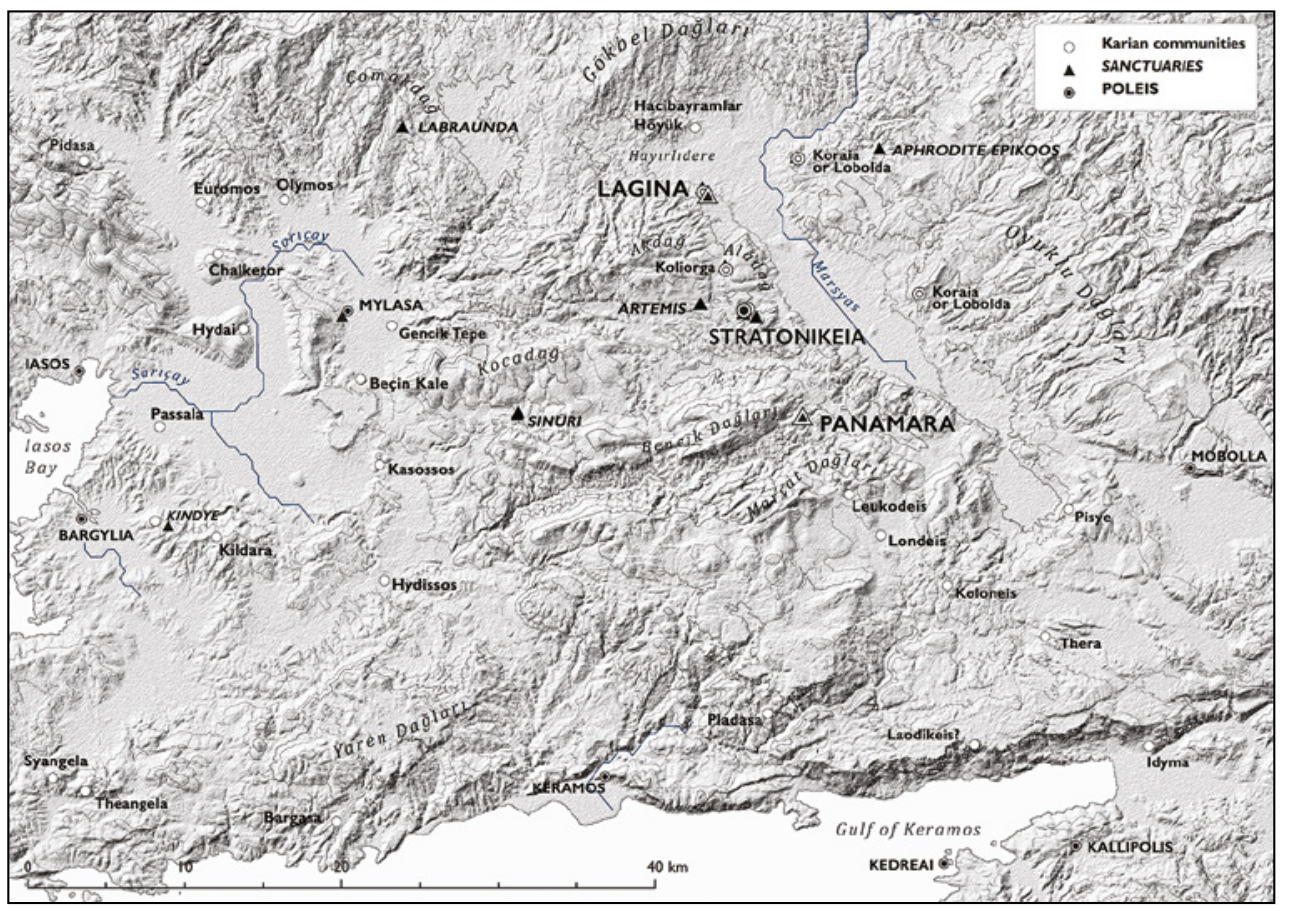

FIGURE 5.1 Map of Stratonikeia and the environment of Lagina and Panamara

city is the temple of Zeus Chrysaoreus, the common possession of all Karians, whither they gather both to offer sacrifice and to deliberate on their common interests. Their League, which consists of villages, is called 'Chrysaorian'. And those who present the most villages have a preference in the vote, like, for example, the people of Keramos. The Stratonikeians also have a share in the League, although they are not of the Karian stock, but because they have villages belonging to the Chrysaorian League. ${ }^{1}$

The sanctuary of Zeus Panamaros, or Zeus Karios as he was originally called, seems to have entirely escaped Strabo's notice, although in his day it surely would have been at least as important as Hekate's sanctuary in Lagina. But what Strabo does show is one of the most important differences between Mylasa and Stratonikeia for this research: while Mylasa was the ancient hometown of the Hekatomnid dynasty which had ruled Karia, Stratonikeia was a newly founded city. The accuracy of Strabo's assertion that the Stratonikeians were 'not of Karian stock' will be disputed below, but it reflects the general

1 Strabo 14.2.25 (transl. H.L. Jones (1929) The geography of Strabo, LCL 223). 
impression of the polis as very much a 'Greek' city, and in any event its origins as a colony. Stratonikeia was in fact founded in a social landscape that was already highly articulated, with archaeological traces of settlement activity that predate the polis. ${ }^{2}$ The sanctuaries at Lagina and Panamara were critical to the physical expansion and consolidation of the chora, or civic territory, but also to its social constitution. They were the primary instruments used in the development of urban identity at Stratonikeia, and for validating the polis in the wider region.

This chapter and the next examine in detail how Stratonikeia appropriated each of these two distant places of cult and utilized them to meet ends, but in different ways. ${ }^{3}$ Below I will first give a framework of the historical development of Stratonikeia before proceeding to examine the sanctuary of Hekate in Lagina. As in the previous chapters, this will begin with a site biography, and a depiction of the available sources, followed by a discussion of the physical environment, and the signs of urban integration, based on monumental space, ritual performances, legal administration, and urban mediatization. It will become apparent that several strategies were simultaneously deployed to create an interlocking pattern of association between cult, place, and polis. The territorial incorporation of these sanctuaries and the areas within their scope will thus have seemed natural and inevitable in the mindset of the wider community. The motives behind this transformation and its impact on the sacred and political landscape, but especially on the communities that lived and worked in them, will be examined after an assessment of the transformations in cult that took place.

\section{$1 \quad$ Stratonikeia - Historical Background}

The area in which Stratonikeia was founded was by no means a vacuum. Finds in the area of the city include two Sub-Mycenaean vases and ceramics from the Geometric period. ${ }^{4}$ Some of these derive from funerary contexts in the necropolis on the northern side of the city. ${ }^{5}$ Several communities in the area are known from the Late Classical and early Hellenistic eras, including Lagina and the nearby community of Koranza, as testified by an inscription under

2 Discussed below.

3 This section draws in part on Williamson (2012), (2013b); van Nijf and Williamson (2015) and (2016).

4 Hanfmann and Waldbaum (1968).

5 I.Stratonikeia III, p. 5. 
Philip II and the satrap Asandros that refers to an asylia originally conferred by Maussollos, stipulating that it was to be posted at the sanctuary in Lagina. ${ }^{6}$

Pausanias mentions of Stratonikeia that the town and its surroundings were once called Chrysaoris. ${ }^{7}$ Stephanus of Byzantium also believed that the first name was Chrysaoris, but was later changed to Idrias, and after this Hekatesia until the new Seleukid settlement. ${ }^{8}$ Shortly before this, however, the name Hiera Kome, or 'Sacred Village', appears in the area. ${ }^{9}$ Şahin argues this as reflecting the home of the sanctuary of Zeus Chrysaoreus, which may have been a strong factor in the Seleukid choice of site; in any case, this name later appears as one of the demes of Stratonikeia. ${ }^{10}$ There are a number of indications that the area of Stratonikeia was either just within, or near, the boundaries of Ptolemaic territory. The Chrysaoric League, for example, was clearly supportive of the Ptolemies and if they met at the sanctuary of Zeus Chrysaoreus at this time then this could have given reason the Seleukids to establish a colony here, as a counterpoint. ${ }^{11}$ Seleukid interest in the area at the time of the founding of the colony is certainly indicated by a heavily fragmented letter by Seleukos I written to an unnamed boule and demos on an architectural block which also carries a list of priests of Zeus Chrysaoreus, ${ }^{12}$ and an honorific decree for a man

$6 \quad$ I.Stratonikeia 5 o1.

7 Paus. 5.21.10, in his discussion of Olympic victor of the pankration and wrestling Aristeas, who was from Stratonikeia; I.Stratonikeia 1042, early first century AD.

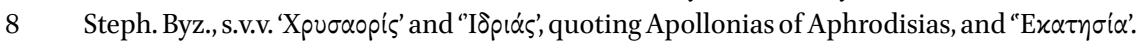
Idrias is also mentioned by Herodotos in 5.118, as a region near the Marsyas, with a place called 'White Pillars' where the Karians met to discuss their strategy. On the names, Sóğüt (2019), 288.

$9 \quad$ I.Stratonikeia 1503 , found at Stratonikeia and pertaining to some issues regarding land between Mylasa and Hiera Kome and arbited by the satrap Asandros; dated to the later fourth century BC.

10 Şahin (1976), 1-15, contra Robert, who suggested that Hiera Kome referred to Lagina as a sacred village, Robert (1937), 555-561; see also I.Stratonikeia III, p. 4-6; Şahin, however, showed that Lagina appears under its own name as a deme of Koranza; his arguments are generally accepted, e.g. Debord (1994) and van Bremen (2000).

11 This is the line of reasoning that Şahin follows in Şahin (1976), 32-33; see also Magie (1950), 995-996, n. 33. The sanctuary of Zeus Chrysaoreus has not yet been located. The Chrysaoric League also met at Labraunda, evidenced by I.Labraunda 43-44, dated to 267 BC, by the mention of Ptolemy II. Other Ptolemaic indications include the earliest text now known from Panamara, I.Stratonikeia 1400, which also mentions Ptolemy II; see Tscherikower (1927), 29 and esp. Debord (2001a), 157-158, and 158-161 mentions the continuing Ptolemaic influence in the urban landscape of Stratonikeia, e.g. attested by the temple to Serapis in Stratonikeia.

12 I.Stratonikeia 1001 is the Seleukid letter, early third century вС, written on the same block as I.Stratonikeia 1063, believed to be from the temple of Zeus Chrysaoreus. 
from Koliorga, a polis that was later absorbed by Stratonikeia, dated to the time of Antiochos II. ${ }^{13}$

Stratonikeia was founded probably in the 26 os BC, by either Antiochos I or II, and was named after Queen Stratonike. ${ }^{14}$ Exactly which shape this took or how this developed in the rest of this century is a rather ambiguous matter. Strabo notes how the city had been 'adorned with costly improvements by the kings,', ${ }^{15}$ but according to Polybius it was soon given to Rhodes after its foundation, by Antiochos II. ${ }^{16}$ If so, this may have been because Rhodes was the most important power in the region that was able to counter-balance the Ptolemies; some believe, however, that Polybius was referring to a gift in the early second century, by Antiochos III. ${ }^{17}$ At least one of the honorific decrees for Rhodians found at Panamara has now been dated to the third century BC, lending support to an early Rhodian influence, if not control, over the entire area. ${ }^{18}$

More certain are the events at the end of the third century and beginning of the second. This is when Philip v occupied the wider area, using Panamara as garrison..$^{19}$ His control lasted only a few years, however, as it was terminated by Antiochos III in 197 BC during his campaign to restore the extent of the ancient Seleukid empire. ${ }^{20}$ In the meantime, Rhodes had tried, unsuccessfully, to take

13 I.Stratonikeia 1030, for Nonnous Arrisios, dated to 'King Antioch, son of Antioch'. Since Koliorga later became a deme of Stratonikeia, Debord inteprets this letter as an indication that Antiochos II, rather than Antiochos I, was the founder of Stratonikeia, Debord (2001a), 157. It is, however, difficult to pinpoint the moment in which Stratonikeia absorbed the surrounding villages and Koliorga may well have retained its independence for some time after the initial foundation of the new polis.

14 Stratonike, daughter of Demetrios Poliorketes, was the wife of Seleukos I (c. 320-281 BC), who gave her in marriage to his son Antiochos I (281-261 BC); according to later accounts because he was violently lovesick for her (Plut. Vit. Demetr. 31, 38; App. Syr. 59). She was also the mother of Antiochos II (261-246 BC) and died at Sardis in 254 BC. On arguments for the foundation under Antiochos I or II, see Debord (2001a), 157.

15 Strabo 14.2.25, quoted at the beginning of this chapter. On the urban infrastructure of Stratonikeia, which was divided into zones marked by temples, see Debord (2001a), 158-162.

16 Polyb. 30.31.6, 'Antiochos son of Seleukos'.

17 Support for a third-century gift of the city to Rhodes is found among Rhodes and Lewis (1997), 272, 349-352; Ma (1999), 68, 277-278; Eckstein (2008), 166; and van Bremen (2008), 1411-1414. On the other hand, Reger (1999), 82-85, and Debord (2001a), 162-163 do not believe that Rhodes actually controlled the area until after it was given it by Antiochos III; Gabrielsen (2000), 171-177 leans towards this view as well.

18 I.Stratonikeia 6, and perhaps I.Stratonikeia 5, through parallels; van Bremen (2008), 1412-1413.

19 I.Stratonikeia 3 and 4 are honorific decrees for Philip and his commander Asklepiades. See also Holleaux (1952), 205-210 on Philip v at Panamara.

20 On this period see especially Ma (1999), 68-71, 277-278. 
Stratonikeia by force, and Livy mentions that they managed to gain control of Tendeba and Astragon, two fortified places in the territory of Stratonikeia. ${ }^{21} \mathrm{He}$ quickly handed Stratonikeia over, or back, to Rhodes, who maintained control over it and most of southern Karia for the next 30 years. ${ }^{22}$ In 167/6 вC, however, Stratonikeia and other communities voiced their objections to Rhodian rule to Rome, and the island power was forced to withdraw from the area. ${ }^{23}$ Rome granted Stratonikeia her freedom and from this time on the polis began to set out on a course of its own. ${ }^{24}$ The second century вC was then a critical era for the young polis, which seems to have had two basic concerns: negotiating the relationship with the overarching powers in the region, and its own internal territorial composition.

The process of territorial development had everything to do with the social identity of the Stratonikeians. The polis may have began as a 'settlement of Macedonians', as Strabo calls it, yet it became an agglomeration of the surrounding local communities, incorporating them into the new polis as demes. ${ }^{25}$ The evidence for this lies in the first place on the regular appearance of five communities in the demotics on the inscriptions from Stratonikeia: Hiera Kome, Koranza, Koliorga, Koraia, and Lobolda. ${ }^{26}$ As stated above, Hiera Kome is believed to be roughly at the site of Stratonikeia, probably named after the sacred village belonging to the sanctuary of Zeus Chrysaoreus. ${ }^{27}$ Koranza is located about eight kilometers to the north, whereas Koliorga, Koraia and

$21 \quad$ Livy 33.18.22. Tendeba and Astragon have not yet been identified.

22 A later alliance between Stratonikeia and Rhodes through the Chrysaoric League is inferred in I.Stratonikeia 1418 (= EA 35 (2003), 1-7).

23 Polyb. 30.21.2-3 mentions how Stratonikeia and Kaunos both complained to Rome about the harshness of Rhodian rule. Rhodes protested Roman ruling, by stating that Stratonikeia had been a gift to them by Antiochos III in 197 BC, and that they had purchased Kaunos for 200 talents, Polyb. 3.31.6-7.

24 The first issues of Stratonikeian coinage date to this time and may be related to municipal endeavours, see Meadows (2002).

25 Strabo 14.2.25. That the demotics referred to pre-existing communities was first observed by Cousin and Diehl (1887), 33 and later developed by Mehmet Çetin Şahin in Şahin (1976), 1-15 and in I.Stratonikeia III, p. 1-8. The demes are further discussed in Debord (1994) and van Bremen (2000).

26 The frequency of the appearance of the demotics in the inscriptions of Stratonikeia are listed by Şahin in I.Stratonikeia III, 2: Koliorga - 179 times; Hiera Kome - 15 o times; Koraia - 13 o times; Koranza - 106 times; and Lobolda -54 times.

27 Şahin (1976), 1-15 and above. The sanctuary for Zeus Chrysaoreus has not yet been identified. Şahin (1976), 14 locates it on a hilltop just $200 \mathrm{~m}$ east of Stratonikeia (Eskihisar), "at the places called Halkalı and Manastır;" Söğüt (2019), 289-29o considers the area east of the bouleuterion more likely. 
Lobolda have only tentatively been identified at the locations indicated in Figure 5.1. ${ }^{28}$

Three of these - Koranza, Hiera Kome, and Koliorga - already appeared in a fourth century inscription from Sekköy. ${ }^{29}$ Some kind of synoikism must have underpinned the process of incorporating these once independent towns, but when this developed and whether it was designated by a central Seleukid or Rhodian authority or was more of a local initiative is unclear. ${ }^{30}$ In any event, the use of the demotic increases in the later second century (although this coincides with the rise in the epigraphic habit here) and towards the end it becomes so common that the demotics are abbreviated. ${ }^{31}$ This reveals two important aspects that are relevant to this research: on the one hand, the demes, as ancient communities, continued to play a vital role in the identity of individuals throughout antiquity, while on the other, the increasing need to specify deme identity shows an intensive activity in the composite sphere that made up Stratonikeia. Debord already observed how Stratonikeian territory was defined by its religious communities - in the two case studies below I will examine this in more detail. ${ }^{32}$

At least two of these communities, Koranza and Koliorga, had once been independent poleis in their own right. ${ }^{33}$ Koranza covered an extensive area that includes Lagina and continues northwest to the southern rim of the

28 I.Stratonikeia III, p. 1-8 discusses possible locations. Two alternative sites have been proposed for Koliorga, both based on inscriptions: Aydaş (2006) places it at Börükçü, between Stratonikeia and Koranza, while Debord (1994) and Şahin (2008a), 79-81 (and more recently in I.Stratonikeia III, p. 7), both locate it on the hill of Maltepe at Gurbet Köy, roughly seven kilometers west-southwest of Stratonikeia; Şahin further locates Koraia at Çatlı, roughly 15 kilometers east of Stratonikeia (Şahin (2008b), 82 and 86; I.Stratonikeia III, p. 7).

29 Blümel (1990), no. 12. Hiera Kome and Koliorga also figure in the early third century inscriptions, I.Stratonikeia 1001 and 1030, mentioned above. Descat suggested an identification for Sekköy as Talagreia, in a new reading of I.Mylasa 11, Descat (2013).

30 Debord (1994), 117: “En fait, et pour l'essentiel, la nouvelle cité est la produit du synoecisme de communautés cariennes et il est bien probable que les cinq démotiques précités, ceux qui sont tirés des noms de Hiérakomé, Koraza, Koliorga, Koraia, Lobolda, donnent ses composantes initiales."

31 Debord (1994), 117-118; van Bremen (2004b), 214-215. The demotics are typically abbreviated as IE (Hiera Kome), KZ (Koraza), ко (Koliorga), K $\Omega$ (Koraia), $\Lambda \mathrm{O}$ (Lobolda); Laumonier (1958), 197-198.

32 Debord and Varinlioğlu (2001), 191.

33 Blümel (1990), no. 12 is a fourth century inscription from Sekköy listing Koranza and Koliorga as poleis. Şahin believes that by analogy the other communities may also have been referred to as poleis, I.Stratonikeia III, p. 2-3. The name Koranza generally appears as Koraza when it is a deme of Stratonikeia, Şahin (1976), 1 n. 6, and (1973), 188. For the sake of clarity, I will simply use the name Koranza in this study to refer to this community. 


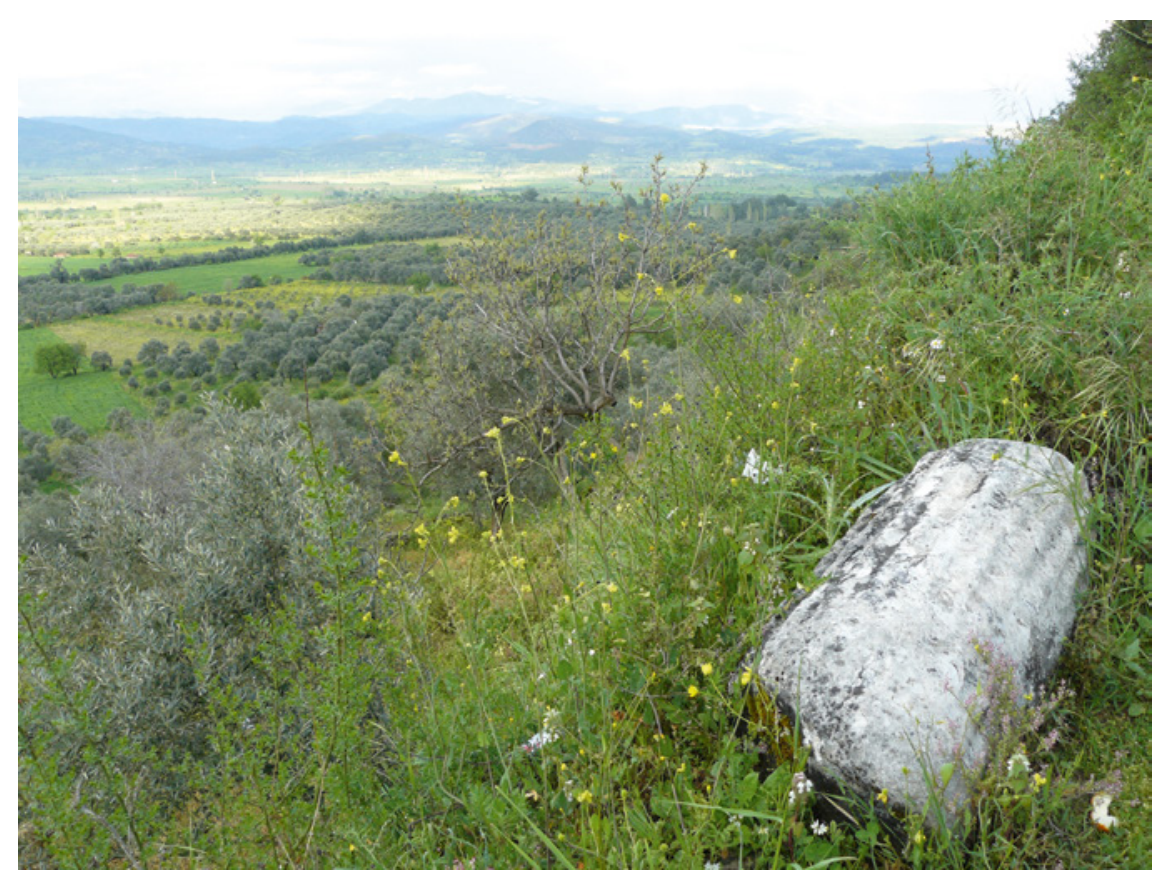

FIGURE 5.2 Koranza. Column from the area of the Apollo and Artemis temple, at the edge of the plateau looking NE, across the Hayrlıdere valley to the Gökbel mountains in the background

PHOTO AUTHOR 2009

Hayırlıdere valley (Figure 5.2) $\cdot{ }^{34}$ Although the character of this polis is unclear, whether there was an urban center or more of a distributed settlement, inscriptions show that Koranza had a political decision-making body, with two archons. ${ }^{35}$ Furthermore, it comprised a number of demes of its own, one of which was Lagina. ${ }^{36}$

34 Indicated by Ahmet Tirpan, pers. comm. in April 2009; sporadic finds support this view and Karian settlements are also typically on hillsides; Debord, however, drew a circle around the lower Hayırlıdere valley to indicate the area of Koranza on his map in Debord (1994).

35 I.Stratonikeia 501 , from 323 BC, refers to a grant of tax exemption (ateleia) made by Maussollos and Koranza; I.Stratonikeia 503 is an honorific decree from 318 вС issued by Koranza, together with the main assembly (ekklesias kyrias) and the sacred heralds (hierokerukes), during the archonship of Hyssollos and Obrokon; see also below.

$3^{6}$ I.Stratonikeia $5^{\mathrm{O} 2}$ is a fourth century inscription from Koranza listing its demes as Hythybira, Patarousa, Angorra, Lagina, and Ondra. 
The sanctuary of Hekate was then part of this community, but was clearly under the control of Stratonikeia by the early second century BC, when they added the administration of the cults of Rhodes and Helios to the priesthood of Hekate. ${ }^{37}$ The young polis then had already set its focus on the sanctuary of Hekate as a political platform by this time; the relationship with Lagina was obviously very tight by the mid-second century when, after Stratonikeia was free to mint its own coinage, the goddess appeared on the very first issues. ${ }^{38}$ Zeus also appeared on these early coins, albeit in a very generic form. ${ }^{39}$ It is tempting to see him as Zeus Karios of Panamara, although this presumes an early date for Stratonikeian control of the cult. At some point between its liberation from Rhodes and the mid-second century, Stratonikeia appointed one of its citizens, a certain Leon, as priest of Zeus at Panamara while the sanctuary was still under the administration of the koinon, or community, of the Panamareis. ${ }^{40}$ This appointment, while praised by the Panamareis, marked the beginning of Stratonikeian control at Panamara. ${ }^{41}$ The priests appearing after Leon were from Stratonikeia and the cult seems to have been wholly administered by the polis from that time on. Only a handful of inscriptions show Panamara in the demotic. ${ }^{42}$ Rather than retaining its identity as a subcommunity, it seems more likely that the koinon of the Panamareis was disbanded or absorbed by the polis and redivided among the other demes.

The sanctuaries of Hekate at Lagina and Zeus at Panamara already demonstrate two different kinds of involvement in the second century ВС - Lagina, along with the town of Koranza some eight kilometers to the north, must have already been absorbed by the polis, whereas Panamara, some ten kilometers to the south, appears to have been part of a more gradual process of territorial expansion in this direction.

Territorial expansion must have been high on the agenda of Stratonikeia in the momentum of its new political identity as a free city in the mid-second century BC, especially in the wake of Rhodes' withdrawal. The island power continued to hold much of the area north of the Bay of Keramos, in the subject

$37 \quad$ I.Stratonikeia 504.

38 A chronology for the Hellenistic coinage of Stratonikeia is the topic of Meadows (2002), discussed in more below under Cult Iconography in Civic Contexts.

39 See also Meadows (2002), Group 1; Meadows believes this is Zeus Panamaros, but gives no arguments, whereas in BMC Caria, Head believed it may also represent Zeus Chrysaoreus.

40 I.Stratonikeia 7 ; van Bremen (2004b) and below in Chapter 6. In Karia, the word koinon can represent a number of degrees of community or federated communities; see Debord (2003).

41 See van Bremen (2004b), discussed below.

42 Şahin counts five or six demotic indications of Panamara, I.Stratonikeia III, p. 2; van Bremen (2004b), 215 . 
peraia of Rhodes. ${ }^{43}$ Pierre Debord believes that Stratonikeia was looking to gain critical mass in order to be able to stand up to its powerful and aggressive neighbor to the south. ${ }^{44}$ Even in the later part of the second century вС, Rhodes still expressed its 'hatred' (apechtheia) of Stratonikeia. ${ }^{45}$ The situation of the polis on the brink of territory controlled by hostile Rhodes also figures in Riet van Bremen's analysis of Stratonikeia's selection of Leon as priest at Panamara. She interprets his appointment as a way for the polis to create goodwill in the regions south towards the Gulf of Keramos, allowing for a corridor of safe passage to the coast through territory still held by Rhodes. ${ }^{46}$ Stratonikeia's later possession of Keramos and its holdings, granted by Sulla after the Mithridatic wars of the 80 B $\mathrm{BC}$, was surely anticipated by a longtime influence of the polis in this area. ${ }^{47}$

Boundary disputes with Mylasa prove that Stratonikeian expansion was not just aimed towards the south, however. ${ }^{48}$ Vincent Gabrielsen found an alternative explanation for Stratonikeia's encroaching policies in the second century $\mathrm{BC}$, a time when it was already considerable in size. ${ }^{49}$ He takes into account Strabo's description of the Chrysaoric League, in which every city had a vote-count which corresponded to the number of Karian villages in its territory; Keramos was an example of a polis with a large share in the vote due to its many villages. ${ }^{50}$ Since Stratonikeia was admitted to the league only by virtue of its Karian villages, Gabrielsen considers that the accrual of territory, with villages, by the polis was primarily to gain greater weight within the League. ${ }^{51}$ In any event, the direct economic benefits was surely at least as attractive as an increased vote in the League.

In the first century $\mathrm{BC}$, Stratonikeia acquired a significant land grant from Sulla after the Mithridatic wars but only because of the suffering which the

43 See e.g. Gabrielsen (2000); Wiemer (2010).

44 Debord (2001a), 164.

45 I.Iasos 612, discussed in Ager 1996, no. 161; this concerns a (territorial?) dispute between Rhodes and Stratonikeia, arbited by a Bargylian, dated to the later second century BC, during the Aristonikos wars.

46 Van Bremen (2004b), 237.

47 Van Bremen (2004b), 216-218.

48 I.Mylasa 134 discussed in Ager (1996), no. 101. Mylasa had expansionist tendencies of its own, and much land was invested in the sanctuaries, probably as some kind of security, e.g. as at the sanctuary at Sinuri, with an increase in land leases etc., I.Sinuri $45^{-72 .}$

49 Gabrielsen (2000).

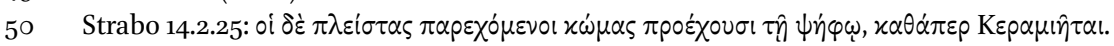

51 Gabrielsen (2000), 156-161; Strabo 14.2.25. See also above Gabrielsen (2011), 341-345, who lists the known members as Mylasa, Stratonikeia, Amyzon, Alabanda, Alinda, Thera, and Keramos, and possibly Panamara. 
polis had endured during its occupation by the Pontic king. Appian relates how Mithridates took the city, imposed a fine, married one of the virgins, and installed a garrison in town. ${ }^{52}$ The violence of the events is reflected through one of the inscriptions, apparently a memorial for the men who died in the war. ${ }^{53}$ Stratonikeia sent an embassy to Rome, to whom it had remained loyal since its freedom, and obtained Sulla's positive reply, the Senatus consultum de Stratonicensibus of 81 вс. ${ }^{54}$ In this document Sulla acknowledges their losses and calls for compensation and the return of the men taken prisoner; he granted Stratonikeia control over the areas of Themessos and Keramos, as well as the lands, harbors, villages, and revenues from the towns, and finally he declared Lagina as inviolate. Sulla's letter was inscribed in full on the walls of Hekate's temple in Lagina, with immediately next to it the list of 57 cities across the Greek world that recognized the asylia and participated in the new festival of the Hekatesia-Romaia celebrating Hekate Soteira Epiphaneia and Thea Rome ${ }^{55}$ The close proximity of these two inscriptions on the wall masks the tremendous effort that Stratonikeia must have invested in organizing the resulting festival and the embassies to all of these cities (Figure 5.25).

A little over 40 years later, Stratonikeia was again under attack, this time by Quintus Labienus. ${ }^{56}$ Labienus had just secured a Parthian contingent to support Brutus in Rome when he learned of his downfall in 42 вС; he changed his plans and took the Parthian troops on a rampage, hoping to conquer Asia Minor, while the Parthians aimed to restore the extent of the old Achaemenid empire. Several cities succumbed or suffered heavy losses, such as Mylasa, but Stratonikeia was one of the few who were able to withstand his attacks. Labienus turned his attention instead towards Lagina, desecrating the sanctuary, and then went to do the same to the sanctuary of Zeus at Panamara. His

$52 \quad$ App. Mith. 21.

53 I.Stratonikeia 1333; van Bremen (2010), 497-499.

54 I.Stratonikeia 505; Sherk and Viereck (1969), 105-111 no. 18; also Sherk (1984), no. 63. The Stratonikeians are also permitted to dedicate a golden crown worth 200 talents to the Roman Senate and to make a sacrifice to Zeus Capitolinus in honor of the victory of Rome, lines $30-33$ and $127-128$. Stratonikeia along with much of Karia seems to have been incorporated in the province of Asia following the Mithridatic wars, rather than after the Aristonikos revolt in the later second century вС; Errington (1987) and Marek (1988).

55 I.Stratonikeia 507-508, discussed among others in Rigsby (1996), 418-423 and Knäpper (2018), 254-256. On incorporating the cult of Thea Romē with a principal deity, see Steuernagel (2010); Buraselis (2012); van Nijf and van Dijk (2020).

56 Cass. Dio 48.26.3-4 shows that of all 'the mainland' cities, Labienus was unable to take Stratonikeia, although he 'besieged it for a long time'. Mylasa and Alabanda were the only other cities to resist him, albeit unsuccessfully. Tac. Ann. 3.62 mentions the 'Parthian' invasion, which Stratonikeia resisted. 
actions verify the intimate bond between the city and these two sanctuaries, as they both came to stand for Stratonikeia: hurting them was an effective way to hurt the polis. ${ }^{57}$ Panamara, however, was also a ready target because of the presence of the Stratonikeian population, whether they took refuge there or were celebrating a festival. In any event, Zeus miraculously intervened in the onslaught that took three days and nights, with lightning, fire, hail, fog, and hallucinations, while the people shouted 'Great is Zeus Panamaros!' Eventually Labienus's troops turned tail and ran off into the wilderness. ${ }^{58}$ This event led to another Stratonikeian embassy to Rome which brought about the Senatus consultum de Panamara, bearing a grant of asylia. ${ }^{59}$ The evidence for the way in which this was celebrated is more poorly preserved than at Lagina, but a fragmented list of cities, mostly Karian, may well be a similar kind of response to the asylia. ${ }^{60}$

By the second and especially first centuries $\mathrm{BC}$, both Hekate of Lagina and Zeus of Panamara had become in every sense the chief urban gods of Stratonikeia, and the polis came to rely on them more than any other deity that resided within the urban limits. The hard-won privilege of asylia which Stratonikeia managed to obtain for both sanctuaries from Rome was precious to the polis and they held on to this as they came to Rome again in $23 \mathrm{AD}$, presenting their case before the reforms tribune under Tiberius, as Tacitus records:

Then the people of Aphrodisias produced a decree of the dictator Cæsar for their old services to his party, and those of Stratonikeia, one lately passed by the Divine Augustus, in which they were commended for having endured the Parthian invasion without wavering in their loyalty to the Roman people. Aphrodisias maintained the worship of Venus; Stratonikeia, that of Jupiter and of Diana of the Cross Ways. ${ }^{61}$

$57 \quad$ Philip v also used this strategy at Pergamon; unable to take the citadel, he instead razed the sanctuary of Athena Nikephoros in the lower plains; Polyb. 16.1.1-9, 18.2.2, 18.6.4; Diod. Sic. 28.5 .

58 Recorded in I.Stratonikeia 10; see also Roussel (1931); Picard (1952); Merkelbach (1968). Discussed further below, in Chapter 6.

59 I.Stratonikeia 11-12; Cousin and Deschamps (1887); Sherk and Viereck (1969), 158-162 no. 27.

$60 \quad$ I.Stratonikeia 21.

61 Tac. Ann. 3.62: Aphrodisienses posthac et Stratonicenses dictatoris Caesaris ob vetusta in partis merita et recens divi Augusti decretum adtulere, laudati quod Parthorum inruptionem nihil mutate in populum Romanum Constantia pertulissent. Sed Aphrodisiensium civitas Veneris, Stratoninicensium Iovis et Trivieae religionem tuebantur (transl. by A.J. Church and W.J. Brodribb eds. (1942) Complete works of Tacitus, New York: Random House). Further discussed in Belloni (1984b) and Berns (2006), among others. 
Stratonikeia thus relied on the historicity of their loyalty to Rome and the resulting claims for their cults of Zeus ('Jove', or Jupiter) and Hekate ('Trivia', associated here with Diana of the Cross Ways). Drawing these two deities, each with their own particular histories and local networks, into such a tight relationship with the polis significantly realigned the fabric of the social, political, and sacred landscapes throughout the area. The hinterland of Stratonikeia was now vast, even for a large polis. George Bean had also already commented that:

As a Hellenistic foundation, Stratonikeia was not divided like Mylasa into tribes and clans, but on the Greek model into tribes and demes. This was, however, a distinction without a difference, for the demes were in fact the old Karian villages, just like the Mylasan clans. ${ }^{62}$

This is Karia, after all. Clusters and networks of communities with nested identities and multiple cross-ties were typical, as Debord observes. ${ }^{63}$ Inscriptions speak of vibrant village life in the countryside of Stratonikeia. ${ }^{64}$ Yet besides the koina and the demes, there was nonetheless a regular Greek-style boule that made decisions with the demos and took action in the interests of the polis of Stratonikeia. ${ }^{65}$ This raises the question of how Stratonikeia, as a new polis, was able to legitimate its identity among all of these multifarious social webs, simultaneously interacting as they had been for ages. The answer appears to lie in the realm of cult - by incorporating those already embedded in these older communities, and by reinventing their rituals and ritual spaces into a newyet-ancient common focus for the polis. The different ways in which the polis pulled this off is the subject of the next two case studies.

$62 \quad \operatorname{Bean}(1971[1989]), 68$.

63 Debord (2003), examining the various kinds of communities labelled with the word koinon.

64 Besides the demes and villages known to exist, several inscriptions show an active rural

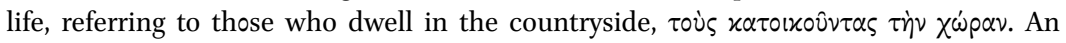
interesting example is I.Stratonikeia 186 from Panamara in the second century AD that specifically mentions Romans as such rural residents; I.Stratonikeia 1325 , lines 11-12 also

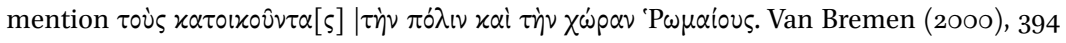
further asserts the demes as the base unit of Stratonikeia, rather than the phylai.

65 For the political system at Stratonikeia, see especially Rhodes and Lewis (1997), 349-352, and Caldesi Valeri (1999). 
The transformation of the modest shrine of Hekate at Lagina into a major urban sanctuary addressed Stratonikeia's needs concerning territorial integrity, social cohesion, and global recognition. Although the origin of this relationship is unclear, it is remarkable given Hekate's traditional role, according to the Oxford Classical Dictionary, as a goddess who is:

possibly of Karian origin ... and certainly outlandish in her infernal aspects, she is more at home on the fringes than in the center of Greek polytheism. Intrinsically ambivalent and polymorphous, she straddles conventional boundaries and eludes definition. ${ }^{67}$

The Karian origins of the goddess are inferred due to the wide popularity of her cult in this region. ${ }^{68}$ Yet even so, Stratonikeia is the only city where the goddess became the poliad deity; unhindered by categorical views of their pantheon, the Stratonikeians seem perfectly at ease as the goddess of the crossroads entered into their mainstream polis religion. They gave a clear definition to her cult at Lagina, and even made sure that it became a focal point on the 'global' map of Greek festivals. The way in which this relationship developed is highly informative of how a sanctuary could serve to consolidate a polis, connect it to a ruling power, in this case Rome, and broadcast its identity to the wider world.

\subsection{Historical Overview of the Sanctuary of Hekate at Lagina}

Although the earliest settlement activity in the area of Lagina dates from the Early Bronze Age, the area was continuously inhabited from the eighth century $\mathrm{BC}$ and onwards, testified by the finds from within the precinct area

66 My thanks again to Professor Ahmet Tirpan for hosting my stay at Turgut with the archaeological team from the Selçuk University of Konya from 14-16 April, 2009, and allowing me to review internal reports and unpublished documents. See also Williamson (2012); Williamson (2013b); Williamson (2013 c).

67 Hornblower and Spawforth (2003) in The Oxford Classical Dictionary, 671. Rutherford (2006), 140 briefly mentions the possibility that Hekate was a Greek or Ahhiyawan import to Karia.

68 Heckenbach in $R E$, 2780, s.v. 'Hekate'; Kraus (1960), 11 and 2o, further discusses the many theophoric names of Hekate in Karia (e.g. Hekatomnos), also Ray (199o), 129; Burkert (1977), 266; Johnston (1999), 205-206. Besides in the area of Stratonikeia, inscriptions indicate that Hekate's cult was known at: Mylasa, I.Mylasa 3o9; Hydai (with Ge), I.Mylasa 905; Herakleia under Latmos, CIG 2897; Hyllarima, Laumonier (1934), 378 no. 41; Tralles, I.Tralleis 11 and 12; on the outskirts of Aphrodisias, Reynolds and Erim (1982), 29; before the gates of Miletos, Milet I.3 133 (lines 25-26 and 28-29). 
of the sanctuary. ${ }^{69}$ This corresponds to a period of general growth throughout this area, with several small settlements developing into sizable communities in the later Archaic and Classical periods (e.g. Koranza, the settlement at Börükçü, the area of Stratonikeia).

The antiquity of the sanctuary of Hekate at Lagina, situated in the community of Koranza some eight kilometers north of Stratonikeia (near modern Turgut), is unknown..$^{70}$ Some of the earliest finds that may be related to the cult include part of a sacrificial decree from the fourth century вс. ${ }^{71}$ Terracotta fragments (votives?) and small golden discs that once adorned clothing, loomweights from the third or early second century, and 387 coins ranging from the fourth to second or perhaps early first century BC. Roughly a third of these are identifiable and show a strong Rhodian presence in the fourth and third centuries, but several are also Macedonian and Seleukid. ${ }^{72} \mathrm{~A}$ few tombs, just north of the sanctuary, coincide with this period. ${ }^{73}$ Towards the end of this century, under the Macedonian satrap Asandros, a decree was posted at the shrine in Lagina acknowledging a grant of asylia originally conferred by Maussollos. ${ }^{74}$

Hekate's place of cult appears to have been architecturally defined prior to the foundation of Stratonikeia, similar to the sanctuary of Artemis and Apollo at Koranza. Roughly 500 meters northwest of Lagina, this sanctuary was situated along the northern perimeter of the plateau of Koranza and looks out across the Hayırlıdere valley to the Gökbel mountains in the north (Figure 5.2). ${ }^{75}$ The several architectural fragments indicate the monumentality. Two fourth-century inscriptions were discovered here: an honorific decree and

69 Tirpan and Söğüt (2005a), 3-4; most of this paragraph draws on this publication.

70 See note 10 above on Lagina or Stratonikeia as Hiera Kome; Robert (1937), 555-561; Şahin (1976), 1-15.

71 I.Stratonikeia 1417 (=EA 34 (2002), no. 1) is a sacrificial decree by a certain Leros and probably his spouse. Şahin dates this inscription to the second half of the fourth century BC, based on analogous letter types with especially I.Stratonikeia 502 . The inscription fragments were discovered during the excavations of the temple cella between 1998 and 20o1, and although Hekate is not explicitly mentioned in the text it seems plausible that her cult is inferred, rather than that of Artemis and Apollo further to the north.

72 These objects were found in the fill of the late second century temple cella, Tirpan and Söğüt (2005a), 3; Trrpan et al. (2012); Büyüközer (2018), with a breakdown of the coins; interestingly 24 coins, second century, were from Alabanda. My thanks to Zeliha Gider for bringing this article to my attention.

73 At Yayalar, between Lagina and Koranza, burials were found dating from the Classical period to the first century AD, Tirpan (1996), 313-320.

74 I.Stratonikeia $5^{\mathrm{O} 1}$, mentioned above.

75 I.Stratonikeia $5^{\circ 2}$ and 503; see further Şahin (1973). Several marble architectural fragments are still visible today. Also Archaic painted terracotta architrave fragments were found in this area (now in Turgut), Trrpan (1996), 54-55. 
a dedication of land to the gods, listing representatives from each of Koranza's five demes. ${ }^{76}$ Both inscriptions thus concern the composition of the polis of Koranza in a sacred context. Combined with the monumental architecture, this indicates the sanctuary of Apollo and Artemis as the religious and political center of Koranza. Hekate, in the meantime, appears to have been more of a peripheral goddess with an open-air cult place along the eastern perimeter of the plateau. It is unknown whether her sacred grove, mentioned in a much later inscription, goes back to this period; in fact very little is known of the features of Hekate's shrine at Lagina prior to Stratonikeia's involvement. ${ }^{77}$

One can only speculate as to why exactly Hekate became Stratonikeia's poliad deity, but it is clear that her cult at Lagina began to blossom with the rise of the polis, rapidly overshadowing the nearby sanctuary of Apollo and Artemis at Koranza. Even while Stratonikeia was under Rhodian rule, the sanctuary at Lagina was used to exhibit political goodwill through the addition of a cult to Helios/Rhodes at Lagina. ${ }^{78}$ Just as significant is an honorific decree by the local Chrysaoric League, whose headquarters were at the sanctuary of Zeus Chrysaoreus just outside Stratonikeia. ${ }^{79}$ But it was at Lagina that they honored a Stratonikeian who had shown benevolence towards the polis Alabanda, referring to an alliance between Stratonikeia and Rhodes during the occupation of the area by Philip v in the Second Macedonian War. ${ }^{80}$ Obviously by the

76 I.Stratonikeia 503 is an honorific decree for Konon, son of Poseidippos, who had shown goodwill towards the polis of Koranza; he is rewarded with citizenship and the right to own land. The heading of this inscription mentions that the decision was taken in the sixth year of the reign of Philip, during the satrapy of Asandros, 318 BC. I.Stratonikeia 502 is a dedication of land by Skoarenos and his wife, listing the ten delegates who were responsible for the inscription; it also shows the land as bordering on land already belonging to Artemis - whether Hekate also owned any land is unknown.

77 Mentioned in I.Stratonikeia 513, which dates from the third century AD.

78 I.Stratonikeia 504 shows the inclusion of the cult of Helios/Rhodes at Lagina. Helios was the principal deity of Rhodes; see also below under Priesthoods.

79 This is not long after they were 'expelled' from Labraunda by Philip v (I.Labraunda 5), see above in Chapter 3; their base at Stratonikeia was the sanctuary of Zeus Chrysaoreus, which has not yet been discovered.

8o I.Stratonikeia 1418 (= EA 35 (2003), 1-7). This inscription was painstakingly pieced together from over eighty fragments, found in the cella fill. It is the second earliest known decree issued by the Chrysaoric League, after I.Labraunda 43, from 267 BC. It goes beyond the scope of this work examine all the ramifications of this document but it implies an alliance between Rhodes and Stratonikeia that is later dispelled during Stratonikeia's 'liberation' from Rhodes by Rome in 167 BC, when Rhodes was expelled from Karia after the Battle of Pydna (Polyb. 30.21.3f). It also implies that Rhodes controlled the area of Stratonikeia both before and after Philip v's invasion at the end of the third century BC, e.g. Ma (1999), 277-278 and Reger (1999), 82-85. Most interesting is that the decree was 


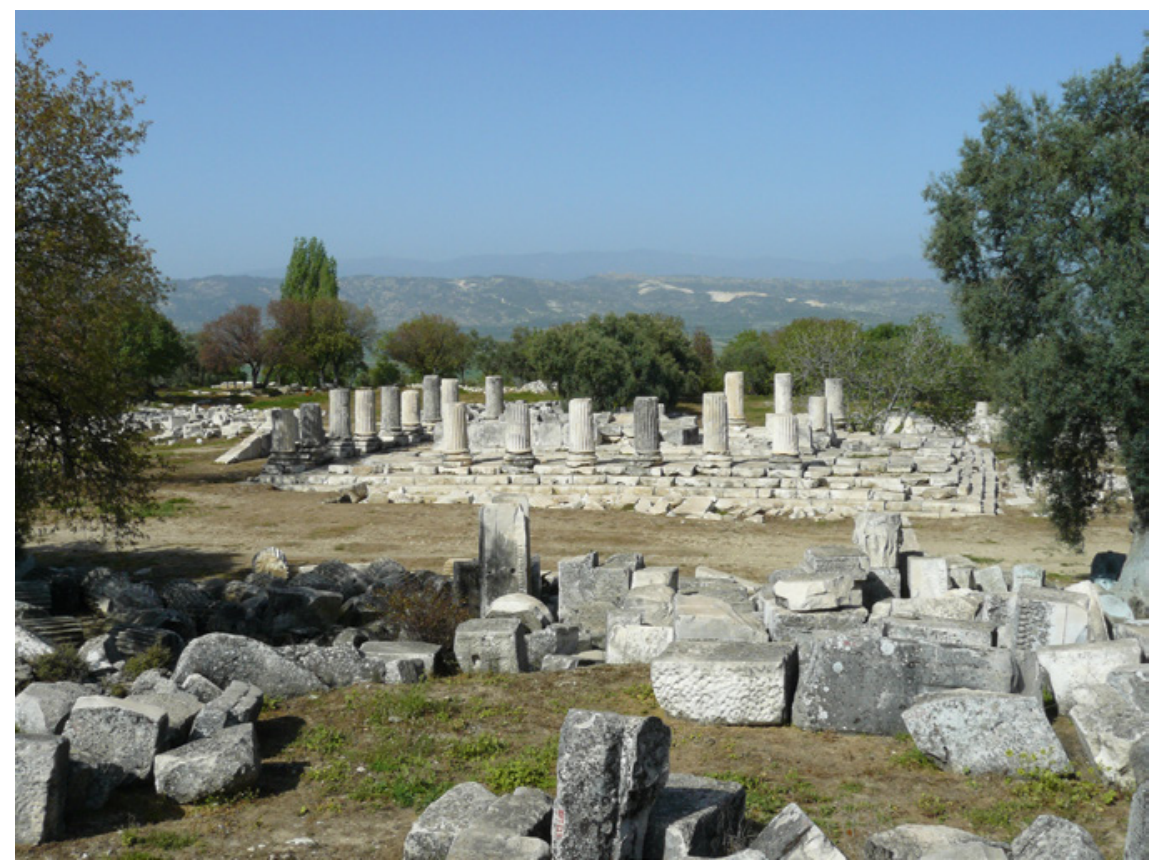

FIGURE 5.3 Lagina. View of the temple from the southwest stoa PHOTO AUTHOR 2008

early second century вС, Lagina was already considered the appropriate place to display ruler support and to honor citizens of Stratonikeia (Figure 5.3).

After Stratonikeia's liberation from Rhodes by Rome in $167 / 6$ вс, Hekate began to appear on the first issues of coins minted by Stratonikeia. By the end of the century her sanctuary was fitted with a monumental stoa complex, altar, and a state-of-the-art temple bearing the well-known frieze with its many allegories to war, peace and the natural order of things. ${ }^{81}$ The sanctuary became an overt symbol of solidarity with Rome after the Mithridatic Wars. The Senatus

inscribed in Lagina while the inscription states that it is to be erected in the sanctuary of Zeus Chrysaoreus, indicating an early political function of the shrine.

81 The frieze has been studied among others by Schober (1933);Junghölter (1989); Baumeister (2007) and van Bremen (2010); interpretations on the date of the frieze, and hence the temple, generally vary from $150-13$ O BC (van Bremen) to after the Mithridatic wars in the 8os BC (Junghölter). While acknowledging the various arguments for these standpoints, for the purposes of this study I will accept Baumeister's proposal of a date for the temple towards the end of the second century BC, i.e. after the Aristonikos revolt of 133-129 BC. This also best corresponds with the coinage as dated in Meadows (2002) (Group 2). On the interpretation of the frieze, see further below. 
consultum de Stratonicensibus of $81 \mathrm{BC},{ }^{82}$ with all its privileges and grants, was inscribed on the temple walls at Lagina for all to see, and the goddess Romē Thea Euergetes was worshiped together with Hekate, now known as Hekate Soteira Epiphaneia. A panhellenic festival, the Hekatesia-Romaia, was held every four years in honor of both goddesses, and cities throughout the Greek world were invited to participate and thus recognize the asylia of this sanctuary near Stratonikeia. This was probably the occasion of the kleidos pompe, the procession in which Hekate's sacred key was carried into the center of town.

The identity of Hekate became thoroughly interwoven with Stratonikeia. This is surely why her sanctuary at Lagina was attacked by Quintus Labienus and his Parthian troops during their invasion in 40 BC. Unable to take the town, they desecrated the sanctuary instead. The substitution of the sanctuary as target instead of the polis already indicates the tight relationship between the city and the goddess. Although the degree to which the sanctuary suffered is unclear, its state of despair did not last long. In fact, this destruction only served to provide yet another opportunity to strengthen ties with Rome when Augustus restored the sanctuary, and Stratonikeia responded by adding the imperial cult to the pantheon in the city and to the games at Lagina, solidifying once more the relationship between city, sanctuary, and ruler, and now empire. ${ }^{83}$

Writing at the time of Augustus, Strabo describes Hekate's sanctuary at Lagina and her festivals as the 'most famous' of Stratonikeia. ${ }^{84}$ Lagina seems to have blossomed in the imperial period; inscriptions testify to the pride taken by the priests of Lagina in their office, as they relate their accomplishments at the end of their term. They furthermore show how the festivals were thoroughly embedded in urban life, along with the cult of Zeus at Panamara. The two cults became more and more intertwined with the city and with each other, as testified by a later inscription on the bouleuterion, prescribing the hymnodes for the festivals at both sanctuaries.

$82 \quad$ I.Stratonikeia 505 with Sulla's reward to Stratonikeia for her loyalty and compensation for her losses incurred during the war.

83 The games of the 'Hekatesia and Kaisareia and Romaia' are referenced in an agonistic inscription, I.Stratonikeia 547. Also, a temple to the Divine Augustus was erected on a platform overlooking the theater in Stratonikeia, Trrpan (1998b). At Lagina a naiskos to the imperial cult was found between the temple and the altar, probably dating from the same period, Tirpan and Söğüt (1999), 156; Söğüt discusses this and a later (second century AD) naiskos for Serapis as likely deriving from the eastern or southern side of the temenos, Söğüt (2008).

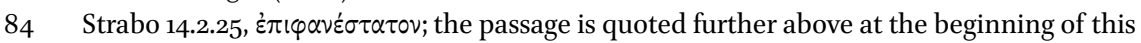
case study. 
It may have been an earthquake that brought the cult to an abrupt end in the fourth century $\mathrm{AD}$, or perhaps a collective conversion of the community to Christianity. A modest church was subsequently built next to the altar, partly incorporating its walls. Towards the end of the century, part of the south wall of the propylon was used for another apsidal structure. Both of these buildings mark the end of one era and the beginning of the next for Lagina, as well as for Stratonikeia.

The cult of Hekate at Lagina lasted for at least five centuries, probably longer. For most of this time it was a place that continuously accumulated meaning and power as an urban platform for Stratonikeia up until the very end. The groundwork for this successful integration lay in the decisions taken in the early period by the polis regarding the cult of Hekate and her sanctuary at Lagina; this will be the focus of the investigations presented below.

\subsection{Data and Sources}

Lagina was first reported by Richard Pococke in 1745 at a place which he refers to as 'Lakena' but was otherwise known as Leïna or Leyne (modern Turgut). ${ }^{85}$ Several expeditions followed in the nineteenth century. ${ }^{86}$ The temple was described among others by C.T. Newton, who discovered sections of the frieze in $1856 .{ }^{87}$ In 1881 an Austrian research team directed by Otto Benndorf traveled through Asia Minor and, after studying the Heroon at Trysa (Göbaşı) in Lykia, they spent some time at Lagina where they produced the first architectural plan of the temple. ${ }^{88}$ They also discovered a number of inscriptions, including the famous Senatus consultum de Stratonicensibus, the letter by Sulla to the Stratonikeians, discussed above; these inscriptions were published in $1884 .{ }^{89}$

In 1891 the illustrious Osman Hamdi Bey, leading figure in Turkish archaeology who excavated at Nemrud Dağ and Sidon and was founding director of the Istanbul Archaeological Museum, visited Lagina together with the French archaeologists J. Chamonard and M. Legrand. ${ }^{90}$ The following year Osman Hamdi Bey began excavations of the site with their assistance, making Lagina

85 Published in Pococke (1745), 65f; William M. Leake observed that the modern name of the site, Leyne (now Turgut) reflected the name of the sanctuary of Hekate, Leake (1824), 23 o.

86 The history of the early investigations and excavations of the site are mentioned in Laumonier (1958), 345-346; Trrpan and Söğüt (2005a), 4-6; Baumeister (2007), 3-5. This section largely draws on their work.

$87 \quad$ Newton and Pullan (1862), 554, including a first sketch of the sanctuary in Table 77.

88 Benndorf (1881).

89 Benndorf and Niemann (1884), 154 f.

90 As an artist, archaeologist, and director, Osman Hamdi Bey (1842-1910) was a true Renaissance man: Radt (2003); Shankland (2004) (Ch. 4); contributions by Ahmet Ersoy (Ch. 9) and Edhem Eldem (Ch. 12) in Inankur et al. (2011); Holod and Ousterhout (2011). 
one of the first fieldwork projects organized and funded by the Ottoman state rather than by foreign institutes. Several sections of the frieze were recovered and transported to the museum in Istanbul, in compliance with the new governmental mandate to prevent more antiquities from going abroad. The Lagina frieze is among the founding pieces in the museum, along with the 'Alexander Sarcophagus' from Sidon. ${ }^{91}$ Subsequent expeditions at Lagina were exclusively focused on the recovery of more inscriptions or sections of the frieze. The frieze, as mentioned above, has been the subject of several studies, the most comprehensive of which was Peter Baumeister's thesis on the style of the frieze which was published in $2007 .^{92}$

Systematic archaeological investigations at the sanctuary were undertaken again nearly a century later, first by Yusuf Boysal in 1966, in connection with investigations of the wider area of Stratonikeia. Long-term fieldwork began in 1993, under the direction of Ahmet Tirpan, of Selçuk University in Konya, with Milas Museum and later Muğla Museum. In 2008, the University of Pammukale, began new excavations of Stratonikeia, under the direction of Bilal Sögüt, who since 2016 is also director of the fieldwork at Lagina. ${ }^{93}$ The surrounding landscape is part of a rescue archaeological project, working ahead of the Yatağan Power Plant that has strip-mined much of the area between Stratonikeia and Lagina, and Panamara, for lignite (brown coal). On a positive note, this has led to a greater archaeological knowledge of this area between the sanctuary and the urban center, more so than at any of the other case studies presented in this volume. As a result, the sanctuary of Hekate is the only one of the case studies that can be demonstrated thus far to have been embedded

91 Radt (2003), 504 mentions Osman Hamdi Bey's unfulfilled plans to rebuild Hekate's entire temple in the gardens of the museum in Istanbul.

92 Baumeister (2007), whose aim is to detect the origins of the different artists at work on the frieze based on stylistic comparison. Previous scholars of the frieze, as mentioned above, include Schober (1933), who first published the frieze in full; Junghölter (1989), who concentrated on the curious 'Nordfries'; Simon (1993), who interprets the frieze from a cosmological point of view, and now van Bremen (2010), who uses comparative epigraphy to re-examine the date and thus the meaning of the frieze, see below under Monumental and Ritual Space.

93 Excavations at Stratonikeia began in 1966 under the direction of Yusuf Boysal. In 1980 the Yatağan Power Plant evacuated the village of Eskihisar, on the site of ancient Stratonikeia, and began open strip-mining - some of the dynamite blasts destroyed the ancient city walls, and Çetin Şahin did what he could to protect the site. In 2008 the University of Pammukale reopened excavations, with the financial help of the Ministry of Culture and Tourism of the Republic of Turkey. A good overview, in English, of the history of fieldwork at Stratonikeia and Lagina is provided in Söğüt (2019), 285, 313-314. 
in an extremely rich cultural landscape, dotted with settlements that date back to at least the Early Bronze Age (indicated in Figure 5.20).

A full publication of the sanctuary is pending, yet several studies of specific features, mostly architectural, have meanwhile appeared by members of the fieldwork team in the new series since 2015 on Stratonikeian research, Stratonikeia Çalıșmaları, edited by director Bilal Söğüt. In 2012, he produced the festschrift From Stratonikeia to Lagina in honour of the previous director, Ahmet Tirpan. New journals, such as Arkhaia Anatolika, regularly feature contributions from the area of Stratonikeia, which also appear in other specialist volumes. ${ }^{94}$ As with all fieldwork in Turkey, general results are summarized annually in the proceedings from the Kazı Sonuçları Toplantısı. The inscriptions have been published by Mehmet Çetin Şahin in the series Inschriften griechischer Städte aus Kleinasien and are being re-examined by Murat Aydaş. ${ }^{95}$ As with every case study discussed in this present volume, a caveat concerning the Hellenistic ceramics must be made as they are underrepresented in the publications. ${ }^{96}$ On the other hand, the coinage of Stratonikeia is a rich source for the relationship between the city and the goddess as Hekate appears on the first issues from the mid-second century BC and onwards. Andrew Meadows' revised chronology for the early issues in his analysis of the Muğla hoard sheds new light in particular on the development of this link as well as the relation between the polis and Panamara, discussed in the next chapter. ${ }^{97}$

\section{Environment of Lagina}

\subsection{Physical Environment}

Located about eight kilometers from Stratonikeia, Lagina is situated near modern Turgut on the northeast perimeter of the lower foothills of the Akdağ, at roughly $470 \mathrm{~m}$ ASL. The sanctuary rests on a gentle slope that descends towards the Hayrrlovasi area, the wide plain between Turgut and the Çine (Marsyas)

94 E.g. Trrpan et al. (2012); Büyüközer (2015). Trrpan's team produced digital reconstructions of the stoa and altar; my thanks here to Aysun Topaloglu and Funda Yürü, for showing me (with permission) their work in the lab at Turgut in April 2009.

95 Die Inschriften von Stratonikeia, 3 vols. (1981-2010), Bonn. Several inscriptions related to Lagina and Koranza have been translated into Turkish by Murat Aydaş (2015).

96 Boysal (1993) mentions the large quantity of Hellenistic material at Lagina.

97 Meadows (2002); the hoard was initially published by Hans von Aulock in von Aulock (1967). Traditional chronologies for Stratonikeian coinage are based on Head's discussions in BMC Caria, esp. Plates 23-24. 


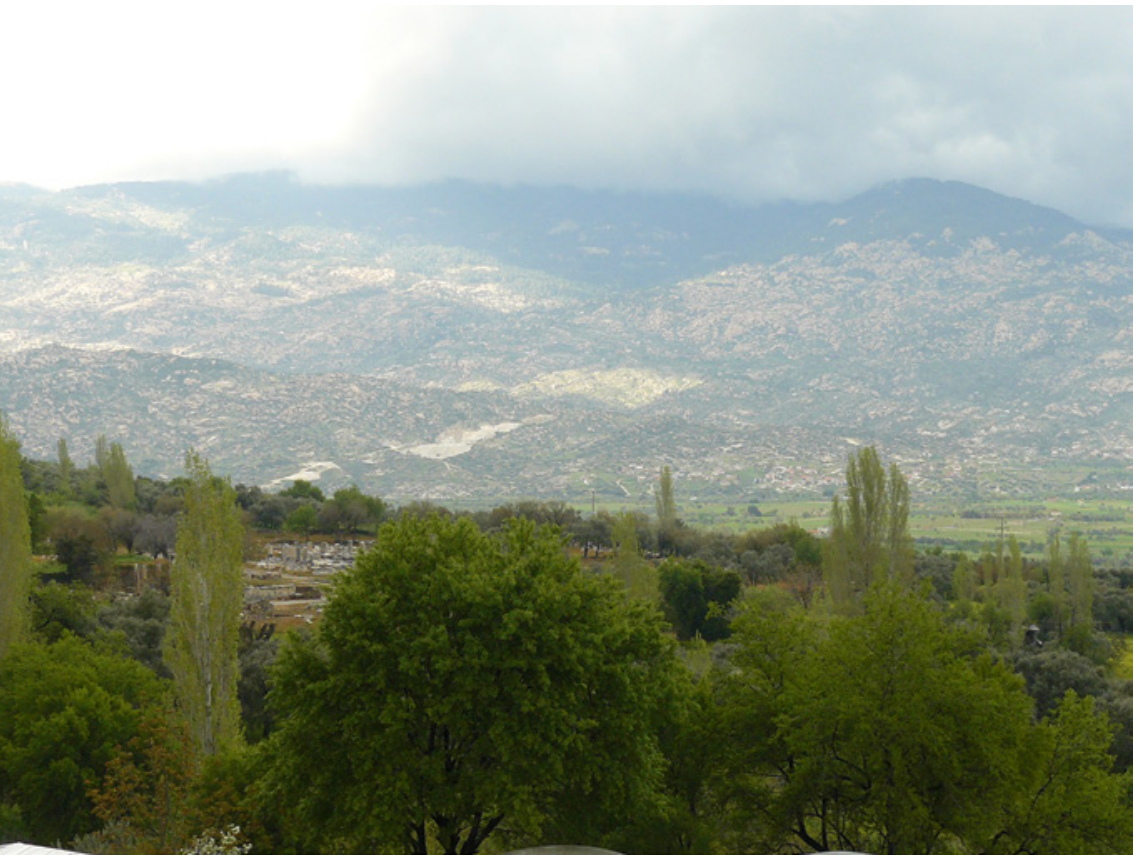

FIGURE 5.4 Lagina. View from the south with the Hayırlıdere valley to the northeast, and the rising Gökbel mountains further north - the Archaic site of Hacibayramlar Höyük was located in the foothills across the valley. The sanctuary of Hekate is visible in the clearing to the left PHOTO AUTHOR 2009

river to the east (Figure 5.4), marking a natural boundary with the Gökbel mountains looming to the north.

The slope circumscribes the eastern end of a plateau which was probably the general area of the ancient community of Koranza. North of this plateau is the green valley of the Hayrrlıdere river, which empties into the Çine (Figure 5.4). Groves of olive trees surround the sanctuary today, with cultivated fields in the Hayırlovasi plain below. The general area is verdant, with several springs and a stream just south of the sanctuary with another further north, near the Apollo and Artemis sanctuary of Koranza. The area is well-watered and prior to excavation the sanctuary was covered by thick layers of sediment from the runoff carried downhill (Figure 5.18 shows the high trench wall left from the excavations, behind the main propylon). In antiquity, drains were laid that would have helped carry away excess water; ${ }^{98}$ today the sanctuary can

98 Terracotta pipes, probably Roman, crisscross the site (personal observation 2008, 2009); Marcus Sempronius Clemens, a Stratonikeian notable from the later second or early third 


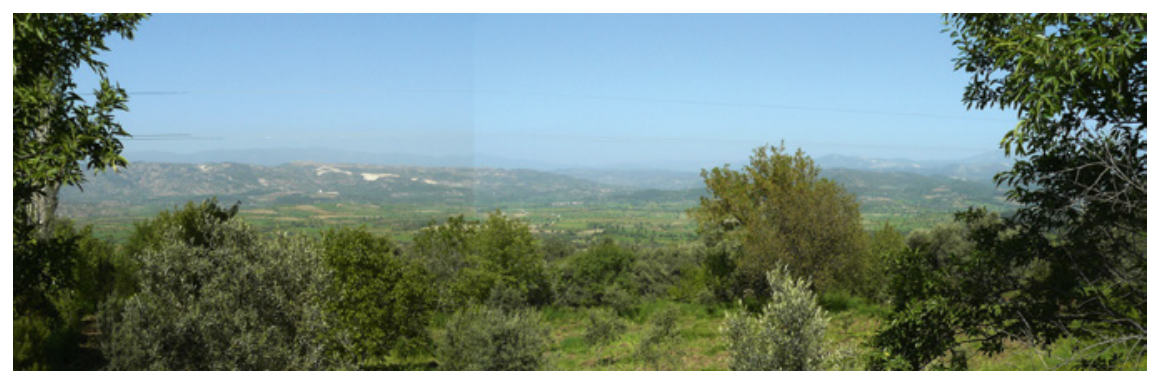

FIGURE 5.5 View from Lagina towards the east-northeast across the Hayırlıvasi area and the Marsyas valley PHOTO AUTHOR 2009

become marshy after rainfall. The impact of earthquakes on the area can still be seen today in the undulating foundation of the temple and altar area. ${ }^{99}$

\subsection{Social-Geographical Location}

Lagina lies on a slope near the eastern rim of the plateau of Koranza. The sanctuary may have marked the extent of the settlement, although the community would likely have kept fields in the fertile plain below. Five-hundred meters to the north lies the sanctuary of Apollo and Artemis, on a steeper part of the plateau and probably marking the northern perimeter of the settled area. With its monumentality, this shrine would surely have been visible from the plain and the mountains to the north, including the Archaic settlement at Hacibayramlar Höyük, located directly opposite the plateau in the foothills of the Gökbel mountains (Figures 5.2, 5.4).

Lagina is located along the western edge of the Marsyas valley (Figure 5.5), the main north-south route that connected Tralles in the Maeander valley with the towns of Alabanda, Stratonikeia, Pisye, and Idyma in the Bay of Keramos. In describing Karia and the distances when crossing it, Strabo notably includes Lagina:

Artemidoros says that, as one goes from Physkos, in the Peraea of the Rhodians, to Ephesos, the distance to Lagina is eight hundred and fifty stadia; and thence to Alabanda, two hundred and fifty more; and to Tralles one hundred and sixty. But one comes to the road that leads into

century AD, claims among his municipal deeds to have commissioned a system to con-

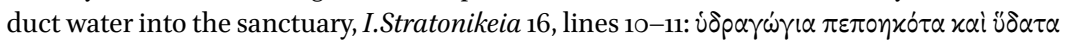

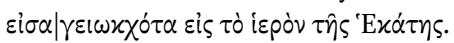

99 Söğüt (2019), 313, 316 mentions earthquakes in 139 AD and 365 AD. 
Tralles after crossing the Maeander River, at about the middle of the journey, where are the boundaries of Karia. ${ }^{100}$

Lagina surely owes its landmark status to the fame of its sanctuary and festivals, as will be shown below, but Strabo probably also mentions it because of its location roughly midway in the Marsyas valley. Physkos is on the southern coast of the Datça peninsula and traveling to Ephesos from there by land would have taken one up the Marsyas valley towards Lagina. Also, Lagina lies just opposite the place where the valley narrows as it makes a sharp bend to the east near Yava, which may have been another one of the demes of Stratonikeia (Koraia or Lobolda?).

Hekate is traditionally the goddess of the wayside, or crossroads, and although this is hardly pronounced in her cult at Lagina - the goddess is never represented as trimorphic - ${ }^{101}$ the very location of her cult place, at the intersection of the two valleys, is nonetheless characteristic. It is likely that the Hayırlıdere river or the Gökbel range to the north marked the northern borders of Stratonikeian territory. The sanctuary of Hekate may well have served as a point of orientation as one traveled north towards Alabanda in the Marsyas valley, from where one would continue on to Tralles in the Maeander valley, and from there to Ephesos (Figures 5.4 and 5.5; see also Figure 2.1). Lagina was clearly well known, perhaps even more than Stratonikeia, which lay in a valley to the west of the Marsyas; envoys could also easily have reached Lagina for the festivals without having to go through Stratonikeia.

Stratonikeia and Lagina were, however, connected by a road that passed between the Akdağ and the Aladağ mountains; the route of the road is discussed in more detail below, including the settlement at Börükçü. The road would have existed long before the foundation of the polis since it would have provided the main means of access between the many settlements already in the area, as Figures 5.1 and 5.20 indicate. In fact, the road continued to be the primary route from the town of Eskihisar (on the site of Stratonikeia) to Yeşilbağçllar and Turgut until the area was evacuated in the 1970s (Figure 5.21). ${ }^{102}$ The modern

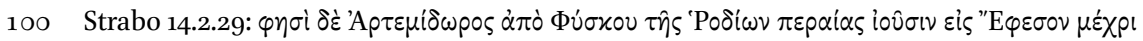

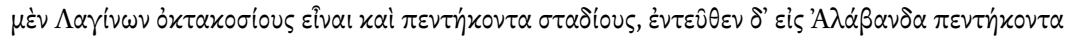

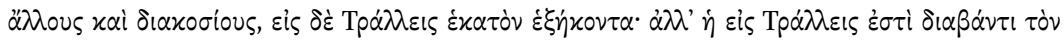

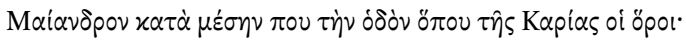

101 Images of Hekate typically show her with three bodies, back-to-back, facing in three different directions (such as the Hekate Chiaramonti in the Vatican museum, a Roman copy of a Hellenistic original); according to Pausanias the trimorphic representation of Hekate was invented by Alkamenes (2.30.2). The goddess' Latin name is Trivia.

102 Hild (2014), 45-46. 
road to Turgut and Lagina now runs through the ancient Marsyas valley, skirting the eastern flank of the Aladağ.

\subsection{Visibility}

A striking aspect of the relationship between Stratonikeia and its urban sanctuaries at Lagina and at Panamara was the lack of intervisibility. As tightly as these sanctuaries were connected to the urban center of Stratonikeia, and as much as they were monumentalized and became landmarks for the environment, neither sanctuary could actually be seen from the town itself. The Aladağ peak and its western foothills blocked the view towards Lagina. Yet several other places in the region did have a view of these sanctuaries. A simple viewshed analysis shows that both of Stratonikeia's major country sanctuaries enjoyed a wide perspective of views, some of which were overlapping but most of which supplemented each other (Figure 5.6).

As described above, Lagina is situated on a hillside in a curve where the Hayırlıdere valley to the north opens onto the Çine (Marsyas) valley to the

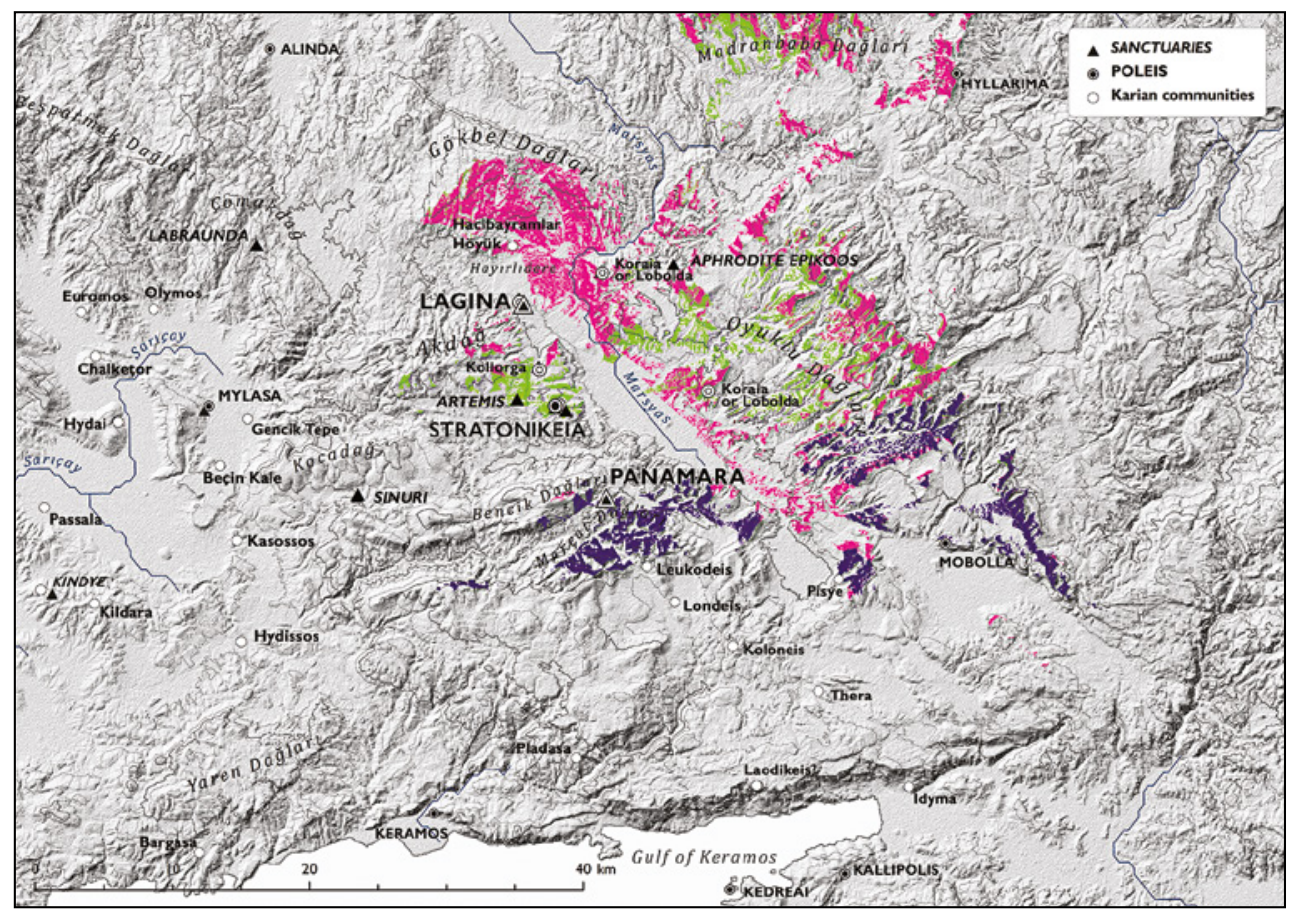

FIGURE 5.6 The combined viewsheds of Stratonikeia (green), Lagina (fuchsia) and Panamara (violet); together these encompassed the known incorporated communities, except Kurbet Köy (possibly Koliorga) to the west 
east. Although the hillside itself obscures the view to the nearby sanctuary of Apollo and Artemis, it does afford a wide panorama to the north, the east in particular, and the southeast. Directly north across the Hayrlıdere was the Archaic site of Hacibayramlar Höyük; the view continues to the Gökbel mountains farther to the north and west along the valley, to the western hills beyond that separate Lagina from the sanctuary of Zeus at Labraunda, some 20 kilometers away. In the opposite direction, just across the Marsyas, the sanctuary of Aphrodite Epekoos at Yava (ancient Koraia or Lobolda?) to the east would have been clearly visible. Far beyond this, to the northeast, are the peaks of Heşimler and Madranbaba, west of the valley of the Akçay (Dandalos); this is the area of the highland Karian towns of Bargasa and Hyllarima. To the east the view from Lagina extends across the Marsyas valley towards the Oyuklu range dominating the other side of the valley (Figure 5.6), near ancient Kys, and continues south beyond Muğla and Pisye; several hills along the western side of the Marsyas valley are also visible, including the range that separates the valley from Panamara. The northern flank of Bencik Dağı, that obscures the view from Stratonikeia to Panamara, is also visible from Lagina. North of Stratonikeia, both the Aladağ peak and the Akdağ mountain, which leads down to the foothills at Turgut and Lagina, are well within view and may even have determined the southwest and southeast axes of the sanctuary, as discussed in more detail below.

Including Lagina within the urban sphere of Stratonikeia was a way of foregrounding this area in the minds of all the Stratonikeians, not just those from Koranza, bringing it mentally closer to the administrative center by association. Moreover, Lagina acted as a visual hinge as it added all of the areas in its own visual region, i.e. the places connected within the same viewshed from the sanctuary, to the visual region of Stratonikeia, thereby also drawing this fertile area of the Marsyas valley into the cognitive collages of the inhabitants. ${ }^{103}$

Signs of Urban Integration at Lagina

While Hekate is characteristically seen as a goddess of the wayside, Stratonikeia turned the cult into the center of public focus, as the goddess become the protective deity of the polis. Although the majority of epigraphic evidence dates from the imperial period, it will be demonstrated that the cult of the goddess and the goals of the polis coalesced in the Hellenistic period, at least by the

103 The terms 'foregrounding', 'visual region', and 'cognitive collages' refer to the cognitive ways of perceiving and remembering space, see Chapter 2. 


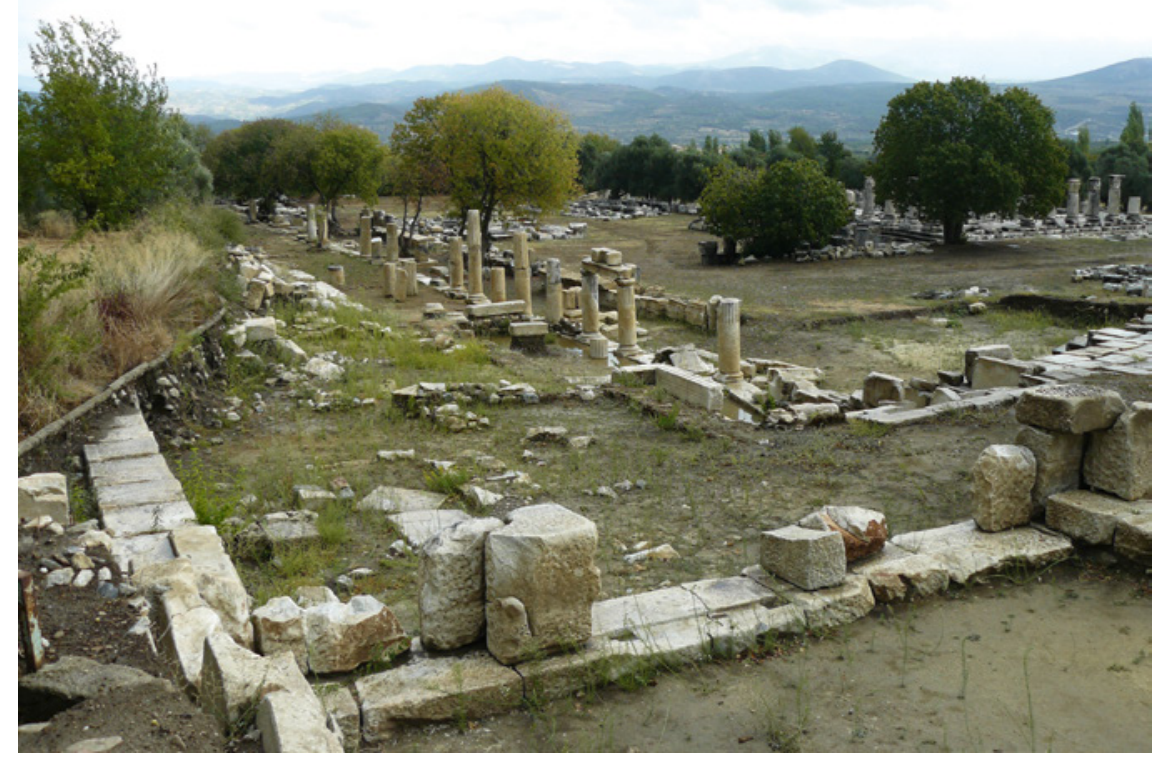

FIGURE 5.7 Lagina. View across the sanctuary from the northwest corner to the east with the Oyuklu mountains in the distance Pното AUTHOR 2011

second century вС if not before. It will also become apparent how the polis used the sanctuary to generate internal social cohesion, develop its civic institutions, and gain external recognition in the wider Greek world.

\subsection{Monumental and Ritual Space at Lagina}

Hekate is seldom associated with monumental temple architecture and her cult place at Lagina was typical in this respect until the construction of the grand complex in the latter part of the second century вС (Figures 5.3, 5.7). ${ }^{104}$ Perhaps part of a wider Stratonikeian building program that commenced some time after its liberation from Rhodes, the design of the complex is certainly worthy of an urban goddess. ${ }^{105}$ Ritual space was radically redefined, as the

104 Hekate also had minor temples at the city gates of Miletos (Milet I.3 172, p. 392), and on Aegina according to Pausanias, with a wooden image made by Myron (2.30.2). Dates for the temple vary between the mid-second century and the early part of the first century $\mathrm{BC}$, see the discussion below on the frieze.

105 The gymnasium was probably one of the first buildings erected at Stratonikeia; Mert (2008), 16-20 and 156-166, dates it to shortly before the mid-second century BC based 
complex created both an inward-facing enclosed area and an external landmark, greatly expanding thereby the spatial and visual impact of the cult in its landscape. Similarly, the frieze, for which the temple is famous, added a new layer of meaning and representation, echoed by the inscriptions that later followed. All of these elements together formed a tremendous vortex, drawing visitors in from the sacred road through the monumental space and towards the temple and altar.

\subsubsection{Architecture}

Architectural evidence suggests a monumental phase of the sacred complex at Lagina in the fourth century BC that includes the temple, propylon, and stoas. ${ }^{106}$ Sondages in the bothros below the temple floor revealed prominent signs of cult activity from the fourth to at least the second and perhaps first century ВС. ${ }^{107}$ The community at Koranza appears to have heavily invested in the temple prior to the advent of Stratonikeia. By the second century BC, the shrine had become a podium for external relations. An early indication is the small Ionic entablature, bearing the inscription of its dedicator, and thought to be from a naiskos, or small shrine, that was possibly erected during Rhodian control of the area in the first part of the second century вс. ${ }^{108}$ Stratonikeia's involvement at the shrine surely predates its liberation from Rhodian control, but visible indications of this only appear in the later second century вС, as it refurbished the temple of Hekate. By this time the precinct comprised roughly a hectare of leveled land, $113 \times 150 \mathrm{~m}$, enclosed by stoas that encompassed the

on inscriptions as well as the style of the Corinthian capital. Rumscheid (1994), 139-140, however, dates it to the same period as the temple of Hekate, based on the similarity of the Corinthian capitals; he dates both structures to the early first century вс. Baumeister observes how fragile the evidence is for a true building program in second-century Stratonikeia, Baumeister (2007), 15, 162, although the gymnasium, theater, bouleuterion, and the temple of Hekate are clearly key projects.

106 Rumscheid (1994), 23; Tirpan et al. (2012), 196-197; Pedersen (2012); Büyüközer (2018).

107 Tirpan et al. (2012), 196-197, discusses the excavations, from 1999-2002, at a depth of $1.75 \mathrm{~m}$ below the floor of the cella, tantalizingly mentions that "... ashes, partially burned pieces of figurines, a great number of glass amulets in various colors, dress ornaments in rosette form, ivory objects, an inscribed stele [I.Stratonikeia 1417, from the second half of the fourth century вС, and I.Stratonikeia 1418, a decree by the Chrysaoric League from the first part of the second century $\mathrm{BC}$ ], and coins dated between the beginning of the 4th с вС and the end of the 2nd с вС were found." Büyüközer (2018), 22, mentions finds from the fourth to early first century $\mathrm{BC}$, indicating this as a terminus post quem for the Corinthian temple.

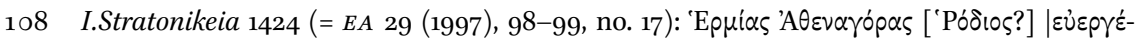
$\tau \eta[\varsigma]$. Şahin believes the benefactor to be Rhodian, based on his Dorian name, and so dates the inscription and entablature to the first part of the second century вС. 


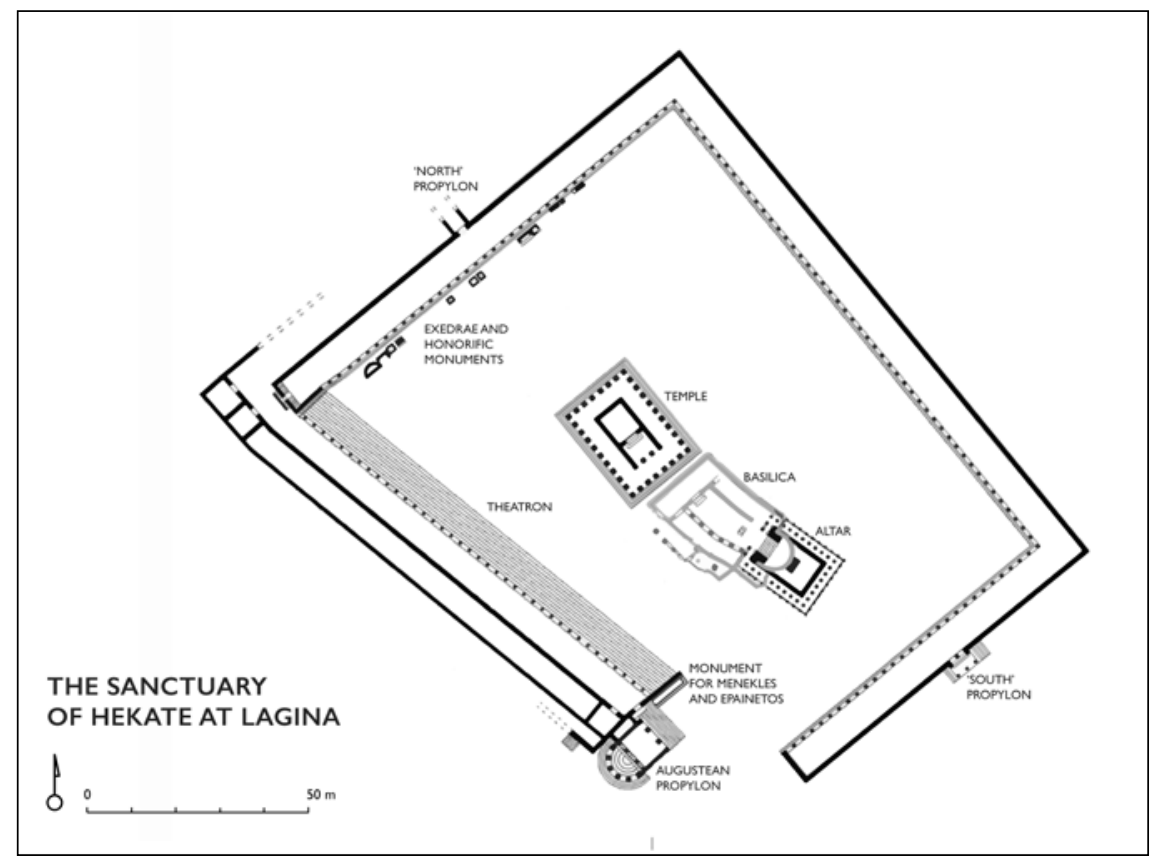

FIGURE 5.8 Plan of the sanctuary complex of Hekate at Lagina by the first century вС PLAN AFTER Z. GIDER, IN GIDER (2012), WITH PERMISSION

temple and altar inside. Inscriptions from the imperial period refer to the complex and environs as the peripolion, indicating a kind of suburb in its own right (Figure 5.8). ${ }^{109}$

Access to Hekate's sanctuary was formally marked by a propylon, or gateway, now one of the most notable features due to the doorway still standing on site (Figure 5.9). The innovative structure, with a semi-circular prostylos

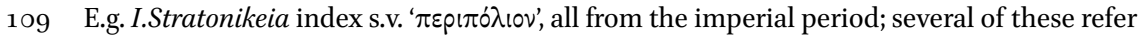
to those living in the peripolion, see below under Local Community. On the peripolion at Lagina, see: Laumonier (1958), 346-347, 363-365, who believes it to refer to the sacred complex, enclosed by the stoai; Schuler (2010), 401 and 411 no. 8 , who discusses this in context with other uses of the term peripolion (e.g. in Lykia, Termessos, Rhodes, Kos) - in Lykia the term typically refers to a politically structured community or village dependent on a polis, perhaps in sympoliteia; İplikçioğlu (2004), $116 \mathrm{n}$. 87 who assesses the uses of the term peripolion in imperial inscriptions form Stratonikeia, concluding that the term specifically refers to the temple complex of Hekate in Lagina, rather than a structured settlement; Aydaş (2015) believes this to refer to Hekate's city. 


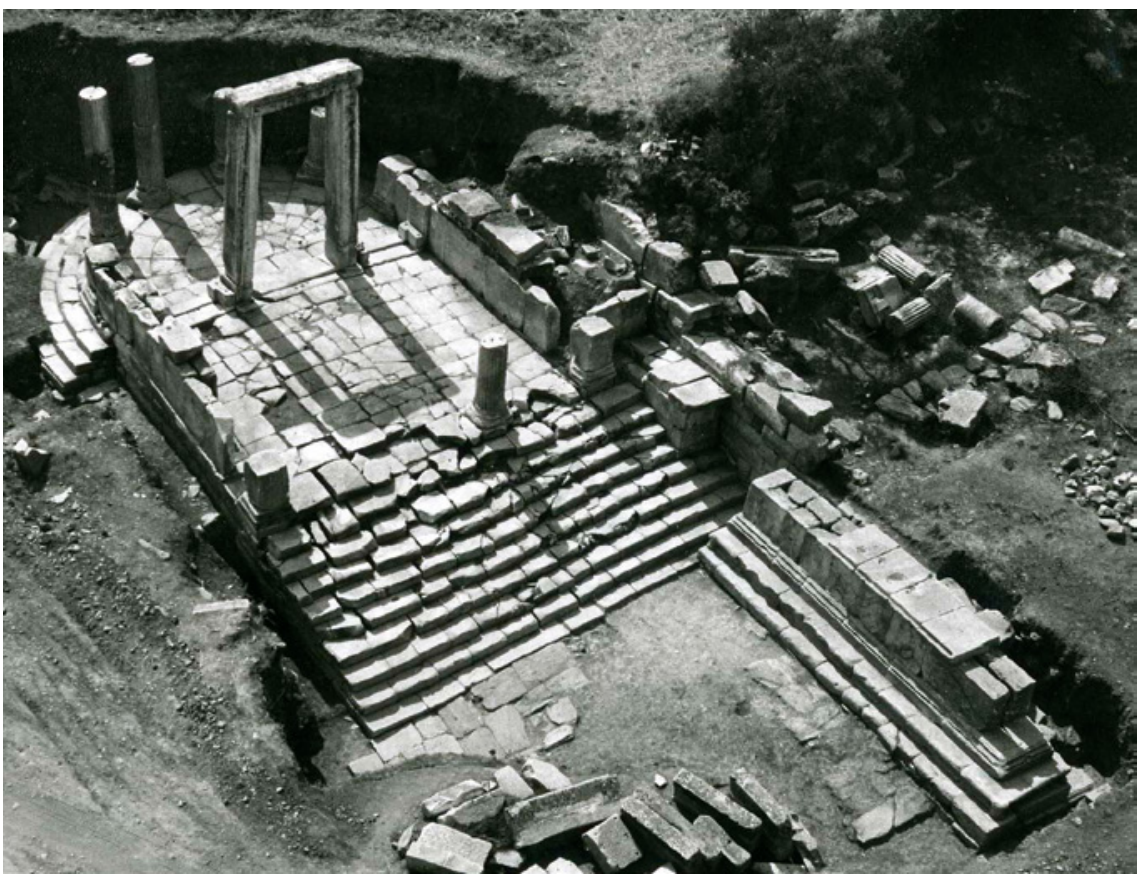

FIGURE 5.9 Aerial photo of the propylon, seen from the east PHOTO COURTESY OF PROF. AHMET TIRPAN

porch on the exterior, was rebuilt by Augustus, but possibly on a Hellenistic foundation. 110

Four steps led the visitor up from the sacred road to the threshold with three gateways. From there he or she would then descend ten steps down into an enclosed temenos defined by the surrounding stoa (Figures $5 \cdot 7$ and 5.10-5.11). The southwest wing, with the theatron, connects to this propylon and was (re)constructed at the same time. ${ }^{111}$ This wing deviates from the orientation of the rest, which follows the alignment of the temple.

110 Based on the consistency of the visible dovetail clamps with third-century architecture, Pedersen (2012), 515-516. The propylon was restored by Augustus, as is recorded in the

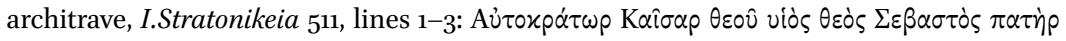

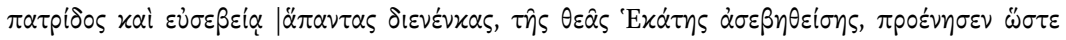

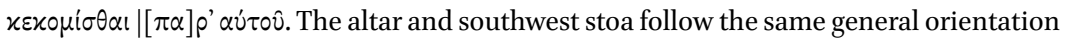
as the propylon and may have been rebuilt at the same time, Tirpan and Söğü (2007b), 592-593. Tırpan and Söğüt (2007b), 592-593; also Tırpan (20o8), 449-451, and Carboni (2013), 64-66.

111 As suggested in Tirpan and Söğüt (2007b), 592-593; also Tirpan (2008), 449-451, and Carboni (2013), 64-66. This was surely the dysmike stoa dedicated by the priest Aristeas, son of Aetion, of Koranza, in I.Stratonikeia 653 . 


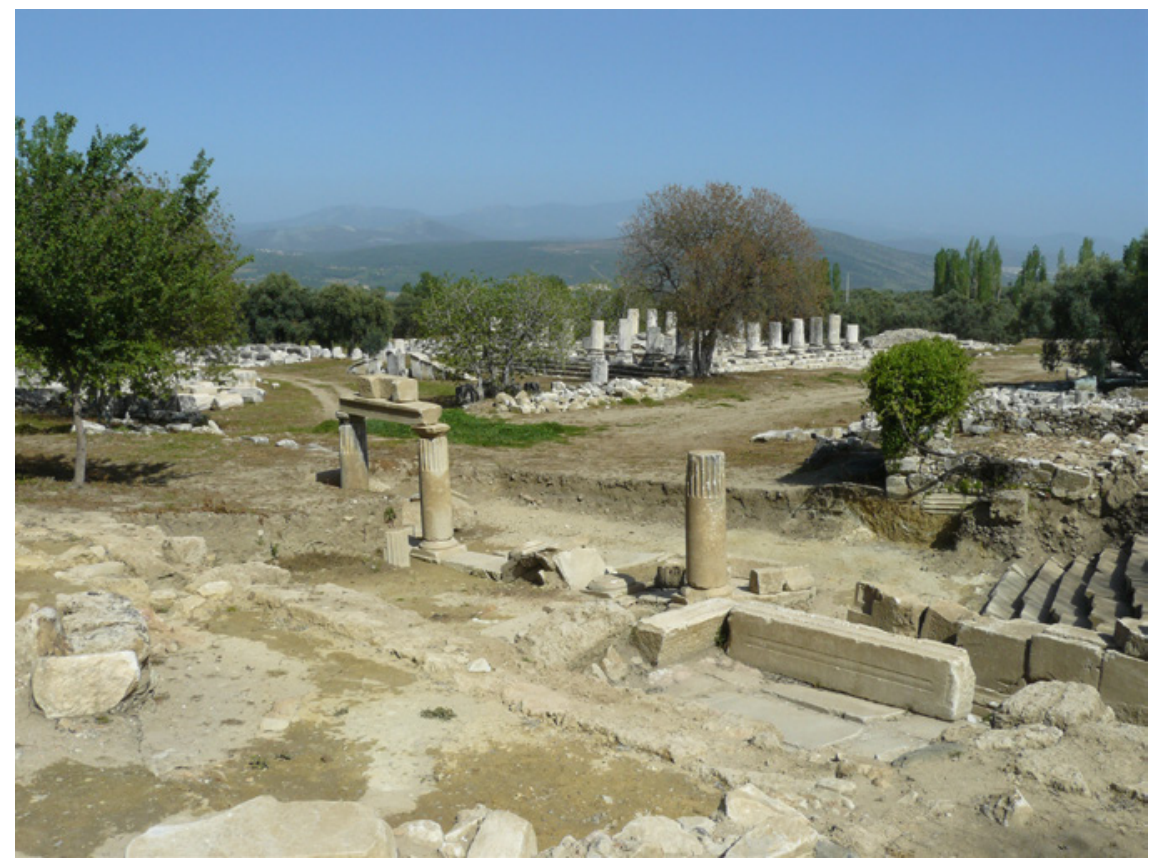

FIGURE 5.10 Lagina. From the northwest corner of the stoa complex. The theatron is visible in the lower right, the temple in the center

PHOTO AUTHOR 2008

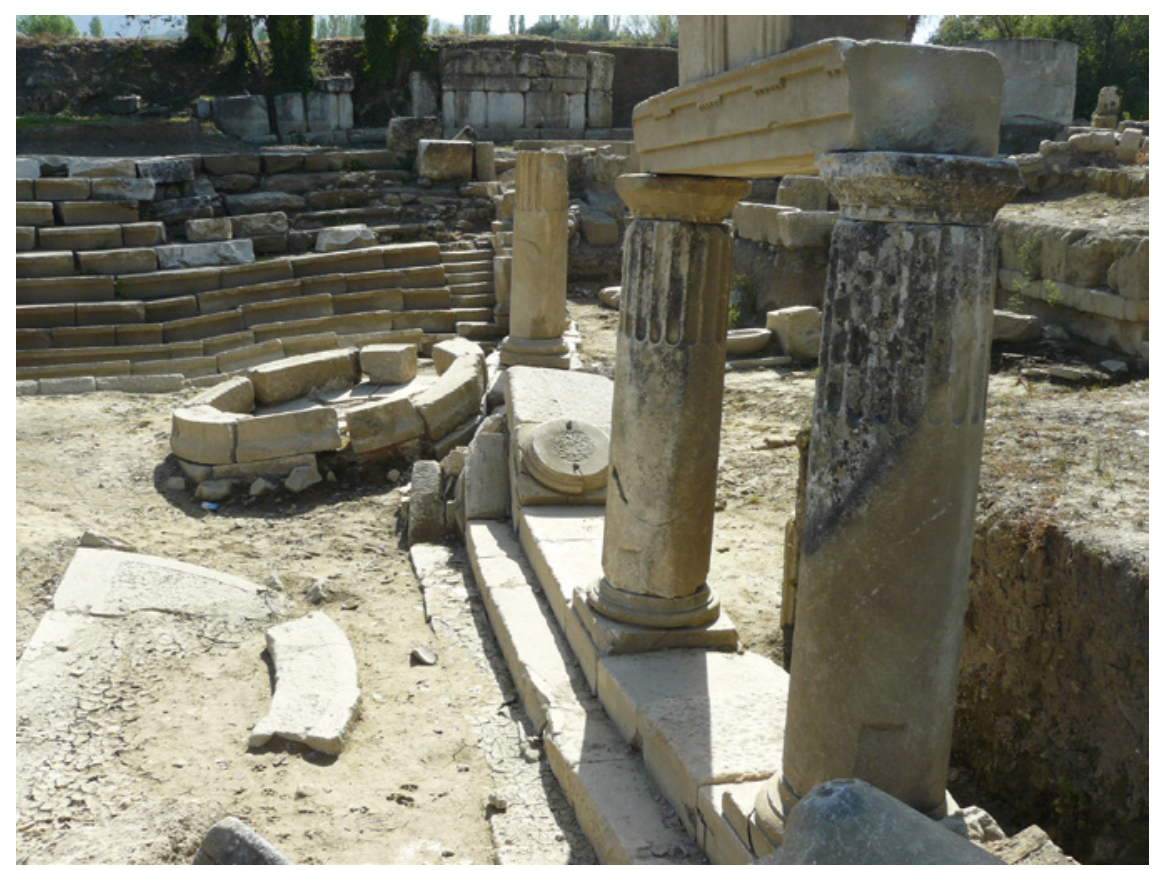

FIGURE 5.11 Lagina. Doric columns with smoothed lower surfaces; the theatron is visible in the background 


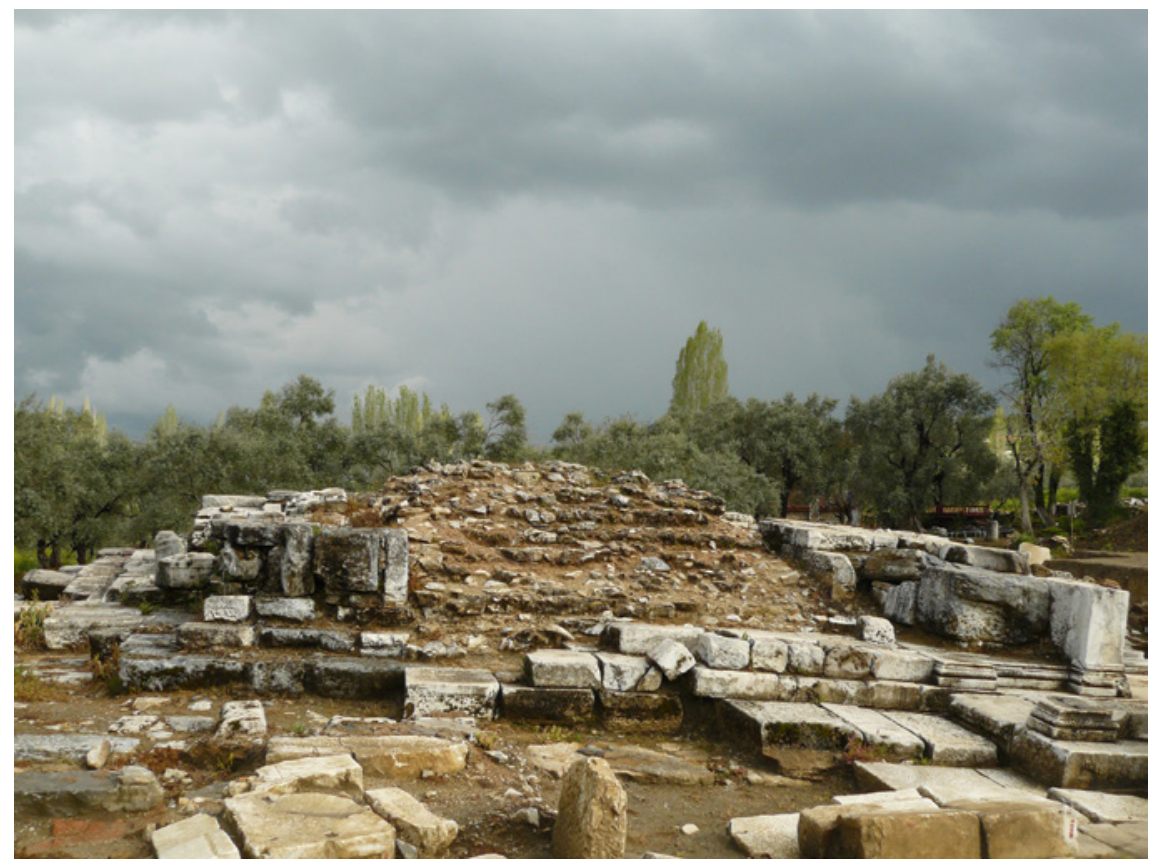

FIGURE 5.12 Lagina. Altar seen from the temple, with marble paving ending in the rubble core supporting the steps

PHOTO AUTHOR 2009

Although the stoa complex now visible is dated to the Augustan era, following the destruction by Labienus (Figures 5.7-5.8, 5.10-5.12), excavations in 2009 revealed a similar configuration from the fourth century BC. ${ }^{112} \mathrm{~A}$ second propylon was discovered in 2011, breaking through the otherwise blank wall of the southeast stoa. ${ }^{113}$ Like the primary propylon, this gateway appears to date from the Augustan era; its unusual design combines Doric capitals with Ionic fluting, and a prostyle porch of three Doric columns that accentuated the double gateway into the temenos. ${ }^{114}$ The porch was entered laterally by steps. Situated across from the open area east of the temple-altar axis, this secondary access may have been connected either with the festival or possibly with other structures or a road outside the temenos to the south. On the opposite side, a third point of access may have been built into the northwest stoa, although

112 Rumscheid (1994), 23; Tirpan et al. (2012), 196-197. Gider (2012), with a plan of the sanctuary on p. 274, Fig. 1 and a reconstruction of the North Stoa on p. 28o, Fig. 19.

113 Büyüközer (2015), with a plan on 68-69 and reconstructions on 72-73.

114 On the Doric architecture at Lagina, Gider (2005). 
this awaits further investigation and publication. ${ }^{115}$ The open space southeast of the propylon must have been filled or blocked since the propylon would otherwise have been pointless - perhaps this was partly occupied by Hekate's sacred grove? ${ }^{116}$

Once inside the sacred space, the visitor arriving through the grand propylon would immediately have noticed the monument for the brothers Menekles and Epainetos, erected in the later first century вс (Figures 5.9, 5.18 and 5.26). ${ }^{117}$ From here one faces the southwest side of the altar, slightly at an angle from the temple, and connected to it by a paved marble path (Figure 5.12). Kinetic linear space was also made tangible inside the sanctuary connecting two distinct places through physical movement. ${ }^{118}$ The altar was also rebuilt under Augustus, and was constructed as a П-shaped colonnaded type; presumably it occupies the place of the older altar, which may explain the unusual orientation, although it may well have shifted during earthquakes. ${ }^{119}$ Cassettes from the ceiling of the altar colonnade, some found in the fill of the later altar, display a wonderfully rich variety of fish, birds, fruit, poppies and other flowers, pine cones, amphoras, human forms and faces, and testify to the importance of fertility and abundance at the shrine. A few even display doubleaxes (Figure 5.13), alluding either to Zeus Labraundos or Karia in general, as at Sinuri. ${ }^{120}$

The complex clearly provided shelter and would have proved useful for several cult activities, including feasting although no formal banqueting rooms were identified. ${ }^{121}$ But most important was the intense sense of enclosure and internal focus that the peripolion provided to the shrine - a regulated and

\footnotetext{
115 Gider (2012).

116 Mentioned in I.Stratonikeia 513, discussed below under Legal Administration; see also Laumonier (1958), 364-365; Tirpan (2008), 451; Carboni (2013), 65-66.

117 I.Stratonikeia 1426 and 1427 (= EA 29 (1997), 85-86, nos. 3-4). Discussed below.

118 Similar to the paved path (in gneiss) between the temple and altar at Mamurt Kale, see Williamson (2014a).

119 The П-shape of the altar echoes earlier sculpted monumental altars as at the Asklepieion on Kos, third century вс, or the altar of Artemis Leukophryene at Magnesia on the Maeander or the monumental altar of Zeus at Pergamon, both from the second century ВC; see also Linfert (1995). Earthquakes are known to have affected the area and two faults appear in the foundation of the altar, Söğü (2019), 262, Fig. 65 and p. 316.

120 At Lagina at least two small cubic stone blocks were found carrying a double-axe. One is a votive altar dedicated to the god Kanebos (I.Stratonikeia $1419=E A 29$ (1997), 103, no. 25, not dated); Kanebos is also known from a Late Classical-Hellenistic inscription from Hyllarima on the sale of priesthoods, $S E G 55$ 1113. The other stone bears no inscription. On the double-axe as a votive, see also above in Chapter 3 , but also Chapter 4 , under $\mathrm{Cult}$ Iconography on the double axe relief at the sanctuary of Sinuri; see also Figures 3.14a-b.

Indicated in I.Stratonikeia 668, see further below on banqueting activities.
} 


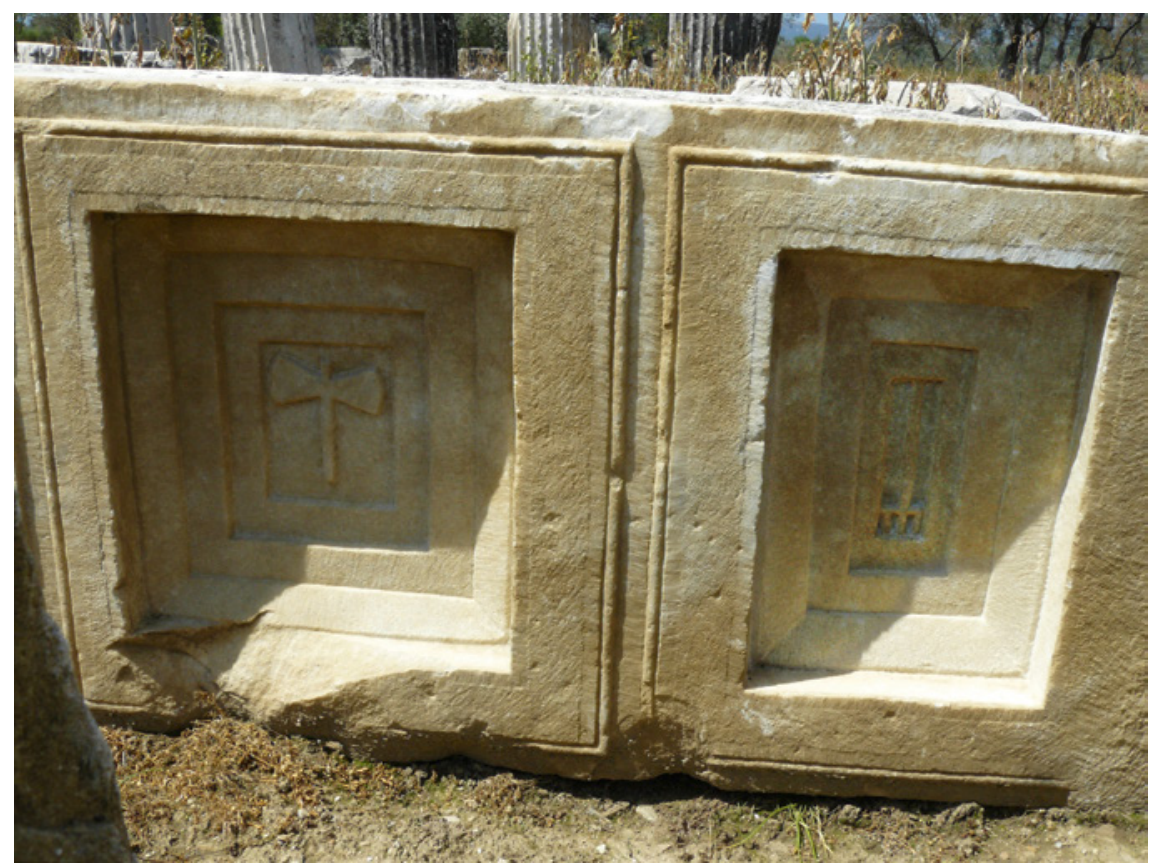

FIGURE 5.13 Lagina. Coffered ceiling fragments, with reliefs of a double-axe and a trident PHOTO AUTHOR 2009

coherent concentric space, more so than at any of the sanctuaries discussed in this study. There would have been a marked contrast between the exterior and the interior of the sanctuary. ${ }^{122}$ Surrounding the interior, the columns of the stoa, with the smooth surfaces of their lower unfluted sections (Figures 5.105.11), created an urban, agora-like setting, with the rhythm of the columns creating a punctuated surface, while the back walls closed off the sanctuary from the external world. ${ }^{123}$ In this sense the sanctuary complex would have resembled a public and especially cosmopolitan space. The only difference

122 A parallel may be found in the sanctuary of Meter Theon at Mamurt Kale, or Pisidian Antioch, see Williamson (2014a) and (in press-a).

123 Columns with non-fluted surfaces on their lower parts were often found in agoras and areas of heavy traffic, perhaps the most well-known example is the Stoa of Attalos in the Athenian agora. Laumonier notes how they also appear in a number of urban Hellenistic sanctuaries, e.g. in Pergamon (Demeter), Magnesia on the Maeander (Artemis Leukophryene), Notion (Athena sanctuary on the acropolis), Teos (Dionysos), Alabanda (Apollo), and Mylasa (Zeus Osogollis); Laumonier (1958), 346-347 n. 1. On form and function in Hellenistic agoras, see Dickenson (2016); Sielhorst (2015). For the compartmentalization of urban space into units articulated by architecture: von Hesberg (199o); Zimmermann (2009), 25-26; and Emme (2013), esp. 225-230 on 'porous' interiors. 
was its location; it seems to have been designed as a suburban annex. ${ }^{24}$ The architecture at the sanctuary would have made it noticeable from a distance, but the bland exterior, relieved only by the entryway on the south and possibly north flank, indicates that its role as landmark was less important than what went on inside.

The unusual southwest wing of the stoa accentuated the internal focus of the complex with its theatron of 11 tiers of seats that lined the entire length, over $100 \mathrm{~m}$, of the inner southwest stoa wing, accessed by steps at either end (visible in Figures 5.10-5.11).125 Allowing for 0.50 m per seat, some 2200 people could have comfortably sat down at the same time, with probably more standing at the top and in the other wings of the stoa. The provision for an audience automatically turned the opposite space before the cella wall of the temple into a podium. Clearly ritual performance at Lagina knew a rich variety, including perhaps reenactments, hymns, crowning victors or bestowing other public honors, besides the sacrifice on the monumental (and theatrical?) altar.

Hekate's temple, near the center of the complex, shows a mixture of traditional and innovative styles and techniques, several of which still puzzle scholars today. The temple faces southeast, and is situated on a shortened stylobate that supported a pseudo-dipteral peripteros of $8 \times 11$ columns $(21.3 \times 28 \mathrm{~m}$ stylobate) in the Corinthian order, an early example of its use on the exterior (Figure 5.14a-c). ${ }^{126}$ This peristyle surrounded an almost square cella, covering an earlier bothros and niche at the back, exactly under the area of the cult statue. ${ }^{127}$ The pronaos is nearly as deep as the cella. The temple lacks an opisthodomos, which by that time was not uncommon on Ionic temples (e.g. the fourth-century Ionic temple of Zeus Labraundos, also the temple of Athena Polias in Priene).

124 Williamson (2013e) on sanctuaries as public and urban space. In the later third century AD, a biotike agora, or 'live market', was part of the sanctuary, adjacent to the southwest wing of the complex, I.Stratonikeia 668, lines 8-10, discussed below under Local Community and Economic Resources. Whether form followed function or function followed form at Lagina, i.e. whether the agora function was already a factor in the Hellenistic design, or came later, is unknown. On sanctuaries as inscribed, and hence cosmopolitan spaces, see Kamphorst (forthcoming).

125 Apparently dedicated by the priest Aristeas, son of Aition of Koranza, in the first century AD, I.Stratonikeia 653 .

126 Tirpan et al. (2012), 184, Fig. 3 shows the plan of the temple. The round temple of Portuna in Rome is dated to the second century BC. On the development of the Corinthian column, initially used exclusively in interiors, see Pollitt (1986), 248-249. Tirpan believes the choice for the Corinthian order as informed by the Seleukid heritage, rather than Roman identity, of the Stratonikeians, Tirpan et al. (2012), 199.

127 Büyüközer (2018) discusses the earlier phases of the temple. 

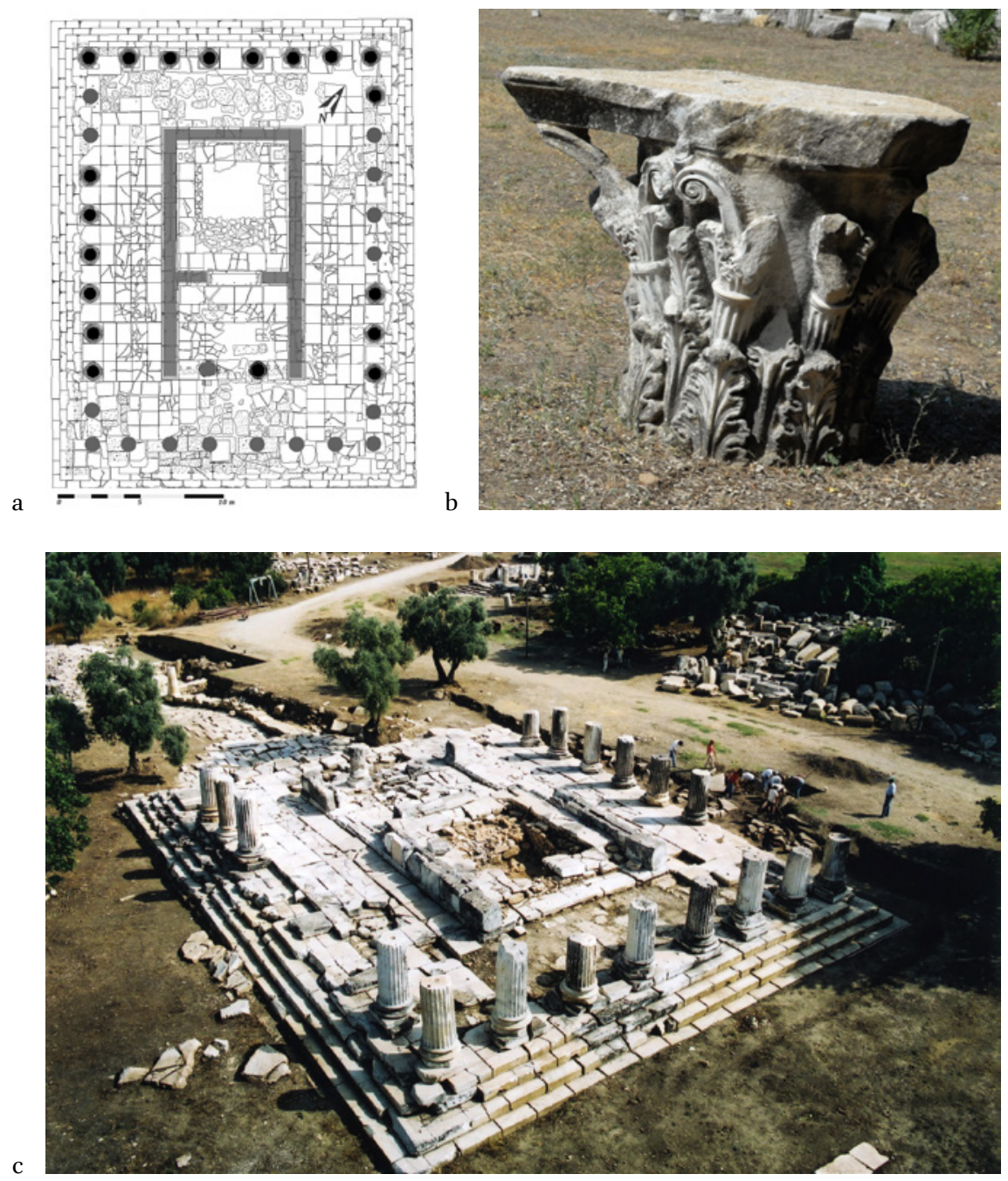

FIGURE 5.14 A-C Lagina. Temple of Hekate. a) Plan, showing $8 \times 13$ Corinthian columns and 2 Ionic columns in antis in the pronaos. (after Tirpan and Sögüt 2007, 401 Resim 1); b) One of the Corinthian capitals from the temple. (photo author 2019) c) Aerial overview from the north

PHOTOS A AND C COURTESY OF PROF. AHMET TIRPAN; PHOTO B AUTHOR 2019

Different scholars have argued for two separate building phases for the temple: the first would be in the early Hellenistic period, close to 300 BC, when the temple simply had two Ionic columns in antis, and a later phase, some time after $200 \mathrm{BC}$, when the order was changed to Corinthian, with the addition of a Corinthian peristyle on the exterior and corresponding Corinthian pilasters 
on the interior. ${ }^{128}$ This suggests an initial construction phase in the context of Koranza, with the later expansions under the aegis of Stratonikeia.

The tympanon was pierced with apertures, similar to other temples in Asia Minor and scholars debate whether this was simply to relieve the weight, as Dinsmoor believed, or to stage an epiphany, as Bammer suggested for Ephesos. ${ }^{129}$ Hekate is 'epiphanic' in at least one of the later inscriptions, and she is depicted in hieratic stance, frontal and detached, in the gigantomachy frieze on the temple, but there are no firm indications of ritual epiphanies. ${ }^{130}$ Concerning the frieze, this is Lagina's central claim to fame in the modern era and has received the most scholarly attention. ${ }^{131}$ This continuous frieze, embellishing the entablature of the peripteros, is divided into four zones that include a gigantomachy on the 'west side' with the epiphanic appearance of Hekate (Figure 5.15), and on the 'east side' the birth of Zeus with Hekate assisting his delivery, allegorical representations on the 'south side', and on the 'north side' a remarkable relief with Amazons and soldiers, with Hekate presiding (Figure 5.16).

The polis of Stratonikeia would in any event have been responsible for the design of the unusual frieze on the entablature of the temple. One of the earliest studies of this frieze was by Schober, ${ }^{132}$ who drew attention to the 'north'

128 Rumscheid (1994), 132-139, argues on stylistic grounds for the two phases, with the second following 13 О ВC; Pedersen (2012), esp. 517, assigns an initial construction phase near 3 оо вс for temple and/or propylon based on the presence of the Karian-Ionian lewis, otherwise known only in the Late Classical and early Hellenistic periods. Pedersen is cautious not to link the date of temple and frieze to political events, instead he more broadly identifies the second phase to the second century $\mathrm{BC}$, as the Corinthian columns show use of the simple lewis that became conventional in this era. See also Trrpan et al. (2012) and now Büyüközer (2018).

129 Reconstruction in Tirpan et al. (2012), 192, Fig. 6. Such apertures are also found in the temples of Artemis in Ephesos and Magnesia on the Maeander, and the temple of Zeus in Aizanoi, discussed in Williamson (2018), 324-325, with references in n. 89; Dinsmoor (1973[1950]), 225, followed for Lagina by Tirpan et al. (2012), on the weight-reduction interpretation; on the epiphany interpretation, Bammer (1972), 10 fig. 6 and 41, fig. 43.

130 I.Stratonikeia 507, discussed further below. On Hekate's epiphany, also Robert (1937), 461-462.

131 Scholars include: Schober (1933); Laumonier (1958); Junghölter (1989); Simon (1993); and especially by Baumeister (2007). See also Herring (2011), who considers the frieze and temple complex in the context of a hybrid Greek-indigenous community, and Carboni (2013), 59-89, in the wider context of cults of Hekate across the Greek world. Karian heroes are further indicated in the roughly contemporary Salmakis inscription from Halikarnassos, Isager (2004).

132 Schober (1933). Perhaps it is because the frieze was studied before the entire temple was excavated that the section above the entrance, showing the birth of Zeus, is called the 'east' frieze, when in reality the entrance faces more to the south-southeast, while the long sides are dubbed 'north' and 'south', but are really more northeast and southwest, 


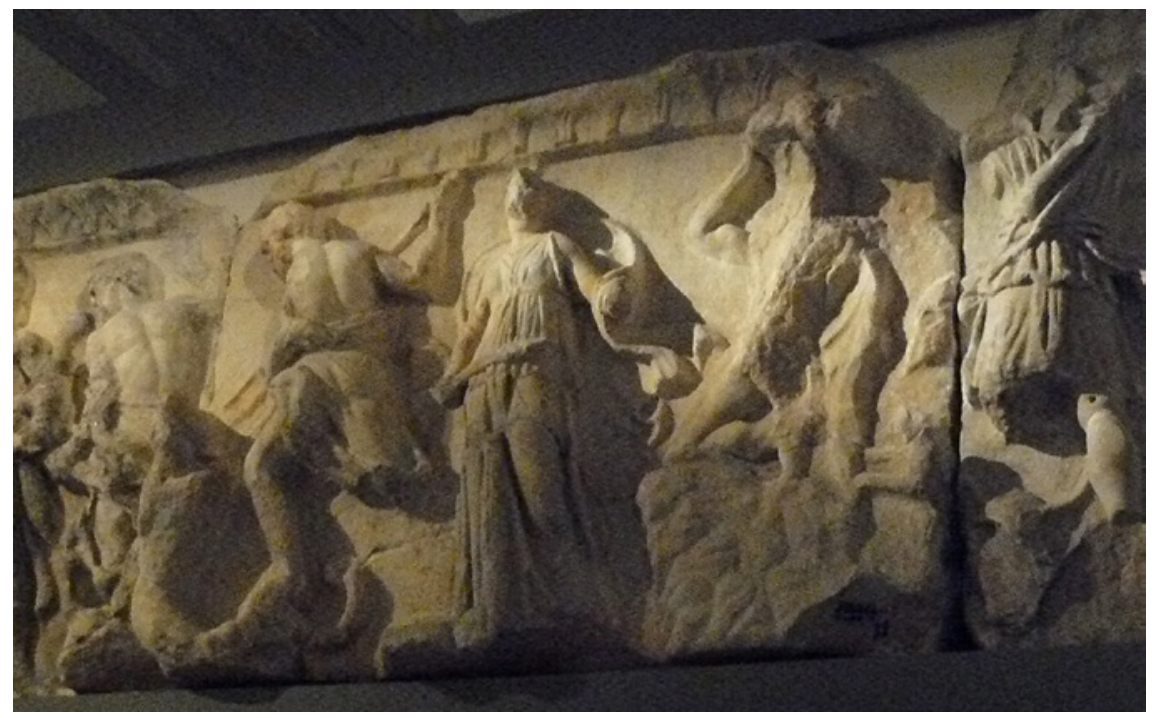

FIGURE 5.15 Lagina. The central part of the 'west' temple frieze, showing Hekate in the midst of a Gigantomachy ISTANBUL ARCHAEOLOGICAL MUSEUM, PHOTO AUTHOR 2009

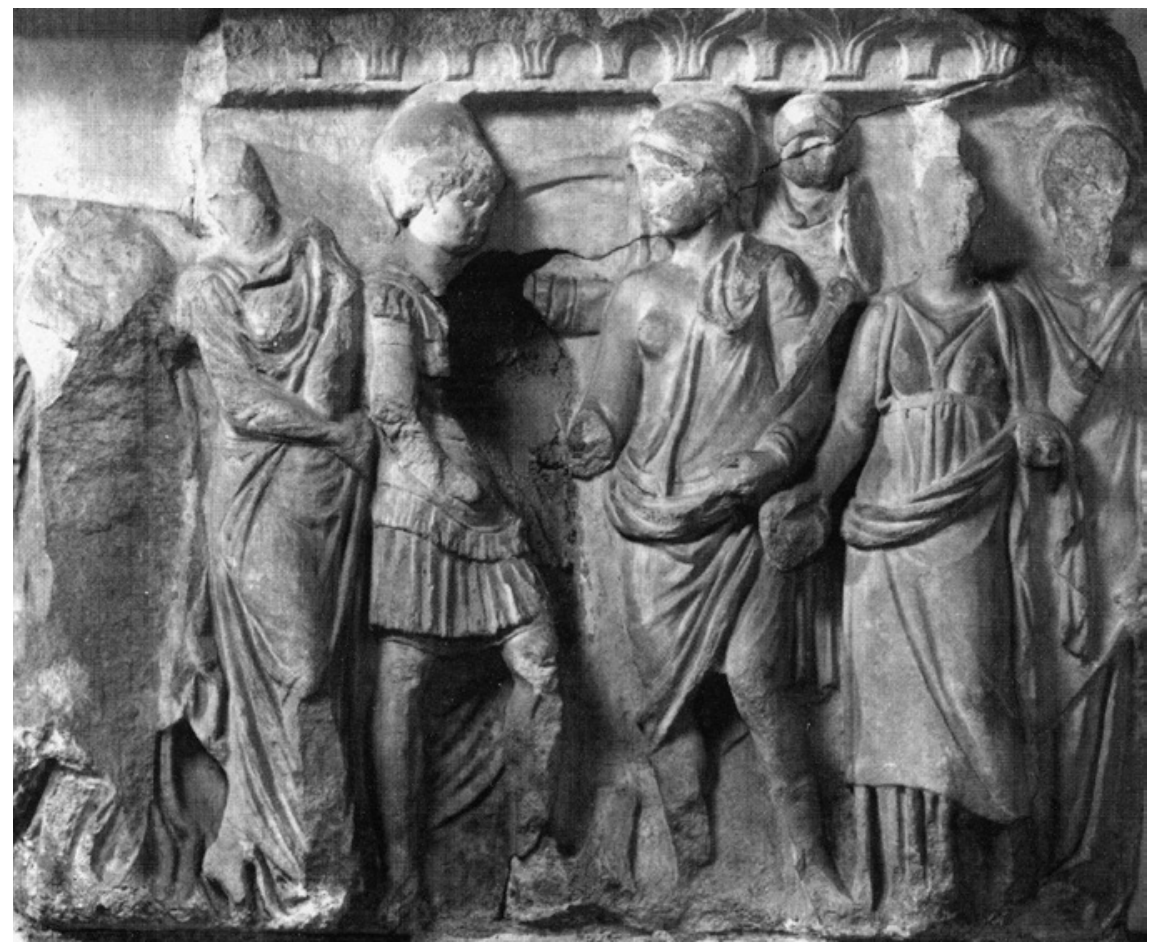

FIGURE 5.16 Lagina. Section of the 'north frieze', showing Amazons and Greek soldiers in amicable relations, with Hekate to the right, holding a phiale PHOTO COURTESY OF PROF. AHMET TIRPAN 
section and its depiction of soldiers and Amazons: these are not engaged in battle as they would be in a regular Amazonomachy, but instead are enjoying cordial relations, shaking hands and clasping shoulders (Figure 5.16).

This anomalous representation has led to much discussion on the interpretations of the frieze and its temporal context, and hence the date of the temple itself. Most of the interpretations view the 'north' frieze as symbolic of a pact with Rome, ${ }^{133}$ with the Amazons representing the Karian cities, and the soldiers representing Rome - the date of the building has thus commonly been linked to one of the events of Roman involvement in Karia, usually either the Aristonikos revolt of $133^{-129}$ вС or the Mithridatic wars of the 8оs вС..$^{134}$ With respect for the various arguments, I will for the purposes of this present study adhere to the findings of Peter Baumeister, who meticulously studied the style, content, and context of the frieze, and proposed a date in the late second century $\mathrm{BC}$, based primarily on stylistic comparisons. ${ }^{135} \mathrm{He}$ observed among others that the uniforms of the soldiers are Greek, not Roman, while the Amazons are more linked to the founding myths of a number of cities in west and northwest Asia Minor. Baumeister thus believes the evocative 'north' frieze is either an historical reference to an alliance between Karia (the soldiers) and some of the cities of west and northwest Asia Minor (the Amazons);

and the opposite end is more northwest than 'west' - see Figure 5.8. However, I will follow the conventional naming for the sake of reference.

133 Laumonier even considers the surrounding figures on the frieze as the 'oath gods' Poseidon, Ares, Aphrodite, and Artemis - who guaranteed the treaty, Laumonier (1958), 351 .

134 Schober (1933) believed the frieze to date after the Aristonikos uprising; Junghölter 1989 connected the temple and frieze to the Mithridatic wars, based on the senatus consultum (I.Stratonikeia 505) inscription carved on the walls of the temple, followed by Rumscheid (1994), 139-140. It goes beyond the scope of this study to discuss all of these views and their ramifications, but for a good review, see Baumeister (2007), 35-40. In the meantime, van Bremen's suggested date between 150 and 13 O ВC (van Bremen (2010)) would roughly coincide with the first coin issues of Stratonikeia, Meadows (2002) Group 1 (see below under Cult Iconography in Urban Contexts). These may have reflected the cult image of Hekate, based on epigraphic comparisons of the orthography of the inscriptions on the temple walls. Van Bremen's caution in linking such a building project with a specific historical event is understandable, "Date and interpretation ... unfortunately have an uncomfortable way of shoring each other up, to no good effect," van Bremen (2010), 502. Nonetheless, festivals and accompanying sacred architecture are often prompted by the celebration of difficult victories.

135 Baumeister (2007), 11-33 and 219-220 on the date of the temple and frieze, with supportive parallels in the similarly 'retrospective' architecture at the pseudo-dipteral temples of Apollo Smintheios in Chryse and Apollo Isotimos in nearby Alabanda, both mid to later second century BC, Baumeister (2007), 154-155. 
alternatively he suggests that it could also be an allegorical depiction of the new paradisiacal age of peace that was made possible by the intervention of Rome during the Aristonikos uprising, and the beginning of the Roman province of Asia. ${ }^{136}$ In either case it seems clear that the military force represented on the frieze is meant to be Karian, rather than Roman.

Baumeister's second interpretation, of a general age of peace, could explain the cosmic presence in the rest of the frieze, with the assembly of Karian gods, heroes, and nature personifications shown on the 'south' side, the rather anemic gigantomachy on the 'west' side with Hekate at the center, and the birth of Zeus, assisted by Hekate, on the 'east' side. ${ }^{137}$ If the iconography of this frieze is a pro-Roman statement, it would be in keeping with Stratonikeia's general disposition towards the superpower. ${ }^{138}$ Stratonikeia had shown nothing but loyalty to Rome since her liberation from Rhodes in $167 / 6$ BC and seemed quite eager to underscore these good relations, as the later installation of the cult for the goddess Thea Romē in Hekate's sanctuary proves. ${ }^{139}$ Yet if the focus were shifted to the 'south' section of the frieze, then one might also view the temple as a very Karian-centered proclamation, perhaps even focused on Stratonikeia with Zeus Karios of Panamara and Hera Teleia taking their enthroned positions in the 'Karian pantheon.' ${ }^{140}$ The allegorical references to natural phenomenon may well have been a way of using the landscape as a symbol for the

${ }_{13} 6$ Baumeister (2007), 'These I' and 'These II', 53-61. The main problem with dating the frieze within the context of the Aristonikos uprising is that the impact which this war actually had on Stratonikeia, or Karia for that matter, is very unclear; Marek (1988), 297-298, sees no reason for Karia to have been involved in the wars at all, nor was it included in the province of Asia until after the Mithridatic wars. Errington observes, however, that Karia was generally pro-Roman after the eviction of Rhodes in $167 \mathrm{BC}$, perhaps lending a great deal of support to Rome during this entire period, Errington (1987).

137 Baumeister (2007), 61-65.

${ }_{13} 8$ The representation of historical events in sacred sculptural programs is complex, e.g. Kuttner (2005), 187. Offering an alternative view, van Bremen (2010), 503, suggests that the frieze has nothing to do with Rome but instead represents the role of Hekate in Karian mythology, and that the 'north' frieze probably indicates a local foundation myth. Both interpretations could be the case, e.g. as with the Pergamon altar, or the Parthenon friezes for that matter, where political realities are framed through mythological narratives. In the absence of further evidence, several hypotheses are plausible.

139 On the cult of Thea Romē see Mellor (1975) and Errington (1987).

140 Baumeister (2007), 36-37 discusses the interpretation of the 'south' frieze. Among the nature allegories and city personifications on the 'south' frieze, the 'Karian pantheon' identified by Baumeister includes an enthroned Hera Teleia (once believed to be Hekate, see Baumeister (2007), 37) and Zeus of Panamara on Block 201 (depicted in Baumeister (2007), Tafel 6-7, figures 3 and 7), and a bare-breasted Aphrodite, armed Athena, Ares, and a young Apollo on Block 202 (Tafel 8, figures 1, 3-5). The sanctuary of Zeus at Panamara, some $10 \mathrm{~km}$ southeast of Stratonikeia, was the other major urban cult of Stratonikeia, 
region of the polis, as discussed in Chapter $2 .{ }^{141}$ In fact, this is the section that faced the audience seated in the theatron of the southwest stoa wing, serving as a backdrop for the ritual performances that took place below. ${ }^{142}$ The 'east' frieze is then interpreted as a Karian 'annexation' of Greek myth, ${ }^{143}$ in a general vision of the natural and cosmic forces as seen through Karian, or more specifically, Stratonikeian eyes.

The frieze represents the official iconographic program of the sanctuary, which Laumonier observes marks the transition between Hellenistic and Roman art. ${ }^{144}$ A second level may literally be found below the frieze, on the krepis and stylobate of the temple, where several outlines of feet are incised (Figure 5.17; with similar 'graffiti' in the propylon). Of course, it is impossible to know for certain how old these less formal markings are, but it indicates the presence of people at the sanctuary, and the desire of people to make their presence known. ${ }^{145}$

In any event, the temple should be seen as a monumental marker of Stratonikeian urban presence in this area of her territory, with the frieze surely

see Chapter 6 below. This frieze would in any event argue for the inclusion of Hera at Panamara by this period, if the Zeus represented here is in fact Zeus of Panamara.

141 'Symbolic shaping' is one of the stages in Paasi's model of building regional identity, Paasi (2009). In this he recognizes the use of landscape as symbol, also referring to Meinig (1979); see Chapter 2.

142 On the use of temples as 'backdrop' for ritual drama, Nielsen (2002), 16. The southwest wing was on the upper side of the slope, making this the natural choice for the location of a theatron; the exact date of this wing is unknown - if the assumed date is Augustan, then it clearly post-dates the temple, and it is unknown whether there was a theatron here in Hellenistic times as well. In any event, at least by the Roman period if not before, the 'south' frieze is the section that people were able to consider the longest, while seated during the ceremonies, whether this was intentional or a coincidence. In this light, it is interesting that this is the only section where Hekate does not appear, but Zeus of Panamara instead, intertwining the two main cults of Stratonikeia even further (see below under Festivals). Also, this is where Riet van Bremen locates the Senatus consultum de Stratonicensibus inscription (I.Stratonikeia 505-507), van Bremen (2010), 493-495, discussed further below.

143 Laumonier (1958), 349; Picard (1933), 401.

144 Laumonier (1958), 353; he also refers to it as an "effort théologico-artistique," p. 349, n. 6.

145 There are other graffiti images as well, including a dog and maybe a cow, but most were pairs of feet. Ahmet Tirpan believes they may be from the later Byzantine period (pers. comm. 16.04.20o9). Feet and footprints on monuments are not uncommon at sanctuaries, possible interpretations are discussed in Dunbabin (1990). See also the four golden

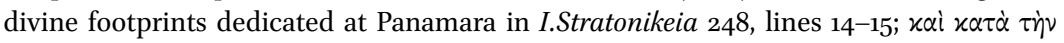

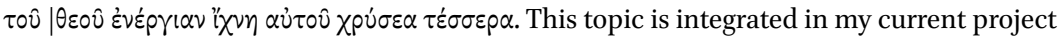
on sanctuaries as multi-scalar hubs of meaning, part of the larger Connecting the Greeks project at the University of Groningen, sponsored by the Netherlands Organisation for Scientific Research (NWO). 


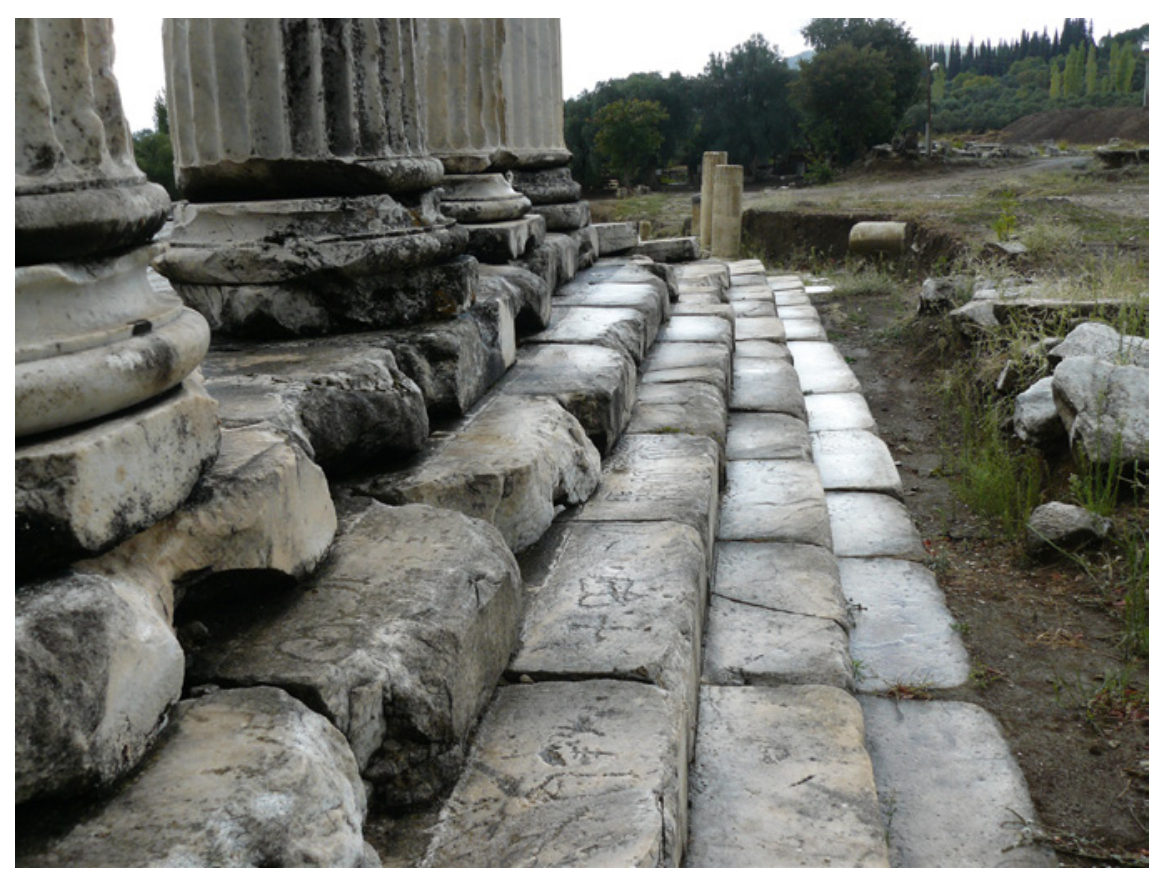

FIGURE 5.17 Lagina. The southwest krepis of the temple. Note the 'graffiti', including several outlines of feet

PHOTO AUTHOR 2011

as an ideological representation of this transformation of physical, political, and ritual space by its depiction of the natural order of the cosmos within a carefully controlled, and thus peaceful, context.

\subsubsection{Public Space - Concentric and Linear}

The temple is situated near the center of the stoa complex and the frieze would have helped to draw the visitor in from the propylon, probably along the altar, in a spiraling motion around the temple. Although the altar was ritually the center of the sanctuary, it actually seems somewhat marginally positioned in the space within the complex. As mentioned above, the architecture of the sanctuary was one of enclosure, ensuring a focus on the interior as a unit, mostly closed off from the outer world. In more ways than one it resembled a Hellenistic agora, marked by the smoothed Doric columns (Figures 5.10, 5.11), with an internal dynamic of its own, in this case accentuated by theatron along the southwest wing.

Within the concentric space at the sanctuary, the altar would have been the prime ritual focus, but the temple itself would have attracted attention, 
drawing visitors around the sides of the temple to 'read' the frieze on the architrave, but also the inscriptions on the temple walls. The Senatus consultum de Stratonicensibus is suggested to have been inscribed on the side opposite the theatron. ${ }^{146}$ This tribune, along the length of the stoa, would have been less suited to mutual interaction a theater 'in the round', but it was surely designed around a common focal point, where everyone could equally observe in the ritual event. In this sense, it created a centripetal concentric space, where a sizable gathering could convene and simultaneously share in the ritual performances, while monitoring each other's reactions at least to a degree. ${ }^{147}$

Except for the sacred road, the concentric space of the sanctuary was largely cut off from the outer world, becoming a separate and distinct zone where time and space took on a very different meaning. Unlike Labraunda, where visual linear space was put to use by emphasizing or even framing sightlines, the views to the outside world at Lagina would mostly have been obscured by the stoa complex, with two important exceptions - the peaks of the Akdağ, rising above modern Turgut and probably ancient Koranza, and the Aladağ, which separated Lagina from Stratonikeia. These mountains may be the key to the unusual orientation of the sanctuary. The temple and complex both follow an unusual southeast orientation (Figure 5.8). Since the conditions of the gentle slope make almost no demands on the layout of the architecture, an explanation must be sought elsewhere. Parallels with other temples of Hekate are lacking, but it is interesting to observe that the propylon, at a near 9o-degree angle from the temple axis, frames the Akdağ (Figure 5.18), while the temple axis aligns with the Aladağ peak (Figure 5.19); I suggest that these two mountains, watching over the sacred way between Lagina and Stratonikeia (Figure 5.20), were instrumental in determining the orientation of the complex (Figure 5.8 and 5.20). ${ }^{148}$ If so, this not only underscored the connection of the sanctuary with the two features visible above the walls of the stoa, but also referenced their role as guardians over the passage between the polis and the shrine. While uncommon, this would befit a goddess of the roads. It would also show how visual linear space was employed to connect the sanctuary to the same visual region as Stratonikeia, which shared the view of these mountains, albeit from the other side.

\footnotetext{
146 Van Bremen (2010), 493-495.

147 On 'inward-facing' circles as the prime means of generating common knowledge, see Chwe (2001), 30-33, further discussed in Chapter 2.

148 The orientation may, however, also be related to astronomical phenomena, such as a lunar cycle; Hekate is typically crowned by a lunar crescent. Ahmet Tirpan discusses the internal visuality from the Augustan propylon, which is higher than the rest of the shrine and offers a good overview, Tirpan (2008), 449-451.
} 


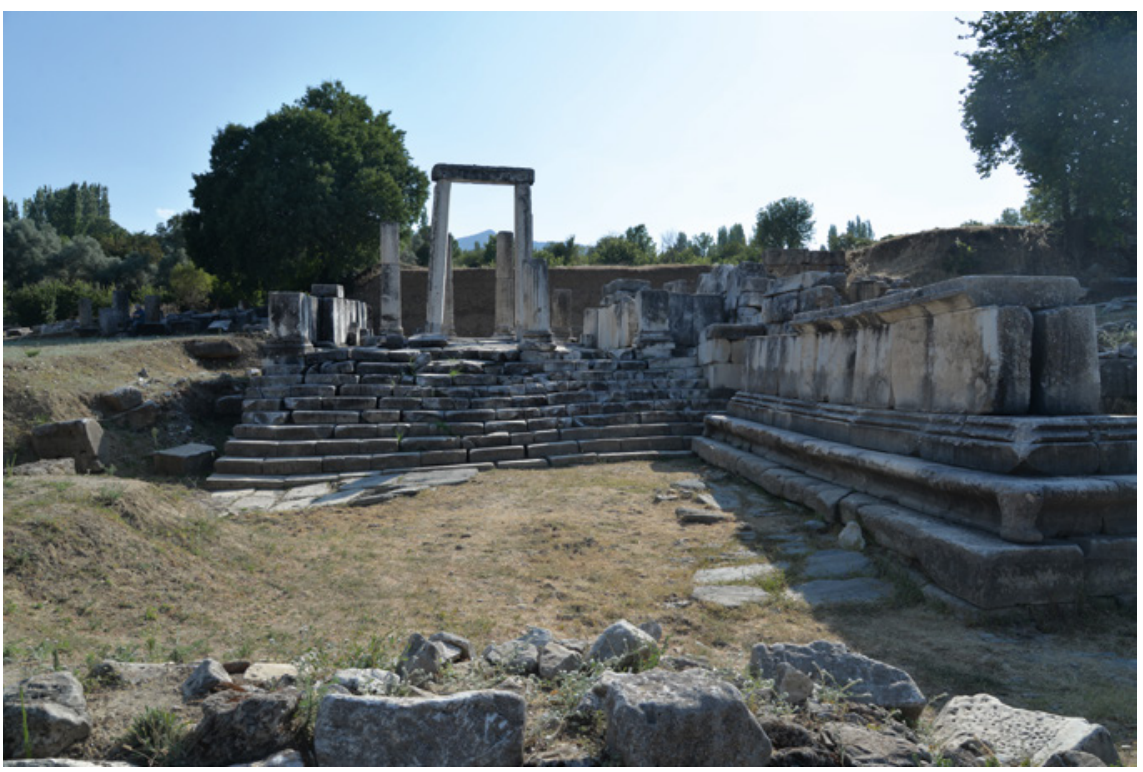

FIGURE 5.18 Lagina. View of the propylon seen from the altar; the Akdağ peak is visible through the doorframe; to the right the monument base for Menekles and Epainetos

PHOTO AUTHOR 2019

Hekate was also the goddess of the gateways, and this may have been one of the reasons why her propylon had such an unusual shape. It vividly marked the entrance to the sanctuary from the sacred road, underscoring the crucial function of the gateway as hinge between sacred and natural or profane areas. It also may have echoed the role of the goddess as mistress of the key, since it would have been the starting point for the festival of the kleidos agoge, where the sacred key was brought from Lagina to Stratonikeia, discussed below. At Stratonikeia it seems that in the imperial period a statue of Hekate was erected by the demos and boule of Stratonikeia next to the bronze doors of the city gates, no doubt on the heavily monumentalized north side of town, where the key would have been received. ${ }^{149}$ The gateways of the sanctuary and the polis thus mirrored each other in a sense, connected by the sacred road, discussed in the next section.

149 Robert (1940), 237-238, in her commentary on I.Stratonikeia 515 in context with I.Stratonikeia 523 and 658 which mention the bronze doors. The Northern City Gate at Stratonikeia, with its monumental fountain, is dated to the second century AD, Mert (2008). 


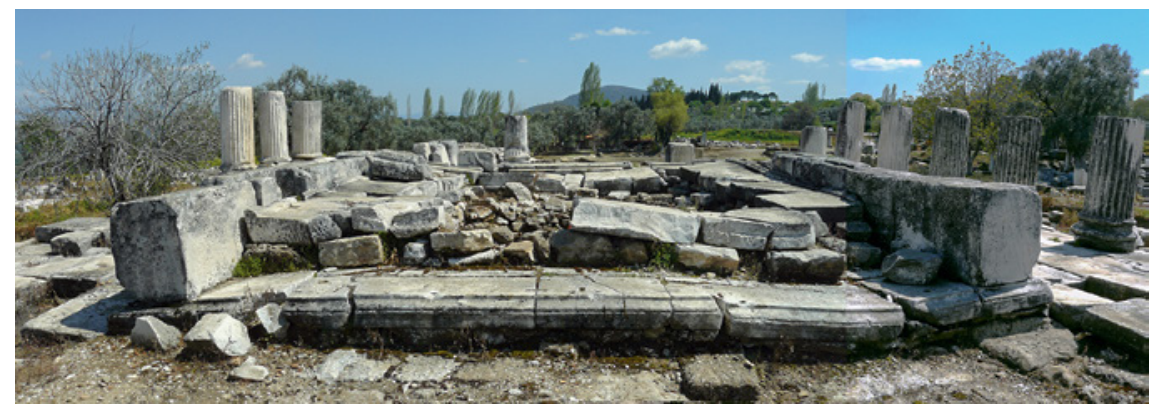

FIGURE 5.19 Lagina. Temple of Hekate looking southeast, with Aladağ peak in the distance PHOTO AUTHOR 2009

\subsubsection{Sacred Road}

Processions became more and more an integral component of festivals in the Hellenistic period, serving to articulate the community while creating a shared focus, emphasized by the sacred target at the end of this kinetic linear space. ${ }^{150}$ The sacred road and the processions that it carried therefore became a critical part of Hekate's festivals from the beginning of the relationship with Stratonikeia. Processions involving country sanctuaries normally move outward from the urban center to the rural sanctuary, where the festivities took place. Yet the festival of Hekate that is known the best is that of the kleidos pompe or kleidos agoge, in which Hekate's sacred key was brought to Stratonikeia in a formal procession, carried by the kleidophoros, a girl or maiden of urban standing. ${ }^{151}$ This was part of the festival of the Hekatesia-Romaia, and its social aspects are discussed in more detail below. The direction of Hekate's processions were thus inverted, and became centripetal rather than centrifugal, as they drew the community out from the countryside and into the town center. ${ }^{152}$ The description of the sacred road will follow the same direction as this route from Lagina to Stratonikeia.

Although strip-mining has eradicated much of the ancient road, enough is left or was already known to reconstruct its path (Figure 5.20); in some places the paved surface may still be seen as the large colorful smooth stones, lined with smaller stones at the edges (Figure 5.21). Several sections of it have been

\footnotetext{
$15^{\circ}$ Discussed in Chapter 2; see also Chaniotis (1995), 158-16o and (2013); Graf (1996); Chankowski (2005).

$15^{1}$ These festivals are discussed below in connection with the Hekatesia; see also Nilsson (1995 [1906]), 400-401. For a reconstruction of the processional experience within the sanctuary in the imperial period, Herring (2020).

$15^{2}$ Graf (1996), 57-59. It is likely that the processions went both ways, yet the emphasis of the kleidos agoge was certainly on the town center.
} 


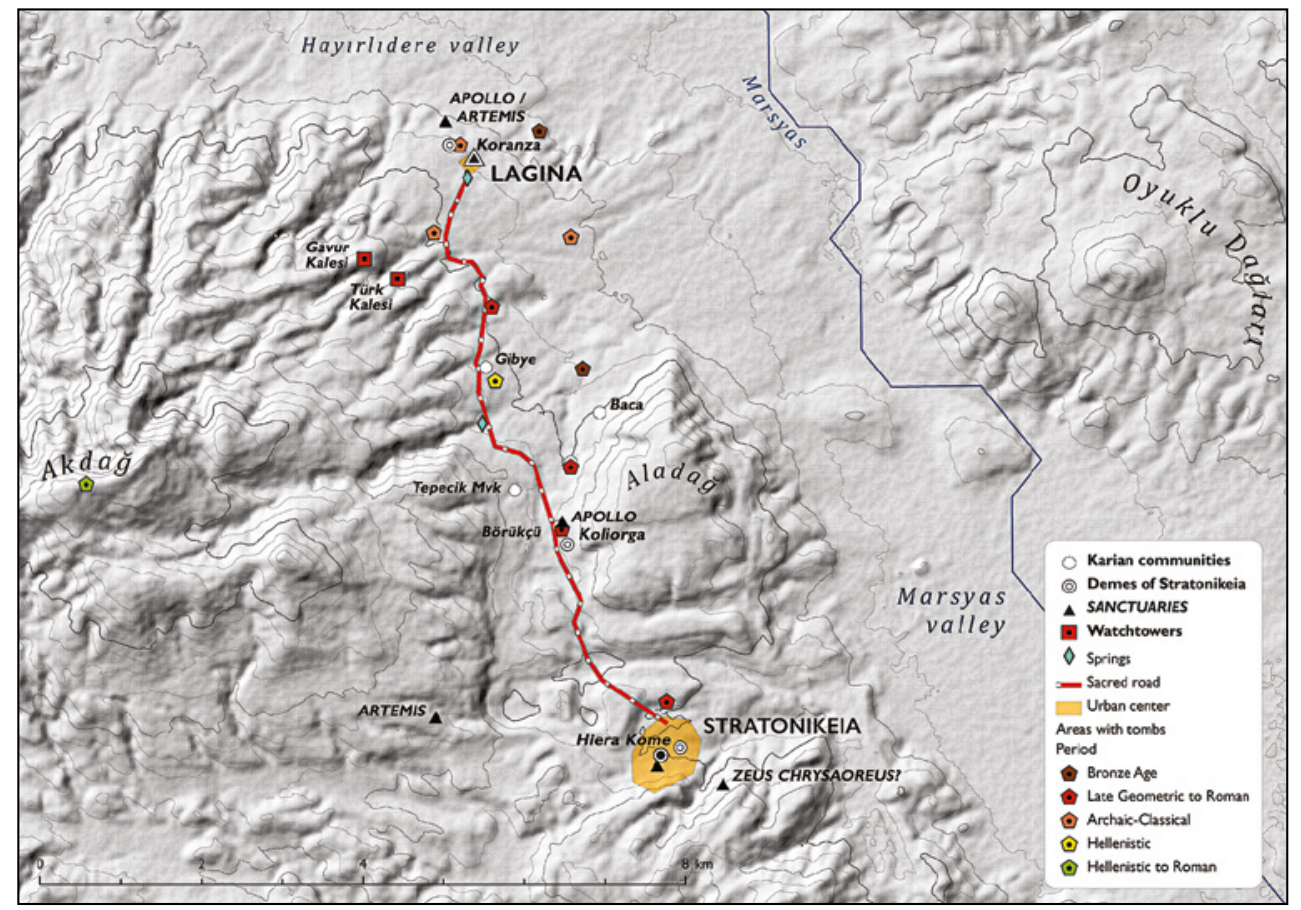

FIGURE 5.20 Map of the sacred road between Stratonikeia and Lagina. Trajectory after Söğüt (2012), Map 1

found between Stratonikeia and Lagina, showing that it largely corresponds with the road used until recently to connect Turgut and Eskihisar. ${ }^{153}$ Thick sediment has covered much of the road near the propylon of the sanctuary of Hekate at Lagina, but the processional route may still generally be traced. The kleidos pompe would certainly have first passed the large round water reservoir, roughly 200 meters to the south (Figure 5.22). This spring-fed reservoir, roughly 10 meters across, stems from the Late Hellenistic or early imperial period, and is interpreted as a sacred pool. ${ }^{154}$ Purification rituals may well have taken place here and the several inscriptions and monumental size certainly point to its public function. ${ }^{155}$

153 On the sacred road, its pavement and its course, see Tirpan and Söğüt (2005a), 52-54 and 71; Söğüt (2012), 555 and Figs. 1 and 9, and Harita 1 for a map of the course of the sacred road; Hild (2014), 45-46, also on the signs of graffiti left by pilgrims at the church later built at Lagina.

154 The pool was discovered during cleaning activities in 1994, Tirpan (1995), 214-215.

155 The inscriptions are published in I.Stratonikeia 1401 and 1402 (= EA 25 (1995), 83-86 nos. 1 and 2). I.Stratonikeia 1401 is restored as a dedication to Zeus Panamaros, based on the 


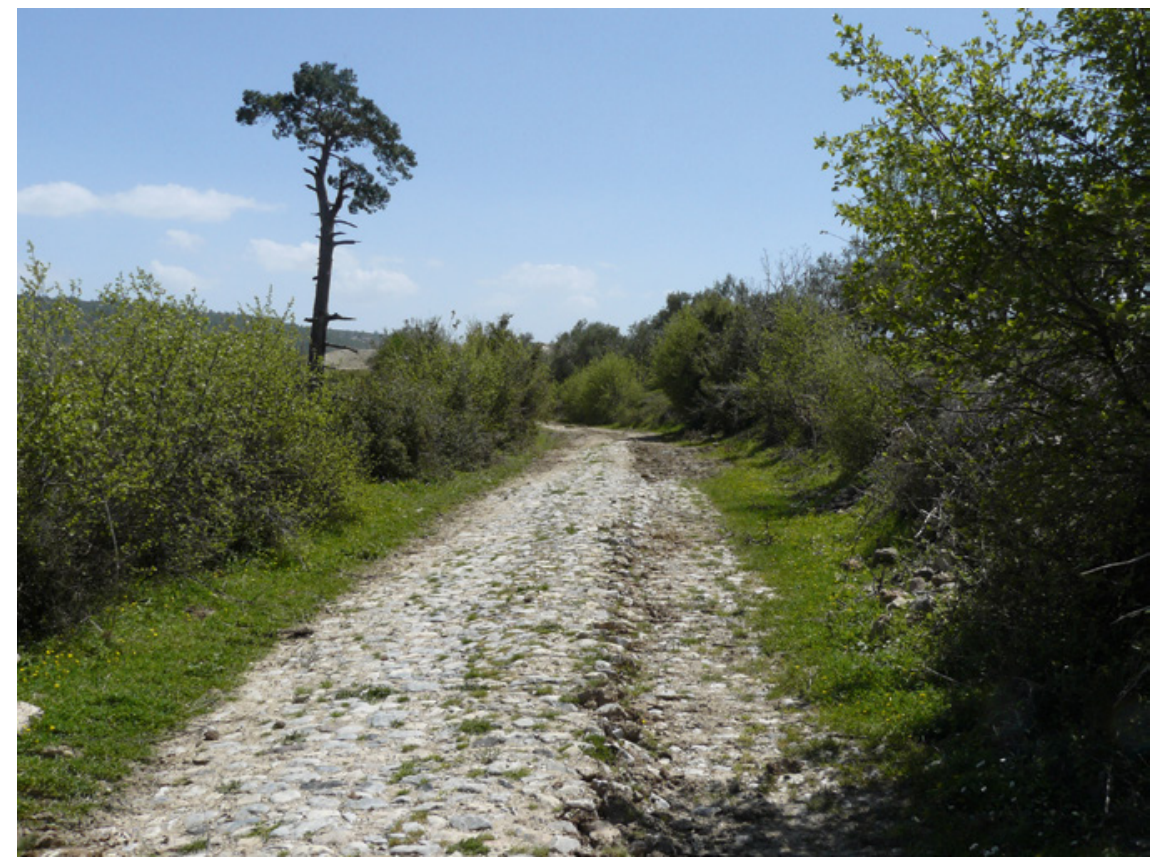

FIGURE 5.21 Sacred road to Lagina, south of Yeşilbağilar Pното AUTHOR 2009

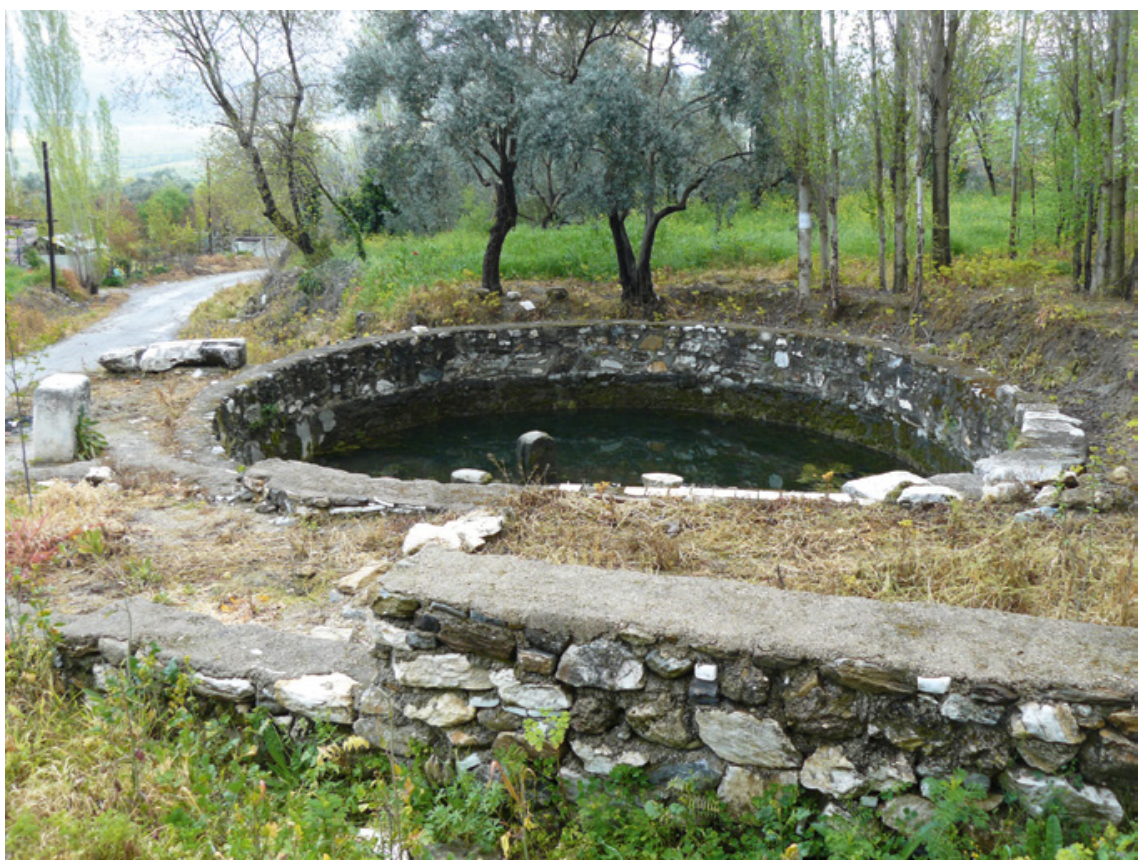

FIGURE 5.22 Lagina. 'Sacred pool' or spring-fed reservoir near the sacred road PHOTO AUTHOR 2009 
The procession would then continue southwest, roughly along the ArchaicClassical tombs of Emirler; to the southwest were two watchtowers, from the Hellenistic and later Roman period, controlling both the northern part of the territory as well as this road and the traffic it carried. ${ }^{156}$ Further to the south, are some Late Geometric graves at Bozukbağ, with more graves, this time Hellenistic, near Yeşilbağcllar (Gibye). South of Yeşilbağcllar is an edified natural spring with material dating from the Archaic period, indicating the use of this road long before the foundation of Stratonikeia. ${ }^{157}$ This spring marks a gentle bend in the road to the southeast, passing Beybağı, occupied from the Late Geometric to Roman times with a peak in the Classical period; in the early Roman period the road appears to have been diverted around a field. ${ }^{158}$ Roughly a half kilometer to the south, along a wadi at Börükçü, is another major settlement which has been identified as Koliorga, a deme which was once a polis in its own right; workshops and tombs line the road with a shrine ('megaron') to Apollo nearby. ${ }^{159}$ This settlement seems to have diminished some after the second century $\mathrm{BC}$, although there are a few tombs from the later Hellenistic and Roman periods. ${ }^{160}$ From here the road passed further south through the valley between the Akdağ and the Aladağ peaks north of Stratonikeia and continued, tomb-lined, to the north gate of town (Figure 5.23). This would surely have been a momentous leg of the journey since Hekate is the goddess who watches not only over the roads and the city gates, but also the transition to the underworld. ${ }^{161}$ There were many reasons for the polis to erect a statue of the goddess at the north gate with its adjacent necropolis; her key may have opened other doors besides the city gates, such as those to life and death.

masculine superlatives typically associated with him. Van Bremen 2003 however, argues that the office of priesthood at Panamara was not for life, which this inscription mentions.

${ }_{15} 6$ Türk Kalesi is from the Hellenistic period, Gavur Kalesi is late Roman, see Tirpan and Söğüt (2005a), 6o.

157 Tirpan and Söğüt (2006), 606.

$15^{8}$ Tirpan and Söğüt (2007b), 398.

159 Aydaş (2006), on the identification of Börükçü as Koliorga. The settlement at Börükçü, between Stratonikeia and Lagina, may have undergone a decline in the Hellenistic period, where over 100 graves were excavated, only a few of which were from the Hellenistic and Roman periods - most were Archaic-Classical: see Tirpan and Söğüt (2004), (2005b), (2006), (2007b), and Söğüt (2012).

16o On the period of activity at Börükçü: Trrpan and Söğüt (2004), 38o and (2006), 6o5-6o6.

161 Nilsson (1995 [1906]), 400-401; Johnston (1999), 206, although she does not address the role of Stratonikeia in Hekate's cult at Lagina. 


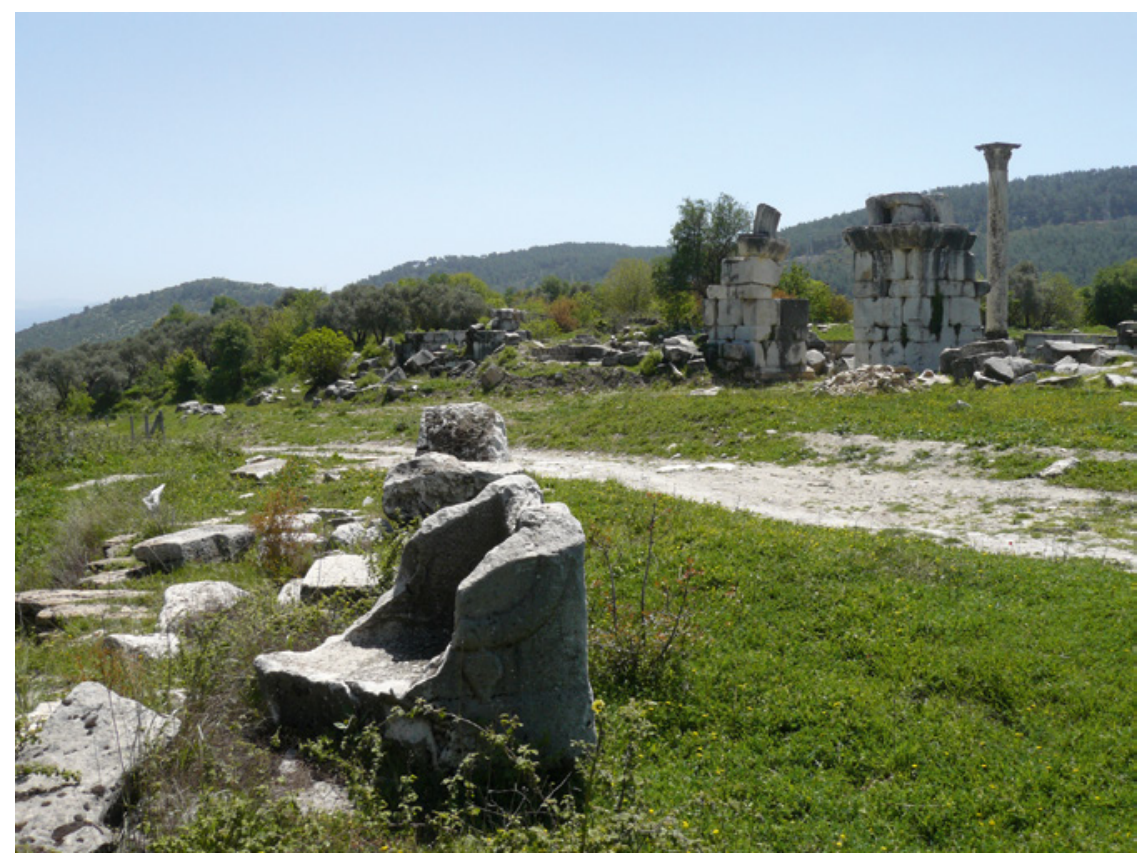

FIGURE 5.23 The North Gate of Stratonikeia, seen from the northwest; the archway is from the later second century AD. Part of the sacred road is visible to the left, next to the sarcophagus PHOTO AUTHOR 2008

Keeping the goddess of Lagina here, close to town, via her statue surely guaranteed her continued vigilance over the living and the dead. ${ }^{162}$

The sacred way was already an important access route between Koranza and the other communities in the area long before its role as a processional route to Lagina. It seems that with the rise of Stratonikeia, settlement activity along the road dwindled. ${ }^{163}$ Although this is a tentative conclusion, it may well correlate with the absorption of the once independent communities into the new polis, discussed above, and the general lure of the urban center with its attractions and enterprises. The processional route however, continued to draw the citizen population across this road, and the passage along the various settlements, local workshops and especially the tombs, must still have formed a kinetic axis for the community, connecting its past with its present. Besides

162 Stratonikeia apparently erected a statue for Hekate at the gates of town in the Roman period - the actual statue is unknown; see Robert (1940), discussed above.

163 Based on the quantities and chronologies of the material from Börükçü, Trrpan and Söğüt (2004) and (2006). 
the pure necessity of transporting Hekate's key to town, the procession was possibly a kind of re-enactment of the formation of the polis, beginning in the 'ancient' town of Koranza and ending in 'modern' Stratonikeia, with some of the older communities, especially the settlement at Börükçü, but also the individual tombs of ancestors, in between. ${ }^{164}$ Rescue archaeology has in any event clearly shown that between the two poles was a vibrant 'spatial continuum' that extended across the different communities, their sanctuaries, tombs, but also their farms and fields (Figure 5.19). ${ }^{165}$

In sum, Lagina was obviously a well-known landmark, as Strabo's guide of Karian distances indicates. ${ }^{166}$ Location was important, but the key to the sanctuary was on the inside. The blank walls of the stoas largely closed off the shrine from the outer world, while the unusual propylon served as a transitional hinge, guiding the visitor from the profane world down into the sacred world of Hekate, but also the urban world of Stratonikeia. Within, nearly a hectare of land was circumscribed by stoas in the Doric order, providing an urban space with the monumental altar and innovative Corinthian temple at its center. The series of friezes on the architrave would have invited circular movement around the temple in order to appreciate the goddess' role in helping at the birth of Zeus, suddenly appearing in the gigantomachy, and presiding over an encounter between Amazons and Greeks. Although Hekate is absent from the paradisiacal relief of Karian gods, city personifications, and nature allegories, this was the section opposite the theatron and was probably seen the most. This seating arrangement along the southwest stoa indicates the theatrical setting of the complex, a concentric space with the temple and altar as focus. ${ }^{167}$ The inner world of Hekate was further connected to the outer landscape through sightlines from the temple to the Aladağ, and the propylon to the Akdağ, the two mountains that framed the sacred road to Stratonikeia. The environment was thus woven into ritual through visual and kinetic linear space, as worshipers traversed the distance from the city to the sanctuary and back again. The

164 Similar to Laumonier (1958), 234-235: "Les cultes de Lagina et de Panamara durent être dès ce moment rattachés à ville par des fêtes annuelles, comportant avant tout une procession qui perpétuait le souvenir de la première entrée des dieux dans la nouvelle ville et leur retour dans les sanctuaires de la campagne et la montagne." Laumonier, however, believes that Lagina and Panamara were both connected to Stratonikeia from the start in a centralized act of Hellenization, ingesting, as it were, the local cults; the idea of a gradual incorporation of the surrounding communities was developed only later by Şahin (1976), Debord (1994), and van Bremen (200o), discussed above at the beginning of this section. See also below, Chapters 5 and 6.

165 On the 'spatial continuum' see Polinskaya (2006), discussed in Chapter 2.

166 Strabo 14.2.29, quoted above.

167 On cultic theaters and ritual drama, Nielsen (2002). 
processions from Lagina, near the northern border of Stratonikeian territory, down the ancient road and into town must have felt like a re-enactment of the development of Stratonikeia, as the older surrounding communities through which they passed had been drawn into the orbit of the polis. In any event it would have expanded the visual region of polis to include that of the sanctuary. The urban setting at the country shrine and the communal processions both fixed the public focus on Stratonikeia itself; Hekate's ritual space was certainly a factor in the 'territorial shaping' of the rising polis. ${ }^{168}$

\subsection{Ritual Performance at Lagina}

Ritual performances inherently provide a shared communal focus and festivals were thus a ready means of creating a bond between sanctuary and polis. Processions were literally the vehicle of festivals, connecting the urban center and the distant sanctuary with the intervening landscape while socially articulating the community en route. As mentioned above, the procession of the key, or kleidos pompe, took place within the context of the annual festival, the kleidos agoge. This festival was one of the ones which served to bind the sanctuary to the city. This section discusses how Hekate's festivals served to set the focus of the community, both local but also international, on Stratonikeia, and how the ritual actions of banqueting and competition reinforced this.

\subsubsection{Festivals}

The investment in the sanctuary in the second century вС proves that Lagina was a monumental cult place for Stratonikeia; large quantities of Hellenistic ceramics were recovered at the site, including loomweights but also unguentaria as at Labraunda. Interpretations of the ritual use of the shrine will no doubt require revision once the ceramics are published. ${ }^{169}$

As it now stands, inscriptions from the first century and later, especially in the Roman period, are our most vocal source of information on the details of Hekate's rituals and festivals. By this period there were several different festivals for the goddess, occurring both in the sanctuary but also in town. Laumonier identifies, for example, the Triakades as a festival held on the 3 oth

\footnotetext{
168 See Paasi (2009) on 'territorial shaping' as the initial phase in defining the identity of a region, discussed above in Chapter 2.

169 Boysal (1993) mentions the large quantity of Hellenistic material found at Lagina, probably from the temple area. On the loomweights, Tırpan and Söğüt (2007a) and (2008). The unguentaria are mentioned in Tirpan (1997) (found between the propylon and the stoa); Tirpan and Söğüt (2000) (several found below the temple floor); also Tirpan and Söğüt (2007a). There was also a settlement at Lagina, discussed below, so these could have had a domestic rather than ritual origin.
} 
of each month, coinciding with the lunar cycle, and the Genethlia, connected with the day of birth of the goddess; during this festival priests would distribute gifts of money and oil among the population, very similar to the practices at Panamara during the festivals for Zeus and Hera. ${ }^{170}$ In this way the cult of Hekate must have played an important role in the personal economic lives of the Stratonikeians, at least by the Roman period. The intrinsic relationship between the goddess and the urban population, however, was established in the Hellenistic period, as discussed above. While major urban festivals were obviously the reason behind the grand architectural program of the second century BC, two important festivals are known to have been developed in the Hellenistic period: the kleidos agoge and the Hekatesia. Each of these bound the remote sanctuary to the city, but in very different ways.

The kleidos agoge was the main festival at Lagina, often referred to as the 'general gathering' (panegyris), the 'sacred month' (hieromenia), or more commonly just the 'festival' (heorte) or 'festival days of the goddess'.171 It lasted for several days and included feasting and perhaps games, but the climactic event was the kleidos pompe, the procession of Hekate's key as it was brought from Lagina to Stratonikeia. ${ }^{172}$ As mentioned above, the exact nature of this key and what it unlocked is uncertain, possibly to the key to the temple, the gates of the city, the key to life and death, a symbol of priestly authority or probably a combination of overlapping meanings. ${ }^{173}$ The earliest mention of the key is in an elegiac text set up in the second or first century BC by a

170 Laumonier (1958), 393-397 the gifts are listed in the accomplishments of priests of the sanctuary as their term came to an end (over 100 of such inscriptions were found, roughly I.Stratonikeia $623-706,714-739,1438$ ); the gifts of money, but also oil, were also typical of the cult of Zeus Panamaros; this aspect is discussed in more detail below, under Administration and Priesthoods, and in Chapter 6 on Panamara.

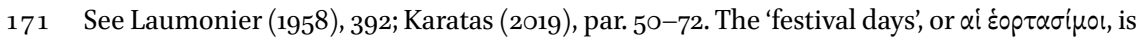
the most frequent, appearing in I.Stratonikeia 530 (lines 7-8), 668 (line 4), 682 (lines 7-8), 685 (line 8), 705 (lines 8-9), and 735 (line 5). I.Stratonikeia 663, lines 9-10 speak of 'the

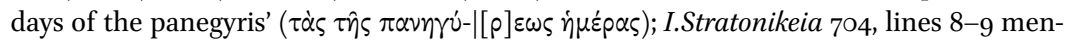
tions the 'the days of the sacred month (and) the the key-bringing of the goddess' ( $\tau \dot{\alpha} \varsigma$

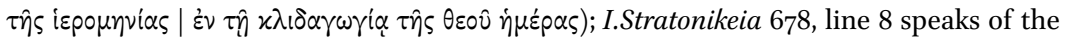

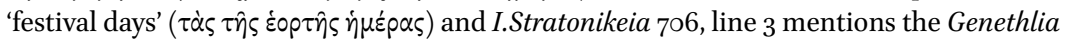

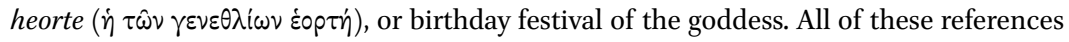
are from the imperial period.

172 The kleidos pompe is mentioned for example in I.Stratonikeia 1048 II.2, p. 34 (fragment), and takes place 'in town' ( $\dot{\varepsilon} \nu \tau \hat{\eta} \pi \dot{\lambda} \lambda \varepsilon \iota)$ as in I.Stratonikeia 701 , line 8; it is sometimes called

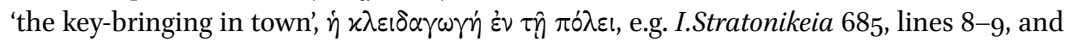
as $\dot{\eta} \tau \hat{\eta} \varsigma x \lambda \varepsilon เ \delta o ́ \varsigma ~ \alpha \gamma \gamma \omega \gamma$ in I.Stratonikeia 735, lines 3-4.

173 See above, also Nilsson (1995 [1906]), 400-401; Laumonier (1958), 398; Kraus (1960), 48-50; Johnston (1990), 41-42; Karatas (2019). 
priestly couple who made their daughter 'Klodiane, a keybearer, dear child, carrying the key in her tender hands' ${ }^{174}$ Klodiane may have been one of the first in a long line of kleidophoroi, girls or maidens who carried Hekate's sacred key during the procession, presumably along the entire eight kilometers from Lagina to Stratonikeia. ${ }^{175}$ The position of kleidophoros was usually fulfilled by the daughter of the priest or priestly couple who served Hekate in that year; she could be accompanied by her brother, the parapompos or kosmophoros. ${ }^{176}$ Being the kleidophoros brought not only honors but also prestige, and it seems that one retained the title for life. This is the case with Triphaina, who later in life, as priestess at Panamara, was referred to as 'daughter of the city and Hekate's kleidophoros.' ${ }^{177}$ In bringing the populace out to the sanctuary and back again, these processions were thus an affirmation of Stratonikeian society, while in their celebration of the elite, they were also an affirmation of its social stratification. ${ }^{178}$

Although there presumably was a corresponding procession out towards the sanctuary, it is especially the movement into town that is interesting; the community was not only assembled at the sanctuary, but was also collectively drawn in across the countryside along the sacred road towards the urban center. ${ }^{179}$ As mentioned above, this may have been a re-enactment of the unification of the religious and administrative centers with the surrounding countryside (also the economic base), creating at the same time a tight

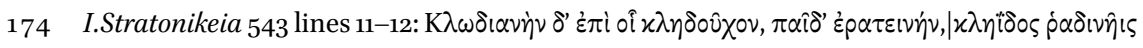

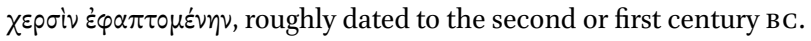

175 I.Stratonikeia $538-543,676,683,690,701,707-713$ either mention the role of kleidophoros, or honor the girl or woman who had assumed that role; these inscriptions continue into the second or third centuries AD.

176 At least on two occasions, I.Stratonikeia 683 and 69o, both from the imperial period.

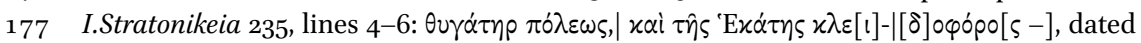
to the first half of the second century AD. Other references to adult women, often priestesses, who had been Hekate's kleidophoros include I.Stratonikeia 17, 256, 326, 327, 1028, and 1048.

178 E.g. Chaniotis (1995), 16o "die Prozession ist das Spiegelbild der polis;" also with political overtones, Chaniotis (2013). Also Chankowski (2005) on the emphasis on harmony and order, and Viviers (2010) on processions, elite display and social hierarchy.

179 Laumonier (1958), 398. On the importance of the direction of the procession, see esp. Graf (1996), 57-59, who discusses 'centripetal' processions, but mostly within the perimeters of the urban center; he juxtaposes this with 'centrifugal' processions, which bring the urban population to out to the rural and peripheral cults. While his discussion is underpinned with structuralist ideas on oppositions such as urban-rural and civilized-wild which simply do not apply in the context of Stratonikeia, given its history and territorial make-up, yet the observation of the need to draw the remote cult of a major deity into town is very useful in this context; see Chapter 2. 
and harmonious relationship in the polis with its territory. ${ }^{180}$ The centripetal direction in this case is crucial, since bringing the cult into town was a way of validating Stratonikeia's role in the territory, while physically ensuring the young polis as the main focus of the entire community.

The kleidos agoge may have been part of the Hekatesia that Strabo apparently refers to as drawing 'great festal assemblies every year.' ${ }^{181}$ Yet an even greater festival would be the Hekatesia-Romaia. This was celebrated after the Mithridatic wars of the $8 \mathrm{os} \mathrm{BC}$, when Stratonikeia received the recognition of asylia (inviolability) by Sulla and the Senate of Rome, as publicly declared in the Senatus consultum of 81 BC posted on the temple walls at Lagina. ${ }^{182}$ Stratonikeia responded by establishing a joint festival for Romē Thea Euergetes (Beneficent Goddess) and Hekate Soteira Epiphaneia (Manifest Savior). ${ }^{183}$ Combining the worship of Hekate, who gave the people of Stratonikeia hope during the hardships they endured under Mithridates VI, with the personification of Rome who brought them deliverance, must have seemed like a logical and natural following step to the Stratonikeians in their relationship with the superpower. ${ }^{184}$ At the same time it was the religious expression of a political reality.

The celebration of the union of these goddesses was not just for the people of Stratonikeia; a penteteria, or quadrennial festival, was to be held that included games. The first reference to this is in an inscription immediately following the Senatus consultum that calls for a list of the names of all the 'cities, kings and rulers', who acknowledge the asylia of the sanctuary and participate in the contests, to be inscribed at the sanctuary. ${ }^{185}$ At least 57 cities responded, voicing their recognition of the asylia, the festivals, and the games (Figure 5.25,

180 Laumonier (1958), 234-235 goes farther in seeing the centripetal procession of Hekate and Zeus Panamaros as "perpétuait le souvenir de la première entrée des dieux dans la nouvelle ville."

181 Strabo 14.2.25, quoted at the beginning of this chapter. Laumonier (1958), 36o, n. 1 believes the Hekatesia was distinguished from the Hekatesia-Romaia through an inscription from Kos (second part of the first century BC) in which it is simply called the 'Hekatesia in Stratonikeia', Iscr.Cos EV 203 (= Syll. ${ }^{3}$ 1066). However, this may have been a shortened reference to the festival.

182 I.Stratonikeia 5 5, dated to $81 \mathrm{BC}$.

183 I.Stratonikeia 507 , see above. A later imperial dedication to Hekate at Lagina refers to athletic victories in the 'Hekatesia and Kaisereia and Romaia', I.Stratonikeia 547, lines 4-5, van Nijf and van Dijk (2020). On the cult of Rome in Asia Minor, see esp. Mellor (1975), Errington (1987), and Chaniotis (2005).

184 Turner (1984) on the relationship between crisis, liminality, and ritual performance.

185 I.Stratonikeia 507, discussed further below under Games and Scope and Network. 


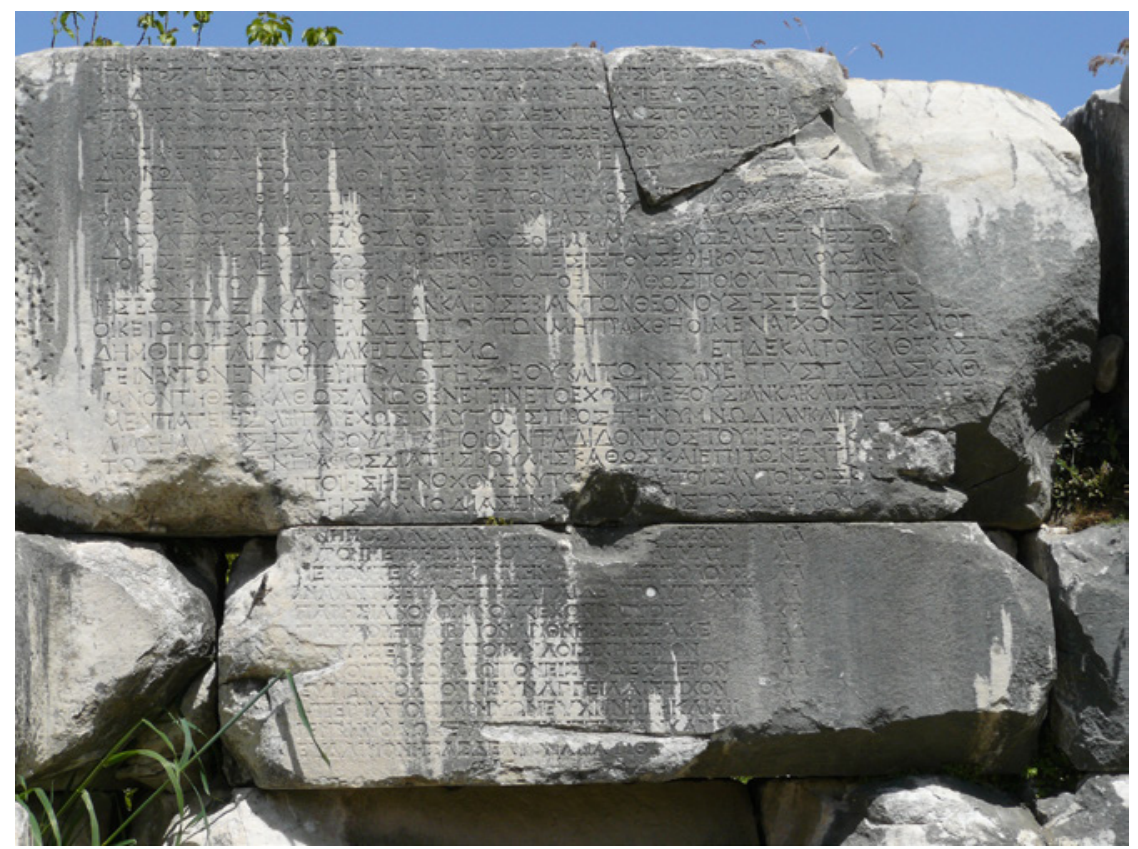

FIGURE 5.24 Section of the Hymnode inscription on the wall of the bouleuterion, I.Stratonikeia 1101. Instructions for the hymnodes during the festivals of Zeus Panamaros and Hekate, third century AD PHOTO AUTHOR 2008

below). ${ }^{186}$ These festivals thus directed the focus of the local and wider community towards Stratonikeia - the Hekatesia-Romaia was an indirect celebration of the position of the relatively young polis as a global player in the wider Greek world, while the kleidos agoge literally brought the key of the cult into the heart of the town, probably to the bouleuterion. ${ }^{187}$ A decree from the later imperial period was inscribed in this building which regulates the hymnodes at the festivals of both Hekate and Zeus (Figure 5.24). ${ }^{188}$ This inscription calls for a choir of 30 ephebes to sing hymns, which were to be written by the secretary of the boule (who happens to be the same person proposing the decree),

186 The significance of this is discussed below in the section on Urban Mediatization.

187 Laumonier (1958), 388 mentions an altar dedicated in the third century AD at the bouleuterion by M. Sempronius Clemens, with statues to Zeus Panamaros, Hekate, Artemis, Asklepios and Hygieia.

188 I.Stratonikeia 1101, proposed by Sosandros, secretary of the boule, widely dated to the later second century AD. The wider ramifications of this inscription are discussed in Chaniotis (2003), 186-189. On hymns and 'singing for the gods' in Archaic and Classical Greece, see Kowalzig (2007b). 
to both Hekate and Zeus Panamaros out of gratitude to both gods for their continuous vigilance over the city. ${ }^{189}$ Chaniotis observes the importance given to the aesthetics, both visually and audibly, of this ritual performance which was to be carried out in the center of town all day long during the festivals. ${ }^{190}$ Although this inscription is much later than the period under examination here, it is significant that it aims to follow, or even revive (or reinvent?) an old tradition, ${ }^{191}$ not only out of piety for the gods, but also to educate the young on proper ritual behavior. ${ }^{192}$ By involving the youth this inscription shows how ritual behavior was a normative process, but especially how it served to create a unifying focus for the public, including the gods.

Although it is otherwise seldom explicitly mentioned, music would have been a major component of the festivals and there are even a few indications for musical competitions during the Hekatesia-Romaia in the Hellenistic

189 Hekate's epiklesis 'Soteira' first appears in the first century BC, I.Stratonikeia 507 and 510, and is probably related to the Mithridatic wars. Some 40 years later Zeus Panamaros protected the city during the attacks of Labienus, see below in Chapter 6 .

190 Chaniotis (2003), 188, who observes the staging directions given in lines 7-10, which he summarizes as follows: "The performance was to take place every morning; thirty young boys, dressed in white, with wreaths and branches in their hands, were to come in a procession led by the paidonos and paidophylakes to the bouleuterion; there, they were to stand in front of the statues of Hekate and Zeus; a herald would accompany them, obviously in order to call for the cultic silence and to say the prayer; a kithara player would provide the musical accompaniment." Although this takes place in the imperial period, he observes how staging directions had become a general concern in Hellenistic inscriptions as well; see also Chaniotis (2013).

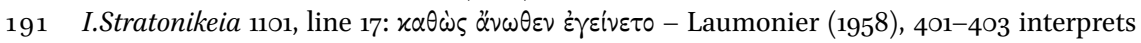
this wider section as involving a second choir of children at the sanctuary (in the peripolion) to sing the traditional hymns, while their urban counterpart sings the new hymns written by the secretary of council; Chaniotis (2003), 186, however, interprets this as renewing "an old tradition which had been neglected" out of piety. In both cases it is unclear how old this tradition would have been, although Chaniotis further points out how hymnody had become popular in the imperial period: "Particularly in the second century, the singing of hymns was regarded as a powerful and effective means of addressing, imploring, and appeasing the gods," Chaniotis (2003), 186. This should further be seen in the context of the 'invention of tradition', Hobsbawm and Ranger (1992).

192 Chaniotis (2003), 186 notes the general moralizing tone of the decree, especially in

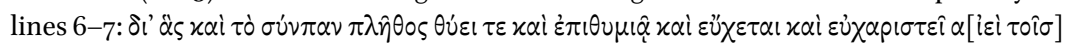

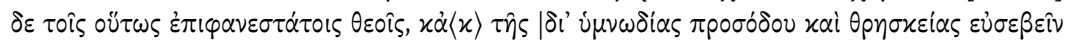

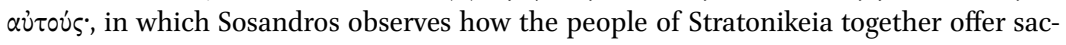
rifices, burn incense, pray, and give thanks, showing their gratitude to the powerful gods, and how they should use hymns in processions to approach the gods (prosodos), showing proper religious worship. 
period. ${ }^{193}$ In the imperial period, a few of the priests at Lagina list among their accomplishments their hiring of professional performers, akroamata, for the festivals. ${ }^{194}$ This was surely within the context of benefactions, the one priest providing even more splendid festivals than the previous, with such special effects.

The acoustic and aesthetic dimensions of the festivals of Hekate underscore how they functioned as grand spectacles in which Stratonikeia shared center stage with the goddess. Mass participation was crucial, not just to witness the ritual events which bound the goddess and the city together, but to enact the relationship by physically being part of it. Besides the processions and the singing of hymns, banqueting and games were two more avenues used by the polis to create social cohesion and thus to solidify its own position in the wider community.

\subsubsection{Banqueting}

At over a hectare in surface area, the sanctuary could obviously accommodate a sizable crowd. Although Lagina did not have the differentiation of banqueting facilities that the Hekatomnids had provided at Labraunda, the large stoa complex did offer a good deal of shelter and was no doubt used for this purpose. ${ }^{195}$

Ritual feasting was an important part of Hekate's festivals, although most of the epigraphic evidence that we have for this derives from the imperial period; by the later second and third centuries AD banqueting had become a main outlet of euergetism, on an increasing scale of expenditure. ${ }^{196}$ These were often

193 IMT SuedlTroas 576 concerns a judge, Amynamenos, son of Bresikleios, from Assos who settled an affair for the Stratonikeians and who consequently is to be honored and crowned by the Stratonikeians during the musical competitions in the celebrations for

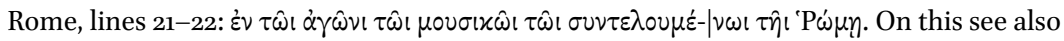
Laumonier (1958), $35^{8}$ and n. 1 ; he contests the editor's date, who places it in the second half of the second century вС, arguing that the festivities for Rome began only after Sulla's letter in $81 \mathrm{BC}$.

194 I.Stratonikeia 530 (lines 9-10) and 668 (line 5), 672 (lines 10-11), and 706 (lines 10-11); all presumably from the second century AD. See also Slater (2004) on the role of akroamata and theatrical performers in general in Stratonikeia.

195 Pottery would surely confirm this activity, and large quantities were found from the Hellenistic period, Boysal (1993). It awaits publication, however.

196 Hekate's banquets were of course part of a wider practice in the city which included the banquets of Zeus Panamaros, but also those of the sanctuaries in town. Laumonier believes that feeding the city in this way was also an act of charity, “... ainsi la majorité pauvre de la population est entretenue littéralement (car les fêtes sont numeraux), par la minorité riche," Laumonier (1958), 397. Although charity was generally not the objective of priestly euergetism (e.g. Veyne (1976), Gordon (1990), Zuiderhoek (2011)), the distributions during the festivals of Lagina and Panamara are explicitly meant for the entire 
paid for by the priests or by another civic official, usually the gymnasiarch; several of the hiereus inscriptions show the priest performing the role of hestiator, and hosting banquets at various locations, and for various groups, i.e. sometimes all of the population or a part, often at the sanctuary but also in town. ${ }^{197}$

The banquets often took place at the sanctuary (peripolion); one late inscription from the third century AD shows how a priest sponsored a buffet table for the goddess, probably during the sacrificial banquet. ${ }^{198}$ Banquets, however, were also often held in town, as were the festivities of the Panamareia, the great urban festival for Zeus Panamaros. ${ }^{199}$ Lagina was in fact one of the venues for ritual feasting during the Panamareia, showing how tightly interwoven the cults of both deities had become with the polis, at least during the imperial period. ${ }^{200}$

This incorporation of the wider landscape of the polis, both local and urban, in ritual dining was a way to tie the various surrounding communities together. The very fact that everyone joins in the same banquet at the same time, even though they may celebrate it in different localities, creates an awareness of community and a sense of unity. ${ }^{201}$ The operative dynamic at work here is virtually the opposite of that at the sanctuary of Sinuri, which clearly served as a geographical magnet for the (dispersed) community of the Pormounos, drawing them in from wherever they lived. Hekate's festival, by contrast, brought the ritual focus out to the people through the banquet, wherever it took place. As it integrated the public and communal places throughout the wider community,

population, rather than the happy few, though clearly creating a system of dependencies; further discussed in Chapter 6.

197 Laumonier (1958), 395 n. 4. Often times these were combined with the position of gymnasiarch during the festival, e.g. I.Stratonikeia 684, from the later second century AD. On a few occasions meals were specifically provided for foreigners, e.g. the Nyseans, I.Stratonikeia 664 and 697 .

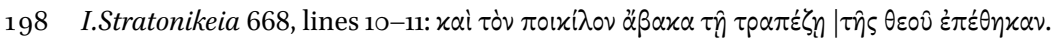

199 Laumonier observes that while priests continued to give out money during the festivals, e.g. I.Stratonikeia 701 , lines $6-8$, that increasing expenditures were made on public banquets, either for the whole population or a part of it, e.g. in I.Stratonikeia 668; Laumonier (1958), 396. On the Panamareia, see below, Chapter 6.

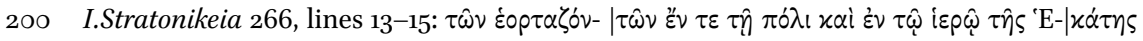

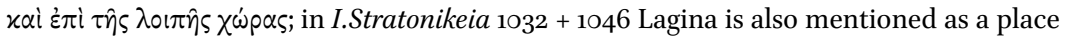
where oil was distributed, perhaps during the festival of the Panamareia as well, see below.

201 A parallel may be drawn with modern religious holidays that center on ritual dining, such as the village panegyri in modern Greece or Şeker Bayramı in Turkey, or even Thanksgiving in America; although the importance of the home as locale in these celebrations is paramount, they are nonetheless religious festivals which use food to help build the idea of community and even national and cultural identity. 
it worked very much like the centripetal procession of the key, moving from the sanctuary at the periphery of urban space into the heart of the town. These rituals helped to establish the pattern of intimacy between goddess and community, which lay at the base of the identity of the polis.

\subsubsection{Games}

Ritual competition was another avenue for building solidarity, by emphasizing group identity and mutual recognition, especially among the many poleis who participated in them and competed against each other. The games were clearly part of the reorganization of the festivals in the Hekatesia-Romaia as they were stipulated in the first decree that also called for a list to be inscribed of the cities and rulers that recognized the asylia of the sanctuary and who participated in the games. ${ }^{202}$

Most of the evidence regarding the types of games and competition stems from the imperial period, but it would seem that the focus was primarily on athletic contests. One such inscription refers to both wrestling and the pankration, a kind of mix between boxing and wrestling with a considerable degree of violence. ${ }^{203}$ Another inscription from Kos, from the later first century вС, is even more revealing of the events but especially the wider context of the games. This inscription lists the accomplishments of a successful young athlete, presumably from Kos, who was twice victorious in the 'Hekatesia in Stratonikeia', winning the pentathlon first in the 'Isthmian boys' category and later in the age category 'beardless pentathlon'.204 But he participated in several other festivals as well, earning victories at Metropolis (in the Kaisareia), Nysa (in the Theogamia), Kolophon (in the Klaria), Halikarnassos (in the Archegesia, three times), Myndos (in the Apollonieia), and in the Eleusinia and Kaisareia festivals, which were presumably on Kos itself as the locations of these festivals is not mentioned. Interestingly, Kos is not on the list of those who initially recognized the asylia of Hekate or participated in the Hekatesia-Romaia (see

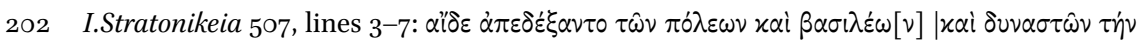

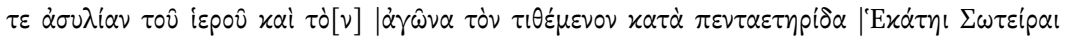

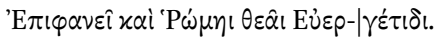

203 In I.Stratonikeia 547, from the imperial period, a certain Eubolos, son of Iason is praised

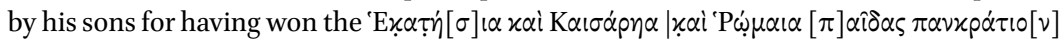

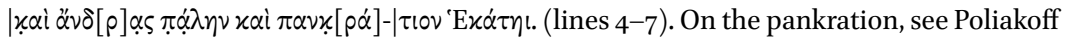
(1982), 10-11.

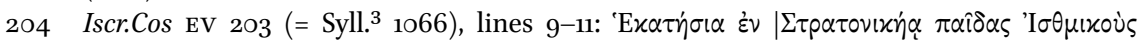

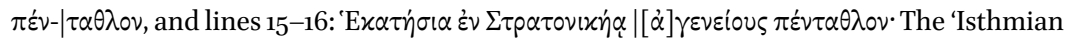
boys' and the 'beardless' pentathlons are also known from Iscr.Cos EV 218, another list of athletic victories from Kos from the first century BC. 
Figure 5.25 below), ${ }^{205}$ but this inscription shows that this list was only a starting point for the expansion of Stratonikeia's network, especially within the region of Karia and its immediate surroundings.

From this inscription we gain a very real mental map of the wider network of festivals and athletic circuits in Karia and the Aegean, of which the Hekatesia was now part. Laumonier observes that Stratonikeia in this way was putting itself on a par with a few of its extended 'neighbors and rivals' in Karia, especially Kos, Magnesia on the Maeander, and Miletos, who had panhellenic and penteteric festivals of their own. ${ }^{206}$ On a higher level, it seems that this was an excellent way for the relatively young polis, which had just suffered severe damage in the Mithridatic wars but now enjoyed the full support of Rome, expressed exactly through this cult, to put itself on the global map as an important city. ${ }^{207}$ In fact, although Lagina was the place which Strabo cites as a Karian milestone, ${ }^{208}$ it was Stratonikeia which the young Koan athlete above remembered in connection with the Hekatesia. It is of course not unlikely that some of the events actually took place in town, as with the procession of the kleidos agoge and the banquets; the point, however, is that the festival of the goddess in Lagina was now inextricably linked with the polis in the memories of the participants and the minds throughout the wider Greek world.

To summarize, little is known of Hekate's rituals prior to the involvement of Stratonikeia, but the later urban festival of the kleidos pompe, with the spectacle of the procession of the goddess' sacred key as it was brought from the sanctuary into town, surely created a strong centripetal force that drew the different local communities into the citizen body. At the same time, it reinforced the new social hierarchy as the most prominent families were literally at the head, with the kleidophoros, the young girl or maiden who led the procession, as star and who kept the prestigious title as she matured. Probably ending at an altar in the heart of town, the processions culminated in sacrifices with a

\footnotetext{
205 I.Stratonikeia 508.

206 Laumonier (1958), 359: "Stratonicée, tard venue dans la communauté hellènique, cherche à se mettre au niveau de ses voisines et rivals, Kos, Magnésie, Milet." On the increasing association of deities on civic coinage in association with games, see Meadows (2018).

207 See van Nijf (2006) and (2010) on the increasing role of athletics in shaping urban identity, also van Nijf and Williamson (2016) on the geopolitics of festivals and van Nijf and van Dijk (2020) for engagement with Rome. This the focus of the research project Connecting the Greeks. Multi-scalar festival networks in the Hellenistic world, at the University of Groningen (2019-2023), sponsored by the Netherlands Organisation for Scientific Research (NWO) and jointly directed by O.M. van Nijf and the author.

208 Strabo 14.2.29, cited above, mentions the distance from Physkos to Lagina, and then from Lagina to Alabanda.
} 
large ritual feast for the population afterwards. ${ }^{209}$ Hekate's banquets were not affixed to the shrine but incorporated the civic landscape and were another important coordinating mechanism that fostered both internal social cohesion and external political networks. While the kleidos pompe principally concerned the internal cohesion of Stratonikeia, the Hekatesia-Romaia had wider geo-political overtones as it put Stratonikeia on the map as an important Greek city, prominent before Rome. The asylia granted by Sulla after the Mithridatic wars was answered with the cultic unification of Stratonikeia's prime goddess with Thea Romē and was celebrated as a panhellenic festival, with contests. In the end, this is exactly what these festivals were about, mass participation around a common focus. This was aimed at the composite community of Stratonikeia through the processions, banquets, and distribution of goods, but also simultaneously at the wider world through games and competitions. The spectacles of Hekate provided both a show and a participatory event that increased the sensory involvement of the observers, capturing the attention of the community at large. ${ }^{210}$ The Stratonikeian festivals of Hekate were in every sense rational rituals. ${ }^{211}$

\subsection{Legal Administration and Organization of Lagina}

The physical and festive expansion of the sanctuary and cult at Lagina was the most prominent part of the reorganization of the cult, streamlined as it was to meet the needs of Stratonikeia. Yet an examination of the administration of the sanctuary, through the priesthood and local community at the sanctuary, brings us closer to the real agents of change. Most of the evidence for the administration of Lagina appears after the reorganization of the festivals, especially the Hekatesia. ${ }^{212}$ The priesthood in particular shows how tightly integrated the sanctuary was with the polis, legally, administratively, and economically. This office was a high-profile position, but there was also a local community at the sanctuary that was intertwined with the polis, and which appears to have had a vital role in the economic dealings at Lagina itself.

209 For the suggestion of the altar as final point, Laumonier (1958), 385 and 398: "En ville s'élevait sans doute un grand autel de la déesse, peut-être au Bouleutèrion ..." Such an altar has not yet been located.

210 On the mnemonic effects of sensory events, e.g. the 'flashbulb memories', and their impact on the recall of ritual, see e.g. McCauley and Lawson (2002), Chapter 2, 38-88 and McCauley and Lawson (2007) 236-238; discussed above in Chapter 2.

211 Chwe (2001), also Rappoport (1979), discussed above in Chapter 2.

212 The priesthoods of Hekate at Lagina and Zeus at Panamara are discussed in more detail in Williamson (2013b); see also Ackermann (2013). 


\subsubsection{Administration and Priesthoods}

Menophilos, son of Leon, is the earliest known priest of Hekate and is mentioned in an inscription in which he is charged by the council, presumably of Stratonikeia, with the priesthoods of Helios and Rhodes as well. ${ }^{213}$ This inscription is dated to the early second century BC when Stratonikeia was part of the Rhodian peraia, and is a premonition of the way in which Hekate's cult was later used to advertise the alliance of the polis with Rome. It shows the significance of the sanctuary already in the early second century, while it was presumably still an open-air shrine. Once the temple was erected, it acquired a secondary function as archive as several documents pertaining to the shrine and its administration were inscribed on its walls. ${ }^{214}$ Besides the Senatus consultum and the ensuing list of cities that recognized the asylia, several lists of priests were also inscribed here from the Hellenistic period. ${ }^{215}$ These appeared after the Senatus consultum was inscribed and show among others that the priesthood of Hekate was annual, as well as who was priest during the great festival, the penteteria. The priesthood was clearly a civic institution by this time. The nature of the priesthood is largely known from the many hiereus inscriptions in which the priests listed their accomplishments and deeds of benefaction performed while in office. ${ }^{216}$ Nearly all of these appear to belong to the imperial period. Together, the hiereus acts and honorific decrees make up by far the largest category of published inscriptions from Lagina (Table 5.1). Most were inscribed on the walls of the temple, wherever space allowed, apparently in no particular order. ${ }^{217}$

Thanks to the naming convention common to Stratonikeia, i.e. namepatronymic-demotic (usually abbreviated), ${ }^{218}$ one can see that priests came from all across the territory of Stratonikeia, since Koranza, Koraia, Koliorga, Lobolda, and Hiera Kome all appear among the demotics of their names. ${ }^{219}$

213 I.Stratonikeia 504. Helios was the main god of Rhodes. The naiskos dedicated by Hermias Athanagoras may have been related to this cult if the dates are correct and he was in fact a Rhodian, I.Stratonikeia 1424.

214 On this phenomenon, see Roels (2018a).

215 I.Stratonikeia 601-622, with fragmented lists in 729, 740-741. Only two of these, I.Stratonikeia 613 and 615 , are known to date from the imperial period.

216 I.Stratonikeia $623^{-739,} 1438$. These 115 inscriptions make up nearly half of the 233 inscriptions found at Lagina.

217 Inscriptions from different periods thus appear almost criss-cross between each other, as observed by Laumonier (1958), 372; see also van Bremen (2010).

218 Discussed above at the beginning of this chapter in connection with the use of the demotic in determining the geographical composition of Stratonikeia.

219 Koranza seems to appear the most often, but too many demotics are unknown or not given (probably in the second or early first century вс, before this was as commonplace) to warrant a statistical quantification or comparison. 
TABLE 5.1 Breakdown of inscriptions at Lagina according to type and period

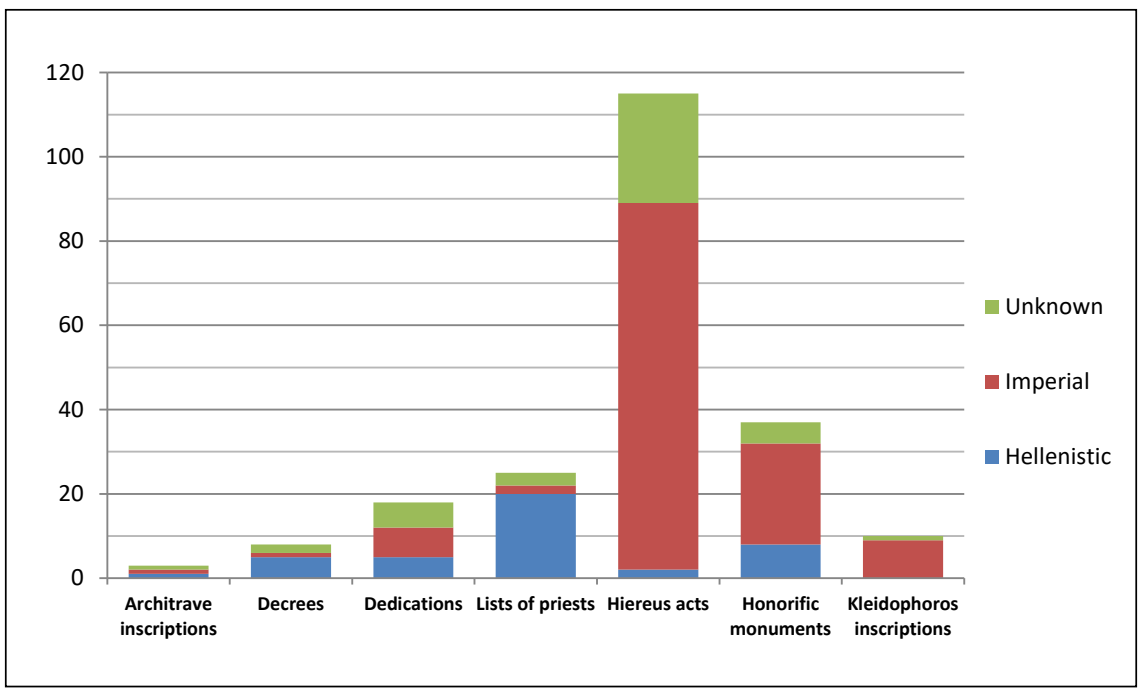

Excluded are the Senatus consultum from 81 вс (I.Stratonikeia 505 ), the list of responding cities (I.Stratonikeia 507), and a single funerary inscription of unknown date (I.Stratonikeia 551)

Also, this convention allows for the identification of many of the individuals and their relations with a considerable degree of precision. Alfred Laumonier was able to use this information to study in detail the priesthood of Hekate at Lagina, drawing a sequence for a general chronology. ${ }^{220} \mathrm{He}$ was thus able to discern 265 individual names, 200 of which were priests prior to the time of Trajan, and 75 before Augustus. Of all of these individuals, 120 names are known only from the lists, while 86 priests provided a summary of their accomplishments. ${ }^{221}$ These 86 priests cover a period of roughly the first two centuries AD.

Strictly speaking the period of these later inscriptions falls outside the scope of this present research, yet they are nonetheless included here to show how the priesthood of Hekate became one of the most high-profile public positions in Stratonikeia. The priesthood was a centralized institution and priests were drawn from the elite of the polis. Laumonier observed a shift in the information level of the documents: whereas the earliest in the Hellenistic period seem

220 Laumonier (1938b), and again in Laumonier (1958), 372-391; he performed a similar study on Panamara, Laumonier (1937) and (1938b). His work on this topic is based in part on the initial findings of Cousin and Diehl (1887), Deschamps and Cousin (1888a-c), and Hatzfeld (1920).

221 Summed up in Laumonier (1958), 372. 
to just record the end of the office of priesthood, ${ }^{222}$ over time they begin to describe with increasing detail the benefactions made by the priest, including giving money to the population, distributing oil among the population, hosting banquets, paying professional performers, but also constructing parts of the sanctuary. ${ }^{223}$ This probably reflects a shift in the expectations of the office towards a more philanthropic or crowd-pleasing role, and Laumonier sees this as the prime reason that the priesthood occurred in smaller circles, especially in the later imperial period.224 Priests were also significantly involved in financing the architecture and its maintenance. The southwest stoa, with the theatron, appears to have been dedicated in the early first century AD by the priest Aristeas, son of Aetion, while Kleinomachos, son of Drakon, gave 6000 drachmas for another wing of the stoa complex, both priests were from Koranza; in the third century AD a stoa was decorated by Epainetos, of Koliorga, and his wife Flavia. ${ }^{225}$ Lavish attention was paid on the shrine by the priestly couple M. Ulpius Alexandros Herakleitos and his wife Ulpia Ammion, both of Koliorga, who appear to have dedicated among others a propylon and stoa for the live market. ${ }^{226}$

The financial burdens that came with the office could be shouldered only by the wealthiest families of Stratonikeia, and these were few in number; recruiting priests was therefore not an easy task, and it is unclear whether this was an elective or voluntary position. ${ }^{227}$ The priesthood of Hekate was often occupied by various generations of the same family, and repeatedly by the same

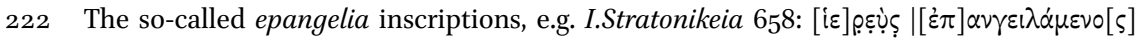

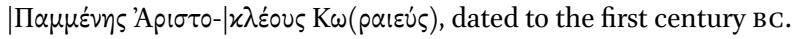

223 Laumonier (1958), 366 and 372; the banquets and performers, i.e. akroamata, are discussed above in the previous section on ritual performance.

224 Laumonier (1958), 366-368.

225 I.Stratonikeia 653 and 651 for the dedications of Aristeas and Kleinomachos, respectively; the dedications of Epainetos (of Koliorga) and his wife Flavia are mentioned in I.Stratonikeia 684 and 685. Phanias, son of (a different) Aristeas, dedicated bronze doors, I.Stratonikeia $65^{8}$, lines $5^{-10}$, second century AD. Meier (2012), 145-151, on construction activities of priests.

226 I.Stratonikeia 530 and 668 , second century AD; especially interesting is the mention of the three stoas.

227 Laumonier (1958), 368. A parallel situation may be found for council members in Egypt, where some of the elite were literally forced to assume the position while others could simply not afford it, see Tacoma (2011). This financial burden may also explain some Mylasa's problems in recruiting priests, as Dignas noticed, Dignas (2002a), 209-210; here she further observes that at Athena sanctuary in Herakleia under Latmos, "... the goddess herself appears as priestess several times during the first half of the first century AD." 
individuals on separate occasions. ${ }^{228}$ Moreover, several individuals occupied both the priesthoods of Hekate at Lagina and Zeus at Panamara, some 18 kilometers away from Lagina to the south. One notable figure, Marcus Sempronius Clemens, even held both offices simultaneously. ${ }^{229}$ By the third century AD, the appointment of the priesthood was sometimes announced as reflecting the divine will of Hekate - for those who could afford it. ${ }^{230}$

By tracing the careers of different priests, Laumonier was able to show that at least by the imperial period the priesthood of Hekate had become one of the highest civic offices in Stratonikeia: "La prêtrise d'Hékate était la plus importante dans la série des grandes prêtrises stratonicéenses; elle couronnait généralement la carrière; on exerçait d'abord à Panamara, puis à Lagina; le cas inverse se présente, mais beaucoup moins souvent, et surtout chez des prêtres qui renouvellent à Panamara." 231 The course of the priesthoods also shows how the two principal cults of Stratonikeia, that of Hekate and that of Zeus Panamaros, became more and more intertwined; Lagina, in fact, was one of the venues for distributing oil to the population during the Panamareia. ${ }^{232}$ Giving out oil and money was a regular feature of the cult at Panamara and seems to have been introduced at Lagina. Also, at Lagina it became custom to have a priestess next to the priest, as at Panamara, although Laumonier believes her role here was much more subordinate. ${ }^{233}$

228 I.Stratonikeia 310 is the priestly inscription of Marcus Sempronius Auruncius Theodotos, son of Arrianos, who set up a statue of his grandfather or great-grandfather ( $\dot{\varepsilon} \pi i \pi \alpha \pi \pi \circ \varsigma)$ (Marcus) Sempronius Claudius, who was one of the most active priests of Zeus and Hekate in the later second century AD, see below. Theodoros, son of Theophilos, was priest of Hekate five different times, with the fifth one falling in the penteteria, I.Stratonikeia 669 (broadly dated to the second century AD), see further Laumonier (1958), 367 and n. 2.

229 I.Stratonikeia 289 (second half of the second century AD) gives the epangelia of Marcus Sempronius Claudius at Panamara in the Heraia, while being priest of Hekate. He had been priest at Panamara on five separate occasions, Laumonier (1958), 367; also Nilsson (1927), 40o. On the career of Marcus Sempronius Claudius in general, see Deschamps and Cousin (1888a); Laumonier (1958), 277-28o, 367; Williamson (2013b).

230 E.g. the appointment of Tiberius Flavius Aeneas from Hierokome in I.Stratonikeia 704,

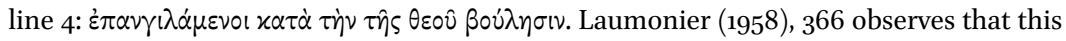
phrase is more frequently used at Panamara, where Aeneas was twice priest; his wife Ulpia Leaena, who joined him as priestess at Lagina, had also been the priestess of Artemis at Koranza, see Laumonier (1958), 385 .

231 Laumonier (1958), 367. Priesthoods at Didyma and Klaros were also occupied by members of the urban elite in the Roman period, see Busine (2013).

232 I.Stratonikeia $1032+1046$, discussed below. The Panamareia formed the longest festival of Zeus at Panamaros and is discussed in more detail in Chapter 6.

233 Laumonier (1958), 368. The role of priestess at Lagina was typically fulfilled by a female related to the priest, either as wife, mother or daughter. Unlike Panamara, where the priestess was clearly responsible for the cult of Hera, the duties at Lagina were not specified 
Young women played a highly visible role in the cult of Hekate at Lagina as the kleidophoros, the girl or maiden who carried the key from Lagina to Stratonikeia during the kleidos pompe, sometimes accompanied by her brother, the parapompos or kosmophoros. ${ }^{234}$ The kleidophoros received separate mention on the walls of the temple, and she was also the one who presided over the distributions of oil and money among the population, usually at the side of her father, the priest. ${ }^{235}$

The image of the priesthood that arises out of this is a high profile public position in which the focus was both on the priests and their families. Occupied by different members of the elite of Stratonikeia, priests no doubt served as role models, which would have been a way to promote general family values while at the same time distinguishing themselves and sustaining a social imbalance through their expenditures, gifts, and monetary distributions.

The administration of the cult was ultimately the responsibility of the priests, although other cult personnel must have been involved in maintaining such a major sanctuary. Besides the priesthood, little is actually known of how the sanctuary was run in the Hellenistic period, although an inscription on one of the antae of the temple, dated to the first century вс, mentions some kind of return after a crisis to the administration of the sanctuary as it had been before according to the traditions and earlier decrees. ${ }^{236}$ Apparently regulations or prescriptions on the organization of the sanctuary were inscribed that are no longer preserved. In the third century AD, mention is made of a neokoros, responsible for the general management of the sanctuary and in this case for overseeing the care of the sacred grove, which was to be maintained by the eunuchs, who were subordinate to the priest. ${ }^{237} \mathrm{~A}$ eunuch was also honored in

and the position seems to have been optional, perhaps even more of an accessory to the priest. The name of the priestess in some cases only appears at the end of the inscription (which is ironically often better preserved than the top part). Van Bremen (1996), 114-115, on the increasing occurrence from the first century BC on of married couples occupying a priesthood together.

234 Laumonier (1958), 368. The parapompos or kosmophoros are mentioned in I.Stratonikeia 683 and 690 , discussed above.

235 Laumonier notes how the names of the kleidophoroi usually appear before those of the priestess in the hiereus inscriptions, and were also mentioned on their own on a number of occasions, Laumonier (1958), 368.

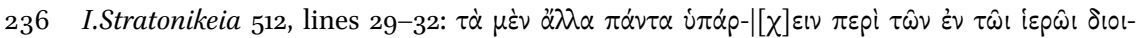

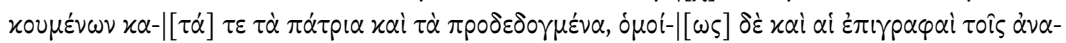
$\theta \dot{\eta} \mu \alpha \sigma \nu \dot{\varepsilon} \pi \imath[-]$. On the location, Tirpan et al. (2012), 195, also n. 57. The date is based on the turbulence of this era, but see van Bremen (2010), 499-502, for an earlier date to the second century вс.

237 I.Stratonikeia 513, line 40 mentions the role of the neokoros, while line 34 shows that the eunuchs were responsible for tending to the grove, discussed below. 
another fragment from the mid-third century. ${ }^{238}$ Much has been made of this appearance of eunuchs and has led to Burkert's one-line summary of Lagina as '... ein Tempelstaat orientalischen Typus, wo es auch 'heilige Eunuchen' gibt," which is entirely misleading. ${ }^{239}$ Their role prior to the third century is unknown, but could hardly have counterbalanced the strong urban nature of Lagina. Burkert's classification seems more concerned with the ethnically biased categorization of sanctuaries in Asia Minor, as developed by Ramsay in the nineteenth century and dismissed by Debord. ${ }^{240}$ All in all the priesthood of Hekate shows that her cult at Lagina was in every sense a polis cult for Stratonikeia.

\subsubsection{Local Community - The 'Katoikountes in the Peripolion'}

Although Lagina may not be the location of Hiera Kome, as Robert had presumed, ${ }^{241}$ the sanctuary nonetheless hosted a community in its own right. Şahin views Lagina as one of the ancient demes of Koranza, although the community at the sanctuary appears to be from a later period. Rather than being known as a deme or a koinon (the term syngeneia is not typically used in Stratonikeia as it is in Mylasa), they are simply referred to as the 'dwellers', or 'settlers' (katoikountes) of the sanctuary. ${ }^{242}$ The sanctuary is generally called the hieron, or more typically the peripolion. ${ }^{243}$

The inscriptions mentioning the katoikountes all date from the second or third century AD, and at present it is difficult to say with any precision how old this settlement may have been; as mentioned at the beginning of this case

238 I.Stratonikeia 544 is a fragment of an honorific inscription for a eunuch of the goddess, showing that this person was highly revered.

239 Burkert (1977), 266; Gimbutas (1982), 197, took this fantasy much farther, assuming that since there were eunuchs there must also have been orgiastic dances at Lagina; see also Johnston (1999), 206. Laumonier (1958), 370 points out the oriental character of eunuchs in general, and how they appear in Karia at least until the seventh century AD, even in Christian circles (p. 370 n. 3), but at Lagina their position seems to have been very low key, as at Ephesos with the cult of Kybele (p. 370 and n. 4, referring to Picard (1922), 135).

240 Ramsay (1890) and Debord (1982), discussed in Chapter 2.

241 Robert (1937), 558, opposed by Şahin (1976), 1-15 and more recently in I.Stratonikeia III, p. 1-8, which argues for the site of Stratonikeia to be Hiera Kome, probably related to the sanctuary of Zeus Chrysaoreus.

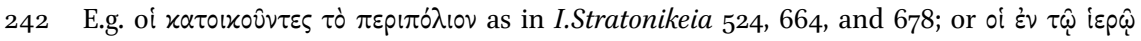

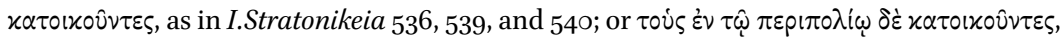
as in I.Stratonikeia 682; no. 672 contrasts those living in the city ( $\tau \dot{\eta} \nu \pi \dot{\lambda} \lambda(v)$ with those liv-

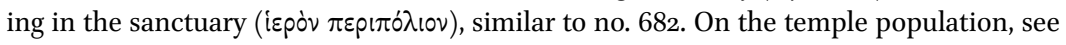
also Caldesi Valeri (1999), 226-23o.

243 The peripolion generally indicates the architectural enclosure; see above under Architecture, with references. 
study, excavations at Lagina are ongoing and have yet to be published. Some of the ceramic material awaiting publication may well be related to settlement activity, including the loomweights and unguentaria. ${ }^{244}$ Nonetheless, it is interesting to note that the consistent designation of 'en toi hieroi katoikountes', or 'en toi peripolio de katoikountes', literally refers to those within the confines of the stoa enclosure, rather than just outside the temenos area, as at Labraunda, ${ }^{245}$ or in a sacred village, as at the sanctuary of Sinuri. This community therefore probably dates from at least some time after the construction of the temple complex. Behind the rather bland designation of katoikountes was a strong local community that on at least four occasions joined the boule and demos in honoring individuals at the sanctuary, including two priests, a kleidophoros, and an agoranomos. ${ }^{246}$ The official and political nature of the honoring bodies in these decrees led Caldesi Valeri to interpret the katoikountes as the remnants of an old religious group associated with the cult. ${ }^{247}$ By the second or third century AD the organization may well have been a century or two old already. Nonetheless, the lack of a more formal designation seems odd, and may indicate that this was a changing group of people, such as cult personnel, travelers, those seeking asylum or other temporary residents.

The katoikountes probably would have included the eunuchs mentioned above, who were responsible for caring for the sacred grove (hieron alsos). ${ }^{248}$ This seems to have been somewhere within the temenos, and it is tempting to project it onto the vacant space on the plan between the propylon and

244 Also discussed above, under Festivals. For loomweights, Tirpan and Söğüt (2007a) and Tırpan and Söğüt (2008). For unguentaria: Tırpan (1997); Trrpan and Söğüt (2007a); Tirpan and Söğüt (2000).

245 Or the sanctuary of Meter Theon at Mamurt Kale, where extensive remains of probably a settlement may be found south and west of the temple complex; Conze and Schazmann (1911), 12 and personal observation.

246 I.Stratonikeia 536 honors the priestess Ammion Apphion with a statue, and I.Stratonikeia 539 honors a priestly couple and their family. I.Stratonikeia 540 honors a kleidophoros; I.Stratonikeia 524 honors an agoranomos, see below.

247 Caldesi Valeri (1999), 226-23o. The (sacred) gerousia (society of older men, usually affiliated with the gymnasium) joined the boule and demos, and the katoikountes in bestowing honors for priests on at least two occasions, e.g. I.Stratonikeia 536 and 539 .

248 I.Stratonikeia 513 concerns the protection of the grove, and the eunuchs who tend to

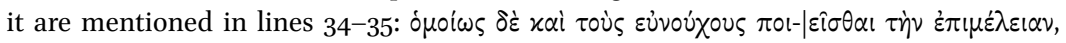
from the third century AD. Sacred woods were common, see Cazanove and Scheid (1993), and Bonnechere (2007). In this study, Labraunda possessed a sacred grove of plane trees (Hdt. 5.119) and at the sanctuary of Sinuri it was the subject of a legal trial (I.Sinuri 2 and 11, discussed in Chapter 5). 
southeast stoa (Figure 5.8). ${ }^{249}$ Laumonier suggests that the wood was a cultivated grove of trees, which could in fact have been anywhere in the sanctuary. ${ }^{250}$ The inscription that primarily concerns the protection of the sacred wood mentions the neokoros and the councillors from the katoikountes who are to be responsible for this duty. ${ }^{251}$

The sanctuary of Hekate at Lagina was clearly a lively place; even the numbers of monuments and statues indicate that it was much fuller than the plan on Figure 5.8 indicates. One of the hiereus inscriptions, albeit from the third century AD, mentions the construction of 'the three stoas for the sacred house, and the propylon with the entrance and the stoa in front of the oikia (house) that (leads to) the biotike agora (food market).'. ${ }^{252}$ This may refer to the southwest wing with the 11 steps - the context is interesting in connection with the 'food market' (biotike agora) that was just next to this.

\subsubsection{Economic Resources}

The biotike agora, live or food market, may well have been the working space of Hermias Chrysaoros of Koraia, the agoranomos who was honored by the katoikountes, together with the polis, for lowering the prices at his own expense during his term. ${ }^{253}$ It is unclear exactly which agora is meant, although the fact that Hermias worked under the priest may imply the market at Lagina. Another agoranomos, Hekaton, son of Hierogenus, of Koranza, dedicated a marble altar to Hekate at Lagina. ${ }^{254}$

249 One inscription prohibits animal herds in the grove: I.Stratonikeia 513 , lines $36-37$ : $\dot{\varepsilon} \alpha \nu$

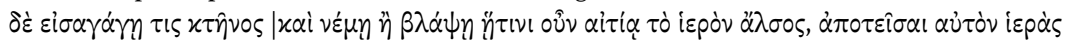
'Exátns. Herds may have been in the area for general grazing, or in preparation for sacrifices, or perhaps in connection with the food market (biotike agora) discussed in the next section.

25 Laumonier (1958), 364 .

251 I.Stratonikeia 513 , line 40.

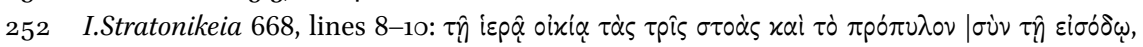

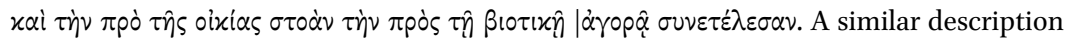
is given in I.Stratonikeia 530, lines 11-13, an honorific decree by the demos, boule and the gerousia for the same priest, Marcus Ulpius, and the same deeds which he listed in his hiereus inscription.

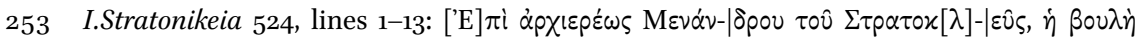

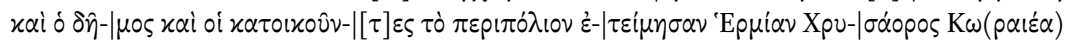

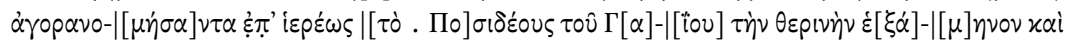

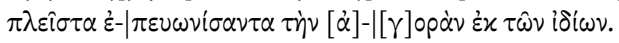

254 I.Stratonikeia 1421 (= EA 34 (2OO2), 6-7, no. 8), dated to the 'Roman period'. The altar was found near the propylon but was probably not in situ. Yet another another agoranomos, Eros, son of Menander, of Koraia, dedicated a statue of Hermes to Hekate Soteira and the demos at Lagina, I.Stratonikeia 516, the inclusion of Hekate's epiklesis Soteira indicates 
In any event, the biotike agora is described as a fixture at the sanctuary in the third century $\mathrm{AD}$, and it is tempting to consider it in connection with the convenient location of Hekate's sanctuary at the crossroads of the Marsyas valley and the Hayırlidere valley, conducive to trade. Perhaps the sanctuary acted as a kind of emporion or 'suburban' market, with easy access from different directions. $^{255}$ This was probably the case at least in the later Roman period. The herds of livestock referenced in connection with the hieron alsos, and perhaps the sacred grove itself if, as Laumonier presumes, it contained cultivated fruit trees, ${ }^{256}$ may have been connected with the produce available at the live market. The financial base of the sanctuary is otherwise unknown, but the decree posted after the Senatus consultum of 81 BC, which mandates the ensuing inscription of the list of cities that acknowledge the asylia, states that the treasurers, or tamiai, are to provide for the inscription of this list using Hekate's funds. ${ }^{257}$ This demonstrates an institutionalized approach to the sanctuary and its holdings, wherever the money actually may have come from.

In the context of the festivals of Zeus Panamaros, oil was distributed to the population at various places in the city but also at Lagina, indicating some kind of role in the economy of the district, at least for the local area. ${ }^{258}$ During the Genethlia, the festival connected with the birthday of the goddess, gifts of money and oil were also distributed by the priests among the population, very similar to the practices at Panamara during the festivals for Zeus and Hera. ${ }^{259}$ The third-century AD hiereus inscription mentioning the food market (biotike agora) also shows that gifts of oil and money were distributed to the needy

a date in at least the first century вс or later. A statue of Hermes was also dedicated to Zeus and Hera at Panamara by the priest, Menander, son of Apollodotos (no demotic preserved) and the demos in I.Stratonikeia 412, dated to the second or first century BC.

255 On festivals as venues for markets and fairs of regional and sometimes of inter-regional importance: de Ligt (1993); Chandezon (2000); Iannaccone et al. (2011); Papazarkadas (2011); García Morillo (2013); Frejman (2020).

256 I.Stratonikeia 513. Laumonier (1958), 364 suggests that the stipulated maintenance of the grove by the eunuchs suggests cultivated fruit trees.

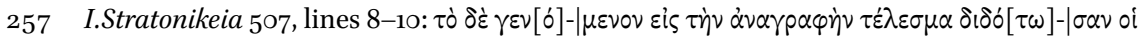

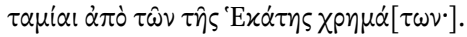

258 E.g. I.Stratonikeia 1032 with 1046.

259 Laumonier (1958), 393-397; the gifts of money, but also oil, were also typical of the cult of Zeus Panamaros, see below in Chapter 6. Typically given from the personal resources of the priest to the population, this was an ostentatious act of a personal euergetism; Dignas (2002a), 210-211, interprets such behavior as an indication of real political power, going beyond urban euergetism. Distributing oil to the entire population was a common phenomenon in imperial Asia Minor, see Zuiderhoek (2009), 89-92, who links the distributions to a general city-wide participation in the identity of the gymnasium culture. 
in the sanctuary year-round. ${ }^{260}$ One instance mentions the priest Hierokles (from Hierokome) and his wife Ada (from Panamara), who provided the grain fund (sitonia). ${ }^{261}$ These distributions indicate that the cult of Hekate, its sanctuary, and particularly its priests played a central role in the local economy, at least by the imperial period, also in sustaining a system of dependencies.

Sacred lands were a vital source of income at the sanctuaries in the chora of Mylasa, yet they are only vaguely alluded to at Lagina. ${ }^{262}$ One inscription from $39 \mathrm{BC}$ is an expression of gratitude to Hekate by the demos for restoring her sacred lands in Alossos and the phylai of Korollos, no doubt after the attacks in the area by Labienus. ${ }^{263}$ This is the closest indication we have of the economic base of Lagina in the Hellenistic period. What the financial situation was further like at the sanctuary, how the sacrifices were paid, or what role it occupied in the local economy remains to be discovered; hopefully the ongoing investigations will shed more light in this area.

In summary, the walls of the temple became a ledger for sacred archives, and one of the most prominent inscriptions was the Senatus consultum of 81 BC. This was apparently a turning point in the organization of the cult and the many lists of priests, corresponding with the years of the quadrennial festival, date from after this time. The organization of the major international festivals of Hekate and Thea Romē would have been a tremendous task and this was no doubt a highly distinguished office held by the elite of Stratonikeia, as it was later in the imperial period, when it became one of the important urban posts for euergetic display, along with the priesthood at Panamara. ${ }^{264}$ The lists of names further show that the priesthood was an annual position, and the diversity of demotics and patronyms prove that it was not restricted to any one family. By the imperial period there was also a more or less permanent population in the peripolion at the shrine called the katoikountes that appeared next to the boule and demos (and sometimes the gerousia) in honoring individuals. The eunuchs

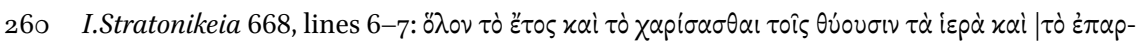

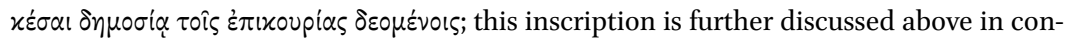
nection with the biotike agora.

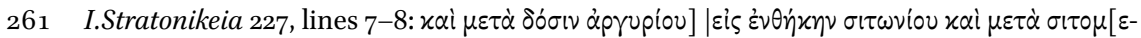
$\tau$ qi $\alpha v$. The inscription was found at Panamara, but only mentions their term as priests of the Great Goddess Hekate.

262 E.g. in I.Stratonikeia 512, lines 21-22 mention 'those who commit sacrilege in our country

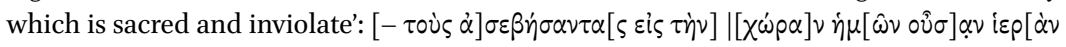

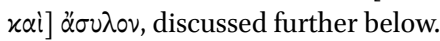

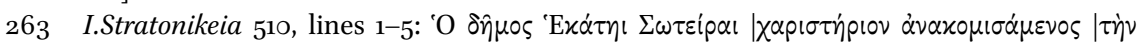

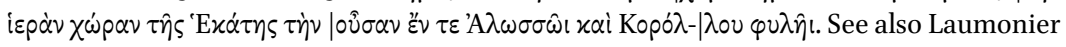
(1958), 365 and Deschamps and Cousin (1887), 238.

264 See below in Chapter 6; also Williamson $(2013 \mathrm{~b})$. 
mentioned in later inscriptions may have been part of this; one of their roles was to cultivate the sacred wood in the sanctuary - perhaps a grove or orchard that yielded produce for the market or local consumption. Regarding the economy, an important feature at Lagina known from later inscriptions is the market, or biotike agora, demonstrating the importance of the shrine in the economy of the wider region. The financial base of the sanctuary during the Hellenistic period, however, is unclear. Sacred lands are not as prominent as those in the territory of Mylasa. Evidence of any major shifts in administration is thus lacking, yet the new scale of festivals must have required additional sources of income. In later periods, both the sanctuary and the priests clearly played a central role in the economic life of the polis, through their benefactions, i.e. gifts of oil and money to the population, and the inclusive banqueting; this mirrors the cult practices at Panamara, as will be shown further below in the next case study.

\subsection{Urban Mediatization at Lagina}

Until now we have examined the impact of Stratonikeia on the sanctuary of Hekate at Lagina, with its festivals and administration, but these changes also impacted the polis in return. The cult of Hekate was used in a number of ways as an icon of the new urban identity. As the focus of the cult was shifted to the polis, the polis simultaneously fixed attention to the cult to gain recognition from a network of Greek poleis. Various kinds of communication at the sanctuary will be discussed here as they concern critical affairs pertaining to global politics and civic territory; even the way in which the goddess was renamed reflects the geo-political needs of the polis. Finally, the coinage of Stratonikeia in particular will be examined as an urban context of the cult, especially showing how the image of Hekate came to stand for the polis itself.

\subsubsection{Scope and Network}

Regarding the extent of its network, the sanctuary of Hekate at Lagina underwent at least three important periods. The first period is when it was a local shrine to Hekate in the marginal, crossroads zone of the polis of Koranza in the Late Classical and early Hellenistic period. Its circle of worshipers seems to consist primarily of the citizens of Koranza. The second phase is when the sanctuary was taken over by the rising polis of Stratonikeia, some eight kilometers to the south, and the goddess adopted as the main patron deity of the polis. This phase no doubt coincides with the absorption of Koranza as a deme into Stratonikeia. Evidence for this phase is found in an early second century inscription showing Stratonikeian involvement and even control, and the appearance of Hekate on the very first coins of Stratonikeia by the mid-second 
century BC, discussed below. In this period Hekate became a mainstream polis goddess, and her sanctuary at the crossroads of the Marsyas and Hayirlidere valleys was by now turned into a regular center of urban activity. Following the Mithridatic wars, a third phase in the expansion of the sanctuary's network began when Stratonikeia successfully petitioned Sulla and the senate of Rome for a grant of asylia (inviolability) for the sanctuary. ${ }^{265}$ Stratonikeia had greatly suffered while supporting Rome: using the sanctuary to obtain these privileges proves both its political and symbolic value for the polis - Sulla's letter was inscribed on the temple walls. Hekate gained international fame as cities from across the Greek world recognized Rome's grant of asylia. The first reference to this is in an inscription immediately following the Senatus consultum, calling for a list to be inscribed at the sanctuary of the names of all the 'cities, kings and rulers' who acknowledged the asylia of the sanctuary and participated in the contests of the penteteria. ${ }^{266}$

The resulting roll-call of 57 cities is an impressive outcome of the manpower invested by the polis in making this festival known throughout the Greek world, with clusters not only in Karia and Ionia, but also Lykia, the Dardanelles, Thrace, the Peloponnese, and even the Eastern Mediterranean (Figure 5.25). ${ }^{267}$ Though not strictly arranged, the list begins with cities in Karia, including Mylasa, ${ }^{268}$ followed by those from Asia Minor, and then expanding to include Delphi, Olympia (Elis), Athens, Argos in the west to Damascus and Seleukeia Pieria along the eastern fringes of the Greek world. Lagina was fixed as a bright central dot on the mental maps of the Greek world, as is evident from Strabo's inclusion of the sanctuary as one of the few Karian places in his description of Karian geography. The panhellenic festivals got much of the Greek world involved in celebrating the cult of Hekate, while making them acknowledge

\footnotetext{
265 Senatus consultum de Stratonicensibus of 81 вс; I.Stratonikeia 505-508.

266 I.Stratonikeia 507 , lines $3^{-7}$, cited above.

267 I.Stratonikeia 508 , though incomplete, lists the 57 cities that recognized the asylia of the sanctuary and participated in the Hekatesia-Romaia. During 1999-2002 several coins were also found at the site from Alabanda, Bargylia, Rhodes, Ephesos, and Miletos, see Tirpan and Sögüt (2007b), 394. The impact of this in terms of network is further discussed in van Nijf and Williamson (2015); van Nijf and Williamson (2016); and more on the Romaia in van Nijf and van Dijk (2020).

268 Stratonikeia had a border conflict with Mylasa in the mid-second century BC, which may have been resolved by this time: I.Mylasa 134, and Ager (1996), no. 101. Mylasa, however, may well have taken advantage of Stratonikeia's weakened position after the Mithridatic wars to continue its own expansionist policy, see Cousin and Diehl (1898), 433-435 (although they place this in the context of the sympoliteia with Olymos and Euromos, which they date to the mid-first century вС; see Reger (2004), 164-168 for an earlier date in the third century вС).
} 


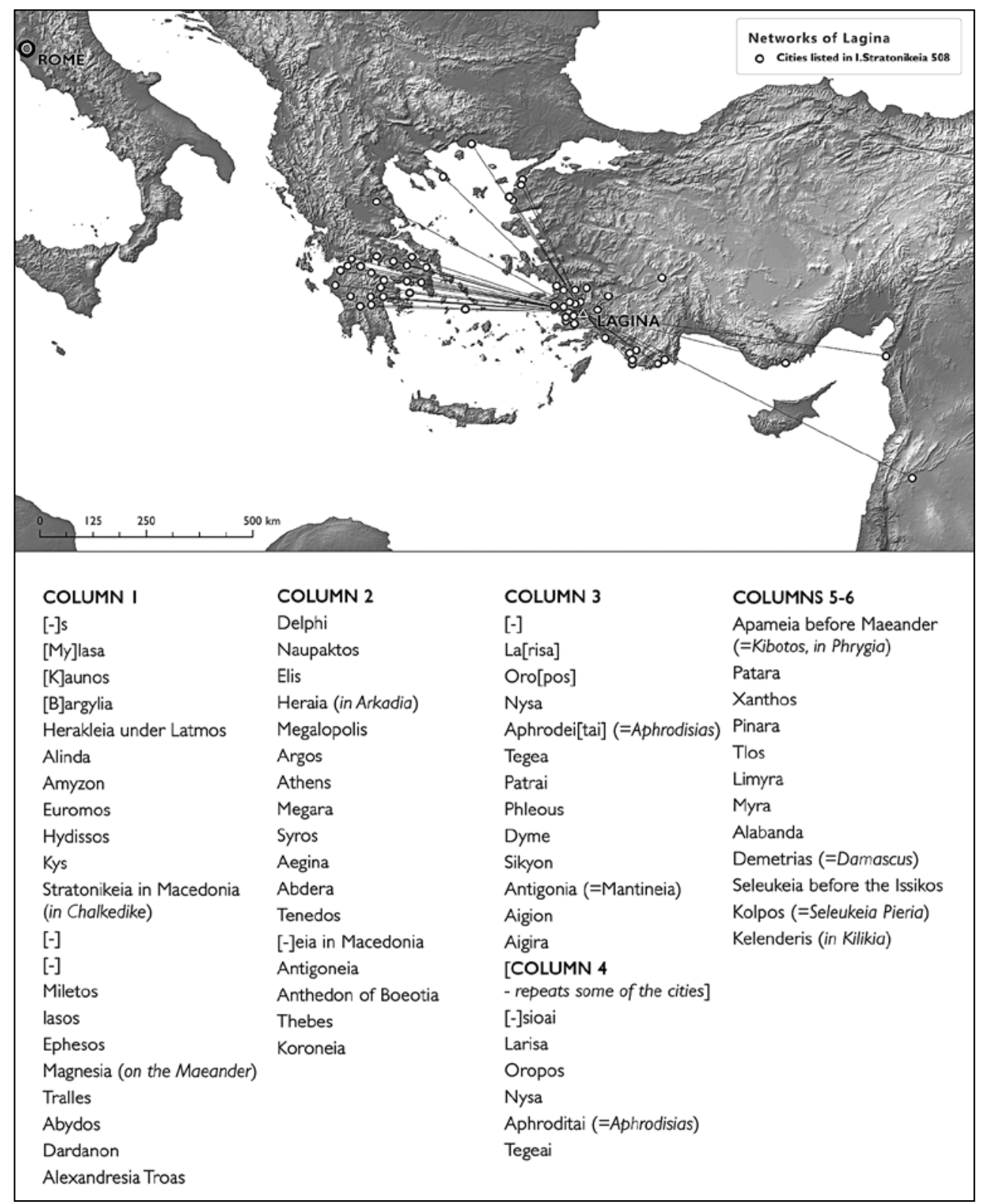

FIGURE 5.25 The social network of Lagina. Map and table show the 57 cities listed on the temple walls of Lagina (I.Stratonikeia 508 ) recognizing the asylia, following the Senatus consultum de Stratonicensibus of $81 \mathrm{BC}$ (I.Stratonikeia 505) and participating in the Hekatesia-Romaia festivals 
the bond between Stratonikeia and Rome. Stratonikeia thus skillfully used the event to achieve 'global' recognition not only for the sanctuary but also for the polis itself; the organization of the festival of the two goddesses ensured a strong network of allies who were obliged to participate, for reasons of both cult and politics. ${ }^{269}$

Stratonikeia clearly used Lagina as its formal debut into the global network of poleis. In this the polis was following the lead of other cities, the most famous of which is Magnesia on the Maeander, who over a century earlier went on a quest in much the same way for worldwide recognition of the sanctuary of Artemis Leukophryene - the first efforts were in vain, but in a renewed offensive they ultimately drew a response from some 16o cities across the Greek world, ranging "from Sicily to Iran." ${ }^{270}$ Magnesia catalogued these responses on the walls of the nearby agora, grouping them geographically, as did Stratonikeia later at Lagina. ${ }^{271}$ John Ma refers to this practice as not just reflecting the active 'mental map' of the times, but specifically creating it from the perspective of the city. ${ }^{272}$ The temple of Hekate at Lagina, then, became Stratonikeia's map of the world, showing its own position among the cities whose esteem mattered most to the developing polis.

The shift in the scope of the sanctuary of Hekate at Lagina is truly impressive. The goddess literally moved from the margins of Koranza into the mainstream as she became a poliad deity of Stratonikeia. At the hands of the polis she was even transported beyond civic territory to being a goddess of international fame with a panhellenic festival, demonstrating the complete symbiosis between the city and the sanctuary.

\subsubsection{Civic Decrees}

Like Labraunda, the sanctuary of Hekate at Lagina was used to mark important political events. It has already been shown above how in the early second century the sanctuary was used to honor the Rhodians by introducing the cults

269 Laumonier observed a parallel with the intertwinement of local and super-regional interests in the Amphiaraia festival in Oropos, on the border between Boeotia and Attica in Greece; this festival was also a celebration of Rome within the cult framework of Amphiaraos, Laumonier (1958), 359; but see also Errington (1987), who shows the worship of Thea Romē as a sign of gratitude in response to Roman intervention of some kind.

270 Rigsby (1996), 18o; p. 179-279 on the 6o asylia inscriptions at Magnesia, with over 100 cities only appearing in lists; van Nijf and Williamson (2016).

271 Rigsby (1996), 180. The temple of Artemis Leukophryene faces the agora.

$272 \mathrm{Ma}(2003), 12-13$, and 20-22 on the asylia of Magnesia on the Maeander and its responses in the context of peer polity interaction. The long list of inscribed sacred land transactions would have had a similar function, as argued in Horster (2010). 
of Helios and Rhodes at Lagina. ${ }^{273}$ The small architrave inscription donated by Hermias Athanagoras, discussed above, may further reflect Rhodian influence if it was in fact dedicated by a Rhodian. ${ }^{274}$ Later, after Stratonikeia was delivered from Rhodes by Rome, the sanctuary was also used to mark observance to the Romans. The question of whether the temple frieze belongs in this category has been discussed above, but the Hekatesia-Romaia festival is proof beyond doubt, along with the official documents pertaining to this festival that were inscribed on the walls of Hekate's temple.

Also like Labraunda, the walls of the sanctuary became an important public and municipal archive. Both sanctuaries contained important letters from the rulers that concerned both sanctuary and city: Labraunda contained the dossier of correspondence with the Hellenistic kings concerning its relationship with Mylasa in the third century $\mathrm{BC}$, and the temple of Hekate at Lagina also bore an important letter by Sulla, the most powerful ruler at that time in the early first century BC. Yet rather than concerning a controversy between city and sanctuary, this letter reveals their already inseparable relationship Lagina is for both parties as good as a code-word for Stratonikeia.

The Senatus consultum de Stratonicensibus from 81 в , was the document in which Rome formally recognized Stratonikeia's loyalty during the Mithridatic wars, acknowledging all the losses incurred by the polis and listing the grants of compensation awarded by the ruling power. ${ }^{275}$ This was an essential and vital political document to the polis that was kept safe in the most sacred place - on the walls of the temple itself. If, as van Bremen suggests, it was inscribed on the southwest wall of the temple, then it would have faced the rows of seats along the southwest stoa (Figure 5.8). ${ }^{276}$ This would have been a highly conspicuous place, forming the visual background to whatever events took place in the area between the temple and the stoa. The document was not only the confirmation of the status of asylia for Lagina, but it also described the significant territorial expansion of Stratonikeia granted by Rome, which included the area

273 I.Stratonikeia 504, discussed above under Priesthoods.

274 I.Stratonikeia 1424 (= EA 29 (1997), 98-99, no. 17); because of his Dorian name, Şahin believes he was Rhodian, p. 26; discussed above.

275 See also Sherk and Viereck (1969), no. 18, 105-111; Rigsby (1996), 418-423; Knäpper (2018), 254-255. Tac. Ann.3.62 mentions Stratonikeia as one of the cities that appeared before the tribune of Tiberius for continued recognition of asylia.

276 I.Stratonikeia 505 is the Senatus consultum de Stratonicensibus of 81 BC. This document and the following list of cities recognizing the asylia (I.Stratonikeia 507-508) were inscribed on the temple walls, Trrpan et al. (2012), 195; van Bremen (2010), 493-495 locates them more specifically on the 'south' (= southwest) wall. 
down to Keramos, Themessos(?) along the coast, as well as the produce from the villages in their countryside. ${ }^{277}$

Of course the extension of asylia was directly relevant to the sanctuary itself, as was the ensuing festival of the Hekatesia-Romaia and the list of the cities throughout the Greek world that further acknowledged this pact and participated in the celebrations (Figure 5.25). ${ }^{278}$ These inscriptions clearly documented a kind of contract between Stratonikeia and Rome, as the cult of Hekate was united with Rome. ${ }^{279}$ The cities further served as witnesses to this union; inscribing them in several columns across the walls of the temple was simultaneously a public, political, and a sacred act, perhaps even part of a ritual performance. ${ }^{280}$

A second manifestation of Hekate's intrinsic relationship with the city is the record of her epiphany. ${ }^{281}$ Mentioned in an elusive document that is not dated, it states that the goddess appeared and intervened in times of danger and sacrilege to the countryside and the sacred lands, as discussed above. ${ }^{282}$ It is tempting to associate this with her epiphany-like appearance on the frieze, especially in the gigantomachy on the northwest section. If her epiphany is connected to the reason behind the construction of the temple, then this would place it towards the end of the second century $\mathrm{BC}$, and would probably refer to some event during the Aristonikos revolt. This would only make sense, however, if the area around Stratonikeia or Lagina had actually been under attack, as Robert and Rostovtzeff believed, but has since been repudiated by

277 The grant of territorial concessions and asylia for Hekate's sanctuary is summed up in

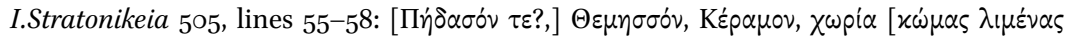

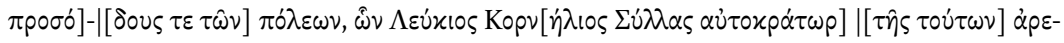

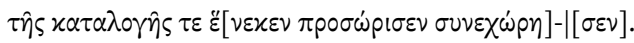

278 I.Stratonikeia $507-508$.

279 This foreshadowed the inclusion of the imperial cult at the sanctuary under Augustus, e.g. the statue of Augustus, I.Stratonikeia 1425 (=EA 34 (2002), no. 4). There may have been a parallel situation in Tralles, where a statue of Hermes was dedicated by the priest of Tiberius, Caesar and Hekate Augusta, I.Tralleis 11.

280 A parallel is found in the lists inscribed on the walls of the agora at Magnesia on the Maeander, mentioned above; Rigsby (1996), 180. See also IAph2007 8.27, the Senatus consultum de Aphrodisiensibus, from 39/8 BC, inscribed on the north parodos of the theater in the third century AD; also Ma (2000), 103.

281 An allusion to Hekate's epiphany is made in I.Stratonikeia 512 , lines $25^{-27}$, discussed further below. See also: Robert (1937), 461-462; Rostovtzeff (1941), 809; Laumonier (1958), 354-355; Marek (1988), 297-29; and van Bremen (2010), 499-502. Epiphanies as a sign of the dependency of the Hellenistic polis on its gods are also discussed in Wiemer (2009), 117 n. 4.

282 See also I.Stratonikeia 513. 
others. ${ }^{283}$ The area certainly was under attack, however, during the occupation of Stratonikeia by Mithridates VI Eupator, as discussed above.

The aftermath of the Mithridatic wars mark the first appearance of Hekate's new title of Soteira Epiphaneia (Epiphanous Savior), in the decree following the Senatus consultum and establishing the penteteric festival for Hekate and Thea Romê. ${ }^{284}$ This episode in the early first century вС is a much more likely context for her epiphany as it points to her role as religious or even spiritual focus during the hardships endured by the community. Adding these titles to the goddess' name was an extremely effective way to commemorate the event, but especially to communicate the sacred bond between the goddess and the city, directly announcing to all the protective role of the goddess and her intimate relationship with Stratonikeia. Using epiphanies in this way was certainly not unusual in the Hellenistic period; especially in the second century BC there seems to have been a surge of these which carried over into the first century $\mathrm{BC}$ - the account of the epiphany of Zeus Panamaros during Labienus's attacks in $40 / 39 \mathrm{BC}$, discussed below, is perhaps one of the most detailed that has survived. ${ }^{285}$

Renaming Hekate through the new epiklesis of Soteira Epiphaneia in essence rewrote her identity as the goddess who protects Stratonikeia. Although Hekate was obviously already heavily involved with Stratonikeia, this new name marked a pivotal moment in time, and place in the landscape, as being endemic to the very identity of the goddess - this is when the divine will of Hekate to protect the polis was made clear and announced to all.

283 Robert (1937), 459-465 and Rostovtzeff (1941), 8 o9 believed Karia to have been a theater of this war, based on Aristonikos's attacks in the Myndos peninsula and the interpretation of Stratonikeia in Karia as the place of his capture (Eutropius iv.2o and Orosius v.1o.1, both fourth century AD). Yet this could also be Stratonikeia on the Kaikos, in Lydia, e.g. Broughton (1934), Magie (1950) II, 1038-1039. Marek (1988), 297-298, sees no reason for Karia to have been involved in the wars at all, since it was beyond the area of Aristonikos's claims. Errington however observes that Rome had much more support outside the province of Asia than within, Errington (1987).

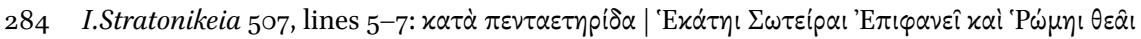

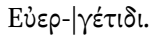

285 I.Stratonikeia 12 relates the miraculous epiphany of Zeus during the three-day onslaught by Labienus at his sanctuary in Panamara, discussed in more detail below, in Chapter 6 . The epiphany of Artemis Leukophryene at Magnesia on the Maeander is otherwise one of the best known, e.g. Chaniotis (1995), 162. Artemis Kindye also performed an epiphany at Bargylia during the Aristonikos wars, see Marek (1988), 297; Hotz (2005). On epiphanies in general, Graf (2004), Rostowzew (1920) and Pritchett (1979), 11-46 on epiphanies in military contexts. 
This is also the moment that was recalled when the goddess was honored as Hekate Soteira for restoring her sacred lands, as mentioned above. ${ }^{286}$ Another inscription speaks of the unanimous devotion and gratitude of the people of Stratonikeia to Hekate who clearly intervened in the wrongs done to her and to them, implying some kind of epiphany or manifestation of divine power. ${ }^{287}$ Although the context is unclear, the reference to 'the sacrilege of our country which is sacred and inviolate' could place this inscription after the Mithridatic wars. ${ }^{288}$ This way of describing the sanctity and inviolability of 'our lands' illuminates the way in which the property of the goddess and the polis were interwoven; one of the aims in obtaining the grant of asylia for the sanctuary after the Mithridatic wars was surely to extend protection over at least a part of civic territory which belonged to the sanctuary.289

The Senatus consultum inscription and her epiphany are two examples of high profile political and religious events that directly concerned the city and the sanctuary, and that were subsequently recorded at Lagina. Another strong indication is the use of the sanctuary as an urban podium, a place where honors were bestowed upon individuals for their selfless deeds and services for the community.

Together with the decrees, the number of honorific monuments makes up the largest category of inscriptions at the sanctuary after the lists of priests, even in the Hellenistic period (see Table 5.1 above). Not all of these can be directly associated with statues, but there are enough to indicate that the

286 I.Stratonikeia 510, see above under Economic resources.

287 I.Stratonikeia 512 was found in numerous pieces - the central eight or so lines seem to be missing. The goddess is honored by the demos for saving them from danger through a positive sign, thereby providing freedom and autonomy, lines 4-9; lines 21-27 show how the desecrators of their sacred and inviolate country were cut down and brought to jus-

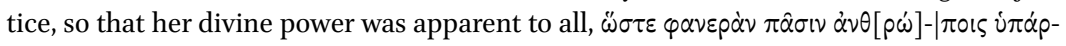
$\chi \varepsilon เ \nu \tau \dot{\nu} \nu \tau \hat{\eta} \varsigma \theta \varepsilon \hat{\alpha} \varsigma \dot{\varepsilon} \nu \alpha \dot{\rho} \gamma \gamma \varepsilon 1 \alpha \nu$ (lines 26-27). This may well be why the inscription was given such a prominent place on one of the antae of the temple, Tirpan et al. (2012), 195; on this phenomenon, Roels (2018a).

288 I.Stratonikeia 512 , lines $21-22$, discussed above. It is true that the historical context is vague, and van Bremen (2010), 499-502 leans towards a date in the second century вс, based on the language and letter shapes. The lack of any epiklesis for Hekate could also support a date prior to the Mithridatic wars, yet on the other hand the clear recognition of asylia argues for a date after the Senatus consultum de Stratonicensibus of $81 \mathrm{BC}$; van Bremen also admits that the destruction which the decree mentions may well indicate a date in the first century вс.

289 On grants of asylia as possible incentives to declare more and more land as 'sacred', see Chapter 4 on the sanctuary of Sinuri. 
interior of the sanctuary must have been rather crowded with them. ${ }^{290}$ One of the earliest inscriptions at the sanctuary, from the early second century BC, is an honorific decree concerning a Stratonikeian who was praised in Lagina by the Karian Chrysaoric League, presumably where his fellow citizens could see it. ${ }^{291}$ Fragments of another honorific decree, widely dated to the first century вс, list the boule and demos praising an individual for his good deeds to population the polis. $^{292}$

Of special interest is a statue base from the second part of the first century dedicated to the brothers Menekles and Epainetos, both adopted by Antipatros of Koraia, and situated in a prime spot, just in front of the propylon next to the west stoa. ${ }^{293}$ For his goodness and benefactions, Menekles was awarded a golden crown, a statue, presumably the one on this monument, and a meal in the prytaneion. Epainetos was to receive a golden crown and a (bronze) statue for the continuous goodwill which he displayed towards the polis. The monument is long, but based on the inscriptions it nonetheless seems to have been intended to hold only the two statues of these brothers. They were honored in perhaps the most prominent place in the sanctuary, since their statues would have been one of the first things encountered upon entry, closing off the theatron at the southeast end and 'framing' the sanctuary in the background (Figure 5.26).

Finally, a more plebeian expression of urban involvement may be found in the informal writing, i.e. 'graffiti', at the temple itself, especially the several outlines of feet on the krepis of the temple, discussed above (Figure 5.17), ${ }^{294}$ but also the figures of a dog, perhaps Hekate's? Although we know neither who etched their feet at the shrine nor when they were carved, they are certainly

290 Honorific decrees are found in I.Stratonikeia $523-543$. See also Laumonier (1958) 364 for a summary of dedications by priests, ex-votos, statues, and even statuettes or medallions

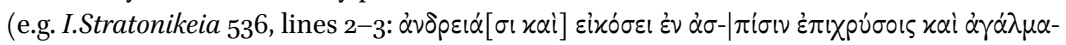
$\sigma \omega v$, awarded to a priestess, see commentary Hatzfeld (1920), 78, no. 8).

291 I.Stratonikeia 1418 (= EA 35 (2003), 1-7), also discussed above in connection with Rhodian presence at Stratonikeia.

292 I.Stratonikeia 1423 (=EA 29 (1997), 95-96, no. 13). The name of the individual has not been preserved, but his deeds may have been of a financial nature, since the tamiai, or treasurers, are also listed in the header.

293 I.Stratonikeia 1426 and 1427; the monument was excavated in 1996, see Tirpan (1997) and Tirpan (1998a) on its restoration. Şahin discusses the fact that the demotic of Koraia was erased in Epainetos's inscription as an indication of perhaps some confusion due to the adoption, p. 27. See also the discussion by van Bremen on the practice of adoption in Stratonikeia, based in part on this monument which had newly been brought to light, van Bremen (2003a), 17-19.

294 Discussed above under Public space. For footprints on monuments, see Dunbabin (1990). 


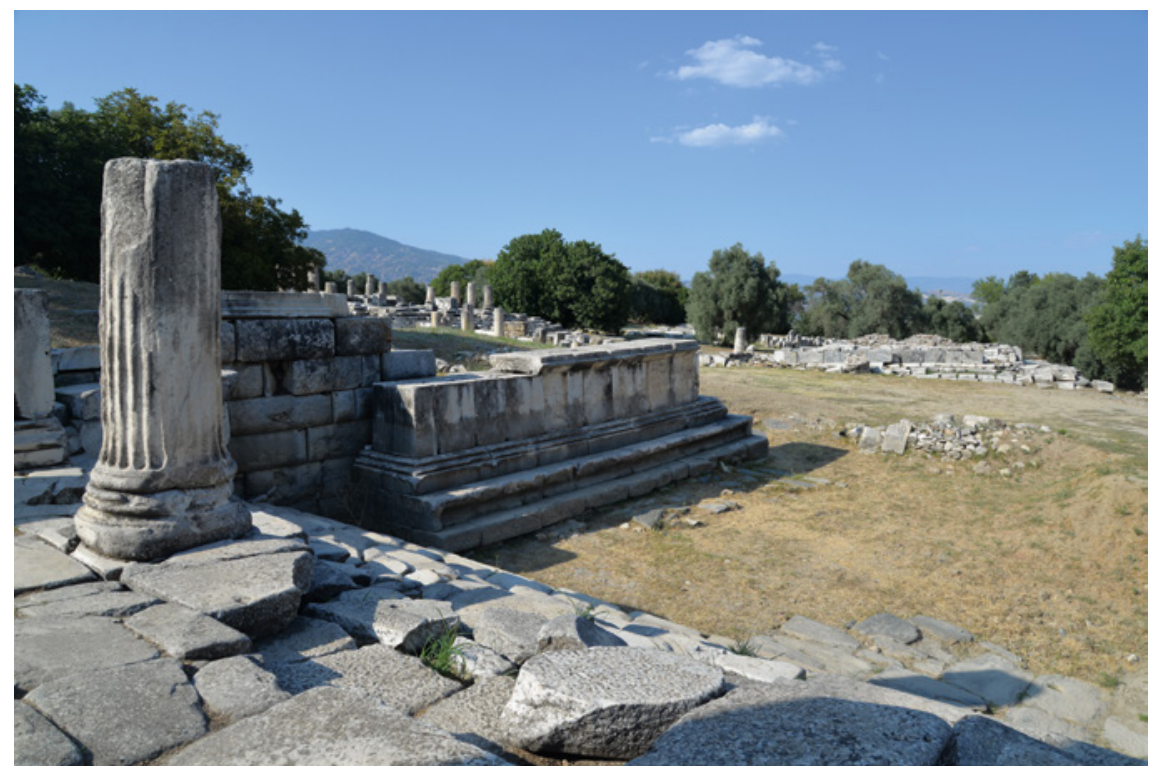

FIGURE 5.26 Lagina. Monument for Menekles and Epainetos, I.Stratonikeia 1426-1427, seen from the propylon with the temple and altar in the background PHOTO AUTHOR 2019

testimonies of the liveliness of the sanctuary. Moreover, while these are all around the temple, they are most concentrated along the southwest side, opposite the theatron. Various topoi 'graffiti' are furthermore found in the propylon, including one of Leon in which he marked his spot ('Leontos topos') below the theatron and between the propylon and the monument for Menekles and Epainetos - a very prominent spot indeed.

The sanctuary clearly functioned as public and urban space, with its decrees and monuments, and historical documents, but also signs of everyday use - it was a lived-in sacred space, used by a large cross-section of the population. With its agora-like setting, it was surely intended as an annex to the urban environment of town.

\subsubsection{Cult Iconography in Urban Contexts}

Imagery can be a highly efficient means of communication, especially on coinage as it passes from hand to hand. The imagery on the coinage of Stratonikeia not only effectively communicated the relationship between the goddess and the polis, but also advertised it and in so doing helped to (re)produce it. Along with Zeus, Hekate is portrayed on the earliest coins of Stratonikeia, issued some time after the city's independence from Rhodes. Andrew Meadows dates 


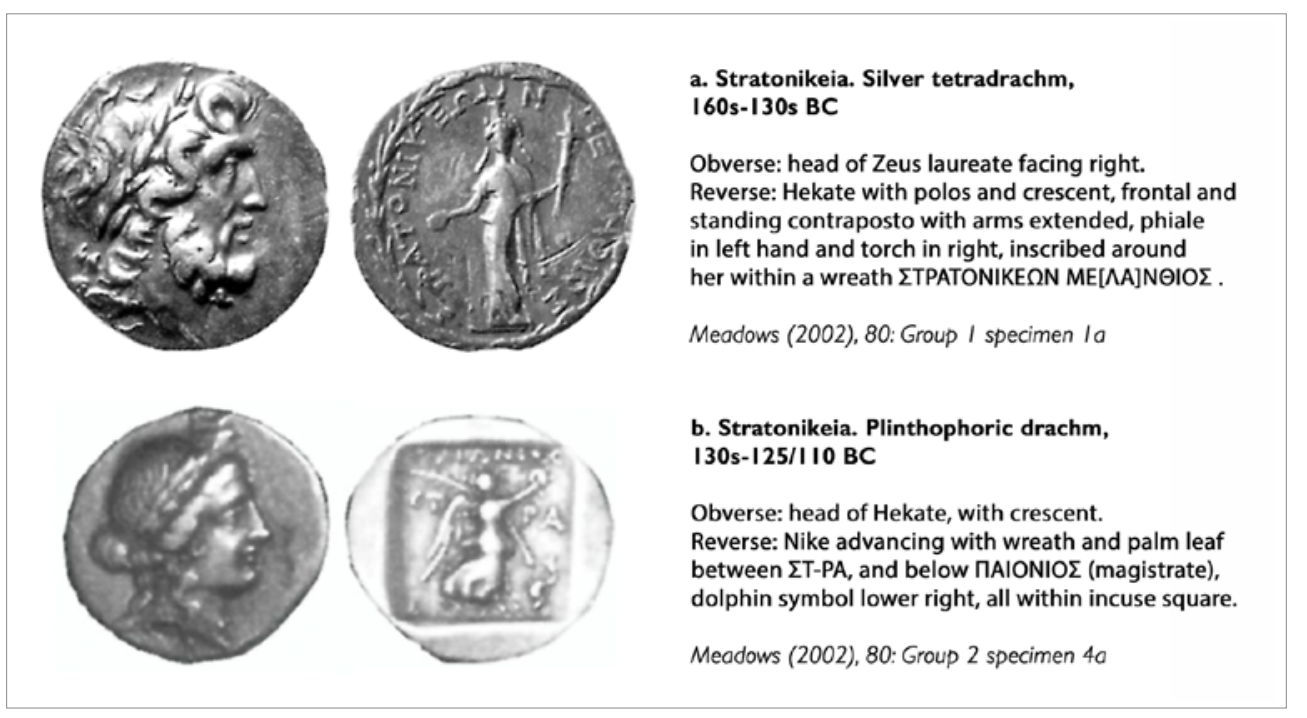

FIGURE 5.27 Stratonikeian coins showing Hekate and Zeus

them to the period between the 16 os and 13 Os BC (Figure 5.27a, Group 1, shows an example from this group). ${ }^{295}$ Hekate is shown on the reverse, standing frontally, wearing a polos with a crescent, and holding a torch in her right hand with a phiale in her left. Stratonikeia is shown either abbreviated or written in the genitive, as $\Sigma$ TPATONIKE $\Omega \mathrm{N}$, encircling Hekate; the name of the stephanephoros, or civic magistrate, appears as well. Generally speaking, Hekate is not a civic goddess and so rarely appears on coins, yet her identity here is unmistakable due to her attributes, particularly the torch and the crescent moon. Her frontal stance and outstretched arms, as in the temple frieze (Figure 5.15), may reflect her cult image. ${ }^{296}$

295 Head's BMC Caria from 1897 was the leading source on Stratonikeian coinage until the discovery of the Muğla hoard in 1965, with 290 silver coins from the second and early first century вс, considerably extended the base for the typology of the Hellenistic coinage; this was first published in von Aulock (1967) and SNG von Aulock. Meadows has done more extensive analyses of this hoard together with other known specimens and has revised the chronology, discerning four typological groups for the silver issues in the Hellenistic and early imperial period; Meadows (2002). During the 1999-2002 excavations at Lagina, another 188 coins were found, more than half of which were minted by Stratonikeia; Tirpan and Söğüt (2007b), 394.

296 If so, this would imply some sort of protective architecture at the sanctuary, since Meadows' dates for this coin group (16os-130s BC) are earlier than the generally believed dates (late second to early first century вс) for Hekate's temple complex at Lagina; for an alternative, earlier view of the temple chronology, see van Bremen (2010), 502 . 
Hekate is later portrayed on the obverse, starting with Meadows' Group 2, as smiling and crowned with her crescent, with an alighting Nike on the reverse, extending a wreath and holding a palm branch (Figure $5.27 \mathrm{~b}$ ). These coins clearly aim to associate the concept of victory with Hekate and Stratonikeia. Meadows connects Group 2 with the Aristonikos revolt, but they may also anticipate or even coincide with the major construction activity at Lagina towards the end of the second century вс. ${ }^{297}$ Group 3, a strongly devaluated version of Group 2, is placed by Meadows in the context of the Mithridatic wars in the early first century вс. ${ }^{298}$ Hekate had a very high profile at this time; the Senatus consultum for Stratonikeia was posted at Lagina, and her enigmatic epiphany, discussed above, may have been related to this turbulent period. 299 Most of the coins known from the hoards from this period depict Hekate rather than Zeus. ${ }^{300}$ In any event, they continue to repeat the familiar pattern of goddess, city, and victory, and Hekate's image remains on the coinage until well into the Roman period; she is often combined with the new Gestalt of Zeus Panamaros, who is shown as a rider-god on horseback (Chapter 6, Figure 6.30a, c). ${ }^{301}$ Besides her festivals and processions, the image of Hekate, in such a close context with the polis, was itself a fundamental building block in the symbolic shaping of the polis. ${ }^{302}$

With their ubiquity, coins were thus an excellent mechanism of advertising the interlocking equation of goddess with city, bringing the idea of this relationship to wherever the coin happened to travel. Other less mobile signs of Hekate in the urban area of Stratonikeia would include her statue, as mentioned above, at the gateway of the city in the Roman period, before the bronze doors, perhaps looking out over the nearby necropolis. ${ }^{303}$ Alfred Laumonier discovered a small marble block or altar showing Hekate in relief worked into the walls of one of the houses in Eskihisar. ${ }^{304}$ Finally, in the later second century, the notable Marcus Sempronius Clemens dedicated a shrine, next to the

297 Meadows (2002), 101-107. But see also van Bremen (2010), 502. Meadows (2018), discusses the rising phenomenon of poliad deities on coins across the Greek world in the second century вС.

298 Meadows (2002), 107-111.

299 See above and I.Stratonikeia 512.

300 Meadows (2002), 107-111.

301 Meadows (2002), Group 4a.

302 Meadows (2018). See Chapter 2 on Paasi's view of symbolic shaping as part of the creation of regional identity, Paasi (2009).

303 Robert (1940), 237-238; see above, under the section on the Sacred road.

304 Laumonier (1936), 321-322, fig. 33. He lists the dimensions as $59(\mathrm{~h}) \times 29(\mathrm{w}) \mathrm{cm}$; the moulding at the top and bottom may indicate a small altar. 
bouleuterion in town, which included a statue to Hekate. ${ }^{305}$ This may have been the statue of the goddess next to that of Zeus Panamaros, before which the choir boys were instructed to stand as they sang their hymns to both the gods during their festivals. ${ }^{306}$

To recapitulate, in the transition towards becoming an urban sanctuary, the scope of Hekate's cult at Lagina underwent three major phases: 1) in the Late Classical and early Hellenistic period when it principally belonged to the polis of Koranza; 2) at some point in the second century, when it was used as a common focus for the new urban population of Stratonikeia; and 3) after the Mithridatic wars in the first century, when it was used to gain recognition from Rome and to connect to the larger Greek world. Especially the second period shows Stratonikeia gaining control over the cult while the area was still under Rhodian rule. Once liberated, Stratonikeia selected Hekate to symbolize the polis on its very first coinage, mediatizing the intimate relationship between the goddess and the polis right from the start. This would have foregrounded Lagina in the mental topography of the citizens of Stratonikeia, giving it a prominent spot in their mind's eye; the goddess became a common focus that helped shape the identity of the polis both symbolically and territorially. ${ }^{307} \mathrm{In}$ the third phase, after the Mithridatic wars, the union between city and sanctuary took on a new direction as the cult of Hekate was used by the polis to engage in geo-politics via the Senatus consultum de Stratonicensibus, then using this to expand the festival of Hekate to include the goddess Roma, and finally by soliciting recognition and participation from the wider Greek world, stretching from Olympia in the west to Damascus in the east. Using Lagina, Stratonikeia positioned itself on the map of places that matter, as Strabo's inclusions of milestones indicates (14.2.29). The Hekatesia-Romaia mediated local, regional, and global networks, under the soft power of empire. Publishing these central inscriptions at the sanctuary was a mass-advertising maneuver that sealed its fame through time, as a monument. In this way the collective memory of the polis, but also the wider Greek world, was shaped to meld the identities of Hekate and Stratonikeia as a powerful and indivisible force. Yet the agency was ascribed to Hekate. The goddess was positioned as the main actor in this new relationship - it was not the manpower of the Stratonikeians that ultimately

305 I.Stratonikeia 289, lines 10-11: Hekate's statue was alongside those of Zeus Panamaros, Artemis, Asklepios, and Hygieia.

306 As prescribed by Sosandros, son of Diomedos, in I.Stratonikeia 1101, line 5; discussed above under Festivals.

307 On 'symbolic' and 'territorial' shaping as one of the stages in building a regional identity, see Paasi (2009), discussed in Chapter 2, and below. 
counted in the public eye, but the divine will of the all-powerful goddess who selected the polis to cherish and protect.

\section{Interpreting Change in the Relationship between Stratonikeia and Lagina}

Whether driven by ritual, geographical or political motives, the new polis of Stratonikeia clearly relied in several ways on the older cult of Hekate at Lagina, implicitly using it to develop its identity as a polis and legitimate its own position. In the process, the city took the cult place of the goddess from being a wayside shrine at the edge of the Marsyas valley to a central focus of the polis, foregrounding it in the cognitive collages of its citizens.

Considering its location, it would be easy to classify Lagina as a frontier sanctuary. It is situated near the natural boundary of the Marsyas river to the east and the rising Gökbel mountains to the north; in fact it significantly extended the visual range of the polis in these directions, as well as a good part of the Marsyas valley looking southeast (Figure 5.6). That this concerns a sanctuary to Hekate is already suggestive of a liminal location. One function at Lagina that coincides with sanctuaries at areas of borders or crossings are the major festivals and especially the element of competition. This fits in with de Polignac's ideas on the need for controlled rivalry as well as mediation at borders, as well as with Sinn's ideas of such sanctuaries as places of refuge, because of their liminal positions. ${ }^{308}$ However, the sanctuaries discussed in their studies were their primarily concerned with border conflicts or rights of passage and refuge. This is very different from the case of Lagina, which was turned into a great inter-state center through recognition of its asylia and its penteteric festival. Except for the unequivocal Stratonikeian presence, nothing else at this sanctuary speaks of the kind of territorial dominance or even aggression that tends to coincide with theories on frontier sanctuaries. ${ }^{309} \mathrm{Had}$ this been the case, then one would expect to see more of a landmark function of the shrine, especially in the direction of the Marsyas valley or the Gökbel mountains. Instead, travelers coming from these directions were apparently met with long blank walls. Added to this is the fact that we do not know the exact extent of Stratonikeian territory; Debord even suggested that it may have spanned the Marsyas to include villages in the lower foothills of the Oyuklu range, east of modern Yatağan, where Londarga and Koraia or Lobolda may

308 De Polignac (1994) and (1995); Sinn (1993).

309 De Polignac (1995), discussed in Chapter 2. 
have been situated (see Figures 5.1 and 5.21). ${ }^{310}$ Hekate is the goddess of the crossroads and Lagina is certainly near some important natural boundaries, yet this is not enough to warrant an interpretation of this wayside shrine as a political frontier sanctuary. There must have been other operative factors in the relationship between the city and the sanctuary.

The first factor is the role of the sanctuary in creating social cohesion within the polis. Ritual space at Lagina created an intense, enclosed space that was largely cut off from the world. This ensured a complete focus of the community onto the events taking place within its walls in a stage-like setting, complete with a theatron for ritual spectators. The spectacle became more and more the subject of the festivals, and it was clearly important that they capture the attention of the crowd. The kleidos agoge, the procession of the key, however is critically important in this regard, as it took the focus from the sanctuary, across the ancient landscape and through the communities still living there, and into the heart of town. This centripetal movement served to ensure the primacy of the new polis within the pre-existing older community. ${ }^{311}$ While one might interpret this as territorial domination, e.g. according with the model of the frontier sanctuary, ${ }^{312}$ in light of rational ritual theory such a sensational - and loud - procession moving through the landscape is viewed as a highly effective means of mass-advertising. ${ }^{313}$ The difference is key, as rather than imposing the ideology of territory, the ritual elicits a communal response. Such prominent ceremonies were excellent vehicles of common knowledge, as they created a unified focus for the community, providing a shared experience and a common bond. In this case the focus would also have been on the centricity of the new polis within the older local network of local communities that had by now been drawn into the polis as its demes. By promoting a goddess whom everyone already knew, but who was not central to any one particular community (although marginal to Koranza), the new urban center was able to pull the disparate communities together under one religious umbrella. Everyone could in principle have an equal share in this cult, regardless of origin or for the most part social standing (with the exception of the priesthood and the kleidophoros). The potential of the cult of Hekate that Stratonikeia realized was its ability to create a common focus for the communities that now constituted the polis, thereby enabling social cohesion.

310 Also the map in Debord (1994).

311 See Graf (1996) on centripetal versus centrifugal processional trajectories; discussed in Chapter 2 and above.

312 De Polignac (1995), 40-41.

313 Chwe (2001) on 'rational rituals', discussed in Chapter 2. 
A second political factor in the potential of the shrine for the polis is its ability to create a sacred, and political, network with peer Greek cities. ${ }^{314}$ The way in which Stratonikeia used the sanctuary after the Mithridatic wars, first to obtain the grant of asylia and the territorial expansion and then to expand its circulation by extending the cult to include Thea Romē, and by creating panhellenic festivals with games and competition, shows how the city was building a political network through cult. ${ }^{315}$ The package deal they created of peer interaction, observance to the superpower Rome (through recognition of the asylia grant and participation in the festivals that now included Thea Romē) and the element of inter-urban competition was apparently an offer that was difficult to refuse. The resulting network of cities involved at the sanctuary is eventually what placed Lagina on the map, with Stratonikeia in its slipstream. The quadrennial festivals with contests were used to elevate the city to the international level of cult recognition, although this network is mostly one dimensional, i.e. consisting of the cities that voluntarily recognized the asylia of Lagina and participated in the games of Hekate and Rome. But thanks to the inscription from Kos, we know that at least on a regional level, the 'local panhellenic' games at Lagina allowed Stratonikeia to join the multi-dimensional network of the athletic festival circuit that was active in Karia and Ionia, including among others Halikarnassos, Miletos, Kolophon, Nysa, and Metropolis. ${ }^{316}$ These added networks were of course on top of the membership which Stratonikeia already had in the Chrysaoric League thanks to the Karian villages in its territory. The live market (biotike agora) may also have contributed to the wider network, if it in fact indicates that the sanctuary functioned as a kind of emporion.

With regard to networks, Stratonikeia may already be seen as part of the network of cities in the Chrysaoric League, with a vote based on its membervillage count. ${ }^{317}$ With the festivals at Lagina, however, the sanctuary would be a strong node with at least 57 ties to all of cities that recognized the asylia and joined in the festival, as well as those such as Kos who were not on the list but

\footnotetext{
314 See Ma (2003) on the peer-polity interaction among poleis in the Hellenistic period.

315 Rutherford (2007), discussed in Chapter 2.

316 Iscr.Cos, EV 203; discussed above under Games.

317 The villages in the League are known to have included Mylasa, Stratonikeia, Amyzon, Alabanda, Alinda, Thera, and Keramos, and possibly Panamara, see Gabrielsen (2011), 341-345. Strabo 14.2.25 mentions that Stratonikeia was admitted by virtue of its Karian villages, and that the members of the Chrysaoric League were allowed a representational vote corresponding to the number of villages in their territory. Gabrielsen (2000), 161 suggests that gaining more villages to increase the weight of the vote was the main reason behind Stratonikeia's policy of expansion.
} 
nonetheless participated in the quadrennial games. Lagina was thus a prime central node in the network, a 'hub' which deserved its place as a milestone in Karia, recognized by Strabo. Strictly speaking, Stratonikeia was itself also a node in this network, but with much weaker ties, occupying a more peripheral position. In a strict sense, the polis may thus be seen as a satellite of the sanctuary, even though it was in fact the main actor that had established this network with the wider Greek world through the combination of cult and politics.

This is a very rudimentary analysis of the networks that were established through Lagina. Further data-mining of the inscriptions could perhaps strengthen or lend nuances to this image, e.g. by examining aspects of reciprocity such as Stratonikeian presence at festivals of the cities who participated in the Hekatesia. However, this preliminary approach already elucidates the important role of Lagina in building a network that reinforced the regional position of Stratonikeia. Building this network and the emphasis on social cohesion both have everything to do with the third factor, constructing the urban identity of Stratonikeia in the wider region. Network and social cohesion were both instrumental to the rising polis in anchoring its position in the area, which of course began when it absorbed the local independent communities, poleis in their own right, and turned them into demes of the polis. As part of Koranza, Lagina was a considerable actor in this initial movement of territorial shaping, the first of four stages in the process of region-building in Paasi's model (discussed in Chapter 2 above), and followed by symbolic shaping, institutionalism, and establishment through external recognition. ${ }^{318}$

Territorial shaping thus took place by the incorporation of the ancient villages and their lands within the scope of the polis. Through this model we can envision Stratonikeia as further shaping, or at least consolidating its relatively new territory and the communities within through the cult of Hekate, who became the symbolic focus for the composite polis. A parallel might be found in the Asklepieion on Kos, thought to have been re-founded partly as a response to the synoikism of 366 в and a means of self-expression by the newly shaped polis. ${ }^{319}$ Sanctuaries clearly function as coordinating mechanisms, weaving together identity out of community and a sense of place. One way of territorial shaping was by adding the viewshed from the sanctuary to that of the polis, thereby greatly expanding its visual region, as the sanctuary and sacred

318 Paasi (2009), 133-137, see Chapter 2.

319 Interdonato (2016), 175, who considers the self-expression of the polis as a complementary motive to the Ptolemaic self-promotion at the sanctuary; she does not go into as much detail on the length of time, nearly a century, between the synoikism and the expansion of the polis, but a similar gap may also be noticed at Lagina. 
road served to connect both spaces and embed them in the mental maps of the worshipers. With Lagina, the processions along the sacred road especially would have helped unify the city, cutting across old boundaries and drawing the population in from the ancient communities towards the new urban center, as they followed the highly symbolic key of the goddess. The spatial memories created in this way allowed them to literally "perform the region," perhaps even re-enacting the foundation of the city. ${ }^{320}$ The frequency of these processions, the festivals, but also her imagery on civic coinage, served to embed a firm mnemonic pattern between the goddess, the city and the territory in the minds of its citizens, much like an emblem or a logo. ${ }^{321}$ This repetition implies a high degree of institutionalism; the demos and boule were already the main actors in this process, but the formation of the priesthood of Hekate and the kleidophoros as new civic roles expanded the range of critical actors that (re)produced this process of regional identity. These roles were fulfilled by members of the elite from different parts, or sub-regions, throughout the territory; this was critical in creating both hierarchy and unity within the area of the polis. $^{322}$

Hekate's emblematic role was further employed as a political tool to gain the grant of asylia for Lagina from Rome as well as a territorial grant which extended the legal reach of the polis down to the coast. The ensuing joint festivals of Hekate and Rome compelled the rest of the Greek world to acknowledge the inviolability of the sanctuary, implicitly acknowledging in the meantime the sovereignty of Stratonikeia and her newly won territory. In this way, the fourth stage in building regional identity, that of establishment through external recognition, was realized for Stratonikeia while strengthening its network ties of cult and politics. When Labienus desecrated the sanctuary of Hekate at Lagina in lieu of Stratonikeia, he was in fact confirming the success of this relationship.

In effect the image of the goddess, with her divine authority, stood for the city and so her epiphany as savior of the city was the logical climax of this relationship. Renaming Hekate as Epiphaneia Soteira presented the goddess as the ultimate actor in the regional identity of Stratonikeia; it was her divine will to protect the integrity of the city and its lands. Cult may have been shaped by the

320 Donaldson (2006); also 'performing the landscape': Dwyer and Alderman (2008); Pearson (2015). For the ritual dynamics, see especially Chaniotis (2013) with bibliography.

321 This would also have been a result of Mylasa's capitalizing on the images of Zeus Labraundos and Zeus Osogollis for its own heterogeneous community, made up of demes and syngeneiai; see Chapter 3 .

322 Paasi (2009), 133 on the importance of local elite as actors in negotiating identity through power relations; see also the priesthood at Panamara below, under Chapter 6 . 
necessity of politics, but politics also followed the authority of cult in - both were intertwined in a symbiotic relationship. Hekate is traditionally a goddess of the liminal zones, and although it is not inconceivable that this may have been one of the reasons why her cult was chosen, i.e. to watch over the borders of the newly formed 'city-state', her shrine at Lagina was in itself not a frontier sanctuary in the defensive sense: if anything, it was a portal of connectivity between the polis, its own citizens, and the wider political world. But her role in identifying with the polis may also explain her shape as a 'regular' monomorphic, rather than trimorphic, deity - for Stratonikeia she needed to be a goddess of unity, rather than ambiguity.

The next case study will show how Stratonikeia repeated much of this pattern with the sanctuary of Zeus Panamaros, at the opposite end of the spectrum of Stratonikeian territory. 


\section{Building Urban Community on the Margins: Stratonikeia and the Sanctuary of Zeus at Panamara}

While Lagina was a local shrine that grew and expanded with Stratonikeia to become its religious center, the sanctuary of Zeus Karios at Panamara was already recognized as an important regional cult center in southern Karia. ${ }^{1}$ However, it, too, was gradually drawn into the orbit of Stratonikeia to become the next major urban sanctuary of the polis. This case study explores yet another kind of dynamic in the transition to polis sanctuary, one that entailed a major lateral shift in scope for Panamara, from the wider region of southern Karia with diverse communities towards the urban center in the north and its demographic base (Figure 6.1, and Figure 5.1 above). Through an examination of this transition it will become apparent how Stratonikeia came to replace, or absorb, the administering body of the sanctuary, but also how Panamara was used to achieve the same kinds of goals of the emerging polis as was Lagina: territorial integrity, social cohesion, and global recognition, albeit in a different way.

Panamara and its environment have unfortunately not been subject to the same systematic archaeological investigations as Lagina, and much of the original landscape in the area has already been lost in the exploitation of lignite, or brown coal, through strip-mining. Our sources for this sanctuary and its environment are therefore severely limited, especially with regard to architecture and processional routes. Fortunately, however, the communities involved with the sanctuary at Panamara left hundreds of inscriptions behind that provide valuable insights into the way in which the sanctuary and cult of Zeus Karios were gradually realigned to meet the needs of Stratonikeia.

1 This section draws on Williamson (2009), (2012), (2013b), (2020b), and (2020c). I would also like to express my thanks to Riet van Bremen, who has kindly commented on an earlier version (Williamson (2012)). Her work has been an inspiration, which will be apparent especially in this case study. 


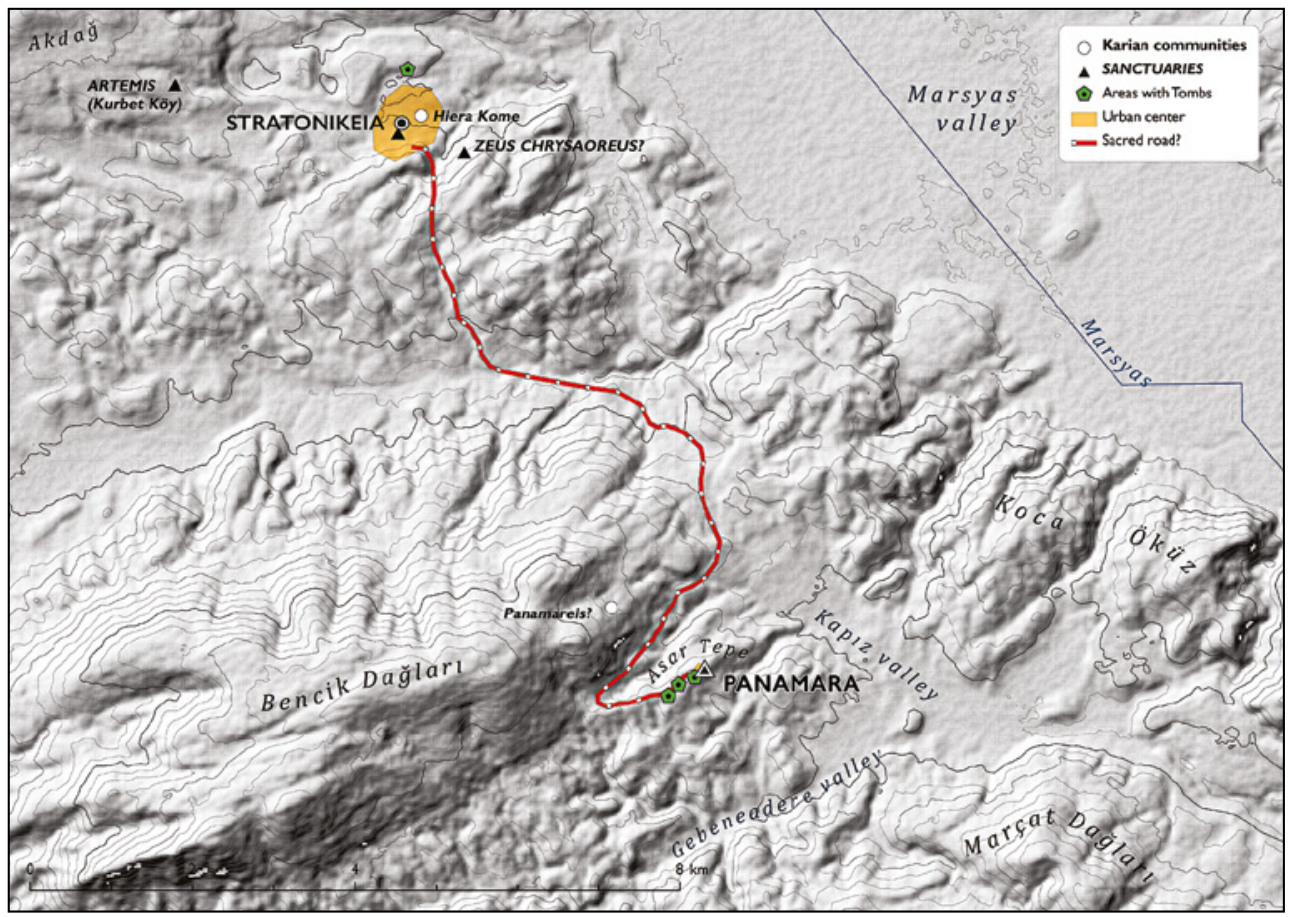

FIGURE 6.1 Panamara and environment, with an indication of the sacred road

The sanctuary of Zeus at Panamara served as a stage for negotiating relations with the changing rulers. ${ }^{2}$ The community at the sanctuary had to deal with the Ptolemies, Philip v, the Rhodians, and finally the polis of Stratonikeia. Riet van Bremen has aptly described it as a barometer of the political upheaval in this area in the third and second centuries BC. ${ }^{3}$ But it is equally a barometer of religious strategy and the communal gravity of cult.

The earliest inscription known from Panamara is dated to the 27os, or just before the Seleukid foundation of Stratonikeia; this is a fragmented decree

2 Panamara is also under study as part of the $\mathrm{PhD}$ research of Serdal Mutlu, at the University of Zurich, on the revival of religious traditions under the Roman Empire, also Mutlu (2015).

3 See van Bremen (2008), 1408: “... le destin mouvementé de Panamara au cours du III ${ }^{\mathrm{e}}$ et du $\mathrm{II}^{\mathrm{e}}$ siècle peut servir en quelque sorte de baromètre pour mesurer les bouleversements politiques affectant la région dans son ensemble." I am grateful to Riet van Bremen for providing access to this article prior to its availability in the Netherlands. 
mentioning Ptolemy II Philadelphus. ${ }^{4}$ Another reference to Ptolemy II in conjunction with Panamara was made in a fragmented inscription from Labraunda. ${ }^{5}$ Both inscriptions support Pierre Debord's observation of Ptolemaic influence in the area of Stratonikeia, or Hiera Kome, in the first part of the third century, prior to the advent of the polis. ${ }^{6}$

Little is known of the sanctuary until the end of this century, although it may for a time already have been under Rhodian control. A decree at Panamara honoring a Rhodian commander, believed to date from the first part of the second century, when Rhodes was formally given control over the area, has been shown by van Bremen to have strong analogies with other decrees from the third century. ${ }^{7}$ This would support John Ma's view of Rhodian possession of the area prior to Philip v's occupation in 201 BC. ${ }^{8}$ This inscription in any event shows that the koinon, or community, of the Panamareis was in control of the sanctuary of Zeus Karios at Panamara, and were using it as a political platform. ${ }^{9}$

At the end of the third century вс, Philip v exploited the strategic setting of the sanctuary and used it as a garrison for his troops who were stationed in this area (Figure 6.2). ${ }^{10}$ That he did this with respect for the cult of Zeus is demonstrated by the honorific decree that the Panamareis had inscribed for him, showing their gratitude for his piety. ${ }^{11}$ They also honored his epistates, or territorial commander, Asklepiades (of Peuma?) for rebuilding the walls of the sanctuary after an earthquake. ${ }^{12}$ Both inscriptions are also the first indications

$4 \quad$ I.Stratonikeia 1400; first published in van Bremen (2003b).

$5 \quad$ I.Labraunda 44. This is interpreted as a decree of ateleia, or tax exemption, for Labraunda on behalf of Ptolemy II issued by the Chrysaoric League, which was active here in this period; the decree is dated to $267 \mathrm{BC}$.

6 Debord (2001a), 160-161, associating this with the evidence for the Serapeion and the worship of the Egyptian gods.

$7 \quad$ I.Stratonikeia 6. On the date see van Bremen (2008), 1412-1413, also discussed below, under Administration and Priesthoods. There are fewer indications for the date of I.Stratonikeia 5 , another honorific decree for a Rhodian, but because of the parallels with I.Stratonikeia 6 , van Bremen suggests it may also have a third century date.

8 Ma (1999), 277-278; see also the overview of Stratonikeian history in the beginning of this chapter.

9 The nature of settlement of the community of the Panamareis is as of yet unknown; typically this would have been a koinon. Koina were common in Karia, the term is loosely used to indicate some form of syndicate or federated identity, ranging from dispersed households to villages, to clusters of communities, see Debord (2003). I.Stratonikeia III, 9-10 suggests that the settlement at Panamara may even have been regarded as a polis.

10 Discussed in Holleaux (1952), 205-210.

11 I.Stratonikeia 3 , dated to 201 BC.

12 I.Stratonikeia 4, dated to 198 вс. 


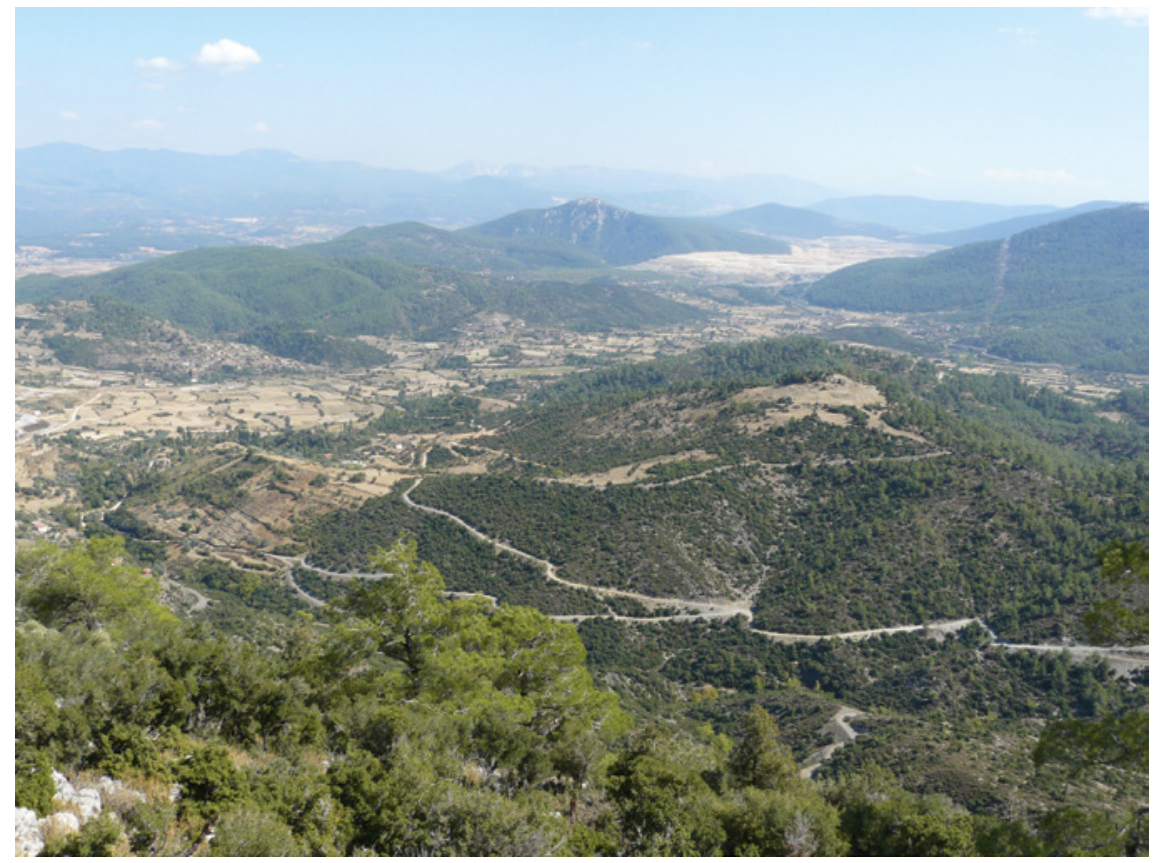

FIGURE 6.2 Panamara, seen from the Bencik Dağı northwest of the sanctuary, looking south. The sanctuary is near the bare spot on the hill just right of the center. Left of Panamara is the Kapız valley with the Koca Öküz hills on the opposite side; the Marsyas valley is in the far left PHOTO AUTHOR 2011

of monumental architecture at the sanctuary, since the decree for Philip was to be inscribed on the door jamb of the temple. ${ }^{13}$

Philip's hold over the area came to an end through Antiochos III in 197 BC, who subsequently handed the area over to Rhodes. ${ }^{14}$ The Panamareis honored a Rhodian epistates at the sanctuary, who had also displayed piety before Zeus. ${ }^{15}$ This event is dated to the priesthood of Archidamos, who was priest of Helios, and one of the eponymous figures used to mark the Rhodian calendar the decree thus appears to date to $18 \mathrm{O}-17 \mathrm{O} \mathrm{BC.} .^{16}$

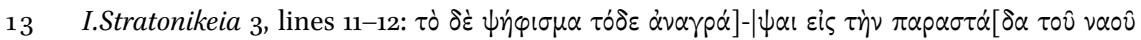

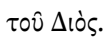

14 This is seen as an indication of Rhodian control prior to Philip's occupation, Ma (1999), 277-278.

15 I.Stratonikeia 9.

16 The names of the eponymous priests of Helios were also stamped as date onto Rhodian amphoras; the chronology of these was initially provided by Grace (1953), but has since 
The eponymous official used to date such decrees points to the identity of the administrative power over the community, which in this case was clearly Rhodes. The earlier decree for Philip's epistates, however, was dated by a stephanephoros, Apollonos, apparently from Stratonikeia. ${ }^{17}$ This raises the question of the degree of control that Stratonikeia may or may not have had over Panamara while it was still being run by the koinon of the Panamareis. Alfred Laumonier believed that Stratonikeia had annexed both Lagina and Panamara early on in its colonial history. For Panamara he bases this primarily on a sacrificial calendar that shows the introduction of Hera to the cult. This had been dated to the third century $\mathrm{BC}$, but is now believed to originate in the later second or first century. ${ }^{18}$ Hans Oppermann understood the sanctuary and especially the koinon of the Panamareis to be much more autonomous, though perhaps not entirely independent from Stratonikeia. ${ }^{19}$ Van Bremen leaves room for both interpretations, explaining the use of the Stratonikeian stephanephoros as a sign that both polis and sanctuary were ultimately ruled by Philip v, who used Stratonikeia as the closest administrative center; in fact he may have been the one to add Panamara to Stratonikeia's territory. ${ }^{20}$ The situation may then have been left intact during Rhodian rule. Jeremy LaBuff considers the possibility of a sympoliteia as a prelude to Panamara's absorption by the polis. ${ }^{21}$

The relationship between the city and the sanctuary in this period was in any event very loose, if it even existed. At some point, however, the polis gained significant clout at Panamara, since they were able to appoint a priest, named Leon, during the administration by the koinon of the Panamareis. ${ }^{22}$ Primarily due to this latitude, the priesthood of Leon is generally dated to the period

been revised by Finkielsztejn (2001); the priesthood of Archidamos is thus seen to fall between the years 180 and $170 \mathrm{OC}$, see van Bremen (2008), 1411-1412.

17 See the discussion in van Bremen (2004b), 231.

18 Laumonier (1958), 234-235. On the date of I.Stratonikeia 1, see van Bremen (2004b), 222227, discussed in more detail below, under Festivals. On Hera at Panamara, Williamson (2020b), also Pirenne-Delforge and Pironti (2016), 186, n. 431 and 194, n. 468.

19 Oppermann (1924), 25-30; see also Debord (1994), 114 and Gabrielsen (2000), 163-167.

$20 \quad$ Van Bremen (2004b), 234.

$21 \quad$ LaBuff (2016), 135 .

22 I.Stratonikeia 7 is a fragment of an honorific decree by the koinon of the Panamareis for the priest Leon, appointed by Stratonikeia; the other two decrees are by the town Kallipolis (I.Stratonikeia 1401 (= Şahin (1995), no. 1)) and by the koinon of the Laodikeis (I.Stratonikeia 1402 (= Şahin (1995), no. 2)). The more recent discovery of the inscriptions from Kallipolis and Laodikeis complements the dedication by the Panamareis, proving that Leon had been appointed by Stratonikeia (I.Stratonikeia 7 , line 23). See van Bremen (2004b) for a detailed discussion of these documents. 
following $167 / 6$ BC, when the Rhodians were forced to withdraw from central Karia by Rome. ${ }^{23}$ A highly motivated man, Leon breathed new life into the cult by using an ancient grant of inviolability, or asylia, which he found in the archives of the sanctuary, to engage several of the communities affiliated with Panamara to acknowledge and celebrate this right, perhaps including Stratonikeia. ${ }^{24}$

These inscriptions reveal many aspects of this transitional period for Panamara and Stratonikeia, who were now both independent from Rhodes. First, the reception of Leon's initiatives and the reference to the past shows that Panamara had apparently slipped into decline under Rhodian rule. Second, Stratonikeia was obviously able to appoint Leon as priest at this sanctuary, several kilometers away, and, third, the koinon of the Panamareis heartily welcomed this intervention; Leon had certainly done them a great service as well. Ironically, however, this is also the last that we hear of them. Leon was clearly building up the cult network of Panamara, and van Bremen suggests that he was not acting out of self-interest. ${ }^{25}$ Panamara is roughly midway between Stratonikeia and the Gulf of Keramos where Stratonikeia's ambitions lay. ${ }^{26}$ Stratonikeia had a vested interest in this area and once freed from Rhodian

23 See especially van Bremen $(2004 \mathrm{~b})$ on the date of the honorific decrees at Panamara for Leon, priest of Stratonikeia. As critical as the timing of Leon's appearance is, the chronology is complicated. Şahin takes a very different view as to the date and origin of the priest Leon, discussed in I.Stratonikeia III, p. 11-12 (in connection with I.Stratonikeia 1401 and 1402). Şahin follows Oppermann (1924), 24-30 and Jacoby (FGrH 278) in assigning Leon's hometown to Alabanda, believing that he acquired Stratonikeian citizenship after his admission into the koinon of the Panamareis; for the chronology, he follows Oppermann's suggestion of shortly before Rhodian control in 188 BC, and for I.Stratonikeia 1401 and 1402 he follows Reger, who suggested a date of $175^{-167}$ BC, i.e. during Rhodian rule, Reger (1998), 16-17. Reger's dating is based on the appearance of the Rhodian priest Eudamos as timestamp for the Laodikeian inscription (I.Stratonikeia 1402); Eudamos also figures on Rhodian amphoras that were dated to this period by Grace (1953). This chronology, however, has since been significantly revised and downdated by Finkielsztejn (2001). The impact of this is of course wide, see Lund (2011), and has consequences for the context of the inscription of the Laodikeis (I.Stratonikeia 1402), as discussed in van Bremen (2004b), 209-210, where she observes that Reger now suggests a later date of $15 \mathrm{O}-148 \mathrm{BC}$ for this inscription. Given the nature of the evidence, any contextual interpretation of these inscriptions will rely on the interpretation of their entangled connections. Van Bremen's chronology and hypothesis of the Leon dossier is compelling and in this study I follow her argumentation.

24 I.Stratonikeia 19 may be Stratonikeia's recognition of the asylia; see also Debord (2001b), 32-33.

25 LaBuff (2016), 137-138 argues that the priesthood, with its prestige, would have been an end in itself for a powerful member of the elite such as Leon.

26 This is one of the main tenets of van Bremen (2004b). 
rule was at liberty to pursue her own agenda. Enhancing the sanctuary, while creating a Stratonikeian presence there, was an excellent means to connect to the communities in this area, creating a corridor of goodwill based on sacred ties through territory still held by Rhodes to the coastal areas. Eventually Stratonikeia did get access to the coast, through the polis of Keramos which was ceded to Stratonikeia through a territorial grant by Sulla in the Senatus consultum de Stratonicensibus, posted at Lagina after the Mithridatic wars. ${ }^{27}$

During the latter part of the second century and throughout the first century $\mathrm{BC}$, the link between the polis and the sanctuary grew tighter by the festivals that drew the population out towards the remote hilltop sanctuary. These aspects are discussed below, such as the inclusion of Hera, with a temple of her own, the priestly dedications to 'Zeus, Hera, and the demos', and perhaps the inclusion of the god of Panamara on the first coinage of the polis in the midsecond century $\mathrm{BC}$, although his image is very generic. ${ }^{28}$ The cult, however, had a relatively low profile in comparison with Hekate in the first part of the first century ВС, after the Mithridatic wars when the attention was firmly fixed on Lagina. The festivals for Zeus and Hera, the Komyria and Heraia, which were targeted at the entire population, citizens, foreigners, and slaves, may well have been going on in this period already.

A major turning point in thelife of the shrine came after the attack by Labienus and the Parthian troops in 39 вс. Unable to take the town, he desecrated the sanctuary of Hekate at Lagina and turned to do the same at Panamara. He apparently stormed the hilltop shrine during one of major festivals; the presence of the population outside the city walls would also explain the rationale and timing of the attack. Labienus was, however, thwarted by the miraculous intervention of Zeus, who protected the people of Stratonikeia and drove off the invading forces in a dramatic scenario worthy of Cecil B. DeMille. ${ }^{29}$ From this time on Zeus bore the toponymic epiklesis 'Panamaros', gradually replacing

$27 \quad$ I.Stratonikeia 505 , lines $54-58$.

28 These have also been interpreted to represent Zeus Chrysaoreus, see below under Civic Iconography.

29 I.Stratonikeia 10 tells the story of Zeus's epiphany at Panamara in an onslaught of three days and nights; this is discussed in more detail below under Urban Mediatization. An epiphany of an unidentified anax with Artemis, who together rescue a certain Pytheas, held hostage at Kindye, is told in the long poem of Hyssaldomos, son of Eirenaios. This remarkable inscription was found at Mylasa in the excavations of the proto-Maussolleion at Uzunyuva, and dates presumably from the later third or early second century вС; now published in Marek and Zingg (2018), with a discussion on who the anax, the saving deity or hero, may have been. On military epiphanies, see also Pritchett (1979), 1-46 (with a detailed summary of I.Stratonikeia 10), and Petridou (2016), Chapter 3 on siege epiphanies, esp. 134, 138-141 on Panamara. 
that of 'Karios'. As with Lagina forty years earlier, the event at the sanctuary was used by Stratonikeia to gain recognition and the grant of asylia from Rome through another senatus consultum..$^{30}$ This, together with the epiphany of the god that saved the city, was surely the rationale behind the third festival, the Panamareia. This took place in town, however, and like Hekate's kleidos agoge, the processions were centripetal, bringing the image of the god down from the hilltop sanctuary into the urban center.

Zeus's epiphany put Panamara on a par with Lagina, and Stratonikeia often minted both patron deities back to back on its coinage from this time on. The cult of Zeus Panamaros, like that of Hekate at Lagina, became more and more institutionalized within the urban realm of Stratonikeia. Even though Strabo seems to have been unaware of the hilltop god, Tacitus recorded Stratonikeia's presentation of 'Jupiter' and 'Trivia' as her two primary gods at the tribune of Tiberius in $23 \mathrm{AD}$, in which reforms were made in the privileges of asylia and cities had to state their case again. ${ }^{31}$

The relationship between the city and the sanctuary, which began to take shape in the second period BC, was obviously successful as it continued at least through the third century $\mathrm{AD}$, triggering the creativity of its community and even picking up new rituals such as the male dedications of locks of hair. The demise of the sanctuary is as obscure as its beginning. None of the published inscriptions date later than the fourth century. Laumonier believes an earthquake may have dealt the final blow, yet the sanctuary had been rebuilt after earthquakes before. More likely a change in interest lay at the root - a Byzantine chapel built from the ruins is recorded among the early investigations of the site..$^{32}$

\section{Data and Sources}

The primary source of information at Panamara are the inscriptions, over 400 of which were found already in the spring of 1886 by Gaston Deschamps and Georges Cousin; they described the hilltop as "white with stelai, as if it had snowed marble" (Figures 6.3 and 6.10). ${ }^{33}$ Over the following years

\footnotetext{
$30 \quad$ I.Stratonikeia 11-12 is the Senatus consultum de Panamara, from 15 August of 39 вс.

31 Tac. Ann. 3.62, quoted in Chapter 5 , note 61.

32 Deschamps and Cousin (1887), 374. An arch from a temple was also found with a cross engraved on it, I.Stratonikeia 168. Laumonier (1958), 222 and 225; see also below under Architecture.

33 A description of their travels in April 1886 is given in Radet (1901), 365-366. On p. 365: "S'ils ne recueillirent, durant le mois suivant, que la menue monnaie des explorations
} 


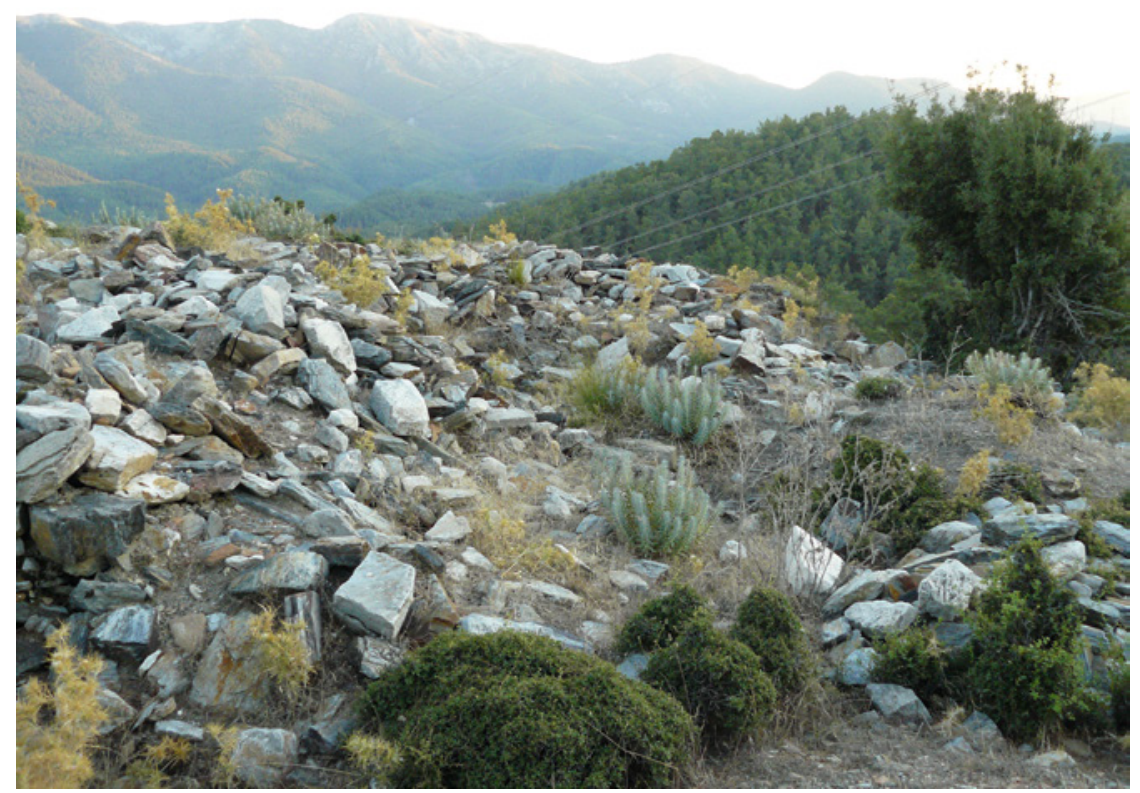

FIGURE 6.3 Panamara. Looking south towards the Gebeneadere valley, with several architectural fragments in the foreground; the Marçat Dağları is in the background

PHOTO AUTHOR 2010

they published many of the inscriptions in the Bulletin de Correspondance Hellénique. ${ }^{34}$ Jean Hatzfeld later visited the site and published the inscriptions which he found in $1927 \cdot{ }^{35}$ Louis Robert stopped at Panamara in 1932, joined by

habituelles, à Baïaca, non loin de Stratonicée, un renseignement donné par le mouhktar, Hadji-Méhémet, leur procura une de ces surprises éclatantes comme il ne s'en était pas vu depuis Le Bas. Leur hôte turc leur ayant dit qu'une jonchée de 'pierres écrit' courronnait le sommet d'un pic voisin, ils escaladèrent le sentier sous sa conduite. Au faîte des rampes, une clairière apparut, toute blanc de stèles, comme si les marbres y eussent neigé. C'était le sanctuaire d'un dieu carien, Zeus Panamaros." The discovery of the 400 inscriptions among the ruins is first mentioned in Cousin and Deschamps (1887), 373ff.

34 E.g. Cousin and Deschamps (1887) on the senatus consultum, and Deschamps and Cousin (1887), on the sacerdotal family of Tiberius Flavius Aeneas; Deschamps and Cousin (1888a-c) on Marcus Sempronius Clemens, ex-votos, and hair dedications, respectively; Deschamps and Cousin (1891) on priesthoods and festivals; and Cousin (1904a) on honorific inscriptions for priests, and Cousin (1904b) on decrees; this collection was complemented by Holleaux (1904) and later. For an overview of the early investigations, see van Bremen (2008), 1406-1407.

Hatzfeld (1927). 


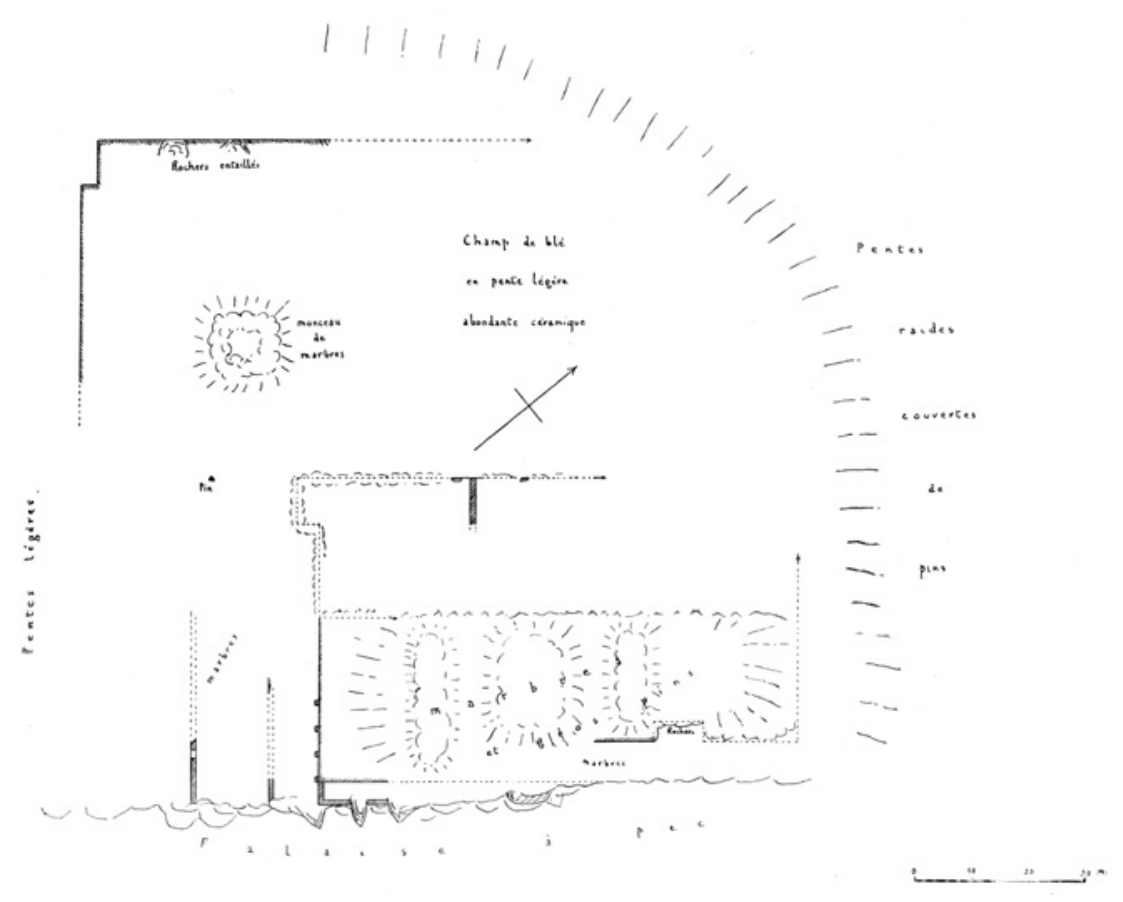

FIGURE 6.4 Sketch by A. Laumonier of the sanctuary at Panamara BCH 60 (1936), PLATE 41

Alfred Laumonier, who revisited the site on his own the next year, investigating the area and taking special notice of the walls. Laumonier published his report in 1936, and the sketch of the sanctuary that he was able to make is still the only plan we have of the site today (Figure 6.4). ${ }^{36}$ Although many wall sections are still in situ, and several architectural fragments and inscriptions that lie scattered across the surface (shown in the figures) bear witness to the centuries of intensive use, a thorough investigation of the hilltop and its context has yet to be conducted. Meanwhile, ongoing illegal diggings threaten the site, and many tombs are now exposed that Laumonier could not have seen in the 1930s (see Figures 6.24-6.26). The wider landscape of the sanctuary fares worse and much of it has already disappeared in the exploitation of lignite, or brown coal, by the Yatağan Power Plant and Güney Ege Linyitleri İşletmesi (GELİ) mining corporation. ${ }^{37}$

36 Laumonier (1936), 324-327, Pl. 41. His analyses of the priestly chronologies at Panamara were published Laumonier (1937) and (1938a).

37 See http://www.yatagantermik.com.tr/en/introduction/maden-direktorlugu. 
While the archaeology of the site has suffered from neglect and opportunists, the inscriptions on the contrary have received a good deal of scholarly attention, including by Alfred Laumonier, and later by Pierre Debord and Riet van Bremen. ${ }^{38}$ They have meanwhile been incorporated by Mehmet Çetin Şahin in the first and third volumes of his Inschriften von Stratonikeia..$^{39}$ Besides the inscriptions, the coinage of Stratonikeia and its depictions of Zeus Panamaros, as well as Hekate, provide another important source of information. Several of these were found in the Muğla hoard and have been re-examined by Andrew Meadows. ${ }^{40}$ Panamara is also now fortunately included in the new impulse of fieldwork in the area around Stratonikeia, under Bilal Söğüt, and Aytekin Büyüközer. ${ }^{41}$ Hopefully this will lead to new discoveries that will challenge the interpretations presented here, as well as promote further protection of the site.

\section{3}

\section{Environment of Panamara}

\subsection{Physical Environment}

Panamara is located nearly 10 kilometers southeast of Stratonikeia (Figures 6.1 and 6.7). The sanctuary is situated on top of a hill known as Asar Tepe, ${ }^{42}$ at a little over $700 \mathrm{~m} \mathrm{ASL}$, which forms the eastern end of a small ridge running southwest-northeast at the northeast end of the Gebeneadere valley (Figures 6.1, 6.5). The hilltop is defined on the northwest by a ravine that separates it from the highlands of the Bencik Dağları and the village of Bağyaka, now abandoned (Figure 6.7). Both ravine and valley empty into the Kapız river in the valley below the eastern side of the hilltop. Beyond the Kapız valley are the Koca Öküz hills which stand between Panamara and the wider Çine (Marsyas) valley (Figure 6.2). The southern side of the Gebeneadere valley is flanked by the Marçat mountains, which run more or less parallel with the Bencik Dağları northwest of the sanctuary. Panamara is thus nestled between the higher peaks of the Bencik and the Marçat ranges. The hills are largely covered in pine trees

38 Debord (2001b) and (2001a), 163-167; van Bremen (2003b), (2004b), and (2008); see also Merkelbach (1968); Drew-Bear and Schwertfeger (1979).

39 Inschriften griechischer Städte aus Kleinasien, Bd. 21 (1981) and Bd. 23 (2010), Bonn.

40 Meadows (2002). The Muğla hoard was initially published in von Aulock (1967); see also above, Chapter 5 , Data and sources.

41 See publications in the series Stratonikeia çalışmaları (2015-) edited by Bilal Söğüt.

42 Mutlu (2015). 


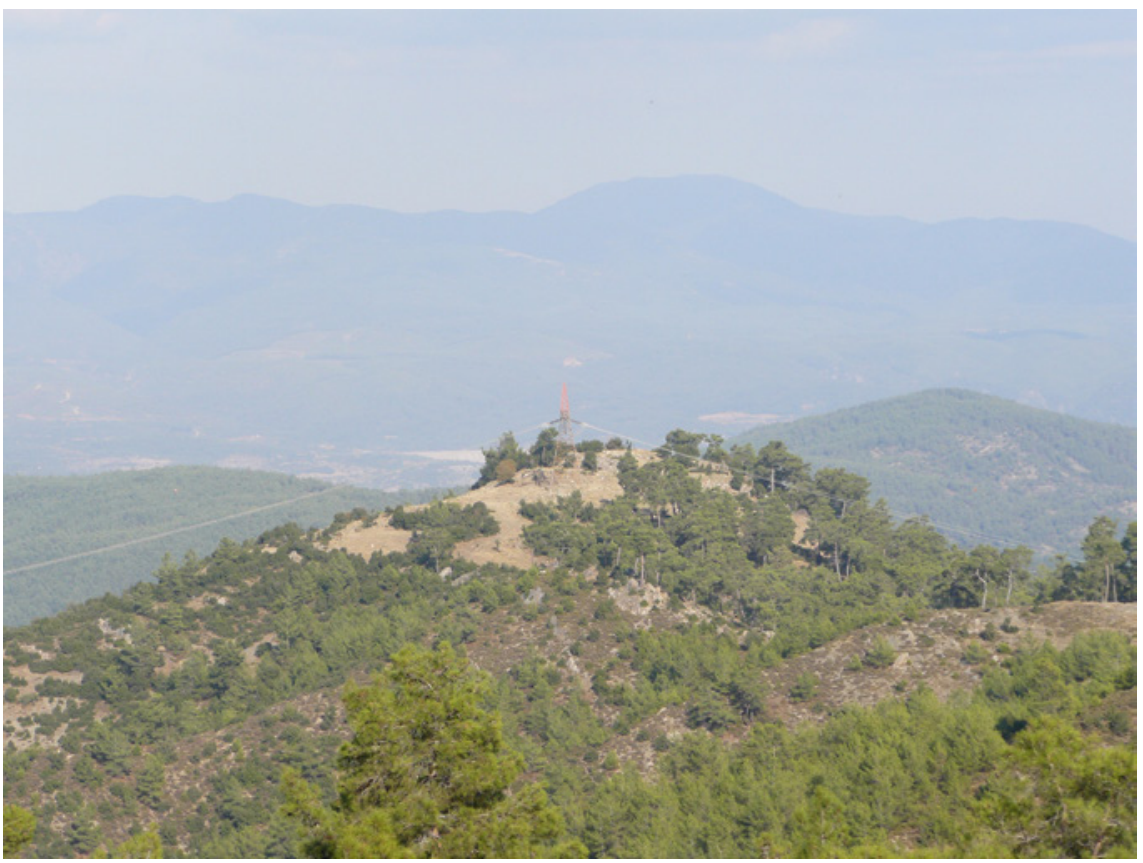

FIGURE 6.5 Panamara. View from the southwest; the sanctuary terraces and temple platform are visible at the top of the hill, to the right of the electricity mast Pното AUTHOR 2011

today, giving an impression of the sacred grove (alsos) that the shrine once possessed (Figure 6.5-6.6). ${ }^{43}$

The hilltop itself is formed of schist, which was used to construct many of the lesser walls within the sanctuary. Several outcrops dot the hillside, protruding in wall-like sections and aligned with the southwest-northeast axis of the length of the ridge. Perhaps these outcroppings, which sparkle in the late afternoon sun, as well as the strategic location, may help explain the location of the cult of this powerful deity on this hilltop.

As mentioned above, the area around Stratonikeia and Panamara is rich in lignite and is under exploitation through explosive strip mining. Although the village of Bağyaka was still inhabited in 2010 (Figure 6.7), in 2011 it had been evacuated, as was the community of Eskihisar at the site of Stratonikeia in the 1970s. The wealth of the natural resources in the area has led to the loss of the

43 The sacred grove at Panamara is mentioned in the Senatus consultum de Panamara as being included in the asylia, I.Stratonikeia 12, lines 15-17:

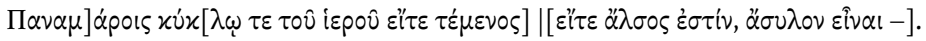




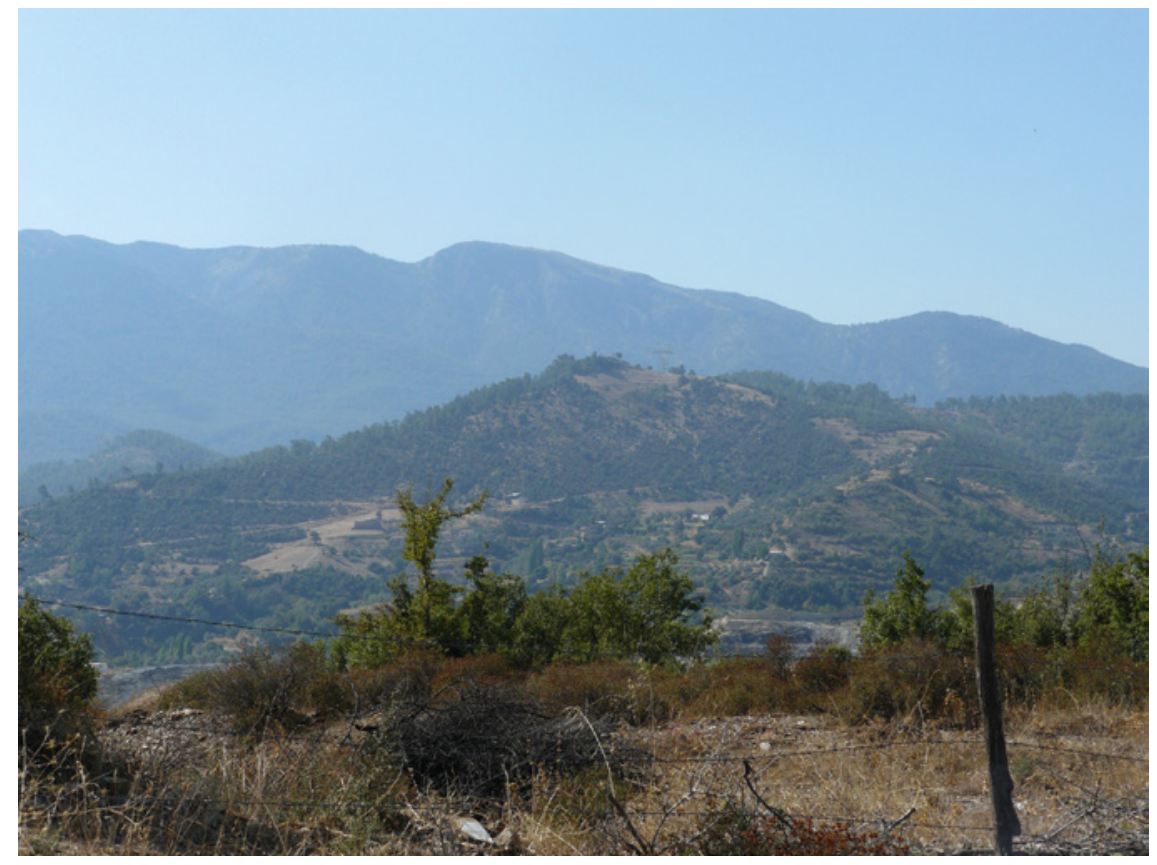

FIGURE 6.6 Panamara. Seen from the north, with the Marçat hills rising in the distance. The electricity mast just to the right of the top marks the northwest corner of the sanctuary PHOTO AUTHOR 2011

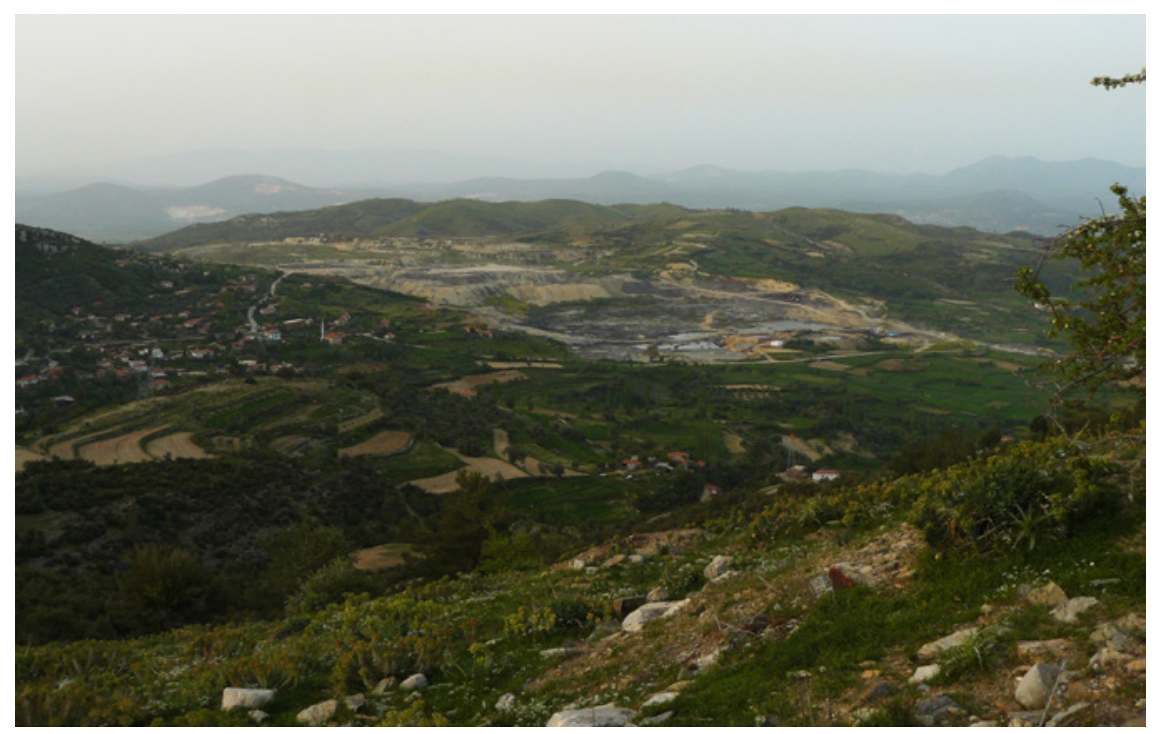

FIGURE 6.7 Panamara. View to the northeast showing the village of Bağyaka to the left before it was given over to the strip mines. The Madranbaba range is just visible in the distance 
archaeological surface record in the vicinity, making it a challenge to understand the integration of the sanctuary within the context of its landscape.

\subsection{Social-Geographical Location}

Panamara is located near the western edge of the Çine or Marsyas valley (Figures 6.1 and 6.2), the main north-south route which today connects Aydın (ancient Tralles) in the Maeander valley with Muğla in the valley and Gökova (ancient Idyma) in the Bay of Keramos, and other points south, via the D550 highway. In antiquity this valley would also have provided access to the towns of Alabanda, Stratonikeia, Pisye, and perhaps Mobolla. ${ }^{44}$ While not directly on this route, the sanctuary strategically oversees much of the surrounding area, as discussed below.

The sanctuary of Zeus Karios at Panamara was the center of the koinon, or community, of the Panamareis, perhaps located on the hill to the north, above Bağyaka, where Laumonier and Şahin each found traces of settlement activity. ${ }^{45}$ This community administered the sanctuary, through very differing political circumstances, until it was entirely absorbed by Stratonikeia. Van Bremen rightly states that "Panamara's location is a key to understanding its history" as the sanctuary is geographically more closely related to southern Karia than to central Karia. ${ }^{46}$ Southern Karia was for some time part of Rhodian territory and the position of Panamara at the edge of this social-political region is, in her view, a prime feature that attracted the interest of Stratonikeia. A number of southern communities were known to be involved with the cult of Zeus Karios at Panamara, prior to the ascension of the polis. The Leukoideis have tentatively been identified through some blocks with inscriptions found at the village of Çırpı in the Marçat mountains, roughly eight kilometers to the south; inscriptions concerning the Londeis were found a little farther to the southeast, at Çiftlik (Figure 6.1). ${ }^{47} \mathrm{~A}$ third community known to have been

44 Mobolla has been identified as the acropolis at modern Muğla, Radet (19o1), 366; Debord and Varinlioğlu (2001), 23-25; but see van Bremen (2004a), 375-377, who is skeptical of this attribution.

45 Laumonier (1936), 324-325, quoted below under Local Community. Şahin in I.Stratonikeia III, p. 13; the exact location, however, is not specified.

46 Van Bremen (2004b), 216.

47 Debord and Varinlioğlu (2001), 139-147 nos. $36^{-38}$ on Leukoideis at Çırpı, and 148-151 nos. 39-40 on Londeis at Çiftlik, where an inscription was found with the dedication of a fountain and nymphaion to Zeus Karios, perhaps of Panamara (no. 39); the map on p. 87 identifies the area between the Marçat mountains and the coast at Akbük as comprising the koinon of the Pisyetai and Pladaseis. See also the discussion on these communities below, under Administration and Priesthoods (in connection with the priesthood of Leon) and under Scope and Network. 
involved with the cult of Zeus at Panamara is that of the Laodikeis; they may have been located along the coast of the Gulf of Keramos, but their settlement has not been identified with any certainty. ${ }^{48}$ The town of Kallipolis, which also worshiped Zeus Karios at Panamara, is believed to be in the hills just across the Bay of Keramos. ${ }^{49}$

By promoting Zeus to one of the city's protective deities, Stratonikeia shifted the focus of the sanctuary north. The trace of the processional road connecting city to sanctuary, however, is largely unknown except for the section closest to the sanctuary, where it is tomb-lined and partly cut from the rock (see below). Alfred Laumonier was able to follow part of the road beyond this to the west, where he believed that it cut across the ravine at a shallower location, and then switched back east, skirting the hill near modern Bağyaka, and apparently connecting to the site which he found higher up on this hill. ${ }^{50}$ The path beyond this is unclear, although it probably crossed through much of the hill country to the north that is now being strip-mined. It is thus impossible with our present knowledge to say how much of a 'spatial continuum' there may have been between the sanctuary and the polis, or what other sites, features or monuments may have served as connecting nodes in between, except for the tombs closer to the sanctuary. ${ }^{51}$ The sanctuary may well have been located near a southern border of Stratonikeia, at least in the second century when the communities to the south appear to have been under Rhodian control.

Further to the west, the Bencik Dağı range eventually connects with the system of hills enclosing the eastern side of the sanctuary of Sinuri, c. 20 kilometers away. The Gebeneadere valley actually forms a kind of canyon-like corridor through the mountains in the direction of the sanctuary of Sinuri, within Mylasan territory; fieldwork would help determine whether there was a road here in antiquity. Yet despite the fact that the sanctuaries of these two deeply Karian gods, Sinuri and Zeus Karios, were contemporary, they were worshiped by distinct communities and no connection between the two is known to have existed. ${ }^{52}$

48 Debord and Varinlioğlu (2001), 212-216 no. 89 (= I.Stratonikeia 1402); on Laodikeia in Karia: Corsten (1995); Ma (1997), Reger (1998); van Bremen (2004a); Şahin in I.Stratonikeia III, p. 13, considers the settlement he discovered just north of the sanctuary as a candidate for Laodikeia.

49 Views on the more exact location of Kallipolis are discussed in I.Rhod.Per. p. 157.

50 Laumonier (1936), 325; the sacred road is discussed in more detail below.

51 On the 'spatial continuum' as a landscape of connecting features, rather than empty space, see Polinskaya (2006), discussed in Chapter 2.

52 The sanctuary at Panamara does however appear in a fragmented section from the thirdcentury decree from Labraunda, by the Chrysaoric League and Ptolemy II, I.Labraunda 44 , line 2. 


\subsection{Visibility}

Panamara's exact situation regarding roads and local communities remains clouded, yet its position in the natural landscape certainly afforded a panoramic view that significantly expanded the visual reach of the polis. As with Lagina, there was no intervisibility between Panamara and Stratonikeia (see Figure 5.6, above). ${ }^{53}$ The countryside in between is very hilly, and the sacred road may have wound through various valleys along the way, as discussed below. Prominent and fortified as it was, the sanctuary would not have been visible upon approach from the polis until one reached the valley where Bağyaka is situated.

On a lower ridge at the end of the Gebeneadere valley between the Bencik Dağı and the Marçat Dağları, Panamara affords a good view to the west, extending to the peaks of the Gübremenladağ, 12 kilometers away (Figure 6.3). To the south, the settlement of the Leukoideis, at Çırpı in the Marçat, may have been visible, although the Londeis, at Çiftlik, were settled further to the southeast. Looking east, a stretch of the Marsyas valley can be seen near Bozarmut, although the Koca Öküz hills obscure much of the valley floor (Figures 6.86.9). Higher up on the eastern side, however, the Oyuklu mountain range is clearly visible. Panamara afforded good intervisibility with the ancient settlement of either Koraia or Lobolda, if this is located near Alaşar, as Debord suggests, ${ }^{54}$ although less so with the area suggested to be Londarga farther north. ${ }^{55}$ Some 40 kilometers well beyond to the northeast, the Madranbaba Dağları, near Hyllarima, crowns the horizon (Figure 6.7). The view north of the sanctuary is quickly met by the foothills of Bencik Dağı that extend to the west, although the peaks of the Gökbel range, beyond Lagina and the Hayırlıdere valley, would be visible on a clear day.

Combined with the natural defensive features of the hilltop, the view was surely of strategic interest to Philip $\mathrm{V}$ and a reason to garrison his troops at the site in 201 BC. $^{56}$ This view would also have been important to Stratonikeia, who had little overview of such features as access routes, economic resources,

53 Figure 5.6 in the previous chapter combines the viewsheds of Stratonikeia, Lagina and Panamara.

54 Debord (1994); also Şahin in I.Stratonikeia III, p. 7 on the location of Koraia at Çatll, between Bozarmut and Alaşar, and p. 8 on Lobolda, for which he can offer no suggestions.

55 The identity of these settlements is discussed in Debord (1994) and Şahin in I.Stratonikeia III, p. 7-8, who suggests the site of Londarga, known from I.Stratonikeia 8, to be at the hill of Akçahisar just east of Kafaca (which is northeast of Lagina), where he saw the ruins of a temple and altar in 1973 .

56 Philip v's use of the sanctuary to station his troops is evident from I.Stratonikeia 3 and 4 , as mentioned above. 


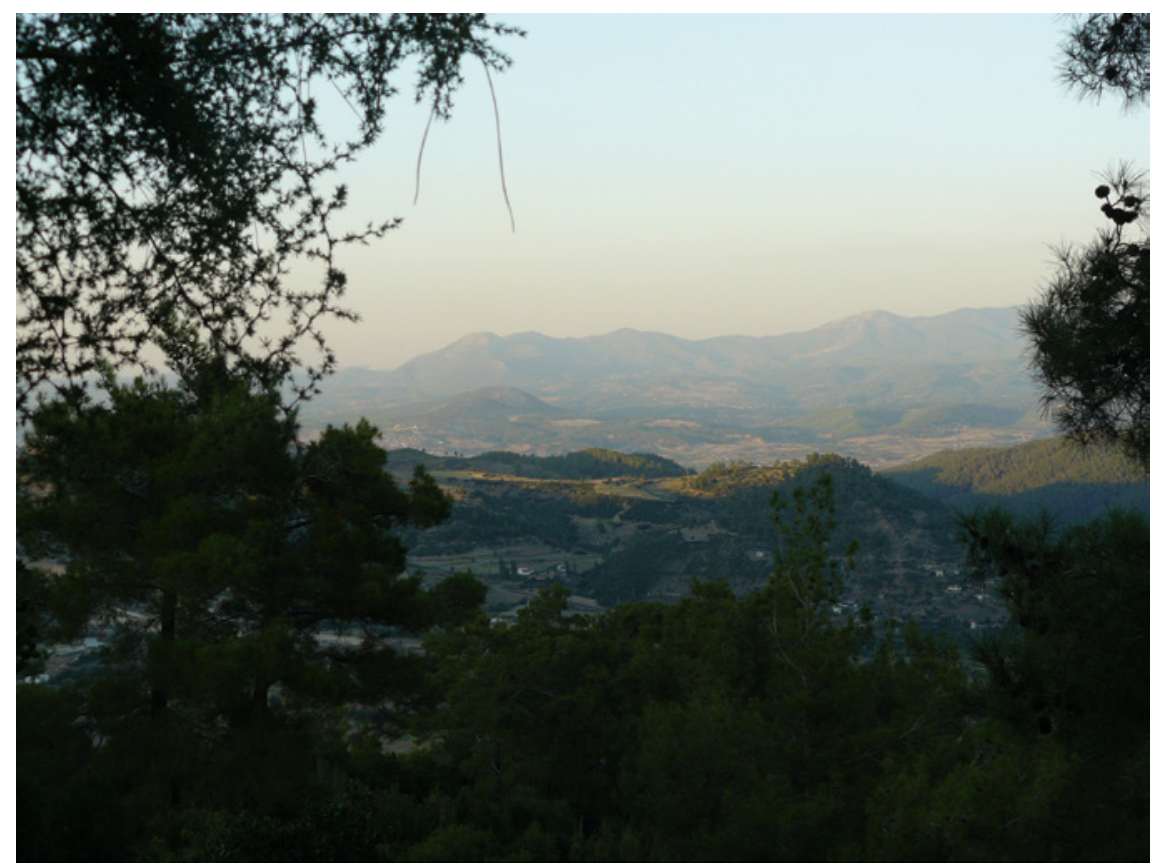

FIGURE 6.8 Panamara. View from the steep east side of the sanctuary. The Koca Öküz hills are in the near foreground, with the Marsyas valley and the southern perimeter of Yatağan (east of Stratonikeia) visible just beyond. In the distance are the northern slopes of the Oyuklu hills РнОTO AUTHOR 2010

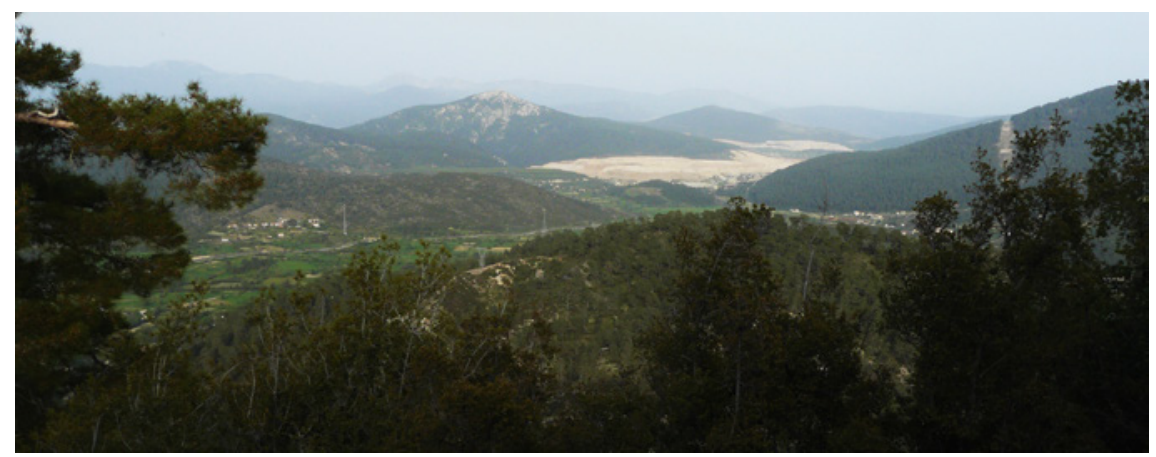

FIGURE 6.9 Panamara. View from the shrine towards the east-southeast. The southern extent of the Koca Öküz is visible in the foreground. The Marsyas valley is on the other side of these (not visible in the picture) with the Oyuklu hills beyond to the left in the far distance

PHOTO AUTHOR 2008 
and boundaries with neighboring communities to the south. Hidden from the urban center, these were prominent features within the viewsheds of Panamara and Lagina, and several were common to both - these sanctuaries thus greatly expanded the scope of vision for the polis. The viewsheds shown in Figure 5.6, in the previous chapter, show several areas of overlap: the Gökbel mountains to the north, the Madranbaba far away to the northeast, sections of the Marsyas valley, and especially the Oyuklu mountain range east of this valley, all areas that merit further scrutiny. This last area is of particular interest as these highlands offer a series of vantage points that encompass not only both sanctuaries, but the urban town center as well, all three of which were blocked from direct visual contact with one another. The settlement on the hill above Bağyaka may in fact have acted as a hinge, connecting the view towards Stratonikeia with the view over Panamara; ${ }^{57}$ this settlement was probably contemporary with the sanctuary, but has not yet been archaeologically investigated.

The overlap in the viewsheds of Lagina and Panamara, at 15 to 20 kilometers away, would not have been distinctive enough to identify specific features, but they clearly expanded the visual region of the polis to include among others much of this lower section of the Marsyas valley. ${ }^{58}$ The area would also have been understood to be Stratonikeian, due to the many associations already transmitted through coins, legends, festivals, the loud processions that must have reverberated through the valley, as well as the smoke rising from the sacrifices. Besides vision, all of the senses would have been engaged in acknowledging Stratonikeian presence in this part of the region; territorial shaping here was clearly accompanied by symbolic shaping through the use of cult, as will be discussed more in the next section on the urban integration of the cult into the polis.

\section{Signs of Urban Integration at Panamara}

The sanctuary of Zeus Karios underwent a number of changes as it was accommodated to suit the needs of the polis. Although the bulk of the information is provided by inscriptions, most of which date from the imperial period, there is nonetheless sufficient data to trace back many of the changes to the second and first centuries ВС as the cult changed hands from the koinon of the Panamareis to the polis of Stratonikeia. From a hilltop god worshiped

57 Laumonier (1936), 324-325, cited below under Local Community.

$5^{8}$ See Chapter 2 on visual regions. 
by dispersed communities in the wider parts of southern Karia, Zeus Karios became a poliad deity, focused on the people and politics of Stratonikeia to the north. This transition eventually had a profound impact on the nature of the cult and its community. The changes that took place, from the early involvement of Stratonikeia in the second century BC, and the potential of the cult regarding territorial expansion, through to the imperial period, show how the focus of the cult came to be fully fixed onto the polis and its social composition. By this period, Panamara had become a counterpart to Lagina through its institutions, and political use to gain external recognition, but especially to build social cohesion.

\subsection{Monumental and Ritual Space at Panamara}

Although the ruined state of the sanctuary leaves little to say about the use of concentric and linear space, there are nonetheless several indications that the sanctuary was heavily monumentalized with prestigious architecture (Figure 6.10). This trend was initiated by the koinon of the Panamareis, who administered the cult until the sanctuary was eventually absorbed by

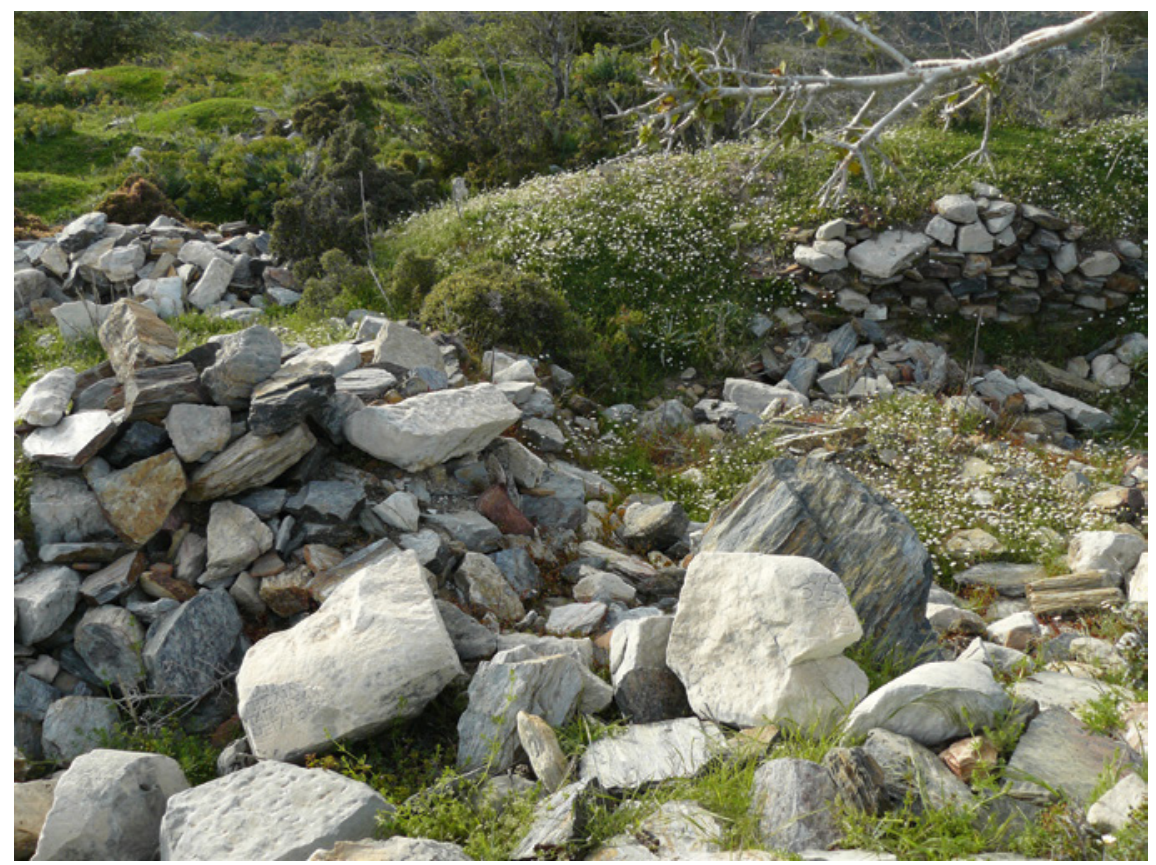

FIGURE 6.10 Panamara. View of the top showing schist walls with mounds of marble and schist blocks. The white marble block to the left in the foreground is a remaining fragment of I.Stratonikeia $257 \mathrm{~b}$, a priestly inscription from the later second century AD РнОTO AUTHOR 2008 
Stratonikeia. Inscriptions point to a major aggrandizement of ritual structures and facilities in the imperial period. The sacred way played an important role and shows some parallels with the sacred road from Mylasa to Labraunda.

\subsubsection{Architecture}

Panamara is described in the second century вс by the citizens of Kallipolis as 'the most prominent sanctuary', no doubt due to its location and regional festivals, but also its monumentality at the time. ${ }^{59}$ Although our appreciation of its architectural layout and development is heavily clouded, the sanctuary of Zeus is nonetheless assumed to have held at least one monumental temple and a bulwark of robust precinct walls by the end of the third century BC when Philip v occupied the sanctuary. Inscriptions mention a door jamb (parastas) which in all likelihood is from the temple, and the walls which were rebuilt after an earthquake. 60

Probably sometime after the hilltop sanctuary was absorbed by the polis, Hera was added to the cult and received a temple of her own, as is evident by the record of its attack by Labienus's troops in the first century вс. ${ }^{61}$ Since it was targeted separately, it was probably located at a distance from the temple of Zeus, perhaps in a more vulnerable spot, possibly near the cliff's edge as the attackers used ladders to get to it. ${ }^{62}$ Little else is known of the temples, although a comparison of architectural details with that of Lagina and Stratonikeia would surely give a better indication of their chronology and wider context within the building program of the polis.

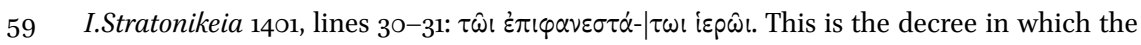
Kallipolitai praise Stratonikeia for appointing Leon to the sanctuary, discussed further below.

6o I.Stratonikeia 3 is an honorific decree for Philip v, dated to $201 \mathrm{BC}$; line 12 specifies that

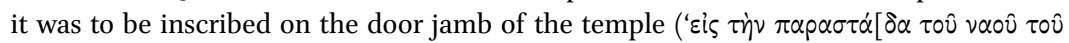
$\Delta i o ̀ \varsigma)$, as the restored transcription indicates. I.Stratonikeia 4 is an honorific decree for Asklepiades of Peuma, appointed by Philip v as security commander of the place: [ $\dot{\alpha} \pi 0-$

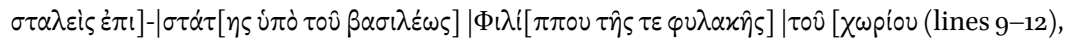

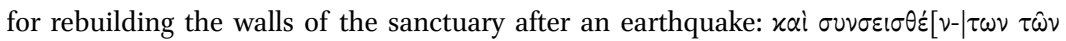

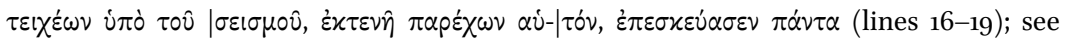
Holleaux (1904), 358-359, on earthquakes and warfare in the region. Van Bremen infers from these inscriptions that the temple and temenos wall must have existed even before the foundation of Stratonikeia in the third century BC, perhaps even going back to the fourth century BC; van Bremen (2004b), 215-216 and (2008), 1409-1411. The walls have not been subject to study but the sections now visible (Figures 6.10-6.14) give no indication of the header-and-stretcher technique characteristic of Hekatomnid construction of the fourth century вС.

$61 \quad$ I.Stratonikeia 10 , lines $25^{-26}$ mention the attack on the temple of Hera.

$62 \quad$ I.Stratonikeia 1o, line 28. 
Inscriptions, however, yield insight into the buildings, especially in the first centuries of the imperial period. One depicts the temple of Hera being 'dedicated' (anetheken) by a certain Posittos, son of Apellos, of Hierokome, who had served as priest but was now neokoros. ${ }^{63}$ More likely Posittos restored the temple (after the attacks?) since this is mentioned in a second inscription in the context of his construction and restoration of several other structures at the sanctuary, including a vaulted structure (psalis), porches (pastades), a safe for the key (kleidophylakion), two doorways worked with marble, and a marble enclosure (endomesis), another building (oikodomia) as well as supporting structures, a roof, and other features in wood - all of which were dedicated to Zeus Karios, Hera and the demos. ${ }^{64}$

Other structures known via inscriptions to have been erected on the hilltop or in the area in the imperial period include a shrine or altar to Artemis of Panamara and other deities, ${ }^{65}$ a third temple erected by Claudius Theophanes in the first century AD, which was associated with the imperial cult. ${ }^{66}$ There was also a fountain called 'Parthenike', ${ }^{67}$ different dining facilities (philotrophion, aristeterion), a magazine for storage (apotheke), as well as houses, stoas,

63 I.Stratonikeia 113 is the honorific decree for Posittos, for building and dedicating the tem-

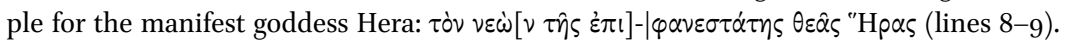
This inscription and I.Stratonikeia 112 are dated to the late first century вС or early first century AD.

64 I.Stratonikeia 112 is the building inscription, on an Ionic entablature, which Hatzfeld believed belonged to Hera's temple, Hatzfeld (1927), 79-81, no. 28, listing the many structures which he provided for the sanctuary, also in Laumonier (1958), 224. I.Stratonikeia

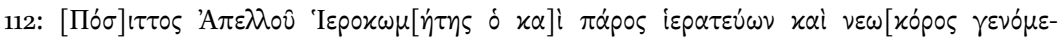

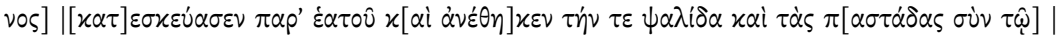

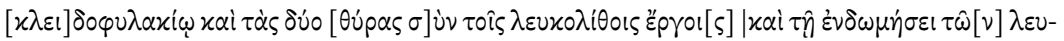

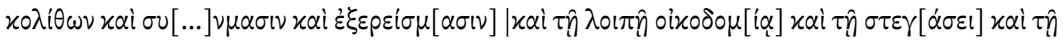

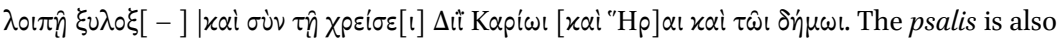
mentioned in I.Stratonikeia 17 , line 19, from the second or third century AD, in connection with a sleeping chamber (koiton). Later second and perhaps third century AD dedications inside the temple of Hera are mentioned in I.Stratonikeia 200 (plaster resurfacing, by priest Titus Flavius Aeneas) and I.Stratonikeia 281 (mosaic work in the naos and pronaos of the temple, by priest Kleoboulos), discussed in Laumonier (1958), 224.

65 I.Stratonikeia 251 speaks of a foundation or shrine for the cult of Artemis of Panamara, $\tau \hat{\eta} \varsigma$

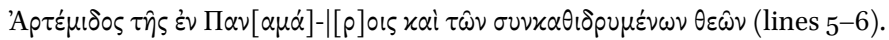

66 I.Stratonikeia 168 ; the dedication is reported in Hatzfeld $1927,82-83$, no. 31, to be on an arch which also bore a cross, the temple may have been converted into a chapel in the Byzantine period.

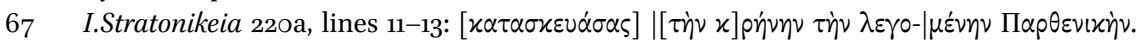
The fountain was dedicated by the priestly pair Flavius Eudemos Korazeus and Flavia Heraeis in the first century AD. 
workshops, and more. ${ }^{68}$ Places for spending the night in the area (kataluseis) are also mentioned in the later imperial period. ${ }^{69}$ One should also imagine non-permanent structures such as tents (skenai) which were known to be erected during the festivities, at least in the second century $\mathrm{AD},{ }^{70}$ along with the general areas for encampment (stratopeda).${ }^{71} \mathrm{All}$ in all, the image emerging from the epigraphic data is a well-known regional sanctuary that was increasingly outfitted with structures to accommodate a sizeable crowd over a period of days.

The complex at Panamara was obviously very impressive, even though little of its splendor is left to be seen on the hill south of Bağyaka. The sheer quantities of ceramics, including tableware, storage vessels, roof tiles, and architectural fragments, in marble but also local schist, as well as the many inscriptions that still lie scattered about, underscore the over six centuries of intensive use of this hilltop sanctuary. In 1933 Alfred Laumonier recorded several stretches of walls around the highest part of the hill at Panamara and interpreted them as the precinct walls of the temenos, enclosing an area of roughly $100 \times 85 \mathrm{~m}$ and oriented south-southwest by north-northeast (Figure 6.4)..$^{72}$ Many of these walls are still visible today (Figures 6.11-6.15).

Laumonier further identified the center of the sanctuary, and the temple, at the steep cliff at the eastern end, where several piles of marble blocks indicated

68 Philotrophion: I.Stratonikeia 267; aristeterion: I.Stratonikeia 17 and 270; apotheke: I.Stratonikeia 144; stoas: I.Stratonikeia 111 (also dedicating an ergasteria (workshop)), 226, 267 , and mentioned in 281 and 310 . See also Laumonier (1958), 224-226. A colorful, if fanciful, depiction is given in MacMullen (1981), 46-48, who laments the lack of academic attention given to the magnificent complex. I wholeheartedly agree.

69 Kataluseis, or lodgings, appear in I.Stratonikeia 248 , line 3, third century AD. Laumonier associates these with some ruins near the road in the Bağyaka valley, Laumonier (1936), 327 .

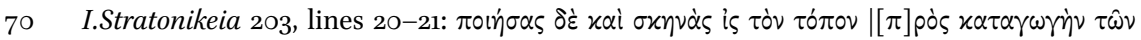
$\dot{\alpha} \nu \rho \omega \omega \dot{ } \pi \omega v$; dated to AD 164/166, the time of Marcus Aurelius. See also the skenas at Olympia, mentioned in the comedy Heniokhos PCG fr. 5. 7-8, used to accommodate the theoroi (with an intentional pun on the theatrical skene), quoted in Kowalzig (2007a), 41.

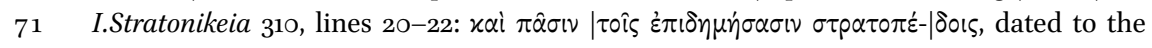
early fourth century AD.

72 Laumonier (1936), 324-327 on the description and layout of Panamara, with a sketch on Plate 41. The hilltop is extremely disturbed and although I discovered several sections of walls, I was unable to verify much of Laumonier's interpretation in my two short visits in 2008 and 2010. Since then several features have been exposed, including a number of schist walls, and especially the tombs discussed below. Laumonier's north arrow may also be off by a few degrees west compared with Google Earth, although the satellite images themselves are not accurately georeferenced for this area. Also, his measurements were probably taken on the ground crossing the steep hillside - an actual plan may appear narrower. 


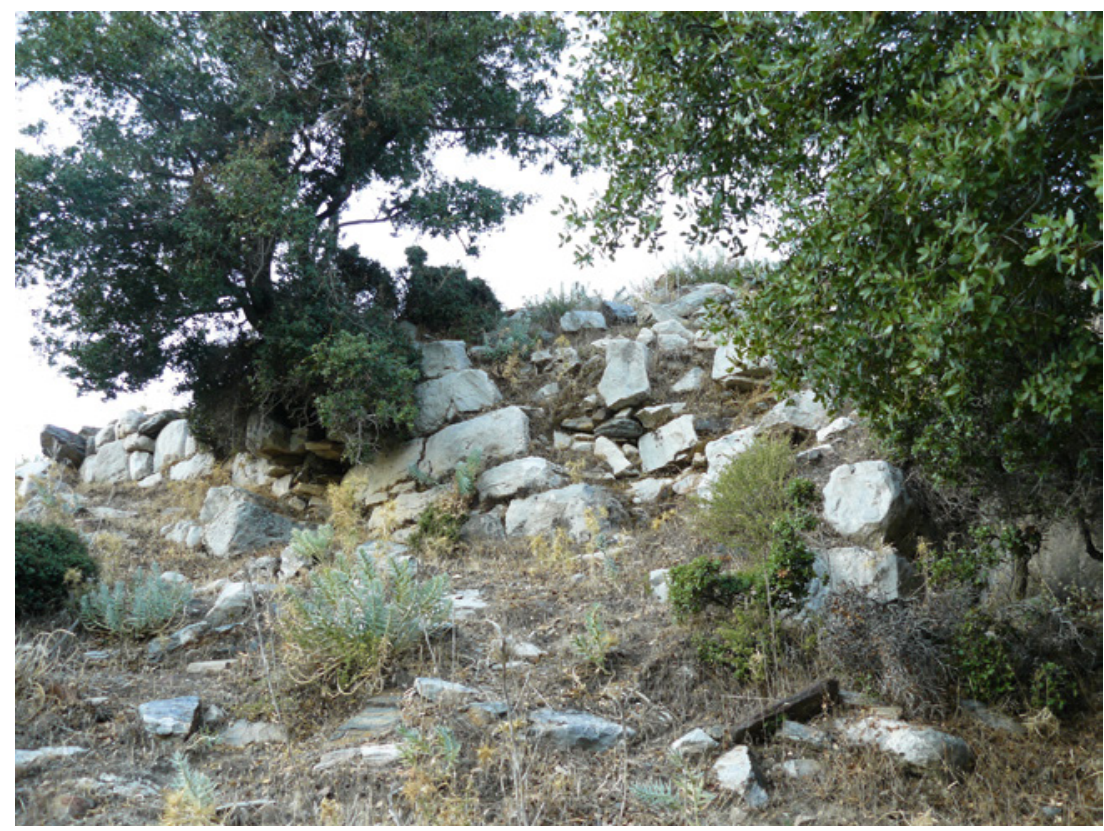

FIGURE 6.11 Panamara. Rustic orthogonal wall at the southwest corner of the temenos PHOTO AUTHOR 2010

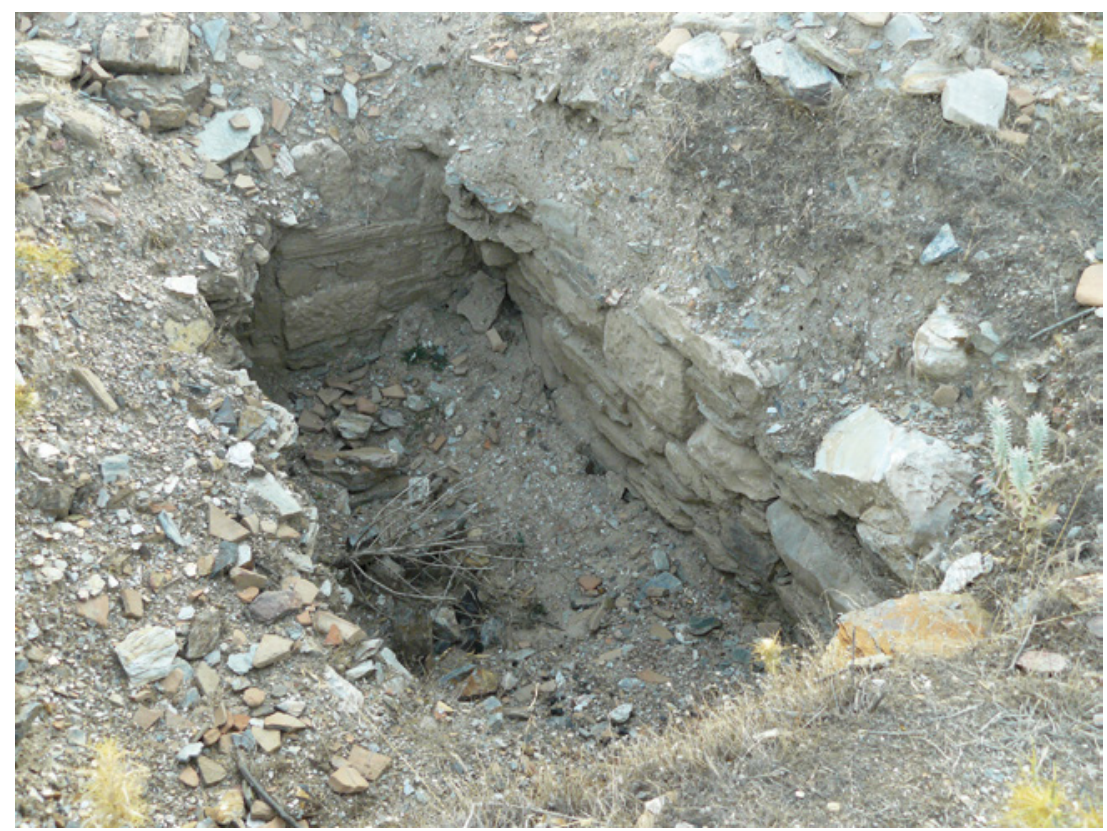

FIGURE 6.12 Panamara. Exposed schist and ashlar walls with fragments of amphora and tile РнОто AUTHOR 2010 


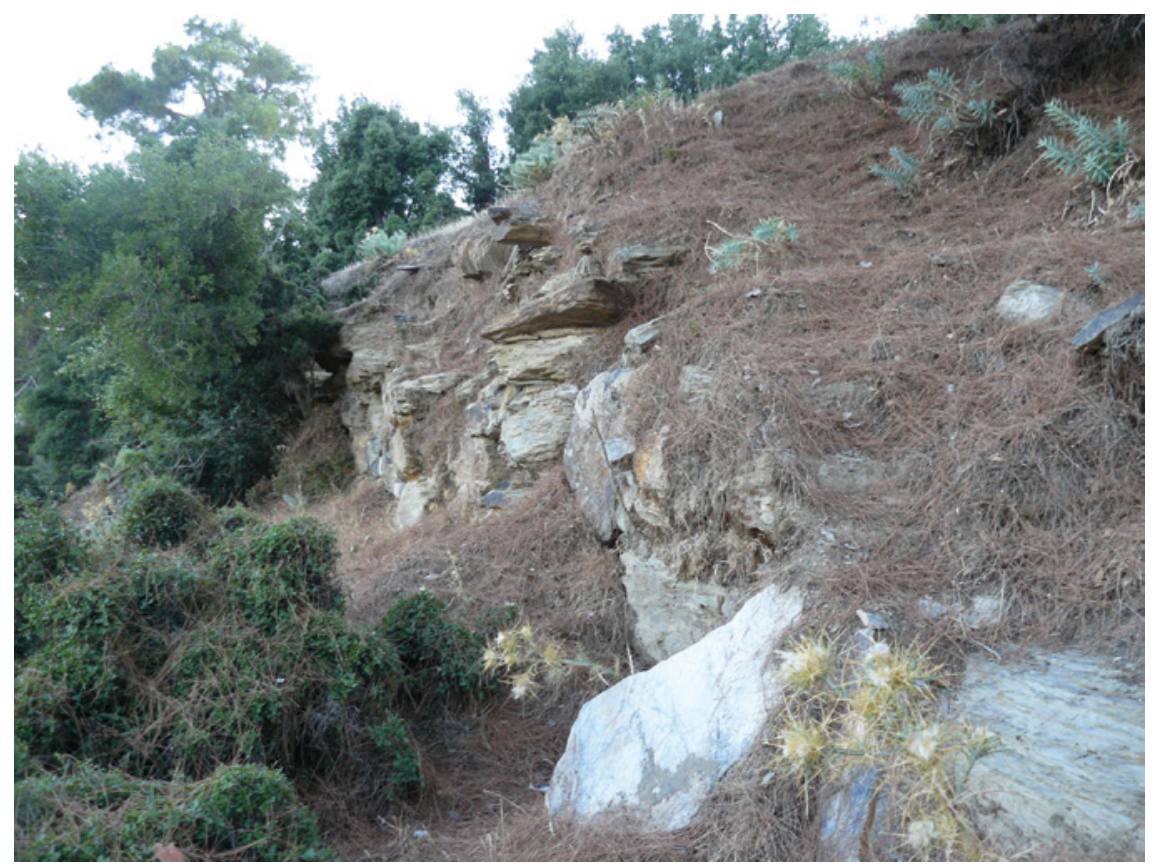

FIGURE 6.13 Panamara. Rock and schist wall along the northeastern perimeter PHOTO AUTHOR 2010

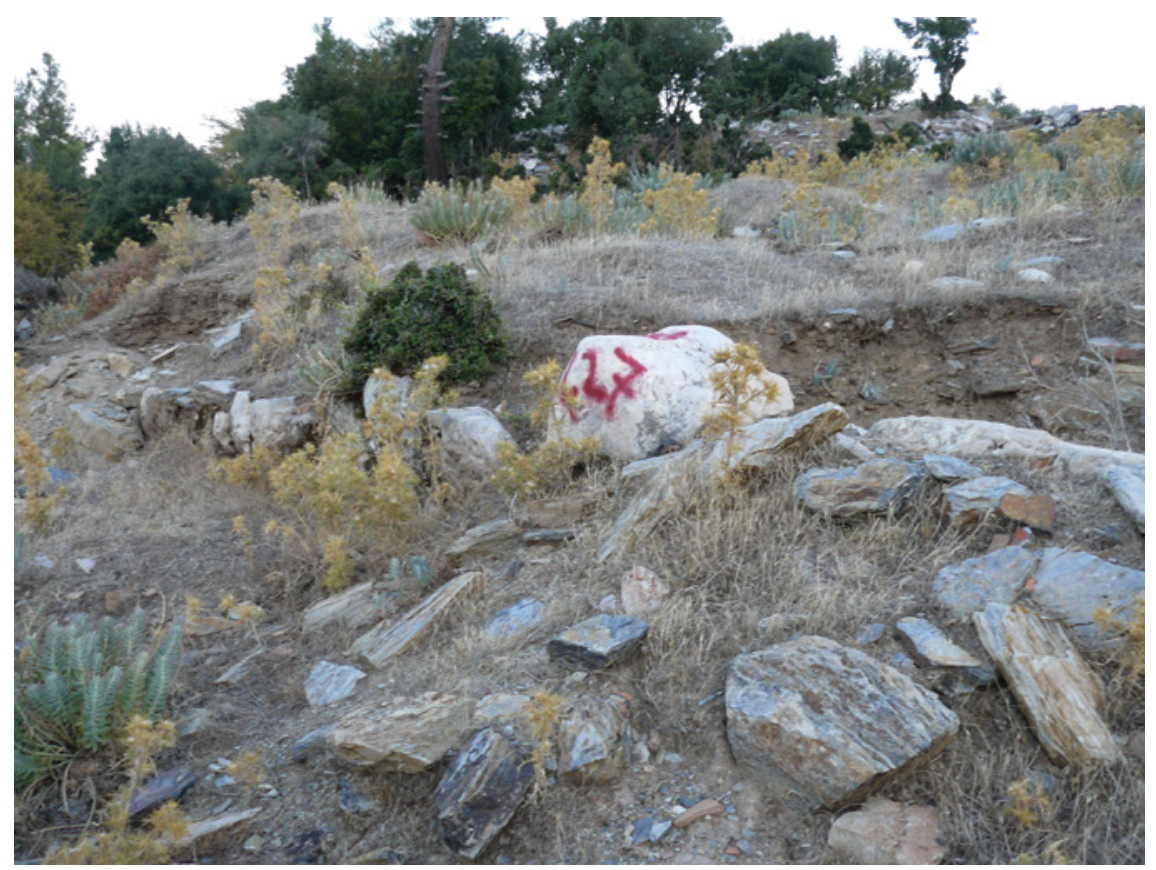

FIGURE 6.14 Panamara, north side. Exposed section of the north temenos wall PHOTO AUTHOR 2010 


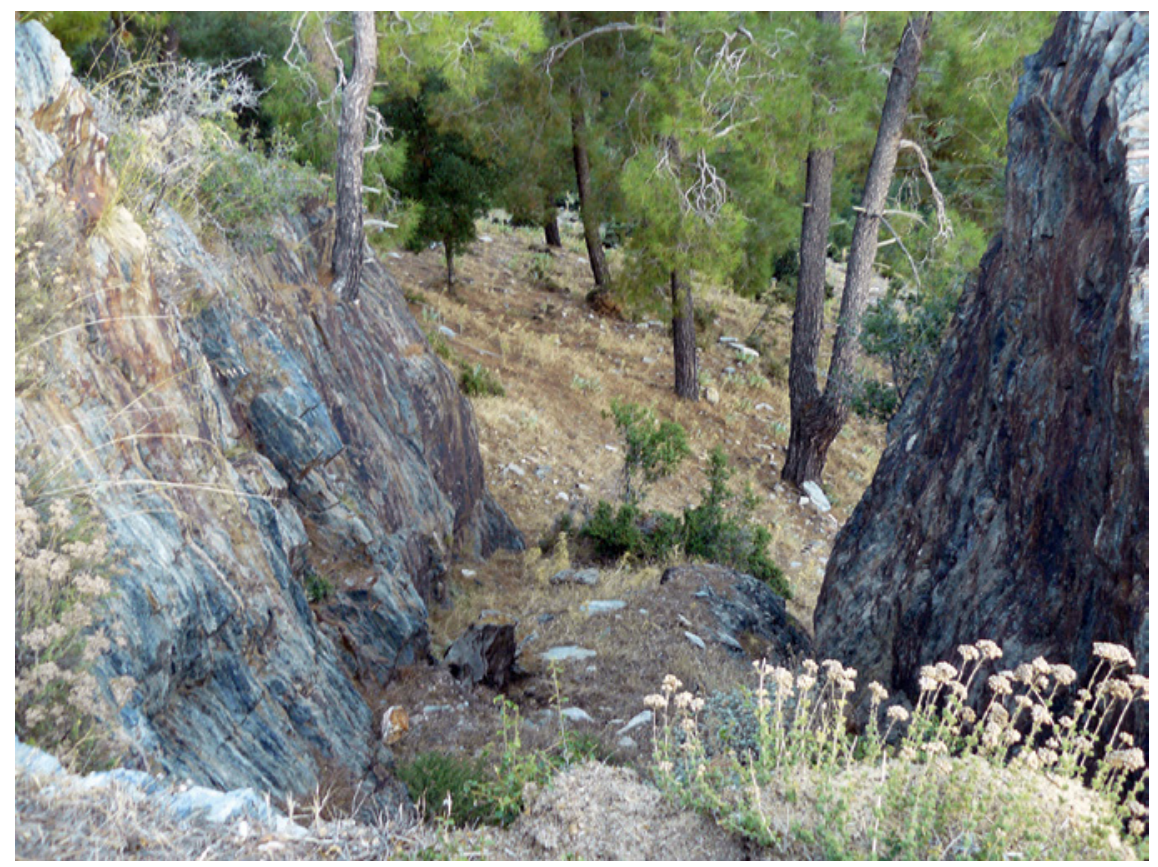

FIGURE 6.15 Panamara. Escarpment along the steep southeast edge of the hilltop PHOTO AUTHOR 2010

an elongated enclosure (Figures 6.16 and 6.17), stretching $50 \mathrm{~m}$ along the walls of the southeast escarpment. The thick outer wall on this side was adjoined by five 'contreforts', or buttresses, and Laumonier described the complex as having the appearance of a terraced fortress. ${ }^{73}$ In the western corner of the temenos was an isolated quadrangular structure, roughly $10 \mathrm{~m}$ long, with another pile of marble blocks which he tentatively identified as the altar. ${ }^{74}$ If this is the case, then the temples which he locates at the eastern end near the escarpment would have faced west, i.e. southwest, assuming they faced the altar. The level area just north of the complex, the 'champ de ble', or wheat field, open and free of stones, may well have been the gathering place for the processions, festivals, and games; this is at a natural point of access to the sanctuary from the sacred road (Figures 6.18-6.19).

73 Laumonier (1936), 325: “... l'ensemble du sanctuaire devait présenter l'apparence d'une forteresse à étages," see also Laumonier (1958), 223.

74 I.Stratonikeia $1413 \mathrm{~A}$ (=EA 41 (2008), no. 12A) is a fragmented inscription of a prohibition, which Şahin dates to the Hellenistic period and believes to come from the corner wall of a monumental "court-altar." 


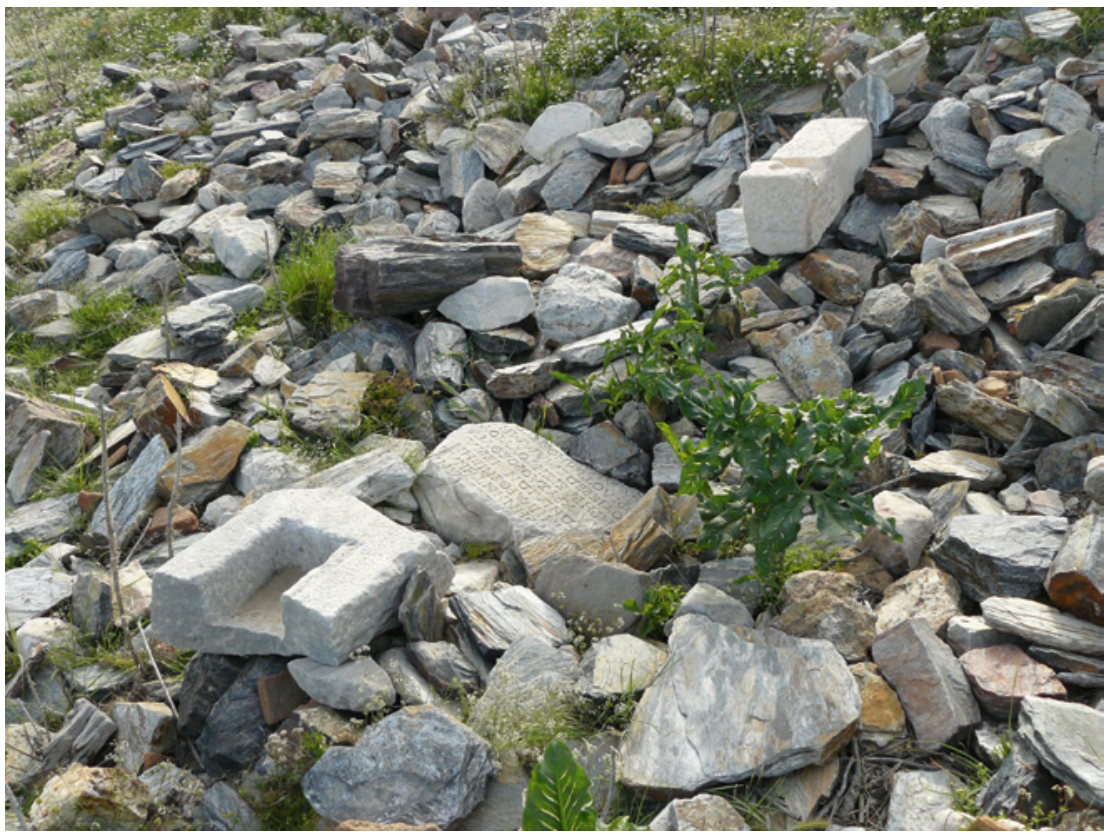

FIGURE 6.16 Panamara. Hilltop with scattered architectural fragments, ceramics, a coffer, and roughly in the center the lower part of the inscription I.Stratonikeia 220a, now further broken

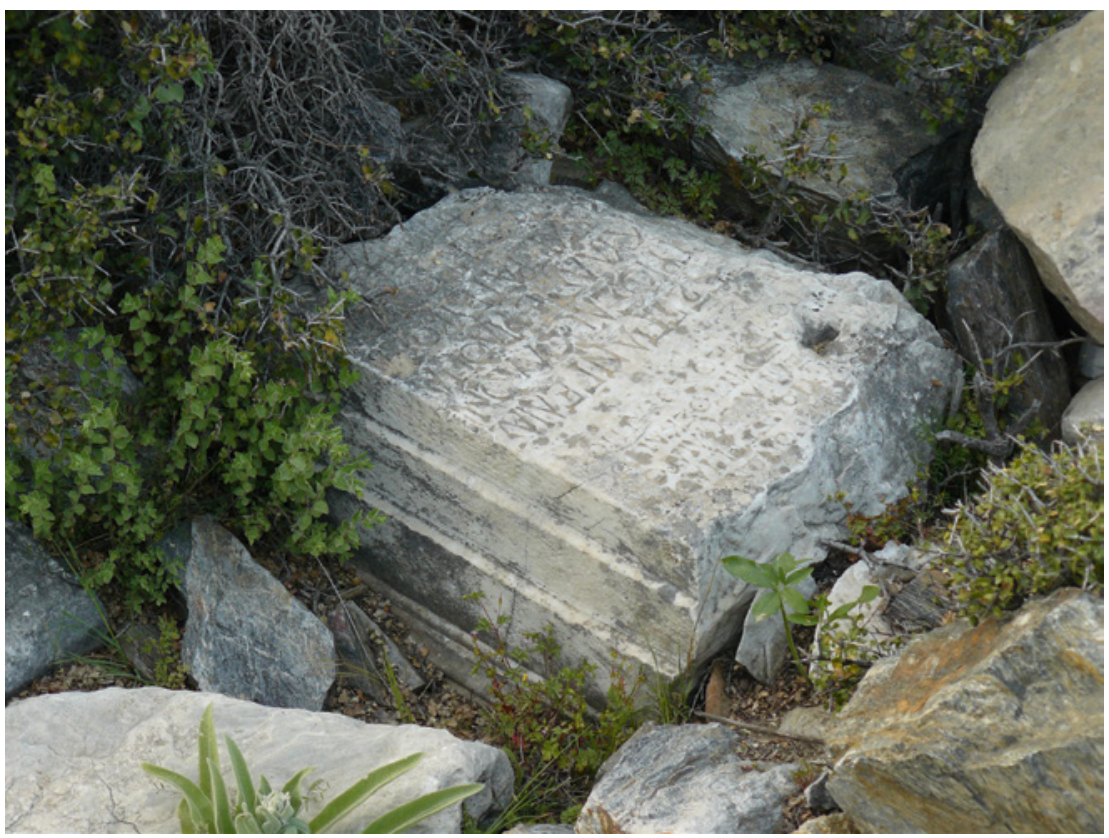

FIGURE 6.17 Panamara. Door jamb (?) fragment with two priestly inscriptions from the Imperial period, I.Stratonikeia 240 and 253, now broken at the top 


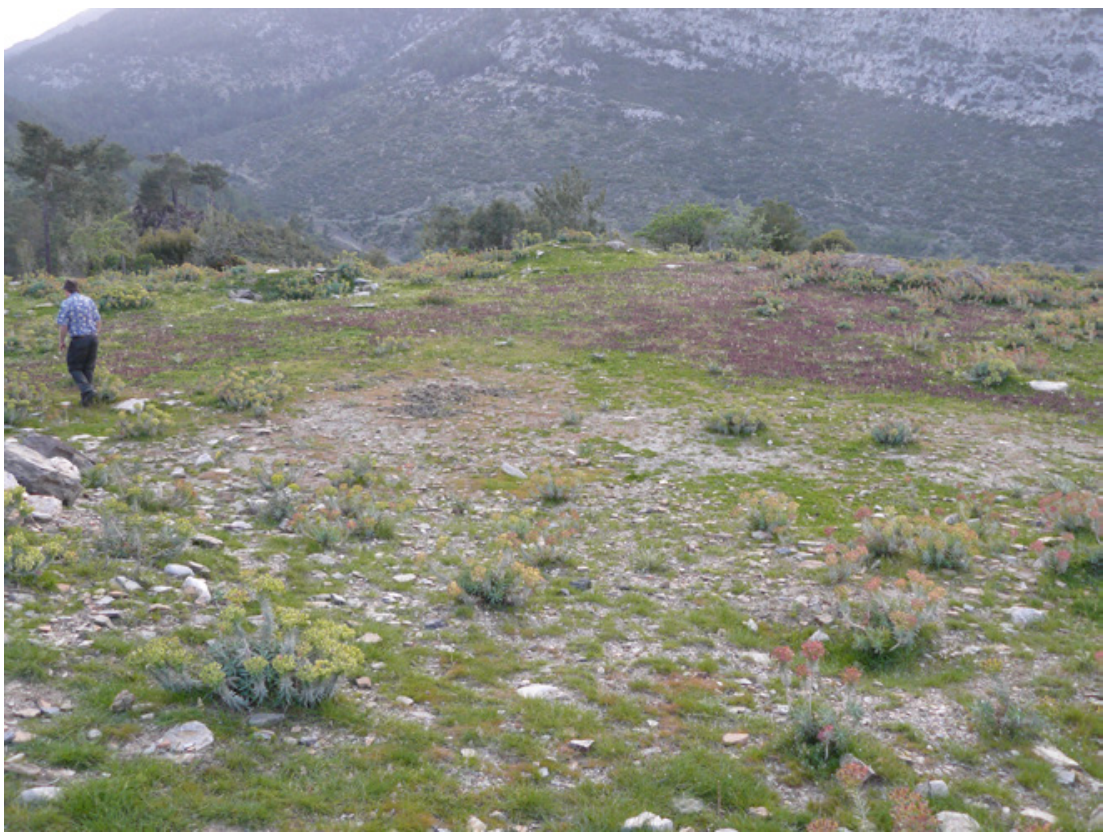

FIGURE 6.18 Panamara and the large terraced area at the northern part of the sanctuary. In the background is the Bencik Dağ PHOTO AUTHOR 2008

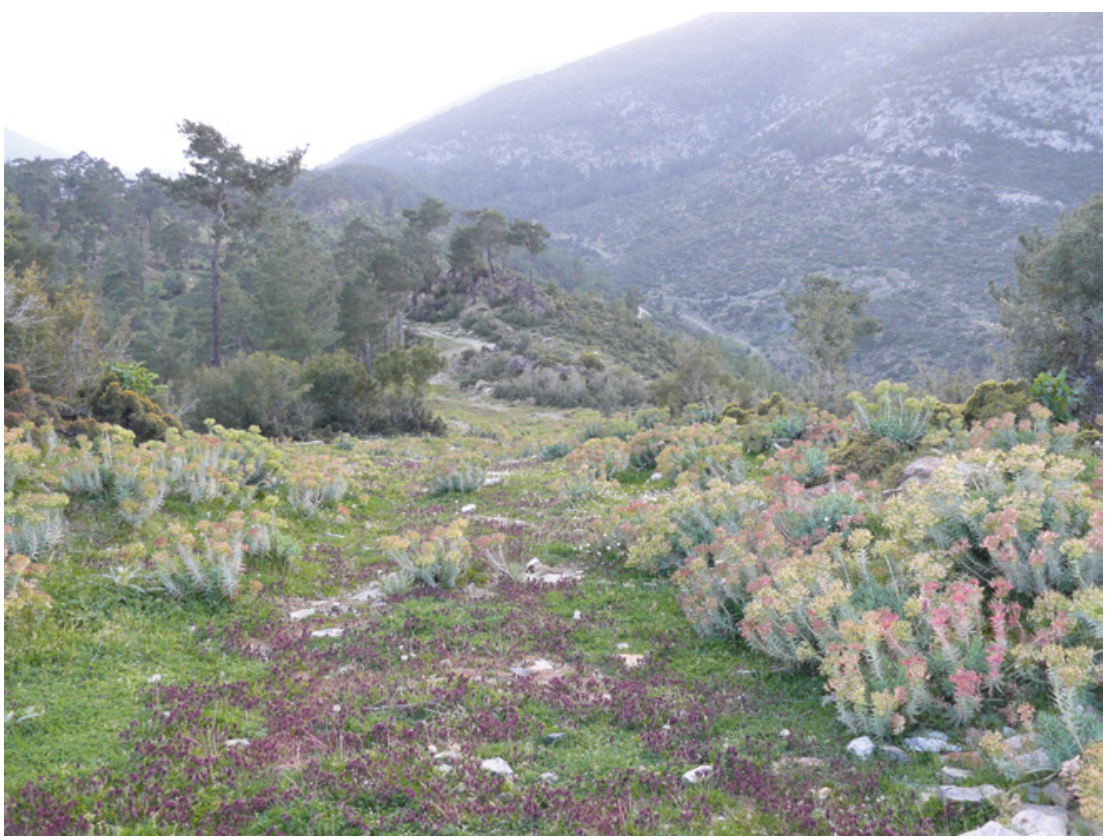

FIGURE 6.19 Panamara. Sacred road leading to the large terraced area PHOTO AUTHOR 2008 
Although a great deal of the sanctuary has been destroyed, the remaining rubble supports the picture given by the inscriptions of a gradual change at Panamara from a robust sanctuary built by a local community at a strategic site, to a grand urban complex with a number of temples in gleaming white marble. Even if the range of its visibility was not as extensive as that of Lagina, the marble temples perched at the eastern edge of the hilltop surely would have been a striking landmark, foregrounding Panamara in the mind's eye of the surrounding communities and especially of the Stratonikeians.

\subsubsection{Public Space - Concentric and Linear}

Due to the current state of the hilltop shrine, we can only speculate as to how public space was shaped and manipulated, with inscriptions as our best source. Laumonier's plan of the sanctuary gives a plausible location of the temenos walls and his identification of one or more temples near the eastern edge is probably correct, but beyond this it is difficult to label any other features with certainty; the 'monceau de marbres' on his plan (Figure 6.4) may well have been an altar, as he suggests, but it could also be the remains of one of the many other structures that are known to have existed at the sanctuary. The site today is unfortunately much more disturbed than when he visited it in the 1930s, precluding any further interpretations based on informal surface investigations. The space at Panamara may or may not have been as clearly articulated as at Lagina, but the number of structures, at least in the imperial period, imply that it was just as well equipped, if not better. Rather than being designed at once, however, inscriptions inform us that the sanctuary developed over time and we can only assume that the additional temples, and especially the stoas or other enclosures (e.g. endomesis, philotrophion), and other structures were arranged to create some kind of logical internal area that would have worked as a concentric space for the whole population of the Stratonikeians, who regularly came out to the festivals at the sanctuary. The sacrifices would surely have formed a focal point, as well as the mysteries that appear in inscriptions from the late second or third centuries AD. ${ }^{75}$

Whether linear space was visually put to work through 'framing' or emphasizing sightlines, or the extent to which the view from the sanctuary was employed in its spatial arrangement, as at Labraunda or Lagina, is impossible to say with the present state of knowledge. Linear space was however used to

\footnotetext{
75 Panamara may well have possessed some arrangement for spectators, as assumed in Nielsen (2002), 139, although there is no evidence of a theatron. On the mysteries at Panamara, see below under Festivals and Administration and Priesthoods for the position of the mystagogos.
} 
physically connect the sanctuary to the city through the processional route known from the epigraphic evidence. ${ }^{76}$

\subsubsection{Sacred Road}

The sacred road leading from Stratonikeia would have passed through one of the city gates, probably in the southern flank of the city wall. The rest of its course through the hills is unknown, although if it took the shortest route it would have passed through the valley now exploited for brown coal. Figure 6.1 at the start of this chapter shows a possible trajectory of the processional route that connected the shrine with the urban center. The last section of the road is more secure. Some stretches leading to the sanctuary were discovered by Laumonier during his travels in $1933 .{ }^{77}$ One section, roughly three meters wide, continued for over a half a kilometer close to the ravine that separates the hilltop from the Bencik mountain to the northwest. The sacred road may have passed first along the north side of the ravine near Bağyaka, continuing southwest until it could be crossed. From here it switched back towards the northeast, climbing up at a gentler angle to the hilltop and to the heart of the sanctuary.

Parts of it were terraced, as may be seen in Figure 6.20, other parts were cut from the rock to facilitate smooth passage. At the lower part of the hill are some tombs and perhaps some structures cut from schist that might indicate some kind of occupation - possibly some of the ruins that Laumonier saw lining the road to Bağyaka (Figure 6.1). ${ }^{78}$

The sacred road thus approached the sanctuary from the western side, following the northern crest of the hill (Figures 6.20-6.23). As at Labraunda, tombs lined the section close to the shrine, cut into the rock and occasionally built up (Figures 6.24-6.25). Although we may never know their exact chronology or to whom they belonged - whether these were local residents, the Stratonikeians from town, or perhaps even the earlier Panamareis - they are an additional testimony to the sanctity of the site and its thorough integration with the community. ${ }^{79}$ On the western side of the hill very close to the sanctuary, and just south of the open terraced area, is a large electricity mast. The construction work for this may have been what initially exposed several marble blocks in situ, but illicit excavations in the following years exposed a doorway

76 The procession is described for example in I.Stratonikeia 266 ; see below.

77 Laumonier (1936), 325, in which he describes traces of a road he tracked from an ancient settlement on the hills above and west of Bağyaka. This is discussed in detail below, under Local Community.

78 Laumonier (1936), 327, suggesting these may have belonged to the 'lodgings' mentioned in I.Stratonikeia 248.

79 See further below under Local Community. 


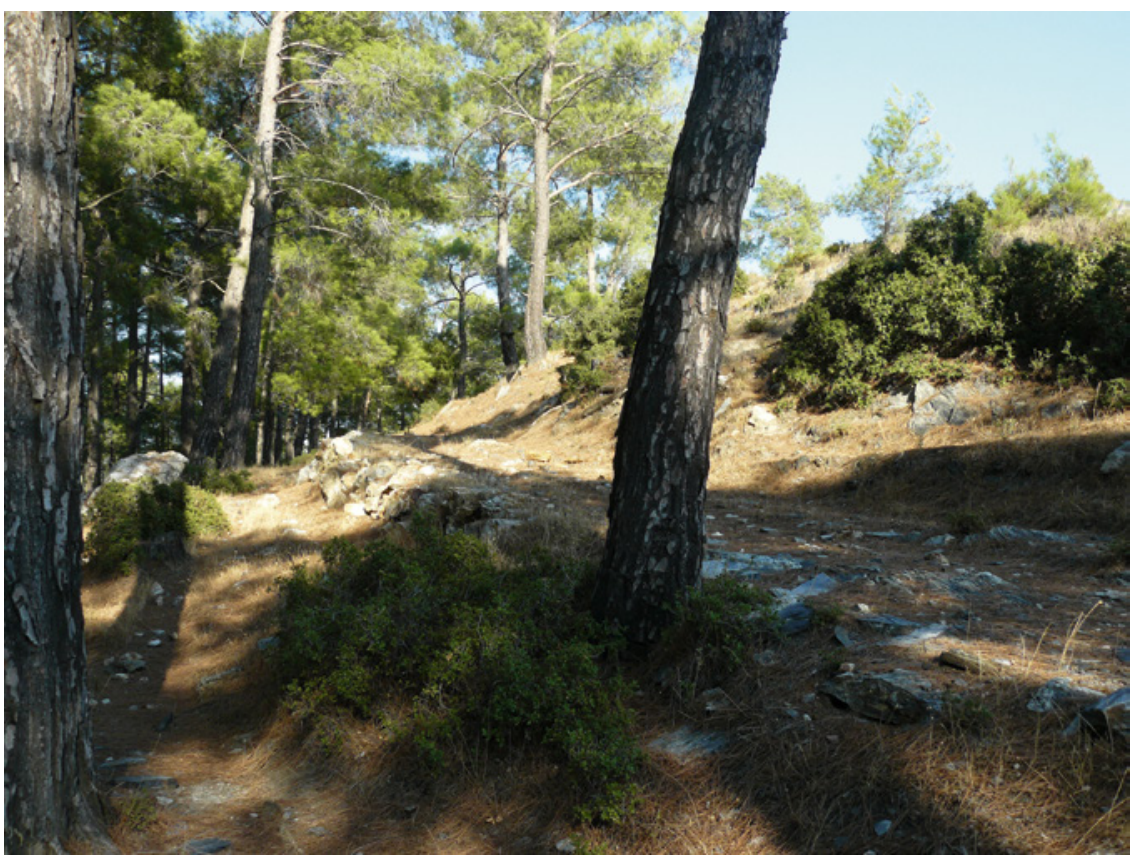

FIGURE 6.20 Panamara. Section of the road, partly terraced as shown here, roughly one kilometer southwest of the sanctuary PHOTO AUTHOR 2011

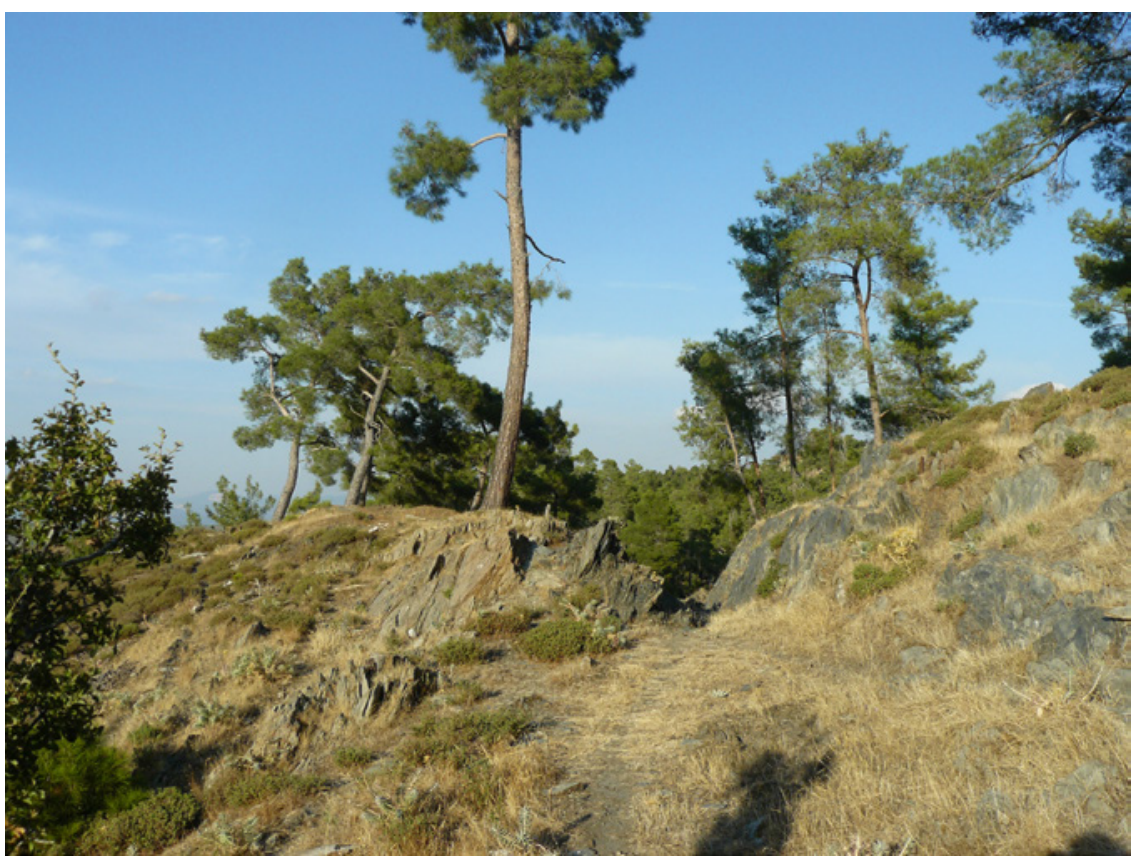

FIGURE 6.21 Panamara. Sections of the sacred way southwest of the sanctuary cut through the rock 


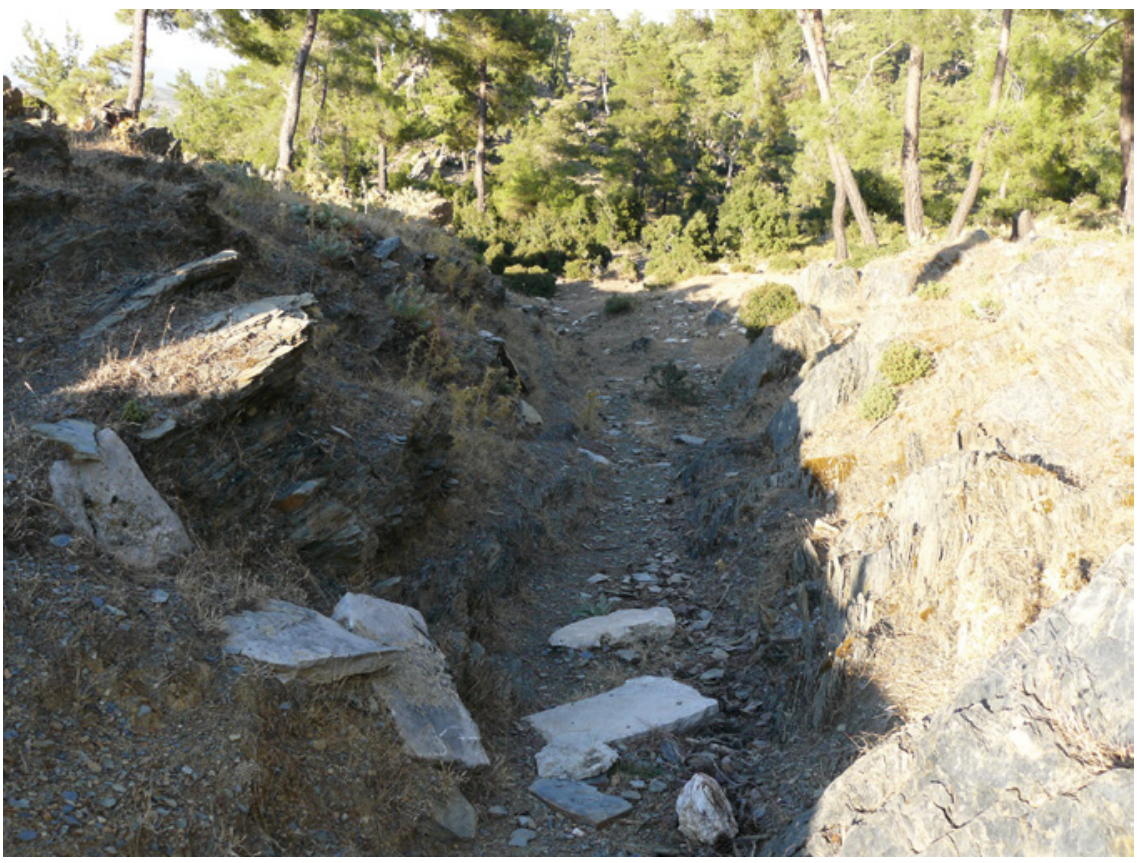

FIGURE 6.22 Panamara. Sections of the sacred way, cut through the rock РнотO AUTHOR 2010

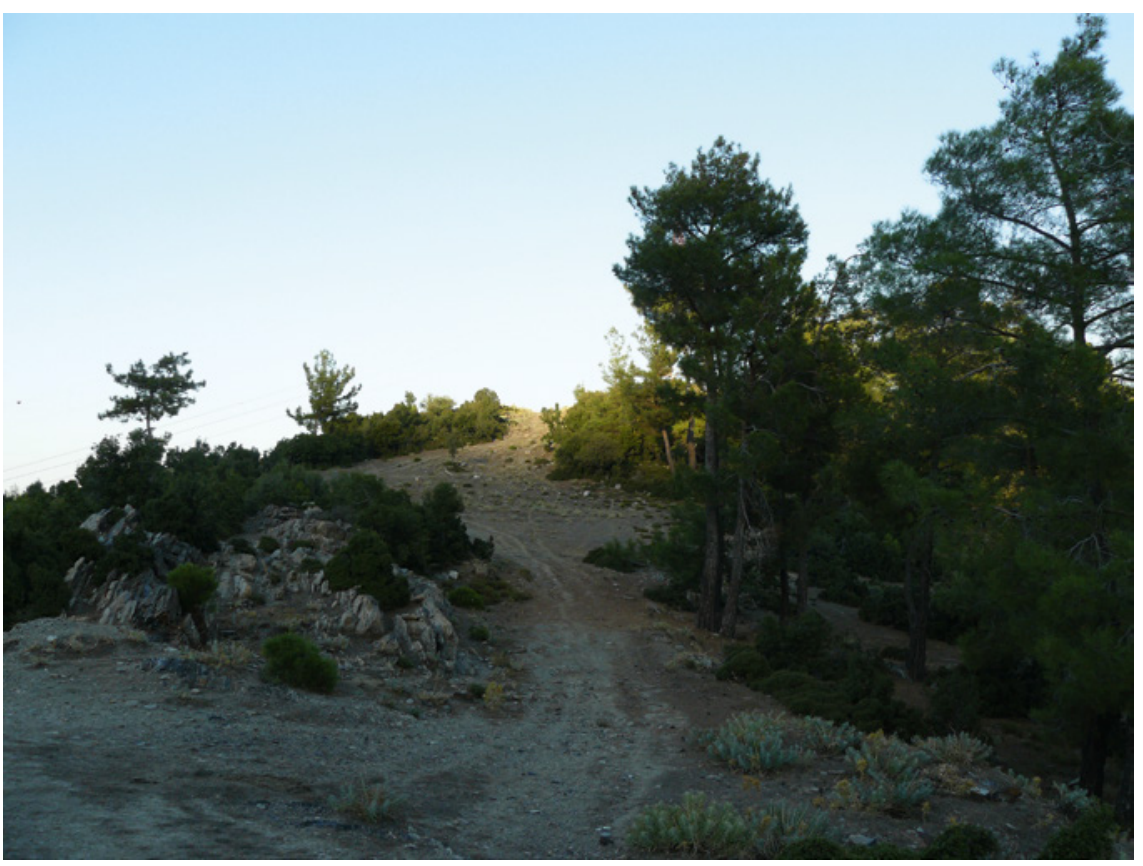

FIGURE 6.23 Panamara. Sections of the sacred way west of the sanctuary PHOTOS AUTHOR 2010 


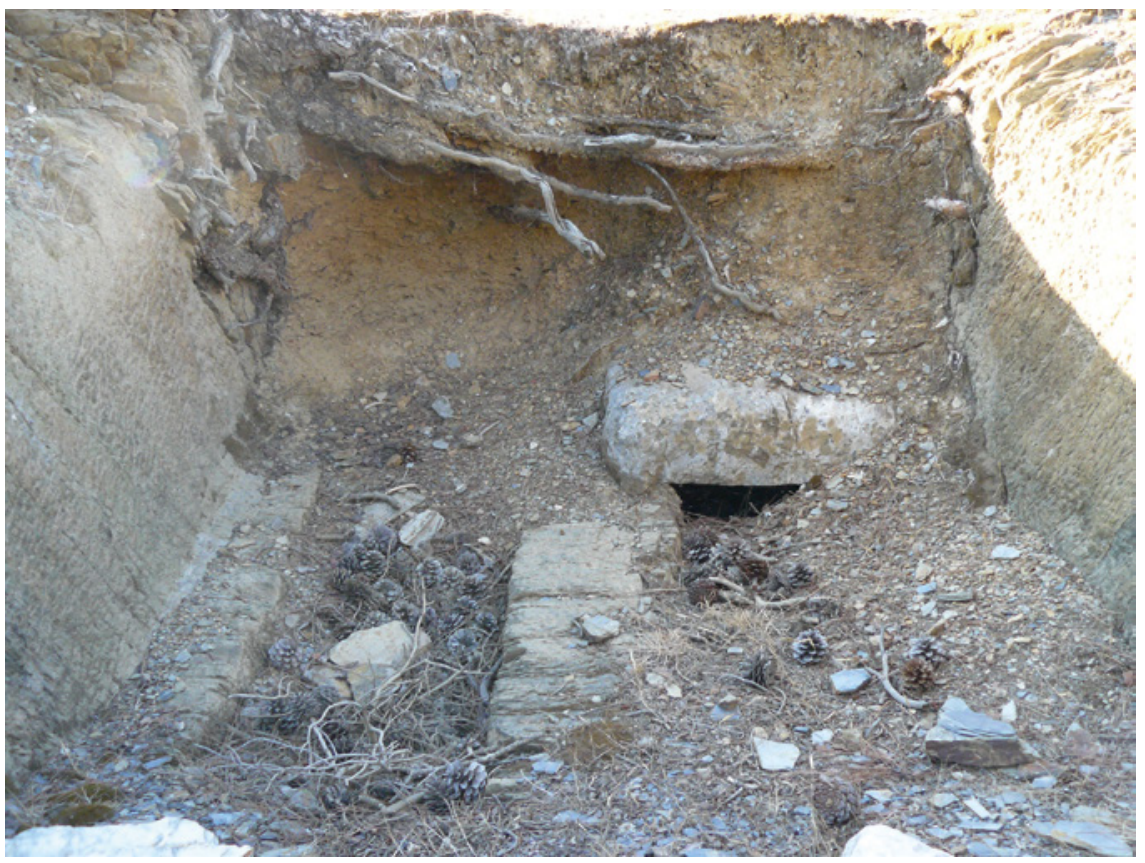

FIGURE 6.24 Panamara. Built tomb along the sacred road near the sanctuary PHOTO AUTHOR 2010

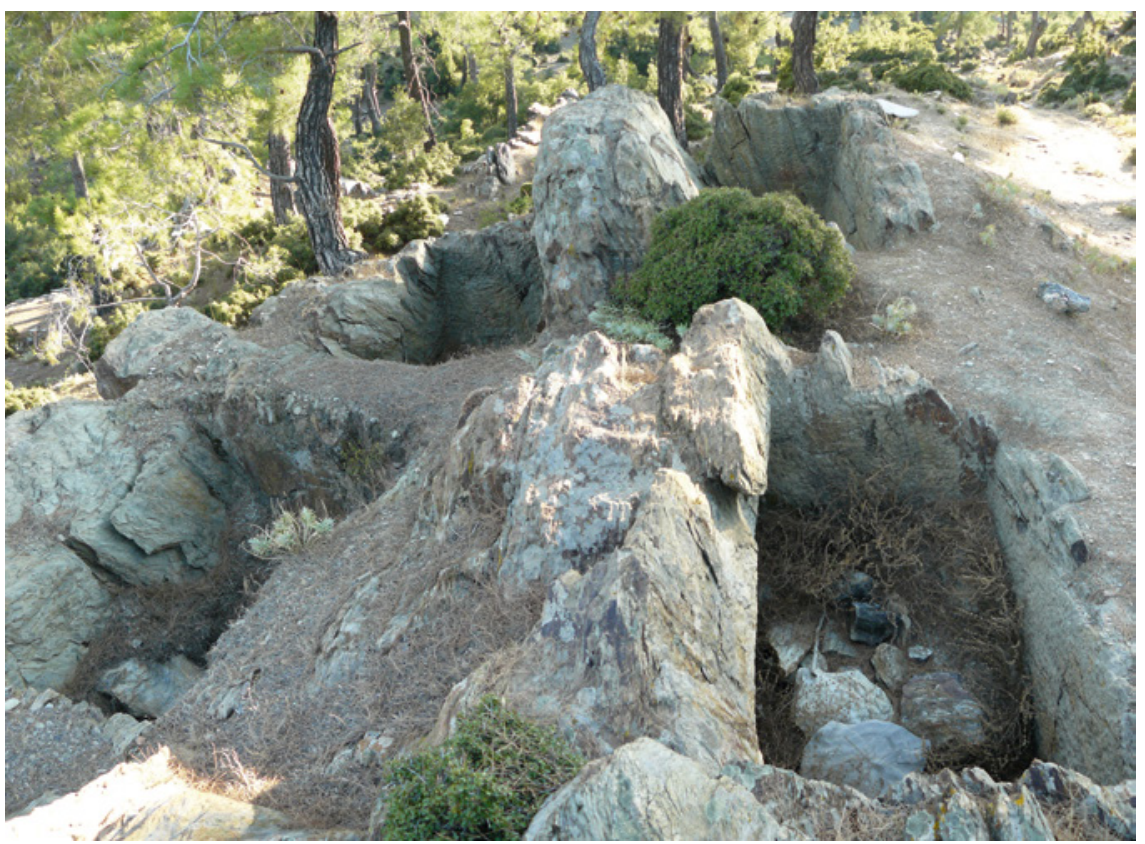

FIGURE 6.25 Panamara. Four adjacent rock-cut tombs along the sacred road west of the sanctuary 


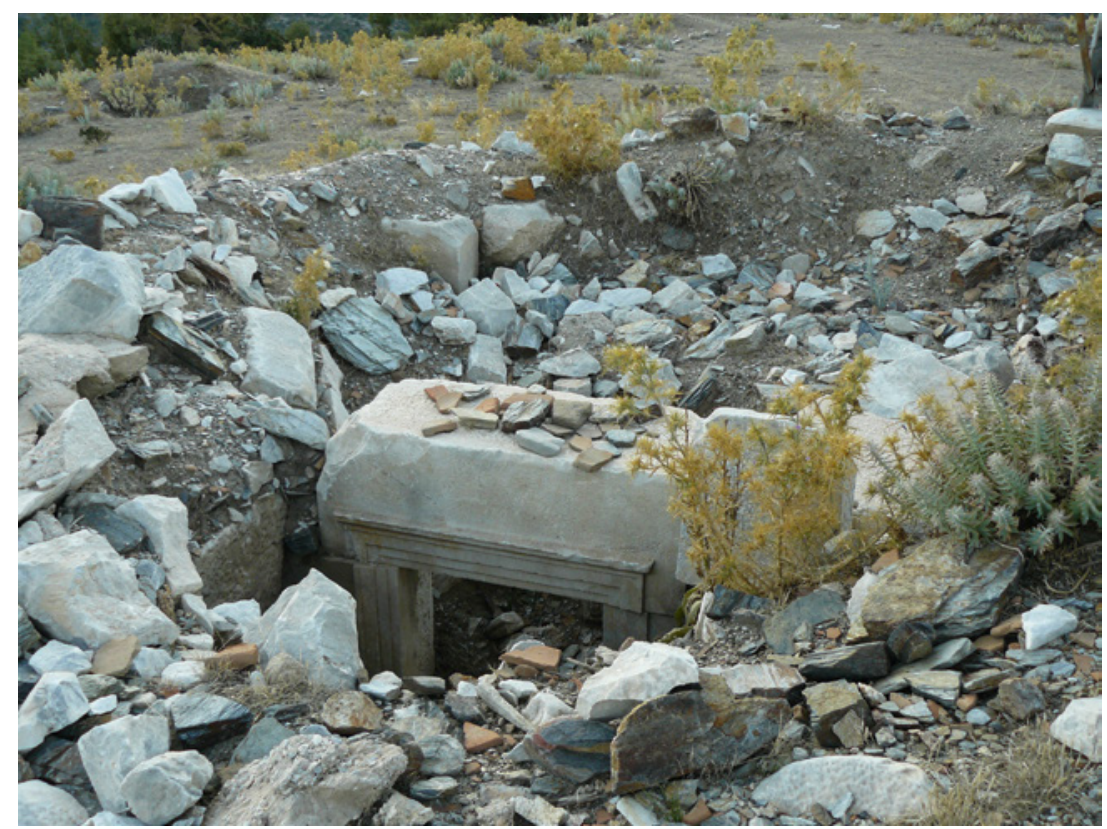

FIGURE 6.26 Panamara. Exposed marble doorway, with a three-faceted frame; the entry is c. $70 \mathrm{~cm}$ wide

PHOTO AUTHOR 2010

made of marble ashlars, with a finely carved three-faceted frame, probably belonging to a monumental chamber tomb (Figure 6.26). ${ }^{80}$ The sacred road was also a funerary road, and, as at Labraunda, this would have given those who joined in the processions a keen sense of time, both through the generations who had passed before as well as those to come.

The sacred road played a key role in the festivals of Zeus and Hera, as it carried the processions that included the entire population out towards the sanctuary for the festivals of the Heraia and the Komyria, discussed in the next section. Yet during the Panamareia, it also brought the cult image of Zeus into town, on horseback, in a majestic ceremony. ${ }^{81}$ Like Hekate's kleidos pompe, which brought the sacred key from Lagina to the bouleuterion, the dynamics of this ritual for Zeus were centripetal, drawing the most emblematic object of the sanctuary into the social, economic, and into the political heart of the city, in a solemn ceremony in which the entire community participated. At the

$80 \quad$ Lars Karlsson noticed similarities with the marble tomb near Labraunda, published in Henry (2011) (pers. comm. 15.09.2011). The doorway was exposed between my visits to the site in 2008 and 2010.

81 E.g. I.Stratonikeia 309, line 15, a later inscription from the third century AD. 
end of the festival, the image was returned to the sanctuary in the ritual of the anabasis, in which it was brought back to the temple. ${ }^{82}$ Anabasis can mean 'ascension' but it can also mean 'mounted', as on horseback, and in this context it is significant that after the mid-first century в С Zeus Panamaros appears as a rider-god on the coinage of Stratonikeia. ${ }^{83}$

The processions physically linking Stratonikeia to the cult of Zeus at Panamara would have been one of the ways in which the rituals of Zeus were transformed by the polis after it absorbed the cult. Until that time, the scope of the sanctuary was primarily oriented towards the southern regions of Karia, particularly around the Marsyas valley. These processions, and the road that carried them, gave a strong northern axis to the sanctuary, emphasizing its connection to the polis. The monumentalization of this road, paved or not, would have been shaped by the ritual habits of the Stratonikeians, as they left their marks on the passage to and from the sanctuary.

In short, the topography and natural defense of the hilltop defined in part the character of the cult of this supreme deity, and the use of the sanctuary throughout much of its history. The Panamareis built a monumental and fortress-like sanctuary that was impressive enough to attract the attention of Philip v, who installed a garrison for his troops at the end of the third century вс. Unlike Lagina, the sanctuary of Zeus Karios was already architecturally developed as a complex prior to the advent of Stratonikeia in the midsecond century BC. Judging from the inscriptions, modifications by the polis came much later, with the addition of a temple for Hera that was attacked by Labienus's troops in the mid-first century вс, and later facilities dedicated by priests, e.g. dining halls, stoas, sleeping accommodations. Although epigraphy is our main source for the impact of the polis on ritual space, and hence the rituals, there are many indications of concentric spaces defined by architecture. Linear space is indicated via the processions known to have taken place, although current mining activities will have obliterated the route. Yet whatever the actual route was, the passage to the sanctuary would have meshed the visual region of Panamara with that of Stratonikeia, creating a sense of closeness between the two while significantly expanding the reach of the polis to the south. Grand urban processions took place that carried the entire population from the city out to the sanctuary and were also centripetal, bringing the sacred cult image of Zeus back into the heart of town. Much like the kleidos

\footnotetext{
82 The return procession of the anabasis is testified in I.Stratonikeia 161, line 9; 295a and b, line 10 (identical texts); 309, line 10; 341, line 3; and in 352, line 7 .

83 Meadows (2002), Group 4 (see Figure 6.30); discussed in more detail below under Civic Iconography.
} 
agoge from Lagina, these processions and the road itself turned the focus of cult towards Stratonikeia, making the sanctuary of Zeus at Panamara a beacon of Stratonikeian presence in the wider region.

\subsection{Ritual Performance at Panamara}

As with the sanctuary of Hekate at Lagina, processions were a critical part of the festivals, ensuring that Stratonikeia was the focus of the community and the cult. Several changes took place in the festivals at Panamara as the city absorbed the cult, regarding their frequency, content, but also the ritual space as the cityscape became integrated into the festival venue. Festivals physically established the bond between community and sanctuary, but they also served to mark this bond in the calendar year and in the cyclical life of the polis. The festivals at Panamara will be seen to have functioned as rational rituals as they were particularly centered on social cohesion, especially through the effectiveness of spectacle and its imprint on collective memory.

\subsubsection{Festivals}

Nearly all of our information pertaining to the festivals at Panamara dates from the later Hellenistic and especially imperial periods. How the cult was organized under the koinon of the Panamareis is largely unknown, although Philip v is known to have dedicated phiales (libation bowls) and a kados (jar) at the sanctuary. ${ }^{84}$ The Panamareis surely bestowed their honors on such individuals during public festivals for Zeus Karios, but the only information that we have of this stems from the dossier of inscriptions pertaining to Leon, the priest from Stratonikeia who expanded the festivals by getting the communities to increase the splendor of their sacrifices, and by getting more communities to participate. ${ }^{85}$

The festivals would have revolved around the altar, but its location is less than clear, as discussed above, and Laumonier suggested it as the isolated pile of marble found at the western end of the sanctuary. Despite our limited knowledge of the configuration of ritual space, numerous testimonies of ritual performances at Panamara can be found in the epigraphic record. Several are listed in I.Stratonikeia 1 . This inscription highlights the intertwinement of music, the molpen, with the sacrifices at Hera's biennial festival, starting with oxen sacrifices and followed by a second part that mentions white cattle, a billy-goat, and a cock as the victims. Initially dated to the third century вс, the

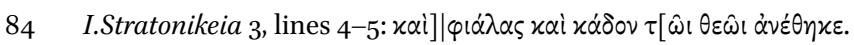

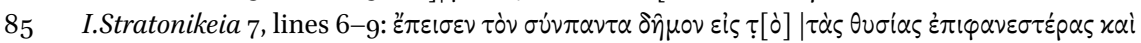

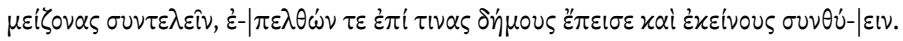


two sections now appear to belong to different inscriptions, and probably date from the later second or first century $\mathrm{BC}$, when the sanctuary and its festivals were organized by Stratonikeia. ${ }^{86}$ Both sections do, however, give us a glimpse into the nature of the sacrifices, with the kinds of animals, apparently all of which were mature. The emphasis on music accompanying the sacrifices is rare and would indicate an especially significant role in the festivities. Music would again be the focus of attention much later, in the second or third century AD, in the inscription of Sosandros, who prescribes the singing of hymns for Zeus and Hekate, according to tradition, all day long during the days of their festivals. ${ }^{87}$

Hera's temple was discussed in the previous section, and I.Stratonikeia 1 shows that her festival had become a regular feature of the cult at Panamara, occurring every other year. The inclusion of Hera in the cult of Zeus was attributed by Laumonier to its takeover by Stratonikeia, in the context of a wider reorganization of the cult. ${ }^{88}$ Although neither the introduction of the cult of Hera nor the absorption of the sanctuary by the city can be dated with any degree of accuracy, the two events seem related, as Laumonier presumed, although probably at a later date. It is difficult to understand the context of the introduction of Hera's cult without a clear chronology for this early phase and van Bremen challenges Laumonier's assumptions with reason. ${ }^{89}$ Yet the inclusion of Hera's cult and the addition of her festival to the calendar of the polis certainly helped coordinate the pre-existing communities within the larger area, shifting their focus to the now urban community. The priestly dedications to 'Zeus, Hera, and the demos' in any event sealed the link between both deities and the polis. ${ }^{90}$

86 I.Stratonikeia 1 is generally interpreted as a calendar, see also Sokolowski, LSAM No. 67, 159-16o. Hatzfeld (1927), 68 n. 1 and No. 9, 69-70, dated it to the mid third century BC, based on the lettering. This is however taken by van Bremen as more characteristic of the first century BC, see van Bremen (2004b), 225-226. The cult of Hera at Panamara is further discussed in Williamson (2020b), also Pirenne-Delforge and Pironti (2016), 186, n. 431 and 194, n. 468.

87 I.Stratonikeia 1101, discussed above in Chapter 5, under Festivals.

88 Laumonier took this inscription, with its date in the third century вС (Hatzfeld (1927), p. $68 \mathrm{n} .1$ and 69 no. 9), as a sign of Stratonikeian reorganization of the cult at Panamara in this early period already, Laumonier (1958), 234-235; followed by Debord (2007), 240. Van Bremen, however, assigns a later date to the inscription, making it even more plausible that the cult of Hera was introduced under Stratonikeian control of the shrine, van Bremen (2004b), 225-226.

89 Van Bremen (2004b), 226-227.

90 Dedications to Zeus, Hera, and the demos in the Hellenistic period appear in I.Stratonikeia 102,103 , and 332, these are discussed below under Administration and Priesthoods. 
The Heraia is the earliest festival mentioned in the inscriptions at Panamara. This took place in and around the sanctuary and was focused on women, but involved the entire population, whether citizen or foreigner, from the city or the countryside. ${ }^{91}$ Sources for the Heraia largely stem from the imperial period. One of the earlier documents from the first century AD, I.Stratonikeia 174, is highly interesting in many respects. The priests are seen to arrange and escort the population out to the sanctuary, presumably in procession, leading the women into the Heraion while the men waited outside, and later escorting them all back to town again..$^{92}$ The adult female population of Stratonikeia is designated as 'the corporate body of women' (to poleiteuma ton gynaikon). ${ }^{93}$ How formal this collective identifier was is uncertain, yet even if it did not reflect institutional power it did create a religious reality. Directly connected to this is a theoria, and so women appear to have been involved in the capacity of bringing expensive and beautiful things to Hera in Panamara. ${ }^{94}$ The term theoria literally means 'seeing the gods', and although it more often refers to delegates at festivals from other poleis, it is also used on occasion to designate a particular segment of local society, usually the ephebes. ${ }^{95}$ The festival was biennial, but a number of inscriptions in the imperial period also refer to a penteteris for Hera. The earliest involves a dedication to Zeus, Hera and the demos by a Leon and Myrtale, a brother and sister priestly couple who held office during the penteteria. ${ }^{96}$ Mysteries were also held for the women during

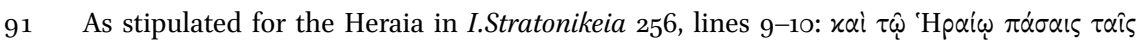

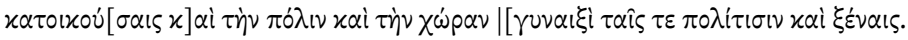

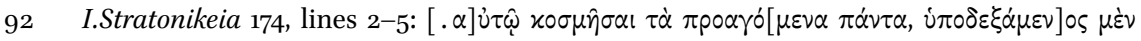

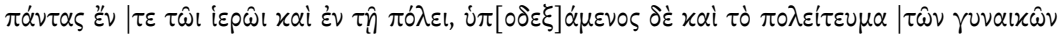

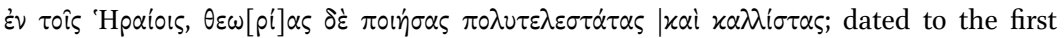
century AD; also I.Stratonikeia 256 . On the normalizing aspects of processions, projecting the ideal nature of the community, see Chankowski (2005).

93 I.Stratonikeia 149, 174, and 352, from the imperial period at Panamara, mention the

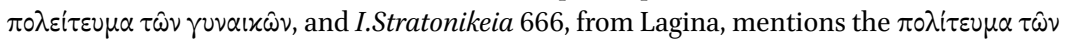

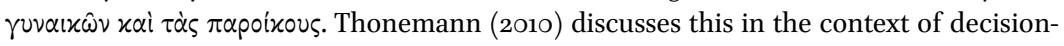
making responsibilities, while Cousin (1904a) observes that a collective group of women ( $\dot{\varepsilon} \rho \alpha v i \sigma \tau \alpha i)$ were among the contributors at Athens (IG II ${ }^{2} 2354$ [30]). Harland (2014), 338, addresses the corporate body of women at Panamara in the context of an association

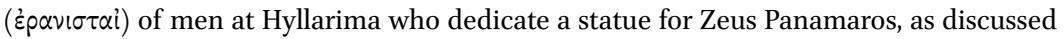
in Robert (1937), 513-515.

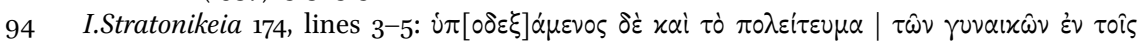

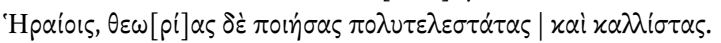

95 Theoroi are typically delegates to festivals of other cities, see e.g. Perlman (2000); Dimitrova (2008); and especially Rutherford (2007) and (2013) on aspects of reciprocity and network building. On ephebes as theoroi, see especially Kowalzig (2007a), 45, 59 .

96 I.Stratonikeia 108 , from the late first century BC or early first century AD. They apparently dedicated a house with a place to lie down, with a stuccoed or stained entrance and 
the festivals of Hera, and priests took great pride in being able to assemble a large group of female citizens and foreigners, from the town and countryside, for these special ritual events. ${ }^{97}$ The dedications of hair that took place in the third century AD were primarily male, but also included some from women, such as Apphion, or general members of the household, including family and slaves. ${ }^{98}$

The Komyria, for Zeus, was restricted to men. The name refers to the Karian deity Komyros, who according to Lykophron was syncretized with Zeus at Halikarnassos. ${ }^{99}$ Whether this reference to the cult allows us to infer its presence at Panamara in the third or second century already, as Hornblower suggests, is debatable. ${ }^{100}$ Inscriptions mentioning the festival at Panamara do not appear until the imperial period. They indicate that the festival took place over two days and included rituals of drinking wine, mysteries, and dedicating locks of hair. This last practice occurred in the second and third century AD and must have been fairly common, given the number of dedications (99 have been published, see Table 6.1 below). ${ }^{101}$ Special containers were made to keep the locks of hair, a number of which may still be found at the sanctuary (Figures 6.27). Some of the letters written by the priest to foreign cities are invitations to participate in the festivals and the mysteries, indicating this as a wider attraction in this period. ${ }^{102}$ In the meantime the women waited

paintings. The bulk of the 23 inscriptions mentioning the penteteria are dated to the first or second century AD, see further Laumonier (1958), 239-240.

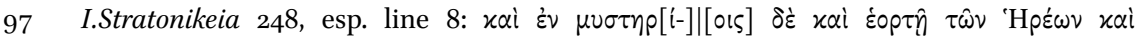

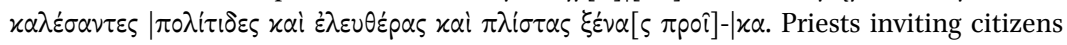
from every category for the Panamareia, and women from town and countryside for the Heraia are seen in I.Stratonikeia 256, esp. lines 9-10.

98 The dedication of Apphion's hair is commemorated in I.Stratonikeia 485, although it should be noted that it is her father, Sosandros son of Hekataios, who takes the initiative to dedicate his daughter's hair, along with statues of Perseus and the Gorgon, to Zeus Panamaros. Other household dedications are represented, as 'familia' in I.Stratonikeia 486-488, or slaves (oiketes or doulos) in I.Stratonikeia 489-491.

99 Lykophr. 459-46o.

100 Hornblower (2015), 85-87. Lykophron refers to the worship of Zeus as Komyros in Halikarnassos, which Hornblower takes to represent all of Karia, in reference to the pri-

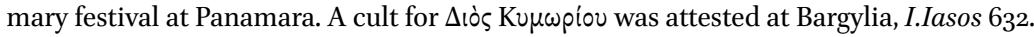

101 I.Stratonikeia 42, 401-50o, 1414; Deschamps and Cousin (1888c), nos. 6o-120 and p. 480. This practice spilled over to Lagina, where two dedications of hair were also made, I.Stratonikeia 545 (to Demeter?) and 1422. Writing in the second century AD, Lucian (De Dea Syria 6o) mentions that the locks of chin hair he once dedicated to the Syrian goddess were still kept in the sanctuary in a vessel with his name on it; he refers to a similar practice in Troizen where youths (male and female) were required to sacrifice locks of hair to Hippolytos prior to marriage.

E.g. I.Stratonikeia 23, to an unknown city, and to Mylasa in I.Stratonikeia 3 o. 

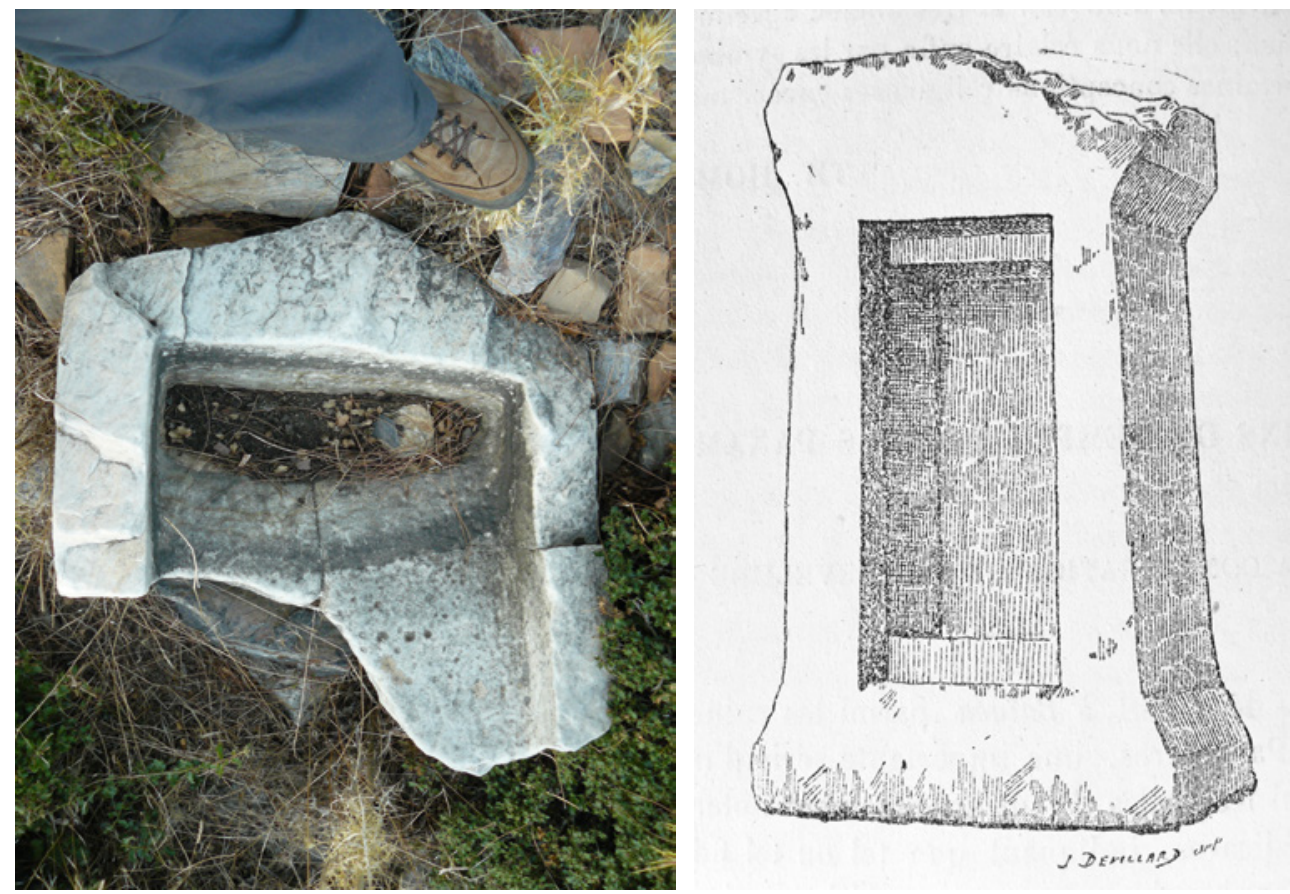

FIGURE 6.27 Panamara. Votive coffers, probably for hair dedications. On the left a marble coffer in the northern area near the temenos wall; illustration of such a coffer from Panamara by J. Devillard

Рното AUTHOR 2010; BCH 12 (1888), 480

outside, perhaps in the large level area at the northern part of the sanctuary (Figure 6.18), where they were tended to with wine and olive oil. In many ways, the Komyria was a mirror of the Heraia, as the festival was targeted gender while simultaneously accommodating the entire population. ${ }^{103}$

Although it is unknown when the major festivals began, it is tempting to associate them with the Senatus consultum after the Mithridatic Wars, when Stratonikeia was granted a wide expansion of territory to the south, down to the Gulf of Keramos. These festivals and their processions certainly enacted Stratonikeia's territorial claims, but rather than staking out boundaries, they were directed at the social structure of civic society. Resulting from a major reorganization of the sanctuary at Panamara by Stratonikeia, they helped

103 For an extensive description of both festivals, based mostly on inscriptions from the imperial period, see Hanslik-Andrée (1949), s.v. 'Panamaros' in the RE. Much of this may be read in I.Stratonikeia 202-203, and 205, and the dedication of hair during the Komyria in I.Stratonikeia 401-500. On the Heraia, see also Lozano 1991-92. Nearly all the priestly inscriptions from the imperial period show that the annual priesthood was held by a couple, with the male priest presiding over both festivals, see below under Administration and Priesthoods. 
produce the very intimate relationship between the polis and the broad base of its community that found expression at this remote shrine. The inclusion in the celebrations of all classes of men and women, slave, free, citizen or foreigner, would have fostered social cohesion, while situating each individual in his or her own specific social context. Inscriptions prove that Stratonikeia was always highly conscious of its deme divisions; the use of the demotic in this case allowed people from the ancient villages to retain their local identities while at the same time being full members of the polis. The processions to Panamara and the festivities there would have served as a focus which helped bring unification to the entire population. Panamara, remote as it was from the administrative center, may well have been an ideal 'neutral zone', where the participants could celebrate the most essential things which they had in common - their gender and their identity as Stratonikeians. The explicit inclusion of foreigners, the xenoi, may well refer to the visitors from the cities who were personally invited by the priest to join in the festivals. ${ }^{104}$ Their presence would no doubt have served to heighten local awareness even more, while extending the cult network in the region.

While these two festivals emphasized the social identity of the community, there was yet another festival of Zeus that was overtly political. The Panamareia marked a turning point in the life of the cult after the epiphany of Zeus of Panamaros that saved Stratonikeia from Labienus's invasions in 4 о вс. ${ }^{105}$ Sources for this festival date from some time after the miracle, yet even an inscription from the later imperial period connects the festival to the miraculous power of Zeus and testifies to a continued awareness of the epiphany. ${ }^{106}$ The festival of the Panamareia was an annual event of great significance for the polis. Oppermann views the term 'succession of the crown', appearing in several inscriptions, as a sign that this was politically the most

104 I.Stratonikeia 22-39 are letters written by the priest of Panamara to various periods; discussed below in more detail. An interesting parallel may be found in Mylasa, where the gymnasiarch Leontiades is honored by the paroikoi, metoikoi, and xenoi who otherwise had no share in the oil distributions in the gymnasium Blümel (2004), 16-17, no. 22; also Blümel et al. (2014), no. 18.

105 The miracle is described in I.Stratonikeia 10, discussed below under Urban Mediatization.

106 I.Stratonikeia 266 (dated to the later second or third century AD), lines 10-22, with

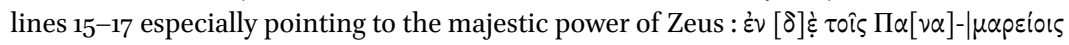

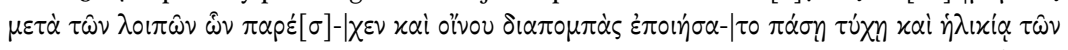

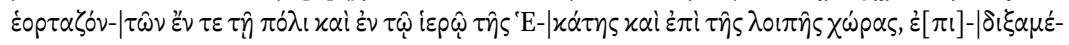

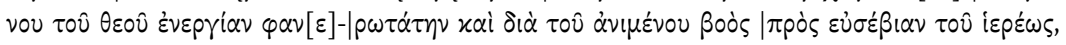

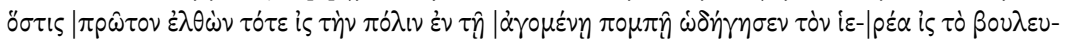

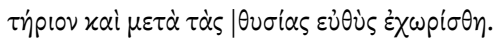


important festival for the city of Stratonikeia. ${ }^{107}$ It was certainly the longest, lasting ten days, ${ }^{108}$ and involved intensive banqueting with gifts of oil, wine, and money for the population. ${ }^{109}$ Priests usually distributed these gifts and some inscriptions explicitly include citizen, foreigner, free, and slave as recipients of their liberal generosity. ${ }^{110}$ Much went on in the countryside too and one inscription even includes the sanctuary of Hekate at Lagina as a scene of festivity during the Panamareia, intertwining the two main deities during this centralizing festival. ${ }^{111}$ Together, both cults were engaged in directing the gaze of the communities towards the polis through cult and spectacle. The awe and wonder would have engrained the festivals into the social memory, thereby ensuring their endurance. ${ }^{112}$

One of the most interesting facets of this festival within the context of this study is that, just like Hekate's festival, it was primarily celebrated in town, not out at the sanctuary. As mentioned above, the image of Zeus was brought from Panamara into town in a procession, possibly on horseback, to reside in the bouleuterion during the festival; afterwards it was returned to the sanctuary during the festival of the anabasis. ${ }^{113}$ For Stratonikeia it was then critical to have some token or representation of the gods physically residing in the urban

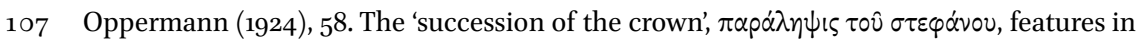
I.Stratonikeia 247, 281, 312, 341, among many others.

108 The length of the Panamareia at ten days (and nights) is attested e.g. in I.Stratonikeia 247,

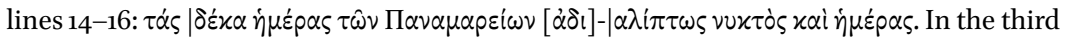

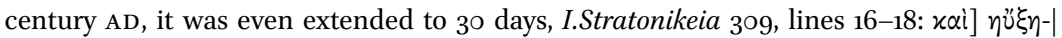

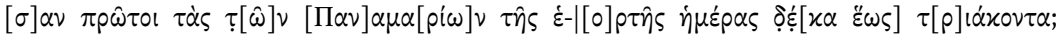
added up with Hekate's kleidos agoge, both festivals took 34 days in this later period:

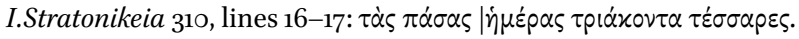

109 For example the distribution of oil during the rite of the 'succession of the crown', in

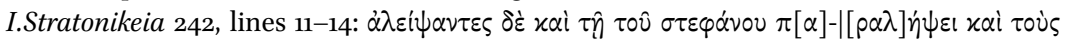

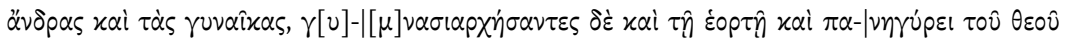

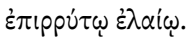

110 The distribution of oil during the rite of the 'succession of the crown' is mentioned in

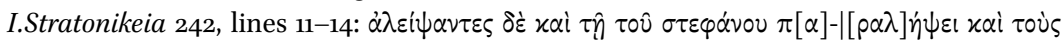

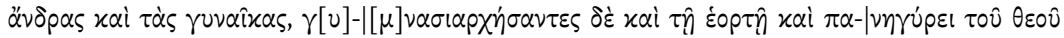

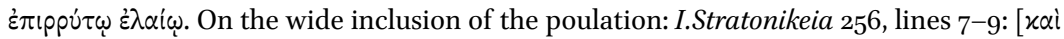

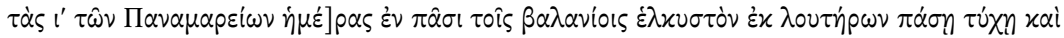

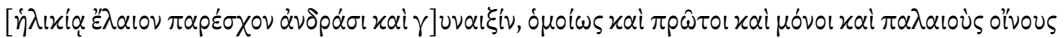

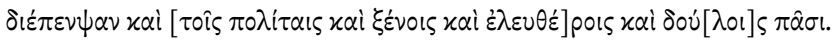

111 I.Stratonikeia 266, lines 11-15, cited above in note 106.

112 See Connerton (1989), 41-71, McCauley and Lawson (2002), 38-88; discussed in Chapter 2.

113 I.Stratonikeia 266, mentions the procession into town lines 18-22, see note 106;

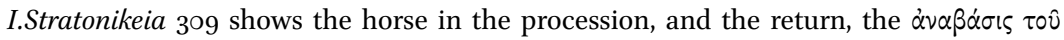
$\theta \varepsilon 0 \hat{v}$, is mentioned in I.Stratonikeia $295 \mathrm{a}-\mathrm{b}$, and 341 . 
center for a period of time, perhaps because they were otherwise visually isolated from the sanctuary, this aspect is further discussed below.

None of the inscriptions referring to the festival of the Panamareia can securely be dated to the pre-Roman phase of Stratonikeia; the majority in fact seem to have been written in a solid imperial context. Oppermann believes the Panamareia to have begun at least after the Mithridatic wars, yet a more fitting context would be the epiphany of the god that saved the polis from Labienus and his Parthian troops in 40 BC. ${ }^{114}$ By this time Panamara was thoroughly integrated with Stratonikeia, and Zeus Panamaros had come to represent, and to protect, the polis.

\subsubsection{Banqueting}

As with the festivals of Hekate, feasting was clearly a major part of the festivals of Zeus Panamaros. This was indicated already in I.Stratonikeia 1, discussed above, where a number of animals are mentioned in connection with the sacrifices and the feasts. This provides us with a glimpse of the role of banqueting in the festivals. A later inscription for an unnamed priest shows how he welcomed and generously fed the entire community at the sanctuary, apparently for two days. ${ }^{115}$ The letters written by the priest to a number of cities invite them to join in the sacrificial banquet. ${ }^{116}$

These are just a few of the many examples that show the central role of feasting as a ritual performance in the festivals at Panamara. Although we can say little about the spatial form which this took at the sanctuary in the Hellenistic period, some structures known through inscriptions from the early imperial period - the stoas and perhaps the vaulted structure ( $p$ salis) and porch (pastas), both built by the priest Posittos, son of Apellos - -117 may at least have provided shelter or even a formal reception area, while the philotrophion and the aristeterion were surely designed for banqueting, built later in

114 Oppermann (1924), 83: 'dies Fest ist also nicht viel älter als Sulla'. Oppermann dates the annexation of Panamara by Stratonikeia to the territorial expansion granted in the senatus consultum after the Mithridatic Wars and postulates the Panamareia as following this event.

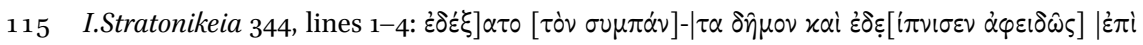

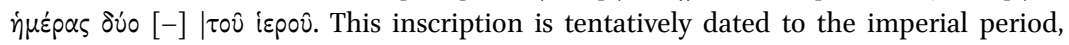
although the phrase $\dot{\varepsilon} \pi \dot{\eta} \dot{\eta} \mu \varepsilon_{p a \varsigma} \delta \dot{0} 0$ is also used in I.Stratonikeia 1409, dated to the Hellenistic period.

116 E.g. I.Stratonikeia 22, the letter to the Rhodians. See also I.Stratonikeia 23 (unknown city); 25 (to Alinda); 29 (unknown city); 33 (unknown city); and 35 (unknown city).

117 I.Stratonikeia 112, discussed above under Architecture. 
the second or third centuries AD. ${ }^{118}$ Besides this, however, the many tents and other provisional structures were surely part of this massive event, as well as general feasting al fresco.

According to the epigraphic record, banqueting in festive Stratonikeia was on the rise in the imperial period. As with the festivals of Hekate this became one of the central communal activities of the Panamareia. ${ }^{119}$ When the procession brought the cult image down from the hilltop sanctuary and into town, the festival descended on the urban landscape. Ritual feasting occurred mostly in the magnificent gymnasium, ${ }^{120}$ but also in places such as the temple for Dionysos. ${ }^{121}$ The countryside was included, too. One inscription even mentions the sanctuary of Hekate at Lagina as a scene of action during the Panamareia, showing the intensive collaboration of both poliad deities during this major festival. ${ }^{22}$

The festivals of Zeus Panamaros and Hera were highly social events, cutting through the regular social boundaries, e.g. male-female, citizen-foreigner, freedman-slave, urbanite-countryman, young-old, and ritual feasting was especially suited for this purpose; ${ }^{123}$ one inscription even explicitly includes Romans among other marginal groups. ${ }^{124}$ Schmitt-Pantel has shown that sacri-

118 The philotrophion was built by the priest Drakon, son of Leon of Koranza, I.Stratonikeia 267 , dated to the later second or third century AD; in the same period the aristeterion is mentioned in I.Stratonikeia 17 , an honorific decree dated to the second or third century AD for an unnamed priest who made improvements, perhaps expansions, to the aristeterion, and who also provided for a sleeping chamber (koiton) in the vaulted room (psalis).

119 E.g. I.Stratonikeia 192, including gifts of olive oil; also discussed in Stavrianopoulou (2009), 178 n. 61.

120 The gymnasium was also a general scene for receptions, e.g. for women in I.Stratonikeia

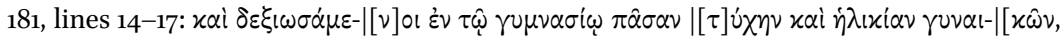

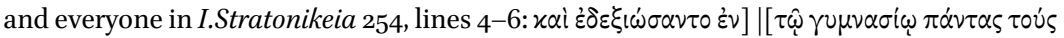

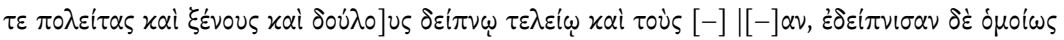

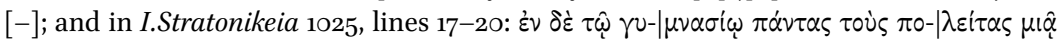
$\dot{\eta} \mu \varepsilon \varepsilon_{\alpha} \alpha \varepsilon \varepsilon \tau v \varepsilon[i]-\mid[\sigma] \alpha \nu \tau o \varsigma$, an honorific decree for the priest Titus Flavius Aeneas (by his brother Titus Flavius Aristolaos). Inscriptions concerning the gymnasium: I.Stratonikeia

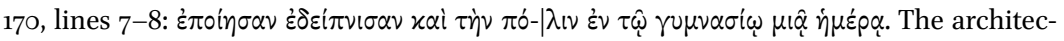
tural development of the gymnasium is described in Mert (2008), 16-20, and 156-166.

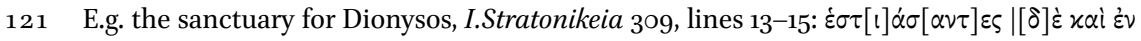

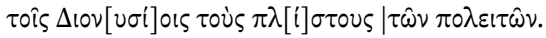

122 I.Stratonikeia 266 , lines 11-15, see above, in note 106.

123 E.g. I.Stratonikeia $172,203,205,210,242,252,255,256,318$, most of which are dated to the second century AD.

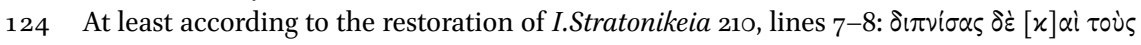

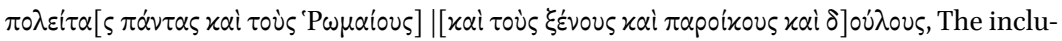
sion is by analogy with I.Stratonikeia 186 and $1325 \mathrm{~A}$, where Romans and other foreigners are mentioned as living in the countryside; Gordon (1990), 226-228. 
fices and the ensuing banquets were a collective and political action that was at the heart of Greek urban experience. ${ }^{125}$ This was certainly true at the festivals of Zeus Panamaros. But especially in the later imperial period we also see that certain banquets were hosted by the priests for specific groups, such as the gerousia, who were exclusively entertained by the priest Theophilos in a banquet held in town. ${ }^{126}$ The festival banquets of Zeus and Hera, but also Hekate, drew the community together, providing a shared focus and a common bond, but at the same time they could also be used to create or confirm social distinctions and establish urban conventions. ${ }^{127}$ As part of a ritual and social meal, banquets such as these were excellent rational rituals - they created both joint attention, and common knowledge, i.e. everyone knew about the banquets and could expect to participate, knowing that others were doing the same at other venues. ${ }^{128}$ Moreover, banqueting throughout the urbanized landscape served as a way of 'shaping territory'.129 Like the processions, it created an indelible link between the chora, the ritual which included the fellow banqueters, the god, and the polis. Not only did it create and maintain social cohesion, but it was also critical in establishing or maintaining the territorial identity of the polis.

\subsubsection{Games}

Although competitive games or athletic contests are not as prominent at Panamara as they are at Lagina, they may nonetheless have been part of the festivals, at least in the later imperial period. Two related inscriptions include games that occurred at the occasion of the anabasis, or the return of the image of Zeus to Panamara. ${ }^{130}$ Theatrical and athletic competitions are mentioned in

\footnotetext{
125 Schmitt Pantel (1985) on the importance of banqueting an sich as a social activity; also Schmitt Pantel (1990). One of the main lines of her thesis is that the division of the victim into equal parts represents the political equality, or isonomia, of a community.

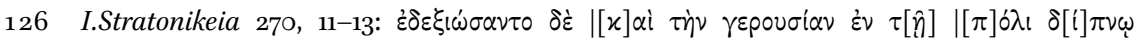
$\dot{\alpha} \pi \circ \varphi \circ \rho \eta \dot{\tau} \omega$.

127 Scheid discusses this aspect in sacrifices in the imperial period, but with respect to the division of the victim in unequal parts, corresponding to social distinction, Scheid (1985). See also the banqueting at Labraunda which was both a communal and segregated event, through the architectural facilities, discussed above in Chapter 3; and at the sanctuary of Sinuri which was the prime communal event in which individuals were distinguished through the sacrificial meal and the division of the meat, see Chapter 4.

128 Chwe (2001) on 'rational rituals', as an effective means of creating common knowledge, discussed in Chapter 2.

129 See 'territorial shaping' as the first stage in Paasi's model of building regional identity, Paasi (2009); discussed above in Chapter 2.

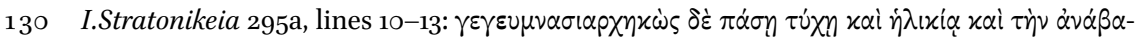

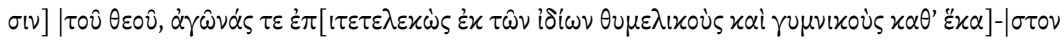


a priestly dedication. ${ }^{131}$ These competitions appear to have taken place toward the end of the Panamareia, perhaps as a kind of closing ceremony in which the city's finest were on display in a memorable performance. Otherwise, much less is known about the games at Panamara, or during the Panamareia, than those at Lagina. Assuming they were costly to organize, then one might imagine Stratonikeian focus on games to be during the Hekatesia, while the festivals at Panamara were more concentrated on social rituals such as mysteries and opulent feasting.

To summarize, the festivals at Panamara clearly helped unite a dispersed population. Regardless of origin or class, from the city or the countryside, citizen and stranger, they were all called upon by the priests to join and were brought out to the sanctuary together to celebrate the festivals of Zeus and Hera. The focus on social gender through the Komyria for men and the Heraia for women cut across all other distinctions, although the presiding priests were clearly members of the urban elite who organized and escorted the community in the processions; their role is discussed in the next section. The processions of the Panamareia, the great festival established after Zeus's miraculous salvation of the Stratonikeians, mirrored the kleidos agoge from Lagina in that they were also centripetal, bringing the image of Zeus on horseback down from the hilltop and into town, probably to the bouleuterion. The emphasis on music in the ritual of the sacrifice is exceptional, or at least exceptionally preserved..$^{132}$ Whatever type of song the molpen was, mentioned in I.Stratonikeia 1, it appears to have been simple and repetitious, supporting the mnemonic mechanisms of ritual and would probably have been memorized by heart. ${ }^{133}$ This surely had a significant role as a rational ritual in creating the shared focus that helped forge the community belonging to the sanctuary. ${ }^{134}$ The sense of community would have been heightened by the communal feasts. The banquets connected to this feast took over much of the urban and rural landscape,

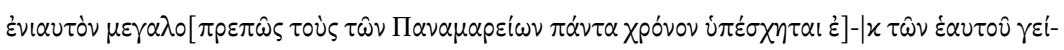
$\nu \varepsilon \sigma \theta \alpha[\iota$ $\alpha \dot{\tau} \tau \cup$ $\varsigma$, as restored by the editor. I.Stratonikeia $295 \mathrm{~b}$ is very similar, but even more fragmented.

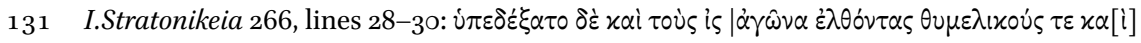
$\mid \xi \cup \sigma \tau \varkappa \propto \nu \dot{\varsigma} \alpha \dot{\theta} \lambda \eta \tau \alpha \dot{\alpha}$.

132 I.Stratonikeia 1 and 1101, respectively. The notation of music at the sanctuary of Sinuri, discussed above, is an interesting exception to the otherwise general dearth that has survived; see however the Delphic hymns, e.g. in Furley (1995).

133 McCauley and Lawson (2002), 38-88, on memory and religion. The element of repetition was surely involved in the hymns that were composed and sung all day long by the choirs of youths at the festivals of Zeus and Hekate in the later imperial period, I.Stratonikeia 1101.

134 Also Kowalzig (2007b). 
even including Hekate's sanctuary at Lagina, demonstrating how intertwined both cults had become by this time. Connecting the symbols of these distant gods to the political heart of the city reinforced the religious axis of the sacred landscape, embracing as it were the young polis. ${ }^{135}$ The games added to the sensory value of the spectacle; using the gymnasium as banquet venue would moreover have been a way of integrating the youth into the fabric of the urban festivals, ensuring continuity into the following generations and reinforcing civic institutions. The later dedications to the demos, alongside Zeus and Hera, show that Stratonikeia had positioned itself at the ritual center of Panamara by the second and first centuries BC. Ritual spectacle and repetition helped foreground the sanctuary in collective memory, thereby shaping the territory through the interlocking pattern of landscape, deity, and polis.

\subsection{Legal Administration and Organization of Panamara}

The degree in which a sanctuary was autonomous or integrated into the institutions of the polis is reflected in particular by the role of the priest and the status of the community at the sanctuary. The history of the administration of the sanctuary of Zeus Karios at Panamara revolves around the koinon of the Panamareis and the polis of Stratonikeia, and the relationship between the two. There is no evidence for a single moment in which the sanctuary passed hands from the koinon to the polis, although the priesthood of Leon seems to mark a shift in the otherwise long transitional period that starts with the control of the sanctuary by Philip v, when the Panamareis appear to have used the stephanephoros of Stratonikeia to date its decrees, ${ }^{136}$ until the later second century $\mathrm{BC}$ when the koinon of the Panamareis disappeared altogether and Stratonikeian control of the sanctuary was firmly established.

\subsubsection{Administration and Priesthoods}

Prior to the incorporation of Panamara into the urban realm of Stratonikeia, the sanctuary of Zeus was administered by the koinon of the Panamareis.

\footnotetext{
135 An interesting analogy may be found in Japan, the Kameshima village in Honshu, which uses "a linear, time-oriented axis from the mountain shrine projecting through the village shrine and to the field shrine," this ritual axis helps link the five fishing villages that make up the community, Thompson (1999).

136 I.Stratonikeia 4 , discussed in van Bremen (2004b), 230-231, who points out that this could be a result of both Panamara and Stratonikeia being controlled by Philip v. During the Rhodian period, until 167/6 BC, she assumes that like Panamara, Stratonikeia would also have followed Rhodian dating conventions. However, other than the installment of the cult of Helios and Rhodes at Lagina, I.Stratonikeia 504, no Stratonikeian inscriptions from this early period are known that would support this hypothesis.
} 
Although we know little of their internal structure, they were apparently able to organize the resources necessary for building a monumental complex with a temple. ${ }^{137}$ The cult may have been administered by a single priest, chosen from the koinon, as Riet van Bremen suggests. She tentatively dates one of the earlier priestly inscriptions to the first half of the second century, that of Androsthenes, son of Zoilos, who makes a simple dedication to Zeus Karios. ${ }^{138}$ This inscription does not inform us whether Androsthenes was appointed by the Panamareis or by Stratonikeia. But we do know that Stratonikeia appointed the Leon, son of Chrysaor, son of Zoilos, son of Polyperchon, of Stratonikeia, as priest of Zeus Karios while the cult was still under the administration of the Panamareis. ${ }^{139}$ It is tempting, as van Bremen observes, to see some kind of family relationship between Androsthenes and Leon (uncle and nephew?) since the name Zoilos (unlike Leon) is uncommon in the inscriptions of Stratonikeia. ${ }^{140}$

Leon's priesthood at Panamara is interesting for a number of reasons, many of which have already been discussed above. ${ }^{141}$ The fact that he is honored at the end of his term indicates that the position was probably annual rather than life-long, even while under the administration of the Panamareis. ${ }^{142}$ Also, the fact that Stratonikeia had the authority, or at least capacity, to appoint a priest at Panamara raises the questions of who ultimately had control over the sanctuary at this time, and the degree of dependency of the Panamareis koinon on Stratonikeia. In any event, the decrees of the Laodikeis and Kallipolis both show Leon to be a good arbiter, as he settled a dispute about an oath that was to be taken. ${ }^{143}$ The Kallipolitai honor Leon but also send a copy of their decree to the Stratonikeians, praising 'them for having appointed an excellent man

137 As evidenced by the architecture described in I.Stratonikeia 3 and 4 . The priesthoods of Zeus at Panamara and Hekate at Lagina are discussed in more detail in Williamson (2013b); see also Ackermann (2013).

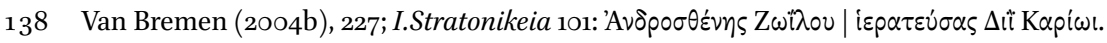

139 Van Bremen (2004b), 210 observes that Leon's long name, tracing him unusually back three generations to Polyperchon, may indicate that he was a descendant from one of the Macedonian colonists. Leon's priesthood is further discussed in LaBuff (2016), 131-139 and Thomas (2019), 158-159. In his commentary of the Kallipolis decree, I.Stratonikeia 1401, Shahin follows the suggestion in Oppermann (1924) that Leon was from Alabanda, and became a Stratonikeian only after his inclusion in the koinon of the Panamareis, I.Stratonikeia III, p. 11.

140 Van Bremen (2004b), 226-227, n. 73.

141 See the Historical Overview at the beginning of this chapter.

142 Leon is honored by the Panamareis in I.Stratonikeia 7 , the polis of Kallipolis in I.Stratonikeia 1401 (= EA 25 (1995), 83-85, no. 1), and the Laodikeis in I.Stratonikeia 1402 (= EA 25 (1995), 85-86, no. 2).

143 I.Stratonikeia 1401, lines 12-13, and I.Stratonikeia 1402, lines 7-8. 
as priest in the most prominent sanctuary'144 Leon's actions at the sanctuary show that he had a wide range of latitude for undertaking the expansion of the cult and reinvigorating its network, which he did by first examining the archives of the sanctuary, then:

having reconstructed that the above-mentioned honours and (grants of) asylia adhered to Zeus and to the Panamareis, he persuaded the entire people to make the sacrifices more splendid and better and going to certain demoi he persuaded them, too, to participate in sacrificing; (in all this) he zealously promoted the cause of the god and of the koinon of the Panamareis not sparing danger or cost or suffering. ${ }^{145}$

Leon was given credit for 'reinventing' the traditions of this seemingly ageold cult and especially for intensifying the contacts with local communities that were once common to it. ${ }^{146}$ Clearly a principal actor at Panamara, he used the past to change the future of the cult, by invoking an ancient grant of asylia to revive and expand the festival network of the shrine. The same dynamics were later used by the polis at Lagina and again through another priest at Panamara, probably in the first century вс. ${ }^{147}$ Stratonikeia may also have been one of the cities to acknowledge the ancient asylia of Panamara, implying some kind of formal relationship. ${ }^{148}$ The Panamareis clearly had some degree of autonomy, and van Bremen dates this inscription to the period of transition in the mid-second century $\mathrm{BC}$, before the sanctuary was entirely controlled by Stratonikeia. ${ }^{149}$ Leon's personal motives for being so deeply invested at Panamara remain unknown. This may have been a means of self-

144 Leon's appointment by Stratonikeia is especially evident in I.Stratonikeia 1401 (EA 25

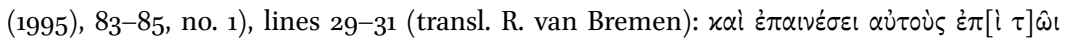

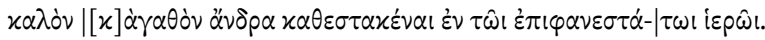

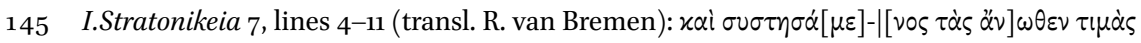

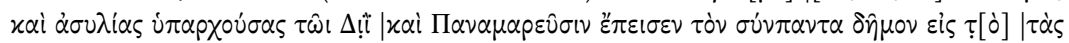

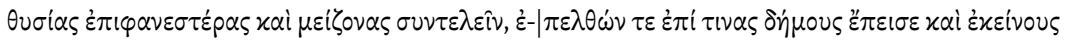

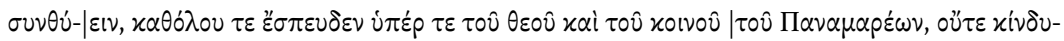

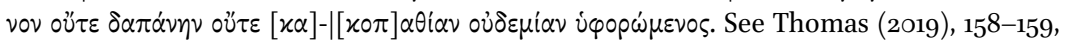
discusses Leon as a historian of the sanctuary.

146 The 'invention of tradition' is the topic of Hobsbawm and Ranger (1992), applied to the surge of festival culture in the Graeco-Roman era in van Nijf and Williamson (2015).

147 On asylia as an indicator for wider social interaction, see Ma (2003), also discussed in Chapter 2, Chapter 5 and below, under Scope and Network.

148 I.Stratonikeia 19.

149 Stratonikeia is apparently liberated from Rhodes, placing this after $167 / 6 \mathrm{BC}$; see further the discussion on the dating in van Bremen (2004b), 208-210 and in the Historical overview section at the beginning of this chapter. 
promotion by an ambitious member of the urban elite, as LaBuff suggests. 150 Equally, Leon may also have been acting on behalf of Stratonikeia in securing a strategic buffer zone of stability and goodwill for the polis down to the coast, as van Bremen argues. ${ }^{151}$ Whatever the original intent, Stratonikeia eventually did gain a foothold to the south, surely accelerated through the presence of the polis at Panamara.

Other remarkable aspects regarding the involvement of Stratonikeia at Panamara are known principally from the hiereus inscriptions, the priestly documents including their dedications and epangelias at the end of their office, summarizing their actions. The appearance of Hera and dedications to both the goddess and the demos of the polis are found among the priestly inscriptions. Menippos, son of Leon of Koranza, made as priest a dedication to Zeus Karios and Hera. ${ }^{152}$ Another inscription, by the priest Hekaton, son of Leon of Koraia, is dedicated to 'Zeus and Hera and the demos'.153 This trend was later followed by two priests, one of which was from Hiera Kome, who made a dedication to 'Zeus and Hera and the demos'. ${ }^{154}$ This would indicate that Stratonikeia shared the focus of cult by this time at least. Whether sudden or gradual, a major change did take place at some point in both the organization and content of the cult at Panamara. The biennial festival of Hera was in any event used as the chronological framework for the priesthoods of Zeus Panamaros into the imperial period - nearly a third of the priestly inscriptions refer to the Heraia.

Later priesthoods show a full integration with Stratonikeia, for example in the later first century BC, the priest Chairemon, son of Hekataios, son of Chairemenos of Koraia, presents an offering of thanks to Zeus Panamaros 'by

\footnotetext{
$150 \operatorname{LaBuff}(2016), 131-139$.

151 Van Bremen (2004b), 216-218, 237.

$15^{2}$ I.Stratonikeia 104; van Bremen (2004b), 226, who dates this "somewhat later" than that of Androsthenes, son of Zoilos, mentioned above; see also Laumonier (1958), 240-241.

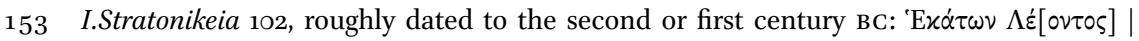

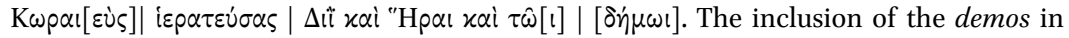
Hekaton's dedication is restored by analogy with I.Stratonikeia 103 .

154 I.Stratonikeia 103 shows Menander, son of Apollodotos dedicating a statue of Hermes to Zeus, Hera and the demos; I.Stratonikeia 332 is a simpler dedication by the priest [...] antos, son of Hydasou from Hiera Kome. This may be later than I.Stratonikeia 102 since the demotic is shown in abbreviation (IE), a practice that began towards the end of the second century вС. Later inscriptions, however, also use the demotic written in full, e.g. the priest Chairemon, son of Hekataios of Koraia writes his demotic in full, I.Stratonikeia 105 and 106, dated to the second half of the first century вС (Chairemon is also mentioned as priest in the miracle, I.Stratonikeia 10, Sherk (1992), 236 no. 145).
} 
vote of the demos, ${ }^{\prime 15}$ demonstrating that the priest is acting as an operative of Stratonikeia towards the god. Chairemon was the priest during the miracle at Panamara and this thank offering, with confirmation by the people of Stratonikeia, may well be an outcome of this momentous event. ${ }^{156}$ The priesthood was clearly a civic function by this later period, tightly interwoven with the administrative body of the polis. That priests had a euergetic role in the Hellenistic period already is demonstrated by a fragment with the priest distributing olive oil and wine to the population during one of the festivals. ${ }^{157}$ This would become a much more prominent feature of the priesthood in the imperial period, as shown by their building dedications. ${ }^{158}$ In the later Roman period, the priest was generally joined by a priestess, as at Lagina, typically his wife or a female relative; a major difference in the roles is that at Panamara the priestess had the official task of accompanying the women during the festivals. 159

The priesthood of Zeus at Panamara, like that of Hekate, became one of the most important and highly esteemed offices in Stratonikeia. Table 6.1 shows the high proportion of inscriptions associated with the priesthood; that it was filled annually, and recorded as the priest left office, is one of the reasons for the large number of these inscriptions found at the sanctuary of Zeus at Panamara, in use as it was over several centuries. ${ }^{160}$ The priesthood was probably an elected position, although the role of benefaction in the festivals became more and more important, as at Lagina, and so the circle of eligible

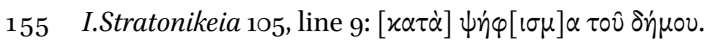

156 I.Stratonikeia 10, line 2 shows Chairemon as priest; see also Sherk (1992), 236 no. 145. Chairemon later became priest at Lagina and appears roughly midway in the list of priests, I.Stratonikeia 6og, lines 13-14 (dated to 38/37-28/27 BC).

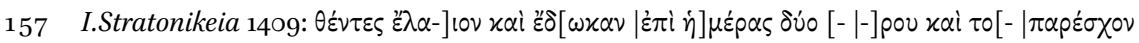
oivo $] \nu \pi \lambda \varepsilon[\hat{\imath} \sigma \tau$ \%

158 E.g. the dedications by Posittos, discussed above (see notes 63 and 64); Meier (2012), 145-151. Arjan Zuiderhoek has drawn attention to how common this phenomenon was in the imperial period, especially in connection with the general culture of the gymnasium, Zuiderhoek (2009), 89-92. See also above, under Festivals; the priesthoods of Hekate were also clearly euergetic, see Chapter 5 , esp. in note 259 .

159 The priesthoods of Panamara, particularly in the imperial period, are discussed in detail in Laumonier (1937), Laumonier (1938a), and (1958), 227-293. For the priestess at Panamara, see esp. Laumonier (1958), 227-228. Also Williamson (2013b) and especially Ackermann (2013) on gender roles.

16o This table only shows the published inscriptions, which derive mostly from chance surface finds and spolia from Bağyaka. Panamara has not been excavated and so proportions here will not be as reflective as they are at the sanctuaries in the other case studies. Even so, with over 400 inscriptions, Panamara has the largest collection by far, over half of which consists of priestly inscriptions. 
TABLE 6.1 Breakdown of inscriptions at Panamara according to type and period ${ }^{\mathrm{a}}$

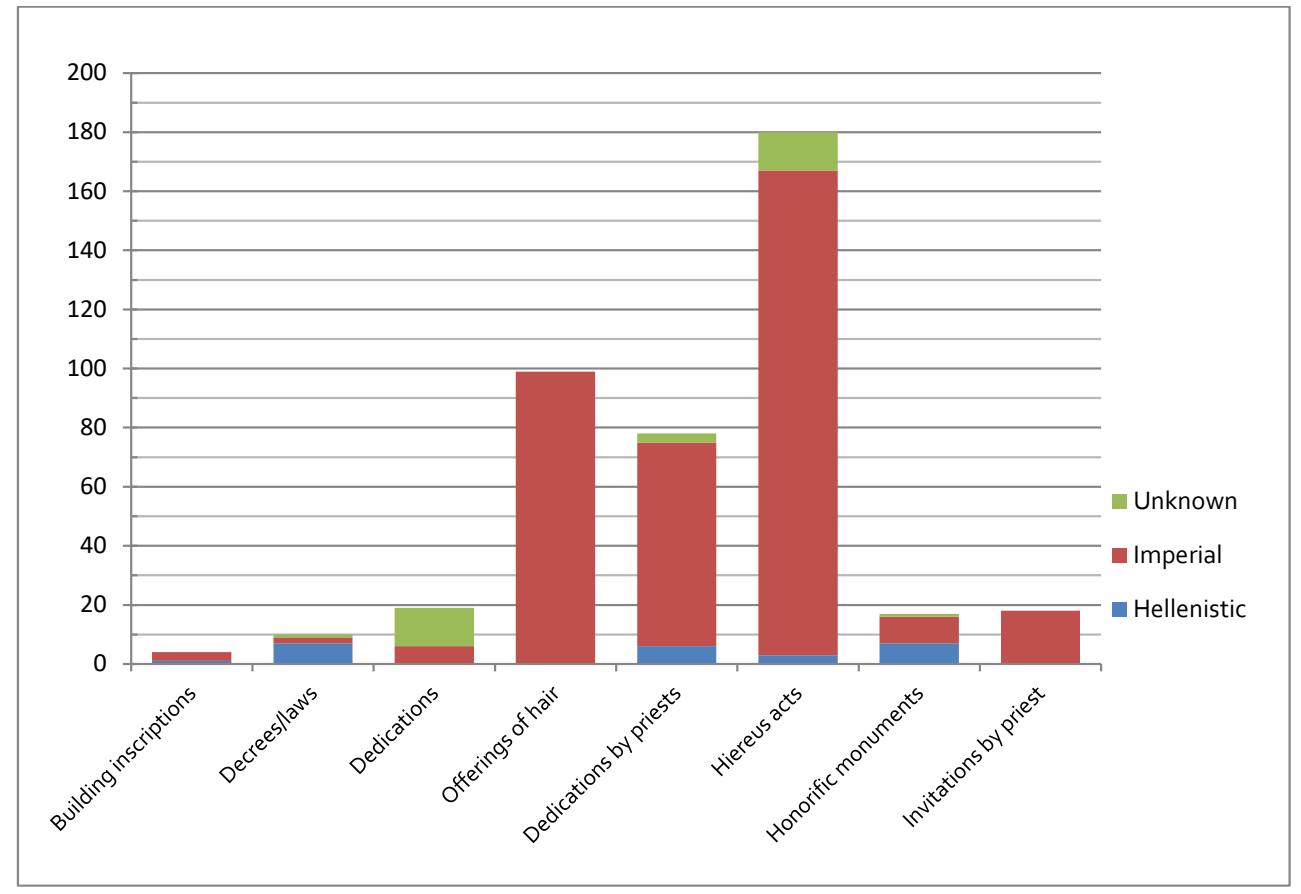

a Not included in this table are: the Senatus consultum de Panamara from 39 BC (I.Stratonikeia 11-12), a list of (responding?) cities (I.Stratonikeia 21), and a list of names from Hiera Kome and Koraia, of unknown date (I.Stratonikeia 45). The hair offerings are mostly from the later second or third centuries AD.

candidates dwindled to the most wealthy. ${ }^{161}$ This may explain why certain persons, such as Marcus Sempronius Clemens, could hold the office on five separate occasions, even combining it with the priesthood of Hekate in one year. ${ }^{162}$ He is not the only person to have held both offices, however; the fact that both priesthoods were on several occasions fulfilled by the same urban leaders, and

161 This may also explain why on occasion young boys or very old men were elected as priests, see Laumonier (1958), 227-228. The problem of recruitment is further discussed above with regard to Lagina, see Chapter 5 under Administration and priesthood.

162 I.Stratonikeia 289 (second half of the second century AD) gives the epangelia of Marcus Sempronius Claudius at Panamara in the Heraia, while being priest of Hekate; cf. I.Stratonikeia 16. His priesthood is extensively discussed in Cousin and Deschamps (1888); Nilsson (1927), 40o; Laumonier (1958), 277-280, 367; Frija (2012), 206-207, on his role as high priest of the imperial cult. 
thus major actors in the creation of cult identity, may also explain why the cults of the two main gods of Stratonikeia began to resemble each other more and more closely. ${ }^{163}$

Leon, mentioned above, provides an example of the initiative and latitude taken by a priest at Panamara in the Hellenistic period. Fragments from an intriguing set of documents, probably from the late first century BC, ${ }^{164}$ show that there was another priest, whose name is unfortunately lost, who also wrote letters to several cities inviting them to participate in the cult (Figure 6.28, discussed below). ${ }^{165}$ These letters are highly unusual, not only because they were recorded here at Panamara, but also because they were personally sent by the priest; neither Stratonikeia nor the koinon of the Panamareis are mentioned. Rather than being formulaic, the invitations were tailored to the situation, implying a personal history with each invited polis. ${ }^{166}$ Also, the invitations were explicitly extended to the entire population, not just envoys, theoroi, or other forms of representation. It would seem that this well-connected and well-informed priest took it upon himself to actively expand the cult network of the sanctuary, and had the knowledge and the means to do so.

This would in a sense seem to underscore the view of the priesthood as a semi-autonomous source of authority in itself, a legacy of the ancient theocratic system in Asia Minor, as Beate Dignas maintains. ${ }^{167}$ Of course the priesthood was fulfilled by members of the urban elite, and Stratonikeia seems to

163 Some individuals also held the priesthood of other cults at Stratonikeia, e.g. in I.Stratonikeia 249 Herakleitos, son of Apollonidos (etc) and his wife Tatarion, daughter of Myonidos had also held the priesthoods of Hekate as well as Zeus Chrysaoreus, besides the priesthood of Zeus Panamaros.

164 Hatzfeld (1927), 71-73; Curty (1995), 173-175, placing it after the epiphany of Zeus during the attacks by Labienus and the following grant of asylia in the Senatus consultum de Panamara of 39 ВС (I.Stratonikeia 11-12).

165 I.Stratonikeia 22 through 39b, discussed in Hatzfeld (1927), 71-73, and Curty (1995), 167175. No particular festival is mentioned in these letters, only mysteries and banqueting. The implications for the cult network of Panamara are discussed below, under Scope and Network.

166 Reminiscent of the great embassies of Magnesia on the Maeander in the second century BC, see Rigsby (1996), 179-279, also Williamson (in press-b) with references.

167 Beate Dignas tends to view the priesthoods of sanctuaries in Asia Minor across the board as a continuation of theocratic power in the Hellenistic and Roman periods, parallel to the city but not necessarily subordinate to it, Dignas (2002a), esp. 243 regarding Panamara and Dignas (2003); see also Laumonier (1958), 417 on Hekate's key as a symbolic remnant of a theocratic system. Dignas is right to point out that the priesthood was not just any civic office, but one with distinct honors and privileges. In Stratonikeia, however, the priesthood appears wholly integrated with the fabric of the polis, rather than as a separate or autonomous entity, although priests could certainly enjoy a wide range of latitude. 
have targeted this group in particular to shoulder the financial burden of the festivals. The transitions were certainly marked in the later Roman period with 'succession of the crown', accompanied by gifts of oil to the population. ${ }^{168}$ And yet to counterbalance this image, it should be observed that the priesthoods were annual and that they were not restricted to a particular family, even though the same names frequently occur. The priesthood was in fact fulfilled by citizens from all across the territory of Stratonikeia, as all five of the major demes are represented in the demotic of their names. ${ }^{169}$ In the imperial period, the priests often occupied the role of gymnasiarch at least during the Panamareia, probably as a way to ensure the smooth running of the festival in which events such as the distribution of oil took place in the gymnasium and other places in and around town. ${ }^{170}$ Although it continued to gain prestige, the priesthood of Zeus Panamaros, and that of Hekate at Lagina for that matter, should not be seen as a pseudo-independent source of power and authority but instead as an office fully in line with the needs of the polis - the polis was after all, at the center of the festivals of both gods and the priesthood one of its prime institutions.

Priests clearly took on the role of urban producer, even more so in the imperial period: they maintained the social fabric by addressing the entire population, while reinforcing the categorical differences (e.g. their generosity was extended even to the 'foreigners' and 'slaves' etc), treating some differently (e.g. special banquets for the gerousia, the different sums of money given to men or women), but especially by creating a level of social dependency on them and

168 Over twenty inscriptions, dated to the later second and third centuries, mention $\tau \hat{n}$

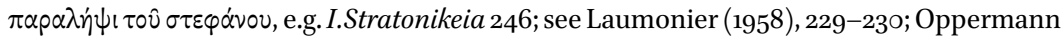
(1924), 57 .

169 Van Bremen (2004b), 239 observes that the earliest priests came from Koraia and Koliorga; these communities have not yet been identified, and so she suggests therefore that these villages were located close to Panamara, and that they were used to incorporate the Panamareis. She then goes further to state "instead of a takeover of the periphery by the centre, we see a very slow transition, within the wider polis context, from a domination of the priesthoods by those who lived in the sanctuary's vicinity, to a more evenly distributed participation across the whole territory later in the Roman period." This idea is attractive but must remain hypothetical until the locations of Koliorga and Koraia are known; none of the suggestions presented until now are particularly close to Panamara, even on Debord's map in Debord (1994), endorsed in van Bremen (2004b), 215. See above, in Chapter 5, Figure 5.1, and note 28, for Koliorga and Koraia, and note 54 of this chapter on Koraia.

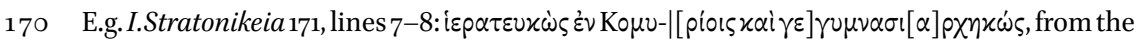

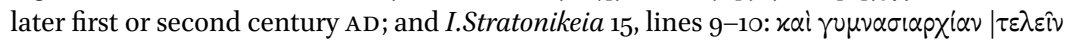

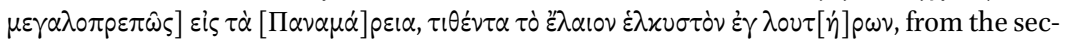
ond century AD. See also Hatzfeld (1927), 67 n. 3 . 
their position, all under the 'veil' of the sacrifices, as Richard Gordon puts it. ${ }^{171}$ Interpreting the euergetic system as a balance of power within the empire, Gordon shows how priests personally made heavy investments in the community, and in return received a high degree of social capital, thus perpetuating the "unequal and steeply stratified society."172 As one of the central institutions of the polis, the priesthood occupied a role of dynamic integration that worked both horizontally and vertically.

Besides the priests, another important sacred official at Panamara was the neokoros, a sort of financial administrator or manager of the sanctuary. This role is attested only once in an important but fragmented decree, now dated to the first century вс, regarding a manifestation of Zeus and the resulting privileges of asylia and ateleia; the neokoros is responsible for producing the inscription itself. ${ }^{173}$ All of the other instances of the neokoroi occur in the imperial period and show that the office is often fulfilled by someone who had been priest before and was probably able to offer guidance or financial assistance to the incumbent priest. ${ }^{174}$ The later imperial period shows a number of other incidental offices at Panamara, including the mystagogue, who presumably officiated at the mysteries of the Komyria. ${ }^{175}$

\subsubsection{Local Community - The Koinon of the Panamareis}

The Panamareis left sporadic indications of how their koinon was organized. Their decisions were taken in a community council, the ekklesia, convening under a demarchos. ${ }^{176}$ The community granted proxeny to a Rhodian citizen,

171 Gordon (1990), who interprets priesthoods in the empire as a repetition of the pattern of dominance at various scales, beginning with the emperor and working down to the local "peripheral" level. His example on p. 226-228 of Kleanax, son of Serapion of Kyme, is a striking parallel: as prytanis, Kleanax spent lavish sums on feasts for a highly diversified community - citizens, Romans, paroikoi, and foreigners - whose divisions "are repeatedly rehearsed, in an almost incantory manner," p. 228 (SEG 32 1243).

172 Gordon (1990), 208. Gordon sees the priesthood further as a critical hinge between the polis and imperial rule; although it extends beyond the focus of this present research to examine this at length, the adjectives 'loving the emperor', 'loving the fatherland', and sometimes even 'loving the Romans', as well as 'son of the polis', are liberally applied in the hiereus inscriptions of especially the second century AD, e.g. I.Stratonikeia 189 describes

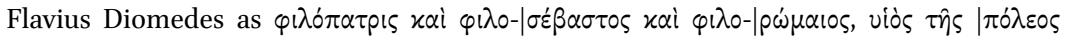
(lines 2-5). These affective usages are addressed in van Nijf (2014).

173 I.Stratonikeia 20 ; for the date see van Bremen (2004b), 22 .

174 Laumonier (1958), 231-232.

175 See Laumonier (1958), 232-233, where he also mentions a bouthytes, a specialist to help with the sacrifice of ten oxen (I.Stratonikeia 6o).

${ }_{176}$ The ekklesia and ekklesia kyria appear in I.Stratonikeia 4 and 9. The earliest inscription, I.Stratonikeia 1400 (= EA 35 (2003), 12-14) is an honorific decree for King Ptolemy, son of 
and extended citizenship (politeia) on at least two occasions, for a Rhodian commander as well as for the priest Leon in the second century вС. ${ }^{177}$ This shows their sense of autonomy, but is not necessarily proof of complete independence; the syngeneia of Korris also extended citizenship at Labraunda while being citizens of Mylasa themselves. ${ }^{178}$ As discussed above, the date of Stratonikeia's incorporation of the sanctuary, including the koinon of the Panamareis is unknown, but Riet van Bremen's hypothesis that it was a slow process, drawn out over some generations, is very likely the case. ${ }^{179}$ At any rate, after the sanctuary was clearly within the administration of the polis, the Panamareis were not heard from again. They may have become a deme of Stratonikeia, but more likely the community was divided among the other demes. ${ }^{180}$

Presumably the Panamareis resided near the hilltop of the sanctuary, since they took their name from the cult; they may well have been a dispersed or composite community, made up of smaller communities, who used the sanctuary as their central meeting place. ${ }^{181}$ Şahin did find evidence in 1975 of a settlement "... with comparatively well-preserved buildings located on a hill north of Panamara, just about $2-3$ kilometers away. The settlement is larger

Ptolemy, and is restored as being dedicated by the Panamareusi, which is taken to indicate that the Panamareis considered their community as a polis; see the discussion on p. 9-10 of I.Stratonikeia 140o. The demarchos is mentioned in I.Stratonikeia 6; van Bremen discusses this position in van Bremen (2004b), 231 n. 85; see also Oppermann (1924), 25-30.

177 I.Stratonikeia 5,6 and 7 , respectively.

178 On the Korris syngeneia see I.Labraunda 11-12, and above Chapter 3, Local community. These features are seen as an indication of Panamara's "autonomy" by Oppermann (1924), 24-31; Debord (1994), 114; Gabrielsen (2000), 163-167. One might also wonder what 'autonomy' meant, when they were clearly dependant upon the persons whom they were honoring. Van Bremen assesses Panamara's later "autonomous behaviour" with regard to the priest Leon as operating under the shadow of Stratonikeia, van Bremen (2004b), 228-231.

179 Van Bremen (2004b), 231, 235-240.

180 Panamareus rarely appears as a demotic, and then in imperial contexts, e.g. in I.Stratonikeia 615, a priest who was the adopted son of Phanios of Panamara; in I.Stratonikeia 227, the priestess Ada from Panamara; in I.Stratonikeia 846, a priest Damonikios, son of Herodos of Panamara - this last inscription was found at Akçahisar, which Şahin believes may have been the site of Londarga (or Lobolda), see Şahin in I.Stratonikeia III, p. 7-8. Laumonier lists Panamara among the demes of Stratonikeia, Laumonier (1958), 197-199, but Şahin believes it may have become a phylai of the polis, Şahin (1976), 37-38; see also van Bremen (2004b), 238-239.

181 Şahin is convinced that the koinon of the Panamareis was a federation of villages, Şahin (1976), 24 n. 78 and $24-25$. 
than what we know of Panamara."182 Laumonier had also noted the remains of a settlement "très ruinés en petites pierres," roughly 1.5 kilometers northwest of Panamara. ${ }^{183} \mathrm{He}$ describes in detail how this is situated along one of the lower slopes above "Bayaka Ova," where the ruins straddle a small ravine and extend for no more than 200 meters. Laumonier observed the foundations of a structure on one of the hilltops, at 30 meters long and 15 meters wide with a bastion or gateway projecting seven or eight meters along the north side. A rock-cut tomb, with a ledge for the lid, was situated in the terrace overlooking the bastion. Just below this was a structure built with Cyclopean walls, measuring eight by five meters. The hilltop further to the south also seems to have contained remains of Cyclopean walls. One follows an ancient road from here to Panamara, three meters wide for over 5 oo meters in embankments on the side of the mountain, along a deep ravine that separates this area from the spur on which Panamara sits. ${ }^{184}$

Laumonier's description is highly intriguing, since the area has not otherwise been systematically surveyed for any evidence of settlement activity, and may never be in light of the strip-mining activities. The proximity with the sacred way surely indicates that this complex was connected with the shrine, perhaps the settlement of the Panamareis, or a later community of cult personnel. If the saddle that Laumonier mentions is the same one on the lower eastern slope of the Bencik Dağı, at an elevation of roughly $730 \mathrm{~m} \mathrm{ASL}$, then it would have visually encompassed most of the territory of Stratonikeia, connecting it with Panamara. A number of tombs, cut from the rock, may now also be observed along the western approach to the sanctuary, marking the course of the sacred way (discussed above, also Figures 6.24-6.25). Since these have 'informally' been brought to light, their chronology will unfortunately remain unknown, yet they strongly resemble the description of the tomb seen by Laumonier in the nearby settlement.

One inscription from the first century BC mentions those who were physically at the sanctuary (the entopioi), local residents that may have worked the lands in the area or kept herds, or possibly cult personnel; their identity

\footnotetext{
182 Şahin in I.Stratonikeia III, p. 13; he discusses this in connection with I.Stratonikeia 1402, since he considers this site a candidate for the village of the Laodikeis, see above.

183 Laumonier (1936), 324. Unfortunately the exact location of the site was not recorded, and I was unable to identify it during my visit in October 2011. It seems likely that it would be situated on the ridge immediately north of Bağyaka - this ridge, however, has been given over to the exploitation of lignite (see Figure 6.7) and as Bağyaka has recently been evacuated, there was no one left in the village to ask.

184 Laumonier (1936), 324-325. The known extent of the road is described above under Sacred road.
} 
is unclear. ${ }^{185}$ If the marble doorway that now lies exposed on the northwest slope (Figure 6.26) was indeed part of a tomb, then it may well have belonged to one of the wealthier priests. For the rest we can only speculate as to whether the people buried near the sanctuary were locals, from one of the nearby settlements discovered by Laumonier and Şahin, or residents from town who wished to be buried near the sacred place. They were in any event not as highly profiled as a group as were the katoikountes, or residents, at Lagina.

\subsubsection{Economic Resources}

The sanctuary of Zeus at Panamara had become a large and extended complex with festivals which must have required a significant financial undertaking, and yet our knowledge of its economic base is poorly informed, as it is at Lagina. Whether the polis had a sacred treasury or reserve for the festivals, or generated their own additional income through the events provided, or whether the sanctuary owned lands that were exploited can only be speculated.

In fact, the only source of income explicitly mentioned is provided by the priests themselves, as they personally host banquets, and give out gifts of oil, wine, and money. These banquets and distributions for the entire population would have provided a significant impulse for the local economic production systems. As the distributions took place throughout the chora, they also would have been another means of shaping the territory through cult while creating social cohesion at the same time. One hiereus inscription from the later imperial period explicitly mentions those living in the city and of the chora, in reference to the Heraia. ${ }^{186}$ Several hiereus inscriptions mention distributions of oil to both citizens and strangers during the festivities. In I.Stratonikeia 310 , shows a prominent priestly couple, distributing gifts in the processions and festivals of the Panamareia as well as Hekate's kleidos agoge, and even providing crowns that were given out during the 34 days of festivities in that year. ${ }^{187}$ Certain segments of the population were frequently singled out, e.g. the women of the city

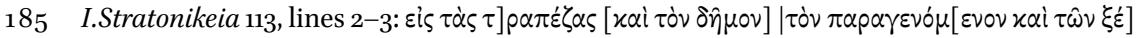
$v \omega \nu$ xal zे $[\tau \circ \pi i \omega v]$.

186 I.Stratonikeia 256, discussed above under Festivals, n. 91 and n. 110. Also I.Stratonikeia 268.

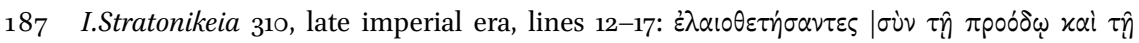

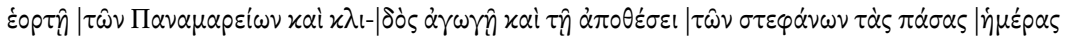

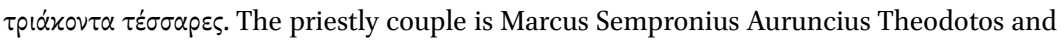
Sempronia Auruncia Arriane, briefly discussed above under Administration and priesthoods; see also above in Chapter 5 , note 228.
} 
and countryside who each received gifts of three drachms, ${ }^{188}$ and the Romans living in the countryside. ${ }^{189}$

While they no doubt fulfilled a real need of the population, these distributions also created a kind of financial dependency, meanwhile generating social capital for the priests themselves. ${ }^{190}$ In any event they underscore the role of the priest as civic producer, creating or maintaining cohesion among the population as well as territorial integrity by using their personal generosity to ensure that the cult and with it the polis was the focus of the entire community.

To summarize, prior to the advent of Stratonikeia, the cult of Zeus at Panamara had been administered by the koinon of the Panamareis. The autonomy of this community, wherever they lived, is unclear, especially in the early second century вС, as they had to deal with Rhodes, Philip v (for a short time), and eventually the rising polis to the north. Riet van Bremen's view of a gradual transfer, in which the Panamareis retained their title to the sanctuary while Stratonikeia began to transform the cult from the inside out, seems most plausible. The appointment by Stratonikeia of Leon as priest is a turning point, at least in the epigraphic record. He clearly had the means and apparently the clout to revive the shrine and get other communities involved too, expanding the network of Panamara while gaining goodwill for Stratonikeia. Leon's strategy worked well, and the koinon even felt that he acted on their behalf, although this actually signalled the end of their administration. Several generations after Leon, another priest also acted as a broker when he personally invited several cities throughout Karia and Ionia to participate in the festivals at Panamara, thereby expanding the network of Stratonikeia through ties of syngeneia and cult. Priests were well-connected statesmen and were most likely included in the envoy sent by the polis to Rome to secure the Senatus consultum de Panamara after the miraculous rescue by Zeus from Labienus. By the imperial period, the euergetic dimension of the priesthood began to escalate into increasingly sumptuous displays of generosity, with gifts of oil,

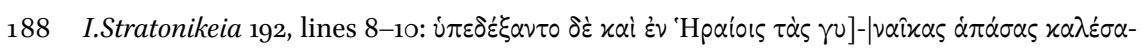

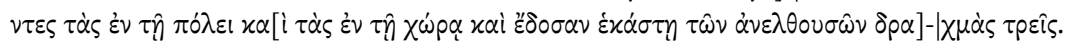
The priestly couple had also given the men five drachms each during the Komyria.

189 I.Stratonikeia 186 is an inscription by a priest who was 'pious towards the gods, having sought honor among the citizens, the Roman residents of the country, and foreigners'

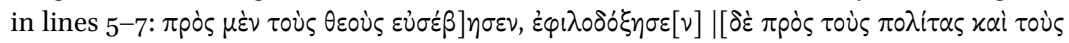

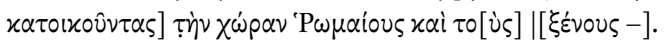

190 Laumonier suggests that the priestly gifts fulfilled a real need among the majority of the population which was poor, Laumonier (1958), 397; Gordon stresses how these gifts established a balance of social inequality, Gordon (1990), also discussed in Zuiderhoek (2009), 94-95 and Zuiderhoek (2011). On social capital, Bourdieu (1986); on the 'social turnover' turnover of euergetism, Zuiderhoek (2009), 133-140. 
wine, and money, as well as banquets and spectacles. This financial burden restricted the position to the highest circles of the urban elite and the office was frequently held by members of the same family in different generations. Some individuals held the position more than once, and some even combined it with the priesthood of Hekate at Lagina. As with the ritual, this overlap of religious domains would have contributed to the growing similarities between the two major cults of Stratonikeia. The priests also played a crucial role in turning the hilltop sanctuary at Panamara into a major urban complex by the imperial period. Most likely there was a local resident community, possibly at the site found by Laumonier on the lower slopes of the Bencik Dağg. ${ }^{191}$ As civic producers, the priests of Zeus, and Hekate, would have seen their euergetic function as a return on investment in the population of 'their' city, creating a communal focus while increasing their social capital. Social cohesion in this diverse population base would have been critical to the stability of the polis. As at Lagina, the priesthood at Panamara was one of the central institutions that helped build the territorial and social integrity of the polis. Priests were clearly central figures in constructing the urban identity of Stratonikeia. ${ }^{192}$

\subsection{Urban Mediatization at Panamara}

The architectural remains, the festivals and the administration of the sanctuary at Panamara have shown how the cult of Zeus was gradually absorbed by the polis of Stratonikeia. This section explores how the sanctuary was used to expand the political network of the polis, but also how the Stratonikeians perceived and expressed their own relationship with Zeus Panamaros, both in the stories they told to each other, but also to the outer world, and in the ways they depicted him on their coinage. These show how the cult of Zeus had become an organizing principle and symbolic focus for the community, creating joint attention for the internal cohesion of the polis, but also for its external manifestation.

\subsubsection{Scope and Network}

The sanctuary of Zeus at Panamara has already been demonstrated to have had a regional significance through the involvement of the surrounding

191 The many tombs lining the sacred road to the sanctuary resemble the one described by Laumonier at the settlement which he discovered and could be from locals or pilgrims. On the settlement, Laumonier (1936), 324-325, cited above under Local community. Whether this is the same site mentioned by Şahin in I.Stratonikeia III, p. 13, which he saw in 1975, is unknown and is unlikely to be verified, since the wider area around Bağyaka has been given over to the Yatağan Power Plant, see above Figure 6.7.

192 Developed more in Williamson (2013b). 


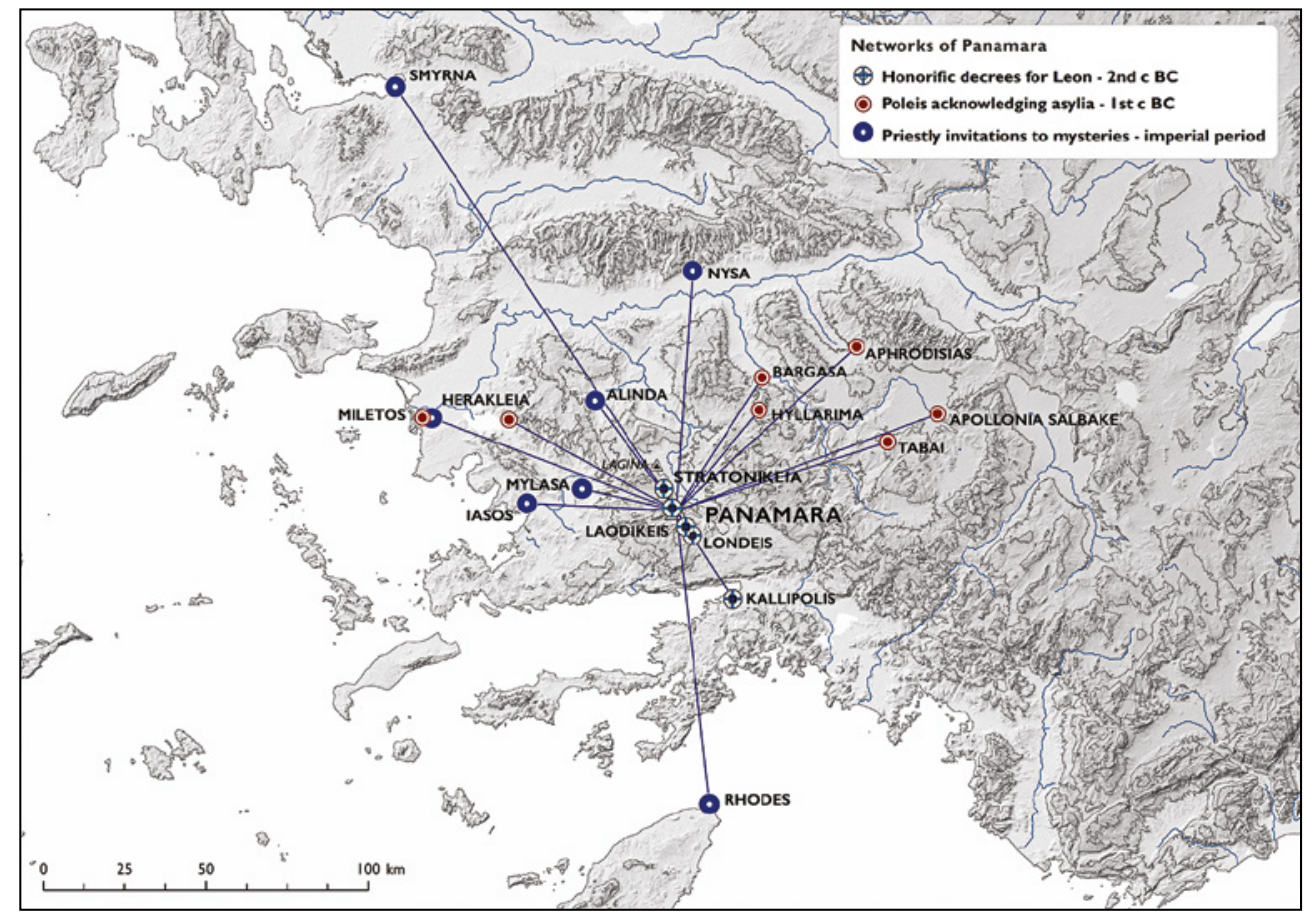

FIGURE 6.28 Social network of Panamara. Map of the identifiable communities involved in the worship of Zeus at Panamara at different times, testified by inscriptions

communities, as well as the attraction it had for Philip v and the Rhodians, both honored by the Panamareis. As discussed in the previous section, priests played an important role in shaping the cult of Zeus at Panamara. Besides their religious function in defining the ritual performances, they also had a political role as actors in extending the urban relations of Stratonikeia through expanding the cult network. This was done in at least three separate periods at Panamara.

The first period of network expansion occurred at the initiative of Leon, assigned by Stratonikeia as priest of the cult of Zeus Karios at Panamara. Communities that we know were active at the sanctuary at this time include the Londeis, the Laodikeis, and the town of Kallipolis, all located to the south (Figure 6.28). Leon exhorted these communities, and others, including Stratonikeia, to acknowledge the (rediscovered?) ancient right of asylia at the sanctuary and to augment the splendor of their sacrifices. Not only did Leon address these communities individually, he also 'achieved a settlement between those who disagreed about the oath', getting them to 
cooperate again. ${ }^{193}$ Nothing is otherwise known of the nature of this oath, or the disagreements, but oaths were a normal part of any human transaction, not only with the divine but also, and especially, between humans as a kind of binding contract. ${ }^{194}$ This oath was most likely central to the operation of the cult network at Panamara, since it is the main reason for the gratitude of the Kallipoliteians and the Laodikeis; smoothing out some of the issues that these two communities both had with the text reinforced the network by ensuring their full cooperation.

In this way the sanctuary once again became a lively center of activity and a bright dot on the mental maps of the surrounding communities. Although we do not know the exact nature of the relationship between Panamara and Stratonikeia at this time, the fact that the young polis was able to appoint a priest at the sanctuary is in itself significant. Leon's priesthood belongs to a period of transition at both Stratonikeia and Panamara, when the shrine was probably within the area liberated from Rhodian rule by Rome in $167 / 6$ вC, along with Stratonikeia, but connected to communities that were still within Rhodian territory, farther to the south. ${ }^{195}$ Rhodes was known to feel 'hatred' (apechtheia) towards Stratonikeia in this period, and the emphasis of Leon's actions as being conducted at personal risk may well have to do with this venture into hostile territory. ${ }^{196}$ Panamara was at the northern edge of this area,

193 The decree of Kallipolis mentions the oath in I.Stratonikeia 1401, lines 12-13: [- xai tov̀

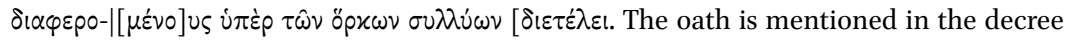

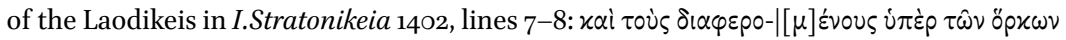
$\sigma 0 \lambda \lambda \dot{\omega} \omega \nu \delta \varepsilon \varepsilon \varepsilon \dot{\lambda} \lambda \varepsilon \mathrm{l}$. Translations of the texts in full are provided in van Bremen (2004b), 241-244. On oaths in general, Williamson (2013a).

194 On Panamara as a center for solving legal problems: Chaniotis (2004), 30-31. On oaths as social contracts: e.g. Bederman (2001), 67-68 and Carawan (2007).

195 The date of Leon's priesthood has been the object of some discussion, see above under Administration and priesthoods, but is now seen as following the liberation from Rhodes by Rome in 167/6 BC; van Bremen (2004b), 209-210. Van Bremen (2004b), 236-237, sees this as reason for the Laodikeis to refrain from stating Leon's origin; they continued to date their decrees according to Rhodian priesthood, showing its dependency, while Rhodes was known to be antagonistic towards Stratonikeia.

196 Rhodes' hatred of Stratonikeia is expressed in I.Iasos 612, discussed in Ager 1996, no. 161; this concerns a (territorial?) dispute between Rhodes and Stratonikeia, arbited by a citizen from Bargylia, dated to the later second century вс, during the Aristonikos wars. The emphasis on Leon's personal risk is in pursuing the interests of Zeus and the Panamareis is shown in I.Stratonikeia 7 , lines 9-11 (cited above). The inscriptions of Kallipolis (I.Stratonikeia 1401, line 15) and the Laodikeis (I.Stratonikeia 1402, line 9) also acknowledge his effort and potential hardships and personal investments. Similar phrasing is used at Keramos in a decree honoring an unnamed citizen, roughly in the same period, who acted in the interests of the polis during a sympoliteia, without regard for personal risk 
and apparently welcomed support from the expanding polis to the north, just as the polis was clearly eager to include the sanctuary within its wider radius of action. Increasing the fame of the sanctuary would reflect well on the polis that held it within scope. Van Bremen sees, however, an ulterior motive behind Stratonikeia's mounting influence at the sanctuary: promoting goodwill at the sanctuary among its constituent communities in the south was a way of creating a friendly corridor through hostile Rhodian country towards the coast, with all its strategic and economic attractions. ${ }^{197}$

A second phase in the expansion of the cult of Zeus at Panamara followed the attack by Labienus on the sanctuary in 39 BC. An inscription at the temple, discussed in the next section, shows how the assault was miraculously thwarted by Zeus - this gave the Stratonikeians reason to appeal to Rome for a second grant of asylia, or inviolability, this time for Panamara, and Laumonier believes that a number of the names of the Stratonikeian ambassadors to Rome probably belonged to families of priests. ${ }^{198}$ Parallel to Leon's actions, and parallel to those at Lagina 42 years before, the grant of asylia, written in the Senatus consultum de Panamara and inscribed on the walls of the temple, ${ }^{199}$ was again used to compel other poleis to acknowledge the status of the sanctuary and per association the corresponding city. The process of gaining this recognition is unfortunately unknown, but a heavily fragmented list of cities from this period may indicate its success. ${ }^{200}$ The only cities whose names were preserved - Miletos, Apollonia (Salbake), Aphrodisias, Tabai, Herakleia, Hyllarima, and Bargasa - are located in central and eastern Karia, with the exception of Miletos (Figure 6.28). This represents a second wave of expansion of Panamara's network to the north and northeast, very likely related to

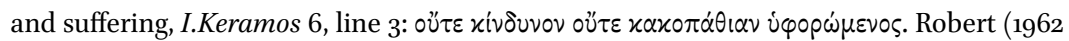
[1935]), 6o-61 suggested that the sympoliteia may have been with Stratonikeia, see also Debord (2001a), 165; van Bremen (2004b), 211 n. 18, however, doubts this interpretation but does acknowledge the risks that such endeavors apparently involved, testified by this inscription.

197 Van Bremen (2004b), 217-218: "The entire subject-Peraia [= Rhodian territory on the mainland - CGW] formed a buffer between Stratonikeia and the sea, with Rhodian dominated koina on either side of the main route along the valley of the Marsyas down to the sea at Idyma; the same applied for the alternative route via Pisye along the valley of the Kartal Deresi (Kocaçay) down to Sarnıç and to the sea at Akbük, which was moreover lined with fortresses." See also van Bremen (2004b), 218, n. 37-38.

198 Laumonier (1958), 239.

199 I.Stratonikeia 11-12, see also Sherk and Viereck (1969), no. 27, 158-162. This is discussed in the next section.

200 I.Stratonikeia 21. Hatzfeld suggested that this list was related to the asylia, Hatzfeld (1927), 68. 
its grant of asylia in the later first century вс. The asylia was in any event used again later to get Rome's attention at the reforms tribune of Tiberius in $23 \mathrm{AD}$, and Stratonikeia was among the rare exceptions to boast two sanctuaries with this privilege. ${ }^{201}$

In the early imperial period, perhaps at the end of the first century BC, another unknown priest took the initiative to send invitations to a number of cities to participate at the sanctuary. ${ }^{202}$ Hatzfeld observed that the objective was to get as many of the surrounding poleis as possible involved with cult activities. $^{203}$ The eighteen letters that survive point to a third wave of the social network of Panamara, but unfortunately only seven names have been preserved: the Rhodians (including those living in Karia), Mylasa, Alinda, Iasos, Miletos, Smyrna, and Nysa (which was already participating in the festivities of Hekate). Mylasa as nearest neighbor is significant while the rest roughly border on the wider region of Karia and Stratonikeia in particular (Figure 6.28). Interestingly, the letters stress a mutual (but surely invented) ancestral bond, i.e. syngeneia, referring to the sacred things which they held in common, as well as homophily, friendship and goodwill. ${ }^{204}$ The shared heritage was presumably stressed in order to strengthen the ties with these communities, obliging them to take part in the cult and mysteries. ${ }^{205}$ Although the events leading to this correspondence are unknown, a wider participation would have not only given a boost to the local economy through additional sacrifices, but also a heightened profile of the sanctuary in the region, as well as the creation of a friendly buffer zone around Stratonikeia's territory.

201 Tac. Ann. 3.62, cited above in Chapter 5. Rigsby (1996), 418-427 on the grants of asylia for Stratonikeia. He observes on p. 418 that "Pergamon supplies a parallel for this double achievement [for the sanctuaries of Athena Nikephoros and Asklepios - CGW], and perhaps Chalkedon."

202 I.Stratonikeia 22 through 39b, mentioned above under Administration and priesthood. They are discussed in Hatzfeld (1927), 71-73, and at length in Curty (1995), 167-175. Syngeneiai, or kinship groups, are discussed in more detail in Chapter 4 in relation to the Pelekos and Pormounos syngeneiai of the sanctuary of Sinuri.

203 Hatzfeld (1927), 72.

204 E.g. I.Stratonikeia 22, the letter to the Rhodians, refers to their cities as $\pi$ pòs $\alpha \lambda \lambda \dot{\eta} \lambda \alpha \varsigma$

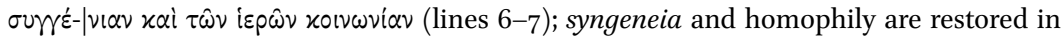
I.Stratonikeia 3o, the letter to the Mylasans, which also includes friendship and goodwill (lines 3-4). On using syngeneia as the base for establishing ties in a network, see esp. Curty (1995), Jones (1999), Lücke (2000), Ma (2003), and Erskine (2003).

205 John Ma presents a parallel usage of syngeneia, by the Kytenians of Greece, who, after suffering earthquakes and wars in the early third century BC, decided to obtain external funding to rebuild their city walls; they did so as true Dorians and asked for contributions from other Dorian-related cities based on syngeneia; $\mathrm{Ma}$ (2003), 9-12. 
Most scholarly opinion places these letters in the second half of the first century BC, probably after the epiphany of Zeus. ${ }^{206}$ If this is true, then there may have been yet another priest who followed in Leon's footsteps by getting the surrounding communities more involved in the cult. Curty suggests as much, and goes even further by stating that it was through the sanctuary at Panamara that Stratonikeia was able to expand its orbit. ${ }^{207}$ Whenever they were written, these letters were critical in creating ties between the polis and the wider region through the sanctuary of Zeus; Ma, in fact, speaks of the discourse of syngeneia as a symbolic map, establishing links with communities in distant regions. ${ }^{208}$ These letters inscribed at the sanctuary thus functioned as a kind of map of places that were important to Panamara and to Stratonikeia. Using asylia to create geopolitical ties was a strategy that Stratonikeia was well familiar with. This had already been used at Panamara to draw in the surrounding communities, much as it had been done at Lagina in the early first century BC - both sanctuaries clearly played pivotal roles as major hubs in the wider political network of Stratonikeia.

\subsubsection{Civic Decrees}

Panamara was a good place to establish political ties. Long before Stratonikeia used the sanctuary to solidify its position in the area, the koinon of the Panamareis used it as their own political platform; they issued a decree to honor Ptolemy apparently even before the Seleukid foundation of Stratonikeia. ${ }^{209}$ Later decrees by the Panamareis show them honoring Philip v, who used the citadel as his base for occupying the region at the end of the third century вс. ${ }^{210}$ They also used the sanctuary to honor Rhodians when they were in control, similar to Stratonikeia's use of Lagina. ${ }^{211}$ I.Stratonikeia 6, for example, is a decree

206 Hatzfeld (1927), 71-73, and Curty (1995), 173-175. Especially the invitation extended to Rhodes is an argument against dating these letters to the period just after the independence of Stratonikeia from Rhodes, since Rhodes is known to express 'hatred' ( $\dot{\alpha} \pi \dot{\varepsilon} \chi \theta \varepsilon 1 \alpha)$

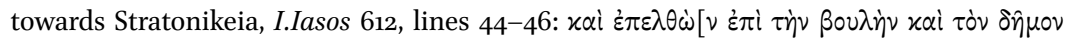

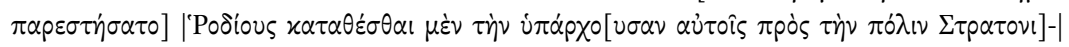
$[\chi] \hat{\eta} \omega \nu \alpha \dot{\alpha} \pi \dot{\varepsilon} \chi \theta \varepsilon ı \nu$, dated to 127 BC.

207 Curty (1995), 175: "Ce sont les légendes de cette Confédération [the ieron koinon in the text] qui permettent de rattacher à Stratonicée des cités dont les mythes ressortissent à des sytèmes fort différents."

$208 \mathrm{Ma}$ (2003), 9-12, 20; discussed above and in Chapter 2.

209 I.Stratonikeia 1400 , dated to the $270 \mathrm{~B} \mathrm{BC.}$

210 I.Stratonikeia 3 , dated to 201 BC; I.Stratonikeia 4 is an honorific decree for Philip's epistates Asklepiades of Peuma, dated to 198 вс.

211 At Lagina this included the cult to Rhodian Helios, I.Stratonikeia 504, and a reference to an alliance between Stratonikeia and Rhodes in I.Stratonikeia 1418 (= EA 35 (2003), 
of proxeny by the Panamareis, which was to be set up in the sanctuary in 'a conspicuous place' (toi epiphanestatoi topoi). ${ }^{212}$ This in itself implies that the sanctuary had some kind of coherent design, although we do not know what this was, and that certain spaces were clearly more in the eye of the public than others. ${ }^{213}$

The honors awarded to Leon, the priest appointed by Stratonikeia, may well represent homage being paid to the rising power of the polis by the koinon. ${ }^{214}$ This is the last act by the Panamareis that we know of, and it signalled the irreversible shift of the center of gravity at the sanctuary towards the polis - the koinon of the Panamareis is not heard from again. The relationship between the sanctuary and the young city before this period is somewhat clouded. As stated above, the Panamareis seem to have used the stephanephoros of Stratonikeia to date its decrees during the occupation by Philip v. This at least indicates the polis as an administrative center for the area, but whether it actually controlled the sanctuary at this time is another matter. ${ }^{215}$

Besides the Leon inscriptions, the first appearance of the polis at Panamara is in a decree by the demos concerning the sanctuary. ${ }^{216}$ This heavily fragmented inscription may well be Stratonikeia's own response to Leon's plea for increased involvement in the festivals, as it seems to acknowledge the right of asylia of Panamara.

Stratonikeian concerns initially seem to revolve around the organization of the sanctuary, as the record left to us mostly consists of simple inscriptions placed by the priests, all of whom seem to have come from the polis. Festivals were no doubt organized but we know very little of these, other than the inscription listing the sacrifices with music. ${ }^{217}$ Otherwise the use of the

1-7) and I.Stratonikeia 1424 (= EA 29 (1997), 98-99 no. 17); at Panamara a Rhodian commander, Plykratidas of Dailochos, was honored in I.Stratonikeia 9, dated to the 18 os BC by van Bremen (2008). Rhodians were also honored in I.Stratonikeia 5 and 6 . Analyzing the letter-types, van Bremen suggests that no. 6 dates to the earlier part of the third century вС, and no. 5 by analogy with no. 6 , van Bremen (2008).

212 I.Stratonikeia 6 , lines $15^{-16}$. On the date of this inscription, see van Bremen (2008), 1412-1413.

213 See also Williamson (2013a) on the installment of oath inscriptions at sanctuaries.

214 Leon is honored by the Panamareis in I.Stratonikeia 7 , discussed above.

215 The stephanephoros in I.Stratonikeia 4 is interpreted as Stratonikeian by van Bremen (2004b), 231, who further points out that both Panamara and Stratonikeia used Rhodian dating conventions during the Rhodian period.

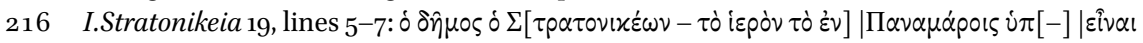
$\delta \varepsilon \hat{~ \tau o ̀ ~} \alpha$ $\sigma u[\lambda \circ v$; dated by van Bremen to the second century BC, van Bremen (2004b), 220. This decree was also meant to be set up in the 'most conspicuous place' ( $\dot{\imath} \nu \tau \hat{\omega} \iota \varepsilon \dot{\varepsilon} \pi \varphi \propto \nu \varepsilon-$

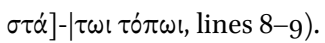

217 I.Stratonikeia 1, discussed above under Festivals. 
sanctuary by the polis appears rather low-key until the second part of the first century $\mathrm{BC}$ when events at Panamara mark an important turning point in the life of the polis.

In $39 \mathrm{BC}$, an account of the miracles performed by Zeus while protecting the sanctuary and people from attack by Labienus and his Parthian troops was recorded in detail in an inscription at Panamara. ${ }^{218}$ For the Stratonikeians it was this epiphany that saved their polis from the continuous onslaught by the Parthian troops - after the city had successfully resisted the assault, Labienus ransacked Lagina instead and turned to do the same at Panamara, probably during one of the festivals in which the population of the city was on the somewhat isolated hilltop. Unlike Lagina, however, Panamara was not taken thanks to the epiphany of Zeus, whose miraculous intervention day after day through fire, thunderstorms, fog, and hallucinations eventually brought total confusion upon Labienus's troops, who ultimately suffered heavy losses and fled into the Karian wilderness. All the while the lamps in Zeus's temple burned brightly, showing the god's presence. The long inscription relates the details of the event in vivid detail and color. Most likely this inscription was written into the walls of the very temple that withstood the attack, turning it into a lieu de mémoire.'219

This collective epiphany triggered a number of visible changes that mark a new phase in the relationship between the sanctuary and the city. In the first place is the inscription itself. As a monument, the record of the miracle was surely intended to imprint the event onto the collective memory of everyone who visited the sanctuary. But especially the way in which it is told, as directly as possible so that the reader is completely caught up in the event, holding his or her breath as they read on in suspense of how it will end, shows that this was also intended as real drama. Even the very reading of the inscription was a kind of re-enactment of the event. Like a legend, this event was meant to be kept alive through time, to be retold, reread, and relived each year by

218 I.Stratonikeia 10. This inscription is one of the few surviving accounts of an epiphany where so much detail is preserved (see also the Lindian Chronicles, and Pausanias's account of the epiphany at Delphi during the Gallic invasions, Paus. 10.23.1-10). It further describes the general setting of the sanctuary, its fortress, and the topographical difficulties Labienus's troops encountered in their attack, including the steep sides of the ravine. Further discussions in Oppermann (1924), Roussel (1931), Merkelbach (1968). Graf (2004), 118-122 observes that collective epiphanies typically involve meteorological phenomena rather than anthropomorphic manifestations; also Pritchett (1979), 11-46 on military epiphanies.

219 Deschamps and Cousin (1888a), 104. On 'lieu de memoire', Nora (1984-1992), also van Nijf (2000), $3^{2}$ and n. 53 and Alcock (2002), 21; see the discussion in Chapter 2 on Spatial memory and visual regions. 
each generation. ${ }^{220}$ The stealth attacks, the battles, the hail, fire and fog, the anguish of the people, and the final triumph, this was true spectacle, and the inscription ensured that everyone's imagination was thoroughly engaged in reliving the way in which Zeus protected the polis of Stratonikeia.

The second spin-off was the sizeable embassy, of 10 to 12 Stratonikeians, that was sent to Rome to remind the superpower once again of the city's loyalty and apply for asylia. By attacking the Stratonikeians through its shrines at Lagina and Panamara, Labienus could not have made the tightness of the bond between the city and its outlying sanctuaries mor clear; the Stratonikeians now used this same relationship in their to appeal to the Senate. They were surely also eager to 'update' the sanctuary's ancient right of asylia to make it current in the modern world. The acquired grant, in the Senatus consultum de Panamara, ${ }^{221}$ dated to August 15th of 39 BC, enabled Stratonikeia to again appeal to the wider community for recognition, while distinguishing the polis among its peers as a city with not one but two sanctuaries that were each officially declared inviolate.

A third important spin-off is the change in the epiklesis of the god from Zeus Karios to Zeus Panamaros, which already appears in the inscription itself as the people shout 'Great is Zeus Panamaros'.222 This inscription marks one of the earliest uses of Panamaros that would eventually replace the older and more regional title. Renaming the god in this way is a highly conscientious act, and it can hardly be a coincidence that it occurred at one of the most critical moments in the history of Stratonikeia. ${ }^{223}$ Emphasizing the place of the cult through the epiklesis of Panamaros, rather than the wider scope indicated by Karios, was in effect a way of annexing that very sanctuary on that very hilltop a

220 On embedding epiphanies into local history, see Rostovtzeff (Rostowzew (1920)), who relates the records of epiphanies at Lindos with the Chersonesean honorific decree, IosPE $I^{2}$ no. 344. This late third century вС decree honors the historian Syriskos for writing down all of the epiphanies of the goddess Parthenos in relationship with the polis of Tauric Chersonesos, the Bosporan kingdom and the other important poleis. I am grateful to Vladimir Stolba who pointed this out to me.

221 I.Stratonikeia 11-12, heavily fragmented. See also Sherk and Viereck (1969), no. 27, 158-162; Rigsby (1996), 423-427. The embassy is discussed in Laumonier (1958), 239, who believes that members of some of the priestly families were among the delegates, as mentioned above.

222 I.Stratonikeia 10, line 13.

223 Contra Oppermann (1924), 85, followed by Magie (1950), 997-998, n. 34, and Laumonier (1958), 241, who believe the epiklesis switch was a resurgence of the indigenous cult, with 'Karios' initially used in Macedonian contexts to distinguish him from Greek Zeus. Laumonier believes that the epiklesis reflects a desire to emphasize locality above ethnicity, downplaying the ethnic connotations of Karios, Laumonier (1958), 241. 
half a day away from town. ${ }^{224}$ Nicole Belayche suggests that the topographical connotations of this new name, which emphasizes the locality while neutralizing its regional appeal, made the cult more accessible for Karians, Greeks, and Romans too. ${ }^{225}$ Using this new name brought along with it an immediate mental image of the event as well as a clear idea of the location of the sanctuary, but most importantly the tight connection with Stratonikeia and its landscape.

This is one of the main reasons to interpret the new festival of the Panamareia as one of the most important spin-offs of this critical event. The event itself showed Zeus as an important actor/agent who took initiative in the relationship with Stratonikeia, much like Hekate before. ${ }^{226}$ It was his divine will and power to protect the population of the polis, who were left exposed at his sanctuary. The logic behind the festival of the Panamareia, then, is that this relationship is taken one step further - the almighty god descends into town, entering the city on horseback, to be among his beloved community of worshipers. The period of intense feasting in and around town and the general celebration of the polis that followed the processions were shared by everyone - citizens, foreigners, the freedmen and slaves, thus cutting across social boundaries, and especially those of origin in the old communities.227 The culmination of the procession at the bouleuterion, and the later imperial portrayal of the choirs of youths singing hymns and waving branches, served to make this event in itself a grand spectacle that would create a shared focus for the entire community.

224 In this context it is interesting to observe the four golden footprints (ichni) that were dedicated at Panamara in the later third century AD, I.Stratonikeia 248, lines 14-15, cited above in Chapter 5 , n. 140. Perhaps, like the feet incised at the sanctuary of Hekate, these could be interpreted in relationship with the divine power manifested on earth in this spot, Dunbabin (1990). Presumably the four footprints belong to Zeus and Hera, perhaps matching the footprints of the priestly couple dedicating them.

225 Rivault (2018) and Belayche (2009) discuss the implications of the name after the miracle in I.Stratonikeia 10. Belayche considers Zeus Panamaros as a completely new and civic-oriented cult, but her suggestion that this is a separate deity, in a kind of synnaos theos relationship with Zeus Karios, seems less plausible than Debord's view of the new epiklesis gradually overtaking the old Debord (2001a), 167. This seems to be supported by the several dedications that include Hera with either Zeus Karios or Zeus Panamaros, although Panamaros appears much more often, see (Williamson $(2013 \mathrm{~b})$ and esp. $(2020 b))$. Belayche gives an interesting interpretation on the later twist in spelling, as $\Pi \alpha \nu \eta \mu \omega ́ p(\imath) \circ \varsigma$, which would set it opposition with Hekate's lunar focus, Belayche (2009), 203. Rivault focuses on the new epikleses of megistos and epiphanestatos, Rivault (2018).

226 Hekate's epiphany is discussed above in Chapter 5 , under Urban mediatization.

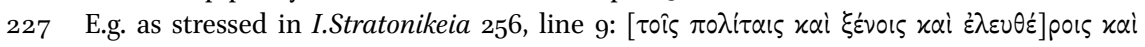
$\delta \circ u[\lambda \circ 1] \varsigma \pi \hat{\alpha} \sigma \mathrm{l}$. The festivals of the Komyria and the Heraia were similarly all-inclusive; see also above under Festivals. 
A final emanation from the epiphany of Zeus and especially the festival of the Panamareia is the change in his imagery on the coinage of the city, since Zeus begins to appear in the mid-first century ВС on horseback, continuing into the later imperial period (Figure 6.30); this is discussed in the next section.

All of these changes in the expression of cult and community through the festivals show the epiphany of Zeus to be a defining moment in the relationship between city and sanctuary. The polis may have institutionalized this relationship, but its origin was clearly presented as the divine will of Zeus Panamaros.

\subsubsection{Cult Iconography in Urban Contexts}

The appearance of Zeus at Panamara is only known from the coinage of Stratonikeia. Zeus and Hekate are portrayed on the earliest coins, issued some time after Stratonikeia's independence from Rhodes (Chapter 5 , Figure 5.27a). Andrew Meadows dates this group to the period between the 16 os and 13 os BC (Group 1). ${ }^{228}$ However, the identity of Zeus on these early issues is somewhat ambiguous. Meadows simply assumes that these coins show Zeus of Panamara, also for his Groups 2 (140/130-125/110 BC) and 3 (80s BC). ${ }^{229}$ Barclay Head had suggested an identity of Chrysaorean Zeus, the god of the Chrysaoric League, based on similarities with coins from Keramos, a member of the League. ${ }^{230}$ Both issues depict Zeus, bearded and laureate on the obverse, with an eagle on a thunderbolt on the reverse (Figures 6.29a-b). Comparisons with other poleis show that a similar laureate male bust with a beard is a rather generic depiction of a resident Zeus. ${ }^{231}$ In the absence of clear indicators it is impossible to conclude which Zeus is actually depicted on the earliest coinage.

Later issues, however, will have surely depicted Zeus of Panamara, as heavily involved as the polis was with his cult at that time. Although Zeus appears

228 Meadows (2002). Sources and interpretations of Stratonikeian coinage are further discussed in connection with Lagina, in Chapter 5 .

229 Meadows (2002), 98, without motivation for his identification of Zeus of Panamara, presumably assuming that Panamara already belonged to Stratonikeia in the period he gives for the first issues (160-13о вС).

230 Head in BMC Caria, lxix: "Whether these types refer to Zeus Chrysaoreus or Zeus Panamaros is doubtful, but the fact that the same types occur on the contemporary hemidrachms of Ceramus ... seems to indicate Zeus Chrysaoreus, whose cultus was common to all Carians ..." Keramos was a prominent member of the Chrysaoric League, Strabo 14.2.25 and Gabrielsen 2000, 159. Magie simply assumes Zeus Chrysaoreus, Magie 1950 II, 10311032, n. 77 .

231 Although Keramos, with Zeus on the obverse and an incuse eagle on the reverse, shows the closest parallels in its coinage with Stratonikeia, other similar curly-haired, bearded, laureate Zeus depictions appear on the Late Hellenistic coins from Euromos, Herakleia Salbake, Tabai, Myndos, and Orthosia. 


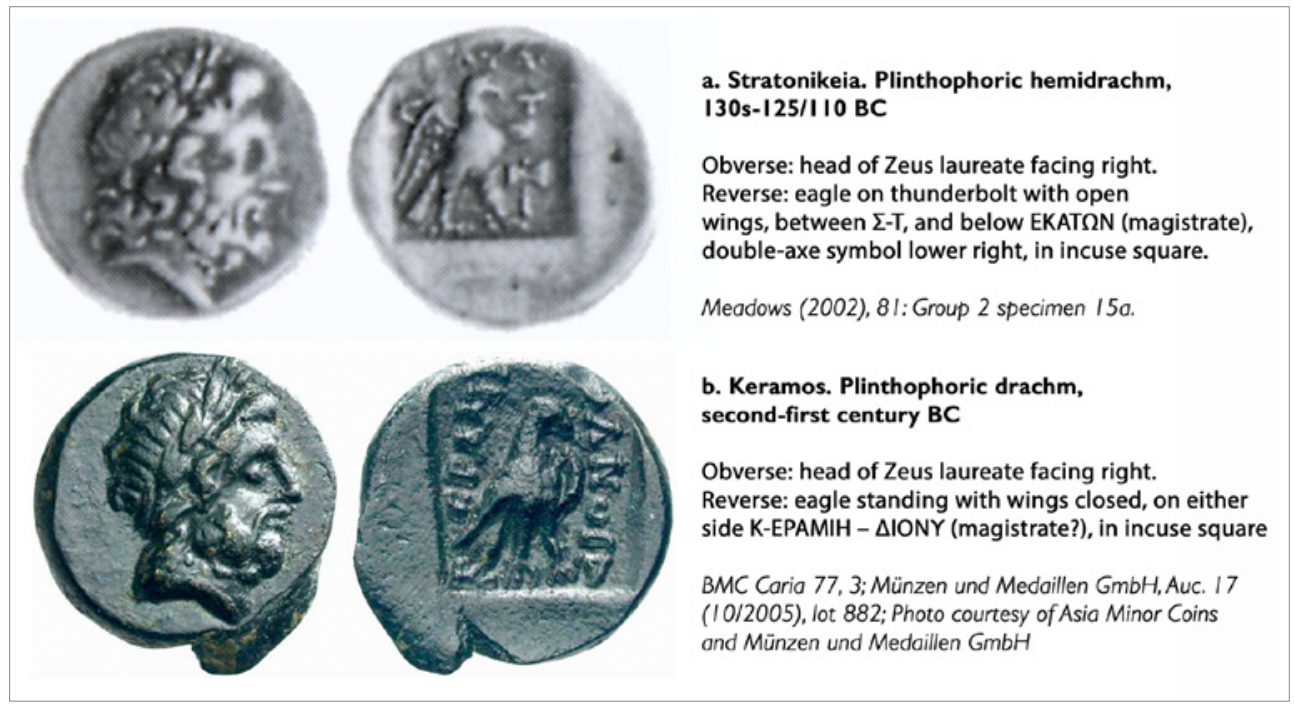

FIGURE 6.29 Zeus on coins from Stratonikeia and Keramos

less frequently than Hekate during the Mithridatic wars, he makes a strong comeback on the coins issued in the wake of the attacks by Labienus in 40 вС (Meadows' Group 4), now mounted on horseback (Figure 6.30a). ${ }^{232}$ This equestrian Zeus who surfaces on the coins after the siege by Labienus and the saving intervention of the god is widely interpreted as Zeus Panamaros. ${ }^{233} \mathrm{But}$ this is not the only occurrence of Zeus astride a horse; a contemporary coin from Apollonia Salbake shows Zeus with a double-axe (as Zeus Labraundos?) riding across a wall-like shape (Figure 6.30b). The aspect of an equestrian Zeus raises several interesting questions as to whether his cult actually began to converge with that of other all-powerful rider-gods, especially Sabazios from Thrace, whose cult was making inroads into Karia in this period, or whether the imagery was borrowed in order to convey a powerful god in contemporary terms that would be understood by all. ${ }^{234}$

On the Stratonikeian coins from this time on, Zeus on horseback must have been reminiscent of his epiphany and his regular appearance in the Panamareia (Figure 6.30a, c), assuming that his cult was brought into town on horseback in

232 Meadows (2002), 111-113.

233 See e.g. Head in BMC Caria, lxxii; LIMC VIII, 381 no. 116; this makes it especially tempting to project this interpretation back to the bearded heads on the earlier coins.

234 The Thracian equestrian god Sabazios is attested in Karia at different places, e.g. Pisye (Debord and Varinlioğlu (2001), 131) and Mylasa (I.Mylasa 34 and 330); the later coins of Attuda also depict Zeus Sabazios (SNG von Aulock 2495). On rider-gods see e.g. Johnston (1992); Delemen (1999); Horsley (1999); and Talloen (2006). 


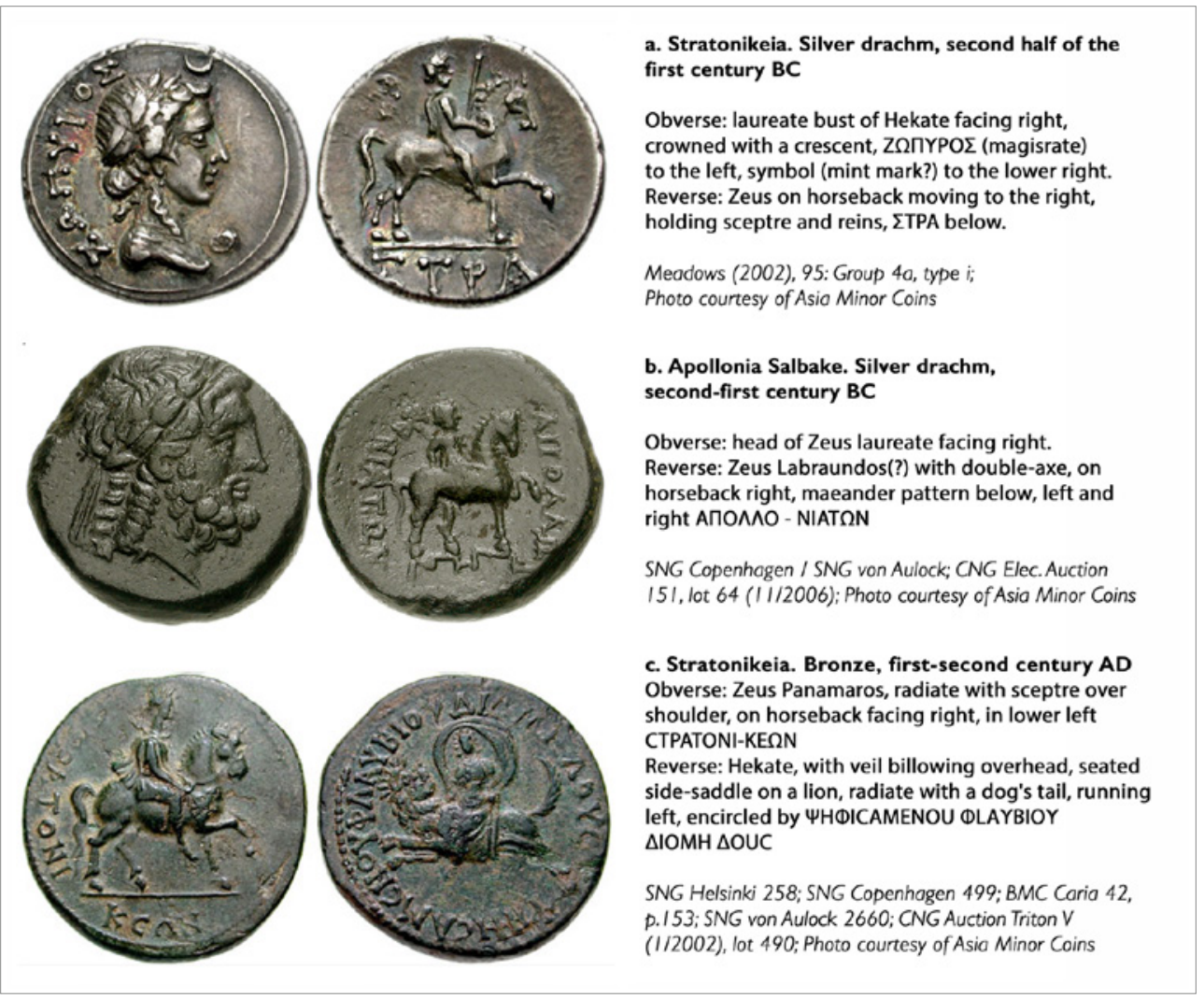

FIGURE 6.30 Stratonikeian coins showing equestrian Zeus and Hekate

the anabasis of the processions. ${ }^{235}$ If this connection is valid, then the fact that this iconography continues well into the Roman period would indicate that the polis signified this event as a defining moment in their history. A number of dedications to Zeus Panamaros have also been found in the urban center of Stratonikeia, dating from the Roman period, and one might expect future excavations to yield more iconographic representations of the deity. ${ }^{236}$

It is no certainly coincidence that Zeus is often combined with Hekate both gods had expressed their energeia, their divine power in protecting Stratonikeia in two different crises. Impressing onto the coins the images of these patron deities, who were both drawn into town at different moments, was not only a way of sanctifying the circulation, but also a way of publicly

235 I.Stratonikeia $1536-1540$ are dedications to Zeus Panamaros found more recently at Stratonikeia.

236 The anabasis is testified in I.Stratonikeia 161, discussed above under Sacred road. 
advertising these gods and their tight bond with the polis. The longevity of the type is a tribute to the symbolic value of both gods for the city.

In sum, the scope of the sanctuary of Zeus at Panamara underwent four major phases: 1) when the sanctuary of Zeus Karios was administered by the koinon of the Panamareis; 2) a transitional period in the early second century $\mathrm{BC}$, beginning with the priesthood of Leon, when the sanctuary was gradually overtaken by Stratonikeia; 3 ) a period of consolidation, during which the sanctuary appears to have been completely controlled by Stratonikeia; and 4) the period following the attacks of Labienus in 4 О ВС and the miraculous epiphany of Zeus, which marked a phase of expansion of cult and its fame for Stratonikeia. Especially the periods of transition in the second and last phases require some comment. As mentioned above, Leon acted on behalf of both the Panamareis and Stratonikeia when he rallied communities in southern Karia, thereby reinforcing the cult network. As van Bremen argued, Leon's show of goodwill may well have been designed to give the polis a foothold in this area towards the south while creating a friendly corridor to the south through Rhodian territory. ${ }^{237}$ Over a century later the cult underwent another major change, after Zeus's miraculous salvation of the Stratonikeians from Labienus. This came to be a defining moment in the life of the polis but also the cult since Zeus was now known as Zeus Panamaros rather than Zeus Karios. The event was inscribed into social memory via the temple walls, and was used by the polis to obtain a second grant of asylia from Rome. This gave Stratonikeia reason to once again engage its larger network, again at the initiative of a priest who this time wrote personal letters of invitations. This second wave seems to have focused on northern Karia and Ionia, perhaps to strengthen relations in the aftermath of Labienus's attacks in the region. Although we can trace the initiatives of the priests and probably the council of the polis as the agency of change in the development of Stratonikeia, it is clear that the Stratonikeians themselves saw this as the divine will of Zeus, and presented him as the uncontested protagonist of the polis. From this perspective, Dignas' argument that it was the older cult that took the peripheral city into its scope is understandable. ${ }^{238}$ The will of the divine is certainly much more impressive than the blood, sweat, and tears of priests and magistrates. But understanding how the relationship between sanctuary and polis was mediatized to create regional networks, territorial expansion, political power, and social cohesion

237 Van Bremen (2004b), 216-218, 237.

238 Dignas (2002a), 243, mentions Panamara in passing as continuing to be "a centre that itself gradually included the administrative centre into its vision and gave it a religious identification." 
allows us to appreciate the craft of deliberately intertwining the identities of city and cult. Ritually moving Zeus's cult image from the hilltop sanctuary down into town was a theatrical expression of the god's active role in protecting the city, as his festival consumed the urban landscape. The image of the god riding into town was surely reflected in the coinage of Stratonikeia from the mid-first century BC and onwards, no doubt referring to the festival, but also to the deep connection between the god, his sanctuary, and the city. This was the 'subliminal' message that was repeated over and over again, through festivals, feasts, songs, and the images multiplied on the coinage. Zeus's epiphany at Panamara became a charter myth for Stratonikeia.

Interpreting Change in the Relationship between Stratonikeia and Panamara

After its liberation in the mid-second century BC, Stratonikeia adopted an expansionist policy and in light of this the incorporation of Panamara may certainly be seen as a push to the south of the frontiers of the polis. Although the exact territorial boundaries are unknown, Stratonikeia and Panamara are both considered within the northern fringe of the Rhodian 'subject Peraia.239 Debord's hypothesis of Panamara as part of a combined strategy between the polis and the sanctuary to be able to stand up to Rhodes certainly places the sanctuary at the frontiers of these two controlling powers. ${ }^{240}$ Van Bremen's interpretation of Panamara as a hinge connecting Stratonikeia with a number of sympathetic communities in the south, and thereby creating a corridor of goodwill through aggressive Rhodian territory, presupposes a frontier role for the sanctuary as it gives Stratonikeia a foothold in the south. ${ }^{241}$ As she warns, however, the evidence does not support a traditional core-periphery model with a Hellenizing urban center versus an indigenous rural periphery. ${ }^{242}$ This same level of caution should be applied in considering more general theories of frontier sanctuaries, grounded as they tend to be in a similar

\footnotetext{
239 Debord (1994) and (2001a); van Bremen (2004a) and (2008).

240 Debord (2001a), esp. 167.

241 Van Bremen (2004a), esp. 237.

242 E.g. Ramsay, echoes of which are heard in Laumonier, who sees Stratonikeia as a Hellenizing center from the start for the indigenous settlements and sanctuaries in its territory, e.g. Laumonier (1958), 234-235, cited above in Chapter 5, in note 164. Van Bremen objects that "even to speak of a symbiosis between 'new city' and 'old sanctuary' is to misunderstand, fundamentally, the nature of the new city itself," van Bremen (2004a), 223.
} 
dualistic approach. ${ }^{243}$ Panamara might initially have been used as a signpost of Stratonikeian presence at the edge of Rhodian territory, but it would be misleading to impose the polarities of marginal landscapes of nature (versus culture), or wild (versus civilized), onto its topography. In fact, the territory of Stratonikeia was in no sense a void but was instead filled with a diversity of human activity and settlements dispersed across various economic zones. The sanctuary itself had been the social, if not geographical, hub for several of these communities and it seems to be exactly this central position in this cultbased network that attracted the polis. ${ }^{244}$

Like Lagina, Panamara is located near certain natural boundaries that would have played a factor in the location of the cult of Zeus here - it lies along the western fringes of the Marsyas, at the eastern head of a deep valley that extends west and is lined by the Marçat range to the south and the Bencik Dağ to the north. Although not on the most prominent peak, the shrine is on a hilltop that was accessible and defensible while providing a good view. This strategic situation may also be applied to frontier sanctuaries, yet it must be borne in mind that the defensive character of the site primarily played a role during the administration of the Panamareis; it was even used as a garrison by Philip v and probably the Rhodians. Except for the encounter with Labienus, however, this was no longer the main feature of the sanctuary after Stratonikeia took control - instead, Panamara began to develop as an urban space.

Of all of the case studies in this present investigation, Panamara is closest qua location to fulfilling the role of a frontier sanctuary. One may even see it as the product of peer-polity interaction, but instead of leading to rivalry and competition, this was one that sought integration and connectivity through the centrality of the cult. Stratonikeia appears to have used Panamara, especially in the beginning, to build bridges rather than establish borders.

The sanctuary was in any event a beacon of Stratonikeian presence, some 10 kilometers south from the urban center. The several changes discussed in the preceding parts of this section serve to show how the polis interjected itself as central focus of the cult. Interpreting Panamara as a frontier sanctuary emphasizes its role as a landmark of Stratonikeian territory for the outer world. Yet a

243 Especially the 'bi-polar model' developed by de Polignac (1984), and de Polignac (1995), for the situation in Archaic Greece, as discussed above in Chapter 2.

244 Frontier sanctuaries could also have a mediatory role; Sinn (1996), esp. 71. describes such sanctuaries at mountain passes in Arcadia as having the acknowledge right of asylia, so as to function as safe channels, providing secure passage for travelers but also for commerce. De Polignac also addresses the aspect of mediation at frontier sanctuaries, although more in the context of competitions, de Polignac (1995). Competition was certainly an aspect at Lagina, but apparently less at Panamara. 
number of other issues were also involved in the dynamics of cult and reflect some of the same concerns that we have already seen at Lagina.

Foremost among these concerns must have been social cohesion. In the second century $\mathrm{BC}$, the young polis was a mixture of local Karian villagers and Greek colonists, their descendants, and newcomers from other areas. Festivals, as at Panamara, were an important means of creating a shared focus for the entire and diverse population, regardless of status or origin, and ensured poliswide involvement. Turner's concept of communitas may comes to mind here Panamara certainly was a 'center out there' and the effort of the journey itself would already have been a step in the preparation of the new inclusive experience of rituals. Barbara Kowalzig addressed this concept in relation to theoria, including the dangers of travel, the investment of delegates and the heightened sense of their reward upon success. ${ }^{245}$ She demonstrates how especially effective ritual is in fostering harmony and social cohesion but also its importance as a measure against the opposite. This is clearly the case at Panamara, with the theoria and the inclusive festivals. But what Panamara especially highlights is how the integrative nature of the festivals worked towards creating a sense of urban community. This is very different from Turner's intended use of the concept, in which ritual communitas creates the 'anti-structure' as an alternative to the structure of the city. At Panamara, ritual communitas actually builds the structure of the city.

Festivals provide a common focus that captures everyone's attention and are thus effective vehicles for the transmission of common knowledge; as such they are rational rituals. ${ }^{246}$ Looking at the individual components at Panamara, we can quickly identify the sensory immediacy of music together with the sacrifices as important channels of common knowledge. ${ }^{247}$ Everyone would have witnessed the sacrifices, smelled the smoke and incense, and shared in eating the meat. The hymns sung during the festivals were probably something that everyone knew by heart, recalling memories and creating associations. New hymns would have been composed in accordance with the slant of the new festivals at the sanctuary, especially the Komyria for men and the Heraia for women. These festivals focused on gender or social roles in a way that cut across social boundaries and the deme divisions that were otherwise so prominent in every urban activity; everyone was invited to join whether citizen, foreigner, freedmen, slaves, urbanites, country-dwellers. While going out

245 Kowalzig (2007b), and esp. (2007a), 72: "Theoria as a form of social interaction lies at the heart of Greek religion, basic to its mobility, and to social structure."

246 Chwe (2001), discussed in Chapter 2.

247 Young (1999). 
to the shrine in these predefined groups would actually have maintained these distinctions, the important point is that they did this together, en masse. ${ }^{248}$ A third festival, that of the Panamareia, went beyond the others by bringing the cult image of Zeus into town, on horseback in a procession, an event that must have been spectacular to see and even more exhilarating to be take part in. These processions of Zeus were centripetal, just like the kleidos agoge of Hekate, and they were perhaps the largest link in a chain of actions that served to literally direct the focus of the festivals and the cult towards the city itself. ${ }^{249}$

Using linear ritual space, the processions in general drew the whole civic body across the territory in both directions. Such processions have been interpreted as a statement of domination and control. Yet this was more likely a ritual means of unifying the composite population with each other and with their territory - nearly everyone would have had some stake in the countryside of Stratonikeia and this was a way to make them all intimately familiar with it. Like Lagina, Panamara extended the visual region of the polis, this time to the south. Ritually traversing the landscape brought this 'new territory' at the same time into three-dimensional view, adding it to the domain of the polis and imprinting it via ritual upon the mind's eye. Following Chwe, the public nature of the processions were in themselves crucial towards creating community, but neither as a display of power (Geertz) or in isolation from the city (Turner). More than a pilgrimage, such a loud, conspicuous, and sumptuous public spectacle catching everyone's attention was a highly effective means of 'saturation advertising. The perfect coordinating mechanism, the spectacle fostered the dissipation of common knowledge that is ultimately at the root of social cohesion and collective identity. ${ }^{250}$ The Stratonikeians 'performed the region' through these processions, both by ritually crossing territory and by doing it as publicly as possible, just as they did with Hekate's kleidos agoge. ${ }^{251}$

Finally, incorporating the entire community, but also the entire civic landscape in the most social part of the ritual, namely the feasting, was a way of creating an intense community focus. Feasting took place not only in the urban center but also throughout the territory, even in Lagina, at Hekate's sanctuary in the far north. Everyone was not only feasting at the same time across this vast area, but everyone knew that everyone was doing it too. More than a shared experience, common knowledge creates a mindset that includes social

248 E.g. as suggested in I.Stratonikeia 174 by the mention of a splendid theoria, apparently as a delegation from the polis itself, in lines $4-5$.

249 See Graf (1996) on centripetal processions, discussed above and in Chapter 5 .

250 Chwe (2001), 21.

251 Donaldson (2006); the kleidos agoge is discussed above in Chapter 5, under Ritual performance. 
memories and expectations. This laid the foundations for cohesion and collective identity across the composite communities of the rising polis.

The festivals of Zeus and Hera were thus reinvented and turned into rational rituals that served to unite the very diverse population base of Stratonikeia, but they were also used to establish networks with communities outside the polis. Especially priests had a large share of this responsibility, as they were the ones who took the initiative in contacting other communities. This began with Leon who, around the mid-second century вС, strengthened the central position of Panamara in the surrounding area by physically going to communities and getting them to increase their involvement in the festivals of Zeus, and so with each other. Although the record is scanty, the scope of his activities appears to have been targeted at the south, towards communities still within Rhodian territory. Over a century later, after the miraculous rescue of the polis by Zeus, priests may well have been behind the delegation to Rome. In any event, the divine intervention was used to obtain the right of asylia from the Senate, enabling Stratonikeia to further promote Panamara among a much wider circle, as it had been done before with Lagina. The evidence is lacunose, yet it seems this time that they were more interested in local Karian communities to the north and northeast, and perhaps Ionia, as Miletos was one of the communities addressed. A third wave is seen by the efforts of yet another priest who took the initiative to expand the cult network of Panamara by personal invitation. This time the targets appear to have been poleis along the northern edge of Karia, and farther along the coast, even including Smyrna, but also the Rhodian community, as he appealed to them based on claims of syngeneia, or kinship, through cult. The sanctuary of Zeus at Panamara served to consolidate the regional network of Stratonikeia by association with the cult of Zeus. Important mediators in the first two waves were grants of asylia, while the ties of syngeneia were pivotal for the third wave of network establishment. As Ma discussed, asylia and syngeneia were concepts of connectivity that were globally understood throughout the Greek world. ${ }^{252}$

Both the emphasis on social cohesion through the cult and the use of it to build wider network developments are important steps in the development of regional identity. As with Lagina, it is easy to follow the ways in which Panamara was instrumental in constructing the identity of the polis when we consider the four basic stages of region building as identified by Anssi Paasi: territorial shaping; symbolic shaping; institutionalism; and the establishment through external recognition. ${ }^{253}$ Territorial shaping already began with the

$252 \mathrm{Ma}$ (2003), discussed in Chapter 2.

253 Paasi (2009), 133-137; see also above in Chapter 5. 
incorporation of the Karian villages around Stratonikeia. The cult of Hekate at Lagina especially seems to have provided a central focus for these communities - her cult already seems to have belonged to the Stratonikeians by the early second century BC, during the period of Rhodian rule. At that time, the cult of Zeus Karios at Panamara was still being administered by the koinon of the Panamareis, and the polis does not appear to have played a leading role at the sanctuary until after the end of Rhodian rule. Drawing Panamara into the orbit of the polis must represent a second phase of Stratonikeian expansion, at whatever pace this took. As the polis gained control of the sanctuary, it came to share the focus of cult with Zeus and Hera, as the dedication including the demos indicates. ${ }^{254}$ It may well be Zeus Karios whose image appeared back-to-back with Hekate on the first coinage of Stratonikeia in the midsecond century вс. By the mid-first century, the symbiotic relationship between Stratonikeia and Panamara was proven by Labienus, who attacked the shrine in lieu of the city. This event in itself marked a critical turning point in this relationship, in which Zeus took on a highly personal role as manifest divine protector of the city.

The polis could not have chosen a more effective symbol than the image of a supreme being whose divine will it was to watch over the city. Even more than the pomp and ceremony of the festivals and processions, this singular miraculous event, with all of its special effects, is the perfect spectacle to create 'flashbulb memories', crucial for accurate recall but also for religious and cultural transmissions. ${ }^{255}$ Whatever took place on the hilltop in $39 \mathrm{BC}$, the important thing that matters is that it was collectively perceived by the Stratonikeians as the intervening hand of their god that saved their city from destruction. ${ }^{256}$ They clearly mattered to Zeus and their very existence was due to his divine will. Gehrke's 'intentionale Geschichtsschreibung' can help interpret the role of epiphanies and their strategic use by cities to highlight their own position along different geopolitical axes. ${ }^{257}$ Public memory is crucial in this regard. The way in which the Stratonikeians dealt with the event is highly self-conscious, given the various ways in which it was commemorated, e.g. the embassy to

\footnotetext{
254 I.Stratonikeia 332.

255 McCauley and Lawson (2002), 56-64.

256 On collective epiphanies and their perceptions, see also Rostowzew (1920) and Graf (2004); also Picard (1952) and Pritchett (1979), 11-46, who both conclude that epiphanies in warfare often take atmospheric shapes, such as unseasonal weather.

257 Gehrke (1994). Dillery understands this 'intentional history' as “... historiography written both to articulate the identity of a given region of the Greek world and to proclaim the region's importance in a larger, changing world," Dillery (2005), 507. For the reference to Zeus Panamaros, Dillery (2005), 519-520.
} 
Rome and the grant of asylia, the festivals of the Panamareia, the processions, the transformation of Zeus as a rider-god on the coinage. All of these manifestations have a potent symbolic value, and yet the greatest symbol was the story itself, inscribed on the walls of the sanctuary, most likely on the temple itself, as 'lieu de memoire', but also in such a way that the story of 'How Zeus Protected the Stratonikeians' would accurately be remembered and told for generations to come, etching itself into social memory. In line with this, re-naming the god from Zeus Karios to Zeus Panamaros re-centered his identity on the very hilltop where this defining event for the polis took place, rather than ambiguously extending it across the wider region of Karia; Zeus himself had also acquired a new focus, and that focus was squarely centered on Stratonikeia.

The third stage in region building is institutionalism, and as with the cult of Hekate, this may be seen through the festivals and especially the priesthoods that were established at Panamara. The active role of the priests of Zeus as statesmen and urban leaders has already been discussed at length, including the suggestion that they had a large role in intertwining the cults of Zeus and Hekate, since the same persons or family members often held both positions at different times, at least in imperial times. The priests at Panamara were perhaps the most important actors in region-building - they certainly occupied the role of 'economic, political and cultural/media elite' that Paasi sees as crucial in establishing the institutions essential towards regional identity. ${ }^{258}$

The final stage of the establishment of the region through external recognition may be seen in the networks, discussed above, of communities that were represented at Panamara, particularly when the polis had full control over the sanctuary. Whether directly following the grant of asylia, or participating in festivals through ties of syngeneia, the cities whose names appear on the list and who were invited to the festivals acknowledged the intricate bond between Zeus Panamaros and Stratonikeia. City and sanctuary were thus linked through a variety of media, including decrees, processions, songs, festivals, name-giving, and even coinage, in a message that was repeated over and over again. This was the best way to imprint the interlocking pattern of deity, city, and place onto collective memory, thus foregrounding this place as a second bright dot on the cognitive topography of the Stratonikeians, as well as the surrounding communities. The longevity of this reiterated message, until the third or even early fourth century AD, testifies to the success of the

$25^{8}$ Paasi (2009), 133: "Region-building can be understood only in a framework of social division of labour and this accentuates particularly the role of (regional) economic, political and cultural/media elites in the production of regions and identity narratives." 
way in which the god was used in the Hellenistic period to symbolically shape the polis.

The incorporation of Panamara shifted the focus of the sanctuary to the north, as it realigned the mental maps of both the Stratonikeians and the surrounding communities. The sanctuary that had once served the southern parts of Karia around the Marsyas valley was now permanently drawn into the orbit of the polis, becoming one of its principal urban platforms. In the relationship between city and sanctuary we should highlight both the agency of the priests, through their initiative, and of the population, through their active participation. Yet in the eyes of the Stratonikeians the principal actor was Zeus himself. In fact, Zeus and Hekate both go to town in their centripetal processions, putting an interesting twist on the idea of center and periphery. The Stratonikeians surely would have appreciated Dignas' view of the agency at the shrine of Zeus Panamaros, as pulling Stratonikeia into the orbit of the god.259 The polis certainly took its religious identity from Zeus, and from Hekate, but in the meantime it rewrote both cults to conform to its own needs of a center of gravity to pull together its heterogeneous population base and establish its position in the greater urban world.

259 Dignas (2002a), 243, cited above in note 239. 


\section{Urban Rituals in Sacred Landscapes}

In this book, I have asked the question why autochthonous, local or regional sanctuaries were so vital to the development of poleis in Hellenistic Asia Minor even though they were located at great distances from the urban center. Although I have focused this research on a few case studies, the phenomenon was fairly common, as discussed in the introduction with the list of cities whose major sanctuaries were situated at a distance, sometimes even in faraway places (Table 1.1). In examining current approaches from archaeological and historical studies, it soon becomes apparent that available models are tailored to answer very different questions, regarding either the rural setting of urban sanctuaries in the context of Archaic and Classical Greece, or the degree of autonomy and economic, social or political dimensions of sanctuaries in Asia Minor. While both approaches have informed the framework of analysis applied here, they nonetheless leave a gap in interpreting the urban roles of major sanctuaries in the chora of poleis in Hellenistic Asia Minor, particularly regarding the dynamics of change that many of these local or regional shrines underwent as they were drawn into the orbit of the polis to become its primary sanctuary. The difference between the two main approaches lies not only in the nature of the disciplines of archaeology and history, but also in the different kinds of material or epigraphic data. I have attempted a synthesis, but have also noticed that the major studies in this area are largely informed by dualistic paradigms, with core-periphery, urban-rural, civilized-wild, and even Greek-non-Greek polarities that are more reflective of modern concerns than ancient realities. Since such biases will inevitably steer the results, I took a step back to look to other disciplines in order to gain a broader perspective on some of the fundamental issues at hand. Perceptions of space and landscape, ritual, cross-community contact, and identity are often taken at face value in studies of antiquity, yet are central concerns to the cognitive, social and spatial sciences. These disciplines help problematize these issues from very different angles, even if they require some tweaking before being applicable to the ancient world.

This current study incorporates relevant issues drawn from these various approaches that should be taken into account. The resulting framework of analysis, discussed in Chapter 2, provides a holistic tool that can help assess the multifarious contexts of sanctuaries in Asia Minor in the Hellenistic period. No two sanctuaries were alike, nor were their relationships with their 
communities. But this tool allows for a deep assessment of the areas of change over time and their urban impact, as well as comparative analyses of different city-sanctuary relationships by pinpointing the most relevant areas of transformation and revealing larger patterns. With its focus on sources, the framework balances theoretical potential with empirical data; its fruitfulness has been demonstrated through the case studies. Before turning to the larger themes, it is worthwhile to briefly review the results, focusing on the role of landscape, major turning points in communal scope and their key interpretations.

This volume opened with a brief sketch of the landscape of Labraunda. Among timeless boulders near a strategic mountain pass and with a view that embraces much of southern Karia, this landscape of power was surely one of the main attractions for the Hekatomnids. They turned the old Karian sanctuary into a center of their domain, with the grand architecture and banqueting halls that framed the splendid views, and placed it within a defense network. This was Karia at its finest. It is no wonder that the polis of Mylasa laid claims to the shrine after the passing of the dynasty. Yet as it does so it shifted the focus of Labraunda from Karia to Mylasa. This marks an important second phase in the scope of the shrine, from encompassing the region (and dynasty) shrine under the Hekatomnids, to concentrating on the polis. This shift in focus met with opposition from the priests as the shrine became contested space. While the formal matter concerned administrative control over the extensive sacred lands, the real debate was who controlled the shrine and its deep heritage. The wealth of Labraunda lay in the layers of memory residing in its monuments, as well as its landscape and panorama that included Mylasa. Both priests and polis laid claims to the Hekatomnid past in their effort to legitimate control over the shrine and its landscape. The need by the democratic polis to engage the memory of the rulers whom they had once called 'tyrants' (I.Labraunda 41), can only be explained by the power of the past. The sanctuary was still visited by other Karian communities, but inscriptions of the Hellenistic era primarily concern political manifestations of the polis, and they mark key spots at the shrine. The city put itself on display here, before all of Karia, with the memory of the Hekatomnids as backdrop. Mylasa was a composite polis and the identity of the sub-groups was typically celebrated at their local shrines, yet Zeus Labraundos gave the polis a single face that it could present to the wider world by capitalizing on its Karian heritage.

The sanctuary of the Karian god Sinuri provides a rich contrast with Labraunda. Tucked away in a valley, the landscape of the sanctuary seems more connected with agriculture, yet the shrine nonetheless also drew the attention of the Hekatomnids. The main shift in scope here concerns the 
administration of the sanctuary, which passed from the Pelekos syngeneia in the late Classical period, who had direct relations with the ruling dynasty and appear to have been independent from Mylasa, to the Pormounos syngeneia. This group appears in the epigraphic record towards the end of the fourth century, and are clearly under the jurisdiction of Mylasa by the second century вс. The two main phases at the shrine of Sinuri are primarily distinguished by a lateral shift in the community using the sacred center. One might argue that in the Hellenistic period the sanctuary does not really qualify as urban space since its scope appears always to have focused on a subset, the syngeneia, rather than the entire body of citizens, and because its priesthood was hereditary, rather than being elected by a central body. Yet their rituals at the shrine clearly show that it functioned like urban space, reflecting civic structures, albeit on a smaller scale. The Pormounos syngeneia used the same Mylasan official jargon in their decrees - they followed the Mylasan calendar, adhered to its legal system, and adopted its institutions of financial administration and overall management of the sanctuary. They were among the most active subgroups of Mylasa in bestowing honors. They also constructed a stoa at the shrine that helped create an enclosed, urban-like space. Although we do not know whether they held processions across their landscape, their inscriptions highlight their sacred lands while their designated locations mark the key ritual spaces at the shrine. The nested levels of identity of the syngeneia would have been typical for most citizens of Mylasa, and probably several poleis in Karia or in Asia Minor for that matter. But their rituals especially show how a sanctuary offered a once-autonomous community a channel to assert its identity, while still being full members of the polis.

These were not the only sanctuaries in the sacred landscape of Mylasa. No doubt the picture would greatly be enhanced if we knew more about the sanctuary of Zeus Karios, or the identity of the god worshiped at Gencik Tepe. One of the most important cults for the polis was that of Zeus Osogollis, of which very little remains besides the inscriptions. ${ }^{1}$ These show nonetheless that it was the fulcrum of much of the religious and political life of Mylasa and formed thereby an important urban counterpart to the sanctuary of Zeus Labraundos. Finally, the pottery record from the Hellenistic period is notoriously difficult to identify - a finer chronological resolution would certainly enhance and challenge many of the interpretations postulated here. While such lacunas in our current knowledge must preclude any hard modeling, there is sufficient evidence to at least confirm that both of these distant country sanctuaries were

1 For a possible connection with the Uzunyuva area in Milas, Marek and Zingg (2018), 125-126. 
critical to the identity of Hellenistic Mylasa, albeit at different levels and for different reasons: Labraunda underwent a fundamental shift in concept as the polis, rather than the priests, assumed final control over the administration of the sanctuary and its assets, which contained besides cash crops the symbolic capital of the memory of the Hekatomnids; on a tighter scale, the syngeneia of Pormounos used the sanctuary of Sinuri to redefine itself as a community under the aegis of the polis and mirroring its institutions. Both show how the city and its surroundings adjusted to the polis model that was gaining momentum in the Hellenistic period.

Stratonikeia was similar in the disparate nature of its citizen base, yet its urban origins were more recent. Whereas Mylasa appears to have undergone an internal synoikism by the early fourth century under the Hekatomnids, the urbanization of Stratonikeia was a new development, having been founded as a Macedonian colony by the Seleukids in the second quarter of the third century вС. The surrounding communities would have merged gradually into the citizen base of the rising polis by the late third century вс. The sanctuary of Hekate at Lagina seems especially to have played a key role in unifying these communities. The shrine is located on a lush hillside near the conjunction of the Hayırlıdere valley and the north-south Marsyas valley. The steep mountains just north of this form a natural border and may well have been the northern limits of the chora of the new polis. The communal scope of the sanctuary underwent at least three phases: 1 ) when it belonged to the local polis of Koranza, in the late fourth and third century; to 2) when it became attached to Stratonikeia as a major urban sanctuary, in the third and second centuries, while Koranza became a deme of the polis; and finally, 3) when the festivals for Hekate and Rome were used to create political networks following the grant of asylia by Rome after the Mithridatic wars. Hekate's appearance on the early coinage attests to the strong bond with the polis in the second phase, as well as the radical transformation of her sanctuary into a large and monumental complex. But it is especially in this last phase that her sanctuary experienced a surge as inscribed urban space, with the many honorific decrees and dedications. Several concern the processions that integrated the diverse communities as the old road was now ritual space, carrying the urban body from the new town towards the sanctuary, but especially back into town, with the centripetal processions of the sacred key, the kleidos agoge. The cult of Hekate and its spectacles served to merge the composite citizen body and its dispersed territory into a unified polis, and later helped position the polis in the world of cities through its festival network. 
Forging a sense of community is a constant theme among these case studies, but is perhaps most evident at Panamara. Situated on a peak in the forested hills near the Marsyas valley south of Stratonikeia, the sanctuary was evidently at a strategic point as Philip V used it to garrison his troops. The scope of the cult of Zeus Karios underwent at least four phases: 1) in the late third and probably early second century BC, when it was administered by the koinon of the Panamareis, and attracted a regional following that extended well into the Rhodian peraia, and even across the Gulf of Keramos; 2) a transitional phase around the mid-second century $\mathrm{BC}$, when the sanctuary was still run by the koinon but with a priest from Stratonikeia, who revived the cult and expanded its network; 3) a period of stability under Stratonikeian control, probably when the cult of Hera was added; and 4) the period following the epiphany of Zeus during the attack by Labienus. This miracle had a galvanizing effect on the identity of the polis and became a common focus. It led to a grant of asylia by Rome and probably to the renewed expansion of cult network, initiated again by one of the priests. Panamara became a focus for urban ritual in a number of ways, with the entire population of Stratonikeia 'performing the landscape' through processions that emphasized male or female unity across the multiplicity of origins and social classes. Perhaps most spectacular was the procession that brought the festival and cult image of Zeus, now with the epithet of Panamaros, rather than Karios, into the center of town. The sanctuary clearly played a mediatory role in forging connections between Stratonikeia and the surrounding communities, creating a focus for the various strata of the polis, while extending its regional network.

The second century вС was a critical time for Stratonikeia, with two essential concerns: internal social cohesion, and territorial integrity. Both sanctuaries were critical in this regard. Drawing the two remote sanctuaries into orbit, and placing their gods at the heart of urban life was an act that bound the polis, sanctuary and landscape together in a locked relationship. Stratonikeia connected to the older communities north of town through the sanctuary of Hekate at Lagina; at the same time this gave it a strong presence in the area overlooking the Marsyas valley. Panamara was located in the hill country south of town, with a good view to the Marsyas valley as well, but also with its own ties to the communities in the southern Marçat mountains. Gaining control over this sanctuary was a major step for Stratonikeia in the direction of the Gulf of Keramos, and surely opened up new economic avenues of commerce for the landbound city. Both Lagina and Panamara were in their own ways determining factors in the territorial development of the polis in the Hellenistic period. 
The success of this is indicated by Strabo who, when giving a bird's eye view of Karia, states:

In the interior are three noteworthy cities: Mylasa, Stratonikeia, and Alabanda. The others are dependencies of these or else of the cities on the coast, among which are Amyzon, Herakleia, Euromos, and Chalketor. As for these, there is little to be said. ${ }^{2}$

Despite real territorial concerns and their likely locations near the edges of the Stratonikeian chora, Lagina and Panamara were nevertheless not true 'frontier' sanctuaries. There were many other issues at stake besides the definition of territorial borders. Strabo paints an image of Stratonikeia as a foreign 'Macedonian colony' dropped onto the landscape, which does not entirely seem to be the case. But unlike Mylasa it was a new polis developing in an environment that was already highly articulated socially, politically and religiously. The road to success lay in the integration of pre-existing communities in such a way that they could maintain their local identities while being incorporated into the larger citizen body of the polis. This was achieved not only by retaining their communities as the new demes of the polis, but especially by mobilizing a sacred center where their various backgrounds could coalesce into a common citizen identity. Lagina and later Panamara both provided excellent outlets where this could take place. Landscape clearly played a role but in a kind of inversion of Turner's theory - here urban communitas was being forged as the rituals at these country shrines served to produce and reinforce urban social structures. The difference is perhaps best articulated by the actions of the polis in inversing the rituals and bringing both cults into the urban center. ${ }^{3}$

Community-building, territorial ambition, and regional networking all must have been involved in Stratonikeia's choice to lay her identity in the gods of these two distant sanctuaries. But this could only take hold when the surrounding communities clearly understood that these gods, their sanctuaries, and the city were now inseparable. Coins, legends, inscriptions, architecture, and especially festivals and processions carried this message in overlapping layers, repeated over and over again until the pattern was simple and

2 Strabo 14.2.22 (transl. H.L. Jones (1929) The geography of Strabo, LCL 223): $\dot{\varepsilon} \nu$ $\dot{\varepsilon} \tau \hat{\eta} \mu \varepsilon \sigma o \gamma \alpha i \alpha_{\alpha}$

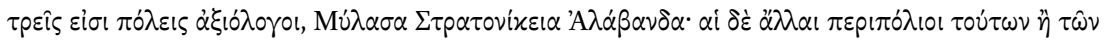

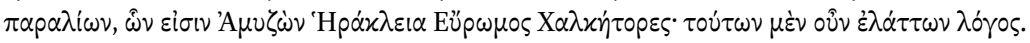

3 This is not quite the same as the formal sanctuary 'doublets' that Madeleine Jost observes in Arkadia, especially with the Lykaion in Megalopolis, but the motivation must have been similar; Jost (1994); also Kravaritou (2016) for the cult of Artemis Iolkia, that was brought to the center of Demetrias in Thessaly. 
commonplace. The sanctuaries thus acted as turning points for the perception of the landscape. By shifting the focus of the sacred landscape to the polis itself, Stratonikeia simultaneously realigned the political composition of this area along the Marsyas as well, with the polis at the logical center of both the physical and the cognitive environment.

The four case studies thus revolved around two cities, Mylasa and Stratonikeia, that were each seeking to define or redefine its position in the wake left by Alexander the Great. Country sanctuaries provided a muchneeded structuring principle - as economic centers, memory theaters, institutional organizations, spaces of geopolitical negotiation and social identity, but also eventually as magnets of urban pride.

\section{Frontier Sanctuaries?}

One of the criteria for selecting these four case studies was their proximity to natural or geographical borders in order to test their potential as frontier sanctuaries. This model is a ready explanation for major 'extra-urban' sanctuaries with a strong urban dimension in the Archaic Greek world. It could also easily be applied to these sanctuaries when considering their acquired urban status in connection with their location on the map. Labraunda, for example, is in a heavily fortified area along a mountain pass between Mylasa and Alinda to the north, and is nearly equidistant from these poleis. Mylasa is known to have aggressively pursued a course of expansion and the shrine of Zeus was clearly a critical concern to the polis; also, the fortress at the shrine was intensively used in the Hellenistic period, but whether this was by Mylasa or more probably by the strategos Olympichos is unclear. Also, Alinda hardly figures in the politics of Mylasa. From a territorial perspective, the sanctuary is much more likely to have been considered as a station at a critical point along the pass, rather than a frontier marker, although the festivals and fairs would certainly have given the road quite a bit of traffic, adding to the mediatory function of the shrine. For Mylasa, however, this border does not seem to have been a prime concern. One might have expected the eastern perimeter, near the shrine of Sinuri, to be a sensitive zone as neighboring Stratonikeia was also eager to expand where possible. Both of these assertive poleis were known to have had at least one border conflict (although the location is unclear). ${ }^{4}$ Looking at the map alone, the monumental sanctuary of Sinuri would seem a likely candidate for a frontier shrine. There are, however, two principal objections to this. One is that despite

4 I.Mylasa 134. 
the attention of the Hekatomnids, this shrine is more tucked away in a pocket rather than at a critical thoroughfare - in fact the terrain to the east becomes much more difficult to cross, although this may have been very different in antiquity. The second and more obvious factor is that, of all the shrines discussed in this volume, the shrine of Sinuri was the least concerned with urban politics. Although absorbed by Mylasa, it was not used to display any form of Mylasan identity other than through the sub-community to which it belonged. At the same time, as Mylasa expanded it seems to have left the sacred centers in its path alone, rather than converting them to 'polis' sanctuaries. This shows a different strategy than the colonies of Magna Graecia presumably followed.

As a colony, Stratonikeia might be a more plausible candidate for the frontier sanctuary model, with not one but two major shrines in the outer reaches of its territory. The sanctuary of Hekate at Lagina was located in a landscape becoming to the goddess of the crossroads. The conjunction of the Marsyas valley and the renown of her sanctuary would be one of the reasons that Strabo (14.2.29) lists Lagina, rather than Stratonikeia, among his few measuring points in Karia. The mountains to the north probably indicate the extent of Stratonikeian territory, but if so, the polis does not appear to have been preoccupied with it as such. It was, however, much more interested in the capacity of the shrine to establish links with communities, both within the territory as well as beyond its confines. Connectivity can be a property of frontier sanctuaries, and the festivals and later markets at Lagina would certainly have drawn crowds from afar, as they did at Labraunda. Yet this was more related to its capacity as network hub than as border mediator. With Panamara, however, borders could have played a more fundamental role in the absorption of the shrine by the polis. The hilltop shrine was presumably situated at the northern frontier of the Rhodian peraia in the early second century BC, and Stratonikeian interest in the cult may well have been related to territorial concerns as it exploited the mediatory role of the shrine. But it does not appear to have used the shrine to accentuate the border in any way. Moreover, by the first century BC the focus of the cult of Zeus at Panamara had clearly shifted inward to urban center, and its festivals were used to unite the disparate population of the polis.

None of the sanctuaries exhibit any signs of marking frontiers, despite their position near what was most likely a territorial boundary. Even their inherent mediatory function seems more related to connecting with other poleis and communities, rather than their immediate neighbors. Certainly these shrines came to signify the polis, but borders were only one of many functions that country sanctuaries could fulfill with regard to geography and civic territory. Labelling them as frontier shrines imposes political border issues that take 
us in the wrong direction with these sanctuaries, as charged as this term has become. The primary concerns of these two rising poleis in Hellenistic Asia Minor has already been shown to lie not at the border, but within. A recurring challenge that shines through each case study is internal social cohesion, and in most cases external connectivity. Both factors would have been a central matter as each city was faced with developing a strategy to position itself within the larger world of cities.

\section{Internal Social Cohesion - Building the Polis}

Dispersed communities were native to Karia, but the polis model was an imported concept, known principally along the coastal fringe. As the model took hold in Karia, cities were often created as agglomerations of much older communities. Mylasa incorporated a multiplicity of older clans with religious hearths and local identities of their own. As a Macedonian foundation, Stratonikeia drew its citizen base from the surrounding communities. The influx of 'Greek' and later 'Roman' citizens will have compounded matters in a way that was by no means limited to Karia. The challenge was to get this diverse and disparate group of people to identify with the idea of the polis together - this kind of coordination problem is exactly what ritual is equipped to deal with.

Ritual is a powerful instrument in creating a common focus, whatever that might be. Theories on the mechanisms of ritual help analyze its capacity as a coordinating mechanism through its focus in performance in space. This involves the mnemonic effect of ritual cognition, the element of spectacle or 'flashbulb memories', as well as the frequency of repetition and creation of ritual habit, regardless of content. Within the contexts of the cults in these case studies, however, the knowledge conveyed and reiterated through ritual is significant as well - the inseparable link between the god, the community, and its territory: this is particularly true at Lagina and Panamara, but also at Labraunda and even the sanctuary of Sinuri, albeit at a smaller scale.

Social cohesion as a conscious goal is particularly apparent at Stratonikeia. The ritual space at Lagina was built to literally embrace the community in a concentrated setting resembling an agora, while the rituals at Panamara aimed at men or women deliberately cut across all of the usual social boundaries, bringing the entire population together under this common denominator. Both cults also turned their gaze to the city, as the processions moved the sacred space and objects of the gods inwards towards the political center. This 
was an excellent means to create a common focus for a diverse, citizen base, with ritual and spectacle burning the shared experience into the minds of the participants, and inscriptions writing this memory into the minds of the community for generations to come.

Once autonomous communities were now subjugated to the polis as its demes and syngeneia. Mylasa seems to have had an even more federated political structure than Stratonikeia, as the hearth of identity continued to reside in the shrines of the clans - this is where honors were bestowed the most, with the shrine of Sinuri as an extreme example. The polis functioned almost as an abstract concept, a distributed model of cooperation as needed. This makes the polis-wide participation in the sanctuary of Zeus Labraundos all the more significant - here Mylasa is represented as a singular entity through the central institutions of the demos and the boule. This is also where international decrees and contracts or grants of proxeny were on display. Labraunda, with its renowned legacy and power of place, was understood to symbolize the polis, both by the Mylasans, but also by the international world of poleis. The sanctuary functioned as the outer face of Mylasa to the world.

Obviously, sanctuaries are all about creating community. Turner argued that this was a fundamental dynamic of distant sanctuaries, 'the center out there'. Yet in his view remote shrines foster an alternative community, an 'antistructure', that is distinct from urban or political identity, often even at odds with it. In this study, we have seen that it is precisely at such sanctuaries where urban identity, as polis religion, is promoted the most visibly. This study has elaborated on the dynamics involved in this in two significant ways. One is that the cults and festivals at these distant sanctuaries actively incorporated the landscape and space itself as part of the ritual focus. A sense of identity but also territorial integrity was constructed through ritual performance. The regular processions, the rituals at the sanctuaries and the memories recalled, and inscribed on the spot, helped configure social but also spatial memory. Such ritual acts and objects were vital towards creating a shared focus, common knowledge, and therefore a sense of unity. A second significant hallmark is that cities in Hellenistic Asia Minor could have a very local interpretation of what polis religion meant between the layers of their social composition. Communities continued to celebrate their older, indigenous identities through their own cult centers, while major shrines were used to shape the contours of evolving urban identity, both internally and externally. Having a central sanctuary for federated communities was in fact a very Karian solution to the problem of coordination, and in this regard the polis functioned as yet another level in the complexity of nested identities. This distinguished these cults from polis 
religion in the sense of classical Greece, where the polis presumably permeated every level of society.

Sanctuaries had an exceptional predisposition towards creating community, but especially their locations helped anchor a sense of polis identity and urban integrity, sealed through ritual. These ritual ties were a critical factor in establishing links with the wider network of communities.

\section{3}

\section{External Connectivity - Festival Networks}

These sanctuaries became involved in the public relations of the polis as it engaged with other poleis and communities. As centers of federated communities, this was a natural function of Karian shrines, but they could also connect communities together through less political ties of cult, such as syngeneia, kinship based on ancestral or mythical ties. The sanctuary of Zeus Karios at Panamara, for example, was held in common by Kallipolis, across the Gulf of Keramos, and the more local koina of the Londeis and the Laodikeis, as well as the Panamareis themselves. Connecting with these communities could have been a reason behind Stratonikeian involvement at Panamara in the first place. The role of such sanctuaries as hubs in a regional network seems to have been one of their main drawing features. Through endowments at the shrine, a polis could initiate a dialogue of goodwill with its communities. This is more apparent with the cults of Stratonikeia than of Mylasa, possibly due to the longestablished presence of Mylasa thanks to the Hekatomnids, while Stratonikeia still needed to legitimate its position. But it does explain in part the claims Mylasa laid on Labraunda. Thanks to their social capital, certain sanctuaries could provide a critical means for the polis to address the wider region at large. This pivotal function, however, was not restricted to major regional sanctuaries; it could also be leveraged at shrines with a more modest scope prior to their incorporation by the polis, as at Lagina. In this case, Stratonikeia used Hekate's festivals not only to coordinate local communities with a common focus, but also to mobilize Rome and the wider Greek world to acknowledge the authority and asylia of the shrine, and thereby the position of the polis. The contests of the festivals further served to promote the polis among the regional circuit of athletic competitions, especially in Karia and Ionia. Festivals, especially those celebrating an epiphany of the god, were important vehicles for poleis on the rise in building inter-urban networks.

Rational rituals, i.e. the means which the polis used to create a shared focus and thus generate common knowledge, worked equally well at this global level 
as it did at the local level of the polis. While the contests and honors allowed for distinction among individuals, as well as individual communities, the collective event helped to create a sense of global community, with the polis hosting the event at the ritual center of the festival, side by side with the deity which was being celebrated. This was a relevant message, and the place of cult in the territory of the polis served to foreground the sanctuary in the minds of the larger world as well, ensuring at the same time its relation with the polis. Besides these political goals, the general circulation of knowledge that traveled with the foreign delegates along the festival circuit surely helped increased the cosmopolitan standing of the polis, while raising awareness of its own place in the wider world.

With the natural function that these sanctuaries already possessed as connectors of communities at multiple levels, it would have been a small step to extend this to engage in the panhellenic trend that was sweeping across the Hellenistic world. ${ }^{5}$ This new tradition was well underway by the time of the Hekatesia-Romaia, although Stratonikeia was one of the earlier cities to involve Rome. By this time, deploying the inherent connectivity of such regional-turned-urban sanctuaries to put the polis on the world stage would have been a natural means to meet both local and geopolitical needs at once.

\section{$4 \quad$ Urban Identity}

The emphasis on social cohesion and internal and external networking indicate urban identity as a root cause for polis involvement at most of the sanctuaries discussed here. Criteria for this involvement with a sanctuary may be traced to aspects such as strategic location, visual region, position as hub in a nexus of communities, and the social and symbolic capital of the deity. All of these factors point to the ability of a cult to both capture and hold public attention while transforming the perception of civic territory at the same time controlling the cult meant controlling its sacred, social and political landscape.

The decisions taken at the polis level and the impact at these sanctuaries coincide well with the steps involved in building 'regional identity', in modern terms, as outlined by Paasi. ${ }^{6}$ He defines the following stages in this process as territorial shaping, symbolic shaping, institutionalism, and finally, establishment through external recognition. Considering the polis through this lens, with administrative, social, and territorial concerns, helps analyze how the

5 Chaniotis (1995); Parker (2004); van Nijf and Williamson (2016); see discussion in Chapter 2.

6 Paasi (2003) and especially (2009), discussed above in Chapter 2. 
different indicators of polis involvement at these sanctuaries coalesced in the construction of urban identity, and why they are especially apparent in poleis that were undergoing a momentous new phase in their development.

The first stage of territorial shaping matches the expansionist tendencies of the poleis discussed in the case studies. Borders were important, yet as we have seen there was much more to defining territory than just establishing its extent. Sanctuaries at sites perceived to be vital to the polis, such as a tactical location in the evolving political landscape, would logically have been 'tagged' for special treatment. The ability of a sanctuary to mobilize a local community or network of communities, discussed in the previous section, would also have been a positive factor for the polis. Another critical factor would have been the scope of a sanctuary's visual region, or viewshed, since this would have been added to the visual region of the polis itself. Of the case studies analyzed in this research, the sanctuaries that came to occupy a central position in the political scope of the polis were those that also possessed broad vistas. This may also explain why the sanctuary of Sinuri, although monumentalized by the Hekatomnids, was much less critical to Mylasa than Labraunda was; it looks out over its valley but not beyond. The sweeping panorama at Labraunda, on the other hand, was surely one of its primary assets - adding its visual region to that of Mylasa, located in the plain below, significantly expanded its visual and strategic reach. Similar observations were made above for the case studies concerning Stratonikeia; located in a narrow east-west valley, the strategic reach of the polis was greatly extended to the north and to the south with the inclusion of the visual regions of Lagina and Panamara. The significance of the sanctuaries helped foreground them in the minds of the local and regional communities, making them seem closer by. This was surely one of the reasons that modest sanctuaries were turned into 'big' places through architecture and their festivals pumped up as major spectacles, and especially why the processions were so crucial as they ensured the entire population physically 'performed the landscape' and inscribed it in their memory. Foregrounding these places in this way was even more effective in making them feel like they belonged to the polis than their legal status or position inside a border.

The second stage in building regional identity is that of symbolic shaping. Here too the sanctuaries, their deities and their festivals played a critical role in creating the shared focus that was necessary for a common identity. Foregrounding the sanctuaries in the minds of the citizens through processions and festivals also turned the landscape of the sanctuary itself into an emblem of the polis, becoming more and more familiar with each procession and each festival until it was naturally equated with the polis. The image of the god also became the icon of the city, especially on its coinage with its wider 
circulation. Mylasa's choice to depict Zeus Labraundos as a conscious echo of his image under the Hekatomnids illustrates the power of divine symbolic capital, especially in a form already familiar to the community while rerecalling its legendary past. The new image of Zeus Panamaros by Stratonikeia on its post-miracle coinage would have had a similar function; portraying Zeus as a rider-god broadcast the contemporary processions of the Panamareia while recalling his miraculous salvation of the polis. Adding epithets or changing them, as with Hekate Soteira and Zeus Panamaros, was also a clear statement in adaptation of cult focus to meet the needs of the polis, creating thereby a new identity for both.

The territorial and symbolic shaping of these sanctuaries were channeled through institutions, with decisions taken at a central level. While this is most evident in polis administration, in several cases a sanctuary was run by a local community. In this study, the syngeneia at Sinuri are seen to have functioned as a kind of polis in miniature. Also the koinon of the Panamareis at Panamara, or the katoikountes at the sanctuary at Lagina, were decision-taking bodies with institutions of their own. But these were not always understood in the same way across the board; a fundamentally different perception of priesthood and its chain of responsibilities seems to lie at the root of the conflict between Mylasa and the priests at Labraunda. The escalation of this is logical considering that the priesthood was one of the most important institutions in leveraging the resources of the sanctuary. This is evidenced by the priest Leon who advanced the link between Stratonikeia and Panamara. Priests were critical actors in tailoring the attention of the local gods to suit the rising polis. As leading figures in the rational rituals that bound polis and sanctuary together, shaping the memories of the citizens and the politics of the region, priests should certainly be seen as professional urban producers, or in Paasi's terms, as part of the cultural and media elite. ${ }^{7}$

Human relationships with the gods were always contingent on divine will. Shifting the focus of a sanctuary would only have been successful if the deity was perceived as principal actor, whose idea it was to take the developing polis under his or her wings. Whereas a complex process of negotiation likely took place, probably between the power brokers of the polis and the local elite at the sanctuary, for all involved it would ultimately have been the decision of the gods. An epiphany, a supernatural act of salvation on the part of the deity was the ultimate seal of godly approval for the polis. This was in turn a major reason to obtain the right of asylia, that could then be used to acquire local, regional, or international recognition, spark festivals and engage in geopolitics; hence

7 Paasi (2009), 132-133; Williamson (2013b). 
the surge in epiphanies in the later Hellenistic period. ${ }^{8}$ This is the final stage in the development of the identity of a region, i.e. polis: its establishment.

This study has demonstrated the importance of a close reading of the data in combination with an awareness of theoretical potential. It has shown the perils of applying models without considering the wider context, but also the necessity of providing alternative interpretations. While all of these sanctuaries were presumably located near frontiers, interpreting them based on this type of location alone will not get us very far. At the other end, a micro view of the epigraphic evidence will give us a story from the perspective of the polis, and a complicated one at that, but not a complete one. Solely empirical approaches will ultimately allow unconscious biases to enter if not tested against different options. In order to understand the evolving relationship between a sanctuary and a nearby urban center, a more holistic approach to the data is needed. Besides expanding the data set, this requires a wider range of theories to draw on in properly assessing the different data, while yielding a list of factors to consider. The framework of analysis applied in this study was developed with this aim in mind. It is now time to assess this framework, starting with the theories borrowed from other disciplines and how they were adapted to this study, and the overall value of this approach.

\section{$5 \quad$ Assessing the Theoretical Approaches}

In the review in Chapter 2, a gap was discerned in studies in the ancient world concerning major country sanctuaries. One the one hand, there is a strong and primarily archaeological focus on the Archaic and Classical Greek world, in which such shrines are largely seen as frontier sanctuaries, defending a sensitive border of a developing polis. On the other, in studies of Hellenistic Asia Minor sanctuaries are caught up in discussions of autonomy, based on economic and social status, or urban-rural bias, and largely based on epigraphy. Each tangent identifies significant facets that should be addressed in any assessment of the impact of urban centers on sacred landscapes, yet they also pursue a different line of inquiry than the present investigation. The difficulties of applying these models has been discussed at length above. In order to fill the gaps, I turned to other disciplines to better conceptualize the processes at work in the developing spatial and social relationships between local or regional sanctuaries and expanding poleis. These are discussed Chapter 2, but because these are 'new'

8 Platt (2011), 124-169. 
approaches to studies of antiquity it is worthwhile to further assess their value and future potential with regard to this kind of research.

\subsection{Visual Regionalization}

Theories on spatial memory are one of the foundations of this research. They show that mental snapshots and 'snippets' of spatial information are pieced together in our mind as 'cognitive collages', as Tversky calls them. ${ }^{9}$ Places appearing within the same 'snapshot' subconsciously feel like they are closer together, no matter what the actual distances in between might be. Ellard calls this effect 'chunking space', emphasizing how the brain zones places in a process of visual regionalization. ${ }^{10}$ Foregrounding spaces, as Hirsch emphasize, creates points of heightened awareness that further help compress space in the mind's eye. ${ }^{11}$ More than 'mental maps', these concepts better describe how spatial memory works and the importance of visual perception in creating mental associations and hierarchies among places.

In the context of this present research, the concept of visual region underscores the importance of viewsheds, or visibility from specific places, in the definition of civic territory. As observed above, combining the visual region of a sanctuary to that of the polis created a greater single unit that would coincide with physical territory. But how were such visual regions integrated? In this present research, ritual action was the key, such as processions that literally melded the visual regions together, but also the grand festivals that took place at the sanctuaries, creating indelible memories. This is what served to foreground these places, together with monumental architecture, literally heightening their visual and symbolic significance in collective memory. Visual regions were therefore especially critical to the territorial shaping of the polis, not only because they increased its strategic reach, but also for their symbolic value, by literally bringing the distant sanctuaries and their landscapes the edges of the territory within emotional reach, thus creating a broad sense of place and belonging that extended across the chora.

\subsection{Concentric and Linear Space}

Breaking space down into functional categories is also a mnemonic device that aids memories of places and how to navigate them. ${ }^{12}$ Two of these are 'nodes' and 'paths', elements that I have combined with the location and

9 Tversky (1993).

$10 \quad$ Ellard (2009), 126-128.

11 Hirsch (1995).

12 Lynch (1960). 
direction of communal focus in defining such spatial types as 'concentric', i.e. with a static central focus, or 'linear', i.e. with a progressive focus involving movement, whether physical or visual. Concentric space - enclosed spaces with a singular and internalizing focus - is characteristic of urban sanctuaries in the Hellenistic period, as it was of most urban spaces. ${ }^{13}$ It is concentric space in which monuments were typically erected, 'in the most conspicuous place', and it is this space which therefore best served as 'memory theater', an arena where past and present continuously flowed through each other in a web of associations that intermingled personal stories with collective memory. Urban sanctuaries were increasingly separated from the outer world by their delimiting architecture, becoming highly intense and focused spaces that were charged with intent and agency at multiple scales.

Linear space, on the other hand, is used to interpret how the sanctuary was integrated in the landscape and connected to places of significance, both physically and visually. The importance of visual linear space has already been stressed in several places as a tool that helps analyze ways that associations were created or emphasized through 'framing'. This should coincide with an analysis of the kinds of places that were visually ignored; although this was not pursued here, it could be relevant to other case studies as a way of addressing reception and resistance. Kinetic linear space refers to embodied movement through the landscape and in this context largely applies to sacred roads. This concept has helped understand the dynamics in processional routes that physically and ritually connected city and sanctuary. Two factors are involved in such routes: one is how they were determined, possibly involving environmental aspects (e.g. the 'shortest path' or 'least-cost corridors') as well as the need to wind it along places of significance; the other concerns the ability of such a route, once established, to attract places of meanings. Of the case studies discussed in this research, the two sacred roads that are known seem to be a combination of these factors. As places where the entire population regularly traveled up and down, they would have been magnets for social activity, accumulating meaning with the passage of time - evidence for this is found near the springs and by the many tombs that typically line the sacred roads near sanctuaries, just as they do around more urbanized areas. Future studies of this kind should search for other kinds, and often difficult to trace, of signs of presence en route.

13 Zimmermann (2009), 25; Emme (2013); Williamson (in press-c). 


\subsection{Rational Rituals}

The shapes of ritual space, concentric and linear, are related to rational rituals in that they provide either a static or a moving focus for the entire community. This visual focus occupies a central place in Chwe's theory on rational rituals as a coordinating device and one of the most direct means of generating common knowledge, a prerequisite for cooperation and social cohesion. ${ }^{14}$ Common knowledge is transmitted directly through joint attention towards a shared focus, which ritual readily provides. Cognitive studies on ritual have shown it to strengthen the neural pathways of memory, particularly through frequency, repetition, and spectacle, i.e. the 'flashbulb' memories. ${ }^{15}$ Of course, a shared focus is in itself not enough to create joint action, but it is a prerequisite according to rational ritual theory.

As straightforward as it seems, this theory has helped interpret a number of phenomena at the sanctuaries and in the cults with regard to the need of social cohesion, particularly in poleis that were made up of heterogeneous communities. Considering public rituals and ceremonies as rational rituals has led to insights into how ritual performance in festivals and processions worked to unite the population, not only by bringing them together in an enclosed space, but by giving them a shared focus embedded in ritual. That this did not automatically produce harmony or the desired effect is evident from the number of sacred laws that were established at various sanctuaries. But these were the exceptions that may prove at least the intention behind the rule.

In focusing on rational rituals as a means of 'saturation advertising' among humans, Chwe's theory purposefully leaves out the authority of the divine, or at least the perception of this authority. Although even this authority was not foolproof - e.g. oaths were often broken and sanctuaries were frequently sacked - it clearly brought the earnest of the rituals to a higher level by making them contingent on the pleasure of the divine will. ${ }^{16}$ The element of supreme power of the deity of the rituals in theory would certainly increase the compulsion to participate in them. This study does not presume that the rituals discussed here were consciously engineered or intended to be 'rational' - they were in the first place religious ceremonies. Nonetheless, understanding festivals and especially the processions as rational rituals makes the logic behind the sanctuaries, the cults, and ultimately the relationship with the polis much

\footnotetext{
14 Chwe (2001).

15 McCauley and Lawson (2002), 38-88, and (2007); Connerton (1989).

16 This is of course the paradox behind the grants of asylia, which enforce a human agreement to protect a sanctuary in recognition of the supreme power of its deity. Yet even this was a common focus, as it was used to attract the attention of peer poleis, as discussed above and in $\mathrm{Ma}(2003)$.
} 
more lucid as it leads to a better comprehension of the effects of ritual, especially by identifying the shared focus, or foci, at these festivals and interpreting the various ways in which it was produced.

\subsection{Network Model}

Network theory is gaining momentum in studies of the ancient world. ${ }^{17}$ One dimension of this concerns webs of associations, the general domain of Actor-Network Theory. ${ }^{18}$ In this study this has proved useful in understanding different levels of the past that can be evoked through architecture, providing another facet to the dimension of 'memory theater'. Network is certainly useful as an analogy to describe the role of sanctuaries as nuclei in a wider nexus of communities. Rigorous network analysis, however, would require a higher degree of data collection than this present book can accommodate as well as a greater consistency of data quality in order to study the weights of nodes and how strong or weak their ties were. But such studies are being conducted..$^{19}$ Future approaches could include agent-based modeling, where computer simulations can help elucidate patterns from incomplete data sets. In this present study, however, even a metaphorical application of network theory has proven fruitful. The information gathered here shows that three of the sanctuaries clearly functioned as a connecting factor between communities, while the larger (ego-)network aspirations of one of these, Lagina, can be traced with a fair degree of accuracy. ${ }^{20}$

Ma's application of the 'peer polity interaction' model has furthermore elucidated the basis of these ties, and how the wider community of poleis was typically founded on the inter-urban recognition of grants of asylia (inviolability) and claims of syngeneia (kinship). ${ }^{21}$ Both terms could be used to draw communities to a sanctuary, as at Lagina and Panamara respectively, and are flags of network activity, as with the other items on Ma's list, the theoria (foreign delegates), and the foreign judges who settled disputes. These two categories are less prevalent at the sanctuaries in the case studies in this research, but should be on the list of things to watch for in discerning the wider interests

17 Horden and Purcell (2000), 457. The Connected Past consortium is particularly active in promoting network analyses in historical and archaeological studies, see connected past.net.

18 Latour (2005); Guggenheim (2009).

19 See the Connected Contests project at the University of Groningen: connectedcontests. org for data on festivals and contestants, used to perform network analysis of inter-civic or panhellenic festival culture.

$20 \quad$ Van Nijf and Williamson (2016).

21 Ma (2003). 
of a polis in a particular sanctuary. Ma's list should furthermore be expanded to include new panhellenic festivals, e.g. the rise of quadrennial festivals, as well as inter-state treaties, such as isopoliteia or sympoliteia, which were often sealed by oaths in a sanctuary of relevance. ${ }^{22}$ Also, the role of rulers in initiating some of these festivals, or festivals initiated by cities in connection with ruler cult, deserves to be addressed from a network perspective, even though Ma excluded this from his equation. In short, network theory is certainly a way forward in considering how ritual served to create ties among cities and as a way for new cities to enter the geopolitical playing field, integrating them into the age-old model of Greek festival culture, but with a new twist that reinforced inter-urban bonds and goodwill with superpowers in the turbulent Hellenistic era.

\subsection{Regional Identity}

Regional identity, as modeled by Paasi, ${ }^{23}$ has already been extensively discussed above as well as in the case studies. This model has proven to be extremely useful in examining how sanctuaries were used to build and establish urban identity. When considering the ancient city-state as a region, then all of the stages which Paasi describes - territorial and symbolic shaping, institutionalism, and establishment through external recognition - remarkably fall into place: the overlap between ritualized landscape and civic territory, a central cult focus, the institutionalization of the priesthood, and the role of priests as urban leaders, and the use of the sanctuary for inter-urban networking. At the same time, Paasi's categories are broad enough to accommodate many of the theories and models previously mentioned. Because of this, very few issues were encountered in transferring the characteristics of this modern concept of 'regional identity' to 'polis identity' in the ancient Greek world.

Nonetheless, based as it is on modern political and geographical studies, a few minor technical modifications were needed. This concerns in the first place the importance of three-dimensional features in the landscape as experienced, e.g. mountains, rivers, and foregrounded places, rather than cartographic outlines, as the primary expressions of territorial shaping in the ancient world. Also, most of the symbolic shaping would have been inundated with cult and ritual, even more so than in modern times, adding the weight of divine authority to the idea of the 'region', i.e. polis. This perception is important in understanding the role of the institutions, particularly the priests, but

22 Kamphorst (forthcoming) addresses terms of connectivity in inter-state relations.

23 Paasi (2009), see above Chapter 2. 
also the wider community who 'performed the region', ${ }^{24}$ as actors who in principal were following the divine will. With these few details in mind, the model of regional identity would also prove useful in studies of the ancient city in general that focus on similar issues of territory, social composition and institutions, and symbolic focus.

\section{Assessing the Framework of Analysis}

The bulk of this book has been channeled through the lens of the framework of analysis, developed in the second chapter (Table 2.2). Perhaps one of the principal assets of this study, this framework provides a tool through which the many changes in the evolving relationship between a shrine and a community can be weighed, analyzed, and compared in all their diversity.

Regarding the historical development, the case studies revealed that each relation between a city and an outlying sanctuary was a unique combination. This was particularly evident in the analyses of just the two cities and their fundamentally different paths of connecting to the major sanctuaries drawn into their orbit. Each shrine initially had a different radius, from local to regional, demanding unique strategies to incorporate them into the civic sphere. This was perhaps most evident with Stratonikeia and the different approaches applied towards Lagina and Panamara as the scope of each was realigned towards the urban community. Inseparable from the chronology of both city and shrine is the role of the environment - the physical and social geography that constituted the foundation of the nature and impact of the cult, if not its essence. The potential relevance of frontiers has already been discussed, but the landscape itself played an important role. The timelessness of the eroding slopes near Labraunda along with the strategic location near a passage and panoramic view over the plain below surely demanded a cult for a primordial and supreme deity. The power of place and cult was neither lost on the dynasty that came to rule nor the nearby city left behind in its wake. Social geography is equally significant. Proximity to local communities and accessibility to road networks may help explain the attraction of Lagina, but for the shrine of Sinuri this is less obvious and leads us to search for alternative explanations, such as its embeddedness in the productive landscape. The rapidly disappearing cultural landscape around Panamara will leave many questions unanswered, but the hilltop shrine would in any case have acted as 
a beacon of urban presence for a region otherwise visually separated from the city. Landscape has an agency of its own in this equation.

The topochronic conditions of shrine and city constitute the foundational layers of their connection, but the shape that this takes is as varied. In assessing the degree of integration of a shrine into the urban sphere, a variety of factors need to be considered individually, before they can be lumped together. One of the most obvious is the physical appearance of the place of cult, the monumental and ritual space. In a quick assessment, one might think that if it looks and acts like a civic sanctuary, then it must be one too. All of the cases here present as such, but a closer investigation shows a marked deviation in intent early on. With the possible exception of Lagina (initially under the aegis of Koranza), monumentalization processes at these shrines were well underway, if not largely completed, prior to the advent of the city. Labraunda was a dynastic showcase that remained one even under Mylasa, while the shrine of Sinuri never became a polis shrine, although the resemblance was strong. Panamara blossomed under Stratonikeia, but its monumentalization began early on as an investment by local communities. Concentric ritual space, so conducive to community-forming as discussed above, was articulated at all of the shrines and this capacity would have been another major asset. Linear space, on the other hand, is in most cases visible with the advent of the polis through the use of processions that connected city and shrine.

Ritual performance is another critical indicator of change that allows us to observe the shift in cultic scope in perhaps even higher resolution, depending on the survival of the sources. The crowds that the shrines drew may be evidenced by increasing water supplies, as at Labraunda and Lagina, ceramics such as tableware or terracottas (although most of this has not been published), but especially inscriptions. Festivals provided a joint focus of attention for the newly incorporated communities and are seen to be increasingly scripted events, particularly at Lagina and Panamara. The element of spectacle was equally on the rise and, besides the sacrifices and singing, collective rituals such as banqueting and especially contests would have sharpened the sense of 'community spirit', even though these rituals were simultaneously used to define and label the various segments of the population. The changes in ritual performance would have been gradual and tailored to each situation.

Sanctuaries in Asia Minor have long been studied with an eye towards their economies, the nature of their priesthoods, and their degree of autonomy. The legal administration and organization of these religious centers, primarily informed in the present cases by epigraphic evidence, is an important barometer of change. Change is evident at all of the cases analyzed in this study, but 
is perhaps the most poignant at Labraunda, which for a time was contested space between the priests and the polis, at odds over administrative control of the resources of the shrine. Economy is certainly an important factor and is especially apparent in the landscape of Mylasa, where a construction allowing for private lands to pass to the sanctuary, only to be leased back to the original owners for further exploitation, originated in the third century. This is another sign that each city devised its own strategy concerning the administration of its shrines, and that this also developed over time. Especially interesting are the fluctuations observed in the local communities who are attached to the sanctuary. While this is best visible with the syngeneiai at the shrine of Sinuri, the other sanctuaries in this study also had communities of their own, e.g. the Korrides syngeneia at Labraunda, or the katoikountes at Lagina; interestingly, the least is known of a residing community at Panamara after the passing of the koinon of the Panamareis.

Cult and festival were clearly instrumental in the urban mediatization strategies of the polis. Mylasa clung to the image of Zeus Labraundos as established by the Hekatomnids while using the grand shrine as civic podium. Besides resetting the scope and focus of the cult onto the city, the incorporated deity could also be used to establish geopolitical connections with peer communities or other powers of authority. Epiphanies were an important precedent as they were used to demonstrate the importance and relevance of the city on the political map. At Lagina an epiphany of Hekate accelerated Stratonikeia's claims of loyalty to Rome that eventually led to an extension of territory and especially the privileged recognition of asylia for the shrine. This in turn gave the polis reason to host a festival and petition for recognition and participation from its peer cities. The gods of these country sanctuaries increasingly appeared on the coinage of the cities, one of a variety of avenues that realigned the cults to their new communities.

This framework provides a lens to examine the many different ways that a sanctuary and its cult could become attached to a community. The outcome may or may not be surprising, but the main merit is three-fold. In the first place, it provides a means for identifying explicit areas of change, allowing us to move beyond a general impression that the available data gives. In the second place, the framework takes into account a wide variety of data, more than can probably be addressed in any one case. But this forces us to integrate the variety of sources and to look across the gaps in data and beyond a single data type. Finally, the structured approach allows for at least a degree of comparative analyses across different sanctuaries, despite the widely differing circumstances. This can help us understand the repertoire of options that cities had, 
leading towards a better understanding of why such sanctuaries were critical to developing cities and how such relationships were forged and maintained. Through this lens we can gain clearer insight into the strategies deployed by developing urban communities as they sought to position themselves and anchor their identity in a world outlined by warfare and local rivalries, but also one with increasing paths of connectivity. Rather than providing a monolithic model, this framework, with its integration of data and structural approach, can expose the wide diversity of solutions, which should lead to new questions in turn.

\section{Final Remarks}

This book began with a description of the shrine of Labraunda and the example of the power of its landscape, asking the question of who it belonged to. As we have seen, the answer is complex and depends on one's perspective in time and place. This may be said of Karia in general, but it may also be said of developing relationships between sanctuaries and cities across Asia Minor in the Hellenistic era, particularly in the later third and second centuries BC. At a time when local lines of organization were being blurred or erased, communities were blending together or being torn apart, and power alliances were constantly shifting, sanctuaries offered a haven of stability and local divine authority, at least on the surface. This is surely a major factor behind the surge in poliad deities that cities begin identify themselves more and more with, a phenomenon designated by Andrew Meadows as the 'Great Transformation.' ${ }^{25}$ The realignment of the scope of local or regional sanctuaries to first include the rising city, sometimes even including a revival of cult, then to solidify the bond, and finally to present it as the will of the gods is no small feat. Continuity of sacred landscapes would need to be stressed all the more as they merged with civic territory, making the presence of the new community appear natural and divinely sanctioned. The logic behind the surge of local and regional sanctuaries being absorbed by rising cities, as shown at the beginning of this book, now seems clear.

Current models address the role of outlying sanctuaries in the Archaic and Classical Greek world in the context of the rise of the polis, but omit Asia Minor or the second rise of the polis in the Hellenistic era. Studies of sanctuaries in Asia Minor have, in turn, focused on their economy and autonomy, but

25 Meadows (2018), a phenomenon which he observes through the increasing portrayal of deities on civic coinage in the second century вс. 
omit their relation to landscape. Both models are driven by disciplinary focus, but lack the holistic approach needed to address the multifarious situation in Asia Minor. And so, a framework of analysis was developed. Informed by a variety of theories, models, and various approaches, the framework provides an approach to these many different sanctuaries and their contexts which is both systematic and yet not too rigid in that it allows for their diversity to become apparent. A handful of case studies were selected that could yield sufficient data to intensively test the framework and allow for comparative analyses of the results. The fruitfulness of this overall and combined approach was demonstrated above. It was shown that these relationships could develop in many ways, with many different manifestations. Each combination of city and sanctuary was unique, yet despite their many differences, a number of recurring concerns emerged - especially social cohesion and the need for external recognition as cities sought to put themselves on the larger map. This study has exposed some strategies that were developed to address these concerns, and it has made clear that sanctuaries such as those examined here were linchpins in this process.

\subsection{Suggestions for Further Research}

A number of issues were raised in the preceding pages, opening up areas of inquiry that deserve further exploration. In the first place a further application of the framework of analysis from this study would help examine the relationships between other expanding poleis and their country sanctuaries, such as those shown in the introduction (Table 1.1). This framework could on the one hand provide interpretations for cities and sanctuaries in analogous situations, such as Pisidian Antioch and the sanctuary of Men Askaenos, or Aizanoi and the sanctuary of Meter Steunene. It could also help with tentative interpretations for sanctuaries whose data sets are much more restricted, such as the sanctuaries in the chora of Myra, or the sanctuary of Zeus Stratios near Amaseia. It might even be of help with sanctuaries whose locations are as of yet unknown - one of the most prominent examples is the extramural Nikephorion of Pergamon, but also the temple of Artemis Pergaia, somewhere outside of Perge - of course the section on geographical data would remain empty but other areas could still be indicative of the role that the sanctuary fulfilled for the polis. With some adaptations it could also help understand the relationship between federation sanctuaries and the poleis which 'hosted' them, such as the Letoon, home of the Lykian League, and Xanthos. This framework of analysis is meant to be dynamic; studies at other sanctuaries and poleis may well lead to very other conclusions, and in any event to a modification of this framework, based on the situation at hand. 
The visual regions of a sanctuary were discussed as an important factor for their being drawn in to the orbit of the polis, as their panoramas were merged with the view from the city, literally expanding its horizons. In this respect a more comprehensive visual analysis of sanctuary viewsheds would be worthwhile, to investigate how these may have been related to their overall function. ${ }^{26}$ Viewshed analysis could be an important research tool for addressing questions such as whether viewshed shapes correspond to particular types of sanctuaries, or whether viewshed size is a valid indicator of a sanctuary's relevance for the polis. Visual studies should also be further incorporated in studies that address polis religion, but also studies that explore other kinds of sensory perception for a holistic approach to understanding how these places and their festivals functioned.

Polis religion, now being reassessed through numerous angles, ${ }^{27}$ should also be viewed through an Anatolian lens. This present study has revealed alternative views on how state cult, or polis religion, may have been interpreted in Karia. At the same time, the function of sanctuaries in integrating heterogeneous societies could be brought into sharper relief through comparative studies with colonization processes in Magna Graecia or the Black Sea region. This could also impact views on Hellenization in general, and at least on the mediatory role of sanctuaries and the porosity of frontiers.

While addressing the indicators of urban involvement in this research, several very different areas pertaining to sanctuaries were explored, such as priesthoods, processions, and ritual performances. A number of studies examine these as institutions in closer detail. ${ }^{28}$ But a deeper analysis of the social composition of the polis and understanding how this was expressed, or at least projected, during the urban festivals of these sanctuaries would certainly enhance our appreciation of the role these sanctuaries had in consolidating community; such analyses might also show the impact of class differentiation, the mechanisms of power, and channels of resistance, and the many voices that invested layers of identity and pride at the shrine. At the same time, a closer examination of communities residing in local settlements at or near country sanctuaries would greatly increase our understanding of their social function. These approaches would surely lead to important refinements of the framework while embedding this relationship in the context of the wider academic discourse on these social and economic topics.

\footnotetext{
26 Williamson (2014b), for a start.

27 Kindt (2012); Eidinow (2015); Eidinow et al. (2016); Mikalson (2016).

28 On priesthoods: Dignas (2002a) and (2002b), Dignas and Trampedach (2008); Horster and Klöckner (2011), and Richardson and Santangelo (2011); and Chaniotis on processions and festivals: e.g. Chaniotis (1995), (2003), (2006b), (2010), (2013).
} 
Cult networks were a central part of the discourse of this study, but these could be subjected to much more detailed network analysis to discover their topologies and reveal patterns of interest, especially concerning aspects of reciprocity. This would include analyzing the weights of nodes, and whether their ties are weak or strong. It might also lead to 'shortest path' connections between poleis via sanctuaries, especially when situated in a geographic information system, with least-cost path analysis, and navigational routes by land or by sea, in combination with seasonal data. Agent-based modelling can also complement insufficient data, with intensive and 'random' simulations that provide material for pattern analysis. This has the potential to reveal local, regional, or even 'global' inter-polis festival circuits. Connected to this should be a study of the other kinds of exchanges that may have taken place between these cities, e.g. not just trade, but perhaps the extension of citizenship to certain foreigners (proxeny), or inter-state treaties (such as sympoliteia). Studying festivals through this lens may very well prove them to have been the glue of international Hellenistic society, and one of the prime facilities through which the global political culture was developed. ${ }^{29}$

Finally, much more archaeology is needed to adequately address the issue of the political and social impact of country sanctuaries in Asia Minor. I have tried as far as possible to indicate the local contexts of sanctuaries, particularly with regard to the locations and nature of their local settlements. But these have hardly been the object of research until now. The last suggestion for further research, with which I will close this work, focuses on understanding the sacred landscapes of these sanctuaries, and of the poleis, in a much higher resolution than is now available. This will entail not only more literary and epigraphic studies, but especially archaeological surveys which will help place the sanctuary in its own social context, including not only the local settlement of the sanctuary, but also other nearby settlements, shrines, necropoleis, but even farmsteads or other kinds of activity. Only through this high resolution can it be determined what the 'spatial continuum' around a sanctuary was actually like. ${ }^{30}$

In short, the results have been promising so far and the framework has proven its worth, highlighting the areas of the greatest change and continuity for cult and community as urban rituals were etched onto sacred landscapes. But much remains to be done.

\footnotetext{
29 Van Nijf (2012); van Nijf and Williamson (2014); (2015); (2016). See also the doctoral research of Sjoukje Kamphorst, University of Groningen, on inscriptions of connectivity. 
Christina G. Williamson - 978-90-04-46127-7 Downloaded from Brill.com04/26/2023 03:25:54PM via free access 


\section{Bibliography}

Ackermann, D. (2013) 'Les prêtrises mixtes. Genre, religion et société', in M. Horster and A. Klöckner (eds), Cities and priests. Cult personnel in Asia Minor and the Aegean islands from the Hellenistic to the Imperial period, Religionsgeschichtliche Versuche und Vorarbeiten 64, Berlin: 7-40.

Adiego, I.-J. (2000) 'La inscripción Greco-Caria de los Hecatómnidas en el santuario del Sinuri', Kadmos. Zeitschrift für vor- und frühgriechische Epigraphik 39: 133-157.

Ager, S.L. (1996) Interstate arbitrations in the Greek world, 337-9o B.C., Hellenistic Culture and Society 18 , Berkeley.

Ager, S.L. (1998) 'Civic identity in the Hellenistic world. The case of Lebedos', Greek, Roman and Byzantine Studies 39: 5-21.

Akarca, A. (1959) Les monnaies grecques de Mylasa, Bibliothèque archéologique et historique de l'Institut français d'archéologie d'Istanbul I, Paris.

Akarca, A. and Akarca, T. (1954) Milâs. Coğrafyası, tarihi ve arkeolojisi, Istanbul.

Alcock, S.E. (1993) 'Spaced-out sanctuaries. The ritual landscape of Roman Greece', in E. Scott (ed.), Theoretical Roman archaeology. First conference proceedings, Worldwide Archaeology Series, Aldershot: 155-165.

Alcock, S.E. (1994) 'Minding the gap in Hellenistic and Roman Greece', in S.E. Alcock and R. Osborne (eds), Placing the gods. Sanctuaries and sacred space in ancient Greece, Oxford: 247-261.

Alcock, S.E. (1997) 'The heroic past in a Hellenistic present', in P. Cartledge, P. Garnsey, and E.S. Gruen (eds), Hellenistic constructs. Essays in culture, history, and historiography, Hellenistic Culture and Society 26, Berkeley: 20-34.

Alcock, S.E. (2002) Archaeologies of the Greek past. Landscape, monuments, and memories, The W.B. Stanford Memorial Lectures, Cambridge.

Alcock, S.E. and Osborne, R. (eds) (1994) Placing the gods. Sanctuaries and sacred space in ancient Greece, Oxford.

Allen, C.D. (2011) 'On Actor-Network Theory and landscape', Area 43: 274-28o.

Almond, G.A. and Verba, S. (1963) The civic culture. Political attitudes and democracy in five nations, Princeton.

Ameling, W. (2013) 'Ein Altar des Maussollos in Labraunda', Zeitschrift für Papyrologie und Epigraphik 187: 215-219.

Ampolo, C. (1993) 'Boschi sacri e culti federali. L'esempio del Lazio', in O. de Cazanove and J. Scheid (eds), Les bois sacrés. Actes du colloque international organisé par le Centre Jean Bérard et l'École pratique des Hautes Études (Ve Section), Naples, 23-25 novembre 1989, Collection du Centre Jean Bérard 10, Naples: 159-167. 
Anderson, B.R. (1983 [2006]) Imagined communities. Reflections on the origin and spread of nationalism, London; New York.

Anderson-Stojanović, V.R. (1987) 'The chronology and function of ceramic unguentaria', American Journal of Archaeology 91: 105-122.

Antonaccio, C. (1994) 'Placing the past. The Bronze Age in the cultic topography of ancient Greece', in S.E. Alcock and R. Osborne (eds), Placing the gods. Sanctuaries and sacred space in ancient Greece, Oxford: 79-104.

Aperghis, G.G. (2005) 'City building and the Seleukid royal economy', in Z. Archibald, J.K. Davies and V. Gabrielsen (eds), Making, moving and managing. The new world of ancient economies, 323-31 BC, Oxford: 27-43.

Aperghis, M. (200o) 'Population - production - taxation - coinage. A model for the Seleukid economy', in Z.H. Archibald and L.A. Hall (eds), Hellenistic economies, London: 69-102.

Asheri, D. (1988) 'A propos des sanctuaires extra-urbains en Sicile et Grande Grèce. Théories et témoignages', in M.-M. Mactoux and É. Geny (eds), Mélanges Pierre Lévêque. I. Religion, Annales littéraires de l'Université de Besançon 367, Centre de recherches d'histoire ancienne 79, Paris: $1-15$.

Ashton, R. and Reger, G. (2006) 'The pseudo-Rhodian drachms of Mylasa revisited', in P.G. van Alfen (ed.), Agoranomia. Studies in money and exchange presented to John H. Kroll, New York: 125-15o.

Ashton, R.H.J., Hardwick, N., Kinns, P., Konuk, K. and Meadows, A.R. (2002a) 'The Pixodarus hoard (CH 9.421)', in A.R. Meadows and M. Price (eds), Coin hoards 9. Greek hoards, Special publication, Royal Numismatic Society 35, London: 159-243.

Ashton, R.H.J., Kinns, P., Konuk, K. and Meadows, A.R. (2002b) 'The Hecatomnus hoard (Ch 5. 17, 8. 96, 9. 387)', in A.R. Meadows and M. Price (eds), Coin hoards 9. Greek hoards, Special publication, Royal Numismatic Society 35, London: 95-158.

Atik, N. and Rheidt, K. (2004) 'Pergamenisches in Anatolien. Aizanoi und seine Beziehungen zur Hauptstadt der Attaliden', Istanbuler Mitteilungen 54: 375-391.

Aubriet, D. (2009) Recherches sur Mylasa et Labraunda à l'époque hellénistique 336-31, PhD diss. Université Paris IV-Sorbonne, Paris.

Aubriet, D. (2012) 'Olympichos et le sanctuaire de Zeus à Labraunda (Carie). Autour de quelques documents épigraphiques', in C. Feyel (ed.), Entités locales et pouvoir central. La cité dominée dans l'Orient hellénistique, Colloque Nancy 3-5 juin 2010, Nancy: $185^{-209 .}$

Aubriet, D. (2013) 'Mylasa et l'identité carienne', in O. Henry (ed.), 4th century Karia. Defining a Karian identity under the Hekatomnids, Varia Anatolica XXVIII, Istanbul, Paris: $189-208$.

Aubriet, D. (2017) 'Helenistik Dönemde Mylasa'nın Limanı: Passala / Passala and Mylasa's Harbour in Hellenistic Times', Studi ellenistici XXXI: 205-221. 
von Aulock, H. (1967) 'Zur Silberprägung des karischen Stratonikeia', Jahrbuch für Numismatik und Geldgeschichte 17: 7-16.

Aydaş, M. (2006) 'Three inscriptions from Stratonikeia in Caria', Epigraphica Anatolica 39: 111-112.

Aydaş, M. (2015) 'Stratonikeia ve Lagina. Polis ve Peripolion', in B. Söğüt (ed.), Stratonikeia ve Çevresi Araștırmaları, Stratonikeia Çalıșmaları 1, Istanbul: 71-77.

Balthis, C. (2006) 'Built altars and religious ritual in Hellenistic East Greece', in J. Werts (ed.), Visualizing rituals. Critical analysis of art and ritual practice, Newcastle.

Bammer, A. (1972) Die Architectur des jüngeren Artemision von Ephesos, Wiesbaden.

Baran, A. (2006) 'The Archaic temple of Zeus Labraundos', Anadolu 3o: 21-46.

Baran, A. (2009) 'Karian architecture before the Hekatomnids', in F. Rumscheid (ed.),

Die Karer und die Anderen. Internationale Kolloquium an der Freien Universität Berlin, 13. bis 15. Oktober 2005, Bonn: 291-313.

Baran, A. (2011) 'The Sacred Way and the spring houses of Labraunda sanctuary', in L. Karlsson and S. Carlsson (eds), Labraunda and Karia. Proceedings of the international symposium commemorating sixty years of Swedish archaeological work in Labraunda. The Royal Swedish Academy of Letters, History and Antiquities, Stockholm, November 20-21, 2008, Acta Universitatis Uppsaliensis. Boreas. Uppsala Studies in Ancient Mediterranean and Near Eastern Civilizations, 32, Uppsala: 51-98.

Batty, M. (2001) 'Exploring isovist fields. Space and shape in architectural and urban morphology', Environment and Planning B Planning and Design 28: 123-150.

Baumeister, P. (2007) Der Fries des Hekateions von Lagina. Neue Untersuchungen zu Monumentund Kontext, Byzas6.Veröffentlichungen des Deutschen Archäologischen Instituts Istanbul, Istanbul.

Bean, G.E. (1971 [1989]) Turkey beyond the Maeander, London.

Becker, T. (2003) Griechische Stufenanlagen. Untersuchungen zur Architektur, Entwicklungsgeschichte, Funktion und Repräsentation, Münster.

Bederman, D.J. (2001) International law in antiquity, Cambridge Studies in International and Comparative Law 16, New York.

Belayche, N. (2009) 'Un dieu est né ... à Stratonicée de Carie (IStratonikeia 10)', in C. Batsch and M. Vartejanu-Joubert (eds), Manières de penser dans l'Antiquité méditerranéenne et orientale. Mélanges offerts à Francis Schmidt, Supplements to the Journal for the Study of Judaism 134, Leiden: 193-212.

Bell, C.M. (1992) Ritual theory, ritual practice, New York.

Belloni, G.G. (1984a) 'Asylia e santuari greci dell'Asia Minore al tempo di Tiberio', Contributi dell'Istituto di Storia Antica dell'Università del Sacro Cuoro 10: 164-180.

Belloni, G.G. (1984b) “Asylia' en santuari greci dell'Asia Minore al tempo di Tiberio', Contributi dell'Istituto di Storia Antica dell'Università del Sacro Cuoro 10: 164-180. 
Bencivenni, A. (2003) Progetti di riforme costituzionali nelle epigrafi greche dei secoli IV-II a.C., Tarsìe studi di antichistica 1, Bologna.

Benedikt, M.L. (1979) 'To take hold of space. Isovists and isovist fields', Environment and Planning B6: 47-65.

Benndorf, O. (1882) 'Vorläufiger Bericht über zwei österreichische Expeditionen nach Kleinasien', Archäologisch-Epigraphische Mitteilungen aus Österreich-Ungarn 6: 151-252, Taf. I-VII.

Benndorf, O. and Niemann, G. (1884) Reisen im südwestlichen Kleinasien, Band I. Reisen in Lykien und Karien, ausgeführt im Auftrage des K. K. Ministeriums für Cultus und Unterricht unter dienstlicher Förderung durch seiner Majestät Raddampfer "Taurus" commandant Fürst Wrede, Vienna.

Berns, C. (2006) 'Konkurrierende Zentren. Überlegungen zur religiösen Repräsentation in Ephesos und in den Städten der Provinz Asia in der Kaiserzeit', in H. Cancik, A. Schäfer, and W. Spickermann (eds), Zentralität und Religion. Zur Formierung urbaner Zentren im Imperium Romanum, 273-208.

Berve, H. and Gruben, G. (1961) Griechische Tempel und Heiligtümer, Munich.

Betts, E. (ed.), (2017) Senses of the empire. Multisensory approaches to Roman culture, London.

Bickerman, E.J. (1938) Institutions des Séleucides, Paris.

Bilde, P.G. and Lawall, M.L. (eds) (2014) Pottery, peoples and places. Study and interpretation of Late Hellenistic pottery, Black Sea Studies, 16, Aarhus.

Billows, R.A. (1989) 'Anatolian dynasts. The case of the Macedonian Eupolemos in Karia', Classical Antiquity 8: 173-206.

Billows, R.A. (1995) Kings and colonists. Aspects of Macedonian imperialism, Columbia Studies in the Classical Tradition 22, Leiden.

Bintliff, J. (2006) 'City-country relationships in the 'Normal Polis", in R.M. Rosen and I. Sluiter (eds), City, countryside, and the spatial organization of value in classical antiquity, Mnemosyne, Supplements 279, Leiden: 13-32.

Bintliff, J. (2008) 'Considerations on agricultural scale-economies in the Greco-Roman world', in R. Alston and O.M. van Nijf (eds), Feeding the ancient Greek city, Groningen-Royal Holloway Studies on the Greek City After the Classical Age 1, Leuven: $17-31$.

Bintliff, J.L. (1977a) Natural environment and human settlement in prehistoric Greece. Based on original fieldwork, 2 vols., Oxford.

Bintliff, J.L. (1977b) 'New approaches to human geography. Prehistoric Greece: a case study', in F.W. Carter (ed.), An historical geography of the Balkans, London: 59-114.

Bintliff, J.L. (1991) The Annales school and archaeology, New York.

Blid, J. (2011) 'Recent researches on the churches of Labraunda', in L. Karlsson and S. Carlsson (eds), Labraunda and Karia. Proceedings of the international symposium 
commemorating sixty years of Swedish archaeological work in Labraunda. The Royal SwedishAcademy ofLetters, History and Antiquities, Stockholm, November 20-21, 2008, Acta Universitatis Uppsaliensis. Boreas. Uppsala Studies in Ancient Mediterranean and Near Eastern Civilizations, 32, Uppsala: 99-108.

Blümel, W. (1989) 'Neue Inschriften aus der Region von Mylasa (1988) mit Nachträgen zu I.K. 34-35', Epigraphica Anatolica 13: 1-15.

Blümel, W. (1990) 'Zwei neue Inschriften aus Mylasa aus der Zeit des Maussollos', Epigraphica Anatolica 19: 29-42.

Blümel, W. (1992) 'Neue Inschriften aus Mylasa (1989-1991) mit Nachträgen zu I.K. 34’, Epigraphica Anatolica 19: 5-18.

Blümel, W. (1995) 'Inschriften aus Karien I', Epigraphica Anatolica 25: 35-64.

Blümel, W. (2004) 'Neue Inschriften aus Karien. 2, Mylasa und Umgebung', Epigraphica Anatolica 37: 1-42.

Blümel, W. (2007) 'Neu Inschriften aus Karien III', Epigraphica Anatolica 40: 41-48.

Blümel, W., van Bremen, R. and Carbon, J.-M. (2014) A guide to the inscriptions in Mılas and its museums, Istanbul.

Boffo, L. (1985) I re ellenistici e i centri religiosi dell'Asia minore, Pubblicazionni della Facoltà di Lettere e Filosofia dell'Università di Pavia 37, Dipartimento di Scienze dell'Antichita, Florence.

Boffo, L. (2003) 'Centri religiosi e territori nell'Anatolia ellenistica', in C. Bearzot, F.L. Gattinoni, and G. Zecchini (eds), Glistatiterritoriali nel mondo antico, Contributi di storia antica 1, Milan: $253^{-269}$.

Bonnechere, P. (2007) 'The place of the sacred grove (alsos) in the mantic rituals of Greece. The example of the Alsos of Trophonios at Lebedeia (Boeotia)', in M. Conan (ed.), Sacred gardens and landscapes. Ritual and agency, Washington, D.C.: 17-41.

Börker, C. (1983) Festbankett und griechische Architektur, Konstanz.

Bourdieu, P. (1986) 'The forms of capital', in J.C. Richard (ed.), Handbook of theory and research for the sociology of education, New York: 241-258.

Boutsikas, E. (2009) 'Placing Greek temples. An archaeoastronomical study of the orientation of ancient Greek religious structures', Archaeoastronomy. The Journal of Astronomy in Culture 21: 4-16.

Boutsikas, E. (2015) 'Landscape and the cosmos in the Apolline rites of Delphi, Delos and Dreros', in L. Käppel and V. Pothou (eds), Human development in sacred landscapes. Between ritual, tradition, creativity and emotionality, Göttingen: 77-102.

Boutsikas, E. and Ruggles, C. (2011) 'Temples, stars, and ritual landscapes. The potential for archaeoastronomy in Ancient Greece', American Journal of Archaeology 115: $55^{-68 .}$

Boyd, T.D. (1978) 'The arch and the vault in Greek architecture', American Journal of Archaeology 82: 83-100. 
Boysal, Y. (1993) 'Stratonikeia 1992 yılı kazısı', Kazı Sonuçları Toplantısı, Ankara: 24-28 Mayıs.

Brandt, H. (1992) Gesellschaft und Wirtschaft Pamphyliens und Pisidiens im Altertum, Asia Minor Studien Bd. 7, Bonn.

van Bremen, R. (1996) The limits of participation. Women and civic life in the Greek East in the Hellenistic and Roman periods, Amsterdam.

van Bremen, R. (2000) 'The demes and phylai of Stratonikeia in Karia', Chiron 30: 389-401.

van Bremen, R. (2003a) 'Notes on some new inscriptions from Lagina', Epigraphica Anatolica 35: 15-19.

van Bremen, R. (2003b) 'Ptolemy at Panamara', Epigraphica Anatolica 35: 9-14.

van Bremen, R. (2004a) 'Laodikeia in Karia', Chiron 34: 367-399.

van Bremen, R. (2004b) 'Leon son of Chrysaor and the religious identity of Stratonikeia in Caria', in S. Colvin (ed.), The Greco-Roman East, Yale Classical Studies 31, Cambridge: $207-244$.

van Bremen, R. (2008) 'La communauté de Panamara entre Rhodes et Stratonicée de Carie. Autour de la date d'un décret des Panamaréens dans le Fonds Louis Robert', Comptes rendus de l'Académie des Inscriptions et Belles-Lettres: 1405-1420.

van Bremen, R. (2010) 'The inscribed documents on the temple of Hekate at Lagina and the date and meaning of the temple frieze', in R. van Bremen and J.-M. Carbon (eds), Hellenistic Karia. Proceedings of the First International Conference on Hellenistic Karia-Oxford, 29June-2July 2006, Bordeaux: 483-503.

van Bremen, R. (2013) 'A property transaction between Kindye and Mylasa. I.Mylasa 11 reconsidered', Epigraphica Anatolica: 1-26.

van Bremen, R. (2016) 'Olympichos and Mylasa. A new inscription from the temple of Zeus Osogō?', Epigraphica Anatolica 49: 1-26.

van Bremen, R. (2017) 'Labraunda and the Ptolemies. A reinterpretation of three documents from the sanctuary of Zeus (I.Labraunda 51, 45 and 44)', Studi ellenistici XXXI: $223-260$.

Bremmer, J. (2007) 'Greek normative animal sacrifice', in D. Ogden (ed.), A companion to Greek religion, Malden, MA: 132-144.

Bresson, A. and Debord, P. (1985) 'Syngeneia', Revue des études anciennes 87:191-211.

Briant, P. (2006) 'L'Asie Mineure en transition', in P. Briant and F. Joannes (eds), La transition entre l'empire achéménid et les royaumes hellénistiques, Paris.

Bringmann, K. and Noeske, H.-C. (200o) Geben undnehmen. Monarchische Wohltätigkeit und Selbstdarstellung im Zeitalter des Hellenismus, Berlin.

Broughton, T.R.S. (1934) 'Stratoniceia and Aristonicus', Classical Philology 29: 252-254. 
Broughton, T.R.S. (1951) 'New evidence on temple-estates in Asia Minor', in P.R. Coleman-Norton (ed.), Studies in Roman economic and social history in honor of A.C. Johnson, Princeton: 236-250.

Brown, P. (1971) 'The rise and function of the Holy Man in Late Antiquity', The Journal of Roman Studies 61: 80-101.

Brughmans, T. (2010) 'Connecting the dots. Towards archaeological network analysis', Oxford Journal of Archaeology 29: 277-304.

Brughmans, T. (2012) 'Facebooking the past. A critical social network analysis approach for archaeology', in A. Chrysanthi, M.P. Flores, and C. Papadopoulos (ed.), Thinking beyond the tool. Archaeological computing and the interpretative process, Oxford: 191-203.

Brughmans, T. (2013) 'Thinking through networks. A review of formal network methods in archaeology', Journal of Archaeological Method and Theory 20: 623-662.

Brughmans, T., Collar, A., and Coward, F. (2016) The connected past. Challenges to network studies in archaeology and history, Oxford.

Brughmans, T., Collar, A., Coward, F., and Mills, B.J. (2015) 'Networks in archaeology: phenomena, abstraction, representation', Journal of Archaeological Method and Theory 22: 1-32.

Bruit Zaidman, L. and Schmitt Pantel, P. (1992) Religion in the ancient Greek city, Cambridge.

Buraselis, K. (2012) 'Appended festival. The coordination and combination of traditional civic and ruler cult festivals in the Hellenistic and Roman East', in J. Rasmus Brandt and J.W. Iddeng (eds), Greek and Roman festivals. Content, meaning, and practice, Oxford: $247-266$.

Burkert, W. (1977) Griechische Religion der archaischen und klassischen Epoche, Die Religionen der Menschheit, No. 15, Stuttgart.

Burkert, W. (1995) 'Greek poleis and civic cults. Some further thoughts', in M. Herman Hansen and K.A. Raaflaub (eds), Studies in the ancient Greek polis, Historia. Einzelschriften 95, Papers From the Copenhagen Polis Centre 2, Stuttgart: 201-210.

Burkert, W. (1997) 'Werwölfe um den Dreifusskessel', in Homo necans. Interpretationen altgriechischer Opferriten und Mythen, Berlin: 97-152.

Busine, A. (2013) 'Oracles and their priests in Roman Asia Minor', in R. Alston, O.M. van Nijf, and C.G. Williamson (eds), Cults, creeds and identities in the Greek city after the Classical age, Groningen-Royal Holloway Studies on the Greek City After the Classical Age 3, Leuven.

Butler, S. and Purves, A. (eds) (2013) Synaesthesia and the ancient senses, Durham.

Buxton, R.G.A. (1992) 'Imaginary Greek mountains', Journal of Hellenic Studies 112: 1-15. Büyüközer, A. (2015) 'Lagina Hekate kutsal alanı güney propylonu / The south propylon to the sanctuary of Hecate at Lagina', Cedrus. The Journal of MCRI 3:67-87. 
Büyüközer, A. (2018) 'The sanctuary of Hekate at Lagina in the 4th century BC', Arkhaia Anatolika 1: 15-30.

Caldesi Valeri, V. (1998) 'Le assemblee di Mylasa', Patavium 6: 93-109.

Caldesi Valeri, V. (1999) 'Le assemblee di Stratonicea in Caria', Minima epigraphica et papyrologica 2 : $185^{-233}$.

Capdetrey, L. (2012) 'Le roi, le satrape et le koinon. La question du pouvoir en Carie à la fin du IV e siècle', in K. Konuk (ed.), Stephanèphoros. De l'économie antique à l'asie mineure, Mémoires 28, Bordeaux: 229-246.

Carawan, E.M. (2007) 'Oath and contract', in A.H. Sommerstein and J. Fletcher (eds), Horkos. The oath in Greek society, Bristol: 73-8o.

Carbon, J.-M. (2016) 'Minor notes on I.Iasos 52', Epigraphica Anatolica 49:67-69.

Carboni, R. (2013) Dea in limine. Culto, immagine e sincretismi di Ecate nel mondo greco e microasiatico.

Carless Unwin, N. and Henry, O. (2016) 'A new Olympichos inscription from Labraunda: I.Labraunda 137', Epigraphica Anatolica 49: 27-45.

Carlsen, J. (2011) 'I.Labraunda 62. Text and context', in L. Karlsson and S. Carlsson (eds), Labraunda and Karia. Proceedings of the international symposium commemorating sixty years of Swedish archaeological work in Labraunda. The Royal Swedish Academy of Letters, History and Antiquities, Stockholm, November 20-21, 2008, Acta Universitatis Uppsaliensis. Boreas. Uppsala Studies in Ancient Mediterranean and Near Eastern Civilizations, 32, Uppsala: 109-120.

Carstens, A. (2009) Karia and the Hekatomnids. The creation of a dynasty, British Archaeological Reports, Oxford.

Carstens, A. (2010) 'The Labraunda sphinxes', in J. Nieling and E. Rehm (eds), Achaemenid impact in the Black Sea. Communication of powers, Aarhus: 41-46.

Carstens, A. (2011) 'Achaemenids in Labraunda. A case of imperial presence in a rural sanctuary in Karia', in L. Karlsson and S. Carlsson (eds), Labraunda and Karia. Proceedings of the international symposium commemorating sixty years of Swedish archaeological work in Labraunda. The Royal Swedish Academy of Letters, History and Antiquities, Stockholm, November 20-21, 2008, Acta Universitatis Uppsaliensis. Boreas. Uppsala Studies in Ancient Mediterranean and Near Eastern Civilizations, 32, Uppsala: 121-131.

Carter, J.C. (2006) Discovering the Greek countryside at Metaponto, Jerome Lectures 23, Ann Arbor.

Carter, J.C., Crawford, M., Lehman, P., Nikolaenko, G. and Trelogan, J. (200o) 'The chora of Chersonesos in Crimea, Ukraine', American Journal of Archaeology 104: 707-741.

Castagnoli, F. (1971) Orthogonal town planning in antiquity, Cambridge MS.

Cavanagh, W.G. (1991) 'Surveys, cities and synoecism', in J. Rich (ed.), City and country in the ancient world, London: 97-118. 
de Cazanove, O. and Scheid, J. (eds) (1993) Les bois sacrés. Actes du colloque international organisé par le Centre Jean Bérard et l'École pratique des Hautes Études (Ve Section), Naples, 23-25 novembre 1989, Collection du Centre Jean Bérard 10, Naples.

Chandezon, C. (1998) 'Paysage et économie rurale en Asie Mineure à l'epoque hellénistique. A partir du quelques baux de Mylasa (II ${ }^{\mathrm{e}}-\mathrm{I}^{\mathrm{er}}$ siècle avant J.-C.)', Histoire et societé rurale 9: 33-56.

Chandezon, C. (2000) 'Foires et panégyries dans le monde grec classique et hellénistique', Revue des études grecques 113: 70-100.

Chandezon, C. (2003) L'élevage en Grèce (fin Ve-fin Ier s. a.C.). l'Apport des sources épigraphiques, Scripta antiqua, Ausonius, 5 , Bordeaux.

Chaniotis, A. (1995) 'Sich selbst feiern? Städtische Feste des Hellenismus im Spannungsfeld von Religion und Politik', in M. Wörrle and P. Zanker (eds), Stadtbild und Bürgerbild im Hellenismus. Kolloquium, München, 24. bis 26. Juni 1993, Vestigia 47, München: 147-172.

Chaniotis, A. (1997) 'Theatricality beyond the theater. Staging public life in the Hellenistic world', in B. Le Guen (ed.), De la scène aux gradins. Théâtre et représentations dramatiques après Alexandre le Grand, Toulouse: 219-259.

Chaniotis, A. (2003) 'Negotiating religion in the cities of the Eastern Roman Empire', Kernos 16: 177-19o.

Chaniotis, A. (2004) 'Under the watchful eyes of the gods. Divine justice in Hellenistic and Roman Asia Minor', in S. Colvin (ed.), The Greco-Roman East, Yale Classical Studies 31, Cambridge: 1-43.

Chaniotis, A. (2005) 'Akzeptanz von Herrschaft durch ritualisierte Dankbarkeit und Erinnerung', in C. Ambos, S. Hotz, G. Schwedler and S. Weinfurter (eds), Die Welt der Rituale. Von der Antike bis heute, Darmstad: 188-204.

Chaniotis, A. (2006) 'Rituals between norms and emotions. Rituals as shared experience and memory', in E. Stavrianopoulou (ed.), Ritual and communication in the Graeco-Roman world, Kernos Supplément 16, Liège: 211-238.

Chaniotis, A. (2007) 'Theatre rituals', in P.J. Wilson (ed.), The Greek theatre and festivals. Documentary studies, Oxford: 48-66.

Chaniotis, A. (2010) 'Dynamic of emotions and dynamic of rituals. Do emotions change ritual norms?', in C. Brosius and U. Hüsken (eds), Ritual matters. Dynamic dimensions in practice, London: 208-233.

Chaniotis, A. (2013) 'Processions in Hellenistic cities. Contemporary discourses and ritual dynamics', in R. Alston, O.M. van Nijf and C.G. Williamson (eds), Cults, creeds and contests in the Greek city after the Classical age, Groningen-Royal Holloway Studies on the Greek City After the Classical Age 3, Leuven: 21-47.

Chankowski, A.S. (2005) 'Processions et cérémonies d'accueil. Une image de la cité de la basse époque hellénistique?', in P. Fröhlich and C. Müller (eds), Citoyenneté et 
participation à la basse époque hellénistique. Actes de la table ronde des 22 et 23 mai 2004, Paris, BNF, organisée par le groupe de recherche dirigé par Philippe Gauthier, de l'UMR 8585 (Centre Gustave Glotz), École Pratique des Hautes Études, IV e section. 3, Hautes études du monde gréco-romain ; 35, Geneve: 185-206.

Cherry, J.F., J.L. Davis and H. Mantzourani (1991) Landscape archaeology as long-term history. Northern Keos in the Cycladic Islands from earliest settlement until modern times, Monumenta archaeologica 16, Los Angeles.

Christaller, W. (1933) Die zentralen Orte in Süddeutschland. Eine ökonomischegeographische Untersuchung über die Gesetzmässigkeit der Verbreitung und Entwicklung der Siedlungen mit städtischen Funktionen, Jena.

Chwe, M.S.-Y. (2000) 'Communication and coordination in social networks', The Review of Economic Studies 67: 1-16.

Chwe, M.S.-Y. (2001) Rational ritual. Culture, coordination, and common knowledge, Princeton.

Ciaceri, E. (1940) Storia della Magna Grecia, Geneve.

Cohen, G.M. (1995) The Hellenistic settlements in Europe, the islands, and Asia Minor, Berkeley.

Cole, S.G. (1994) 'Demeter in the ancient Greek city and its countryside', in S.E. Alcock and R. Osborne (eds), Placing the gods. Sanctuaries and sacred space in ancient Greece, Oxford: 199-216.

Cole, S.G. (1995) 'Civic cult and civic identity', in M.H. Hansen (ed.), Sources for the ancient Greek city-state. Symposium August, 24-271994, Acts of the Copenhagen Polis Centre; 2 / Historisk-filosofiske Meddelelser / Det Kongelige Danske Videnskabernes Selskab; 72, Copenhagen: 292-325.

Cole, S.G. (1999-200o) 'Landscapes of Artemis', The Classical World 93: 471-481.

Cole, S.G. (2004) Landscapes, gender, and ritual space. The ancient Greek experience, Berkeley, CA.

Cole, S.G. (2008) 'Professionals, volunteers, and amateurs. Serving the gods kata ta patria', in B. Dignas and K. Trampedach (eds), Practitioners of the divine. Greekpriests and religious officials from Homer to Heliodorus, Hellenic studies 30, Washington DC: $55^{-72}$

Collar, A. (2007) 'Network theory and religious innovation', Mediterranean Historical Review 22: 149-162.

Collar, A. (2013) Religious networks in the Roman empire. The spread of new ideas, Cambridge; New York.

Collins, R. (2004) Interaction ritual chains, Princeton Studies in Cultural Sociology, Princeton. 
Connelly, J.B. (2011) 'Ritual movement in sacred space. Towards an archaeology of performance', in A. Chaniotis (ed.), Ritual dynamics in the ancient Mediterranean. Agency, emotion, gender, and representation, Stuttgart: 313-346.

Connerton, P. (1989) How societies remember, Themes in the social sciences, Cambridge. Constantakopoulou, C. (2007) The dance of the islands. Insularity, networks, the Athenian empire, and the Aegean world, Oxford.

Constantakopoulou, C. (2015) 'Beyond the polis. Island koina and other non-polis entities in the Aegean', in C. Taylor and K. Vlassopoulos (eds), Communities and networks in the ancient Greek world, Oxford: 213-238.

Constantakopoulou, C. (2017) Aegean interactions. Delos and its networks in the third century, Oxford.

Conze, A.C.L. and Schazmann, P. (1911) Mamurt-Kaleh, ein Tempel der Göttermutter unweit Pergamon, Jahrbuch des Kaiserlich Deutschen Archäologischen Instituts. Ergänzungsheft 9, Berlin.

Cook, J.M. (1961) 'Some sites of the Milesian territory', Annual of the British School at Athens 57: 90-101.

Cook, R.M. (1992) 'The wild goat and fikellura styles: some speculations', Oxford Journal of Archaeology 11: 255-266.

Corbin, J.M. and Strauss, A.L. (2008) Basics of qualitative research. Techniques and procedures for developing grounded theory, Los Angeles, Calif.

Corsten, T. (1995) 'Das Koinon der Laodikener in Panamara', Epigraphica Anatolica 25: $87-88$.

Corsten, T. (2006) 'Review: Beate Dignas. Economy of the Sacred in Hellenistic and Roman Asia Minor', Classical World 99: 189-19o.

de Coulanges, N.D.F. (1864) La Cité antique. Étude sur le culte, le droit, les institutions de la Grèce et Rome, Paris.

Cousin, G. (1904a) 'Inscriptions du sanctuaire de Zeus Panamaros. I. Inscriptions en l'honneur des prêtres', Bulletin de Correspondance Hellénique 28: 20-53, 238-262.

Cousin, G. (1904b) 'Inscriptions du sanctuaire de Zeus Panamaros. II. Décrets (?)', Bulletin de Correspondance Hellénique 28: 345-352.

Cousin, G. and Deschamps, G. (1887) 'Le sénatus-consulte de Panamara', Bulletin de Correspondance Hellénique 11: 225-239.

Cousin, G. and Diehl, C. (1887) 'Inscriptions de Lagina', Bulletin de Correspondance Hellénique 11: 5-39.

Cousin, G. and Diehl, C. (1898) 'Mylasa et Olymos', Bulletin de Correspondance Hellénique 22: 421-489.

Crowther, C.V. (1993) 'Foreign judges in Seleucid cities', Journal of Ancient Civilizations 8: 40-77. 
Crowther, C.V. (1995) 'Iasos in the second century BC. 3. Foreign judges from Priene', Bulletin of the Institute of Classical Studies 40: 91-138.

Curty, O. (1995) Les parentés légendaires entre cités grecques. Catalogue raisonné des inscriptions contenant le terme syngeneia et analyse critique, Hautes études du monde gréco-romain, 20, Genève.

Cusumano, N., Gasparini, V., Mastrocinque, A. and Rüpke, J. (2013) Memory and religious experience in the Greco-Roman world, Potsdamer Altertumswissenschaftliche Beiträge Bd. 45, Stuttgart.

Czachesz, I. (2010) 'Long-term, explicit memory in rituals', Journal of Cognition and Culture 10: 327-339.

De Angelis, F. (1998) 'Ancient past, imperial present. The British Empire in T.J. Dunbabin's the western Greeks', Antiquity 72: 539-550.

Debord, P. (1969) 'Sur les inscriptions de la période d'Olympichos à Labraunda', Revue des études anciennes LXXI: 383-389.

Debord, P. (1982) Aspects sociaux et économiques de la vie religieuse dans l'Anatolie gréco-romaine, Etudes préliminaires aux religions orientales dans l'Empire romain t. 88, Leiden.

Debord, P. (1994) 'Essai sur la géographie historique de la région de Stratonicée', in M.-M. Mactoux and É. Geny (eds), Mélanges Pierre Lévêque. 8, Religion, anthropologie et société, Annales littéraires de l'Université de Besançon; 499. Centre de recherche d'histoire ancienne; 124, Paris: 107-121 carte.

Debord, P. (1999) L'Asie mineure au IV e siècle (412-323 a.C.). Pouvoirs et jeux politiques, Études / Ausonius 3, Bordeaux.

Debord, P. (2001a) 'Questions stratonicéennes', in A. Bresson and R. Descat (eds), Les cités d'Asie mineure occidentale au II' siècle a.C., Études / Ausonius 8, Paris: 157-172.

Debord, P. (2001b) 'Sur quelques Zeus Cariens. Religion et politique', Studi ellenistici 13: 19-37.

Debord, P. (2003) 'Cité grecque - village carien. Des usages du mot koinon', Studi ellenistici 15: 115-180.

Debord, P. (2005) 'Côte/intérieur. Les acculturations de la Carie', La Parola del Passato. Rivista di studi Antichi 6o: 357-378 ill. carte.

Debord, P. (2007) 'Religion et société. Les fêtes d'Hécate et de Zeus à Stratonicée de Carie', in J. Dalaison (ed.), Espaces et pouvoirs dans l'Antiquité de l'Anatolie à la Gaule: hommage à Bernard Rémy, Grenoble: 239-25o.

Debord, P. (2011) 'Who's who in Labraunda', in L. Karlsson and S. Carlsson (eds), Labraunda and Karia. Proceedings of the international symposium commemorating sixty years of Swedish archaeological work in Labraunda. The Royal Swedish Academy of Letters, History and Antiquities, Stockholm, November 20-21, 2008, Acta 
Universitatis Uppsaliensis. Boreas. Uppsala Studies in Ancient Mediterranean and Near Eastern Civilizations, 32, Uppsala: 133-147.

Debord, P. and Varinlioğlu, E. (2001) Les hautes terres de Carie, Bordeaux.

Delemen, I. (1999) Anatolian rider gods. A study on stone finds from the regions of Lycia, Pisidia, Isauria, Lycaonia, Phrygia, Lydia and Caria in the late Roman period, Asia Minor Studien Bd. 35, Bonn.

Delrieux, F. (1999) 'Les monnaies de Mylasa aux types de Zeus Osogôa et Zeus Labraundeus', Numismatic Chronicle 159: 33-45.

van der Spek, R.J. (1986) Grondbezit in het Seleucidische rijk, Diss. Vrije Universiteit Amsterdam, Amsterdam.

van der Vliet, E.C.L. (2011) 'Pride and participation. Political practice, euergetism, and oligarchisation in the Hellenistic polis', in O.M. van Nijf and R. Alston (eds), Political culture in the Greek city after the Classical age, Groningen-Royal Holloway Studies on the Greek City After the Classical Age 2, with the assistance of C.G. Williamson, Leuven: $155^{-184}$.

Descat, R. (2013) 'Mylasa, les dieux et le village carien au 4e s. aC. Retour sur I.Mylasa 11', in O. Henry (ed.), 4th century Karia. Defining a Karian identity under the Hekatomnids, Varia Anatolica XXVIII, Istanbul, Paris: 91-10o.

Descat, R. (2014) 'Toujours I.Mylasa 11. Autorité et territoire dans la Carie Hékatomnide', Epigraphica Anatolica 47.

Descat, R. and Pernin, I. (2008) 'Notes sur la chronologie et l'histoire des baux de Mylasa', Studi ellenistici 20: 285-314.

Deschamps, G. and Cousin, G. (1887) 'Inscriptions du temple de Zeus Panamaros. Une famille sacerdotale: Tibérius Flavius Aeneas et ses enfants', Bulletin de Correspondance Hellénique 11: 373-391.

Deschamps, G. and Cousin, G. (1888a) 'Inscriptions de temple de Zeus Panamaros. Le prêtre Sempronius Clemens', Bulletin de Correspondance Hellénique 12: 82-104.

Deschamps, G. and Cousin, G. (1888b) 'Inscriptions du temple de Zeus Panamaros. Ex-voto et dédicaces, Bulletin de Correspondance Hellénique 12: 249-273.

Deschamps, G. and Cousin, G. (1888c) 'Inscriptions du temple de Zeus Panamaros. La consécration de la chevelure', Bulletin de Correspondance Hellénique 12: 479-49o.

Deschamps, G. and Cousin, G. (1891) 'Inscriptions du temple de Zeus Panamaros. Les prêtrises. Les fêtes locales', Bulletin de Correspondance Hellénique 15: 169-209.

Detienne, M. and Vernant, J.-P. (1974) Les ruses de l'intelligence. La mètis des Grecs, Paris.

Devambez, P. (1959) Le sanctuaire de Sinuri près de Mylasa. Seconde partie. Architecture et céramique, Mémoires de l'Institut français d'archéologie de Stamboul, 8, Paris.

Dickenson, C.P. (2016) On the agora. The evolution of a public space in Hellenistic and Roman Greece (c. $323 B C-267 A D)$, Mnemosyne, Supplements 398, Leiden. 
Dignas, B. (2000) 'The leases of sacred property at Mylasa. An alimentary scheme for the gods', Kernos 13: 117-126.

Dignas, B. (2002a) Economy of the sacred in Hellenistic and Roman Asia Minor, Oxford Classical Monographs, Oxford, New York.

Dignas, B. (2002b) 'Priestly authority in the cult of the Corybantes at Erythrae', Epigraphica Anatolica 34: 29-40.

Dignas, B. (2003) 'Urban centres, rural centres, religious centres in the Greek East. Worlds apart?', in E. Schwertheim and E. Winter (eds), Religion und Region. Götter und Kulte aus dem östlichen Mittelmeerraum, Asia Minor Studien Bd. 45, Bonn:77-91.

Dignas, B. and Trampedach, K. (2008) Practitioners of the divine. Greek priests and religious officials from Homer to Heliodorus, Cambridge, MA.

Dillery, J. (2005) 'Greek sacred history', The American Journal of Philology 126: 505-526.

Dimitrova, N.M. (2008) Theoroi and initiates in Samothrace. The epigraphical evidence, Hesperia Supplement 37, Princeton, NJ.

Dinsmoor, W.B. (1939) 'Archaeology and astronomy', Proceedings of the American Philosophical Society 80.

Dinsmoor, W.B. (1973 [1950]) The architecture of ancient Greece. An account of its historical development, New York.

Dmitriev, S. (2011) The Greek slogan of freedom and early Roman politics in Greece, Oxford, New York.

Donaldson, A. (2006) 'Performing regions. Territorial development and cultural politics in a Europe of the Regions', Environment and Planning A 38: 2075-2092.

Drauschke, M.-K. (forthcoming) Zwischen religiöser Absicherung und politischer Inszenierung. Die Aufstellung zwischenstaatlicher Vereinbarungen in griechischen Heiligtümern, $\mathrm{PhD}$ diss. Westfälische Wilhelms-Universität Münster.

Drew-Bear, T. and Schwertfeger, T. (1979) 'Zur Topographie und Epigraphik von Panamara in Karien', Zeitschrift für Papyrologie und Epigraphik 36: 195-205.

Dunbabin, K.M.D. (1990) 'Ipsa deae vestigia ... : footprints divine and human on GraecoRoman monuments', Journal of Roman Archaeology: 85-109.

Dunbabin, T.J. (1948) The western Greeks. The history of Sicily and South Italy from the foundation of the Greek colonies to 480 B.C., Oxford.

Durand, J.-L. (1989) 'Ritual as instrumentality', in M. Detienne and J.-P. Vernant (eds), The cuisine of sacrifice among the Greeks, Chicago: 119-128.

Durkheim, É. (1912) Les formes élémentaires de la vie religieuse. Le système totémique en Australie, Paris.

Durusoy, E. (2014) From an ancient road to a cultural route. Conservation and management of the road between Milas and Labraunda, Patrimoines au présent 5 , Istanbul.

Dwyer, O.J. and Alderman, D.H. (2008) 'Memorial landscapes. Analytic questions and metaphors', GeoJournal 73: 165-178. 
Eckstein, A.M. (2008) Rome enters the Greek East. From anarchy to hierarchy in the Hellenistic Mediterranean, 230-170 BC, Malden, MA, Oxford.

Edlund-Berry, I.E.M. (1988) The gods and the place. The location and function of sanctuaries in the countryside of Etruria \& Magna Graecia (700-40o B.C.), Stockholm.

Eich, A. (2004) 'Probleme der staatlichen Einheit in der griechischen Antike', Zeitschrift für Papyrologie und Epigraphik 149: 83-102.

Eidinow, E. (2015) 'Ancient Greek religion: 'embedded' ... and embodied', in C. Taylor and K. Vlassopoulos (eds), Communities and networks in the ancient Greek world, Oxford: $54-79$.

Eidinow, E., Kindt, J., and Osborne, R. (2016) Theologies of ancient Greek religion, Cambridge Classical Studies, New York.

Ellard, C. (2009) You are here. Why we can find our way to the moon, but get lost in the mall, New York.

Elsner, J. and Rutherford, I. (2005) Pilgrimage in Graeco-Roman and early Christian antiquity. Seeing the gods, Oxford, New York.

Emme, B. (2013) Peristyl und Polis. Entwicklung und Funktionen öffentlicher griechischer Hofanlagen, Urban Spaces 1, Berlin.

Engels, B., Huy, S., and Steitler, C. (eds) (2019) Natur und Kult in Anatolien. Viertes Wissenschaftliches Netzwerk an der Abteilung Istanbuldes Deutschen Archäologischen Instituts, BYZAS 24, Istanbul.

Errington, M. (1987) ‘ $\Theta \varepsilon \dot{\alpha}$ 'P $\omega$ ' $\mu \eta$ und römischer Einfluss südlich des Mäanders im 2. Jh. v. Ch.', Chiron 17: 97-118.

Erskine, A. (2003) 'Distant cousins and international relations: "syngeneia" in the Hellenistic world', in K. Buraselis and K. Zoumboulakis (eds), The idea of European community in history. Conference proceedings. Vol. 2. Aspects of connecting "poleis" and "ethne" in Ancient Greece, Athens: 205-216.

Fabiani, R. (2015) 'IIIasos 52 e il culto di Zeus Idrièus', in Epigrafi di Iasos. Nuovi supplementi. II. in memoria di Giovanni Pugliese Carratelli, Studi classici e orientali 61: 163-202.

Faucounau, J. (1994) 'Remarks on the Carian alphabet from Sinuri', in M.E. Giannotta (ed.), La decifrazione del cario. Atti del $1^{\circ}$ simposio internazionale, Roma, 3-4 maggio 1993, Rome: 233-236.

Fehr, B. (1970) 'Plattform und Blickbasis', Marburger Winckelmann-Programm 1969: 31-67.

Finkielsztejn, G. (2001) Chronologie détaillée et révisée des éponymes amphoriques rhodiens, de 270 à 108 av. J.-C. environ, BAR International Series 99o, Oxford.

Finley, M.I. (1951) Studies in land and credit in ancient Athens, 500-200 B.C.. The Horos-inscriptions, New Brunswick, NJ. 
Finley, M.I. (1977) 'The ancient city. From Fustel de Coulanges to Max Weber and beyond, Comparative Studies in Society and History 19: 305-327.

Flashar, M. (1999) 'Panhellenische Feste und Asyl. Parameter lokaler Identitätsstiftung in Klaros und Kolophon', Klio: Beiträge zur Alten Geschichte 81: 412-436.

Frank, T., Broughton, T.R.S., and Collingwood, R.G. (eds) (1933-1940) An economic survey of ancient Rome, Baltimore.

Fraser, P.M. (1996) Cities of Alexander the Great, Oxford.

Freitag, K. (2015) 'Poleis in Koina. Zu den auswirkungen von bundesstaatlichen Organisationsformen auf Strukturen in griechischen Poleis der hellenistischen Zeit unter besonderer Berücksichtigung der Polis Megara', in A. Matthaei and M. Zimmermann (eds), Urbane Strukturen und bürgerliche Identität im Hellenismus, Die hellenistische Polis als Lebensform, Band 5, Berlin: $5^{6-67}$.

Frejman, A. (2018) 'Some thoughts on ancient maps, travel, and the location of Greek rural sanctuaries', Thiasos. Rivista di archeologia e architettura antica 7: 101-110.

Frejman, A. (2020) With gods as neighbours. Extra-temenal activity at Greek rural sanctuaries, 70o-20o BCE, PhD diss. Uppsala Universitet.

Frejman, A. (in press) 'Zeus, a landscape architect? Spatial planning at the sanctuary of Labraunda', in B. Vergnaud and N. Carless Unwin (eds), Anatolian landscapes. Inhabiting western Anatolia in antiquity, Istanbul.

Friese, W., Handberg, S., and Kristensen, T.M. (eds) (2018 (forthcoming)) Ascending and descending the Acropolis. Movement in Athenian religion, Monographs of the Danish Institute at Athens, vol. 20 Aarhus.

Frija, G. (2012) Les prêtres des empereurs. Le culte impérial civique dans la province romaine d'Asie, Rennes.

Furley, W.D. (1995) 'Praise and persuasion in Greek hymns', Journal of Hellenic Studies 115: 29-46.

Gabrielsen, V. (2000) 'The Rhodian Peraia in the third and second centuries B.C.', Classica et mediaevalia. Revue danoise de philologie et d'histoire (Danish Journal of Philology and History) 51: 129-183.

Gabrielsen, V. (2011) 'The Chrysaoreis of Caria', in L. Karlsson and S. Carlsson (eds), Labraunda and Karia. Proceedings of the international symposium commemorating sixty years of Swedish archaeological work in Labraunda. The Royal Swedish Academy of Letters, History and Antiquities, Stockholm, November 20-21, 2008, Acta Universitatis Uppsaliensis. Boreas. Uppsala Studies in Ancient Mediterranean and Near Eastern Civilizations, 32, Uppsala: 331-353.

García Morcillo, M. (2013) 'Trade and sacred places. Fairs, markets and exchange in ancient Italic sanctuaries', in M. Jehne, B. Linke, and J. Rüpke (eds), Religiöse Vielfalt und soziale Integration. Die Bedeutung der Religion für die kulturelle Identität und 
politische Stabilität im republikanischen Italien, Studien zur alten Geschichte Bd. 17, Heidelberg.

Garland, R. (1990) 'Priests and power in Classical Athens', in M. Beard and J. North (eds), Pagan priests. Religion and power in the ancient world, Ithaca, NY: 73-91.

Garland, R.S.J. (1984) 'Religious authority in archaic and classical Athens', The Annual of the British School at Athens 79: 75-123.

Gauthier, P. (1984) 'Les cités hellénistiques. Épigraphie et histoire des institutions et des régimes politiques', in A.G. Kalogeropoulou (ed.), Praktika tou E'Diethnous Synedriou Hellenikes kai Latinikes Epigraphikes, Athena, 3-9 Oktovriou 1982, Athens: 82-107.

Gauthier, P. (1987-1989) 'Grandes et petites cités. Hégémonie et autarcie', Opus 6-8: 187-202.

Gauthier, P. (1999) 'Nouvelles inscriptions de Claros. Décrets d'Aigai et de Mylasa pour des juges colophoniens', Revue des études grecques 112: 1-36.

Geertz, C. (1980) Negara. The theatre state in nineteenth-century Bali, Princeton, NJ.

Geertz, C. (1983) 'Centers, kings, and charisma. Reflections on the symbolics of power', in Local knowledge. Further essays in interpretive anthropology, New York: 121-146.

Gehrke, H.-J. (1994) 'Mythos, Geschichte, Politik. Antik und modern', Saeculum 45: 239-264.

Geus, K. and Thiering, M. (eds) (2014) Features of Common Sense Geography. Implicit knowledge structures in ancient geographical texts, Antike Kultur und Geschichte, Bd 16, Vienna.

Giannelli, G. (1924) Culti e miti della magna Grecia. Contributo alla storia piu antica della colonie greche in Occidente, Pubblicazioni del R. Istituto di Studi Superiori Pratici e di Perfezionamento in Firenze, Sezione di filosofia e filologia, N.S., Vol. 5, Florence.

Gider, Z. (2005) Lagina'daki dor mimarisi / Doric architecture in Lagina, $\mathrm{PhD}$ diss. Pammukale University, Denizli.

Gider, Z. (2012) 'Lagina kuzey stoanın ön cephe düzenlemesi / Façade arrangement of North Stoa at Lagina', in B. Söğüt (ed.), Stratonikeia'dan Laginaya Ahmet Adil Tirpan Armagani / From Stratonikeia to Lagina. Festschrift in Honour of Ahmet Adil Tirpan, Istanbul: $263-28$ o.

Gimbutas, M. (1982) The goddesses and gods of old Europe, 6500-3500 BC. Myths and cult images, Berkeley.

Glaser, B.G. and Strauss, A.L. (1967) The discovery of grounded theory. Strategies for qualitative research, Chicago.

Glaser, C.L. (2010) Rational theory of international politics. The logic of competition and cooperation, Princeton.

Gluskina, L.M. (1977) 'Asylia in Hellenistic cities and the policy of Delphi', Vestnek Drevnej Istorii (Revue d'Histoire Ancienne) 139: 82-94. 
Gordon, R. (1990) 'The veil of power. Emperors, sacrificers and benefactors', in M. Beard and J. North (eds), Pagan priests. Religion and power in the ancient world, Ithaca, NY: 199-231.

Gould, R.V. (1993) 'Collective action and network structure', American Sociological Review 58: 182-196.

Grace, V.R. (1953) 'The eponyms named on Rhodian amphora stamps', Hesperia.Journal of the American School of Classical Studies at Athens 22: 116-128.

Graf, F. (1982) 'Culti e credenze religiose della Magna Grecia', in Megale Hellas. Nome e immagine, Atti del xxI Convegno di studi sulla Magna Grecia, Taranto, 2-5 ottobre 1981, Taranto: 157-185.

Graf, F. (1996) "Pompai' in Greece. Some considerations about space and ritual in the Greek polis', in R. Hägg (ed.), The role of religion in the early Greek polis. Proceedings of the third international seminar on ancient Greek cult, organized by the Swedish Institute at Athens, 16-18 October 1992, Skrifter utgivna av Svenska Institutet i Athen. 8; 14, Jonsered: 55-65.

Graf, F. (2004) 'Trick or treat? On collective epiphanies in antiquity', Illinois Classical Studies 29: 111-130.

Graninger, D. (2011) Cult and koinon in Hellenistic Thessaly, Brill Studies in Greek and Roman Epigraphy, Leiden.

Granovetter, M. (1973) 'The strength of weak ties', American Journal of Sociology 78: 136o-138o.

Granovetter, M. (1983) 'The strength of weak ties. A network theory revisited', Sociological Theory 1: 201-233.

Gregory, A.P. (1995) 'A Macedonian dynastes. Evidence for the life and career of Pleistarchos Antipatrou', Historia. Zeitschrift für alte Geschichte 44: 11-28.

Grimes, R.L. (1999) 'Jonathan Z. Smith's theory of ritual space', Religion 29: 261-273.

Gruben, G. and Hirmer, M. (1966 [1986]) Die Tempel der Griechen, München.

Guano, E. (2013) 'Inside the magic circle. Conjuring the terrorist enemy at the 2001 Group of Eight summit', in A. Sen (ed.), Making place. Space and embodiment in the city, Bloomington IN: 69-94.

Guggenheim, M. (2009) 'Building memory. Architecture, networks and users', Memory Studies 2: $39-53$.

Gunter, A.C. (1989) 'Sculptural dedications at Labraunda', in T. Linders and P. Hellström (eds), Architecture and society in Hecatomnid Caria. Proceedings of the Uppsala symposium 1987, Acta Univ. Upsaliensis. Boreas, 17, Stockholm: 91-98.

Guzzo, P.G. (1987) 'Schema per la categoria interpretativa dei 'santuari di frontiera", Scienze dell'antichità. Storia, archeologia, antropologia 1: 373-379.

Habicht, C. (1956) 'Über die Kriege zwischen Pergamon und Bithynien', Hermes. Zeitschrift für klassische Philologie 84: 90-110. 
Habicht, C. (1972) '[Rez. zu:] 'Labraunda. Swedish excavations and researches, 3, 1. The Greek inscriptions 1-12 (period of Olympichus)”, Gnomon 44: 162-170.

Halbwachs, M. (1992) On collective memory, The Heritage of Sociology, Chicago.

Hall, J.M. (1995) 'How Argive was the 'Argive' Heraion? The political and cultic geography of the Argive Plain', American Journal of Archaeology 99: 577-613.

Hall, T.D., Nick Kardulias, P. and Chase-Dunn, C. (2011) 'World-Systems Analysis and archaeology. Continuing the dialogue', Journal of Archaeological Research 19: 233-279.

Hamilakis, Y. (2014) Archaeology and the senses. Human experience, memory, and affect, Cambridge.

Hanfmann, G.M.A. and Waldbaum, J.C. (1968) 'Two Submycenaean Vases and a Tablet from Stratonikeia in Caria', American Journal of Archaeology 72: 51-56.

Hansen, M.H. (1997) 'The polis as an urban centre. The literary and epigraphical evidence', in M.H. Hansen (ed.), The polis as an urban centre and as a political community. Symposium August, 29-31 1996, Acts of the Copenhagen Polis Centre 4, Historisk-filosofiske Meddelelser, Det Kongelige Danske Videnskabernes Selskab 75, Copenhagen: 9-86.

Hansen, M.H. (2004) 'The concept of the consumption city applied to the Greek polis', in T.H. Nielsen (ed.), Once again. Studies in the ancient Greek polis, Stuttgart: 9-47.

Hansen, M.H. (2007) The return of the Polis. The use and meanings of the word Polis in Archaic and Classical sources, Historia - Einzelschriften 198, Papers from the Copenhagen Polis Centre 8, Stuttgart.

Hansen, M.H. and Nielsen, T.H. (2004) An inventory of archaic and classical poleis, Oxford.

Hanslik-Andrée, J. (1949) s.v. 'Panamaros', in G. Wissowa, W. Kroll, and K. Mittelhaus (eds), Paulys Real-Encyclopädie der classischen Altertums-wissenschaft. Neue Bearbeitung, Stuttgart: $45^{\mathrm{O}-455}$.

Hanson, J.W. and Ortman, S.G. (2017) 'A systematic method for estimating the populations of Greek and Roman settlements', Journal of Roman Archaeology 30: 301-324.

Harland, P.A. (2014) Greco-Roman associations. Texts, translations and commentary. Volume II. North coast of the Black Sea, Asia Minor, Beihefte zur Zeitschrift für die neutestamentliche Wissenschaft 204, Berlin.

Hatzfeld, J. (1920) 'Inscriptions de Lagina', Bulletin de Correspondance Hellénique 44: 70-100.

Hatzfeld, J. (1927) 'Inscriptions de Panamara', Bulletin de Correspondance Hellénique 51: $57-122$.

Häussler, R. and Chiai, G.F. (2019) Sacred landscapes in antiquity. Creation, manipulation, transformation, Oxford. 
Hauvette-Besnault, A. and Dubois, M. (1881) 'Antiquités de Mylasa (1). II. Inscriptions', Bulletin de Correspondance Hellénique 5: 95-119.

Hedlund, R. (2014) 'Antae in the afternoon. Notes on the Hellenistic and Roman architecture of Labraunda', in L. Karlsson, S. Carlsson, and J. Blid Kullberg (eds), LABRYS. Studies presented to Pontus Hellström, Acta Universitatis Upsaliensis. Boreas. Uppsala Studies in Ancient Mediterranean and Near Eastern Civilizations 35, Uppsala: $57-70$.

Held, W. (2011) 'Mischordnungen in Labraunda als Räpresentationsform persischer Satrapen', in L. Summerer, A. Ivantchik, and A. von Kienlin (eds), Kelainai-Apameia Kibotos. Développement urbain dans le contexte anatolien / Stadtentwicklung im anatolischen Kontext, Kelainai I, Bordeaux: 383-39o.

Hellström, P. (1965) Labraunda. Swedish excavations and researches. Vol.II. Part 1. Pottery of classical and later date, terracotta, lamps and glass, Acta Instituti Atheniensis regni Sueciae, Series in 4, V, II, 1, Lund.

Hellström, P. (1971) Pottery of classical and later date, terracotta, lamps and glass, Lund. Hellström, P. (1989a) 'Formal banqueting at Labraunda', in T. Linders and P. Hellström (eds), Architecture and society in Hecatomnid Caria. Proceedings of the Uppsala symposium 1987, Acta Univ. Upsaliensis. Boreas, 17, Stockholm: 99-104.

Hellström, P. (1989b) 'Labranda 1988', Kazı Sonuçları Toplantısı, Antalya: 18-23 Mayıs.

Hellström, P. (1990) 'Labraunda 1989', Kazı Sonuçları Toplantısı, Ankara: 28 Mayıs1 Haziran.

Hellström, P. (1991a) 'The architectural layout of Hekatomnid Labraunda', Revue Archéologique: 297-308.

Hellström, P. (1991b) 'Labraynda 199o', Kazı Sonuçları Toplantısı, Çannakale:27-31 Mayıs.

Hellström, P. (1996a) 'The andrones at Labraynda. Dining halls for Protohellenistic kings', in W. Hoepfner and G. Brands (eds), Basileia. Die Paläste der hellenistischen Könige. Internationales Symposion in Berlin vom 16.12.1992 bis 20.12.1992, Mainz am Rhein: 164-169.

Hellström, P. (1996b) 'Hecatomnid display of power at the Labraynda sanctuary', in B. Alroth and P. Hellström (eds), Religion and power in the ancient Greek world. Proceedings of the Uppsala symposium 1993, Uppsala: 133-138.

Hellström, P. (2007) Labraunda. A guide to the Karian sanctuary of Zeus Labraundos, Ancient Cities of Anatolia, Istanbul.

Hellström, P. (2009) 'Sacred architecture and Karian identity', in F. Rumscheid (ed.), Die Karer und die Anderen. Internationale Kolloquium an der Freien Universität Berlin, 13. bis 15. Oktober 2005, Bonn: 267-290.

Hellström, P. (2011a) 'Feasting at Labraunda and the chronology of the Andrones', in L. Karlsson and S. Carlsson (eds), Labraunda and Karia. Proceedings of the international symposium commemorating sixty years of Swedish archaeological work in 
Labraunda. The Royal Swedish Academy of Letters, History and Antiquities, Stockholm, November 20-21, 2008, Acta Universitatis Uppsaliensis. Boreas. Uppsala Studies in Ancient Mediterranean and Near Eastern Civilizations, 32, Uppsala: 149-157.

Hellström, P. (2011b) 'Labraunda. The rediscovery', in L. Karlsson and S. Carlsson (eds), Labraunda and Karia. Proceedings of the international symposium commemorating sixty years of Swedish archaeological work in Labraunda. The Royal Swedish Academy of Letters, History and Antiquities, Stockholm, November 20-21, 2008, Acta Universitatis Uppsaliensis. Boreas. Uppsala Studies in Ancient Mediterranean and Near Eastern Civilizations, 32, Uppsala: 19-47.

Hellström, P. (2015) 'A cultic theatre at Karian Labraunda. The monumental stairs and the propylon courtyard', in S. Faust, M. Seifert and L. Ziemer(eds), Antike. Architektur. Geschichte. Festschrift für Inge Nielsen zum 65. Geburtstag, Aachen: 107-120.

Hellström, P. (2019) 'Early Labraunda. Excavations on the Temple Terrace 1949-1953', in O. Henry and K. Konuk (eds), Karia arkhaia. La Carie, des origines à la période pré-hékatomnide. Istanbul 14-16 novembre 2013, 4èmes rencontres d'archéologie de l'IFEA; CNRS USR-3131, Istanbul: 61-88.

Hellström, P. and J. Blid (2019) Labraunda 5. The Andrones, Stockholm: Swedish Research Institute in Istanbul.

Hellström, P. and Karlsson, L. (2004) 'Labraynda 2003', Kazı Sonuçları Toplantısı, Konya: 24-28 Mayıs.

Hellström, P. and Thieme, T. (1982) Labraunda. Swedish excavations and researches. Vol. I. Part 3. The temple of Zeus, Acta Instituti Atheniensis regni Sueciae, Series in 4, IV, I, 3, Lund.

Henry, O. (2010) 'Hekatomnos, Persian satrap or Greek dynast? The tomb at Berber İni', in R. van Bremen and J.-M. Carbon (eds), Hellenistic Karia. Proceedings of the First International Conference on Hellenistic Karia - Oxford, 29 June-2 July 2006, Bordeaux: 103-122.

Henry, O. (2011) 'Hellenistic monumental tombs. The П-shaped tomb from Labraunda and Karian parallels', in L. Karlsson and S. Carlsson (eds), Labraunda and Karia. Proceedings of the international symposium commemorating sixty years of Swedish archaeological work in Labraunda. The Royal Swedish Academy of Letters, History and Antiquities, Stockholm, November 20-21, 2008, Acta Universitatis Uppsaliensis. Boreas. Uppsala Studies in Ancient Mediterranean and Near Eastern Civilizations, 32, Uppsala: 159-176.

Henry, O. (2013) 'A tribute to the Ionian Renaissance', in O. Henry (ed.), 4th century Karia. Defining a Karian identity under the Hekatomnids, Varia Anatolica XXVIII, Istanbul, Paris: 81-9o.

Henry, O. (2014) 'Then whose tomb is that?', in L. Karlsson, S. Carlsson and J. Blid Kullberg (eds), LABRYS. Studies presented to Pontus Hellström, Acta Universitatis 
Upsaliensis. Boreas. Uppsala Studies in Ancient Mediterranean and Near Eastern Civilizations 35, Uppsala: 71-86.

Henry, O. (2017) 'Sanctuaire et pouvoir. Nouvelles pistes de réflexion à partir des recherches archéologiques récentes sur le site de Labraunda en Carie (Turquie)', Comptes rendus de l'Académie des Inscriptions et Belles-Lettres: 545-579.

Henry, O. and Aubriet, D. (2015) 'Le territoire de Mylasa et le serment d'Olympichos. Autour d'une nouvelle inscription découverte au sanctuaire de Zeus Labraundos en Carie', Comptes rendus de l'Académie des Inscriptions et Belles-Lettres: 673-702.

Henry, O., Karlsson, L., Blid, J., Hedlund, R., Vergnaud, B., Hellström, P., Thieme, T., Freccero, A., Durusoy, E., Güliz Biligin-Altınöz, A., Bağdatlı-Cam, F., Frejman, A., and Lebouteiller, P. (2013) 'Labraunda 2012 - rapport préliminaire', Anatolia Antiqua 21: 285-355.

Henry, O., Bilgin Altınöz, A.G., Blid, J., Çakmaklı, Ö.D., Dufton, A., Freccero, A., Gosner, L., Hedlund, R., Lebouteiller, P., Lungu, V., Rojas, F., Tobin, F., Vergnaud, B., and Waters, A. (2014) 'Labraunda 2013 - rapport préliminaire', Anatolia Antiqua 22: 255-325.

Henry, O., Andersson, E., Bost, C., Çakmaklı, Ö.D., Commito, A., Cormier-Huguet, M., De Staebler, P., DuPont, P., Ergenç, D., Frejman, A., Kepenek, B., Lebouteiller, P., Nilsson, H., Rojas, F., and Vergnaud, B. (2015) 'Labraunda 2014 - rapport préliminaire', Anatolia Antiqua 23: 301-394.

Henry, O., Andersson, E., Bost, C., Çakmaklı, Ö.D., Cederling, F., Commito, A., Cormier-Huguet, M., Coutelas, A., Dolea, A., Ergenç, D., Freccero, A., Frejman, A., Lebouteiller, P., Lesguer, F., Löwenborg, D., Lungu, V., Marchand-Beaulieu, F., De Staebler, P., and Vergnaud, B. (2016) 'Labraunda 2015 - rapport préliminaire', Anatolia Antiqua 24: 339-457.

Henry, O., Löwenborg, D., Marchand-Beaulieu, F., Tucker, G., Frejman, A., Lamesa, C., Bost, C., Vergnaud, B., Stojanovitc, I., Carless Unwin, N., Schibille, N., Çakmaklı, Ö.D., and Andersson, E. (2017) 'Labraunda 2016', Anatolia Antiqua 25: 161-185.

Henry, O., Andersson, E., Blid, J., Bost, C., Çakmaklı, Ö.D., Carless Unwin, N., Çimen, G., Eyigör, A., Freccero, A., Frejman, A., Georgescu, C., Goussard, E., Guimier-Sorbets, A.-M., Hauchart, M., Hedlund, R., Lamare, N., Lungu, V., Marchand-Beaulieu, F., Sitz, A., Stojanovitc, I., and Vergnaud, B. (2018) 'Labraunda 2017', Anatolia Antiqua 26, 209-301.

van Henten, J.W. and Houtepen, A. (2001) Religious identity and the Invention of Tradition. Papers read at a Noster Conference, Soesterberg, January 4-6, 1999, Studies in Theology and Religion 3 , Leiden.

Hepp, A., S. Hjarvard and K. Lundby (2015) 'Mediatization: theorizing the interplay between media, culture and society', Media, Culture \& Society 37, 314-324.

Herda, A. (2006) Der Apollon-Delphinios-Kult in Milet und die Neujahrsprozession nach Didyma. Ein neuer Kommentar der sog. Molopoi-Satzung, Milesische Forschungen, Bd. 4, Mainz am Rhein. 
Herda, A. (2011) 'How to run a state cult. The organization of the cult of Apollo Delphinios in Miletos', in M. Haysom and J. Wallensten (eds), Current approaches to religion in ancient Greece. Papers presented at a symposium at the Swedish Institute in Athens, 17-19 April, 20o8, ActaAth-8 ${ }^{\circ}$, Stockholm: 57-93.

Hermann, W. (1965) 'Santuari di Magna Grecia e della madre patria', in Megale Hellas. Nome e immagine, Atti del Iv Convegno di Studi sulla Magna Grecia, Taranto-Reggio Calabria 11-16 ottobre 1964, Napoli: 47-57.

Herring, A. (2011) Structure, sculpture and scholarship. Understanding the sanctuary of Hekate at Lagina, PhD diss. University of California, Los Angeles.

Herring, A. (2020) 'Reconstructing the sacred experience at the sanctuary of Hekate at Lagina', Journal of the Society of Architectural Historians 79: 247-263.

Herrmann, P. (1984) 'Die Selbstdarstellung der Hellenistischen Stadt in den Inschriften. Ideal und Wirklichkeit', in A.G. Kalogeropoulou (ed.), Praktika tou E' Diethnous Synedriou Hellenikes kai Latinikes Epigraphikes, Athena, 3-9 Oktovriou 1982, Athens: 109-119.

Hervieu-Léger, D. (2000) Religion as a chain of memory, Cambridge.

von Hesberg, H. (1990) 'Platzanlagen und Hallenbauten in der Zeit des frühen Hellenismus', in Akten des XIII. Internationalen Kongresses für Klassische Archäologie, Mainz: 231-241.

von Hesberg, H. (2009) 'Archäologische Charakteristika der Inschriftenträger staatlicher Urkunden - einige Beispiele', in R. Haensch (ed.), Selbstdarstellung und Kommunikation: die Veröffentlichung staatlicher Urkunden auf Stein und Bronze in der römischen Welt. Internationales Kolloquium an der Kommission für Alte Geschichte und Epigraphik in München (1. bis 3. Juli 2006): 19-56.

Hild, F. (2014) Meilensteine, Straßen und das Verkehrsnetz der Provinz Karia, Vienna. Hirsch, E. (1995) 'Landscape. Between space and place', in E. Hirsch and M. O'Hanlon (eds), The anthropology of landscape. Perspectives on space and place, Oxford Studies in Social and Cultural Anthropology, Oxford: 1-30.

Hjarvard, S. (2008) 'The mediatization of religion. A theory of the media as agents of religious change', Northern Lights. Yearbook of Film \& Media Studies 6, 9-26.

Hobsbawm, E.J. and Ranger, T.O. (eds) (1992) The invention of tradition, Cambridge.

Holleaux, M. (1904) 'Remarques sur les décrets trouvés dans le sanctuaire de Zeus Panamaros', Bulletin de Correspondance Hellénique 28: 353-363.

Holleaux, M. (1952) Études d'épigraphie et d'histoire grecque, IV, 1. Rome, la Macédoine et l'Orient grec, Paris.

Hollinshead, M.B. (2012) 'Monumental steps and the shaping of ceremony', in B.D. Wescoat and R.G. Ousterhout (eds), Architecture of the sacred. Space, ritual, and experience from classical Greece to Byzantium, Cambridge: 27-65. 
Hollinshead, M.B. (2015) Shaping ceremony. Monumental steps and Greek architecture, Wisconsin Studies in Classics, Madison, WI.

Holod, R. and Ousterhout, R.G. (2011) Osman Hamdi Bey \& Amerikalılar. Arkeoloji, diplomasi sanat / Osman Hamdi Bey \& the Americans. Archaeology, diplomacy, art, İstanbul.

Hölscher, T. (2013) 'Die griechische Polis und ihre Räume. Religiöse Grenzen und Übergänge', in M.A. Guggisberg (ed.), Grenzen in Ritual und Kult der Antike. Internationales Kolloquium, Basel, 5.-6. November 2009, Schweizerische Beiträge zur Altertumswissenschaft, Bd. 40, Basel: 47-68.

Hopkins, T.K. and Wallerstein, I.M. (1982) World-systems analysis. Theory and methodology, Explorations in the world-economy, vol. 1, Beverly Hills.

Horden, P. and Purcell, N. (200o) The corrupting sea. A study of Mediterranean history, Oxford, Malden, MA.

Hornblower, S. (1982) Mausolus, Oxford, Oxfordshire; New York.

Hornblower, S. (2015) Lykophron: Alexandra. Greek text, translation, commentary, and introduction, Oxford.

Hornblower, S. and Spawforth, A. (eds) (2003) The Oxford classical dictionary, Revised third edition, Oxford.

Horsley, G.H.R. (1999) The Rider God steles at Burdur Museum in Turkey, The Museum of Antiquities Maurice Kelly Lecture 3, Armidale.

Horster, M. (2004) Landbesitz griechischer Heiligtümer in archaischer und klassischer Zeit, Religionsgeschichtliche Versuche und Vorarbeiten 53, Berlin.

Horster, M. (2010) 'Le concept de "paysage religieux" I. Religious landscape and sacred land. Connections of space and cult in the Greek world', Revue de l'histoire des religions 227: 435-459.

Horster, M. (2013) 'Layers of corporate memory in the sanctuary of Demeter and Kore in Eleusis', in A. Gangloff (ed.) Lieux de mémoire en Orient grec à l'époque impériale, Bern: $155^{-178 . ~}$

Horster, M. and Klöckner, A. (eds) (2011) Civic priests. Cult personnel in Athens from the Hellenistic period to Late Antiquity, Religionsgeschichtliche Versuche und Vorarbeiten 58 , Berlin.

Horster, M. and Klöckner, A. (eds) (2013) Cities and priests. Cult personnel in Asia Minor and the Aegean islands from the Hellenistic to the Imperial period, Religionsgeschichtliche Versuche und Vorarbeiten 64, Berlin.

Hotz, S. (2005) 'Bigger, better, more. Die Kleinstadt Bargylia im Bann eines Festes', in C. Ambos, S. Hotz, G. Schwedler, and S. Weinfurter (eds), Die Welt der Rituale. Von der Antike bis heute, Darmstad: 59-65.

Houby-Nielsen, S. (2001) 'Sacred landscapes of Aetolia and Achaea. Synoecism processes and non-urban sanctuaries', in J. Isager (ed.), Foundation and destruction. 
Nikopolis and northwestern Greece. The archaeological evidence for the city destructions, the foundation of Nikopolis and the synoecism, Aarhus: 257-277.

Huet, V. (2015) 'Watching rituals', in R. Raja and J. Rüpke (eds), A companion to the archaeology of religion in the ancient world, Blackwell companions to the ancient world: 144-154.

Huizinga, J. (1949) Homo ludens. A study of the play-element in culture, London.

Hull, K.L. (2014) 'Ritual as performance in small-scale societies', World Archaeology 46: 164-177.

Humphreys, S.C. (1978) Anthropology and the Greeks, International Library of Anthropology, London, Boston.

Hunt, L. (1984) Politics, culture, and class in the French Revolution, Studies on the History of Society and Culture 1, Berkeley.

Hurter, S. (1998) 'The Pixodarus hoard. A summary', in R.H.J. Ashton, S. Hurter, G.l. Rider and R. Bland (eds), Studies in Greek numismatics in memory of Martin Jessop Price, London.

Iannaccone, L.R., Haight, C.E. and Rubin, J. (2011) 'Lessons from Delphi: Religious markets and spiritual capitals', Journal of Economic Behavior and Organization 77: $326-338$.

Inankur, Z., Lewis, R. and Roberts, M. (2011) The poetics and politics of place. Ottoman Istanbul and British Orientalism, Suna and Inan Kirac Foundation Pera Museum, Istanbul, Seattle, WA.

Ingold, T. (1993) 'The temporality of landscape', World Archaeology 25:152-174.

Ingold, T. (2000) Perception of the environment. Essays in livelihood, dwelling and skill, London.

Ingold, T. (2011) Being alive. Essays on movement, knowledge and description, London. Ingold, T. (2016 [2007]) Lines. A brief history, London.

Interdonato, E. (2016) 'Architecture and rituals in the Hellenistic age. The case of the Asklepieion in Kos', in M. Melfi and O. Bobou (eds), Hellenistic sanctuaries. Between Greece and Rome, Oxford: 170-181.

İplikçioğlu, B. (2004) 'Ländliche Siedlungen und das Territorium von Termessos (Pisidien)', in F. Kolb (ed.), Chora und Polis, Schriften des Historischen Kollegs Kolloquien 54, Munich: 103-125.

Isager, S. (1990) 'Kings and gods in the Seleucid empire. A question of landed property in Asia Minor', in P. Bilde, T. Engberg-Pedersen, L. Hannestad and J. Zahle (eds), Religion and religious practice in the Seleucid kingdom, Studies in Hellenistic Civilization 1, Aarhus: 79-90.

Isager, S. (1992) 'Sacred and profane ownership of land', in B. Wells (ed.), Agriculture in ancient Greece. Proceedings of the seventh international symposium at the Swedish Institute of Athens, 16-17 May 1990, Stockholm: 119-122. 
Isager, S. (2004) 'The pride of Halikarnassos', in S. Isager and P. Pedersen (eds), The Salmakis inscription and Hellenistic Halikarnassos, Odense: 217-237.

Isager, S. (2011) 'The epigraphic tradition at Labraunda seen in the light of Labraunda inscription no. 134. A recent addition to the Olympichos file', in L. Karlsson and S. Carlsson (eds), Labraunda and Karia. Proceedings of the international symposium commemorating sixty years of Swedish archaeological work in Labraunda. The Royal SwedishAcademy ofLetters, History and Antiquities, Stockholm, November 20-21, 2008, Acta Universitatis Uppsaliensis. Boreas. Uppsala Studies in Ancient Mediterranean and Near Eastern Civilizations, 32, Uppsala: 199-216.

Isager, S. and Karlsson, L. (2008) 'A new inscription from Labraunda. Honorary decree for Olympichos: I.Labraunda No. 134 (and No. 49)', Epigraphica Anatolica 41: 39-52. Isager, S. and Pedersen, P. (2014) 'Dining rooms in the sanctuary. Old and new epigraphic evidence from Halikarnassos', in L. Karlsson, S. Carlsson and J. Blid Kullberg (eds), LABRYS. Studies presented to Pontus Hellström, Acta Universitatis Upsaliensis. Boreas. Uppsala Studies in Ancient Mediterranean and Near Eastern Civilizations 35, Uppsala: 457-466.

Işık, F. (2013) 'Der neue Sarkophag der Hekatomniden aus Mylasa. Zur Ikonographie der Sarkophagbilder', conference paper presented at Zwischen Satrapen und Dynasten: Kleinasien im 4. Jahrhundert v. Chr. 25.02.2013-26.02.2013, Westfälische Wilhelms-Universität Münster.

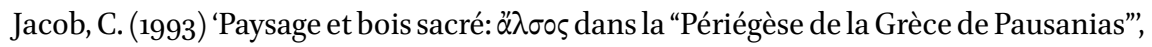
in O.d. Cazanove and J. Scheid (eds), Les bois sacrés. Actes du colloque international organisé par le Centre Jean Bérard et l'École pratique des Hautes Études (Ve Section), Naples, 23-25 novembre 1989, Coll. du Centre Jean Bérard 10, Naples: 31-44.

Jeppesen, K. (1955) Labraunda. Swedish excavations and researches. Vol. I. Part 1. The propylaea, Acta Instituti Atheniensis regni Sueciae, Series in 4, IV, I, 1, Lund.

Johnston, S.I. (1990) Hekate Soteira. A study of Hekate's roles in the Chaldaean oracles and related literature, American Classical Studies, 21, Atlanta.

Johnston, S.I. (1992) 'Riders in the sky. Cavalier gods and theurgic salvation in the second century A.D.', Classical Philology 87: 303-321.

Johnston, S.I. (1999) Restless dead. Encounters between the living and the dead in ancient Greece, Berkeley.

Jones, A.H.M. (1940) The Greek city from Alexander to Justinian, Oxford.

Jones, C.P. (1999) Kinship diplomacy in the ancient world, Revealing Antiquity 12, Cambridge, MA.

Jones, N.F. (1987) Public organization in ancient Greece. A documentary study, Philadelphia. 
Jost, M. (1994) 'The distribution of sanctuaries in civic space in Arkadia', in S.E. Alcock and R. Osborne (eds), Placing the gods. Sanctuaries and sacred space in ancient Greece, Oxford: 217-230.

Junghölter, U. (1989) Zur Komposition der Lagina-Friese und zur Deutung des Nordfrieses, Europäische Hochschulschriften. Reihe 38, Archäologie Bd. 29, Frankfurt.

Kamphorst, S. (forthcoming) Carving communities in stone. Inscriptions as a medium of Hellenistic globalisation, $\mathrm{PhD}$ diss. University of Groningen.

Kantner, J. (2008) 'The archaeology of regions. From discrete analytical toolkit to ubiquitous spatial perspective', Journal of Archaeological Research 16: 37-81.

Kantor, G. (2016) 'Towards the dating of the inscriptions of foreign judges at Mylasa', Epigraphica Anatolica 49: 131-136.

Karatas, A.-M.-S. (2019) 'Key-bearers of Greek temples. The temple key as symbol of priestly authority', Mythos 13: https://doi.org/10.400o/mythos.1219.

Karlsson, L. (2008) 'Labraunda 2004-2007. A preliminary report on the Swedish excavations, with contributions by Olivier Henry and Jesper Blid', Istanbuler Mitteilungen 58: 109-133.

Karlsson, L. (2010) 'Labraunda 2009. A preliminary report on the Swedish excavations with contributions by Jesper Blid and Olivier Henry', Opuscula. Annual of the Swedish Institutes at Athens and Rome 3: 61-104.

Karlsson, L. (2011) 'The forts and fortifications of Labraunda', in L. Karlsson and S. Carlsson (eds), Labraunda and Karia. Proceedings of the international symposium commemorating sixty years of Swedish archaeological work in Labraunda. The Royal Swedish Academy of Letters, History and Antiquities, Stockholm, November 20-21, 2008, Acta Universitatis Uppsaliensis. Boreas. Uppsala Studies in Ancient Mediterranean and Near Eastern Civilizations, 32, Uppsala: 217-252.

Karlsson, L. (2013a) 'Combining architectural orders at Labraunda. A political statement', in O. Henry (ed.), 4th century Karia. Defining a Karian identity under the Hekatomnids, Varia Anatolica XxvıII, Istanbul, Paris: 65-80.

Karlsson, L. (2013b) 'Kybele at Labraunda', conference paper presented at Arkhaia Karia, IFEA Istanbul.

Karlsson, L. (2013c) 'The sanctuary of the Weather God of Heaven at Karian Labraunda', in A.-L. Schallin (ed.), Perpectives on ancient Greece. Papers in celebration of the 6oth anniversary of the Swedish Institute in Athens, Stockholm: 173-189.

Karlsson, L. (2015a) 'The sanctuary of Zeus with the double axe at Labraunda. From nature sanctuary to Persian Paradeisos', in E. Winter and K. Zimmermann (eds), Zwischen Satrapen und Dynasten. Kleinasien im 4. Jahrhundert v. Chr., Asia Minor Studien Bd. 76, Bonn: 75-82.

Karlsson, L. (2015b) 'The terracottas from Labraunda', in E. Lafli and A. Muller (eds), Figurines de terre cuite en Méditerranée grecque et romaine 2 - Iconographie et 
contextes (Colloque, Izmir, Juin 2007), Presses universitaires du Septentrion vol. 1599, Villeneuve d'Ascq: $523-527$.

Karlsson, L. (2019) 'Kybele at Labraunda', in O. Henry and K. Konuk (eds), Karia arkhaia. La Carie, des origines à la période pré-hékatomnide. Istanbul 14-16 novembre 2013, 4èmes rencontres d'archéologie de l'IFEA; CNRS USR 3131, Istanbul: 89-10o.

Karlsson, L. and Carlsson, S. (eds) (2011) Labraunda and Karia. Proceedings of the international symposium commemorating sixty years of Swedish archaeological work in Labraunda. The Royal Swedish Academy of Letters, History and Antiquities, Stockholm, November 20-21, 2008, Acta Universitatis Uppsaliensis. Boreas. Uppsala Studies in Ancient Mediterranean and Near Eastern Civilizations 32, Uppsala.

Karlsson, L. and Henry, O. (2009) 'A Carian graffito from Labraunda', Kadmos. Zeitschrift für vor- und frühgriechische Epigraphik 47: 171-176.

Karlsson, L., Henry, O. and Blid, J. (2008) 'Labraunda 2004-2007. A preliminary report on the Swedish excavations', Istanbuler Mitteilungen 58: 109-133.

Kindt, J. (2009) 'Polis religion - a critical appreciation', Kernos 22: 9-34.

Kindt, J. (2012) Rethinking Greek religion, Cambridge.

Kirsten, E., Lehmann, H. and Philippson, A. (1956) Die griechische Polis als historischgeographisches Problem des Mittelmeerraumes, Colloqium geographicum, Band 5 , Bonn.

Kızıl, A. (2009) 'Das Baltalı Kapı in Mylasa. Die Labrys und die Augen des Zeus', Anatolia Antiqua 17: 255-264.

Kızıl, A. (2013) 'The architecture of Hekatomnos' monumental tomb in Mylasa', conference paper presented at Zwischen Satrapen und Dynasten. Kleinasien im 4. Jahrhundert v. Chr. 25.02.2013-26.02.2013, Westfälische Wilhelms-Universität Münster.

Kızıl, A., Konuk, K., Doğan, T., Laroche, D., Le Quere, E., Lungu, V., Prost, F. and Vergnaud, B. (2018) 'Eurômos. Rapport preliminaire sur les travaux realises en 2017', Anatolia Antiqua 26: 165-208.

Kleibrink, M., Jacobsen, J.K. and Handberg, S. (2004) 'Water for Athena. Votive gifts at Lagaria (Timpone della Motta, Francavilla Marittima, Calabria)', World Archaeology 36: $43-67$.

Knäpper, K. (2018) Hieros kai Asylos. Territoriale Asylie im Hellenismus in ihrem historischen Kontext, Historia Einzelschrift 250, Stuttgart.

Konuk, K. (1994) 'Quelques réflexions sur le monnayage des satrapes hécatomnides de Carie', in T. Hackens and G. Moucharte (eds), Actes du ne Congrès International de Numismatique (Louvain-la-Neuve, 1993), I, Louvain-la-Neuve, Brussels: 237-242.

Konuk, K. (2013) 'Coinage and identities under the Hekatomnids', in O. Henry (ed.), 4th century Karia. Defining a Karian identity under the Hekatomnids, Varia Anatolica XXVIII, Istanbul, Paris: 101-122. 
Koparal, E. (2019) 'Frontier sanctuaries and rural cult places in the khorai of Klazomenai and Teos', in B. Engels, S. Huy and C. Steitler (eds), Natur und Kult in Anatolien. Viertes Wissenschaftliches Netzwerk an der Abteilung Istanbuldes Deutschen Archäologischen Instituts, BYZAS 24, Istanbul: 333-354.

Kowalzig, B. (2007a) 'Mapping out communitas. Performances of theoria in their sacred and political context', in J. Elsner and I. Rutherford (eds), Pilgrimage in Graeco-Roman and early Christian antiquity, Oxford: 41-72.

Kowalzig, B. (2007b) Singing for the gods. Performances of myth and ritual in Archaic and Classical Greece, Oxford Classical Monographs, Oxford.

Kraus, T. (1960) Hekate. Studie zu Wesen und Bild der Göttin in Kleinasien und Griechenland, Heidelberger kunstgeschichtliche Abhandlungen N.F. 5, Heidelberg.

Kravaritou, S. (2016) 'Sacred space and the politics of multiculturalism in Demetrias (Thessaly)', in M. Melfi and O. Bobou (eds), Hellenistic Sanctuaries. Between Greece and Rome, Oxford: 128-151.

Kristensen, T.M. and Friese, W.(2017) Excavating pilgrimage. Archaeological approaches to sacred travel and movement in the ancient world, Routledge Studies in Pilgrimage, Religious Travel and Tourism, London; New York.

Kuhn, G. (1985) 'Untersuchungen zur Funktion der Säulenhalle in archaischer und klassischer Zeit',Jahrbuch des Deutschen Archäologischen Instituts 100: 169-317.

Kuttner, A. (2005) “Do you look like you belong here?" Asianism at Pergamon and the Makedonian diaspora', in E.S. Gruen (ed.), Cultural borrowings and ethnic appropriations in Antiquity, Oriens et Occidens. Studien zu antiken Kulturkontakten und ihrem Nachleben, 8, 137-206.

LaBuff, J. (2016) Polis expansion and elite power in Hellenistic Karia, Alexander the Great and the Hellenistic world, Lanham; Boulder; New York; London.

Laffi, U. (1971) 'I terreni del tempio di Zeus ad Aizanoi. Le iscrizioni sulla parete interna dell'anta destra del pronaos', Athenaeum 49:3-53.

Lang, F. (1999) 'Stadt und Umland. Ein komplementäres System', in E.-L. Schwandner and K. Rheidt (eds), Stadt und Umland. Neue Ergebnisse der archäologischen Bauund Siedlungsforschung. Bauforschungskolloquium in Berlin vom 7. bis 10. Mai 1997 veranstaltet vom Architektur-Referat des DAI, Diskussionen zur archäologischen Bauforschung 7, Mainz: 1-18.

Langenohl, A. (2005) 'Mental maps, Raum und Erinnerung. Zur kultursoziologischen Erschließung eines transdisziplinären Konzepts', in S. Damir-Geilsdorf, A. Hartmann and B. Heinrich (eds), Mental maps - Raum - Erinnerung. Kulturwissenschaftliche Zugänge zum Verhältnis von Raum und Erinnerung, Kulturwissenschaft. Forschung und Wissenschaft, Bd. 1, Münster: 51-69.

Latour, B. (1987) Science in action. How to follow scientists and engineers through society, Cambridge, MA. 
Latour, B. (2005) Reassembling the social. An introduction to Actor-Network Theory, Oxford.

Laumonier, A. (1934) 'Inscriptions de carie', Bulletin de Correspondance Hellénique 58: 291-380.

Laumonier, A. (1936) 'Archéologie carienne', Bulletin de Correspondance Hellénique 6o: 286-335.

Laumonier, A. (1937) 'Recherches sur la chronologie des prêtres de Panamara', Bulletin de Correspondance Hellénique 61: 236-298.

Laumonier, A. (1938a) 'Complément aux recherches sur la chronologie des prêtres de Panamara', Bulletin de Correspondance Hellénique 62: 167-179.

Laumonier, A. (1938b) 'Recherches sur la chronologie des prêtres de Lagina', Bulletin de Correspondance Hellénique 62: 251-284.

Laumonier, A. (1940) 'Les baux d'Olymos', Revue des études anciennes 42: 201-213.

Laumonier, A. (1958) Les cultes indigènes en Carie, Paris.

Leake, W.M. (1824) Journal of a tour in Asia Minor, with comparative remarks on the ancient and modern geography of that country, by William Martin Leake, London.

Lehmann, P.W. (1954) 'The setting of Hellenistic temples', The Journal of the Society of Architectural Historians 13: 15-20.

Leone, R. (1998) Luoghi di culto extraurbani d'età arcaica in Magna Grecia, Studi e materiali di archeologia 11, Florence.

de Ligt, L. (1993) Fairs and markets in the Roman Empire. Economic and social aspects of periodic trade in a pre-industrial society, Amsterdam.

Liljenstolpe, P. and von Schmalensee, P. (1996) 'The Roman stoa of Poleites at Labraynda. A report on its architecture with an appendix by J. Flemberg', Opuscula Atheniensia: acta Inst. Athen. Regni Sueciae 21: 125-148.

Linfert, A. (1995) 'Prunkaltäre', in M. Wörrle and P. Zanker (eds), Stadtbild und Bürgerbild im Hellenismus. Kolloquium, München, 24. bis 26. Juni 1993, Vestigia 47, München: 131-146.

Llobera, M. (2007) 'Reconstructing visual landscapes', World Archaeology 39: 51-69.

Lohmann, H. (2005) Ein Survey bei Kazikli (Mugla), Möhnesee.

Lohmann, H., Höhfeld, V. and Herbordt, S. (eds) (2019) Feldforschungen im Latmos. Forschungen im Umland von Herakleia am Latmos, Asia Minor Studien Bd. 93, Bonn. Low, S.M. (2000) On the plaza. The politics of public space and culture, Austin.

Lücke, S. (2000) Syngeneia. Epigraphisch-historische Studien zu einem Phänomen der antiken griechischen Diplomatie, Frankfurter althistorische Beiträge 5, Frankfurt am Main.

Luginbühl, T. (2015) 'Ritual activities, processions and pilgrimages', in R. Raja and J. Rüpke (eds), A companion to the archaeology of religion in the ancient world, Blackwell Companions to the Ancient World, Oxford: 41-59. 
Lund, J. (2011) 'Rhodian transport amphorae as a source for economic ebbs and flows in the Eastern Mediterranean in the second century BC', in Z.H. Archibald, J.K. Davies and V. Gabrielsen (eds), The economies of Hellenistic societies, third to first centuries $B C$, Oxford: 280-295.

Lynch, K. (1960) The image of the city, Cambridge, MA.

Ma, J. (1997) 'The koinon of the Laodikeis in the Rhodian Peraia', Epigraphica Anatolica 28: 9-10.

Ma, J. (1999) Antiochos III and the cities of Western Asia Minor, Oxford.

Ma, J. (2000) 'The epigraphy of Hellenistic Asia Minor. A survey of recent research (1992-1999)', American Journal of Archaeology. The journal of the Archaeological Institute of America. 104: 95-121.

Ma, J. (2003) 'Peer polity and interaction in the Hellenistic age', Past and Present 180: 9-39.

MacDonald, W.L. (1986) The architecture of the Roman Empire. II. An urban appraisal, Yale publications in the history of art 35, New Haven.

Mackil, E. (2013a) Creating a common polity. Religion, economy, and politics in the making of the Greek koinon, Hellenistic Culture and Society 55, Berkeley.

Mackil, E. (2013b) 'The Greek koinon', in P. Bang and W. Scheidel (eds), The Oxford handbook of the state in the ancient Near East and Mediterranean, Oxford.

MacMullen, R. (1981) Paganism in the Roman empire, New Haven, CT.

Madden, D. (2010) 'Urban ANTs. A review essay', Qualitative Sociology 33: 583-589.

Maddoli, G. (2007) 'Epigrafi di Iasos. Nuovi supplementi I', La Parola del Passato. Rivista di studi Antichi 62: 193-372.

Maddoli, G. (2010) 'Du nouveau sur les Hékatomnides d'apres les inscriptions de Iasos', in R. van Bremen and J.-M. Carbon (eds), Hellenistic Karia. Proceedings of the First International Conference on Hellenistic Karia - Oxford, 29 June-2 July 2006, Bordeaux: 123-131.

Magie, D. (1950) Roman rule in Asia Minor, to the end of the third century after Christ, Princeton.

Malkin, I. (1996) 'Territorial domination and the Greek sanctuary', in P. Hellström and B. Alroth (eds), Religion and power in the ancient Greek world. Proceedings of the Uppsala symposium 1993, Acta Universitatis Upsaliensis. Boreas 24, Uppsala: 75-82.

Malkin, I. (2005) Mediterranean paradigms and classical antiquity, London.

Malkin, I. (2011) A small Greek world. Networks in the ancient Mediterranean, New York.

Malkin, I., Constantakopoulou, C. and Panagopoulou, K. (2007) 'Preface: Networks in the Ancient Mediterranean', Mediterranean Historical Review 22: 1-9.

Marchese, R.T. (1989) The historical archaeology of Northern Caria, BAR international series; 536, Oxford, England. 
Marek, C. (1988) 'Karien im Ersten Mithridatischen Krieg', in P. Kneissl and V. Losemann (eds), Alte Geschichte und Wissenschaftsgeschichte. Festschrift für Karl Christ zum 65. Geburtstag, Darmstadt: 285-308.

Marek, C. and Zingg, E. (2018) Die Versinschrift des Hyssaldomos und die Inschriften von Uzunyuva (Milas/Mylasa), Asia Minor Studien Bd. 9o, Bonn.

Martin, R. (1951) Recherches sur l'agora grecque. Études d'histoire et d'archéologie urbaines, Bibliothecque des Écoles françaises d'Athènes et de Rome CLXXIV, Paris.

Martin, R. (1973) 'Rapports entre les structures urbaines et les modes de division et d'exploitation du territoire', in M.I. Finley (ed.), Problèmes de la terre en Grèce ancienne, Paris: 97-112.

Martin, R. (1974) L'urbanisme dans la Grèce antique, ze éd., Paris.

Martin-McAuliffe, S. and Papadopoulos, J.K. (2012) 'Framing victory. Salamis, the Athenian acropolis, and the agora', Journal of the Society of Architectural Historians 71: $33^{2-}-361$.

Mastrocinque, A. (1979) La Caria e la Ionia meridionale in epoca ellenistica, 323-188 a. C, Problemi e ricerche di storia antica 6, Roma.

Mastrocinque, A. (1979-1980) 'Due note elleniche: I. Plistarco, fratello di Cassandro, II. L'imperatore Marciano e l'ombra dell'aquila', Atti dell'Istituto Veneto di Scienze, Lettere ed Arti, Classe di Scienze Morale e Lettere 138: 551-562.

Mastrocinque, A. (1984) 'Città sacre e asylia alla fine della guerra tra Roma e Antioco III', Contributi dell'Istituto di Storia Antica dell'Università del Sacro Cuoro 10: 142-163.

McCauley, R.N. and Lawson, E.T. (2002) Bringing ritual to mind. Psychological foundations of cultural forms, Cambridge.

McCauley, R.N. and Lawson, E.T. (2007) 'Cognition, religious ritual, and archaeology', in E. Kyriakidis (ed.), The archaeology of ritual, Los Angeles: 209-254.

McInerney, J. (2006) 'On the border. Sacred land and the margins of the community', in R.M. Rosen and I. Sluiter (eds), City, countryside, and the spatial organization of value in classical antiquity, Mnemosyne, Supplements 279, Leiden, Boston: 33-6o.

McInerney, J. (2013) ‘Polis and koinon. Federal government in Greece', in H. Beck (ed.), A Companion to Ancient Greek Government 466-479.

Meadows, A.R. (2002) 'Stratonikeia in Caria. The Hellenistic city and its coinage', Numismatic Chronicle 162: 79-134.

Meadows, A.R. (2018) 'The Great Transformation. Civic coin design in the second century BC', in P.P. Iossif, F. de Callatäy and R. Veymiers (eds), TYPOI. Greek and Roman coins seen through their images. Noble issuers, humble users? Proceedings of the International Conference Organized by the Belgian and French Schools at Athens, 26-28 September 2012, Série Histoire 3, Liège: 297-318.

Meier, L. (2012) Die Finanzierung öffentlicher Bauten in der hellenistischen Polis, Die hellenistische Polis als Lebensform, Band 3 , Heidelberg. 
Meijers, E. (2007) 'From Central Place to Network Model. Theory and evidence of a paradigm change', Tijdschrift voor Economische en Sociale Geografie 98: 245-259.

Meinig, D.W. (1979) 'Symbolic landscapes. Some idealizations of American communities', in D.W. Meinig (ed.), The interpretation of ordinary landscapes. Geographical essays, New York, Oxford:164-192.

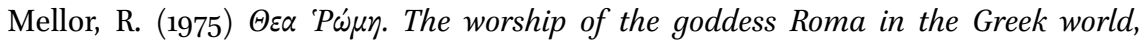
Hypomnemata 42, Göttingen.

Merkelbach, R. (1968) 'Zum Mirakel des Zeus Panamaros', Zeitschrift für Papyrologie und Epigraphik 2: 39-40.

Mert, İ.H. (2008) Untersuchungen zur hellenistischen und kaiserzeitlichen Bauornamentik von Stratonikeia, Istanbuler Forschungen 5o, Tübingen.

Middleton, D. and Brown, S.D. (2005) The social psychology of experience. Studies in remembering and forgetting, London, Thousand Oaks, CA.

Mikalson, J.D. (2016) New aspects of religion in ancient Athens. Honors, authorities, esthetics, and society, Religions in the Graeco-Roman world 183, Leiden.

Miles, M.M. (2016) 'Birds around the temple. Constructing a sacred environment', in J. McInerney and I. Sluiter (eds), Valuing landscape in classical antiquity. Natural environment and cultural imagination, Proceedings from the Penn-Leiden Colloquia on Ancient Values VIII, Leiden: 151-195.

Mileta, C. (2009a) 'Poleis - indigenous cities - military colonies. Reflections on the urban system of Hellenistic Asia Minor', Mnemon (St. Petersburg) 8: 131-146.

Mileta, C. (2009b) 'Überlegungen zum Charakter und zur Entwicklung der neuen Poleis im hellenistischen Kleinasien', in A. Matthaei and M. Zimmermann (eds), Stadtbilder im Hellenismus, Berlin: 73-93.

Morgan, C. (1990) Athletes and oracles. The transformation of Olympia and Delphi in the eighth century B.C., Cambridge Classical Studies, Cambridge; New York.

Morgan, C. (1997) 'The archaeology of sanctuaries in early Iron Age and archaic Ethne. A preliminary view', in L.G. Mitchell and P.J. Rhodes (eds), The development of the 'polis' in archaic Greece, London, New York: 168-198.

Morgan, C. (2003) Early Greek states beyond the polis, London, New York.

Mutlu, S. (2015) 'Zeus Panamaros kutsal alanı ve bayramları', in B. Söğüt (ed.), Stratonikeia ve Çevresi Araștırmaları, Stratonikeia Çalıșmaları 1, Istanbul: 79-94.

Mylonopoulos, J. (2006) 'Greek sanctuaries as places of communication through rituals. An archaeological perspective', in E. Stavrianopoulou (ed.), Ritual and communication in the Graeco-Roman world, Kernos Supplément, Liège: 69-110.

Mylonopoulos, J. (2013) 'Commemorating pious service. Images in honour of male and female priestly officers in Asia Minor and the eastern Aegean in the Hellenistic and Roman times', in M. Horster and A. Klöckner (eds), Cities and Priests. Cult personnel 
in Asia Minor and the Aegean islands from the Hellenistic to the Imperial period, Religionsgeschichtliche Versuche und Vorarbeiten 64, Berlin: 121-154.

Mylonopoulos, J. (2019) 'The power of the absent text. Dedicatory inscriptions on Greek sacred architecture and altars', in A. Petrovic, I. Petrovic, and E. Thomas (eds), The materiality of text. Placement, perception, and presence of inscribed texts in classical antiquity, Brill Studies in Greek and Roman Epigraphy 11, Leiden: 231-274.

Newton, C.T. and Pullan, R.P. (1862) A history of discoveries at Halicarnassus, Cnidus \& Branchide, Vol. I: Plates; Vol. II: Text (2 parts), London.

Nielsen, I. (2002) Cultic theatres and ritual drama. A study in regional development and religious interchange between East and West in antiquity, Aarhus.

van Nijf, O.M. (1999) 'Athletics, festivals and Greek identity in the Roman East', Proceedings of the Cambridge Philological Society 45: 176-200.

van Nijf, O.M. (2000) 'Inscriptions and civic memory in the Roman East', in A.E. Cooley (ed.), The afterlife of inscriptions. Reusing, rediscovering, reinventing \& revitalizing ancient inscriptions, Bulletin of the Institute of Classical Studies, Supplement 75, London: $21-36$.

van Nijf, O.M. (2001) 'Local heroes. Athletics, festivals and elite self-fashioning in the Roman East', in S. Goldhill (ed.), Being Greek under Rome, Cambridge: 306-334. van Nijf, O.M. (2002) 'Athletics, andreia and the askesis-culture in the Roman East', in

I. Sluiter and R.M. Rosen (eds), Andreia. Studies in manliness and courage in classical antiquity, Leiden: $263^{-286 .}$

van Nijf, O.M. (2006) 'Global players. Athletes and performers in the Hellenistic and

Roman world', in I. Nielsen (ed.), Between cult and society. The cosmopolitan centres of the ancient Mediterranean as setting for activities of religious associations and religious communities, Hamburg: 225-235.

van Nijf, O.M. (2008) 'Steden, feesten en identiteit in de wereld na Alexander. De Griekse polis na Alexander: ondergang of bloei?', Groniek. Historische Tijdschrift: $39-53$.

van Nijf, O.M. (2010) 'Athletics, festivals and Greek identity in the Roman East', in J. König (ed.), Greek athletics, Edinburg: 175-197.

van Nijf, O.M. (2012) 'Political games', in L'organisation des spectacles dans le monde romain, Entretiens sur l'antiquite classique 58, Genève: $47-95$.

van Nijf, O.M. (2014) 'Affective politics. The emotional regime in the imperial Greek city', in A. Chaniotis and P. Ducrey (eds), Unveiling emotions II. Emotions in Greece and Rome. Texts, images, material culture, HABES - Heidelberger Althistorische Beitrage und Epigrafische Studien Vol. 55, Stuttgart: 351-368.

van Nijf, O.M. and Alston, R. (2011) 'Political culture in the Greek city after the classical age. Introduction and preview', in O.M. van Nijf and R. Alston (eds), Political culture 
in the Greek city after the Classical age, Groningen-Royal Holloway Studies on the Greek City After the Classical Age 2, Leuven: 1-26.

van Nijf, O.M. and van Dijk, S. (2020) 'Experiencing Roman power at Greek contests.

Romaia in the Greek festival network', in K. Berthelot (ed.), Reconsidering Roman power. Roman, Greek, Jewish and Christian perceptions and reactions, Rome: https:// doi.org/10.400o/books.efr.5704.

van Nijf, O.M. and Williamson, C.G. (2014) 'Netwerken, panhelleense festivals en de globalisering van de Hellenistische wereld', Groniek. Historische Tijdschrift 200: $253^{-265}$.

van Nijf, O.M. and Williamson, C.G. (2015) 'Re-inventing traditions. Connecting contests in the Hellenistic and Roman worlds', in D. Boschung, A. Busch and M.J. Versluys (eds), Reinventing 'The Invention of Tradition'? Indigenous pasts and the Roman present, Morphomata 32, Paderborn: 95-111.

van Nijf, O.M. and Williamson, C.G. (2016) 'Connecting the Greeks. Festival networks in the Hellenistic world', in C. Mann, S. Remijsen, and S. Scharff (eds), Athletics in the Hellenistic world, Stuttgart: $43^{-71}$.

Nilsson, H. (2011) 'The coins from the excavations at Labraunda', in L. Karlsson and S. Carlsson (eds), Labraunda and Karia. Proceedings of the international symposium commemorating sixty years of Swedish archaeological work in Labraunda. The Royal Swedish Academy of Letters, History and Antiquities, Stockholm, November 20-21, 2008, Acta Universitatis Uppsaliensis. Boreas. Uppsala Studies in Ancient Mediterranean and Near Eastern Civilizations, 32, Uppsala: 253-256.

Nilsson, M.P. (1927) Die Religion der Griechen, Tübingen.

Nilsson, M.P. (1995 [1906]) Griechische Feste von religiöser Bedeutung. Mit Ausschluss der Attischen, Stuttgart.

Nixon, L. (2006) Making a landscape sacred. Outlying churches and icon stands in Sphakia, southwestern Crete, Oxford.

Noack, J. (1951) Phratria und Syngeneia. Untersuchungen zur Entwicklung griechischer Gemeindeordnungen in hellenistischer Zeit, Heidelberg.

Nohlen, K. and Radt, W. (1978) XII. Kapıkaya. Ein Felsheiligtum bei Pergamon, Altertümer von Pergamon XII, Berlin.

Nora, P. (1984-1992) Les lieux de mémoire, 4 vols, Paris.

Nordquist, G.C. (2013) 'The ancient and sacred Greek landscape', in S.W. Nordeide and S. Brink (eds), Sacred sites and holy places. Exploring the sacralization of landscape through time and space, Turnhout: 141-185.

Ober, J. (2008) Democracy and knowledge. Innovation and learning in Classical Athens, Princeton.

Oldfather, W.A. (1912) 'Die Ausgrabungen zu Lokroi', Philologus. Zeitschrift für das klassische Alterthum 71: $321 \mathrm{ff}$. 
Oppermann, H. (1924) Zeus Panamaros, Religionsgeschichtliche Versuche und Vorarbeiten 19. Bd., H. 3, Gießen.

Osborne, R. (1987) Classical landscape with figures. The ancient Greek city and its countryside, London.

Osborne, R. (1988) 'Social and economic implications of the leasing of land and property in classical and Hellenistic Greece', Chiron 18: 279-323.

van Oyen, A. (2016) How things make history. The Roman Empire and its terra sigillata pottery, Amsterdam archaeological studies, 23, Amsterdam.

Paasi, A. (2003) 'Space, boundaries and the social construction of territorial identities', in S. Chaturvedi and M.M. Pur (eds), Rethinking boundaries. Geopolitics, identities and sustainability, New Delhi.

Paasi, A. (2009) 'The resurgence of the 'Region' and 'Regional Identity'. Theoretical perspectives and empirical observations on regional dynamics in Europe', Review of International Studies 35: 121-146.

Paasi, A. (2010) 'Re-visiting the region and regional identity. Theoretical reflections with empirical illustrations', in R. Barndon, A. Engevik and I. Øye (eds), The archaeology of regional technologies. Case studies from the Palaeolithic to the age of the Vikings, Lewiston, NY.

Papazarkadas, N. (2011) Sacred and public land in ancient Athens, Oxford Classical Monographs, Oxford.

Parker, R. (2004) 'New 'panhellenic' festivals in Hellenistic Greece', in R. Schlesier and U. Zellmann (eds), Mobility and travel in the Mediterranean from Antiquity to the Middle Ages, Münster: 9-22.

Parker, R. (2017) Greek gods abroad. Names, natures, and transformations, Berkeley.

Parkin, D. (1992) 'Ritual as spatial direction and bodily division', in D. de Coppet (ed.), Understanding rituals, London, New York: 11-25.

Pateman, C. (1980) 'The civic culture. A philosophical critique', in G.A. Almond and S. Verba (eds), The civic culture revisited, Boston, Toronto: 57-102.

Paul, S. (2018) 'Sharing the civic sacrifice. Civic feast, procession, and sacrificial division in the Hellenistic period', in J.H. Blok, R. Strootman and F. van den Eijnde (eds), Feasting and polis institutions, Leiden: 315-339.

Pearson, M. (2015) In comes I. Performance, memory and landscape, Exeter Performance Studies, Exeter.

Pedersen, P. (1991) The Maussolleion at Halikarnassos. Reports of the Danish archaeological expedition to Bodrum. 3. The Maussolleion terrace and accessory structures. 1. Texts and appendices, 2. Catalogue, Jutland Archaeological Society Publications 15, 3, 1 \& 2, Aarhus.

Pedersen, P. (2001-2002) 'Reflections on the Ionian Renaissance in Greek architecture and its historical background', Hephaistos: 19-20; 97-130. 
Pedersen, P. (2004) 'Pergamon and the Ionian Renaissance', Istanbuler Mitteilungen 54: 409-434.

Pedersen, P. (2009) 'The palace of Maussollos in Halikarnassos and some thoughts on its Karian and international context', in F. Rumscheid (ed.), Die Karer und die Anderen. Internationale Kolloquium an der Freien Universität Berlin, 13. bis 15. Oktober 2005, Bonn: $315-348$.

Pedersen, P. (2012) 'Lagina and the Ionian renaissance / Lagina ve Ionia Rönesansi', in B. Söğüt (ed.), Stratonikeia'dan Laginaya Ahmet Adil Tırpan Armagani / From Stratonikeia to Lagina. Festschrift in Honour of Ahmet Adil Tirpan, Istanbul: 513-525. Pedersen, P. (2013) 'The 4th century BC 'Ionian Renaissance' and Karian identity', in O. Henry (ed.), 4th century Karia. Defining a Karian identity under the Hekatomnids, Varia Anatolica XXVIII, Istanbul, Paris: 33-64.

Pedersen, P. (2017) 'The Totenmahl tradition in classical western Asia Minor and the Maussolleion at Halikarnassos', in E. Mortensen and B. Poulson (eds), Cityscapes and monuments of western Asia Minor. Memories and identities, Oxford: 237-255.

Pedley, J.G. (2005) Sanctuaries and the sacred in the ancient Greek world, Cambridge; New York.

Perlman, P.J. (2000) City and sanctuary in ancient Greece. The Theorodokia in the Peloponnese, Hypomnemata, Heft 121, Göttingen.

Pernin, I. (2014) Les baux ruraux en Grèce ancienne. Corpus épigraphique et étude, Travaux de la Maison de l'Orient, no 66, Lyon.

Petridou, G. (2016) Divine epiphany in Greek literature and culture, Oxford.

Picard, C. (1922) Éphèse et Claros. Recherches sur les sanctuaires et les cultes de l'Ionie du Nord, École Française Athenai 1, Paris.

Picard, C. (1933) 'Remarques sur les sculptures monumentales du sanctuaire d'AléaAthéna à Tégée. I. L'Autel fédéral', Revue des études grecques 46: 381-422.

Picard, C. (1952) 'Miracles atmosphériques de guerre en séries, dans l'Asie antique', Revue Archéologique 40: 75-76.

Piejko, F. (1990) 'To the inscriptions of Labraunda', Opuscula Atheniensia: acta Inst. Athen. Regni Sueciae 18: 133-156.

Pimouguet-Pédarros, I. (2000) Archéologie de la défense. Histoire des fortifications antiques de Carie (époques classique et hellénistique), Besançon.

Piras, D. (2010) 'Who were the Karians in Hellenistic times? The evidence from epichoric language and personal names', in R. van Bremen and J.-M. Carbon (eds), Hellenistic Karia. Proceedings of the First International Conference on Hellenistic Karia - Oxford, 29June-2July 2006, Bordeaux: 217-233.

Pirenne-Delforge, V. and Pironti, G. (2016) L'Héra de Zeus. Ennemie intime, épouse définitive, Paris. 
Pirson, F. (2012) 'Hierarchisierung des Raumes? Überlegungen zur räumlichen Organisation und deren Wahrnehmung im hellenistischen Pergamon und seinem Umland', in F. Pirson (ed.) Manifestationen von Macht und Hierarchien in Stadtraum und Landschaft, BYZAS 13, Istanbul: 187-232.

Pitts, M. and Versluys, M.J. (2014) Globalisation and the Roman world. World history, connectivity and material culture, Cambridge.

Platt, V. (2011) Facing the gods. Epiphany and representation in Graeco-Roman art, literature and religion, Greek Culture in the Roman World, Cambridge.

Pococke, R. (1745) A Description of the East, and some other countries ... by Richard Pococke. Pt. 2. Observations on the islands of the Archipelago, Asia Minor, Thrace, Greece, and some other parts of Europe., London.

Pöhlmann, E. and West, M.L. (2001) Documents of ancient Greek music. The extant melodies and fragments, Oxford.

Poliakoff, M. (1982) Studies in the terminology of the Greek combat sports, Beiträge zur Klassischen Philologie 146, Königstein, Hain.

de Polignac, F. (1984) La naissance de la cité grecque. Cultes, espace et société VIII ${ }_{-}$ VII ${ }^{e}$ siècles avant J.-C, Paris.

de Polignac, F. (1994) 'Mediation, competition, and sovereignty. The evolution of rural sanctuaries in Geometric Greece', in S.E. Alcock and R. Osborne (eds), Placing the gods. Sanctuaries and sacred space in ancient Greece, Oxford: $3^{-18}$.

de Polignac, F. (1995) Cults, territory, and the origins of the Greek city-state, Chicago.

Polinskaya, I. (2003) 'Liminality as metaphor. Initiation and the frontiers of ancient Athens', in D.B. Dodd and C.A. Faraone (eds), Initiation in ancient Greek rituals and narratives. New critical perspectives, London: 85-106.

Polinskaya, I. (2006) 'Lack of boundaries, absence of oppositions. The city-countryside continuum of a Greek pantheon', in R.M. Rosen and I. Sluiter (eds), City, countryside, and the spatial organization of value in classical antiquity, Mnemosyne, Supplements 279, Leiden: 61-92.

Pollitt, J.J. (1986) Art in the Hellenistic age, Cambridge [Cambridgeshire]; New York.

Portugali, J. (1996) The construction of cognitive maps, GeoJournal Library 32, Dordrecht.

Price, S. (2012) 'Memory and ancient Greece', in B. Dignas and R.R.R. Smith (eds), Historical and religious memory in the ancient world, Oxford: $15^{-36 .}$

Pritchett, W.K. (1979) The Greek state at war. Part III. Religion, Berkeley.

Pugliese Carratelli, G. (1962) 'Santuari extramurani in Magna Grecia', La Parola del Passato LXXXV: 241-246.

Radet, G. (1901) L'histoire et l'oeuvre de l 'École française d'Athènes, Paris.

Radt, W. (1969/70) 'Kuyruklu Kalesi. Fluchtburg und Tyrannenfestung von Mylasa in Karien', Istanbuler Mitteilungen 19/20: 165-176. 
Radt, W. (2003) 'Carl Humann und Osman Hamdi Bey. Zwei Gründerväter der Archäologie in der Türkei', Istanbuler Mitteilungen 53: 491-507.

Ramsay, W.M. (189o) The historical geography of Asia Minor, London.

Ramsay, W.M. (1911) 'Sketches in the religious antiquities of Asia Minor', The Annual of the British School at Athens 18: 37-79.

Ramsay, W.M. (1915) The bearing of recent discovery on the trustworthiness of the New Testament, London.

Ramsay, W.M., Byrne, M.A. and Labarre, G. (2006) Nouvelles inscriptions d'Antioche de Pisidie. D'après les Note-books de W.M. Ramsay, Inschriften griechischer Städte aus Kleinasien, Bd. 67, Bonn.

Rappoport, R.A. (1979) 'The obvious aspects of ritual', in R.A. Rappoport (ed.), Ecology, meaning, and religion, Berkeley, CA: 173-221.

Ray, J.D. (199o) 'A Carian text. The longer inscription from Sinuri', Kadmos. Zeitschrift für vor- und frühgriechische Epigraphik 29:126-132.

Readinger, W.O. (2002) 'Representing and partitioning visual space. Applying isovist field theory to human perception', Journal of Vision 2: 515, 515a.

Redfield, R. (1953) The primitive world and its transformations, Ithaca, NY.

Reger, G. (1999) 'The relations between Rhodes and Caria from 246 to 167 BC', in V. Gabrielsen, P. Bilde, T. Engberg-Pedersen, L. Hannestad and J. Zahle (eds), Hellenistic Rhodes. Politics, culture, and society, Studies in Hellenistic civilization 9, Aarhus: $76-97$.

Reger, G. (2007) 'Regions revisited. Identifying regions in a Greco-Roman Mediterranean context', FACTA. A Journal of Roman Material Culture Studies 1: 65-74.

Reger, G. (2010) 'Mylasa and its territory', in R. van Bremen and J.-M. Carbon (eds), Hellenistic Karia. Proceedings of the First International Conference on Hellenistic Karia - Oxford, 29June-2July 2006, Bordeaux: 43-57.

Reger, G. (2011) 'Inter-regional economies in the Aegean basin', in Z.H. Archibald, J.K. Davies and V. Gabrielsen (eds), The economies of Hellenistic societies, third to first centuries BC, Oxford: $368-389$.

Reger, G. (2013) 'Economic regionalism in theory and practice', in D. Viviers and A. Tsingarida (eds), Pottery markets in the ancient Greek world (8th to ist centuries BC). Proceedings of the international symposium held at the Université libre de Bruxelles, 19-21 June 2008, Études d'archéologie 5, Brussels: 119-131.

Reger, G.L. (1998) 'The koinon of the Laodikeis in Karia', Epigraphica Anatolica 30: 11-17. Reger, G.L. (2004) 'Sympoliteiai in Hellenistic Asia Minor', in S. Colvin (ed.), The Greco-Roman East, Yale Classical Studies 31, Cambridge: 145-180.

Renfrew, C. and Cherry, J.F. (1986) Peer Polity Interaction and socio-political Change, New Directions in Archaeology, Cambridge. 
Reynolds, J.M. and Erim, K.T. (1982) Aphrodisias and Rome. Documents from the excavation of the theatre at Aphrodisias conducted by Professor Kenan T. Erim, together with some related texts, Journal of Roman studies monographs, No. 1, London.

Rhodes, P.J. and Lewis, D.M. (1997) The decrees of the Greek states, Oxford.

Richardson, J.H. and Santangelo, F. (eds) (2011) Priests and state in the Roman World, Alte Geschichte. Potsdamer altertumswissenschaftliche Beitrage, Bd. 33, Stuttgart.

Ricl, M. (2003) 'Society and economy of rural sanctuaries in Roman Lydia and Phrygia', Epigraphica Anatolica 35: 77-101.

Rigsby, K.J. (1996) Asylia. Territorial inviolability in the Hellenistic world, Hellenistic Culture and Society 22, Berkeley.

Rivault, J. (2018) 'Les mises en scène de l'épiphanie du nouveau dieu de Stratonicée, Zeus Panamaros', Pallas. Revue d'études antiques 107: 95-116.

Robert, J. (1940) 'Inscriptions de Carie', Revue de philologie, de littérature et d'histoire anciennes: 231-244.

Robert, J. and Robert, L. (1983) Fouilles d'Amyzon en Carie, Paris.

Robert, L. (1934) 'Note préliminaire sur des inscriptions de Carie', Bulletin de Correspondance Hellénique 58: 512-517.

Robert, L. (1935a) 'Rapport sommaire sur un premier voyage en Carie', American Journal of Archaeology 39: 331-340.

Robert, L. (1935b) 'Rapport sommaire sur un second voyage en Carie', Revue Archéologique 6: 152-163.

Robert, L. (1935c) Villes d'Asie Mineure. Études de géographie antique, Études Orientales; l'Institut francais d'archéologie de Istanboul 2, Paris.

Robert, L. (1937) Études anatoliennes. Recherches sur les inscriptions grecques de l'Asie mineure, Paris.

Robert, L. (1949) 'Décret d'une syngeneia carienne au sanctuaire de Sinuri', Hellenica VII: $59-68$.

Robert, L. (1962 [1935]) Villes d'Asie Mineure 2, (Second edition, 1962), Paris.

Robert, L. (1984) 'Documents d'Asie Mineure', Bulletin de Correspondance Hellénique 108: $457-532$.

Robert, L. and Robert, J. (1954) La Carie. Histoire et géographie historique avec le recueil des inscriptions antiques, Paris.

Roels, E. (2017) 'Der Tempel als monumentaler Schriftträger. Die Inschriften am Zeus-Tempel in Aizanoi (157 n.Chr.)', 5300 Jahre Schrift: 50-53.

Roels, E. (2018a) Textual monuments. Epigraphic dossiers on civic buildings in Hellenistic and Imperial Asia Minor, PhD diss. Universität Heidelberg.

Roels, E.J.J. (2018b) 'The Queen of inscriptions contextualized. The presence of civic inscriptions in the pronaos of ancient temples in Hellenistic and Roman Asia Minor (fourth century BCE-second century CE)', in S. de Blaauw and E. van Opstall 
(eds), Sacred thresholds. The door to the sanctuary in Late Antiquity, Religions in the Graeco-Roman World, Leiden: 221-253.

Roos, P. (2011) 'The stadion at Labraunda', in L. Karlsson and S. Carlsson (eds), Labraunda and Karia. Proceedings of the international symposium commemorating sixty years of Swedish archaeological work in Labraunda. The Royal Swedish Academy of Letters, History and Antiquities, Stockholm, November 20-21, 2008, Acta Universitatis Uppsaliensis. Boreas. Uppsala Studies in Ancient Mediterranean and Near Eastern Civilizations, 32, Uppsala: 257-266.

Rose, C.B. (2012) 'Architecture and ritual in Ilion, Athens, and Rome', in B.D. Wescoat and R.G. Ousterhout (eds), Architecture of the sacred. Space, ritual, and experience from classical Greece to Byzantium, Cambridge: 152-174.

Rostovtzeff, M.I. (1923) 'Notes on the economic policy of the Pergamene kings', in W.H. Buckler and W.M. Calder (eds), Anatolian studies presented to Sir W.M. Ramsay, London: 359-39o.

Rostovtzeff, M.I. (1941) The social and economic history of the Hellenistic world, Oxford. Rostovtzeff, M.I. (1957) The social and economic history of the Roman Empire, Oxford.

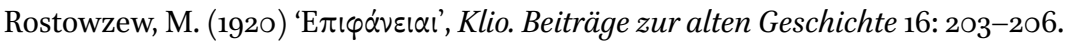

Roussel, D. (1976) Tribu et cité. Études sur les groupes sociaux dans les cités grecques aux époques archaïques et classique, Annales littéraires de l'Université de Besançon, 193; Centre de Recherches d'Histoire Ancienne, v. 23, Paris.

Roussel, M. (1931) 'Le miracle de Zeus Panamaros', Bulletin de Correspondance Hellénique 55: 70-116.

Rowlands, M. (1993) 'The role of memory in the transmission of culture', World Archaeology 25: 141-151.

Rumscheid, F. (1994) Untersuchungen zur kleinasiatischen Bauornamentik des Hellenismus, Beiträge zur Erschliessung hellenistischer und kaiserzeitlicher Skulptur und Architektur 14, Mainz.

Rumscheid, F. (1999a) 'Milas 1997', Araştırma Sonuçları Toplantısı 16: 165-186.

Rumscheid, F. (1999b) 'Mylasas Verteidigung. Burgen statt Stadtmauer?', in E.-L. Schwandner and K. Rheidt (eds), Stadt und Umland. Neue Ergebnisse der archäologischen Bau- und Siedlungsforschung. Bauforschungskolloquium in Berlin vom 7. bis 10. Mai 1997 veranstaltet vom Architektur-Referat des DAI, Diskussionen zur archäologischen Bauforschung 7. Von der Vorgeschichte bis in byzantinische und islamische Zeit, Mainz: 206-222.

Rumscheid, F. (1999c) 'Vom Wachsen antiker Säulenwälder. Zu Projektierung und Finanzierung antiker Bauten in Westkleinasien und anderswo', Jahrbuch des Deutschen Archäologischen Instituts 114: 19-63.

Rumscheid, F. (2005) 'Zur Herkunft der neuen karischen Inschrift aus der Region von Mylasa', Kadmos. Zeitschrift für vor- und frühgriechische Epigraphik 44: 187. 
Rumscheid, F. (2010) 'Maussollos and the 'Uzun Yuva' in Mylasa. An unfinished proto-Maussolleion at the heart of a new urban centre?', in R. van Bremen and J.-M. Carbon (eds), Hellenistic Karia. Proceedings of the First International Conference on Hellenistic Karia - Oxford, 29June-2 July 2006, Bordeaux: 69-102.

Ruschenbusch, E. (1985) 'Die Zahl der griechischen Staaten und Arealgrösse und Bürgerzahl der "Normalpolis", Zeitschrift für Papyrologie und Epigraphik LIX: 253-263.

Rutherford, I. (2006) 'Religion at the Greco-Anatolian interface. The case of Karia', in M. Hutter and S. Hutter-Braunsar (eds), Pluralismus und Wandel in den Religionen im vorhellenistischen Anatolien. Akten des religionsgeschichtlichen Symposiums in Bonn (19.-20. Mai 2005), Münster: 137-144.

Rutherford, I. (2007) 'Network theory and theoric networks', Mediterranean Historical Review 22: 23-37.

Rutherford, I. (2013) State pilgrims and sacred observers in ancient Greece. A study of theōriā and theōroi, Cambridge.

Ruzé, F. (1983) 'Les tribus et la décision politique dans les cités grecques archaïques et classiques', Ktèma 8, 299-306.

Ruzicka, S. (1992) Politics of a Persian dynasty. The Hecatomnids in the fourth century B.C., Oklahoma Series in Classical Culture, Norman OK.

Sadalla, E.K., Burroughs, W.J. and Staplin, L.J. (1980) 'Reference points in spatial cognition', Journal of Experimental Psychology. Human learning and memory: 516-528.

Säflund, G. (1956) 'The Swedish Excavations at Labraunda, 1953', Türk Arkeoloji Dergisi 6: 3 f.

Şahin, M.Ç. (1973) 'Two new inscriptions from Lagina (Koranza)', Anadolu 17: 187-195.

Şahin, M.Ç. (1976) The political and religious structure in the territory of Stratonikeia in Caria, Ankara.

Şahin, M.Ç. (1995) 'Two Hellenistic Decrees from Panamara', Epigraphica Anatolica 25: $83-86$.

Şahin, M.Ç. (2008a) 'Recent excavations at Stratonikeia and new inscriptions from Stratonikeia and its territory', Epigraphica Anatolica 41: 53-81.

Şahin, M.Ç. (2008b) 'Two lists of priests from Koraia, a phyle of Stratonikeia', Epigraphica Anatolica 41: 82-86.

Sakellariou, M.V. (1989) The polis-state definition and origin, Athens; Paris.

Salway, B. (2001) 'Travel, itineraria and tabellaria', in C. Adams and R. Laurence (eds), Travel and geography in the Roman Empire, London: 22-66.

Samuel, R. (1994) Theatres of memory. Vol. 1 : Past and present in contemporary culture, London. 
Savalli-Lestrade, I. (2001) 'Amici del re, alti funzionari e gestione del potere principalmente nell'Asia Minore ellenistica', in Simblos. Scritti di storia antica, 3, Università degli Studi di Bologna. Dipartimento di Storia Antica, Bologna: 263-294.

Savalli-Lestrade, I. (2005) 'Devenir une cité. Poleis nouvelles et aspirations civiques en Asie Mineure à la basse époque hellénistique', in P. Fröhlich and C. Müller (eds), Citoyenneté et participation à la basse époque hellénistique. Actes de la table ronde des 22 et 23 mai 2004, Paris, BNF, organisée par le groupe de recherche dirigé par Philippe Gauthier, de l'UMR 8585 (Centre Gustave Glotz), École Pratique des Hautes Études, IV ${ }^{\mathrm{e}}$ section. 3 Hautes études du monde gréco-romain 35, Geneve: 9-37.

Säve-Söderbergh, T. and Hellström, P. (1997) 'Excavations at Gencik Tepe, 1938', Acta Archaeologica 68: 75-107.

Schachter, A. (1992) 'Policy, cult and the placing of Greek sanctuaries', in A. Schachter and J. Bingen (eds), Le sanctuaire grec. Huit exposés suivis de discussions, Entretiens sur l'antiquité classique 37, Genève-Vandœuvres: 1-64.

Schalles, H.-J. (1985) Untersuchungen zur Kulturpolitik der pergamenischen Herrscher im dritten Jahrhundert vor Christus, Istanbuler Forschungen 36, Tübingen.

Scheer, T.S. (ed.) (2019) Natur - Mythos - Religion im antiken Griechenland / Nature Myth - Religion in Ancient Greece, Potsdamer Altertumswissenschaftlichte Beiträge, Bd. 67 , Stuttgart.

Scheid, J. (1985) 'Sacrifice et banquet à Rome. Quelques problèmes', Mélanges de l'Ecole française de Rome. Antiquité: 193-206.

Schmitt Pantel, P. (1985) 'Banquet et cité grecque. Quelques questions suscitées par les recherches récentes', Mélanges de l'Ecole française de Rome. Antiquité: 135-158.

Schmitt Pantel, P. (1990) 'Collective activities and the political in the Greek city', in O. Murray and S. Price (eds), The Greek city from Homer to Alexander, Oxford:199-213. Schober, A. (1933) Der Fries des Hekateions von Lagina, Istanbuler Forschungen 2, Baden bei Wien.

Schuler, C. (2010) 'Sympolitien in Lykien und Karien', in R. van Bremen and J.-M. Carbon (eds), Hellenistic Karia. Proceedings of the First International Conference on Hellenistic Karia - Oxford, 29June-2 July 2006, Bordeaux: 393-413.

Schuler, C. and Walser, A.V. (2015) 'Sympolitien und Synoikismen. Gesellschaftliche und urbanistische Implikationen von Konzentrationsprozessen in hellenistischer Zeit', in A. Matthaei and M. Zimmermann (eds), Urbane Strukturen und bürgerliche Identität im Hellenismus, Die hellenistische Polis als Lebensform, Band 5, Berlin: $35^{\circ}-359$.

Scott, J. and Carrington, P.J. (2011) The SAGE handbook of social network analysis, London; Thousand Oaks, CA.

Scully, V.J. (1962) The earth, the temple, and the gods. Greek sacred architecture, New Haven. 
Seed, P. (1995) Ceremonies of possession in Europe's conquest of the New World, 14921640, Cambridge; New York.

Segré, M. (1936) 'Osservazioni epigrafiche sulla vendità di sacerdozio', Rendiconti dell'Istituto Lombardi 69: 811-83o.

Segré, M. (1948) 'L'institution des Nikephoria de Pergame', in L. Robert (ed.), Hellenica. Recueil d'épigraphie, de numismatique et d'antiquités grecques, $V$, Paris: 102-128.

Semple, E.C. (1927) 'The templed promontories of the ancient Mediterranean', Geographical Review 17: 352-386.

Shankland, D. (2004) Archaeology, anthropology and heritage in the Balkans and Anatolia. The life and times of F.W. Hasluck, 1878-1920, 2 vols., Istanbul.

Shcheglov, A.N. (1992) Polis et Chora. Cité et territoire dans le Pont-Euxin, Annales littéraires de l'Université de Besançon; 476, [Besançon] Paris.

Sherk, R.K. (1984) Rome and the Greek East to the death of Augustus, Cambridge [Cambridgeshire]; New York.

Sherk, R.K. (1992) 'The eponymous officials of Greek cities IV: The Register: Part III: Thrace, Black Sea Area, Asia Minor (Continued)', Zeitschrift für Papyrologie und Epigraphik 93: 223-272.

Sherk, R.K. and Viereck, P. (1969) Roman documents from the Greek East. Senatus consulta and epistulae to the age of Augustus, Baltimore.

Sherratt, A. (1993) “'Who are you calling peripheral?" Dependence and independence in European prehistory', in C. Scarre and F. Healy (eds), Trade and exchange in prehistoric Europe, Oxbos Monographies; 33, Oxford: 245-255.

Shields, R. (1991) Places on the margin. Alternative geographies of modernity, International library of sociology, London, New York.

Shipley, G. (2002) 'Hidden landscapes. Greek field survey data and Hellenistic history', in: D.E. Ogburn ed. The Hellenistic world. New perspectives, London: 177-198.

Sielhorst, B. (2015) Hellenistische Agorai. Gestaltung, Rezeption und Semantik eines urbanen Raumes, Urban Spaces 3 , Berlin.

Simon, E. (1993) 'Der Laginafries und der Hekatehymnos in Hesiods Theogonie', Archäologischer Anzeiger 2: 277-284.

Sinn, U. (1993) 'Greek sanctuaries as places of refuge', in N. Marinatos and R. Hägg (eds), Greek sanctuaries. New approaches, London \& New York: 88-109.

Sinn, U. (1996) 'The influence of Greek sanctuaries on the consolidation of economic power', in P. Hellström and B. Alroth (eds), Religion and power in the ancient Greek world. Proceedings of the Uppsala symposium 1993, Acta Universitatis Upsaliensis. Boreas 24, Uppsala: 67-74.

Slater, W.J. (2004) 'Where are the actors?', in C. Hugoniot, F. Hurlet and S. Milanezi (eds), Le statut de l'acteur dans l'Antiquité grecque et romaine. Actes du colloque qui s'est tenu à Tours les 3 et 4 mai 2002, Tours: 143-16o. 
Smith, J.Z. (1987) To take place. Toward theory in ritual, Chicago studies in the history of Judaism, Chicago.

Söğüt, B. (2008) 'Naiskoi from the sacred precinct of Lagina Hekate. Augustus and Serapis', in Cult and sanctuary through the ages (from the Bronze Age to the Late Antiquity). Proceedings of the International Symposium, Castá-Papiernicka, 16-19 November 2007. Dedicated to the 1oth anniversary of the Department of Classical Archaeology and to the 15 th anniversary of Trnava University., Anodos. Studies of the ancient world 2006/2007, Trnava: 421-431.

Söğüt, B. (2012) 'Börükçü 2003-2006 Yılları Kazıları', in B. Söğüt (ed.), Stratonikeia'dan Laginaya Ahmet Adil Tirpan Armagani / From Stratonikeia to Lagina. Festschrift in Honour of Ahmet Adil Tirpan, Istanbul: 553-586.

Söğüt, B. (2019) Stratonikeia (Eskihisar) ve kutsal alanları, Stratonikeia Çalışmaları 5, Istanbul.

Sökmen, E. (2009) 'Characteristics of the temple state in Pontos', in J.M. Højte (ed.), Mithridates VI and the Pontic kingdom, Aarhus: 277-288.

Sokolicek, A. (2009) 'Zwischen Stadt und Land. Neues zum Magnesischen Tor in Ephesos. Erste Ergebnisse', Jahreshefte des Österreichischen Archäologischen Institutes in Wien 78: 321-347.

Sourvinou-Inwood, C. (1988) 'Further aspects of polis religion', Annali dell'Istituto universitario orientale di Napoli, Dipartimento di studi del mondo classico e del Mediterraneo antico, Sezione di archeologia e storia antica X: 259-274.

Sourvinou-Inwood, C. (1990) 'What is polis religion?', in O. Murray and S. Price (eds), The Greek city from Homer to Alexander, Oxford: 295-322.

Sperber, D. (1996) Explaining culture. A naturalistic approach, Oxford, Cambridge, MA. Stavrianopoulou, E. (2009) 'Die Bewirtung des Volkes. Öffentliche Speisungen in der römischen Kaiserzeit', in O. Hekster (ed.), Ritual Dynamics and Religious Change in the Roman Empire: Proceedings of the, 159-180.

Stavrianopoulou, E. (2015) 'The archaeology of processions', in R. Raja and J. Rüpke (eds), A companion to the archaeology of religion in the ancient world, Blackwell companions to the ancient world, 349-361.

Stek, T.D. (2009) Cult places and cultural change in Republican Italy. A contextual approach to religious aspects of rural society after the roman conquest, Amsterdam Archaeological Studies 14, Amsterdam.

Steuernagel, D. (2010) 'Synnaos theos. Images of Roman emperors in Greek temples', in J. Mylonopoulos (ed.), Divine images and human imaginations in ancient Greece and Rome, Religions in the Graeco-Roman world 170, Leiden: 241-256.

Stewart, A.M., Keith, D. and Scottie, J. (2004) 'Caribou crossings and cultural meanings. Placing traditional knowledge and archaeology in context in an Inuit landscape', Journal of Archaeological Method and Theory 11: 183-211. 
Stillwell, R. (1954) 'The siting of Classical Greek temples', The Journal of the Society of Architectural Historians 13: 3-8.

Stoddart, S. (1999) 'Urbanization and state formation', in G. Barker (ed.), Companion Encyclopedia of Archaeology, London: 9o8-949.

Strootman, R. (2014) Courts and elites in the Hellenistic empires. The Near East after the Achaemenids, c. 300-30 BCE, Edinburgh.

Strootman, R. (2018) 'The Return of the King. Civic feasting and the entanglement of city and empire in Hellenistic Greece', in J.H. Blok, R. Strootman and F. van den Eijnde (eds), Feasting and polis institutions, Leiden: 273-296.

Strootman, R. and Williamson, C. (2020) 'Creating a royal landscape. Hekatomnid use of urban and rural sacred sites in fourth-century Karia', in S. Caneva (ed.), The materiality of ruler cult, Kernos Supplément 36, Liège, 105-124.

Summers, D. (2003) Real spaces. World art history and the rise of Western modernism, London/New York.

Tacoma, R. (2011) 'The councillor's dilemma. Political culture in third-century Roman Egypt', in O.M. van Nijf and R. Alston (eds), Political culture in the Greek city after the Classical age, Groningen-Royal Holloway Studies on the Greek City After the Classical Age 2, 243-262.

Talbert, R.J.A. and Brodersen, K. (2004) Space in the Roman world. Its perception and presentation, Antike Kultur und Geschichte, Bd. 5., Münster.

Talloen, P. (2006) 'Pious neighbours. Pisidian religious ties with Lycia. The case of the rider deities', in K. Dörtlük and e. al. (eds), The IIIrd International Symposium on Lycia, 07-10 November 2005, Antalya. Symposium Proceedings, II, Istanbul: 747-759.

Tambiah, S.J. (1985) 'A performative approach to ritual', in S.J. Tambiah (ed.), Culture, thought, and social action. An anthropological perspective, Cambridge, MA:123-166.

Tarn, W.W. (1931) Hellenistic civilization, London.

Thieme, T. (1993) 'The architectural remains of Archaic Labraunda', in J.D. Courtils and J.-C. Moretti (eds), Les grands ateliers d'architecture dans le monde égéen du $V^{e}$ siècle av.J.-C., Varia Anatolica 3, Istanbul: 47-55.

Thomas, R. (2019) Polis histories, collective memories and the Greek world, Cambridge.

Thompson, F.D. (1999) 'Bringing home the gods. The Japanese perception of urban space', The Architectural Review 206: 92-96.

Thompson, H.A. (1963) '[Reviewed work: The earth, the temple, and the gods. Greek sacred architecture, by V. Scully]', The Art Bulletin 45: 277-280.

Thonemann, P.J. (2009) 'Estates and the land in early Hellenistic Asia Minor', Chiron 39: 363-394.

Thonemann, P.J. (2010) 'The women of Akmoneia', Journal of Roman Studies 100: $163^{-178 .}$ 
von Thünen, J.H. (1826) Der isolirte Staat in Beziehung auf Landwirthschaft und Nationalökonomie, Hamburg.

Tilley, C.Y. (1994) A phenomenology of landscape. Places, paths, and monuments, Explorations in anthropology, Oxford.

Tilley, C.Y. (2004) The materiality of stone. Explorations in landscape phenomenology, Oxford.

Tırpan, A.A.(1995) 'Laginakazısı1993-1994’,KazıSonuçları Toplantısı, Ankara:29Mayıs-2 Haziran.

Tırpan, A.A. (1996) 'Lagina Hekate temenosu', Kazı Sonuçları Toplantısı 18: 309-336.

Tirpan, A.A. (1997) 'Lagina Hekate propylonu 1996', Kazı Sonuçları Toplantısı 19: 173-194. Tırpan, A.A. (1998a) 'Lagina Hekate temenosu, propylon ve altardaki kazı çalışmaları 1997', Kazı Sonuçları Toplantısı, Tarsus: 25-29 Mayıs.

Tırpan, A.A. (1998b) Stratonikeia I. Augustus Imperatorlar Tapınağı, Konya.

Trrpan, A.A. (2008) 'The temenos of Lagina Hekate in Koranza', in Cult and sanctuary through the ages (from the Bronze Age to the Late Antiquity). Proceedings of the International Symposium, Castá-Papiernicka, 16-19 November 2007. Dedicated to the 1oth anniversary of the Department of Classical Archaeology and to the 15th anniversary of Trnava University, Anodos. Studies of the ancient world 2006/2007, Trnava: $445^{-452 .}$

Trrpan, A.A., Gider, Z. and Büyüközer, A. (2012) 'The temple of Hekate at Lagina', in T. Schulz (ed.), Dipteros und Pseudodipteros. Bauhistorische und archäologische Forschungen, Byzas 12, Istanbul: 181-202.

Tırpan, A.A. and Söğüt, B. (1999) 'Koranza kazıları 1998', Kazı Sonuçları Toplantısı, Ankara: 24-28 Mayıs.

Tırpan, A.A. and Söğüt, B. (200o) 'Lagina Hekate temenosu 1999 yılı çalışmaları', Kazı Sonuçları Toplantısı 22: 153-162.

Tırpan, A.A. and Söğüt, B. (2004) 'Lagina ve Börükçü 2003 yılı çalı çalışmaları', Kazı Sonuçları Toplantısı, Konya: 24-28 Mayıs.

Tirpan, A.A. and Söğüt, B. (2005a) Lagina, Yatagan.

Tırpan, A.A. and Söğüt, B. (2005b) 'Lagina ve Börükçü 2004 yılı çalı çalışmaları', Kazı Sonuçları Toplantısı, Antalya: 3o Mayıs-3 Haziran, 2005.

Tırpan, A.A. and Söğüt, B. (2006) 'Lagina ve Börükçü 2005 yılı çalı çalışmaları', Kazı Sonuçları Toplantısı, Çannakale: 29 Mayıs-2 Haziran.

Tırpan, A.A. and Söğüt, B. (2007a) Lagina Hekate kutsal alanı ve Börükçü kazıları 2007 yilı envanterlik eser fişleri.

Tırpan, A.A. and Söğüt, B. (2007b) 'Lagina ve Börükçü 2006 yılı çalı çalışmaları', Kazı Sonuçları Toplantısı, Kocaeli: 28 Mayıs-1 Haziran.

Tırpan, A.A. and Söğüt, B. (2008) Lagina Hekate kutsal alanı ve Börükçu kazıları 2008 yılı enventarlik eser fişleri. 
Tolman, E.C. (1948) 'Cognitive maps in rats and men', Psychological Review 55: 189-208. Tomasello, M. (2009) Why we cooperate, Boston Review Book, Cambridge, MA.

Tomlinson, R.A. (1976) Greek sanctuaries, London.

Toner, J. (ed.), (2016) A cultural history of the senses in antiquity, London, Oxford.

Tscherikower, V. (1927) Die hellenistischen Städtegründungen von Alexander dem Grossen bis auf die Rörnerzeit, Philologus: Zeitschrift für das klassische Altertum; Supplementband 19, Leipzig.

Tuan, Y.-F. (1977) Space and place. The perspective of experience, Minneapolis.

Turchin, P. (2006a) 'The myth of self-interest and the science of cooperation', in P. Turchin (ed.), War and peace and war. The life cycles of imperial nations, New York: Chapter 5: 107-137.

Turchin, P. (2006b) War and peace and war. The life cycles of imperial nations, New York. Turner, V. (1969) The ritual process. Structure and anti-structure, Ithaca, NY.

Turner, V. (1973) 'The center out there: pilgrim's goal', History of Religions 12: 191-230.

Turner, V. (1974a) 'Pilgrimages as social processes', in V. Turner (ed.), Dramas, fields, and metaphors. Symbolic action in human society, Ithaca, NY: 166-23o.

Turner, V. (1984) 'Liminality and the performative genres', in J.J. MacAloon (ed.), Rite, drama, festival, spectacle. Rehearsals toward a theory of cultural performance, Philadelphia: 19-41s.

Turner, V.W. (1974b) Dramas, fields, and metaphors. Symbolic action in human society, Symbol, myth, and ritual series, Ithaca NY.

Tversky, B. (1993) 'Cognitive maps, cognitive collages, and spatial mental models', in A.U. Frank and I. Campari (eds), Spatial information theory. A theoretical basis for GIS, Berlin: 14-24.

Umholtz, G. (2002) 'Architraval arrogance? Dedicatory inscriptions in Greek architecture of the Classical period', Hesperia. The Journal of the American School for Classical Studies at Athens 71: 261-293.

Vallet, G. (1968) 'La cité et son territoire dans les colonies grecques d'Occident', in P. Romanelli (ed.), La città e il suo territorio, Atti del settimo convegno di studi sulla Magna Grecia. Taranto 8-12 ottobre 1967, Naples: 67-142.

Van Dyke, R.M. and Alcock, S.E. (eds) (2003) Archaeologies of memory, Oxford.

Vernant, J.-P. (1965a) 'Hestia - Hermès. Sur l'expression religieuse de l'espace et du mouvement chez les Grecs', in J.-P. Vernant (ed.), Mythe et pensée chez las Grecs. Étude de psychologie historique, Paris: $155^{-201 .}$

Vernant, J.-P. (1965b) Mythe et pensée chez les Grecs. Études de psychologie historique, Coll. Les textes à l'appui, 13, Paris.

Vernant, J.-P. and Vidal-Naquet, P. (1972) Mythe et tragédie en Grèce ancienne, Coll. Textes à l'appui, Paris.

Veyne, P. (1976) Le pain et le cirque. Sociologie historique d'un pluralisme politique, Paris. 
Virgilio, B. (1987) 'Strutture templari e potere politico in Asia Minore', Athenaeum 65: 227-231 (reprinted in Studi ellenistici 222 (1987), 1199-1207).

Virgilio, B. (2001) 'Roi, ville et temple dans les inscriptions de Labraunda', Revue des études anciennes 103: 429-442.

Virgilio, B. (2003) Lancia, diadema e porpora. Il re e la regalità ellenistica, 2nd ed., Studi ellenistici 14, Pisa.

Virgilio, B. (2010) 'L'epistola reale dal santuario di Sinuri presso Mylasa in Caria, sulla base dei calchi del Fonds Louis Robert della Académie des Inscriptions et Belles-Lettres', in S. Bussi and D. Foraboschi (eds), Roma e l'eredità ellenistica. Atti del convegno internazionale, Milano, Università statale, 14-16 gennaio 2009, Studi Ellenistici 23, Pisa, Roma: 55-108.

Virgilio, B. (2011) Le roi écrit. Le correspondance du souverain hellénistique, suivie de deux lettres d'Antiochos III à partir de Louis Robert et d'Adolf Wilhelm, Studi ellenistici 25, Pisa.

Viviers, D. (2010) 'Élites et procesions dans les cités grecques. Une géométrie variable?', in L. Capdetrey (ed.), La cité et ses élites. Pratiques et représentation des formes de domination et de contrôle social dans les cités grecques. Actes du colloque de Poitiers, 19-20 octobre 2006, Études 25, Bordeaux: 163-183.

Vogt, E.Z. (1968) 'Some aspects of Zinacantan settlement patterns and ceremonial organisation', in K.C. Chang (ed.), Settlement archaeology, Palo Alto: 154-173.

Voigtländer, W. (1991) 'Der 'Zeus-Karios' Bau in Milas', in A. Hoffmann (ed.), Bautechnik der Antike. Internationales Kolloquium in Berlin vom 15.-17. Februar 1990, Diskussionen zur archäologischen Bauforschung, 5, Mainz am Rhein: 246-251.

Voyatzis, M. (1999) 'The role of temple building in consolidating Arkadian communities', in T.H. Nielsen and J. Roy (eds), Defining ancient Arkadia. Symposium, April 1-4, 1998, Historisk-filosofiske Meddelelser, Det Kongelige Danske Videnskabernes Selskab 78, Acts of the Copenhagen Polis Centre; 6, Copenhagen: 130-168.

Walser, A.V. (2009) 'Sympolitien und Siedlungsentwicklung', in A. Matthaei and M. Zimmermann (eds), Stadtbilder im Hellenismus, Die hellenistische Polis als Lebensform, Band 1, Berlin: 135-155.

Warburton, D.A. (2017 (2018)) 'Lists versus plans and maps. The ancient near eastern approach to geographical and topographical information - and its possible importance for the history of cartography', Orbis Terrarum 15: 131-196.

Ward-Perkins, J.B. (1972) 'Central authority and patterns of rural settlement', in R. Tringham, P.J. Ucko and G.W. Dimbleby (eds), Man, settlement and urbanism. Proceedings of a meeting of the Research Seminar in Archaeology and Related Subjects held at the Institute of Archaeology, London University, Gloucester: 867-882. Ward-Perkins, J.B. (1974) Cities of ancient Greece and Italy. Planning in classical antiquity, New York. 
Wasserman, S. and Faust, K. (1994) Social Network Analysis. Methods and applications, Cambridge.

Watts, D.J. and Strogatz, S.H. (1998) 'Collective dynamics of 'small-world' networks', Nature 393: 440-442.

Weingast, B.R. (1995) 'A rational choice perspective on the role of ideas. Shared belief systems and state sovereignty', Politics and Society 23:449-465.

Werbner, R.P. (1977) Regional cults, London.

Wescoat, B.D. and Ousterhout, R.G. (eds) (2012) Architecture of the sacred. Space, ritual, and experience from classical Greece to Byzantium, Cambridge.

Westholm, A. (1963) Labraunda. Swedish excavations and researches. Vol. I. Part 2. The architecture of the hieron, Acta Instituti Atheniensis regni Sueciae, Series in $4^{\circ}$, IV, I, 2, Lund.

Wheatley, D. (2014) 'Connecting landscapes with built environments. Visibility analysis, scale and the senses', in E. Paliou, U. Lieberwirth and S. Polla (eds), Spatial analysis and social spaces. Interdisciplinary approaches to the interpretation of historic and prehistoric built environments, Topoi 18 Berlin Studies of the Ancient World, Berlin: ${ }^{115-134 . ~}$

Wheatley, P. (1972) 'The concept of urbanism', in R. Tringham, P.J. Ucko and G.W. Dimbleby (eds), Man, settlement and urbanism. Proceedings of a meeting of the Research Seminar in Archaeology and Related Subjects held at the Institute of Archaeology, London University, Gloucester: 6o3-637.

Wiegand, T. (1904) Priene. Ergebnisse der Ausgrabungen und Untersuchungen in den Jahren 1895-1898, Berlin.

Wiemer, H.-U. (2009) 'Bild der Polis oder Bild des Königs? Zur Repräsentatonsfunktion städtischer Feste im Hellenismus', in A. Matthaei and M. Zimmermann (eds), Stadtbilder im Hellenismus, Die hellenistische Polis als Lebensform, Band 1, Berlin: 116-131.

Wiemer, H.-U. (2010) 'Structure and development of the Rhodian Peraia. Evidence and models', in R. van Bremen and J.-M. Carbon (eds), Hellenistic Karia. Proceedings of the First International Conference on Hellenistic Karia - Oxford, 29 June-2 July 2006, Bordeaux: $415^{-434}$.

Wilhelm, A. (1947) Zu den griechischen Inschriften aus dem Heiligtum des karischen Gottes IINYPI; Zu einem Beschluss der Athener aus dem Jahre 128 v. Chr; Epigramme aus Side, Akademie der Wissenschaften in Wien. Philosophisch-historische Klasse. Sitzungsberichte. 224. Band, 4. Abhandlung, Vienna.

Will, É. (1995) 'Syngeneia, oikeiotès, philia', Revue de philologie, de littérature et d'histoire anciennes 69: 299-325.

Williamson, C.G. (2009) 'Panamara. The (mis)fortunes of a Karian sanctuary', Groniek. Historische Tijdschrift: 211-218. 
Williamson, C.G. (2012) 'Sanctuaries as turning points in territorial formation. Lagina, Panamara and the development of Stratonikeia', in F. Pirson (ed.), Manifestationen von Macht und Hierarchien in Stadtraum und Landschaft, Byzas 13. Veröffentlichungen des Deutschen Archäologischen Instituts Istanbul, Istanbul: 113-150.

Williamson, C.G. (2013a) 'As God is my witness. Civic oaths in ritual space as a means towards rational cooperation in the Hellenistic polis', in R. Alston, O.M. van Nijf and C.G. Williamson (eds), Cults, creeds and identities in the Greek city after the Classical age, 3, Groningen-Royal Holloway Studies on the Greek City After the Classical Age 3, Leuven: 119-174.

Williamson, C.G. (2013b) 'Civic producers at Stratonikeia. The priesthoods of Hekate at Lagina and Zeus at Panamara', in M. Horster and A. Klöckner (eds), Cities and Priests. Cult personnel in Asia Minor and the Aegean islands from the Hellenistic to the Imperial period, Religionsgeschichtliche Versuche und Vorarbeiten 64, Berlin: 209-245.

Williamson, C.G. (2013c) 'Karian, Greek or Roman? The layered identites of Stratonikeia via the sanctuary of Hekate at Lagina', Tijdschrift voor Mediterrane Archeologie $5^{\circ}$ : $1-6$.

Williamson, C.G. (2013d) 'Labraunda as memory theatre for Hellenistic Mylasa. Code-switching between past and present?', HEROM - Journal on Hellenistic and Roman Material 2: 141-165.

Williamson, C.G. (2013e) 'Public space beyond the city. The sanctuaries of Labraunda and Sinuri in the chora of Mylasa', in C.P. Dickenson and O.M. van Nijf (eds), Public space in the postclassical city, Caeculus. Papers on Mediterranean Archaeology and Greek and Roman Studies, 7, Leuven: 1-36.

Williamson, C.G. (2014a) 'Power of place. Labraunda, Mamurt Kale and the transformation of landscape in Asia Minor', in C. Moser and C. Feldman (eds), Locating the sacred. Theoretical approaches to the emplacement of religion, Joukowsky Institute Publication 3, Oxford: 87-110.

Williamson, C.G. (2014b) 'Power, politics and panoramas. Viewing the sacred landscape of Zeus Stratios near Amaseia', in T. Bekker-Nielsen (ed.), Space, place and identity in Northern Anatolia, Geographica Historica 29, Stuttgart: 175-188.

Williamson, C.G. (2014c) 'A room with a view. Karian landscape on display through the andrones at Labraunda', in L. Karlsson, S. Carlsson and J. Blid Kullberg (eds), LABRYS. Studies presented to Pontus Hellström, Acta Universitatis Upsaliensis. Boreas. Uppsala Studies in Ancient Mediterranean and Near Eastern Civilizations 35, Uppsala: 123-138.

Williamson, C.G. (2016a) 'A Carian shrine in a Hellenizing world. The sanctuary of Sinuri, near Mylasa', in M. Paz de Hoz Garcia-Bellido, J.P. Sánchez Hernández and 
C. Molina Valero (eds), Between Tarhuntas and Zeus Polieus. Cultural crossroads in temples and cults of Graeco-Roman Anatolia, Colloquia Antiqua 17, Leuven: 75-10o.

Williamson, C.G. (2016b) 'Mountain, myth, and territory. Teuthrania as focal point in the landscape of Pergamon', in J. McInerney and I. Sluiter (eds), Valuing landscape in classical antiquity. Natural environment and cultural imagination, Proceedings from the Penn-Leiden Colloquia on Ancient Values VIII, Leiden: 70-99.

Williamson, C.G. (2018) 'Filters of light. Greek temple doorways as portals of epiphanies', in S. de Blaauw and E. van Opstall (eds), Sacred thresholds. The door to the sanctuary in Late Antiquity, Religions in the Graeco-Roman World, Leiden:309-340.

Williamson, C.G. (2020a) 'Constructing the sublime. Landscape, architecture and human encounter in Hellenistic sanctuaries', in A. Müller and A. Haug (eds), Hellenistic architecture and human action. A case of reciprocal influence, Scales of Transformation in Prehistoric and Archaic Societes 10, Leiden: 101-124.

Williamson, C.G. (2020b) 'Hera on the mountain. Complexities of the cult of Zeus at Panamara under Stratonikeia', in H. Bumke, J. Breder and I. Kaiser (eds), Kulte im Kult. Sakrale Strukturen extraurbaner Heiligtümer, Rahden: 143-168.

Williamson, C.G. (2020c) 'Panamara Zeus Kutsal Alanı - Karia Tapınağından Kent Kutsal Alanına / The sanctuary of Zeus at Panamara. From Carian shrine to urban sanctuary', in O. Henry (ed.) Karialılar. Denizcilerden kent kuruculara / The Carians. from seafarers to city builders, Istanbul: 140-155.

Williamson, C.G. (in press-a) 'Crowned heights. Sacred mountains and developing political landscapes in Asia Minor', in B. Vergnaud and N. Carless Unwin (eds), Anatolian landscapes. Inhabiting western Anatolia in antiquity, Istanbul.

Williamson, C.G. (in press-b) 'The strength of festival ties. Ritual networks, 'portable communities' and the transmission of common knowledge in the Hellenistic world', in A. Collar (ed.) Strong ties. Digital network methods and ideas in the ancient Mediterranean, Digital Research in the Arts and Humanities series, London.

Williamson, C.G. (in press-c) 'Sacred circles. Enclosed sanctuaries as urban repeaters in festival networks', in Z. Newby (ed.) The material, visual and spatial dynamics of ancient festivals in the imperial Greek east, Cambridge.

Wulf, U. (1999) 'Vom Herrensitz zur Metropole. Zur Stadtentwicklung von Pergamon', in E.-L. Schwandner and K. Rheidt (eds), Stadt und Umland. Neue Ergebnisse der archäologischen Bau- und Siedlungsforschung. Bauforschungskolloquium in Berlin vom 7. bis 10. Mai 1997 veranstaltet vom Architektur-Referat des DAI, Diskussionen zur archäologischen Bauforschung 7, Mainz: 33-49.

Yates, F.A. (1966) The art of memory, Chicago.

Young, J.O. (1999) 'The cognitive value of music', The Journal of Aesthetics and Art Criticism 57: 41-54. 
Zawadzki, T. (1952-1953) 'Quelques remarques sur l'étendue et l'accroissement des domaines des grands temples en Asie mineure', Eos. Commentarii Societatis philologae Polonorum 46: 83-96.

Zimmermann, M. (2009) 'Stadtraum, Architektur und öffentliches Leben in der hellenistische Stadt', in A. Matthaei and M. Zimmermann (eds), Stadtbilder im Hellenismus, Die hellenistische Polis als Lebensform, Band 1, Berlin: 23-40.

Zuiderhoek, A. (2009) The politics of munificence in the Roman Empire. Citizens, elites, and benefactors in Asia Minor, Cambridge.

Zuiderhoek, A. (2011) 'Oligarchs and benefactors. Elite demography and euergetism in the Greek east of the Roman Empire', in O.M. van Nijf and R. Alston (eds), Political culture in the Greek city after the Classical age, Groningen-Royal Holloway Studies on the Greek City After the Classical Age 2, with the assistance of C.G. Williamson, Leuven: $185^{-196 .}$

\section{Internet References}

Connected Contests in the post-classical world (University of Groningen). URL: connectedcontests.org (accessed o9.12.2020).

Connected Past. People, networks and complexity in archaeology and history. URL: connectedpast.net (accessed o9.12.2020).

Connecting the Greeks. Multi-scalar festival networks in the Greek and Roman worlds (University of Groningen). URL: connectingthegreeks.com (accessed o9.12.2020).

Daily Sabah. Monumental tomb in Turkey opens new horizons in history of archaeology, 01.08.2018. URL: dailysabah.com/travel/2018/o8/o1/monumental-tomb-in-turkeyopens-new-horizons-in-history-of-archaeology (accessed o9.12.2020).

Labraunda (excavation website). URL: labraunda.org (accessed o9.12.2020).

United States Department of Agriculture Economic Research Service. Measuring Rurality: Rurual-Urban Continuum Codes.uRL:wayback.archive-it.org/5923/20120620120804/ http://www.ers.usda.gov/Briefing/Rurality/RuralUrbCon/ (accessed o9.12.2020).

Yatağan Termik enerji Üretim A.Ş. Maden Direktörlügü. URL: yatagantermik.com.tr/en/ introduction/maden-direktorlugu (accessed o9.12.2020). 


\section{Indices}

Page numbers in italics indicate figures.

\section{Index of Ancient Sources}

\subsection{Literary Sources}

(Largely abbreviated according to OCD convention.)

Ael.
NA 12.30
$107 n \cdot 5^{2}$

Aeschin.

1.157 $30 n .67$

App.

Mith.

$\begin{array}{ll}21 & 25^{1 n .5^{2}} \\ 66,70 & 105^{n .42} \\ \text { Syr. } & \\ 59 & 245^{n .14} \\ & \\ \text { Ach. } 202 & 30 n .67\end{array}$

Cass. Dio

$$
\text { 48.26.3-4 251, n.56 }
$$

Diod. Sic.

$$
28.5 \quad 25^{2 n .57}
$$

Gow Machon Fr.8 (=Ath.viII.337c)

Hdt.

$\begin{array}{ll}1.171 .23-30 & 96 \text { (cited) } \\ 5.37 & 96 n .9 \\ 5.118 & 244 n .8 \\ 5.119 & 96 n .9,98 n .17\end{array}$

104-105 (cited), 107,

$110 n .67,115,135 n .153$,

$155^{n .247,308 n .248}$

$5.121 \quad 96 n .9$

$6.134 \quad 30$. 67

Livy

$\begin{array}{ll}33.18 .22 & 246,246 n .21 \\ 38.39 .8 & 101 n .30 \\ 45.25 .11-13 & 101 n .30\end{array}$

Luc.

Syr.D. 60

Lycoph.
Alex.

459-46o

368, 368n.99,

$368 n .100$

Paus.

$\begin{array}{ll}2.30 .2 & 264 n .101,267 n .104 \\ 5.21 .10 & 244 \\ 10.23 .1-10 & 396 n .218\end{array}$

Plin.

HN $32.16 \quad 107 n \cdot 5^{2}$

Plut.

Vit. Demetr. 31, $38 \quad 245^{n .14}$

Polyb.

\begin{tabular}{ll}
$3 \cdot 31.6-7$ & $246 n .23$ \\
$16.1 .1-9$ & $25^{2 n} .57$ \\
18.2 .2 & $25^{2 n} .57$ \\
18.6 .4 & $25^{2 n} .57$ \\
21.46 .4 & $101 n .30$ \\
30.5 .11 & $101 n .30$ \\
$30.21 .2-3$ & $246 n .23,256 n 80$ \\
30.31 .6 & $245 n .16,246 n .23$, \\
$256 n .80$ & \\
Oikon 2.2.13 (1348a, 12ff) \\
\multicolumn{2}{c}{$97 n .15$}
\end{tabular}

Senatus consultum de Panamara

252, 338, 339,

341, 342n. 43382 , 382n.164, 388, 392,

397

Senatus consultum de Stratonicensibus

251, 257-258, 259,

279n.134, 281n.142,

283, 294, 302, 310,

311, 313, 313n.265, 314,

$316-320,323,324$,

$337,369,372 n .114$

Steph. Byz.

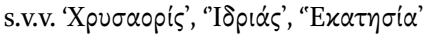

244

Strabo

12.2.23 $97^{n .13}$ 


\begin{tabular}{|c|c|}
\hline $12 \cdot 3 \cdot 36$ & $45^{n .130}$ \\
\hline $12.5 \cdot 3$ & $35^{n .88}($ cited $)$ \\
\hline 14.2 .22 & 13,416 (cited) \\
\hline \multirow[t]{4}{*}{14.2 .23} & $91 n .283,94$ (cited), \\
\hline & 97n.14, 105n.42, 107, \\
\hline & 127 (cited), 135n.153, \\
\hline & 148,16 on. 276 \\
\hline 14.2 .24 & 102 \\
\hline \multirow[t]{4}{*}{14.2 .25} & $92 n .284,241-242$ \\
\hline & (cited), 245, 246, 250, \\
\hline & $258,294,327 n .317$ \\
\hline & $399 n .230$ \\
\hline \multirow[t]{2}{*}{14.2 .29} & $263-4$ (cited), 29o, \\
\hline & $300,324,418$ \\
\hline
\end{tabular}

Tac.

Ann. 3.62

Thuc.

2.16 .1 251n.56, $25^{2}$ (cited), 316n.275, 338n.31, 393n.201

19

\section{$\mathbf{1 . 2}$
IAph20o7}

$$
8.27
$$

Epigraphic Sources

I.Iasos

$$
22
$$

$5^{2}$

612

632

I.Keramos

6

I.Knidos I

31

I.Labraunda

1

2

3

\section{$57 n .178$}

$156 n .256$

25on.612, 391n.196, $394 n .206$

$368 n .100$

391-2n.196

23o-1n.189

49n.152, 109,

140n.182, 141n.184, 141n.185, 157n.26o, 161n.28o, 161n.285, $163 n .291$

109, 140n.182,

157n.26o, 161n.289 49n.152, 10on.24, 109, 140n.182, 141n.186, 142n.187, 154n.246, 157n.26o, 158n.265, 161n.28o, 161n.285, $163 n .291$

109, 131n.144, 141n.182, 142n.189, 144, 144n.198, 15on.226, 157n.26o, 161 n.28o, 10on.25, 106n.49, 107n.5०, 109, 141n.182, 142n.189, 142n.19o, 143n.192, 144, 144n.138, 149n.223, 151, 153n.244, 154n.246, 157n.26o, 161n.28o, 256n.79 109, 131n.144, 141n.182, 142n.189, 144, 157n.261, 161n.28o, 17on.311 109, 141n.182, 142n.189, 144, 144n.198, 157n.26o, 161 . 28 o

109, 152n.235,

152n.236, 152n.237, 158n.265, 158n.266, 159n.274, 16o, 16on.275, 16on.276, 162n.29o, 163n.291, 170n.310, 203n.59, 213n.103, 224n.161, $225^{n .163}$ 109, 129n.134, 16on.277, 162n.29o, 163n.291, 165, 203n.59 109, 163n.291 109, 139n.175, 139n.176, 147n.212, 149, 149n.224, 149n.225, 162n.287, 165, 229n.181, 236n.204, 385 n.178 109, 147n.212, 149n.224, 162n.287, 165, 229n.181, $385^{n .178}$ 120n.96, 124n.11o, $173 n .322$ 


\begin{tabular}{|c|c|c|c|}
\hline & & 62 & $158 n .268,162 n .287$, \\
\hline \multirow{2}{*}{$\begin{array}{l}\text { I.Labraunda (cont.) } \\
\qquad 15\end{array}$} & \multicolumn{2}{|l|}{ 123n.106, 124n.11o, } & $163 n .293,165$ \\
\hline & $144 n .195$ & 63 & $158 n .268,162 n .287$ \\
\hline \multirow[t]{2}{*}{16} & 121n.97, 123n.106, & & 165 \\
\hline & $144 n .195$ & 67 & 128n.132, 135n.154, \\
\hline \multirow[t]{2}{*}{17} & $122 n .100,123$ & & $155^{n .249,} 15^{6 n .254}$ \\
\hline & $123 n .106,144 n .195$ & & $161 n .284$ \\
\hline \multirow[t]{2}{*}{18} & 123n.106, 129n.134, & 68 & $129 n .134,162 n .289$ \\
\hline & $144 n .195$ & 69 & $162 n .289,225^{n .163}$ \\
\hline 19 & 123n.106, 144n.195 & 70 & $161 n .287$ \\
\hline 23 & $120 n .96,173^{n} \cdot 3^{22}$ & 71 & 126n.12o, $162 n .287$ \\
\hline 27 & $128 n .131,161 n .283$ & 72 & $155^{n .249,156 n .254}$ \\
\hline 28 & $128 n .131,161 n .283$ & 83 & $128 n .132$ \\
\hline 29 & $\begin{array}{l}126 n .123,159 n .269 \\
162 n .287,165\end{array}$ & 84 & $\begin{array}{l}158 n .267,162 n .289 \\
164\end{array}$ \\
\hline 37 & $156 n .254$ & 86 & $162 n .287$ \\
\hline 40 & $128 n .132,157 n .257$ & 89 & $162 n .287,164$ \\
\hline \multirow[t]{3}{*}{41} & 159n.270, 161n.285, & 90 & $15^{2 n .240,162 n .287}$ \\
\hline & 164, 174n.324, & 93 & $162 n .287,165$ \\
\hline & $177 n \cdot 333,412$ & 110 & $156 n .254$ \\
\hline \multirow[t]{2}{*}{42} & $157 n .257,162 n .287$ & 134 & $109 n .63,119 n .94$ \\
\hline & 164 & & 129n.134, 141n.182, \\
\hline \multirow[t]{4}{*}{43} & $100 n .23,106 n .49$, & & $157 n .261,157$ \\
\hline & 142n.191, 143n.193, & & $157 n .262,158 n .263$ \\
\hline & $162 n .287,165,244 n .11$ & & $158 n .264,15^{8}$ \\
\hline & $256 n .8$ o & & 158n.266, 162n.29o, \\
\hline \multirow[t]{3}{*}{44} & $100 n .23,106 n .49$ & & $163 n .291,165$ \\
\hline & $162 n .287,164,244 n .11$ & 137 & $101 n .31,109 n .63$ \\
\hline & $333^{n} \cdot 5^{2}, 345^{n .5^{2}}$ & & $132 n .144,140-$ \\
\hline \multirow[t]{2}{*}{45} & 126n.12o, 148n.219, & & $141 n .182,142 n .187$ \\
\hline & $162 n .287$ & & 153n.137, 161n.285, \\
\hline \multirow[t]{3}{*}{46} & $101 n .28,107 n .46$ & & $172 n \cdot 318$ \\
\hline & $129 n .134,162 n .299$ & I.Mylasa & \\
\hline & $182 n .11,223 n .15^{2}$ & 1 & $102 n .34,135^{n .155}$ \\
\hline \multirow[t]{2}{*}{47} & 129n.134, 159n.271, & & $159 n .270,215^{n .113}$ \\
\hline & $162 n .288,164$ & 2 & $102 n .34,135 n .155$ \\
\hline \multirow[t]{2}{*}{48} & $158 n .268,161 n .281$ & & $215^{n .113}$ \\
\hline & $165,236 n .204$ & 3 & $102 n .34,135^{n .154}$ \\
\hline \multirow[t]{3}{*}{49} & $119 n .94,157 n .261$ & & 135n.155, 212n.96, \\
\hline & $158 n .266,162 n .290$ & & $215^{n .113}$ \\
\hline & $163 n .291,165$ & 8 & $155^{n .249}$ \\
\hline $5^{\circ}$ & $15^{2 n .239}$ & 11 & $153 n .243,212 n .96$ \\
\hline $5^{1}$ & $162 n .287,164$ & & $247 n .11$ \\
\hline 53 & $135^{n .154,155^{n .248}}$ & 12 & $212 n .96$ \\
\hline 54 & $135^{n .154}$ & 34 & $400 n .234$ \\
\hline 59 & $148 n .218,149 n .222$ & $\mathrm{~T}_{51}$ & $158 n .267$ \\
\hline 60 & $148 n .218,149 n .222$ & & $101-157$ \\
\hline 61 & $162 n .289$ & & $236 n .204$ \\
\hline
\end{tabular}




\begin{tabular}{|c|c|c|c|}
\hline 102 & $148 n .213,236 n .204$ & 211 & 16on.274, 219n.131, \\
\hline 103 & 214n.108, 236n.204 & & $221 n .145,225 n .163$, \\
\hline 106 & $236 n .203,236 n .204$ & & $236 n .203$ \\
\hline $109-111$ & 23on.189, 236n.2O4 & 212 & 16on.274, 219n.131, \\
\hline \multirow[t]{2}{*}{110} & 23on.189, 236n.2o3, & & $221 n .145,225$ n.163, \\
\hline & $236 n .204$ & & $228 n .175$ \\
\hline 112 & $236 n .203,236 n .204$ & 213 & 16on.274, 221n.145, \\
\hline \multirow[t]{2}{*}{113} & $209 n .82,236 n .203$ & & $225^{n .163}$ \\
\hline & $236 n .204$ & 214 & 16on.274, 221n.145, \\
\hline 114 & 23on.189, 236n.204 & & $225 n .163,236 n .203$ \\
\hline \multirow[t]{2}{*}{115} & $236 n .203$ & 215 & 16on.274, 219n.131, \\
\hline & $236 n .204$ & & $221 n .145,225^{n .163}$ \\
\hline 117 & $209 n .82,236 n .204$ & 216 & 16on.274, 221n.145, \\
\hline 119 & $209 n .82,236 n .204$ & & $225 n .163,236 n .203$ \\
\hline \multirow[t]{3}{*}{121} & $102 n .36,209 n .82$, & 217 & 214n.108, 221n.145, \\
\hline & $215^{n .114}, 236 n .203$ & & $225 n .163,228 n .178$ \\
\hline & $236 n .204$ & 222 & 219n.131, 221n.145, \\
\hline \multirow[t]{2}{*}{122} & $102 n .36,215^{n .114}$ & & $225^{n .163}$ \\
\hline & $236 n .204$ & 230 & 16on.274, 221n.145, \\
\hline \multirow[t]{4}{*}{134} & $92 n .285,185 n .134$ & & $225^{n .163}$ \\
\hline & 236n.204, 239n.212, & 231 & $221 n .145,225 n .163$, \\
\hline & 25on.48, 313n.268, & & $230 n .189$ \\
\hline & $417 n .4$ & $25^{1-26 o}$ & $221 n .145$ \\
\hline 136 & $209 n .82,236 n .204$ & 301 & $231 n .189,236 n .203$ \\
\hline 154 & $236 n .203,236 n .204$ & 302 & $214 n .110$ \\
\hline $15^{6}$ & $236 n .203,236 n .204$ & 309 & $254 n .309$ \\
\hline \multirow[t]{2}{*}{157} & 23on.189, 236n.2о3, & 311 & $165^{n .296}$ \\
\hline & $236 n .204$ & $312-314$ & $165 n .296$ \\
\hline \multirow[t]{2}{*}{201} & $212 n .96,221 n .145$ & 326 & $148 n .216$ \\
\hline & $225^{n .163}$ & 330 & $400 n .234$ \\
\hline $201-232$ & $221 n .145,225^{n .163}$ & 406 & $148 n .213$ \\
\hline \multirow[t]{2}{*}{203} & $219 n .131,221 n .145$ & $5^{\mathrm{O} 1}$ & $103 n .37,148 n .213$ \\
\hline & $225^{n .163}, 23$ on.189 & & $151 n .233$ \\
\hline \multirow[t]{2}{*}{204} & 16on.274, 221n.145, & $5 \mathrm{O} 2$ & $194 n .45$ \\
\hline & $225^{n .16}, 236 n .203$ & 533 & $165^{n .296}$ \\
\hline \multirow[t]{2}{*}{205} & 219n.131, 221n.145, & 632 & $236 n .204$ \\
\hline & $225^{n .16} 3$ & 634 & $236 n .204$ \\
\hline \multirow[t]{2}{*}{206} & $219 n .131,221 n .145$ & 762 & 16on.274 \\
\hline & $225^{n .16} 3$ & 763 & 214n.109, 228n.177 \\
\hline \multirow[t]{4}{*}{207} & 16on.274, 17on.311, & 801 & 170n.311, 212n.10o, \\
\hline & $219 n .131,221 n .145$ & & 219n.131, 221n.145, \\
\hline & $225^{n .163,230 n .189}$ & & $231 n .189$ \\
\hline & $236 n .293$ & $801-854$ & $221 n .145$ \\
\hline \multirow[t]{2}{*}{208} & $221 n .145,225^{n .163}$ & 802 & $221 n .145,231 n .189$ \\
\hline & $236 n .203$ & 803 & 170n.311, 212n.10o, \\
\hline \multirow[t]{2}{*}{209} & $221 n .145,225^{n .163}$ & & $221 n .145$ \\
\hline & $236 n .203$ & 804 & $212 n .100,221 n .145$ \\
\hline
\end{tabular}




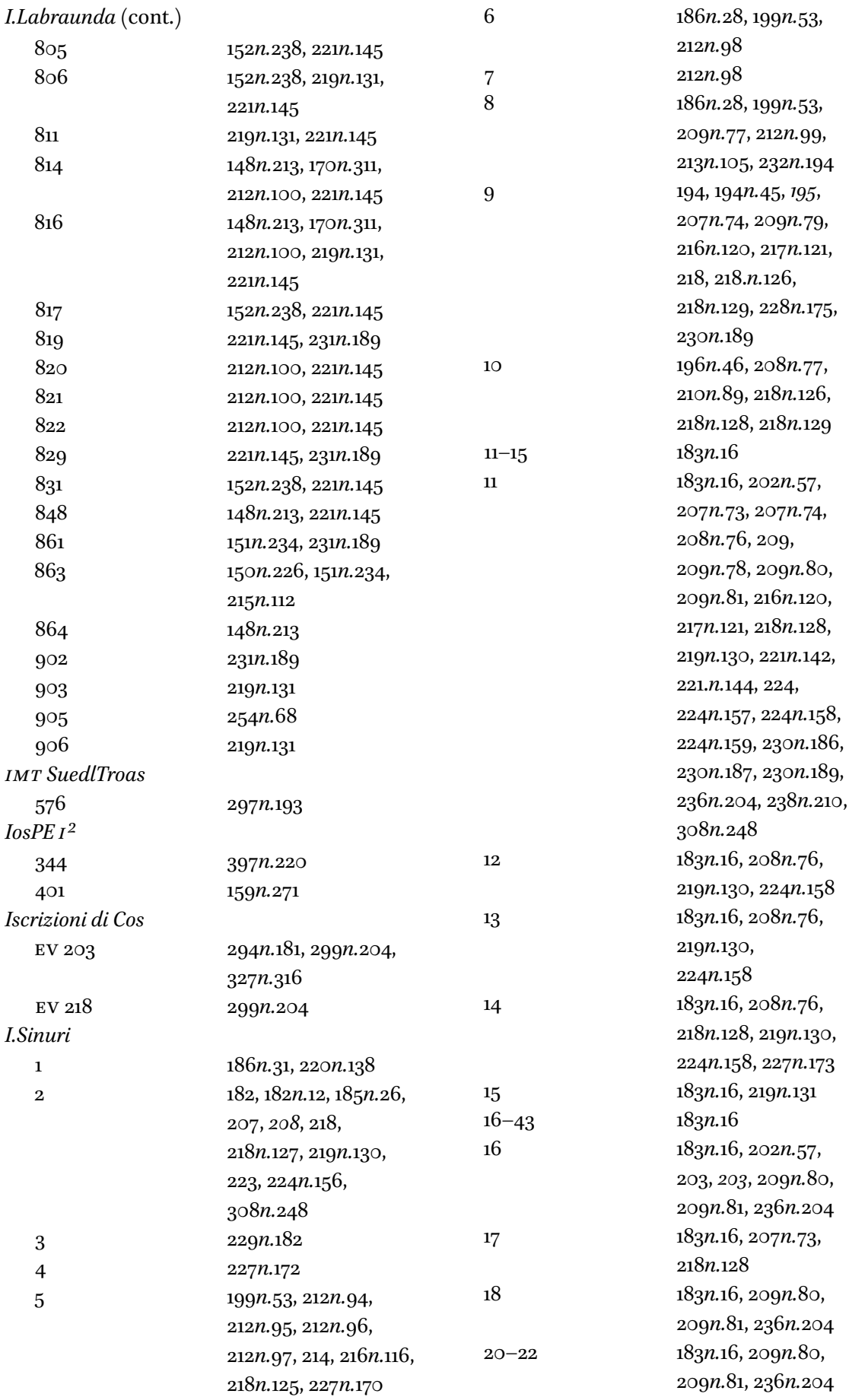


24

25

28

31

32

33

37

44

$45^{-72}$

45

46

47

48

49

$5^{\circ}$

53

56

58 183n.16, 207n.73,

209n.78, 216n.12o, 23on.187, 23 on.189

183n.16, 207n.73,

207n.74, 209n.78,

216n.12o, 218n.128, 228n.179, 23on.187, 23on.189

183n.16, 202n.57

183n.16, 197n.47,

197n.48, 202n.57,

$203 n .5^{8}$

183n.16, 197n.47

183n.16, 202n. 57

183n.16, 2ogn.8o,

$236 n .204$

216, 216n.119,

216n.120, 217, 229,

23o, 23on. 184

183n.16, 225n.163,

25 on. 48

183n.16, 212n.98,

217n.121, 227n.173,

25 on. 48

183n.16, 203n.46,

217n.121, 218n.128,

223n.155, 225n.163,

228n.175, 25on.48

$103 n .37,183 n .16$,

213n.10o, 217n.121,

219, 219n.131,

219n.132, 239n.133,

221n.144, 224n.162,

225n.163, 227n.174,

25 on. 48

183n.16, 224n.162,

225n.163, 25on.48

183n.16, 213n.10o,

225n.163, 25on.48

103n.37, 183n.16,

219n.131, 225n.163,

227n.174, 25on.48

183n.16, 219n.132,

225n.163, 25 on. 48

183n.16, 219n.132,

225n.163, 25 on. 48

183n.16, 219n.132,

$225^{\text {n.163 }}$, 25 on. 48
61

$73^{-76}$

73

74

75

76

77-8o

81

I.Smyrna

655

I.Stratonikeia

1

3

4

5

6

7

9 183n.16, 224n.162, 225n.163, 250n.48

$183 n .16$

99n.2o, 181n.7,

183n.16, 207n.71, 212,

$215,215^{n .115}, 216$,

216n.117, 216n.12o,

218n.123, 226n.166,

229, 229n.181

99n.2о, 181n.8,

183n.16, 207n.72,

218n.124, 229,

$229 n .182$

99n.2o, 181n.7, 181n.8, 183n.16, 217, 218n.123, 218n.124, 229n.182 181n.5, 183n.16, 191n.39, 202, 207 $183 n .16$

183n.16, 207n.75

3on. 67

$335^{n .18}, 365,366$, 366n.86, 372, 375n.132, 395n.217 245n.19, 333n.11, 334n.13, 346n.56, 35on.6o, 365n.84, 377n.137, 394n.210 245n.18, 333n.12, 385n.177, 35on.6o, 376n.136, 377n.137, 384n.176, 394n.21o, $395^{n .215}$

245n.18, 333n.7, $385^{n .177}, 395$ n.211 216n.12o, 245n.18, $353 n .7,385 n .176$, 385n.177, 394, $395^{n .211}, 395^{n .212}$ 249n.40, 335n.22, 365n.85, 377n.142, 378, 378n.145, 385n.177, 391n.196, 395 n.214 $346 n .55$ 334n.9, 384n.176, 395n.211 


\begin{tabular}{|c|c|c|c|}
\hline I.Stratonikeia (cont.) & & 102 & 366n.9o, 379n.153, \\
\hline \multirow[t]{6}{*}{10} & 61n.198, 252n.10, & & $379 n .154$ \\
\hline & 337n.29, 35on.61, & 103 & 366n.9o, 379n.153, \\
\hline & 35on62, 370n.105, & & $379 n .154$ \\
\hline & 379n.154, 38on.156, & 104 & $379 n .15^{2}$ \\
\hline & 396n.218, 397n.222, & 105 & 379n.154, 38on.155 \\
\hline & $398 n .225$ & 106 & $379 n .154$ \\
\hline \multirow[t]{3}{*}{11} & $25^{2 n} \cdot 59,33^{8 n} \cdot 3$, 381 , & 108 & $367 n .108$ \\
\hline & $382 n .164,385 n 178$ & 111 & $35^{2 n} .68$ \\
\hline & $392 n .199,397 n .221$ & 112 & $35^{1 n} .63,351 n .64$ \\
\hline \multirow[t]{4}{*}{12} & $25^{2 n .59,} 318 n .285$ & & $372 n .116$ \\
\hline & $33^{8 n} .30,342 n .43,3^{81}$, & 113 & $35^{1 n} .63,387 n .185$ \\
\hline & $382 n .164,3^{8} 5^{n 178}$ & 144 & $35^{2 n .68}$ \\
\hline & 392n.199, 397n.221 & 149 & $367 n .93$ \\
\hline 15 & $383 n .170$ & 161 & $364 n .82,401 n .236$ \\
\hline 16 & $263 n .98,381 n .162$ & 168 & $33^{8 n} \cdot 3^{2}, 351 n .66$ \\
\hline \multirow[t]{2}{*}{17} & 293n.177, 351n.64, & 170 & $373^{n .120}$ \\
\hline & $35^{2 n .68}, 373^{n .118}$ & 171 & $383^{n .170}$ \\
\hline \multirow[t]{2}{*}{19} & $336 n .24,378 n .148$ & 172 & $373^{n .123}$ \\
\hline & $395^{n .216}$ & 174 & $367,3^{67 n .92,}$ \\
\hline 20 & $384 n .173$ & & $367 n .93,367 n .94$ \\
\hline \multirow[t]{2}{*}{21} & 252n.6o, 381, & & $406 n .248$ \\
\hline & $392 n .200$ & 181 & $373^{n .120}$ \\
\hline $22-39 a$ & $\begin{array}{l}\text { 69n.248, 37on.104, } \\
382 n .165\end{array}$ & 186 & $\begin{array}{l}253 n .64,373^{n .124} \\
388 n .189\end{array}$ \\
\hline \multirow[t]{3}{*}{22} & 69n.248, 370n.104, & 189 & $384 n .172$ \\
\hline & $372 n .116,382 n .165$ & 192 & 373n.119, $388 n .188$ \\
\hline & 393n.2O2, 393n.2O4 & 200 & $35^{1 n} .64$ \\
\hline \multirow[t]{3}{*}{23} & 69n.248, 368n.102, & $2 \mathrm{O} 2$ & $369 n .103$ \\
\hline & 37on.104, 372n.116, & 203 & $35^{2 n .70}, 369 n .103$ \\
\hline & $382 n .165$ & & $373^{n .123}$ \\
\hline \multirow[t]{2}{*}{25} & 69n.248, 370n.104, & 205 & 369n.103, \\
\hline & $372 n .116382 n .165$ & & $373^{n .123}$ \\
\hline \multirow[t]{2}{*}{29} & 69n.248, 370n.104, & 210 & $373 n .123,373 n .124$ \\
\hline & $372 n .116,382 n .165$ & 220 & $35^{1 n} .67,35^{6}$ \\
\hline \multirow[t]{3}{*}{30} & 69n.248, 368n.102, & 226 & $35^{2 n .68}$ \\
\hline & 37on.104, 382n.165, & 227 & $311 n .261,38$ on.18o \\
\hline & $393 n .204$ & 235 & $293^{n .177}$ \\
\hline \multirow[t]{2}{*}{33} & 69n.248, 370n.104, & 240 & 356 \\
\hline & $372 n .116382 n .165$ & 242 & 371n.109, 371n.11o, \\
\hline \multirow[t]{2}{*}{35} & 69n.248, 370n.104, & & $373^{n .123}$ \\
\hline & $372 n .116,382 n .165$ & 246 & $383 n .168$ \\
\hline \multirow[t]{2}{*}{39} & 69n.248, 370n.104, & 247 & $371 n .107,371 n .108$ \\
\hline & $382 n .165,393 n .202$ & 248 & 281n.145, 352n.69, \\
\hline 42 & $368 n .101$ & & $359 n .78,368 n .97$ \\
\hline 45 & 381 & & $398 n .224$ \\
\hline $6 \circ$ & $384 n .175$ & 249 & $382 n .163$ \\
\hline 101 & $377 n .138$ & 251 & $35^{1 n} .65$ \\
\hline
\end{tabular}


$373 n .123$

$5 \mathrm{O} 2$

$5^{\circ} 3$

$373 n .123$

293n.177, 367n.91,

367n.92, 368n.97,

371n.110, 373n.123,

387n.186, 398n.227

349 fig 6.10

298n.2oo, 359n.76, 370n.106, 371n.111, 371n.113, 373n.122, $375^{n .131}$

352n.68, 373n.118 $387 n .186$ 352n.68, 374n.126 351n.64, 352n.68, 371n.107 305n.229, 324n.3०5, $381 n .162$ 364n.82, 371n.113, 374n.13o, 375n.13o 363n.81, 364n.82, 371n.108, 373n.121 305n.228, 352n.68, 352n.71, 371n.108, $387,387 n .187$

371n.107

$373 n .123$

293n.177

366n.9o, 379n.154,

$408 n .254$

$293 n .177$

364n.82, 371n.107,

$371 n .113$

$372 n .115$

364n.82, 367n.93

368n.101, 369n.103

310n.254, 368n.101, $369 n .103$

368n.98, 368n.101,

$369 n .103$

368n.98, 368n.101,

$369 n .103$

368n.98, 368n.101,

$369 n .103$

244n.6, 248n.35,

$255 n .74$ 248n.36, 255n.71, $255^{n .75}, 256 n .76$ 248n.35, 255n.75, $256 n .76$ 249n.37, 256n.78, 302n.43, 316n.273, 376n.136, 394n.211 251n.54, 258n.82, 279n.134, 281n.142, 294n.182, 303, 313n.265, 314, 316n.276, 317n.277, $337 n .27$

281n.142, 313n.265 251n.55, 277n.13o, 281n.142, 294n.183, 294n.185, 296n.189, 299n.202, 3०3, 310n257, 313n.265, 313n.266, 316n.276, 313n.265, 313n.266, 316n.276, 317n.277, $318 n .284$

251n.55, 300n.205, 313n.265, 313n.267, 314, 316n.276, $317 n .277$ 296n.189, 311n.263, 319n.286

270n.110

306n.236, 311n.262, 317n.281, 319n.287, 319n.288, 323n.299 256n.77, 273n.116, 306n.237, 308n.248, 3०9n.249, 309n.251, 310n.256, 317n.282 284n.149, 306n.237 $3 \circ 9 n .254$ 320n.29o 284n.149, 320n.29o 307n.242, 308n.246, 309n.253, 320n.29o 292n.171, 297n.194, 304n.226, 309n.252, $320 n .290$ 307n.242, 308n.246, 3o8n.247, 320n.29o 


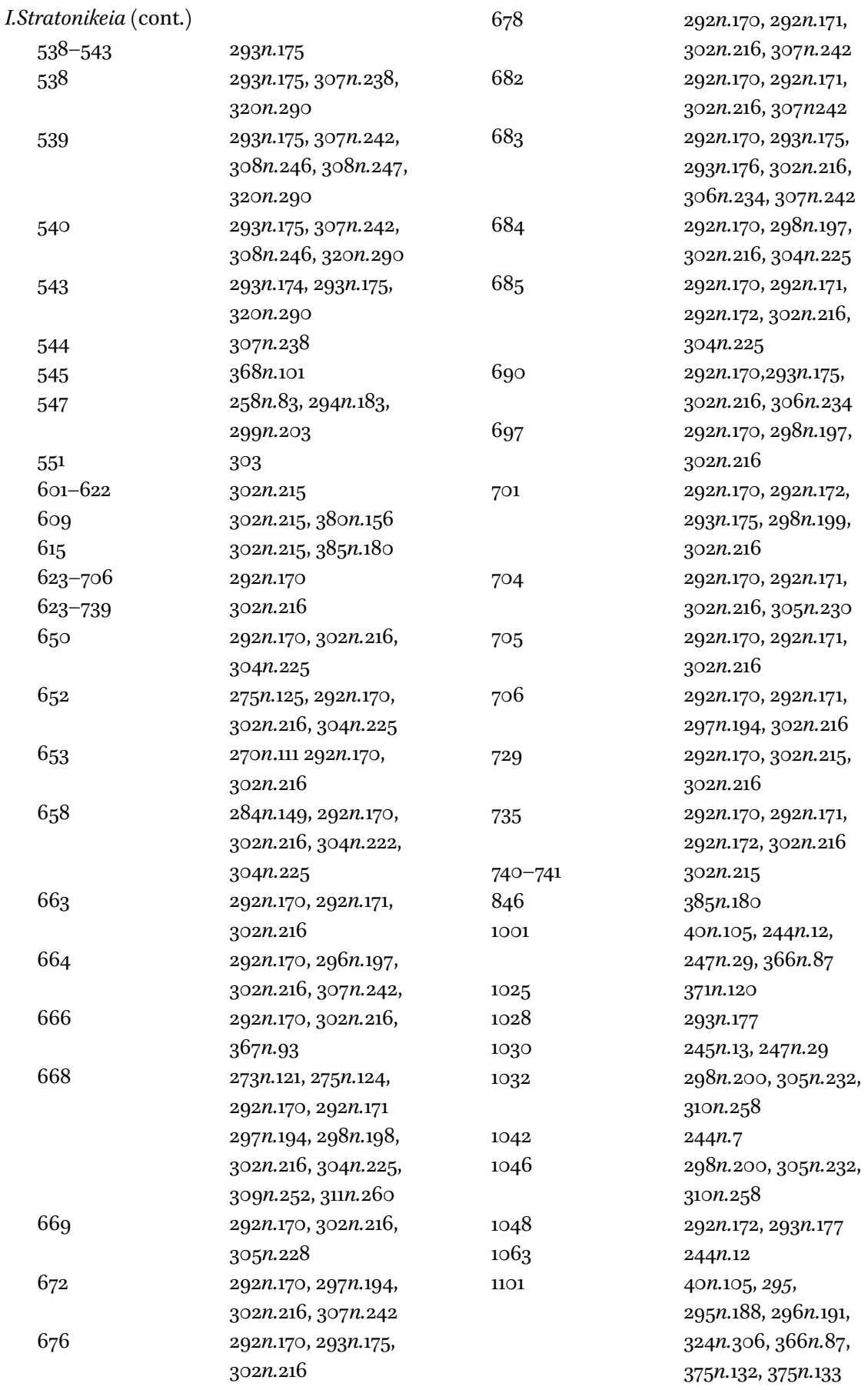




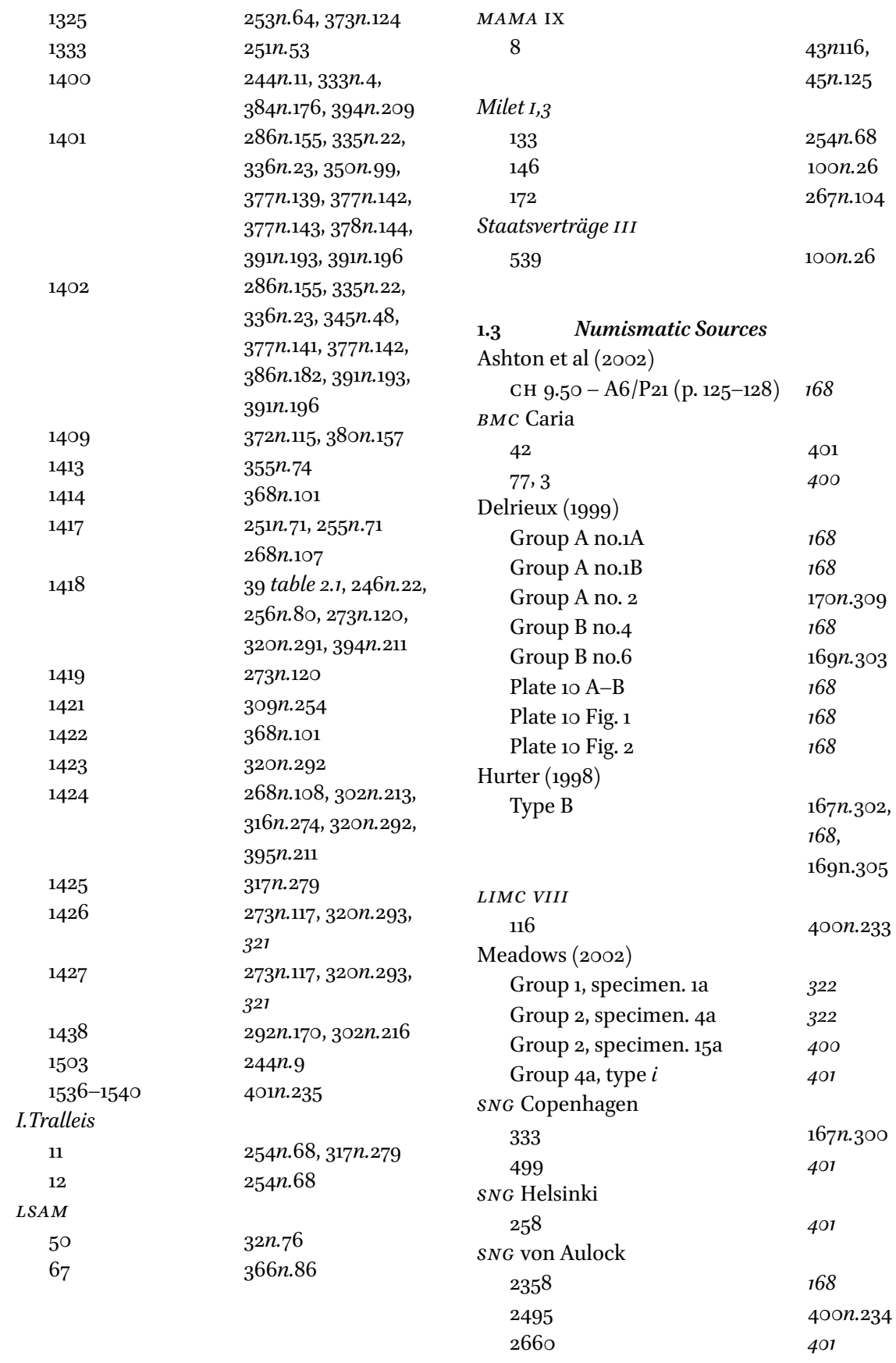




\section{Index of Persons}

Alexander the Great $\quad 2-6,100 n .21,417$ Amynamemnos, son of Bresikleios 297 Antigonids 99

Antigonos Doson 141-142,

Philip II 244

Philip V 106-107, 129,138, 141-144, 162, $245,252 n .57,256,332-335,346,35$ o, 364, 376, 39o, 394-395, 404, 415

Apollonios, son of Diodotos (Ptolemaic official) 142n.191

Apollonios Demetrios, son of Python(?) (Ptolemaic official, at Labraunda) $\quad 165$

Apollonos (stephanephoros at Stratonikeia?) 335

Apphion, daughter of Sosandros, son of Hekataios (at Panamara) 368

Archidamos (Rhodian priest of Helios) 334

Aristeas Melanos, son of Apollonios 227

Ariarames, son of Maussollos (at Labraunda) 128, 161

Arlissis (of Mylasa) 159n.270

Artaxerxes II 96

Asandros 97n.12, 157, 244, 255

Asklepiades of Peuma (epistates under Philip v) 245n.19, 25on.6o, 333, 335, 350n.6o, 394n.210

Claudius Theophanes (at Panamara) $\quad 35^{1}$

Cornelis Lentulis (at Labraunda) $\quad 165$

Demetrios, son of Poution (at Labraunda) $\quad 165 n .296$

Demetrios, son of Python (at Labraunda) 126, 159

Demetrios, son of Thraseas (at Labraunda) $\quad 165$ n.296

Diodotos Melanos, son of Politos (at Mylasa) 212n.10o

Dionysios, son of Leon of Kosetios (at Sinuri) 209, 224, 230

Dionysios, son of Timonax (at Labraunda) $\quad 165,171$

Eros, son of Menander, of Koraia (agoranomos honored at Lagina) 3ogn.254
Euthydemos, son of Theoxenos (at Mylasa, priest of Zeus Eleutherios) 170n.311

Eupolemos (Macedonian strategos) 157 n.257, 164

Flavius Diomedes (of Stratonikeia) $\quad 384 n .172$

Gnaius Domitius, son of Gnaisu (statue at Labraunda) $\quad 162 n .287,165$

Hekatomnids $\quad 1,13-14,93-99,102-106$, $113-115,124-125,127,134-135,137-138$, $143^{-144,}, 146-147,156,157,165,171,173-$ 178, 179-181, 192-194, 216-218, 225-226, 232, 242, 297, 412-414, 417-418, 421, 423,433

Ada $145,155,167,181,216,218,226,229$

Artemisia 128n.132

Idrieus $97,105,115,119-121,123,145,155$, $156 n .256,167,169 n .305,18$ o-181, 216, 218, 226, 229

Hekatomnos 96, 121n.98, 123-124, 128, 137-138, 161

Maussollos 96, 97-98, 105-106, 115, 118-120, 122n.99, 123-124, 128, 157, 161, 181, 244, 255

Pixodaros 10on.21, 169, 176n.332

Hekatomnos, son of Ouliades (of Mylasa) $103,15^{2 n .238,148 n .213,170 n .311}$

Hekaton, son of Hierogenus, of Koranza (agoranomos honored at Lagina) 309

Hellenistic rulers 99-100

Antigonos Doson 142

Antiochos III 100, 106-107, 181-182, 213, 221-223, 238-239

Olympichos (strategos of Seleukos II) 10o, 106, 141-147, 149-150, 152-154

Philip V 100, 106-107, 129, 142

Seleukos II 100, 106, 141-142

Zeuxis (strategos of Antiochos III) 100, 107

Hermias Athanagoras (Rhodian benefactor at Lagina) 268n.108, 302n.213, 316

Hermias Chrysaoros, of Koraia (agoranomos honored at Lagina) 309

[Hyps]ikles (of Herakleia) $\quad 156$

Hybreas, son of Polykritos (stephanephoros at Mylasa) 214n.108, 228 
Hyssaldomos, son of Eirenaios (poet) 121n.98, 337n.29

Hyssollos and Obrokon (archons of Koranza) 248

Kleanax, son of Serapion (of Kyme) $384 n .171$

Klodiane (kleidophoros at Lagina) 293

Konon, son of Poseidippos 256

Leon Iasonos (at Sinuri) 195

Leontiades (gymnasiarch at Mylasa) 370n.104

Menekles and Epainetos

(of Stratonikeia) 273, 320, 321

Menippos, son of Hieronymos (at Sinuri) 208n.77

Mithridates VI Eupator 250-251, 294, 318

Nesaios (at Sinuri) $\quad 207,216,229$

Olympichos 100, 105, 109, 131, 140-146, 157-164, 213, 417

Ouliades, son of Hekatomnos (of Mylasa) 148n.213

[Ou]liades Po[...] (at Sinuri) 203

Pammenes, son of Hermogenos 103n.37, 227

Peldemos, sons of (of Mylasa) $\quad 102 n .34$

Philetairos (of Pergamon) 123n.105, 124n.113

Poleites (of Mylasa) 120, 126

Posittos, son of Apellos (at Panamara) 351, 372,380 . $15^{8}$

Priests

at Labraunda 140-149

Hekatomnos, son of Korris $\quad 141 n .182$, 142-145

Korris 46,49 n.152, 140-143, 145, 148, $149,151,153$

Pollis 148

at Sinuri $\quad 49$ n.148, 212-215

Hiereus, son of Iatrokles 212,224 , $227 n .173$

Hybreas, son of Krateros 214, 228

Pellekos 212, 233n.197

Pixodaros 214n.108

Menippos, son of Hieronymos 212, $232 n .194$
Thargylios, son of Aristomenos

214

Thyssos 212, 228

from Stratonikeia

Ammion Apphion (at Panamara) 308n.246

Androsthenes, son of Zoilos (at Panamara) 377, 379n.152

Aristeas, son of Aetion 304

Chairemon, son of Hekataios 379n.154, 38o

Damonikios, son of Herodos $\quad 385 n$.18o

Epainetos and Flavia 304

Flavius Eudemos (of Koranza) and Flavius Heraeis (at Panamara) 351n.67

Herakleitos, son of Apollonidos and Tatarion, daughter of Myonidos $\quad 382 n .163$

Hierokles and Ada (couple at Panamara) 311, 385n.18o

Hekaton, son of Leon (at Panamara) 379

Kleinomachos, son of Drakon 304

Kleobouulos 351n.64

Leon, son of Chrysaor (at Panamara) $249,335^{-337,365}$, 376-379, 382, 385, 388, 39o-392, 395, 402, 407, 415

Leon and Myrtale $\quad 367$

Marcus Sempronius Auruncius Theodotos and Sempronia Auruncia Arriane, priestly couple $305 n .228,387$

Marcus Sempronius Claudius $\quad 305^{n .228-229}$

Marcus Sempronius Clemens 262n.98, 295n.187, 305, 323-324, 339n.34, 381

Marcus Ulpius Alexandros Herakleitos and Ulpia Ammion (priestly couple at Lagina) 304, 309n.252

Menander, son of Apollodatos 310n.254, 379n.154

Menippos, son of Leon (at Panamara) 379

Menophilos, son of Leon 302 Phanias, son of Aristeas $304 n .225$ Theodoros, son of Theophilos 305 n.228 
Priests (cont.)

Theophilos (at Panamara) 374

Tiberius Flavius Aeneas and Ulpia Leaena 305 n.23o, 339n.34

Titus Flavius Aeneas $351 n .64$

Triphaina (kleidophoros at Lagina, priestess at Panamara) 293

Unidentified priest of the letters 382 , $388,390,393,402,407$

Ptolemies 99-100, 142n.191, 143n.193, 244, 328n.319, 332-333, 384n.176, 394

Ptolemy II Philadelphus 7on.256, 164, 244n.11, 332-333, 345 n.52

Pytheos (architect) 121n.98

Romans $158,253 n .64,316,373,384 n s .171-$ $172,388,398,419$

Augustus 258, 273, 317n.279

Brutus 251

Quintus Labienus $101-102,251-252,258$, 372,408

\section{3}

\section{Index of Deities}

Agathe Tyche $\quad 227-228$

Aphrodite 24, 210n.87, 232, 279n.133

Epekoos (Yava) 242, 265, 266

Apollo 24, 274n.123

Didyma 91, 100, 114

Halikarnassos, Zephyrion peninsula $106,167,168$

Koliorga 286, 288

Apollo and Artemis

Hydai 219n.131

Olymos $148 n .213,152,172,219 n .131$

Koranza 248, 255-256, 262, 263, 265, 266, 286, $305^{n .230}$

Ares $279 n .133$

Artemis 25, 26, 279n.133

Amyzon 39, 107, 180, 182, 191, 206, 223

Ephesos 39, 167

Iolkia $416 n \cdot 3$

Kindye $\quad 318 n .285,337 n .29$

Koliorga 242, 265, 286, 332

Pergaia 39, 435

Leukophryene (Magnesia on the

Maeander) 25, 39, 273n.119, 274n.123, $300,315,318 n .285$

Panamara 351
Sulla $\quad 25^{\circ}-251,258,313,316,337$

Tiberius, Tribune $\quad 252$

Samiades, son of Theodotou

(at Sinuri) 216n.119, 217, 230

Seleukids 1, 13-14, 99, 244, 247, 255, 332-333

Antiochos I or II 100, 245

Antiochos III 47, 70n.253, 100-101, 107, 129n.134, 162, 181-182, 213n.104, 221-223, 238-239, 245-246, 334

Laodike $\quad 152,159 n .274$

Seleukos II 49n.152, 100, 106, 141-143, $146,154,161,163$ n.291, 169,

Stratonike 245

Sosandros, son of Diomedos

(at Stratonikeia) $\quad 295^{n .187}, 295^{n .188}$, 324n.306, 366,

Sosandros, son of Hekataios

(at Panamara) 368n.98

Zeuxis (strategos under Antiochos III) 100-101, 107, 181-182, 221, 223

Stratonikeia $\quad 295^{n .187}, 324 n \cdot 305$,

Asklepios

Kos 120n.95, 124n.113, 273n.119, 328,

Pergamon 39, 393n.201

Stratonikeia, with Hygieia $\quad 295 n .187$, $324 n .305$

Athena 24

Polias (Athens) 147n.209

Polias (Priene) 39, 121, 275

Ilion 39, 57n.180

Nikephoros (Pergamon) 57, 252n.57, 435

Festival Panathenaia $\quad 27$

Demeter 25, 33, 274n.123

Demos (with Zeus and Hera at

Panamara) $\quad 367$

Dionysos 25, 27, 274n.123, 373

Dioskouroi 212-213, 2332

Great Gods (Megaloi Theoi, Samothrace) 208n.77, 212-213

Hekate $1,5,13,39,74,232,254-259,337,366$, $371,373,374,38 \mathrm{o}-381,382 n .163,383,389$, $398,400,408,410,414-415,418,421,433$ 
Augusta (with imperial cult) 317 n.279

Soteira Epiphaneia 73n.271, 251, 258, 294, 296n.189, 318-319, 329, 424

Trimorphic 264n.101

Festivals, Genethlea 292, 310

Festivals, Hekatesia, Hekatesia-

Romaia 251, 258, 285, 292, 294-296,

299, 301, 311, 316-318, 324, 329, 375, 422

Festivals,

Hekatesia-Kaisareia-Romaia $\quad 258 n .83$

Festivals, Kleidos agoge $\quad 258,284$, 285-286, 291, 292-296, 300, 338, 363, $364-365,371 n .108,375,387,406,414$

Festivals, Triakades $\quad$ 291-292

Helios (Rhodes) 249, 256, 302, 315-316, 334, 376n.136, 394n.211

Hera 25, 26, 337, 350, 351, 364, 366, 369, 373, $374,398 n .225,407-408,415$

Teleia 28 o

Festivals, Heraia (Panamara) 310, 337, $363,364,365-369,375,405$

$\begin{array}{ll}\text { Kanebos } & 273^{n .120} \\ \text { Komyros } & 368\end{array}$

Men Askaenos 5, 35, 37n.98, 39, 435

Meter/Kybele

Labraunda 111,134

Steunene (Aizanoi) $\quad$ 5, 435

Theon (Mamurt Kale) 5, 57, 123n.105, 274n.122, 308n.245

Poseidon 26, 33, 147n.209, 279n.133,

Sabazios 400

Serapis $\quad 244 n .11,258 n .83,333^{n} .6$

Sinuri $5,13,39,98-99,101,107,152,179-240$, 232-234, 241, 345, 412, 414, 417-418, 419, 423

Festivals, Bouthysia $\quad$ 207-209, 234

Festivals, Kotamia $\quad$ 207-209

Festivals, Syennia $\quad$ 207-209, 229

Tarhuntas 111

Thea Romē 251, 258, 280, 301, 311, 327

Romē Thea Euergetes 258, 294

Festivals, Romaia (see also Hekate) 311, 318
Zeus $\quad 25$

Aganiteon (Mylasa) 103n.38, 209n.82, $236 n .203$

Akraios (Halikarnassos) 137

Ammon (Cyrene) 29

Capitolinus 251n.54

Chrysaoreus 13, 39, 47n.141, 241, 244, 246, 249n.39, 256, 257n.80, 286, 307n.241, 332, 337n.28, 382n.163, 399n.230, 382n.163, 399

Eleutherios (at Mylasa) 170n.311

Hyarbesyton (Mylasa) 103n.38, $236 n .203$

Hypsistos 227-228

Idrieus (Iasos) $\quad$ 156n.256

Karios 13, 73n.271, 94, 95n.4, 96, 98, 242, 249, 280, 331-410, 337-338, 345, 349, 397-398n.225, 402, 409, 413, 415, 421

Labraundos $\quad$ 1, 5, 13, 39, 74, 103-178, 168 Fig.3.15, 18o, 206, 239, 241, 266, 273, 275, 413, 420, 424, 433

Lepsynos (Euromos) 122

Lykaios (Arkadia) 7, 416n.3

Maunniton (Mylasa) 103n.38, $236 n .203$

Osogollis (Mylasa) $\quad 45^{n .125}, 94,96 n \cdot 7$, 100, 103, 109n.62, 130, 143n.193, 148, 152, 158, 159-161, 161n.279, 163n.291, 167-170, 168, 175-176, 179, 213, 219, 221-222, 224-225, 236, 274n.123, 329n.321, 413, $324 n .305$

Otorkondeon (of Mylasa) 103, 236n.203

Panamaros 5, 13, 39, 74, 232n.192, 241, 242, 249, 28o, 286n.155, 295-296, 297n.196, 305, 310-311, 323-324, 330, 331-410, 337-338, 397-398, 402, 409, 415,424

Epiphany of $\quad 252,318,392,394$, $396-398,402,415,424$

Stratios 105, 135

Festivals, Komyria (Panamara) 337, 363, 368-369, 375, 384, 388, 405

Festivals, Panamareia (Panamara) 298, 305, 363, 369-372, 373, 375-376, 383, 398-400, 406, 408-409, 424

Festivals, panegyris (Labraundos) 135-136, 139-140, 155 


\section{4 \\ Index of Places}

Aegina 267n.104, 314

Aigai $\quad 3,4,5,39$

Aizanoi $3,4,5,39,43,45^{\text {n.125, 277n.129, }}$ 435

Alabanda 4, 5, 39, 91, 105, 112, 114, 25on.51, 251n.56, 256, 263-264, 274n.123, 3oon.208, 313n.267, 314, 327n.317, $336 n .23,344,390,392-393,416$

Alinda $\quad 91,93,112,114,172,25$ on.51, 265, 314, $327 n .317,372 n .116,390,393,417$

Amaseia 3, 4, 5, 105n.42, 435

Amyzon 4, 5, 39, 91, 107, 180, 182, 191, 206, 222-223, 25on.51, 314, 327n.317, 416

Apollonia Salbake 39-4O, 45n.124,47n.142, 48n.145, 49-5o, 91, 141n.183, 147n.210, $390,392-393,400$

Aphrodisias $\quad 39-40,156 n .255,252,254 n .68$, $390,392-393$

Argos 313, 314

Athens 19, 26-27, 33, 57n.18o, 157, 237, 274n.123, 313, 314

Bargasa $\quad 93,114,242,265,266,390,392-393$

Bargylia 91, 93, 113, 114, 156n.254, 242, 25on.45, 313n.267, 314, 318n.285, 368n.10o, 391n.196

Beçin Kale $93,96 n .8,97,113,114,173^{n} .321$, $184,186,242,265$

Carthage 29

Chalketor $93,101,112,113,114,242,265,416$ Chersonessos (Tauric) 159n.271, 397n.220

Corinth 33

Cyprus $\quad 156$

Cyrene 29

Damascus $313,314,324$

Delphi 313,314

Didyma $\quad 3,28,38,40,43,91,100,114,305^{n .231}$

Egypt 156,304 n.227

Eleusis 33

Ephesos 4, 5, 39-40, 203n.59, 263-264, 277, $313 n .267,314$

Etruria 22, 33.n.82
Euromos 93, 101, 112, 113, 114, 122, 130, 155n.25o, 158, 162n.289, 164, 167n.3००, 172-173, 242, 265, 313n.268, 314, 399n.231, 416

Gencik Tepe (near Mylasa) 93, 95, 97, 113, 114, 130, 173n.321, 179, 242, 265, 413

Gordion 43

Hacibayramlar Höyük (near Lagina) 91, 93, 114, 242, 262, 263, 265, 266

Halikarnassos $\quad 91,93,97-98,104,106,113$, 114, 121n.98, 122n.99, 123n.108, 134, 137, 141n.183, 147n.210, 156n.255, 157n.259, $186,299,327,369$

Hattuša 43

Herakleia under Latmos $\quad 91,93,114,390$, $156 n .255,157,254 n .68,314,39$ o, 392-393, 416

Hiera Kome (near Stratonikeia) 39-40, 219-220, 221n.144, 224n.162, 238, 244, 246-247, 255n.70, 286, 302, 307n.241, $332,333,379,381$

Hydai $\quad 46,93,101,114,130,231 n .189,179,242$, $254 n .68,265$

Hydissos $93,113,114,179,181,185,188,242$, 265,314

Hyllarima 39, 91, 226-227, 254n.68, 265, 266, 273n.12o, 346, 367n.93, 39o, 392-393

Iasos 4, 5, 57n.178, 91, 112, 113, 114, 145-146, $156 n .256,242,314,390,393$

Idyma 114, 242, 263, 265, 344

Ilion $57 n .180$

Isthmia $\quad 33,299$

Kale Mevkii (near Mylasa) 95, 111n.69, 130, 179

Kallipolis $91,114,242,265,335^{n .22, ~ 345, ~ 350, ~}$ $377,390,390-391,421$

Kalymnos $\quad 187,188$

Kapıkaya (sanctuary of Meter near Pergamon) $3,4,5,57$

Karyanda 93, 114, 156n.254

Kasossos 93, 114, 179, 181, 185, 242, 265

Kastabos (sanactuary of Hemithea) 5 , 39,91 
Keramos 91, 93, 114, 242, 249-251, 263, 265, $317,327 n .317,336-337,391 n .196$

Gulf of $91,93,113,114,242,25 \circ, 265,336$, $345,369,399,415,421$

Kindye $91,93,101 n .32,114,153 n .243,242,265$, $337 n .29$

Klaros 3, 43, 91, 305n.231

Klazomenai 29

Knidos 91, 97, 231n.189

Knossos 128n.132

Koliorga $242,245^{-247}, 265,286,288,3$ o2, $383 n .169$

Kolophon $39,143 n .193,299,327$

Komana 3 on.66, 35, 39, 45 n.13o

Koraia $\quad 246-247,264,265,266,302,346,381$, $383 n .169$

Koranza 41 n.107, 112, 243, 246-249, 255-256, $262-263,266,277,283,286,289-29$, $302,312-315,324,328$

Demes of Koranza (Hythybira, Patarousa, Angorra, Lagina, and Ondra) 248n.36, 255-256

Kos 91, 114, 97, 124n.113, 156n.254, 273n.119, 299-300, 327, 328

Kuyruklu Kalesi (fortification near Mylasa) 100, 113, 130, 179

Kyme $3,4,5$

Labraunda $\quad 1,3,4,5,13-14,16,39,46,49-5^{\circ}$, 54-57, 59n.187, 57n.189, 66, 71, 87, 9o-92, 91, 93-178, 191, 203n.59, 206, 215n.112, 231, 236n.204, 241, 266, 275, $297,316,35$ o, 363, 385, 412, 414, 418, 420-421, 423-424, 432-434

Lagina $\quad 1,3,4,5,13-14,16,28,39,44,55$, $59 n .187,64,66,71,73,87,90-93,112,114$, 219n.132, 241-330, 346, 348, 349, 350, $374,380,387,389,394,406,407-408$, 414-416, 418-419, 420-421, 423-424, $429,432-433$

Laodikeis $93,114,265,335$ n.22, 336n.23, 345, 377, 39o-391, 39o, 421

Larysynia (near Mylasa) 101n.31, 153n.243 Limyra 156n.256, 314

Leukoideis $265,344,346$

Lobolda 242, 246-247, 264, 265, 266, 302, 346
Londeis $93,114,242,265,344,346,390,390$, 421

Lykaion (Arkadia) $\quad$ 7, 416n.3

Magna Graecia $\quad$ 20-23, 29, 78

Magnesia on the Maeander $\quad 25,39,91$, 273n.119, 274n.123, 277n.129, 300, 314, 315, 317n.28o, 318n.285

Mamurt Kale (sanctuary of Meter Theon) 3, 4, 5, 57, 123n.105, 124n.113, 273n.118, 274n.122, 308n.245

Megara 33, 314

Metropolis $39,299,327$

Miletos $3,4,5,28,38,39,91,93,100,114$, 156n.255, 158, 254n.68, 267n.104, 30о, 313n.267, 314, 327, 39o, 392-393

Mobolla 91, 114, 242, 265, 344

Mylasa $1,3,4,5,13-14,16,39,46-48,5$, $54-57,66,73,75-76,87,90-92,91$, 93-240, 241-242, 250-251, 254n.68, $265,274 n .123,313,314,327 n .317,35$ \%, $385,390,392-393,413-414,416-421$, 423-424, 432-433

Myndos 93, 112, 114, 188, 299, 399n.231

Notion 91, 274n.123

Nysa 4, 5,39, 91, 299, 314, 327, 390, 393

Olymos 46, 93, 101, 112, 114, 130, 131n.142, 132n.144, 148n.213, 15on.226, 151-152, 16on.274, 17on.311, 172-173, 212n.10o, 215ns.112-114, 219n.131, 221, 230, 231n.189, 242, 265, 313n.268

Olympia $313,324,35^{2 n} .70$

Oropos $316 n .269,314$

Panamara $1,3,4,5,13-14,16,39,44,59 n .187$, 64, 71, 74, 75, 87, 90-92, 91, 93, 114, 179, 184, 241, 242, 243, 245, 25on.51, 251-252, $258,260,265,266,292,305,310-311$, $327 n \cdot 317,331-410,415-416,418-419,421$, 423-424, 429, 432-433

Passala, the 'little sea' (near Mylasa) 93, 101n.32, 114, 143n.194, 146n.204, 242, 265

Patara $3,4,5,39,91,314$

Pedasa 93, 114, 157 
Pergamon $3,4,5,39,43,57,124 n .113$, 252n.57, 273n.119, 274n.123, 28on.138, 435

Perge 4, 5, 39, 435

Pessinus 35,39

Physkos 114, 263-264, 300n.208

Piraeus 156

Pisidian Antioch $\quad 3,4,5,35,39,274$ n.122, 39-40, 435

Pisye 114, 263, 265, 266, 344

Priene 4, 5, 39, 91, 121, 123n.105, 275

Rhodes 14, 91, 97, 99, $101245^{-247}$, 249-25०, 255-257, 267, 268, 28。, 302, 313n.267, 315-316, 324, 332-336, 372n.116, 376n.136, 378, 384-385, 389-392, 39o, 39o-392, 393, 394, 402, 404, 407-408

Rhodian peraia $101,263-264,391-392,403$, 415,418

Rome 29, 47, 100-101, 163, 246, 250-254, 256-258, 279-28o, 294-296, 297n.193, 30o-302, 311, 313-318, 324, 327, 329, $336,338,388,391-392,397,402,407$, 409, 414-415, 421-422, 433

Sardis 4, 5, 39, 43

Seleukeia Pieria $\quad 313,314$

5

\section{General Index}

Achaemenid influence $90,93,115,117 n .84$, 119, 134, 137-138, 140, 146n.205, 152n.235, 229n.181, 251

Actor-Network Theory (Latour) $\quad 65-67,71$, 174-176

Anabasis 364, 371, 374, 398-399, 400-401, 403

Architectural framing $56-57,82,124,202$, 2o6, 234, 274-275, 283, 320, 358, 427

Architectural orders

Corinthian order $\quad 115 n .78,268 n .105$, $275^{-276,290}$

Doric order $\quad 115 n .78,119,121 n .98,123,125$, 194-197, 202, 218, 272, 290

Ionic order $119,268,275^{-276}$

Unfluted (smoothed) columns

274,282
Sinuri $1,3,4,5,13-14,16,46,55,59 n .187$, 87, 90-93, 95, 98-99, 101, 107, 113, 114, 155 n.25o, 179-240, 242, 25on.48, 232-234, 241, 265, 298, 345, 412, 414, $417-418,419,423,432-433$

'acropole' 186, 187, 188, 194, 197-202, 198-200, 204-205, 212, 219-220

Smyrna 39, 390, 393, 407

Stratonikeia $1,3,4,5,13-14,16,39-40$, 41n.107, 71, 73, 74, 75-76, 87, 9o-93, 101, $112,114,155^{n .25}$, 179, 185, 239, 241-410, $414-424,432-433$

Tabai 91, 39o, 392-393, 399n.231

Tegea $155,167,314$

Telmessos (Myndian) 141n.183, 147n.210

Teos 25, 29, 39, 274n.123

Themessos (near Keramos) 251, 317

Thera (member of Chrysaoric

Federation) 93, 114, 242, 250n.51, 265

Tralles 4, 5, 39, 91, 254n.68, 263, 313n.279, 314,344

Troizen 368n.101

Trysa 4, 5, 259

Xanthos 4, 5, 39, 5, 91, 435

Yeşilbağcılar (Gibye) $\quad 288$

Aristonikos revolt 163,25 on.45, 279-28o, 317, 323, 391n.196

Asylia (inviolability) 28, 37-38, 42, 44, 69-71, 75-76, 86, 10o-101, 182n.11, 223, 243-244, 251-252, 255, 258, 294, 299, 301, 302, 310, 313-315, 316-319, 325, 327, 329, 336, 338, 378, 382n.164, 384, 39o, 392-395, 397, 402, 404n.244, 407, 409, $414-415,421,424-425,428 n .16,429$, 433

Tiberius's reforms tribune $\quad 25^{2-253}$, 316n.275, 338, 393

Ateleia (tax exemption) 37-38, 42, 44, 181, 229, 384

Autonomy $15,17,36,38,46,49,51,68,75$, 76,8 o, $84,85,89,140,141$ n.183, 145, 216, 
319 n.287, 378, 385, 385n.178, 388, 411, $425,432,434$

Biotike agora (live market) 275n.124, 309-312

'Bi-polar' model (de Polignac) 8, 18, 23n.28, 25-32, 404n.243

Banqueting 118, 136-138, 140, 210-212, 273, 297-299, 301, 372-374, 398, 403, 406, 432

Battle of Pydna $\quad 256$

Biotike agora (live market) 304, 309-310, 327

Boffo, L. $\quad 36,37-43,47-48,5^{1}$

Bouthysia (oxen-sacrifice) 234

Calendars 19, 84, 181, 207, 209, 225, 230n.85, 237n.206, 292, 334-335, 365-366, 413

Ceramics $15,88-90,108,109,125,135^{-137}$, 18。, 182-183, 186, 191n.37, 199, 204-206, 210, 220, 232, 243, 255, 261, 291, 352, 413, 432

Chwe, M. S.-Y. $\quad 15,60-65,406$

Civic pride $7,11,26,52,154,202,226,239$, $258,368,375,412,417,418,422-425,436$

Cognitive approaches $\quad 15,52,53,58,60-61$, 79,428

'Cognitive collages' (Tversky) 53-54, 79, 266n.103, 426

Cognitive maps $53-59,76,82,300,324$, 409-410, 426

Coinage $\quad 165^{-170}, 168,175^{-176}, 3^{21-323}, 3^{22}$, 399-402, 400, 401

Collective (or social) memory $\quad 58-59$, 6o-61, 79, 211, 235, 329, 365, 371, 396, 402, 406-409, 412, 426

Common knowledge $\quad 60-65,70,77,79$, 234-235, 301, 324, 326, 374, 398, 405, $421-422,428$

'Communitas' 7-8, 405, 416

Connectivity $59,67,69,180,330,404,407$, 418-419, 421-422, 434

Continuum perspective $28,30-34,81,404$, 437

Coordinating mechanisms $10,62,301,370$, 374-375, 39o-391, 398, 406, 415, 419, 421, 428

Core-periphery model $\quad 18-25,27,67,76$, 410, 411
'Country sanctuaries', as term $\quad 1,6-9,13-14$, $16,17-19,23,28,29,34,5^{1-52}, 59$, $64-65,76-77,87,265,285,413,417-418$, $425,433,435^{-437}$

Debord, P. $\quad 9,36,37-51,67,70,145^{-147}, 154$, 247,25 ०, 253, 341, 403

Demes 9, 27, 92, 15on.226, 215, 219n.132, 244, 246-249, 253, 255-256, 264, 307, 326, $328,383,385,416,420$

De Polignac, F. $\quad 8,18,25^{-} 30,31,63,67,172$, 325,404

Dignas, B. $36,41-43,49-50$

Doors, doorways, and gateways $57,82,88$, 191, 194, 197, 202-205, 269, 272, 284, 288, 304n.225, 323, 334, 35on.6o, 351, $356,359-36 \circ, 363,387$

Double-axe (labrys) $\quad 132,130,133,157$, $163-167,166,170,232-233,240,274,400$

Durkheim, E. $\quad 9-10,61$

Egdikoi (legal representatives) 182n.12, 207, $215,218-219,223-224$

Ekklesia (assembly, kyria ekklesia) 102, 384

Eleutheria (freedom) 38

Elite, cultural/media $\quad 8,29,75^{-76}, 84,96$, 119n.94, 124-126, 138, 147, 293, 297. 303-3o6, 310-311, 329, 336n.25, 375, $379-384,388-389,409,424,430$

Emporia $\quad 35 n .88,43,85,89,310,327$

Ephebes 295, 367

Epiphanestatos topos ('the most conspicuous place') 59n.19o, 16o-161, 203n.59, 316, 394-395, 427

Epiphanies 277, 294, 316-319, 337-338, 372, 392, 394, 396-398, 400-401, 402, 424-425

Eunoia (goodwill) $\quad 37-38$

Eunuchs 306-309, 311

Euergetism 297, 310-311, 380, 383-384, 388-389

'Extra-urban' sanctuaries $3-6,8,17,18-34$, $37 n .98,5^{1-52,63 n .217, ~ 78, ~ 8 o, ~ 214 n .107, ~}$ 417

Eusebia (piety) $\quad 37-38$

Federations (see also Koina)

in Karia 100, 241, 253 
Federations (see also Koina) (cont.)

Chrysaoric League $\quad 13,100,106,141 n .182$, 141-144, 154, 162n.287, 244-245, 25o, 256, 268n.107, 320, 327n.317, 345n.52, 399

Karian League $\quad$ 13, 95n.4, 105, 137n.163, 138n.169, 155

Panamareis 39, 249, 332, 333-336, $348,349,359,364,365,376-379,382$, 384-39o, 394-395, 402, 404, 408, 415, $421,424,433$

Federation sanctuaries $3,43-44,94,100$, 235n.202, 241, 253

'Flashbulb memories' 6o-61, 301n.210, 408, 419, 428

Footprints $281,282,320-321$

'Foregrounding' (Hirsch) 54, 77, 177-178, 266n.103, 358, 409, 423, 426

Foreigners $157,298 n .197,337,367,370-371$, $373,383-384,388 n .189,398,405,437$

Fortifications $112-113,130,130-131$

Framework of analysis $\quad 12-13,77-92,88-89$, 411-412, 425, 431-435

Frontier sanctuaries $\quad 25-30,172,239$, 325-326, 330, 403-404, 417-419, 425

Games $\quad 28,61,89,116,127,135,138-140,157$, 158, 294-295, 299-301, 355, 374-375, 422

Geertz, C. $\quad 9-10,63,406$

Gerousia 47n.142, 308n.247, 309n.252, 311, 374,383

Globalizing tendencies $\quad 2,6,28,40,42,52$, 76, 241, 254, 295, 300, 312, 315, 324, 331, $407,421,422,437$

'Graffiti' 281, 282, 320-321

Greek-indigenous bias $20,37,41-43,48-5$, 154, 411

Gymnasia 267n.105, 298, 308n.247, 310n.259, 37on.104, 373, 376, 38on.158, 383

Gymnasiarchs $\quad 298,370 n .104,383$

Hair dedications $\quad 338,356,368-369,369,381$ Hiera kome (sacred village, see also Hiera

Kome under Places) 39, 47, 78, 219-220, 221n.144, 224n.162, 238
Hierodouloi (sacred slaves) $\quad 44-46$

Hymns $258,295^{-296,295, ~ 324, ~ 375, ~ 398, ~}$ 403, 405, 409, 432

'Imagined communities' (Anderson) 11, 178,220

Ionian revolt $\quad 96 n \cdot 9,104,105^{n .42}$

'Intentional history' (Gehrke) 408

'Inward-facing circles' 62-65, 128, 206, 234, $283,316,427$

Isopoliteia 100, 158, 430

'Isovist fields' $\quad 55^{-56,204}$

Katoikoi, katoikouuntes $\quad$ 47-48, 307-309, 311, $387,424,433$

Kleidophoria (Lagina) 258, 285, 292-294, 300, 306, 308, 326, 329

Koina (see also Federations) 13, 46, 79, 216, $253,307,333,384-387,420-421$

Ktematonai (overseer of sacred lands) 103n.37, 215, 219, 227

Laumonier, A. $\quad 36,108,303,323,335,338$, $340-341,344,345,352-355,386,392$, $403 n .242$

Legal administration and organization $84-85$

'Lieux de mémoire' (Nora) $\quad 5^{8-59,70}$

Memory approaches $\quad 15,5^{8-59}, 77,79,420$

'Memory theater' 59, 104, 125n.115, 173-175, $412,417,427,429$

Mental maps, see Cognitive maps

Mithridatic Wars 101, 250-251, 257, 279, 294, 296n.189, 300, 313, 316-319, 323-324, $327,337,369,372,400,414$

Mountains $24,32,33,72,82,90,98,107$, 110, $112,113,130,132,179,184,188,199,255$, $262-263,266,283,290,325,341,344$, $345,348,414,415,418,43$ o

Music $258,295^{-297}, 324,366,375,398,403$, 405, 409, 432

Mysteries $\quad 367-368,384$

Neokoros (cult personnel) 148-149, 306, 309, 384

Network theory $15,17,5^{2}, 65^{-71}, 77,429$ 
Networks based on cult $79,300,313-318$, 324, 327-328, 330, 389-394, 404, 414, $416-417,421-425,429-43$ o, 437

Oaths $129,142,159,161,162,164,171$, 279n.133, 377, 39o-391, 428, 43 o

Paasi, A. 11, 15, 72-76, 291, 328-329, 407-409, 422, 424, 430-431

Panegyris $105 n .43,135,139-140,198 n .201,292$

Panhellenic festivals $28,42,70,84-85,89$, $301,327,430$

Parthian invastions (see also Quintus

Labienus under Persons) 101-102, 251-252, 258, 272, 311, 329, 337-338, 35०, 37O, 372, 392, 396-397, 4OO, 4O2, 404, 415

Peer-Polity Interaction (Ma) 68-70, 429-430

Penteteric festivals 294, 300, 302, 313, 318, $325,327,367,43$ o

'Performing the landscape' (Donaldson) $73^{n .267}, 3^{29 n .320,415,423}$

Peripolion 269, 273-274, 296, 298, 307-309, 311

Phylai 97, 102-103, 154n.246, 157, 209, 217, 236

Hyarbesytai phyle (of Mylasa) 102, 103n.38, 151, 215, 23on.189, 236n.203, 237

Konodorkondeis phyle (of Mylasa) 102, 151, 2ogn.82, 215, 236n.204, 237

Korollos phyle (of Stratonikeia) 311

Otorkondeis phyle (of Mylasa) 102-103, 151, 209n.82, 212n.96, 215, 219n.131, 222, 225, 227, 230, 236ns.203-204

Poliad deity (protective or tutelary civic god) 2, 11, 29, 167, 170, 254, 256, 266, 315, 318, 323 n.297, 345, 349, 373, 434

Polis religion $16,42,237,436$

Priesthoods $48-50,78,125,140-149,154$, 212-215, 249, 301-307, 375, 376-384, 39o, 392, 407, 409, 424, 430, 432-433

Priestly conflicts with other authorities 46-47, 49-5o, 75n.277, 125, 140-148, $152-154,157,173,175,177,424$

Priestly deeds (hiereus and epangelia inscriptions) $\quad 302-3 \circ 5,309,337,379,387$

Priestly gifting $301,304-306,310-311$, $368-369,371,38 \circ, 383,387$
Processions (see also Sacred roads) 63-65, 82, 117, 132-134, 157, 204-206, 285-291, 292-294, 300-301, 306, 326, 329, $348,359-365,370,374,375,398,406$, $408-410,413,414,415,416,420,423$

Ramsay, W.M. $\quad$ 9, 35-36, 43, 44-45, $403 n .242$

'Rational rituals' (M. S.-Y. Chwe) 15, 17, $60-65,77,79,211,301,326,365,374-$ $375,405-406-407,421-422,428-429$

Regional identity $11-12,15,17,52,71-76,77$, 79, 178, 291, 324, 328-329, 374, 387, 389, 407-408, 416, 422-424, 430-431

Rider-gods $323,364,400,409,424$

Ritual performance $11,58,61-64,66,73$, 76, 83-84, 134-140, 206-211, 235, 275, 291-301, 329, 365-376, 419, 420, 433

Ritual space $58,82,326,365,413,414$, $426-427,432$

Concentric space (see also Inward-facing

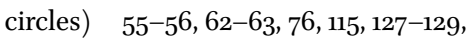
175, 202, 206, 234, 273, 282-284, 290, 299, 326, 358-359, 364, 426-427, $43^{2}$

(Kinetic) linear space (see also Processions) $\quad 56-57,63-64,72-73$, $76,115,124,129-134,175,177,202-204$, 273, 282-291, 326, 358-359, 364, 406, $426-427,432$

Rivers 1, 32, 72, 104, 110, 112, 219, 262, 264, $325,341,430$

Robert, L. $\quad 182-183,207,208,212,215^{-217}$, 317-318, 339

Rostovtzeff, M. $\quad 19 n .6,35,44 n s .122-123,149$, $317-318,397$ n.220

Sacred grove (hieron alsos) 4 45.128, 110, $115,185,218$ n.127, 224, 256, 273, 306, 308-310, 312, 342

Sacred lands (hiera chora) 43-48, 141-142, 149n.221, 152-154, 159-161, 311-312, 317-319

Mylasan lease construction $\quad 15^{2-153}$, 159-161, 170n.311, 181, 203n.58, 209, 221-226, 228, 234

Sacred roads $112,130-134,130,204-206$, 218-219, 285-291, 286, 287, 332, 350, 355, $357,359-365,360-362,427$ 
Sacred village, see Hiera kome

Sacrifice 55, 136, 157, 170, 207-211, 234-235, $242,275,375$

Sensory rituals $60,83,174,301,376,405$

Slaves 370, 373, 383, 405

'Social capital' (Bourdieu) 74, 384, 388-389, 421

Social cohesion $\quad 7,9,15,52,61,65,76,79$, $84,86,128,178,233,235,241,254,267$, 297, 301, 326, 328, 331, 349, 365, 370, $374-375,387-389,398,402,405-407$, $414-416,419-421,422,428,435,436$

Spatial approaches $15,17,52,53-59$, 62-65

Spatial memory $17,52,53-59,67,77,420$, 426

'Spatial continuum' $30-34,82,85,290,345$, 437

Spatial socialization (Shields) $\quad 73,75$

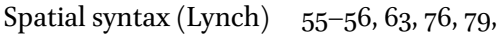
206

Spectacle $\quad 58,60-64,77,83,117-118$, 296-297, 300-301, 304, 325, 376, 406, 408-409, 420, 428, 432

Stadion $\quad 62,64,116,127,138-139,150$

Sympoliteia $\quad$ 9, 157, 335, 391n.196, 430, 437

Syngeneia 46, 69-71, 75-76, 79, 86, 97, 99, 102-103, 147, 149-151, 154, 179-240, 307, $388,393,394,407,409,413,420,421$, 424, 433

Aganiteis syngeneia (of Mylasa) 102-103, 209n.82, 236n.203, 237

Korrides syngeneia (of Labraunda) 102-103, 149-151, 215-216, 385, 433

Maunnites syngeneia (of Mylasa) 102, 151n.233, 214n.108, 215, 236n.203

Ogondeis syngeneia (of Mylasa) 237

Pelekos syngeneia (of Sinuri) 46, 181, 185-186, 207-208, 211, 212, 214, 215-217, 225-226, 229, 232, 236, 413, 424

Pormounos syngeneia (of Sinuri) 46, 102-103, 151, 180-182, 185-186, 194, 203, 206, 207-209, 211, 214, 215-226, 228-232, 236-240, 298, 413-414, 424

Tarkondoreus syngeneia (of Mylasa) 151 in.233,215, 227
Synoikism 9-10, 13-14, 29, 76, 91, 97, 102, 173, $215,236-237,247,328,414$

Tamiai (treasurers) 182n.12, 207, 208, 215, 218, 223-224, 310, 320n.292

Temple architecture 116-127, 190-202, 268-282, 350-358

Frieze of Temple of Hekate at Lagina $\quad 277-281,278,290$

Temple as archive $\quad 140,157-164,223 n .152$, 225-226, 238-239, 302, 311, 316-317, $319 n .287,320-321,392,395,402,409$

Temple orientation $57-58$, 116, $183 n$.21, 196, 206, 220, 264, 270, 273, 283, 285, 352,

'Temple states' $37,45^{-46}$

Terraced sanctuaries $\quad 56-57,124,129$, 192-194

Territorial integrity and control $1,6,8$, $26-28,52,72,77,80,99,243,246,254$, $331,369,374,387-388,402,406-407$, 415-416, 419, 420, 423, 426, 430-431, 434

Theoria (sacred delegations) 69, 294-295, $367,382,405,429-430$,

Theatron 117-118, 270, 271, 275, 281, 282, 29o, 304, 316, 320-321, 326, 358n.75

Tombs near sanctuaries $\quad 51,54,58,73,81,82$, $88-89,130,132,134,150,173 n .321,182$, 201, 205, 220, 228, 359-363, 362-363, $386-387,427$

Treaty of Apamea 101

Turner, V. $\quad 7-8,64,405-406,416,420$,

Urban-rural bias (see also Core-periphery) 7 , 18-20, 24, 30-31, 34, 36, 40-41, 48, $5^{\circ}-51,76,172,293 n .179,403-404,411$, 425

'Urban mediatization' $12,16,78,82,85^{-86}$, 154-171, 226-234, 433

'Urban rituals' $\quad 8,211,51,86,239,415,437$ Uzunyuva monument (Mylasa) 98, 137, $165 n .296,337 n .29$

Viewsheds xiv, 15, 55, 81, 114, 188, 265, 348, 423,436

Visual regions $53,54-59,76-77,81,206$, $266,348,406,423,426,436$ 
Visuality $\quad 54-59,76-77,81$

Water $1,24,54,58,81,88,89$, 106, 110-111, $118,123,125^{-127}, 128,130,131,134$, 138-139, 140, 152-153, 171, 173, 175, 210, $262,263,284$ n.149, 286-288, 287, 338, $344 n .47,351,427,432$
Windows $\quad 56-57,82,113 n .73,119-120$, 123n.106, 124, 129, 138, 141n.183, 178

Women in ritual $136,293 n .177,306,367-$ $369,370,373,375,38 \circ, 383,387-388$, $398,405,415,419$ 